Fall 1963

\title{
1963 Miracle Yearbook
}

\section{Cedarville College}

Follow this and additional works at: https://digitalcommons.cedarville.edu/yearbooks

Part of the Higher Education Commons, Organizational Communication Commons, and the Public Relations and Advertising Commons

\section{Recommended Citation}

Cedarville College, "1963 Miracle Yearbook" (1963). Yearbooks. 20.

https://digitalcommons.cedarville.edu/yearbooks/20

This Book is brought to you for free and open access by DigitalCommons@Cedarville, a service of the Centennial Library. It has been accepted for inclusion in Yearbooks by an authorized administrator of DigitalCommons@Cedarville. For more information, please contact digitalcommons@cedarville.edu. 



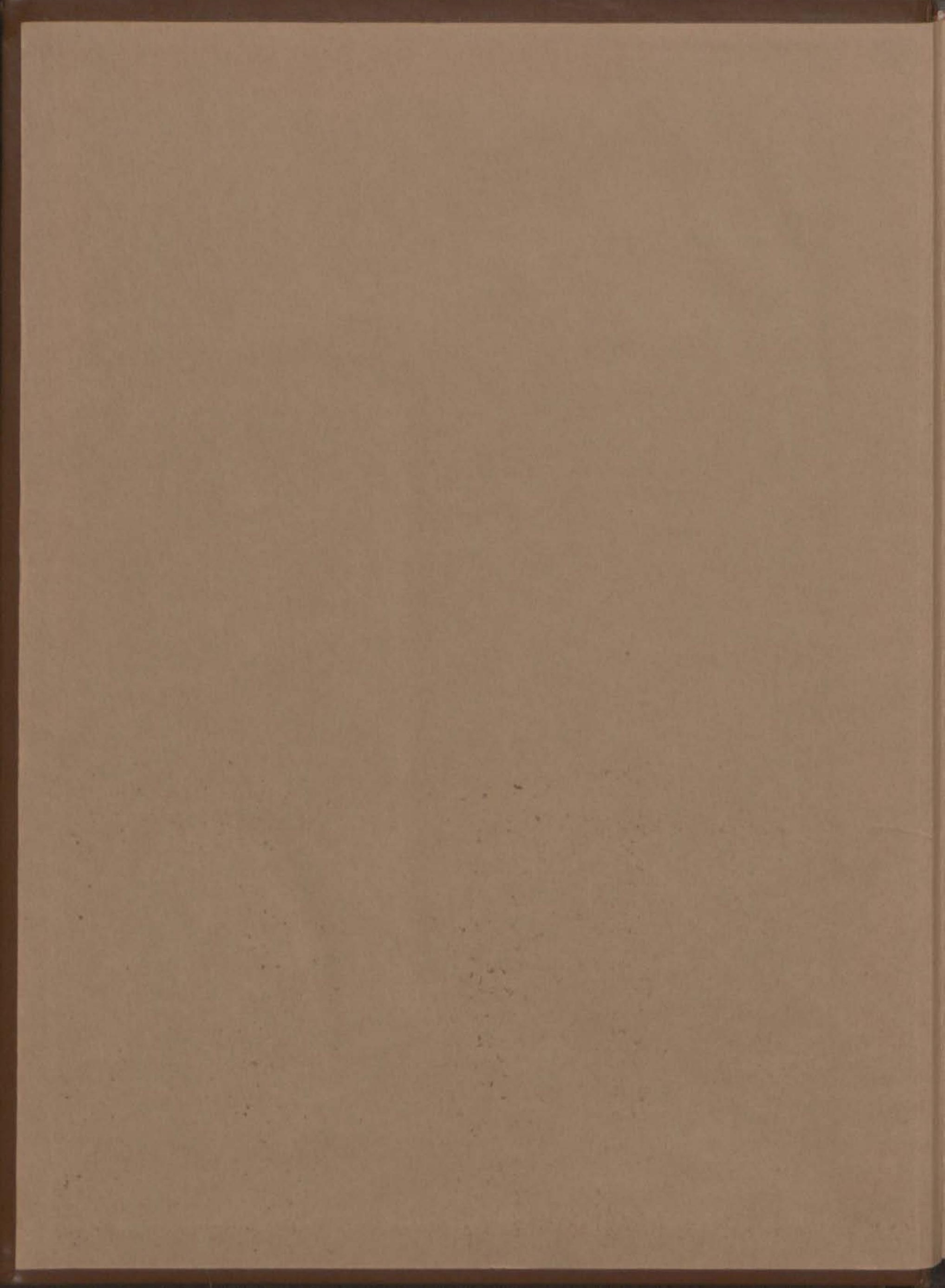


A Decade of Progress, the Record of Miracles 



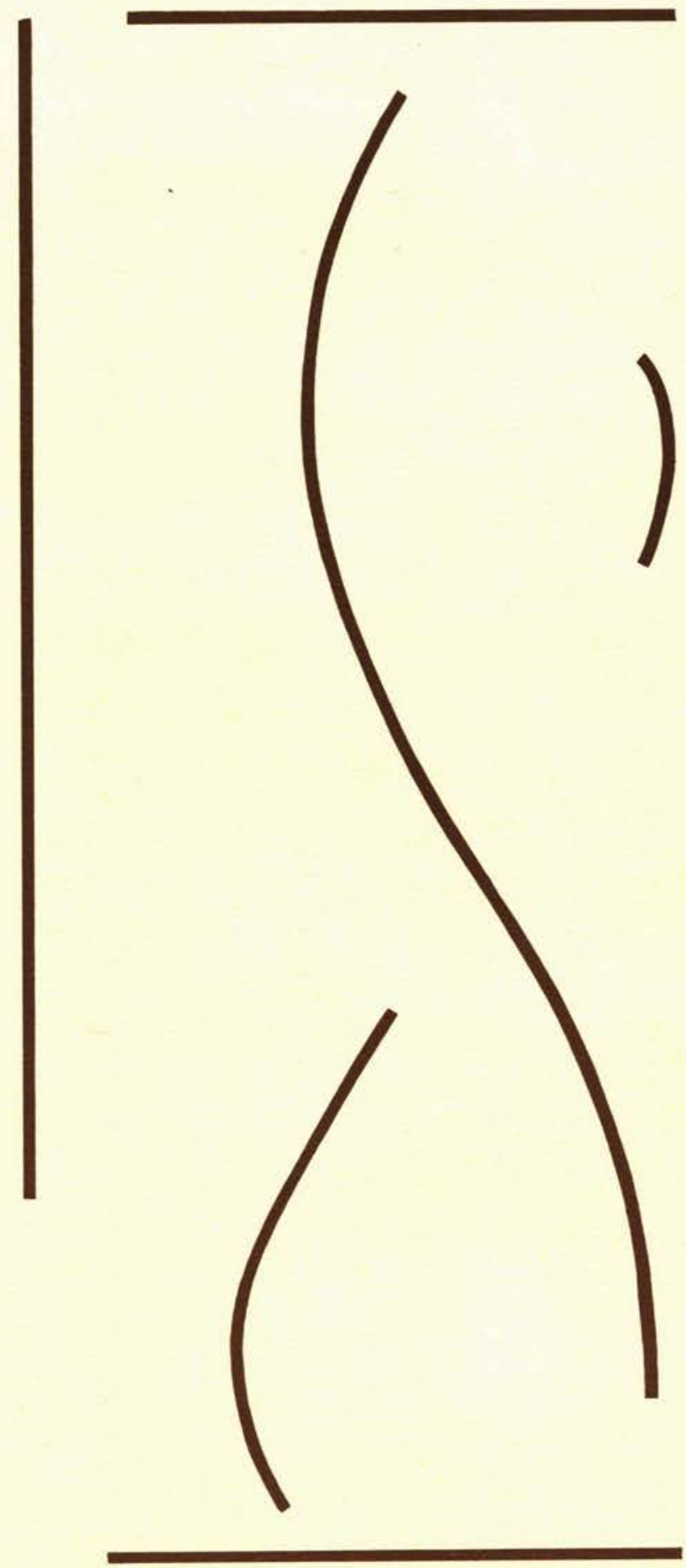




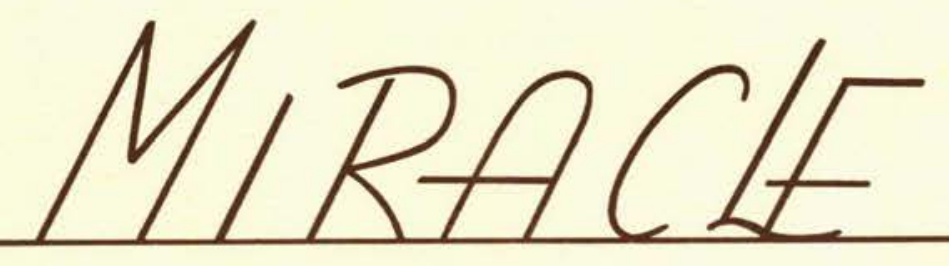

PUBLISHED BY THE JUNIOR CLASS CEDARVILLE COLLEGE CEDARVILLE, OHIO 


\section{Foreword}

A DECADE OF PROGRESS, THE RECORD OF MIRACLES. The last ten years in the history of Cedarville College has been a period of decision, expansion, growth - a time of progress. At times the task has seemed humanly impossible but God has given strength and wisdom. Cedarville College has experienced a decade of Divine direction.

This publication then, becomes the testimonial of this advancement. In a decade of progress, this is the record of miracles.

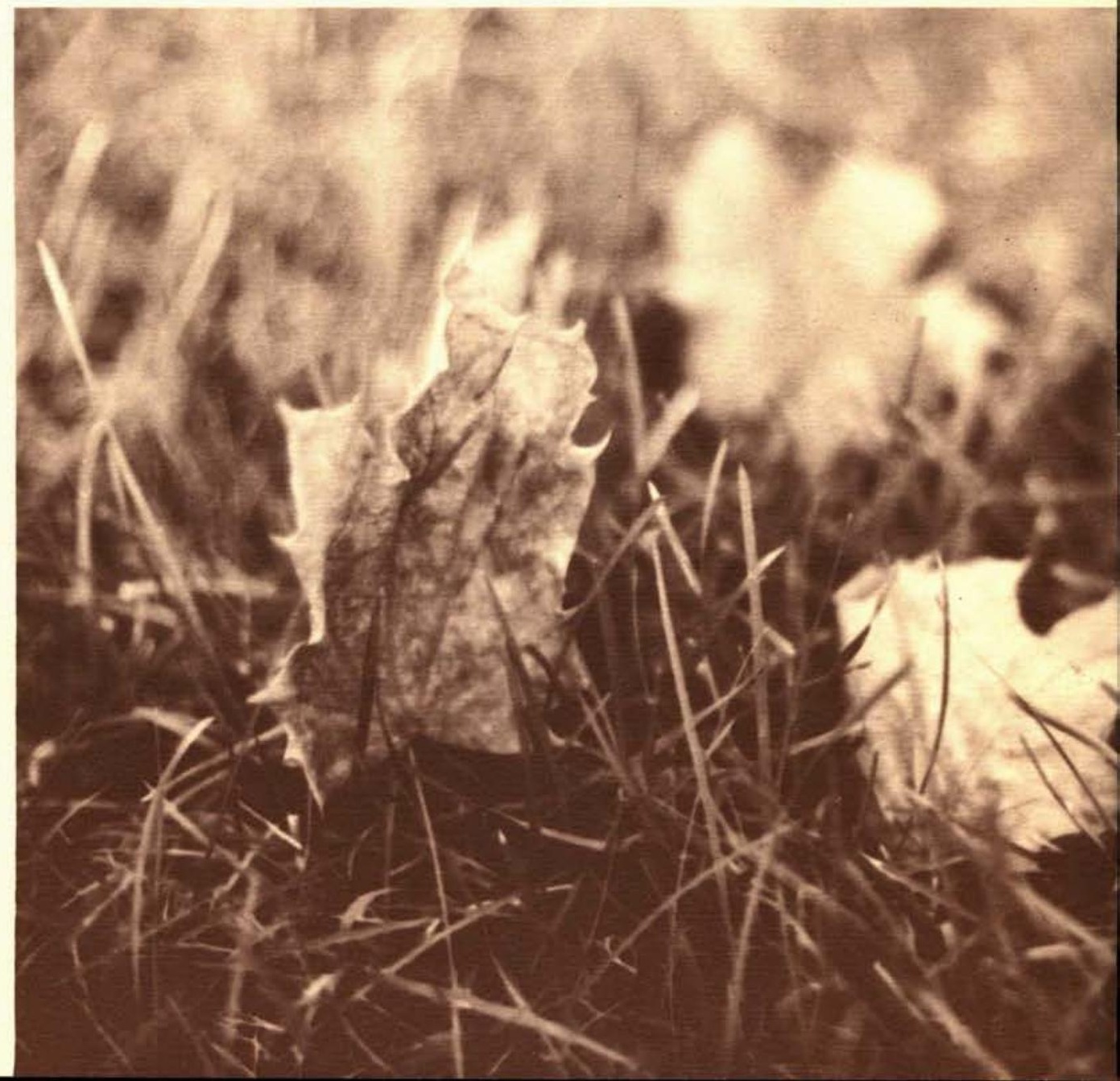




\section{Contents}

HISTORY

ACADEMICS

SPIRITUAL LIFE 58

Christian Service 60

Chapel 66

Special Meetings 70

ACTIVITIES 76

Organizations 78

Special Events 102

ATHLETICS 116

STUDENTS 136

Seniors 138

Juniors 150

Sophomores 160

Freshmen 170

STAFF 180

PATRONS 186

INDEX 208 


\section{In Memoriam}

Born-February 7, 1938; Died-December 17, 1962 Not lost but gone before ... gone before to see Him whom we know but in part ...

Elinor Keefer Marshall - A college staff worker with a smile of ready encouragement . . . an energetic worker, a captivating warmth ... a life in the pattern of the Almighty.

No longer darkly, but face to face.
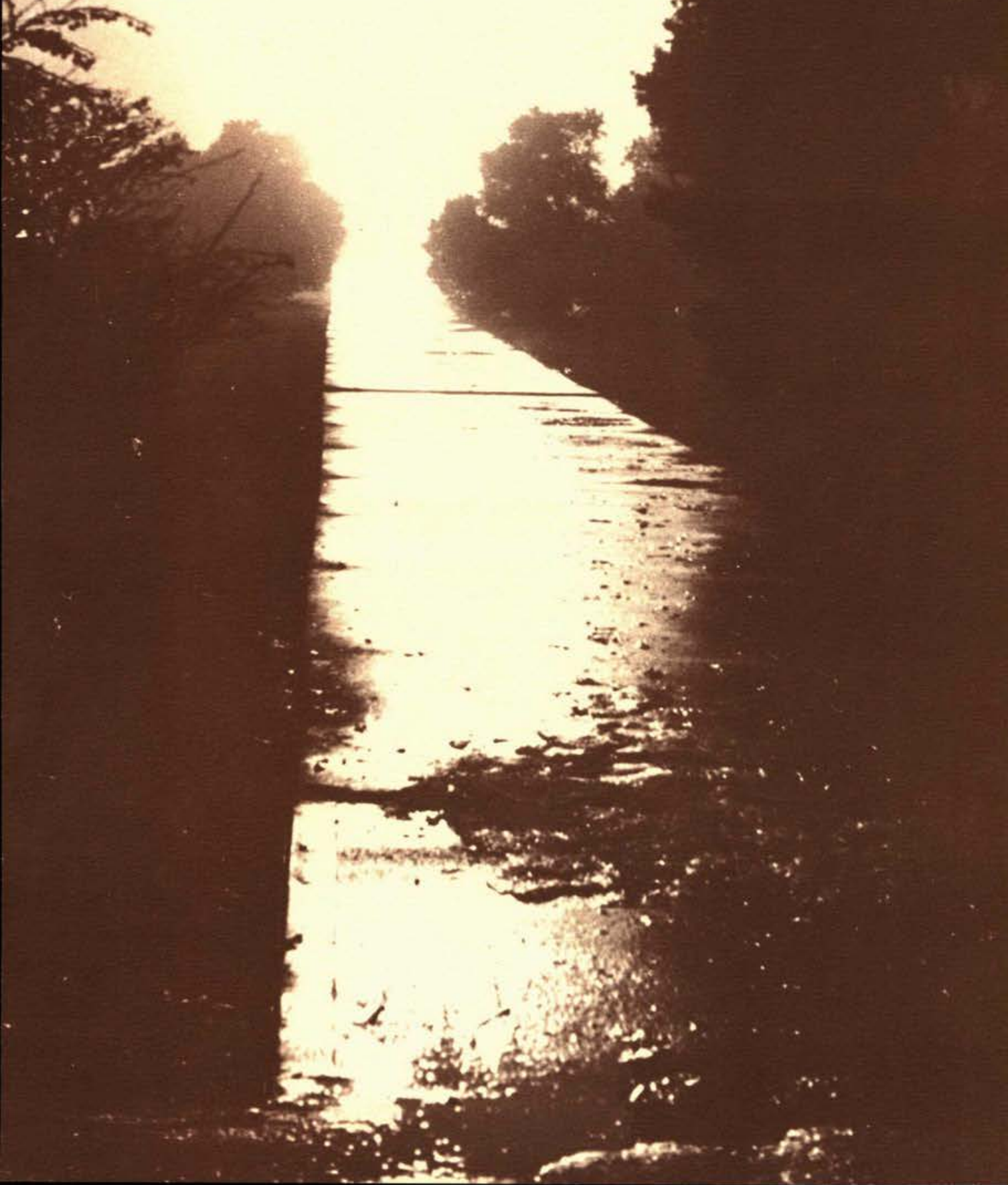

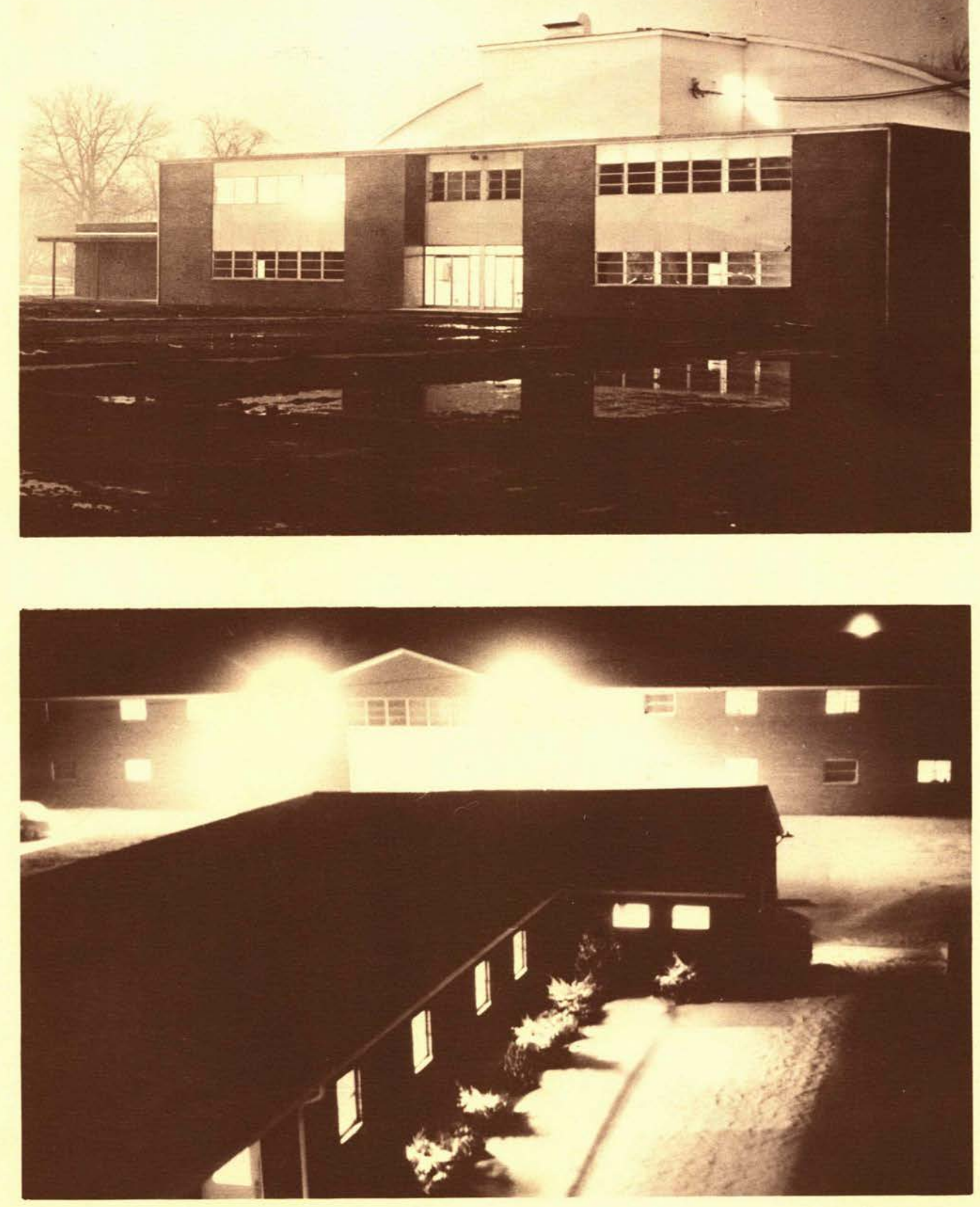

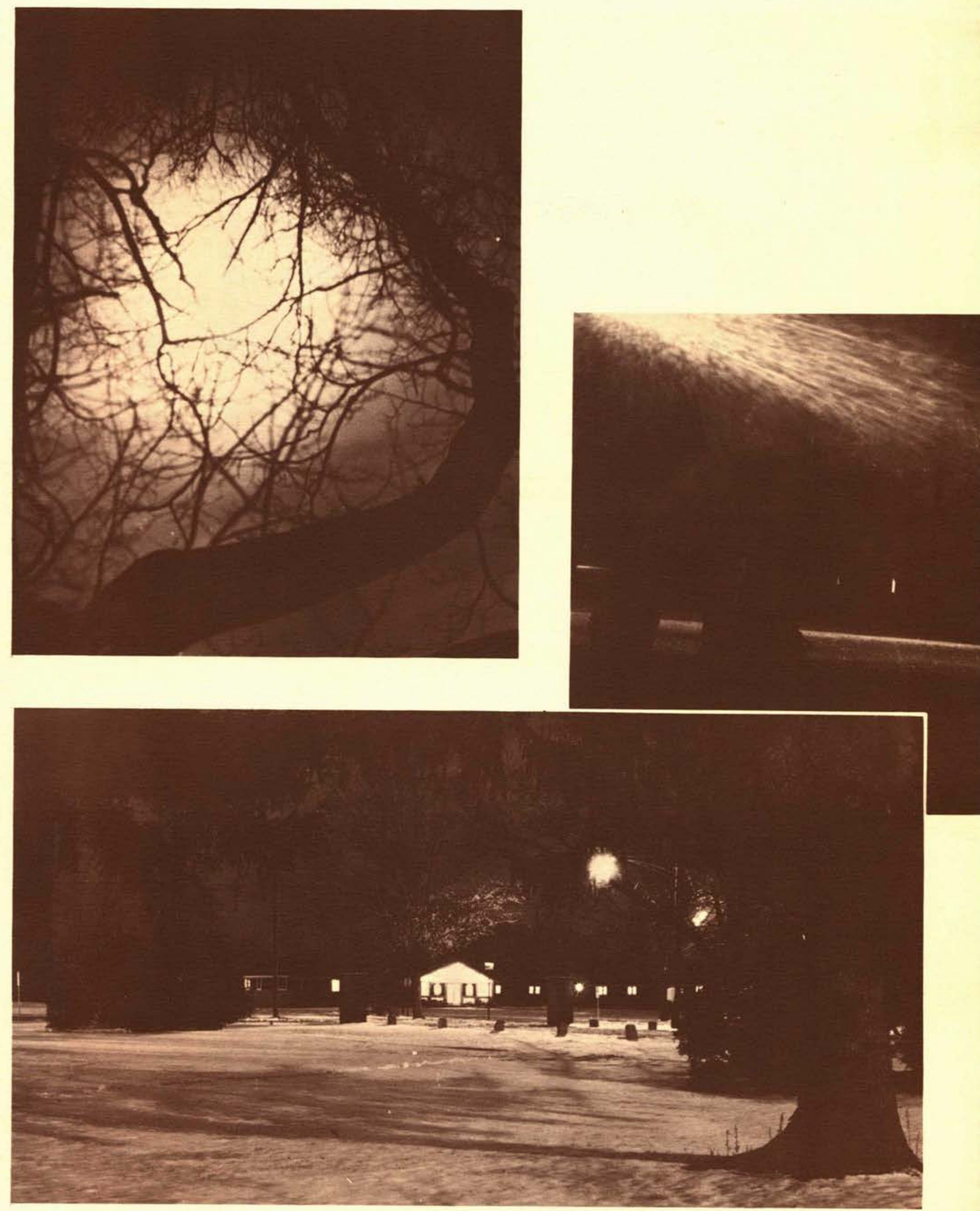

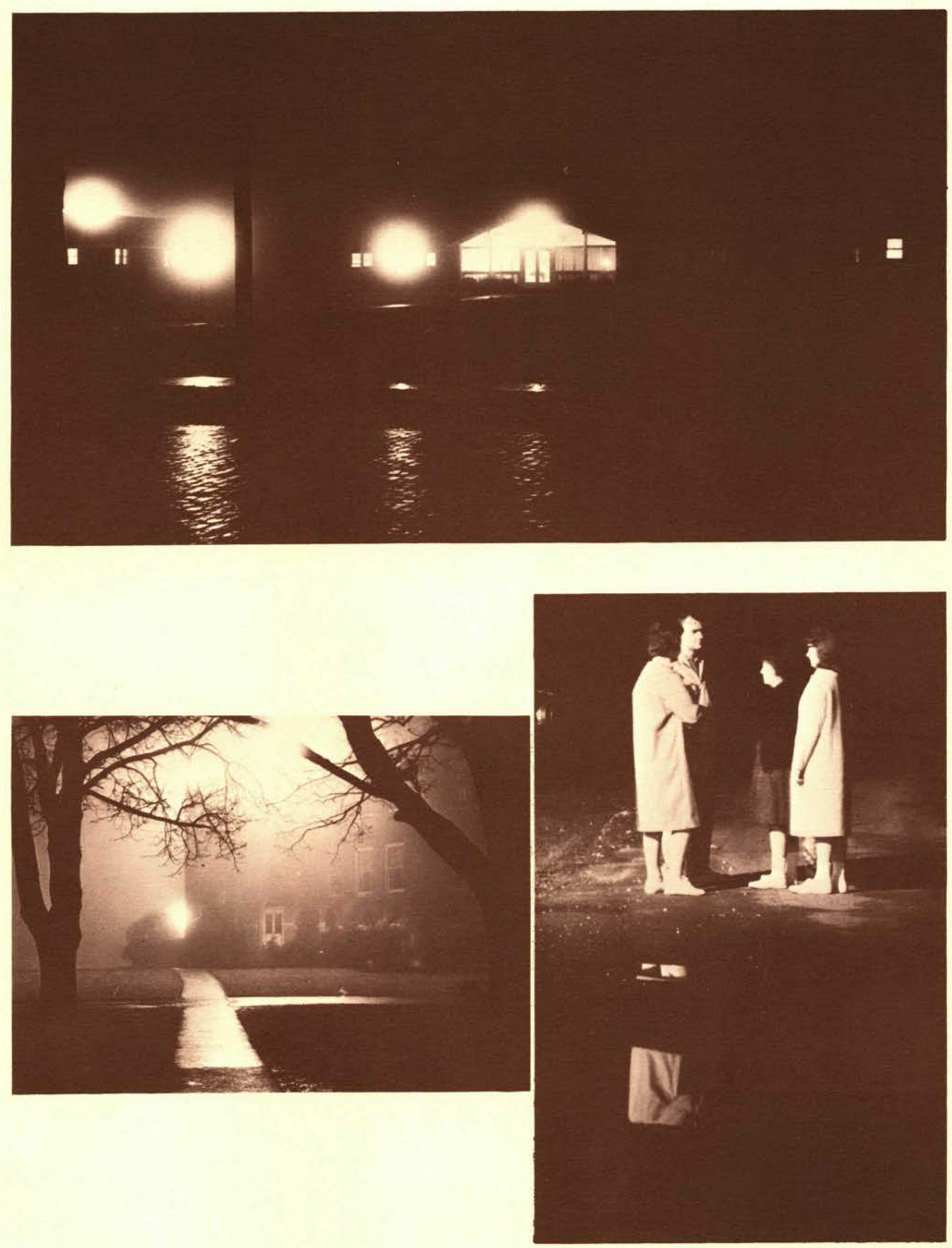

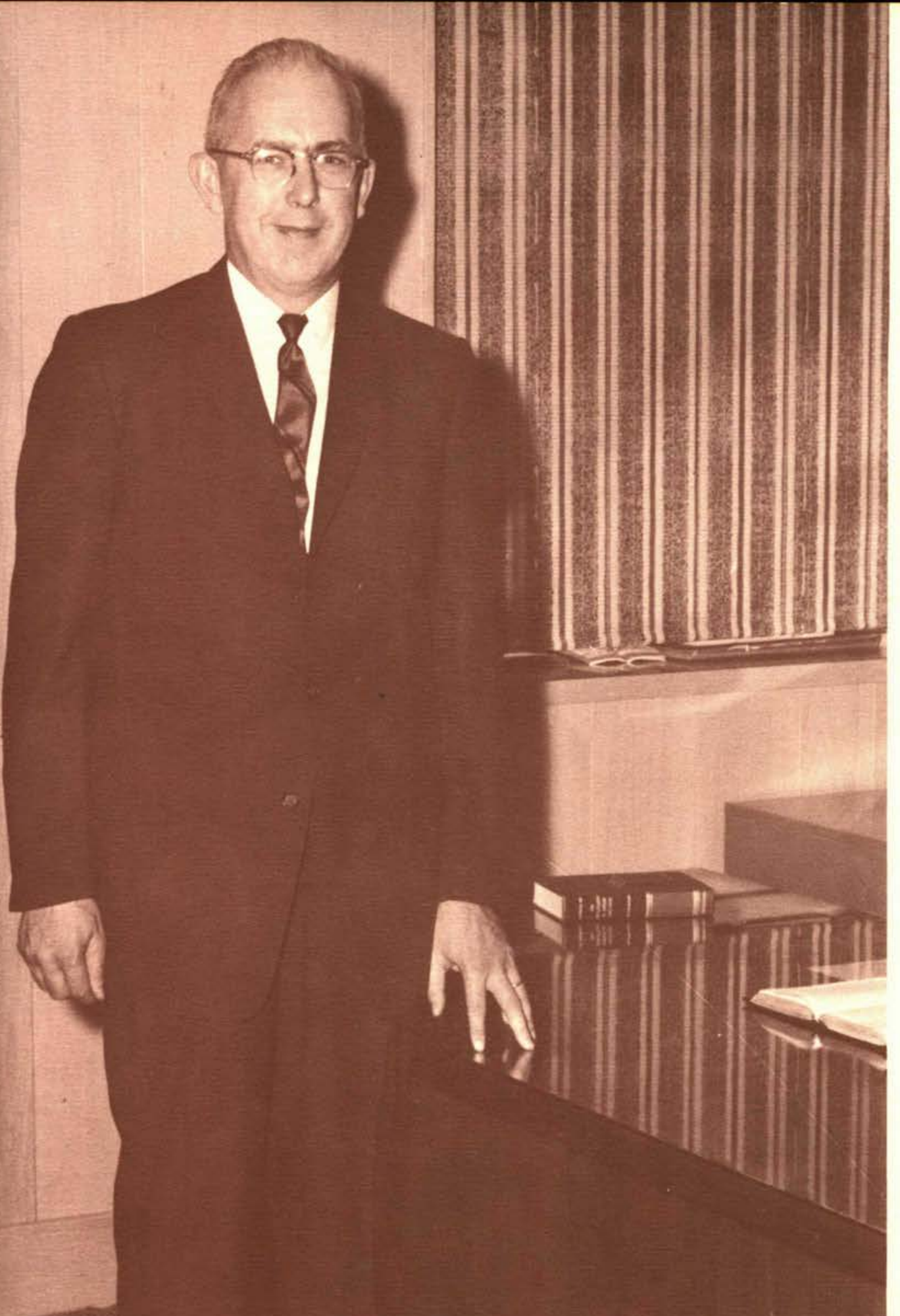

Dr. James T. Jeremiah President 


\section{President's Message}

Ten years ago the Regular Baptists assumed the responsibility of operating Cedarville College. These years have been filled with lessons in the life of faith for, in a small measure at least, the Cedarville College family has learned that "we walk by faith, not by sight." ( 2 Cor. 5:7)

During this decade of Divine direction, we have seen Him bring into reality that which many observers said would be impossible. The enrollment has been increased beyond all expectations; new buildings have been erected; the faculty has been increased in number; and new facilities have been provided.

It is appropriate at this milestone in our history to give special praise to the One who has made all of this possible. Our God has made "all grace abound toward" us that we "may abound in every good work." (2 Cor. 9:8) We gratefully acknowledge that every accomplishment for good on the Cedarville College campus is due entirely to the undeserved blessing of our God. 
Mr. Richard McIntosh

Miss Joy Mackay
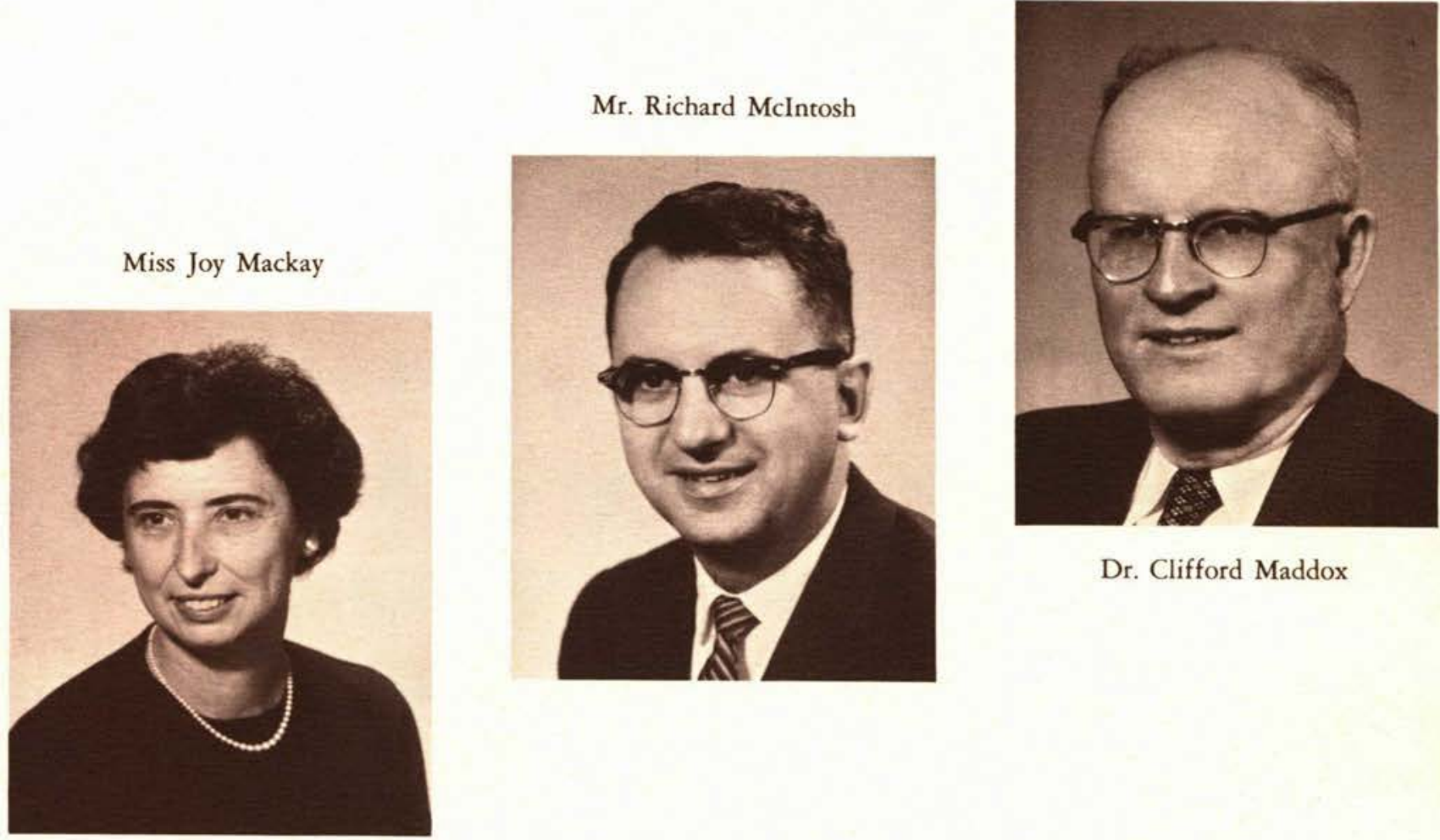

Dr. Clifford Maddox

\section{ADMINISTRATION}

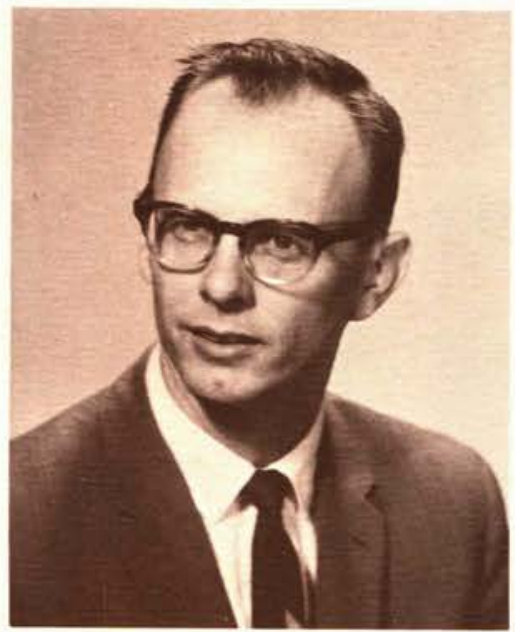

Dr. Clifford Johnson

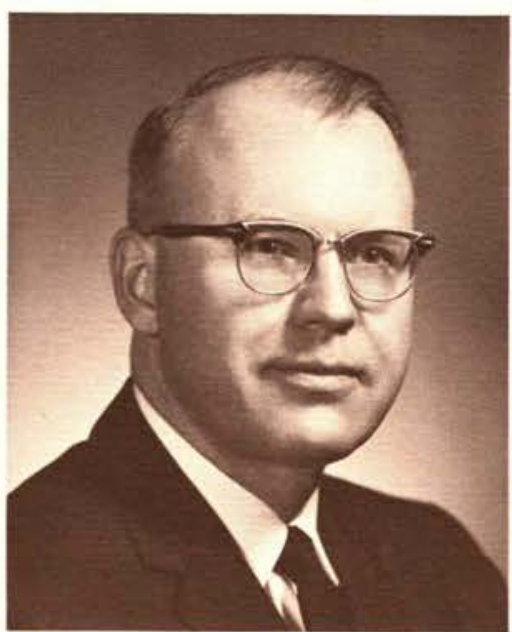

Mr. George Boyd, C.P.A., Treasurer
Mr. Lloyd Miller

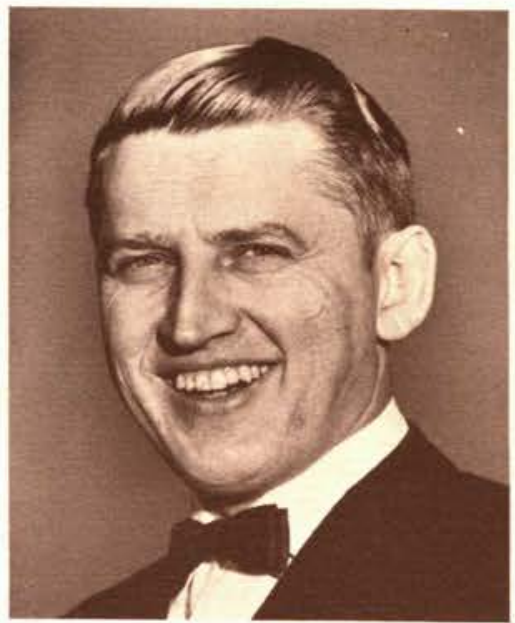




\section{College Trustees}

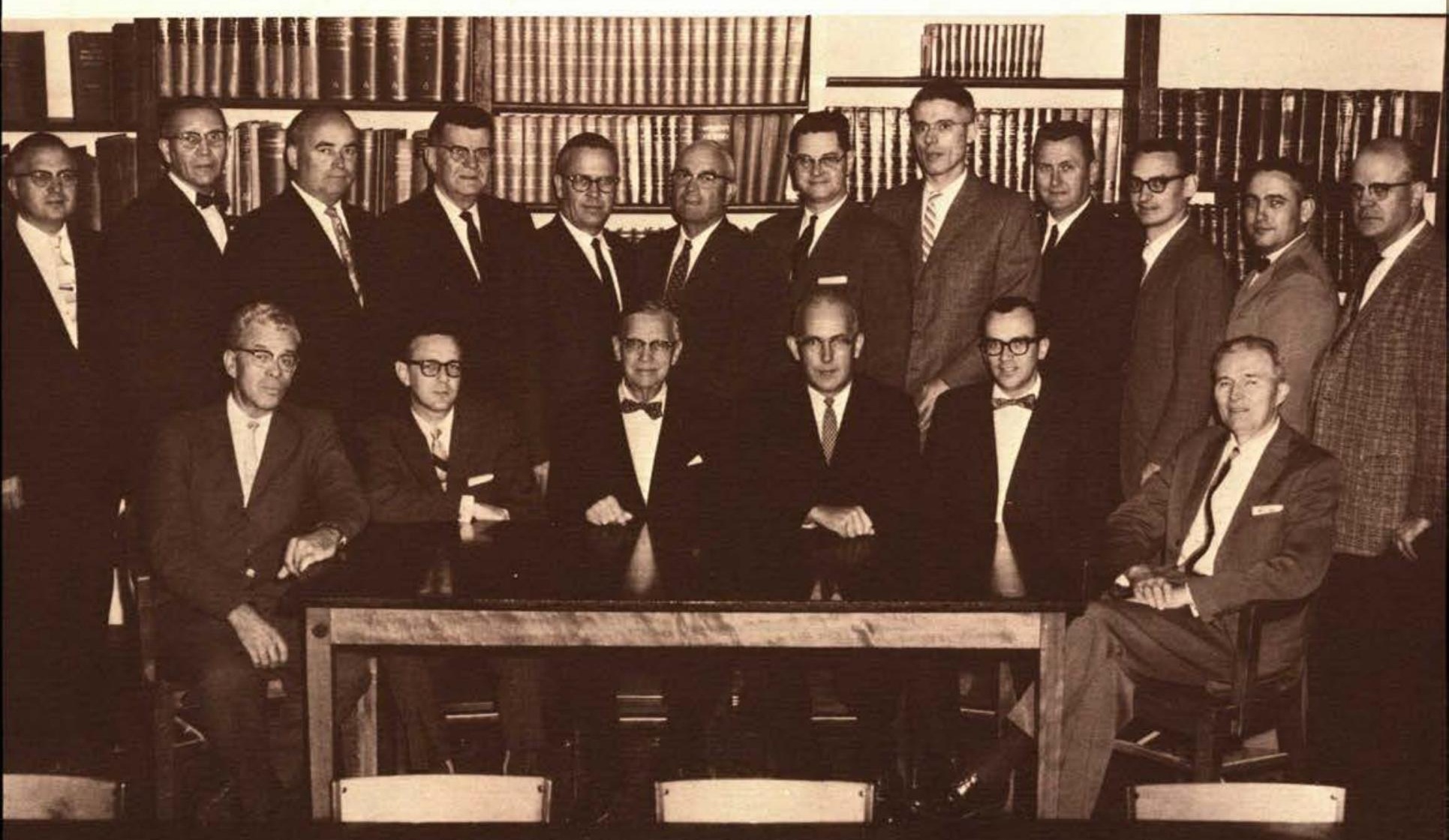

Top Row, Left to Right: Mr. John Draxler, Rev. George Bates, Mr. James Richardson, Mr. Rudolph Bedford, Mr. George O'Bryon, Mr. Charles Barth, Rev. Gerald Smelser, Mr. Arthur Dyke, Mr. J. Dale Murphy, Mr. Roy Guenin, Dr. Jack Cline, Rev. Glenn H. Davis. Front Row: Mr. William Patterson, Rev. William A. Brock, Vice-Chairman; Dr. George S. Milner, Chairman; Dr. James T. Jeremiah, Rev. Thomas Younger, Secretary; Rev. Earl V. Willetts. Not Pictured: Mr. George L. Boyd, C.P.A., Treasurer; Rev. Alfred Colwell, Rev. Wilber Rooke, Mr. Eugene Smith, Mr. Charles Wallace, Rev. Donald Woodby. 


3.

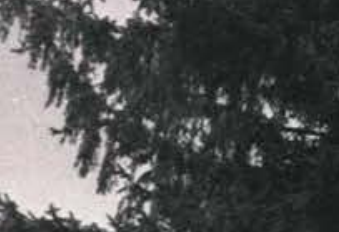

3.

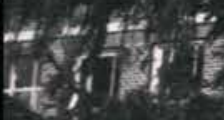




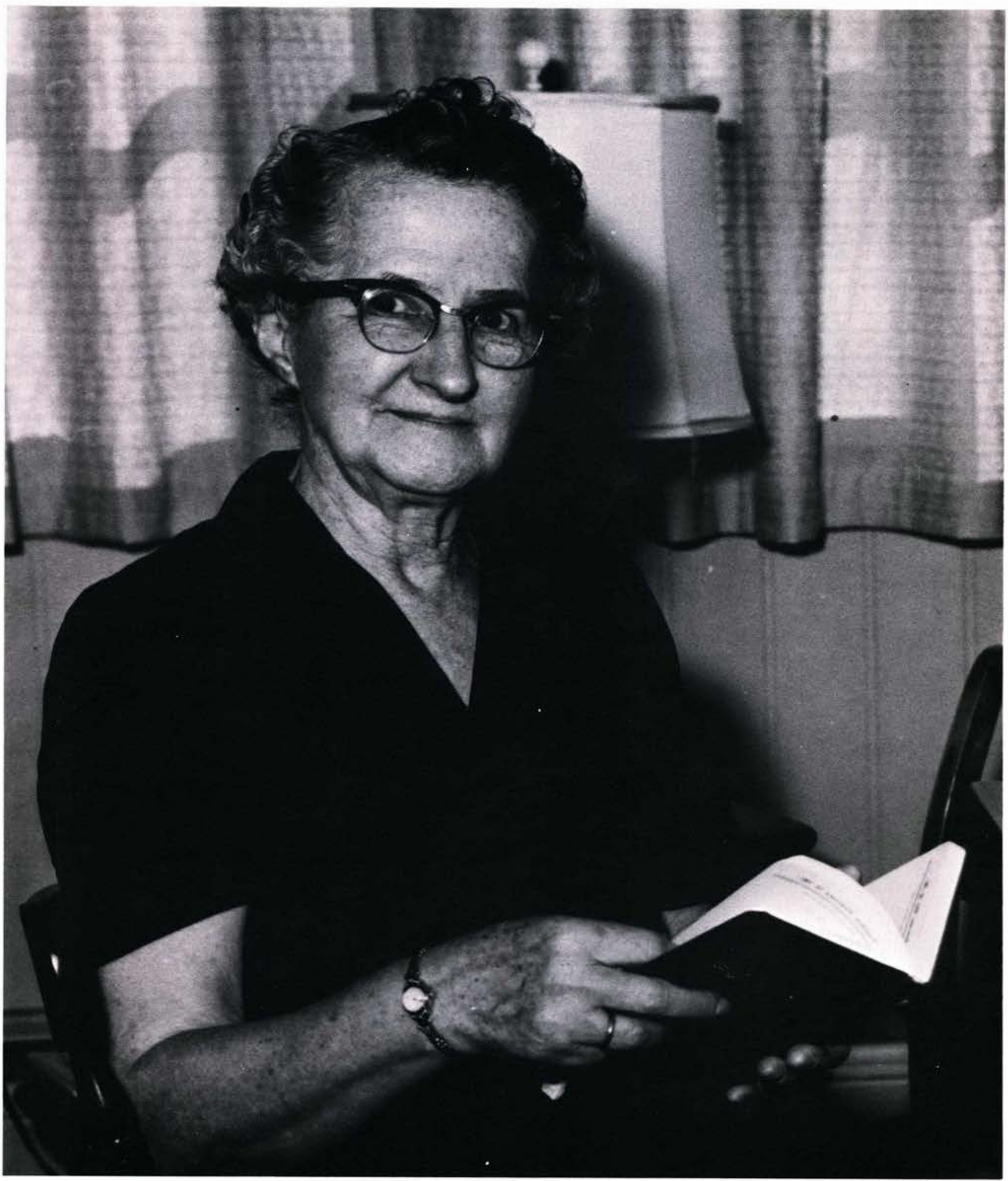




\section{Dedicated}

\section{To}

\section{Ruth Underwood}

". . for she hath been a helper of many . . ." Rom. 16:2

The recognition and honor that God bestows upon women in the Bible gives credence to and a reminder of the place of women in Christian life and work. Numbered among these is a woman who has exercised well her gifts in her ministry at Cedarville College. Having upon her heart the cares, desires, and spiritual needs of the College and the students, she faithfully carries them to the throne of grace. In her years with us, since 1957, she has become known to many as one of God's most precious prayer-warriors. This former Dayton Sunday school teacher has gone beyond the call of duty in making the mail room the efficient service that it is, and in giving the residence hall the spiritual emphasis because of her faithful guidance.

To you, Ruth Underwood, we, the Junior Class, are proud to dedicate the 1963 Miracle. In no better way can we express our appreciation for your tireless, ceaseless efforts, and faithful prayers. 
Cedarville College ... a dream ... a prayer ... a reality. The prayer for a liberal arts college where the Bible is believed and honored as the Word of God was answered in 1953 when Cedarville College became a school approved by the Regular Baptists. The purchase of the college, founded by the Reformed Presbyterians in 1894, was the result of fervent prayer, the realization of a dream.

Even today carries on its original purpose through its educational program to prepare Christian young people for service so that their work may be Christ centered and their practice Christ honoring.

Not only has the Lord blessed in the gift of Cedarville College but has also allowed for area expansion, building improvement, and a student body increase. Cedarville College ... established in the Word of God . . . a vivid testimony of what He will do for those who hunor His word.

\section{History}

God hath provided:

in the past ... a beautiful campus of 15 acres, for the present ... an added area of 80 acres.

in the past ... nine buildings for classes and dorms, for the present ... a total of fourteen buildings.

in the past ... a faculty of seven, for the present ... thirty-four faculty members.

in the past ... a student body of approximately 100 , for the present ... an enrollment of 454 . 

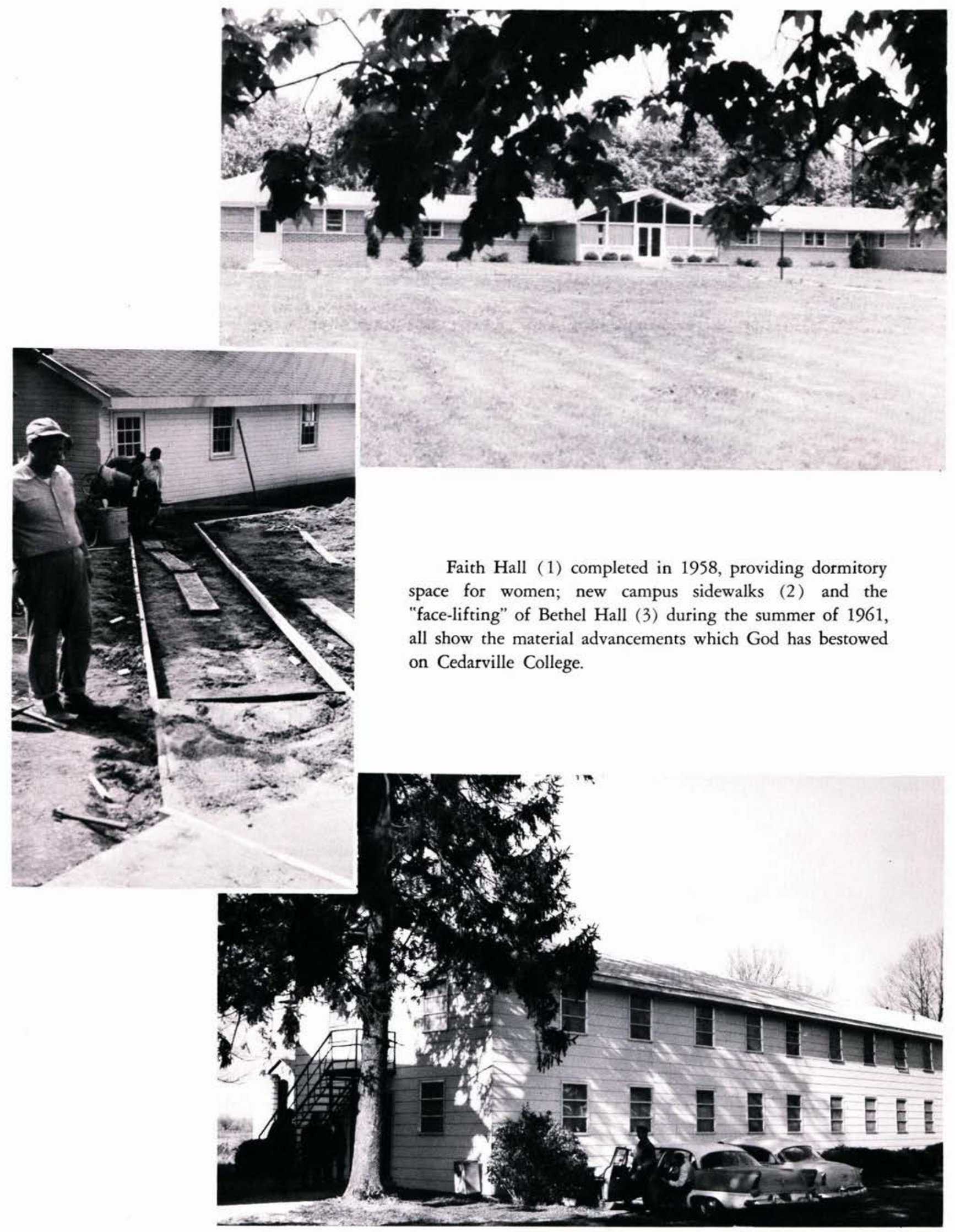

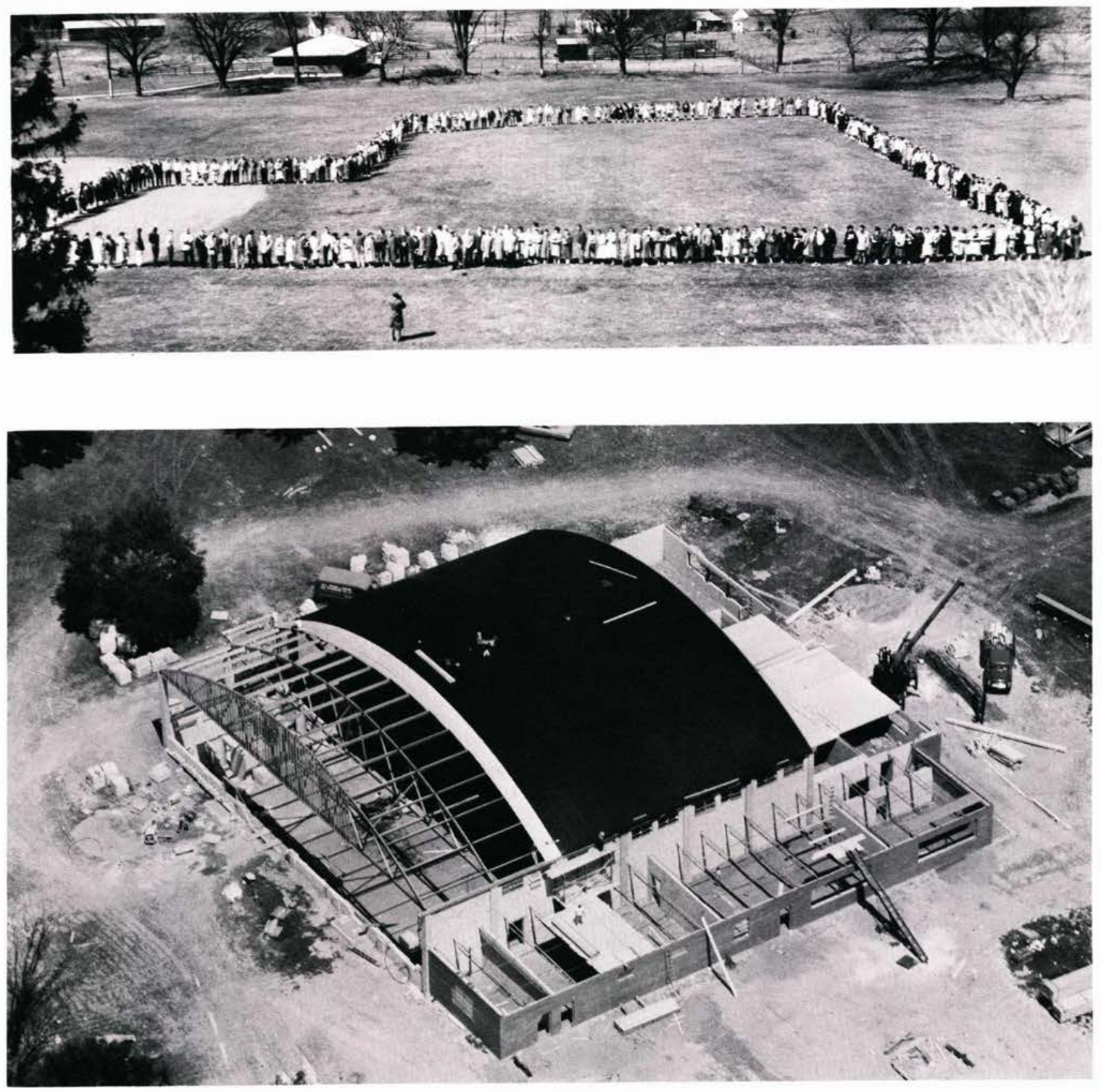

In the spring of 1962 the students of Cedarville College formed an outline of the new student center-gymnasium at the ground-breaking ceremony. In the fall of ' 62 the building is well on its way to completion. It will accommodate approximately 500 students, and will house a regulation basketball floor, lounge, book room. snack bar, game room, and banquet hall. 


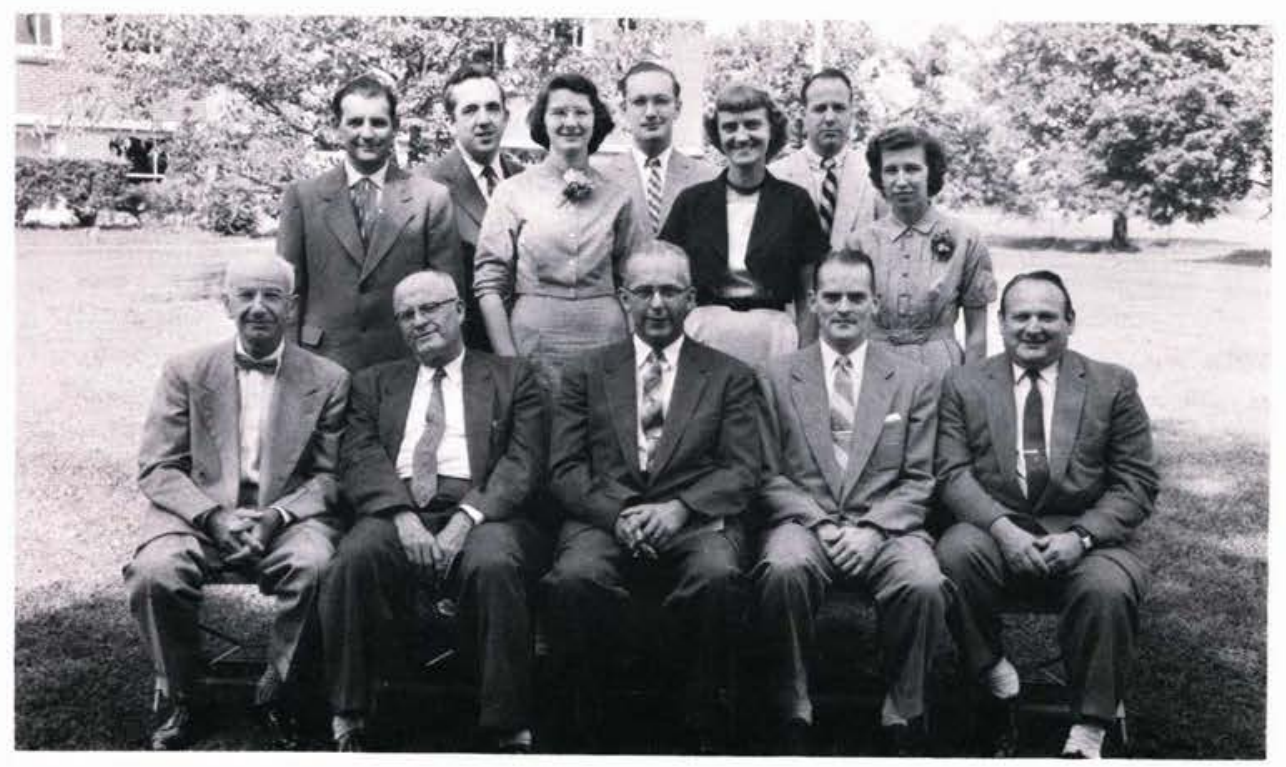

Cedarville College faculty -1956

\section{God Hath}

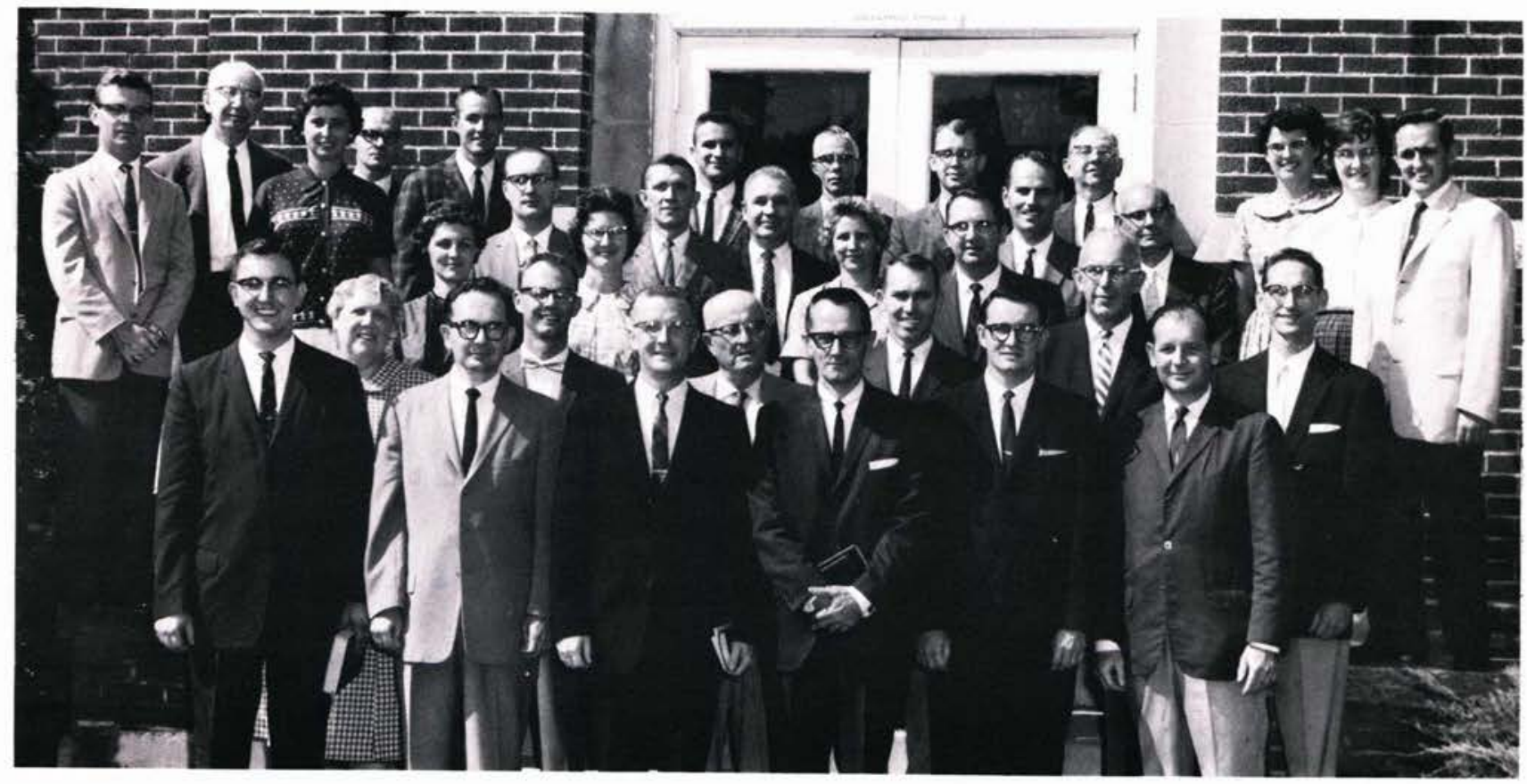

Cedarville College faculty -1962 


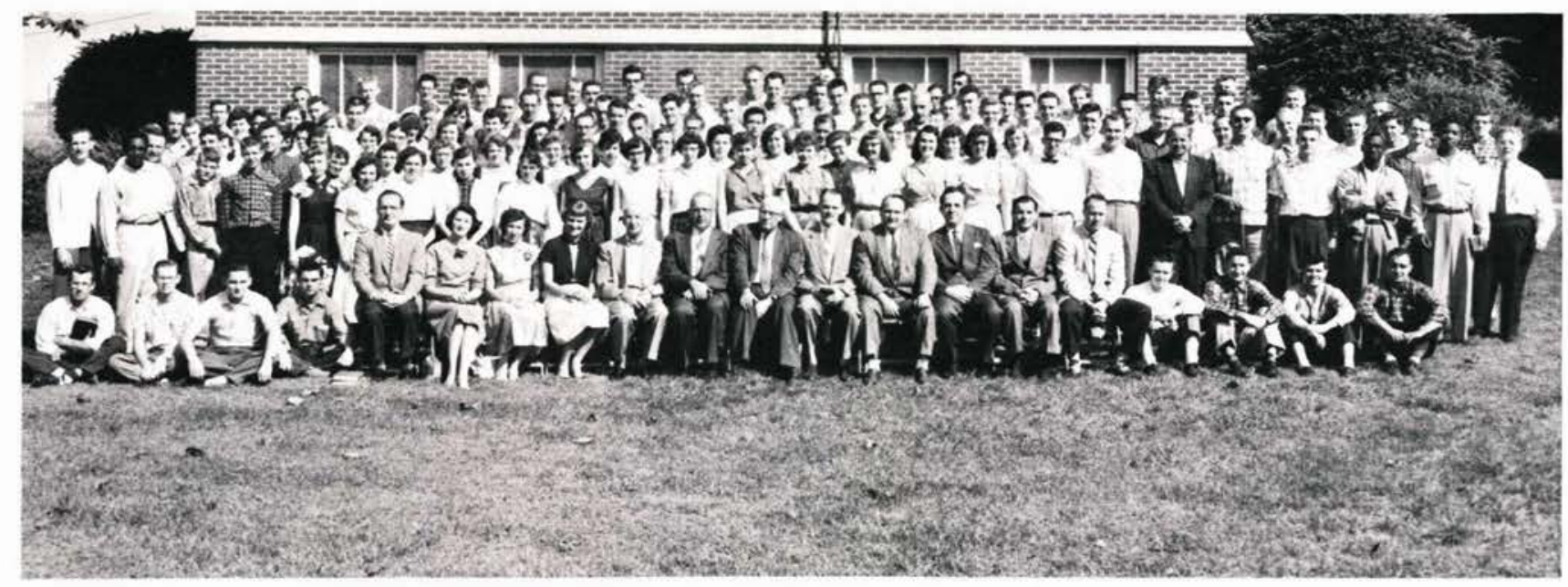

The student body of 1956

\section{Provided}

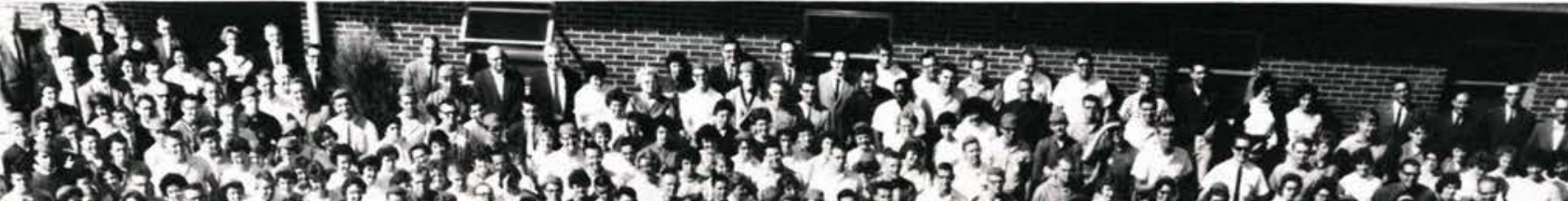

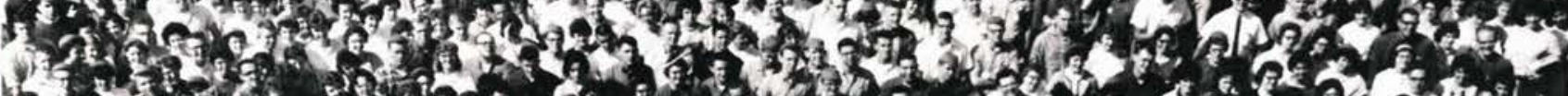

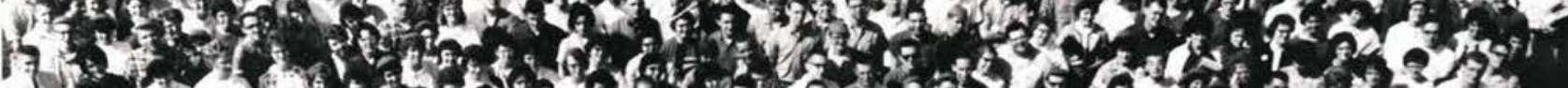

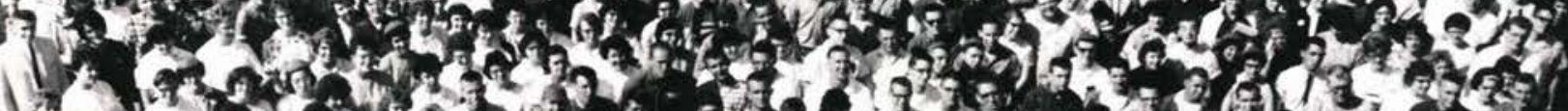

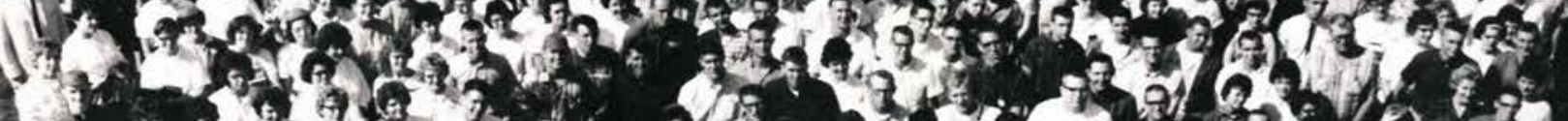

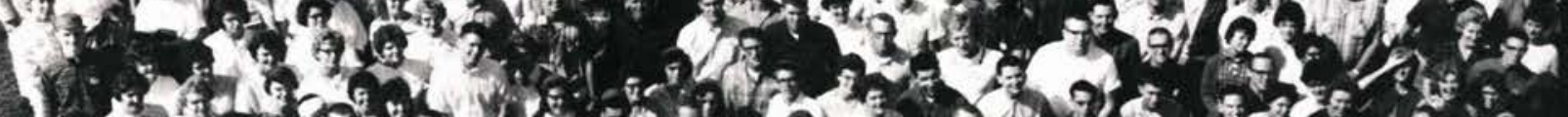

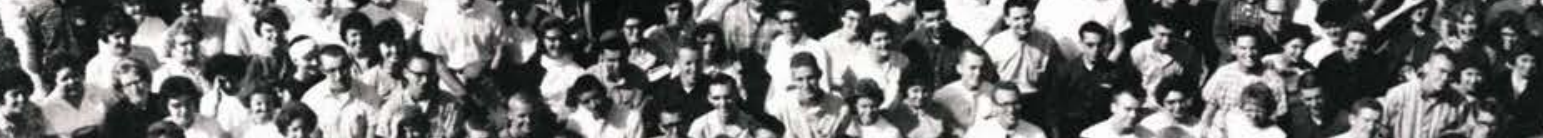

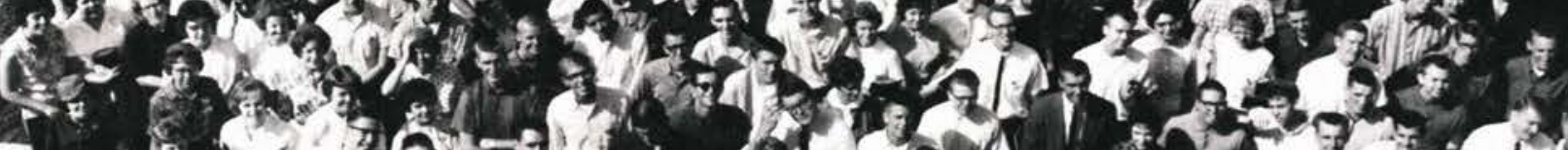
Fol

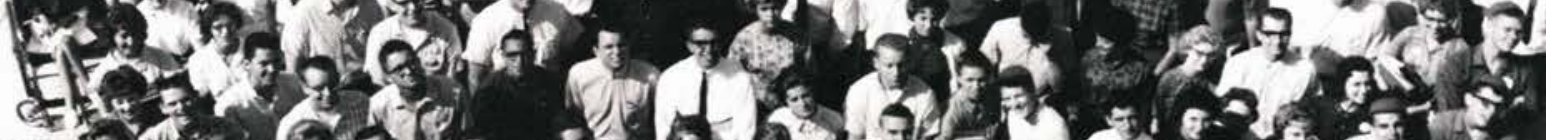

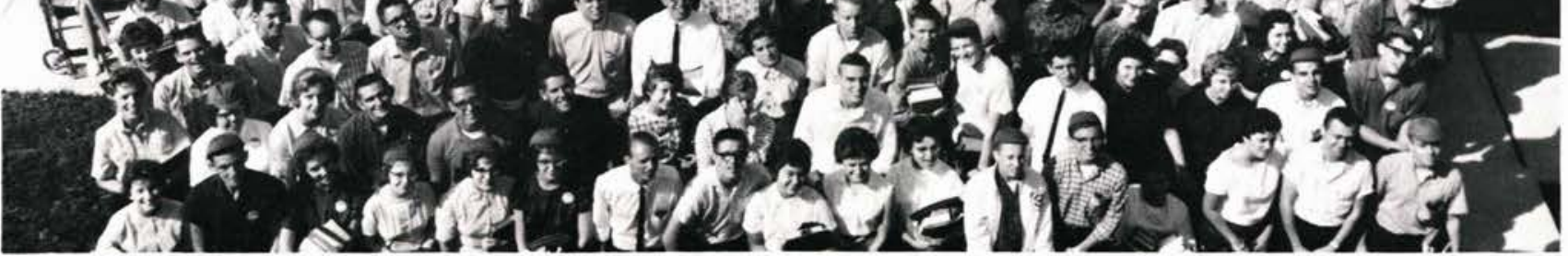

The student body of 1962 
Progress is evidenced at Cedarville College in its building program. The Bookstore Dormitory (1) built in 1959 is a men's dormitory and also houses the college bookstore and snack shop. That year also saw the dining hall (2) enlarged and remodeled to accommodate the present student body.

Milner Hall (3), formerly Milner Chapel, received in 1959 the addition of a wing of practice rooms for music students plus a brick exterior as opposed to its white one, (4). Now Milner Hall serves for classrooms as the student body has blossorned once again, necessitating a larger building.

The New Women's Dormitory (5) completed in 1960 houses 105 coeds, the school nurse, and the office of the

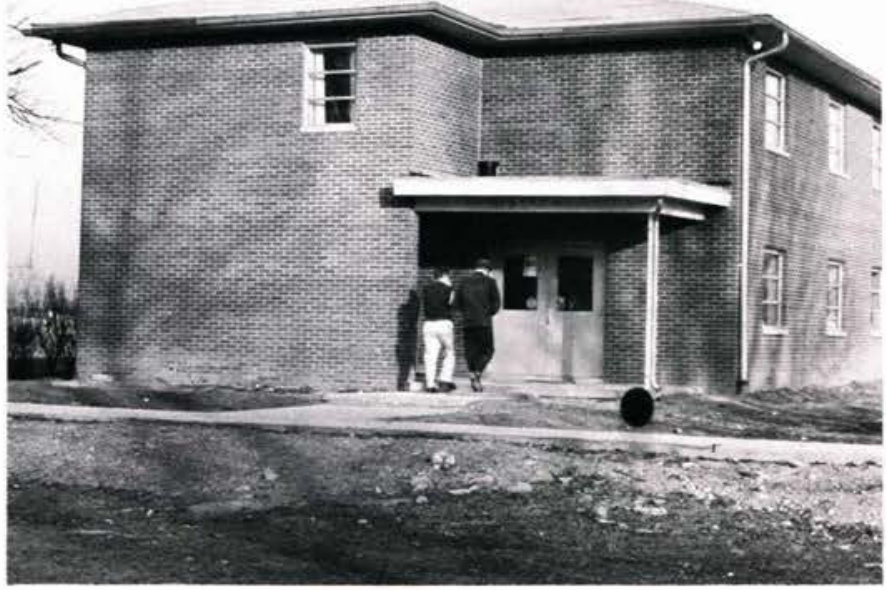

Dean of Women.

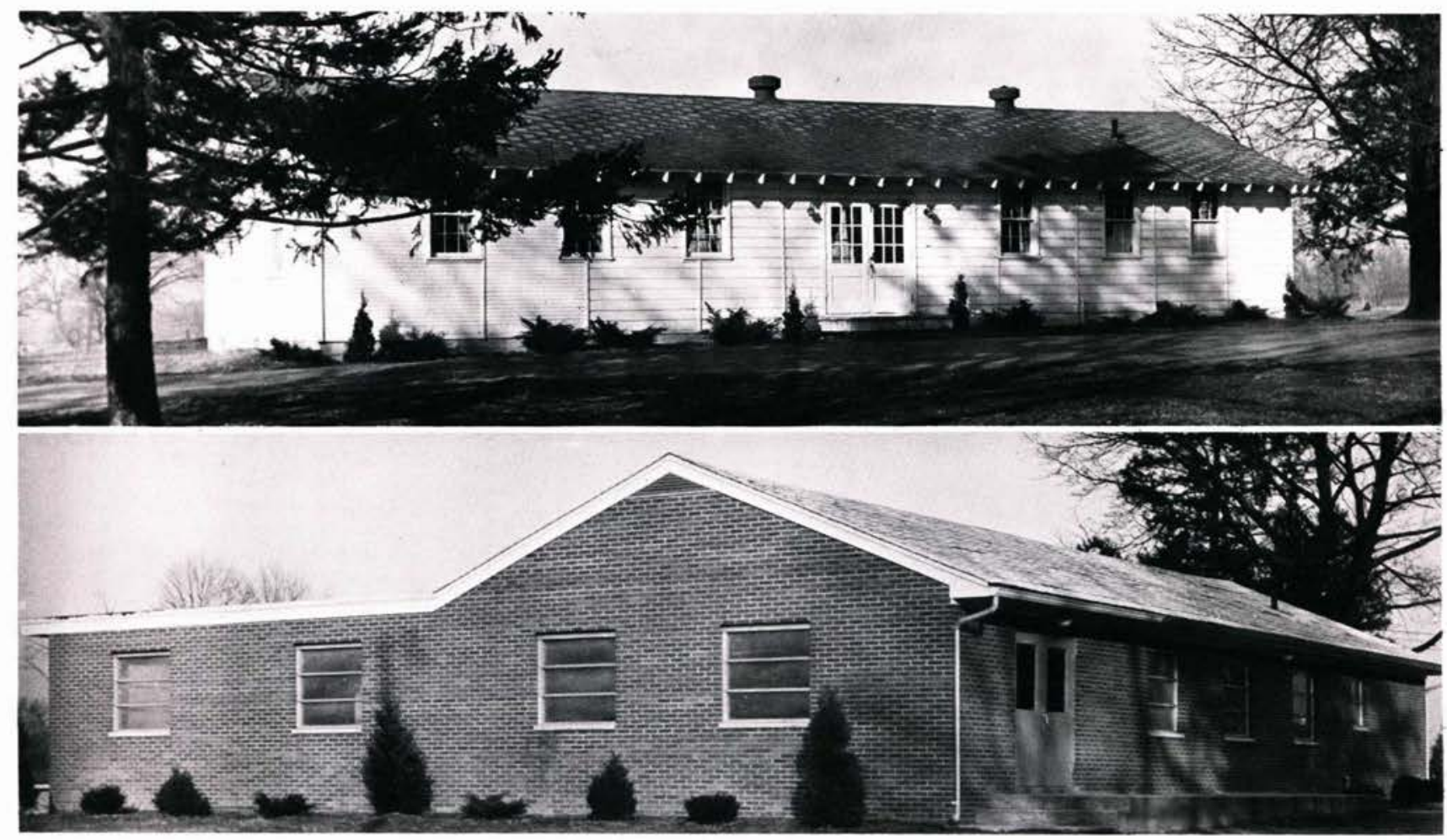




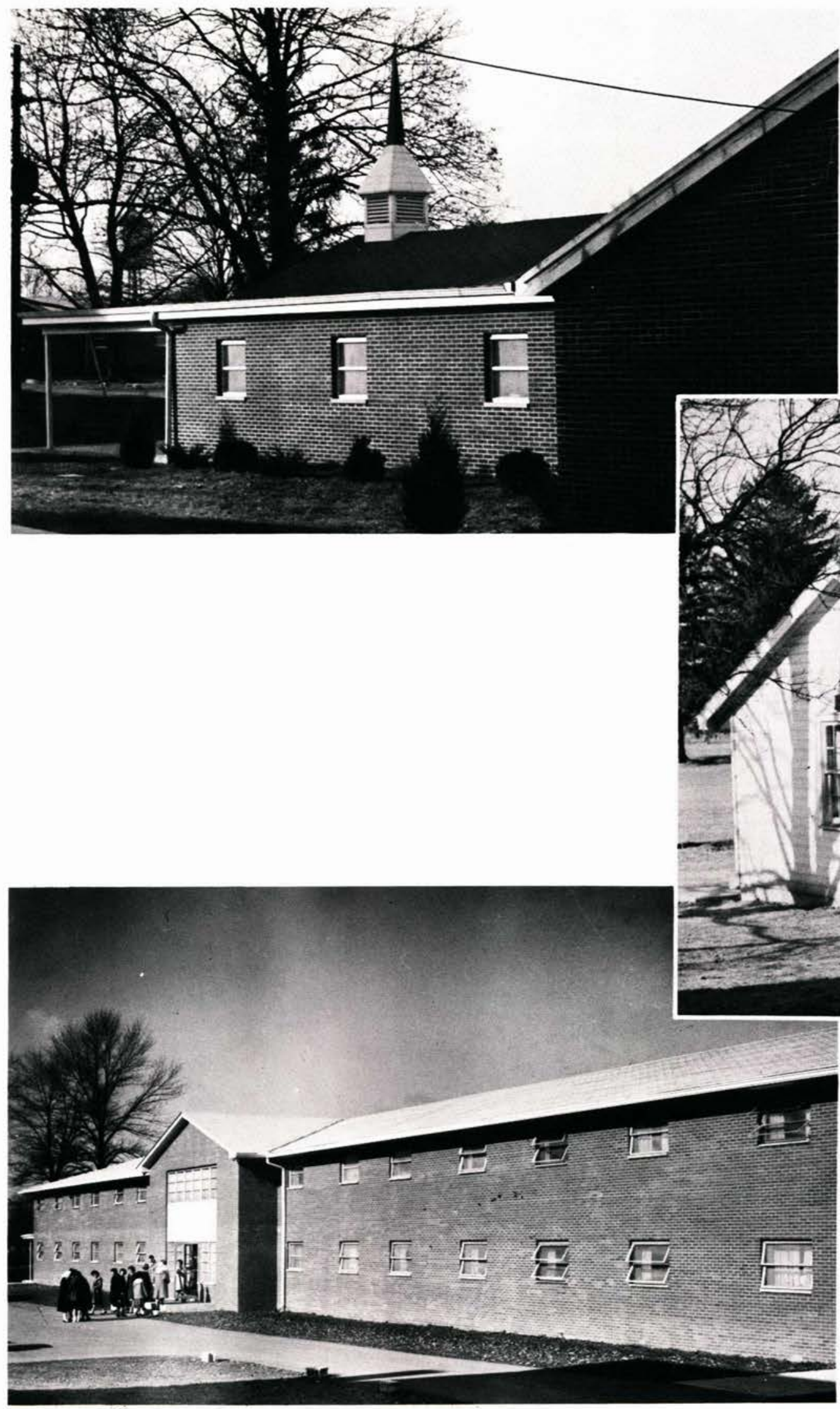


The purpose of Cedarville College is to communicate knowledge. This communication is to be the student's liberal education from which he gains understanding - that bond of interest and information between the individual and the world.

In his education the student tries to cultivate and develop in himself Christian character through the attainment of sound knowledge and genuine wisdom. He seeks to be established in the fundamentals of the Christian faith, and to be led into a continuing, progressive experience of spiritual victory and to a practical expression of the Christian life. He learns to develop the understandings, attitudes, and habits necessary for him to participate constructively in the social and civic life of his community.

Wisdom comes from this knowledge; culture, from this understanding.

\section{Academics}

\section{Division Of Biblical Education}

Division Of Languages And Literature Division Of Fine Arts

Division Of Health And Physical Education Division Of Social Sciences Division Of Science 


\section{Division Of Biblical Education}

Christian Education

Practical Theology

Biblical Studies 


\section{Christian Education}

The combining of Christian principles with learning and experience is Christian education. The learning takes place in the classroom where the student receives spiritual lessons for himself, valuable information on human behavior, and extensive files of material for future reference.

Practice teaching is the utilization of methods taught in class. Such an opportunity arises at Grace Baptist Church in Cedarville, where Christian education students conduct Junior church and youth groups. Here, they find that Christian education is the application of the Word of God.

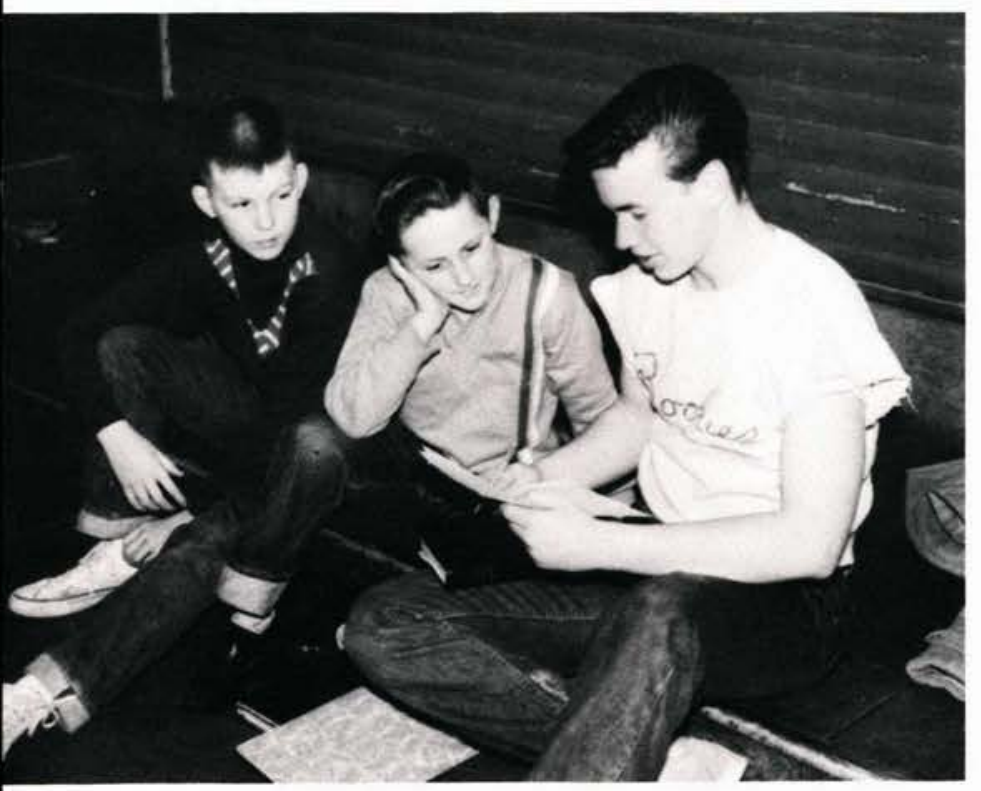

The molding of young minds through the Word of God Christian Education in action.

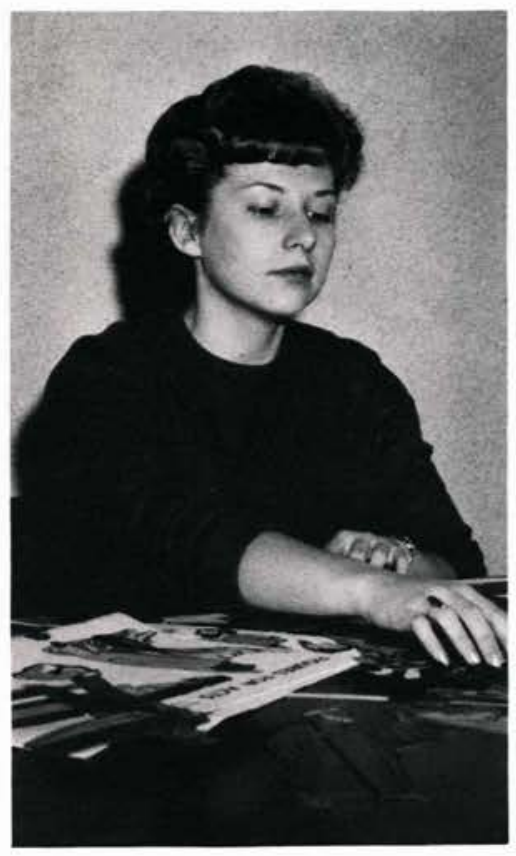

Visual aids are used to reinforce words and to leave lasting impressions.

Jean Fisher B.R.E., M.A.

Joy Mackay A.B., M.A.

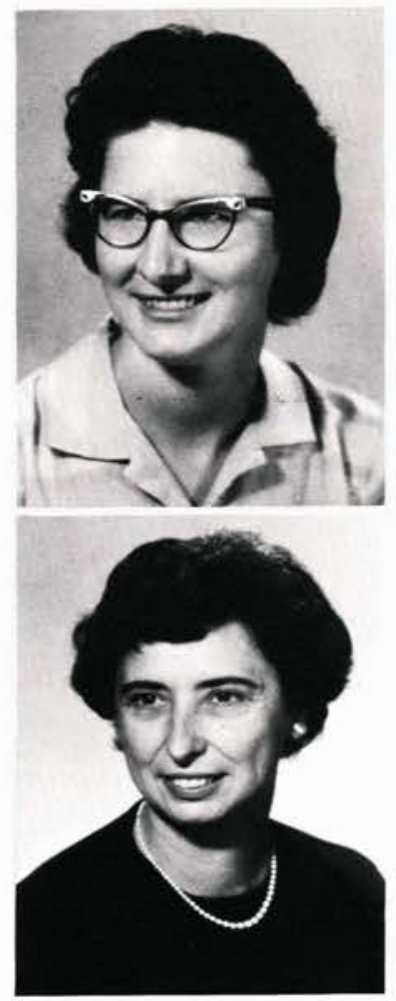




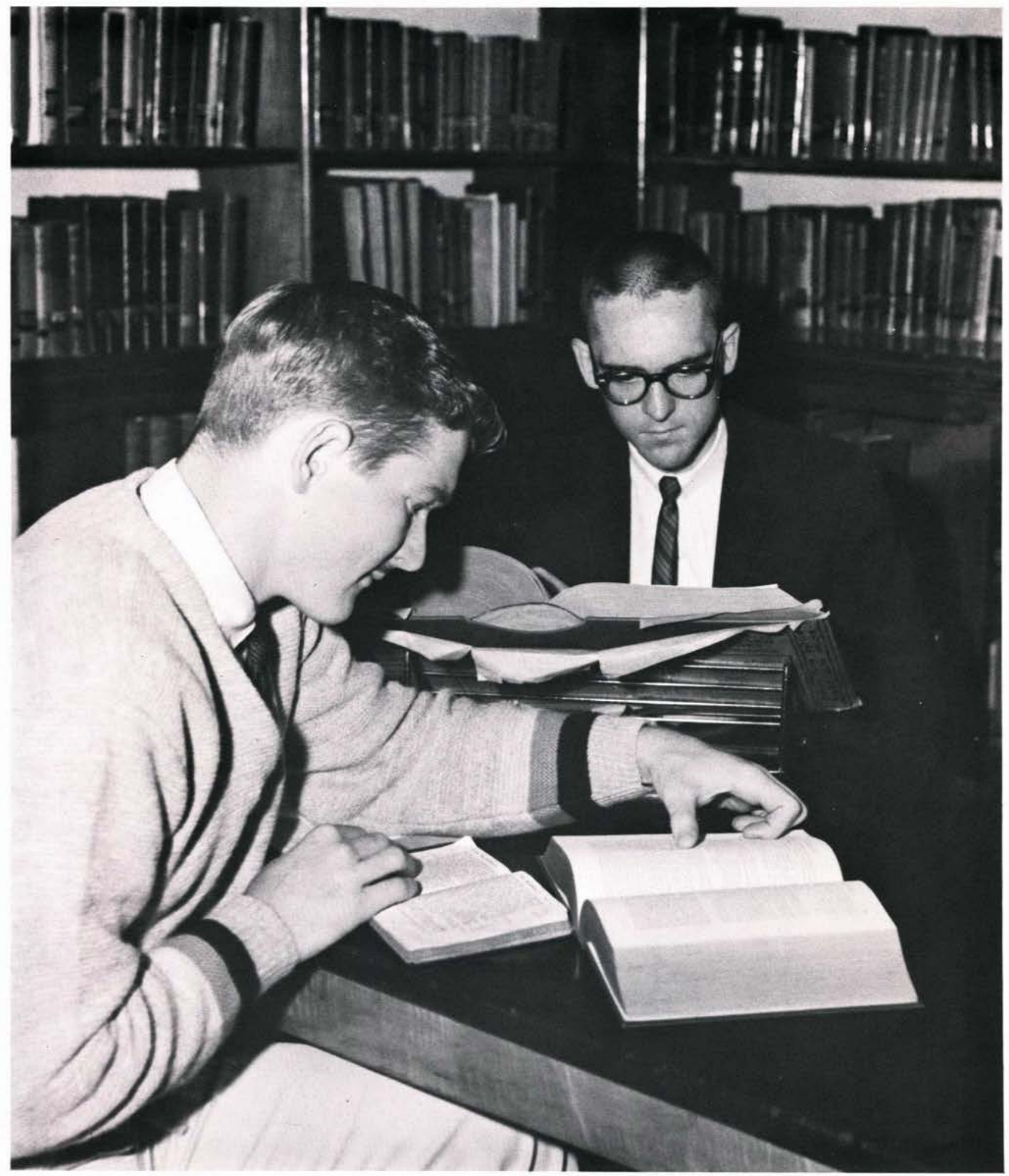

The requirement-diligent study; the result-a useful tool. 


\section{Biblical Studies \\ Practical Theology}

God's revelation to man through His Word has proved to be an inexhaustible study down through the centuries. Man has studied it to understand it, attempted to discredit it, but has not been able to disprove it. $\mathrm{He}$ has written books about it, made famous speeches on it, and has even died for it.

Here, the Bible is studied that the content may be fully appreciated, learned, and used. Its content is to be the criterion of living, and is to be taught to others.

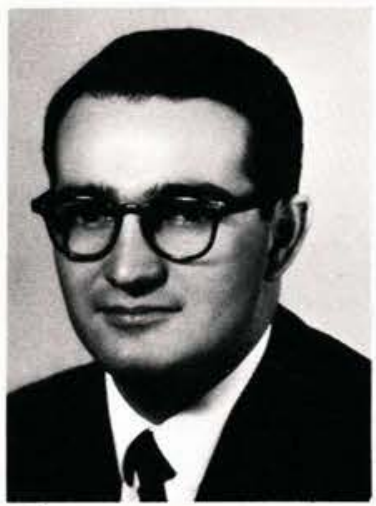

Robert Gromacki, Th. B., Th. M. James T. Jeremiah, A.B., D.D.

George Lawlor, A.B., B.D., Th. M.

Richard McIntosh, A.B., B.D., Th. M.

Arthur Williams, A.B., D.D.

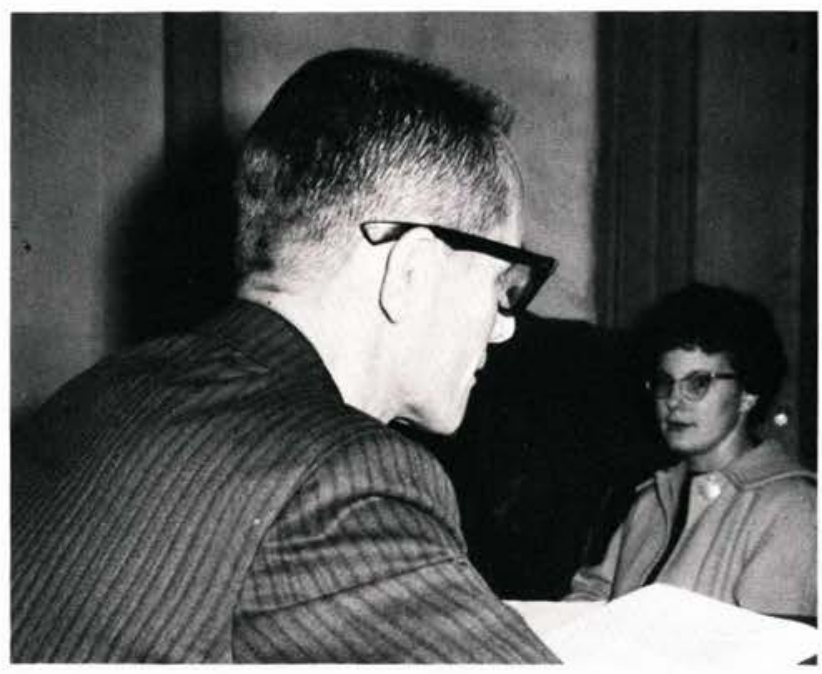

The exposition of Biblical truths.

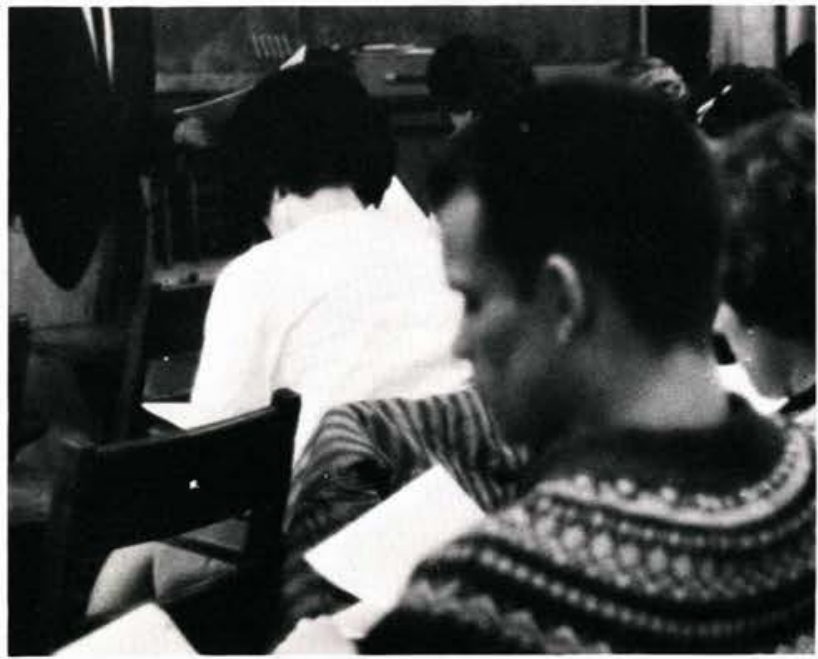

Reward for perseverance.
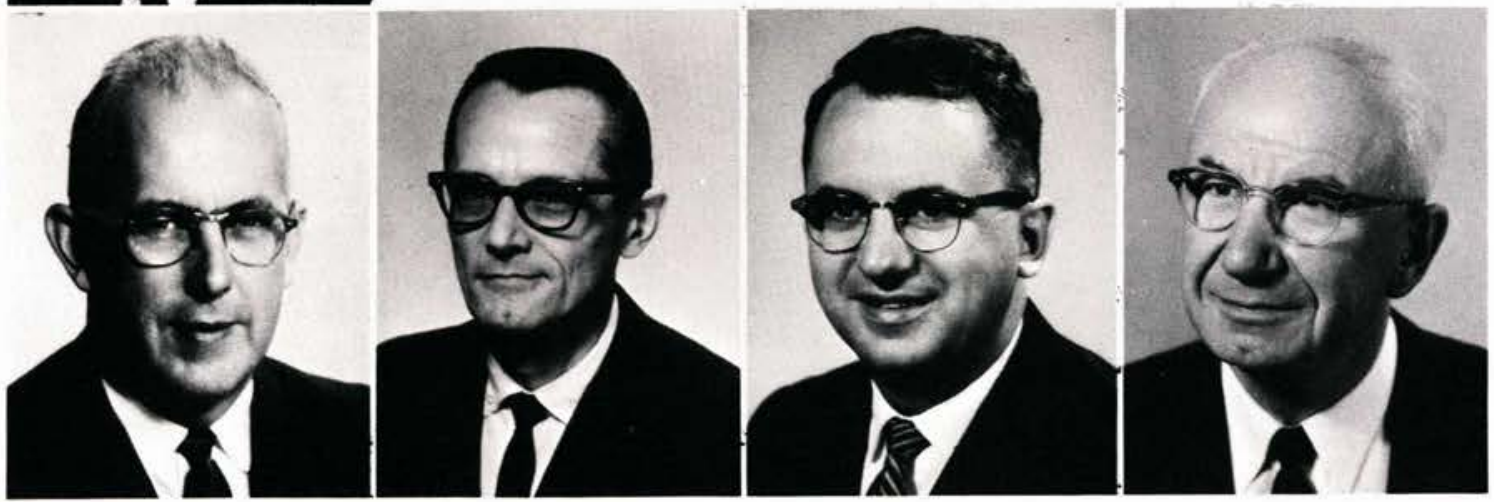


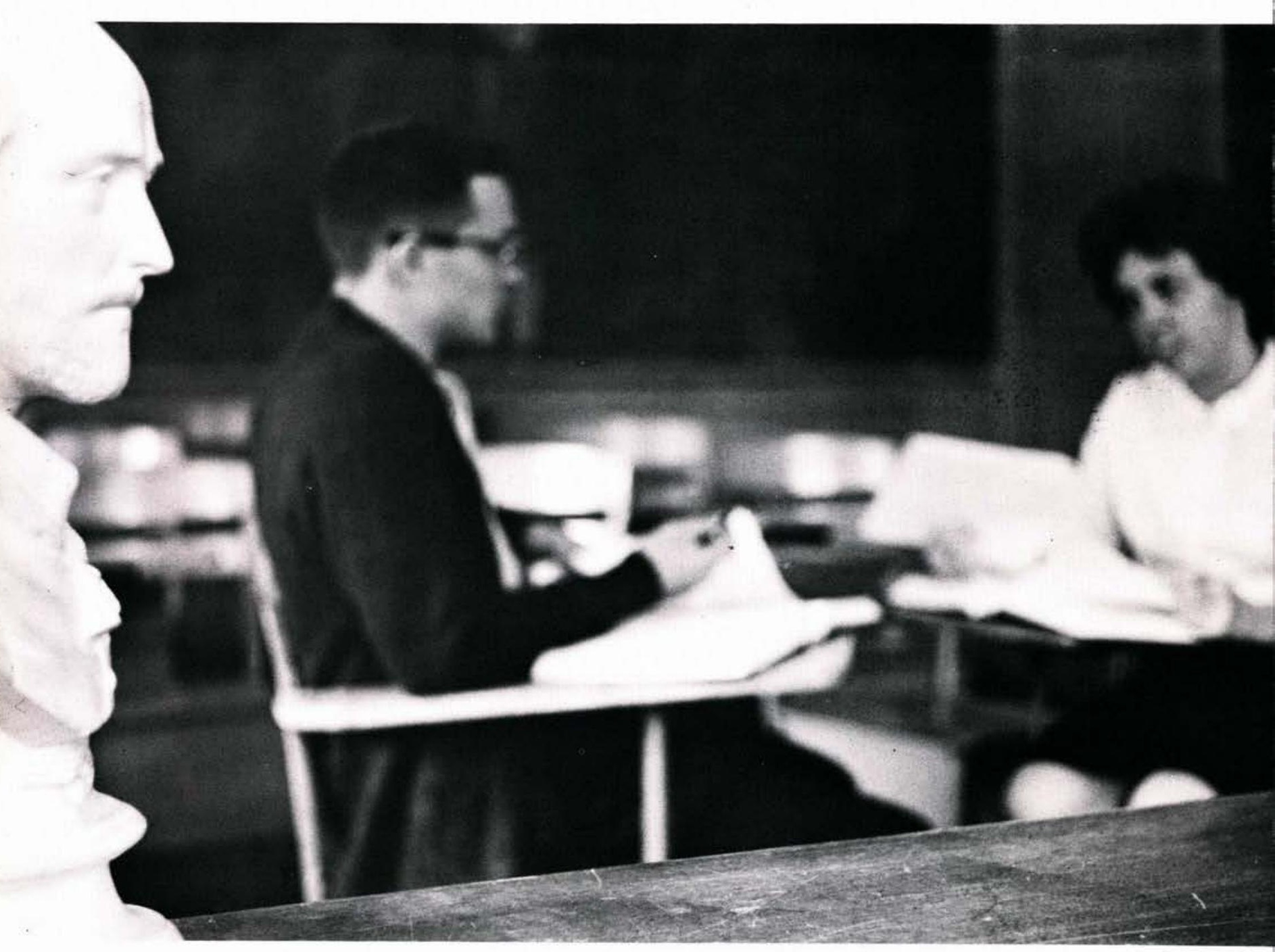

Division Of Languages And Literature

English

Foreign Languages

Speech 


\section{English}

The words we speak - how are they formed? what do they mean? how are they used? The literature we read who wrote it? what is its philosophy? for what purpose was it written? Why do we study the English language and its literature?

Those students who find themselves possessing a deep interest in English, major in this field and search for the answers to these questions. Their motivation may be skills in applying what they learn, or it may be knowledge, in and for itself. They may find themselves thinking deeper thoughts, setting higher ideals, and knowing the satisfaction of achievements that have lasted through the ages.

Raymond Bartholomew, A.B., M.A.

Kathi Dempsey, A.B.

Richard McIntosh, A.B., B.D., Th. M.

Edward Spencer, A.B., B.D.

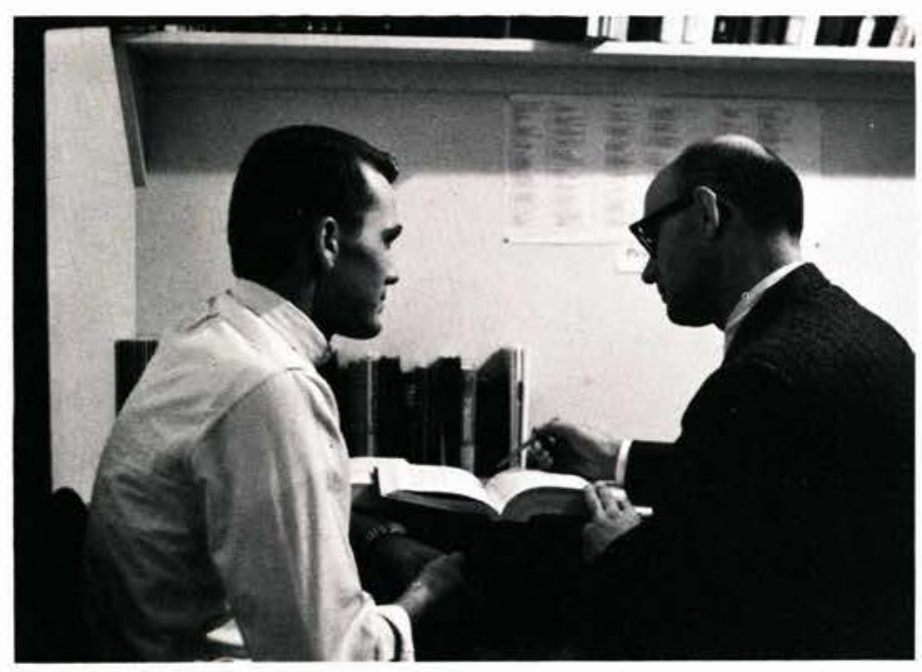

A personal problem solved by the personal approach.

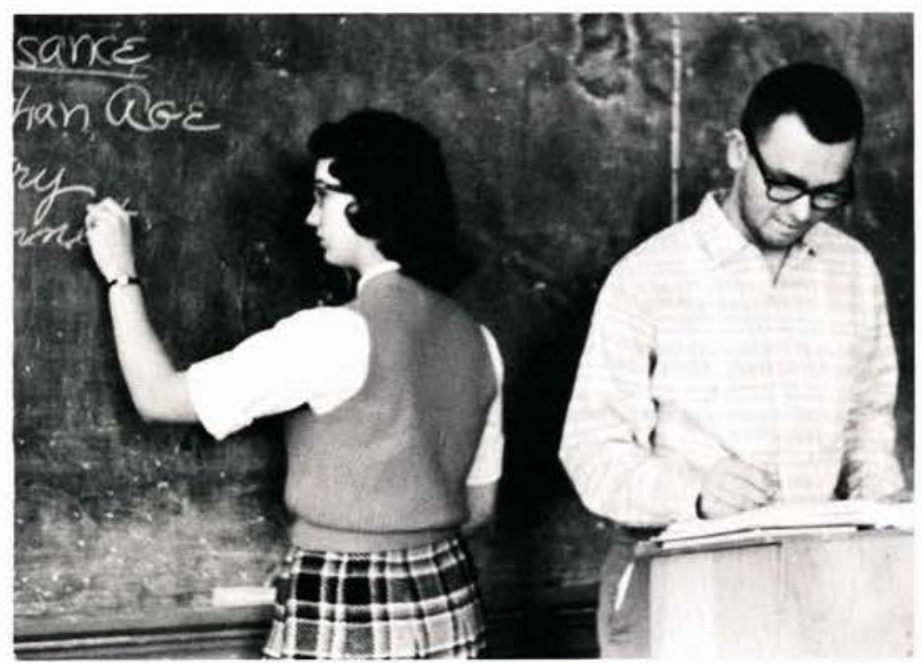

Literature ... recorded symbols . . communication of ideas.
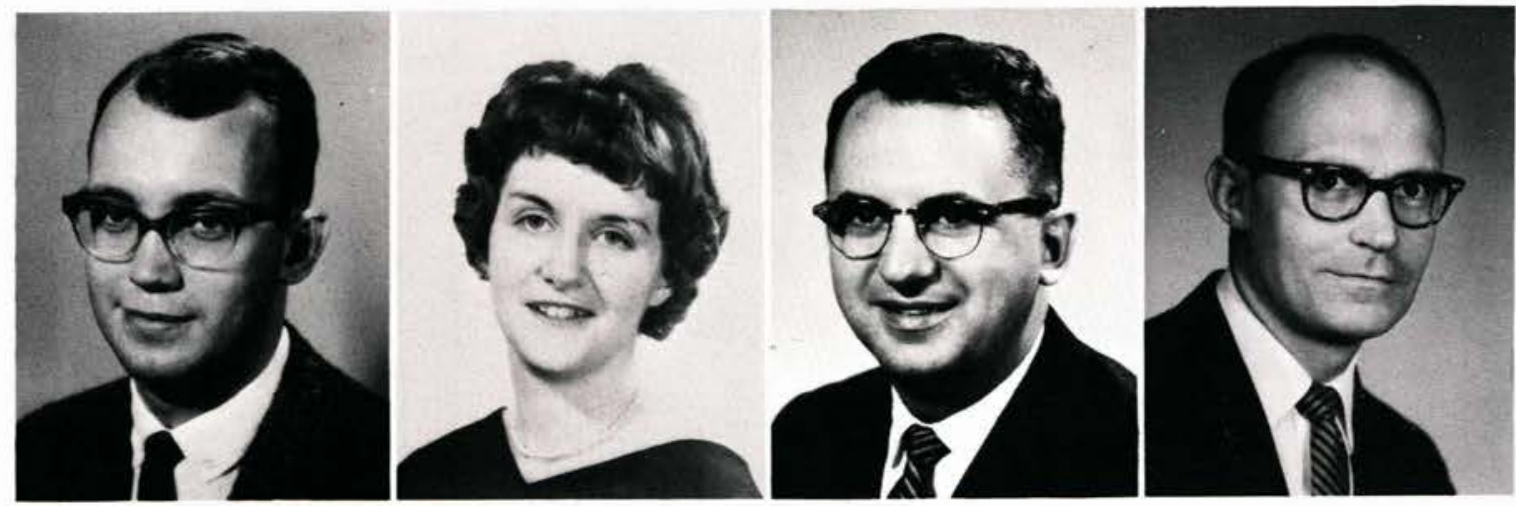


\section{Foreign}

\section{Language}

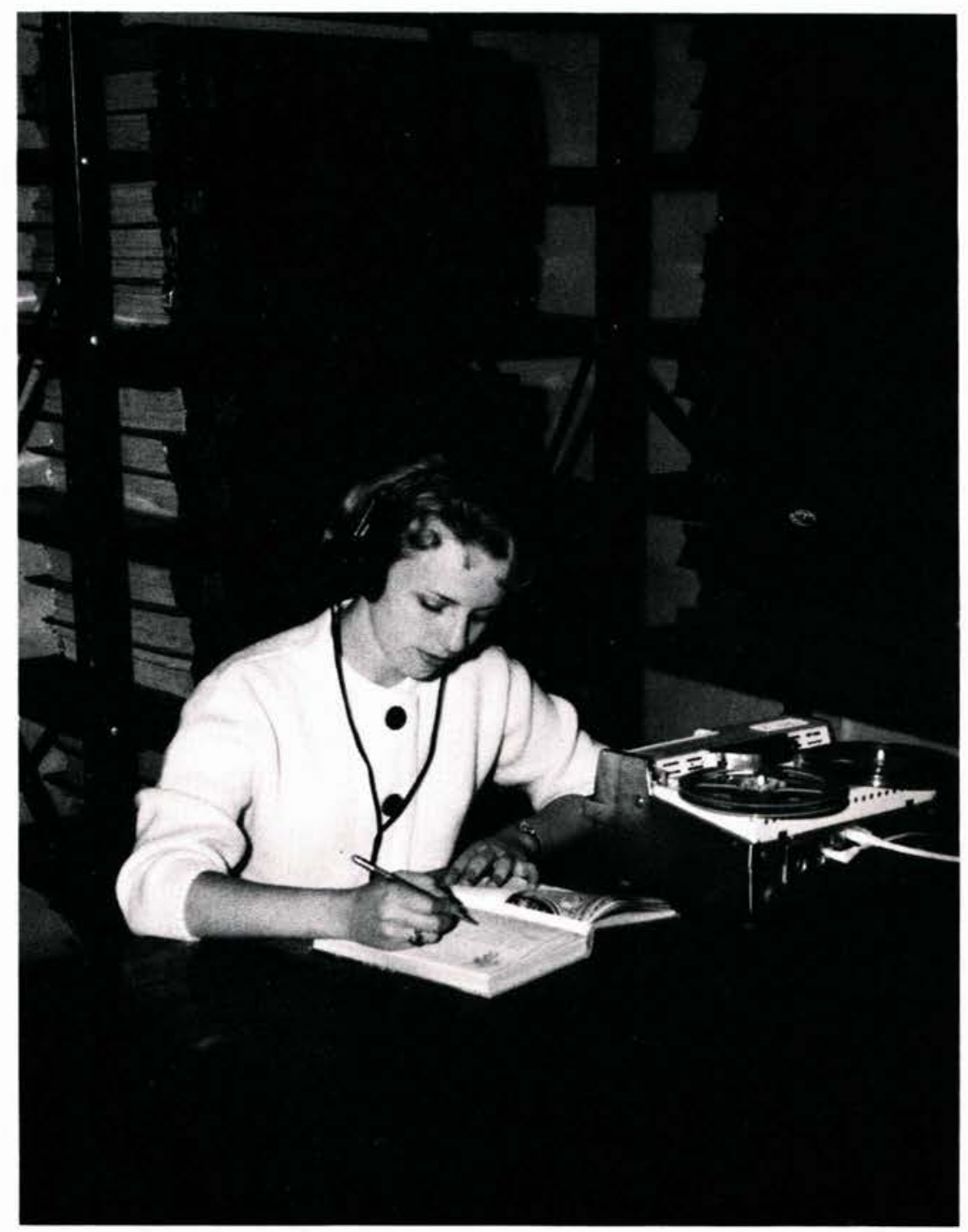

Concentration is required to absorb the elements of another culture.

When a student is first confronted with a foreign language, he often wonders how people can think and speak in reverse. But, as he finds English words which equal the foreign ones, sees the similarities and differences in structure, and learns the idiomatic phrases, the strange becomes familiar to him.

The beauty of French, the terseness of German, and the rhythm of Spanish, hold a new and challenging world of study and thought for him. He thinks, studies, learns, masters, and then begins to think in a new way.
Harmon Bergen, A.B.

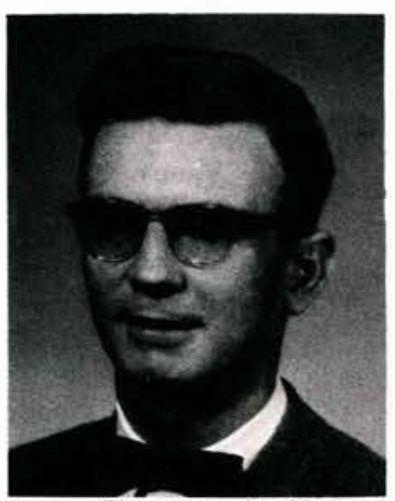




\section{Speech}

Through the aid of various courses, the Speech Department endeavors to help the student know what something means, know how to convince others that certain ideas are right, and know how to demonstrate the power to say accurately and effectively what he means. The right word supported by voice inflection, pitch, timing, and the proper gesture combines to create a mental picture worth a world of meaning.

Communication is the purpose of speech - the use of words expressing what the student wishes to say and the listeners perceiving that intended meaning. Speech is the rendezvous of comprehension and communication, each of which is incomplete without the other.

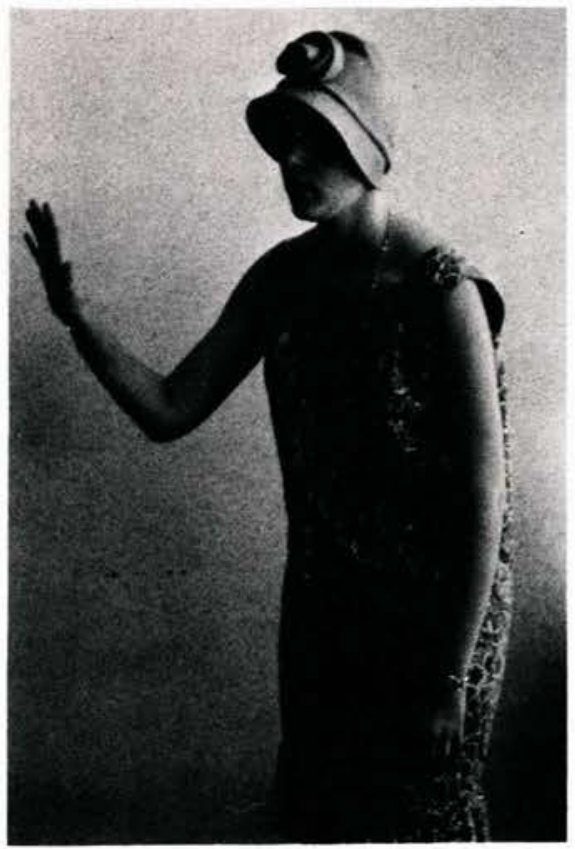

Characterization in costume

Miriam Maddox

A.B.

John Reed

A.B., B.D., M.A.

Radio communication - a combination of vocal and mechanical skills.
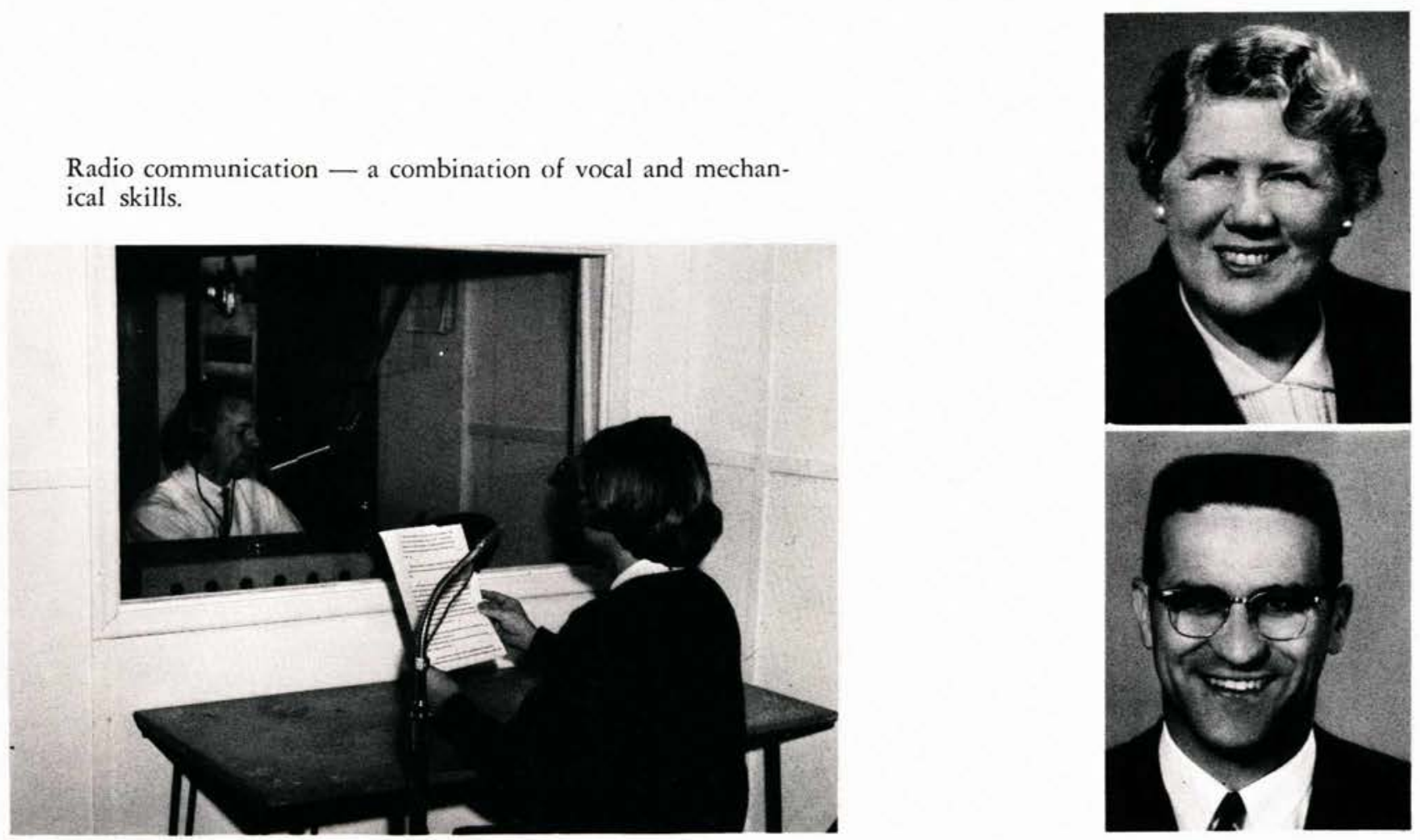


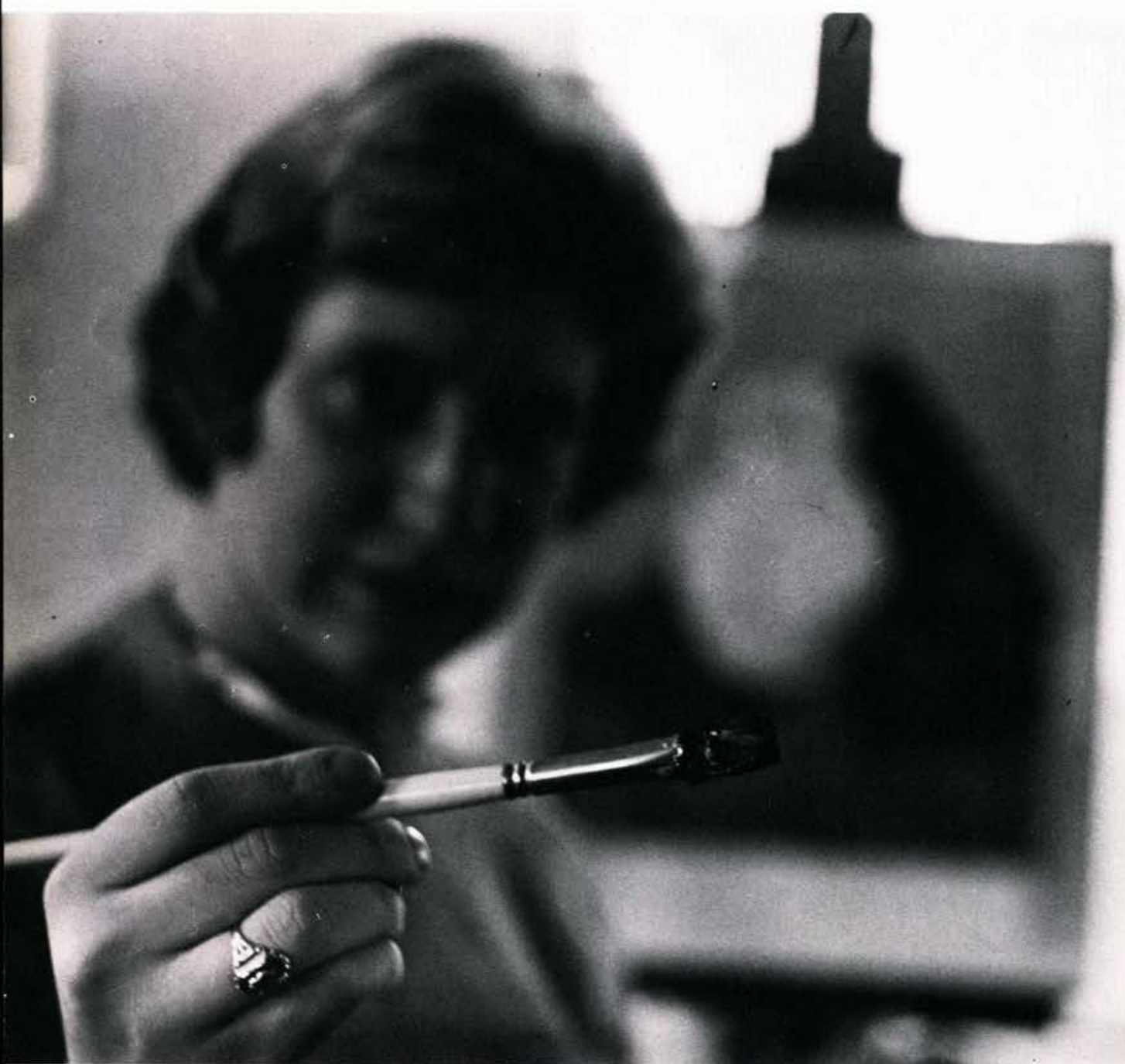

Division Of Fine Arts

Art

Music 


\section{Art}

The artist reproduces and portrays that which he perceives. Capturing life in its grandeur and simplicity, he shows the beauty of the commonplace - as well as the ugliness in reality.

His tools are the pencil and pen, the brush and palette, a drawing board, a canvas. Through these handguided instruments he freezes in time that which would otherwise melt from memory. Unity, design, and motion are characteristic of life and must necessarily be incorporated in his re-creation of it.

Here, in his course of study, he continues his natural talent with technical study and constant practice. This, he believes, will make him truly an artist.

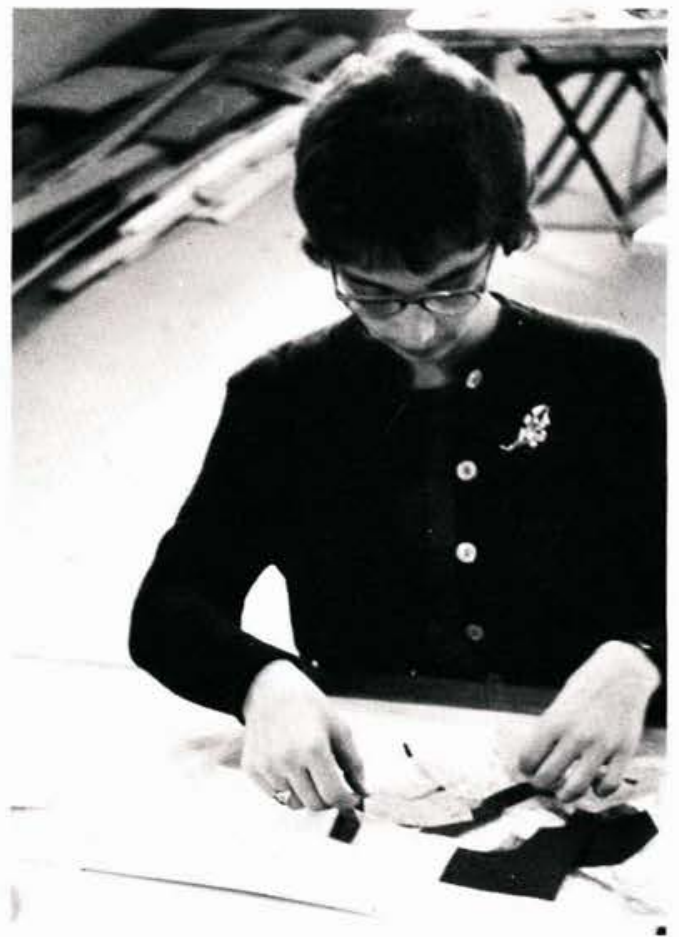

As patterns are fitted together, the abstract becomes concrete.

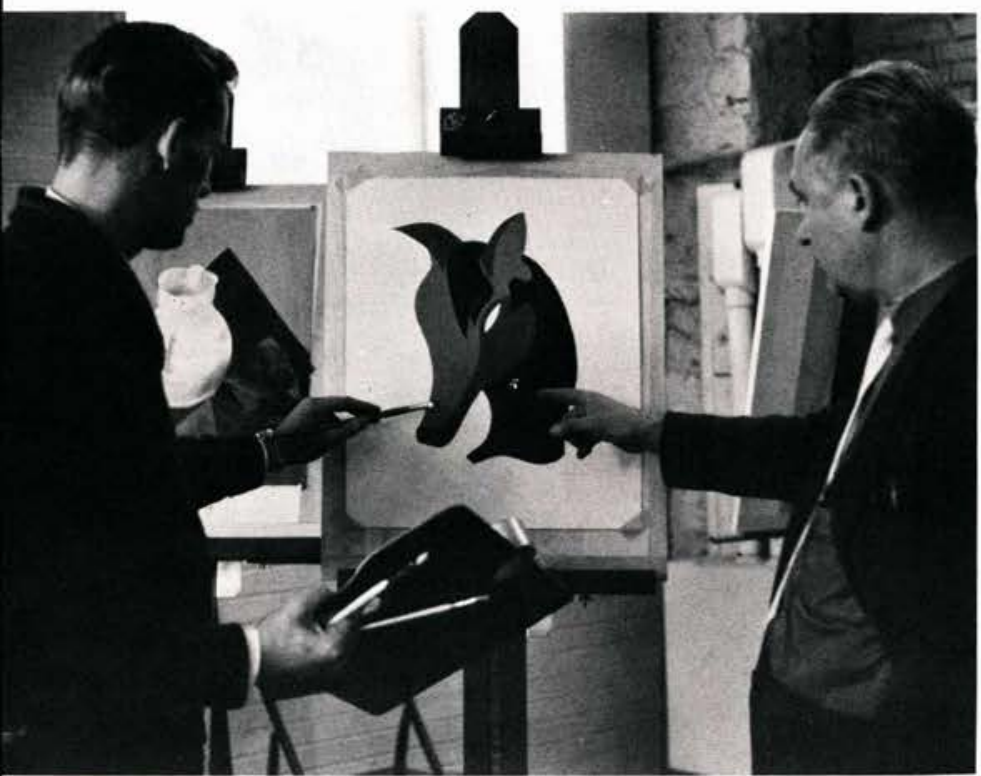

James Russell

A.B., B.D., M.A.

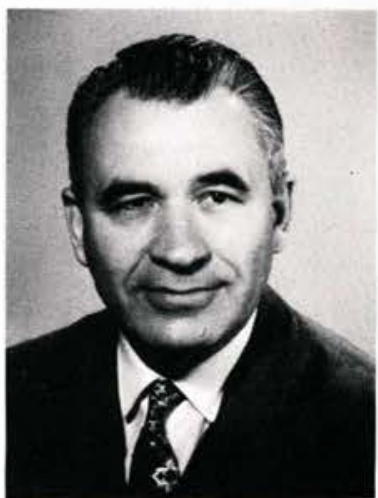

A corrective stroke, a perfected image. 


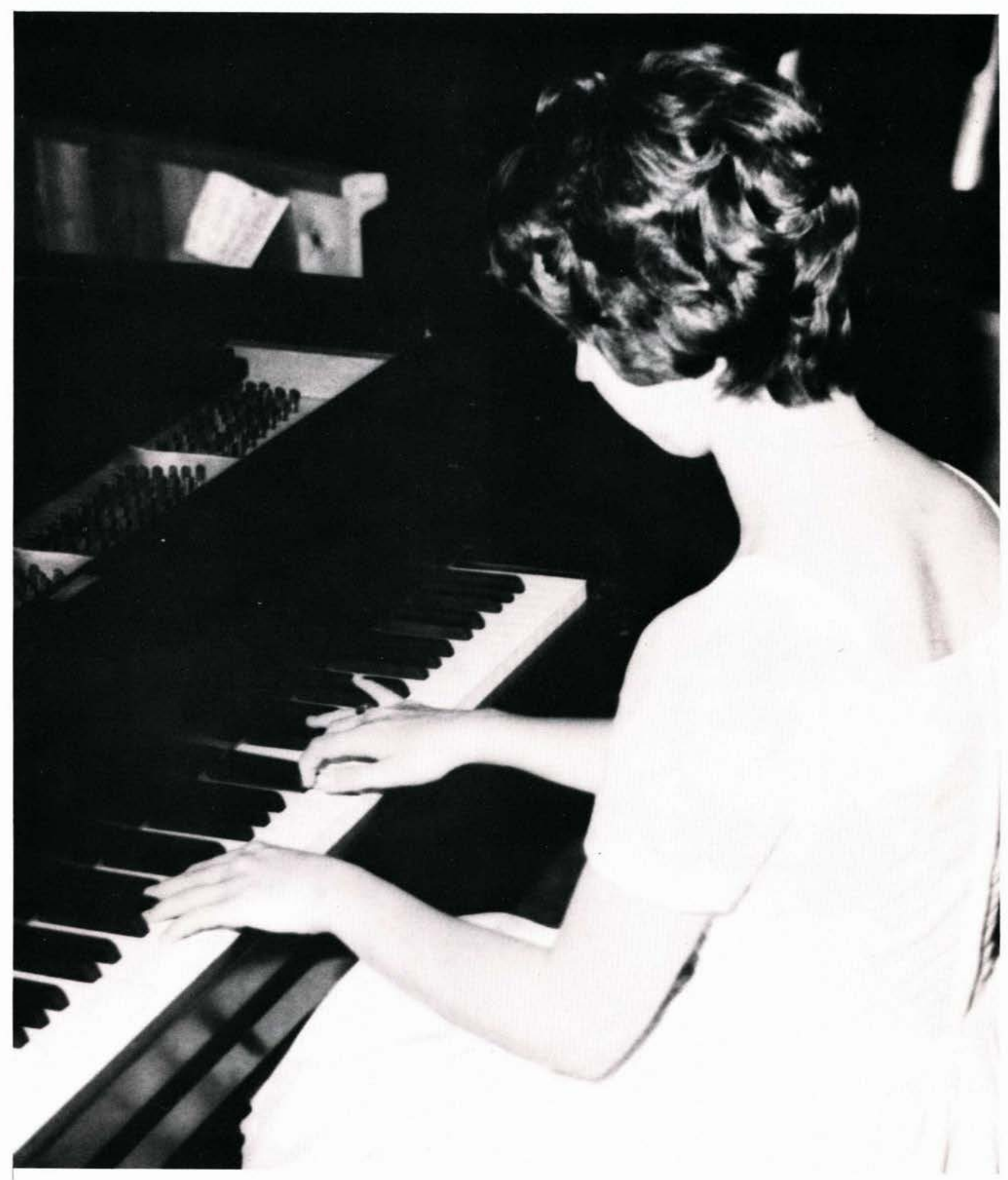

Yesterday's practice—today's perfection. 


\section{Music}

Rebecca Cooke, B.S.

Richard Cooke, B.S., M.S.

Ruth Smith, B. Mus., M. Mus.

William Thornton, B.S., M.A.

Warren Webber, A.B., B.M.E., M.M.E.

George Zinn, A.B.
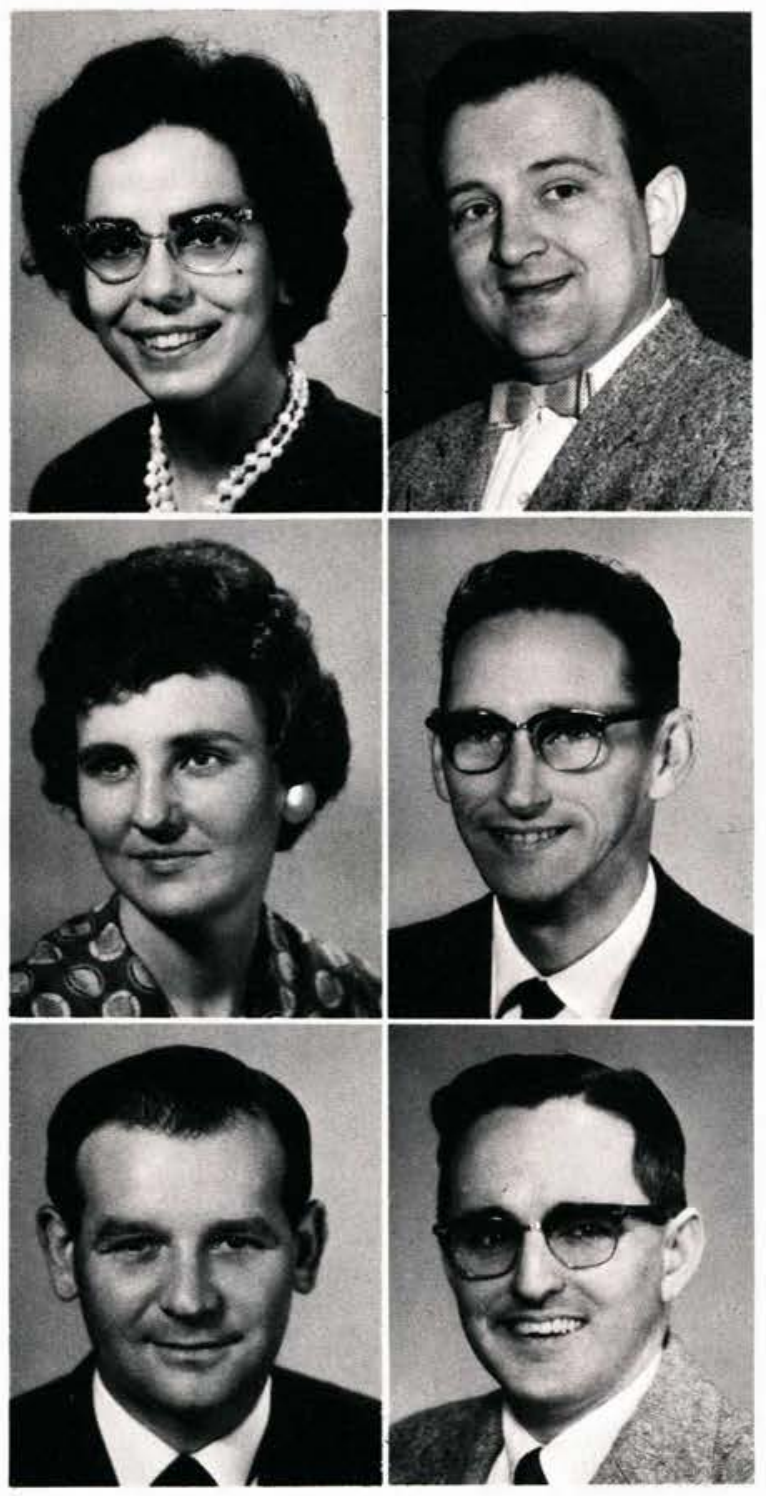

Even after the music has ceased, the melody lingers on. The sweetest sounds are still inside. The student visualizes notes on the staff, imagines the vibrations in the air, realizes the feelings and depths that lie therein ... he hears the sound.

As he studies the works of the masters, he is inspired by the obstacles and handicaps that were overcome in their strivings for immortality. He also has the unique experience of studying the poetic co-ordination in hymns and Christian music, which have been written to express love, devotion and gratitude toward God.

He applies form, convention, and the novelty of his own personality to his creations.

Music . . a perspective of beauty . . . an expressive sound ... another world of symbols.

Clarity of tone and sweetness of melody blend into meaning and enjoyment.

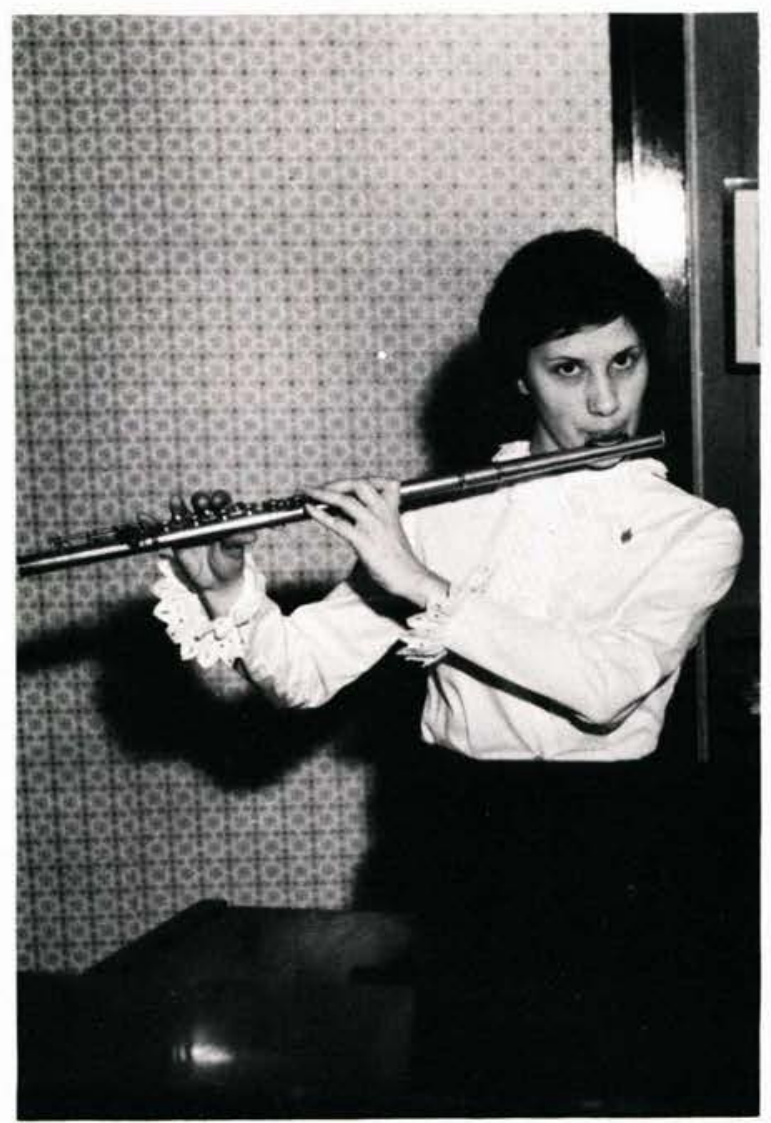




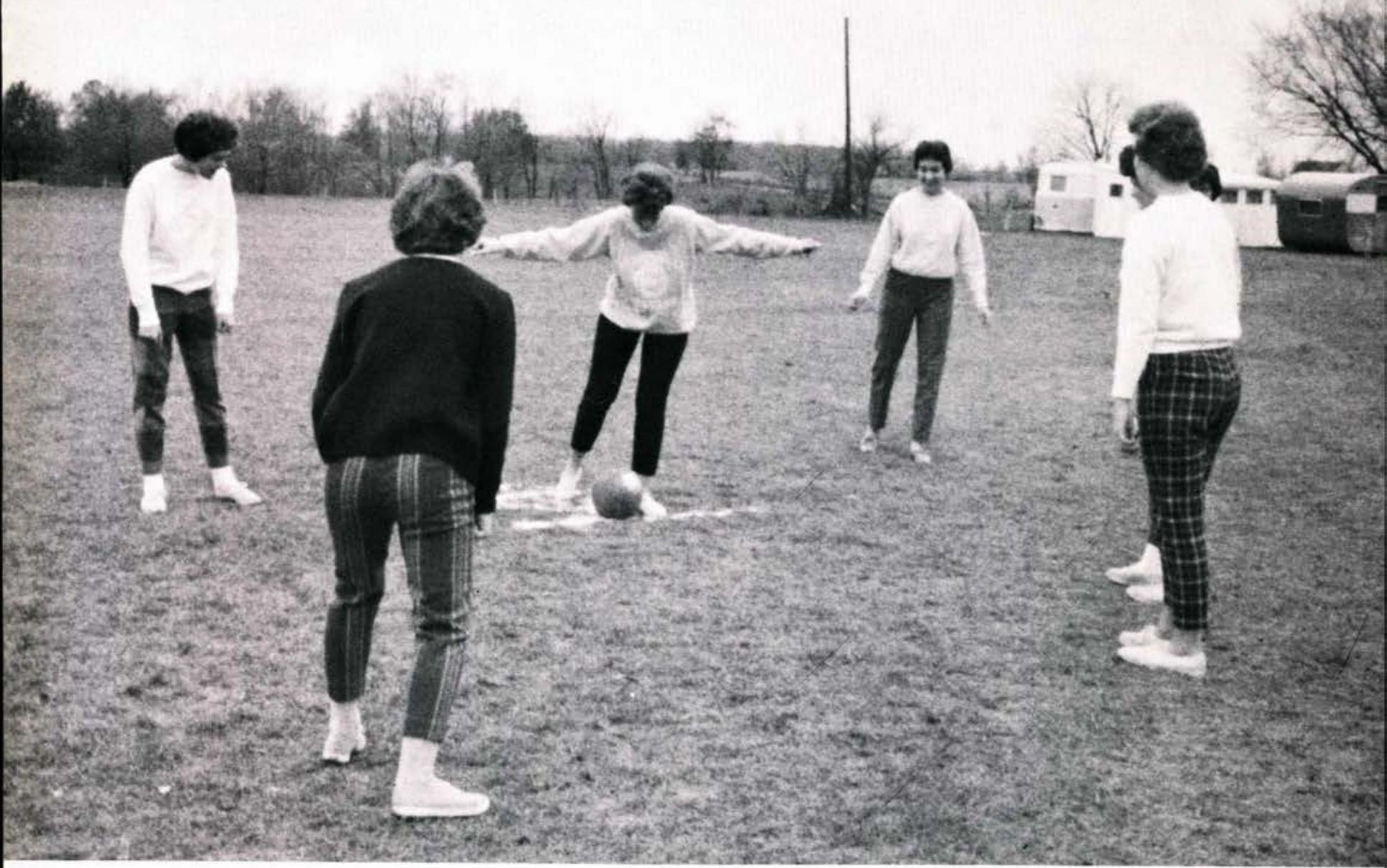

\section{Division Of Health And Physical Education}




\section{Health And}

\section{Physical Education}

The program of physical education is one that the student realizes very little use for until he has actually used it. That required hour where his muscles are exercised and the built-in balance and co-ordination of his body are discovered.

The hours of constant practice where he tries and tries again to perfect what he attempts. At last the reward is received in the attainment of precision, rhythm and gracefulness.

The Cedarville College student discovers that the scope of education includes not only the enlightening of the mind, but the molding of the whole man.

Donald Callen, B.S., M.S.

June Kearney, B.S.

Joy Mackay, A.B., M.A.

Lane Moody, A.B., M.A.
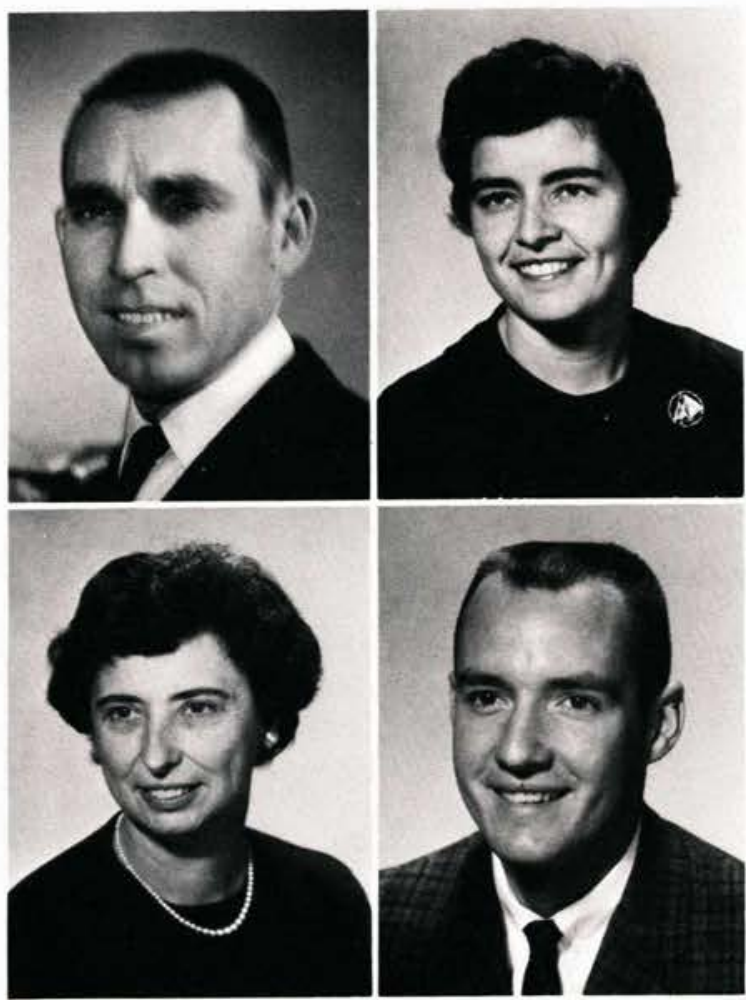
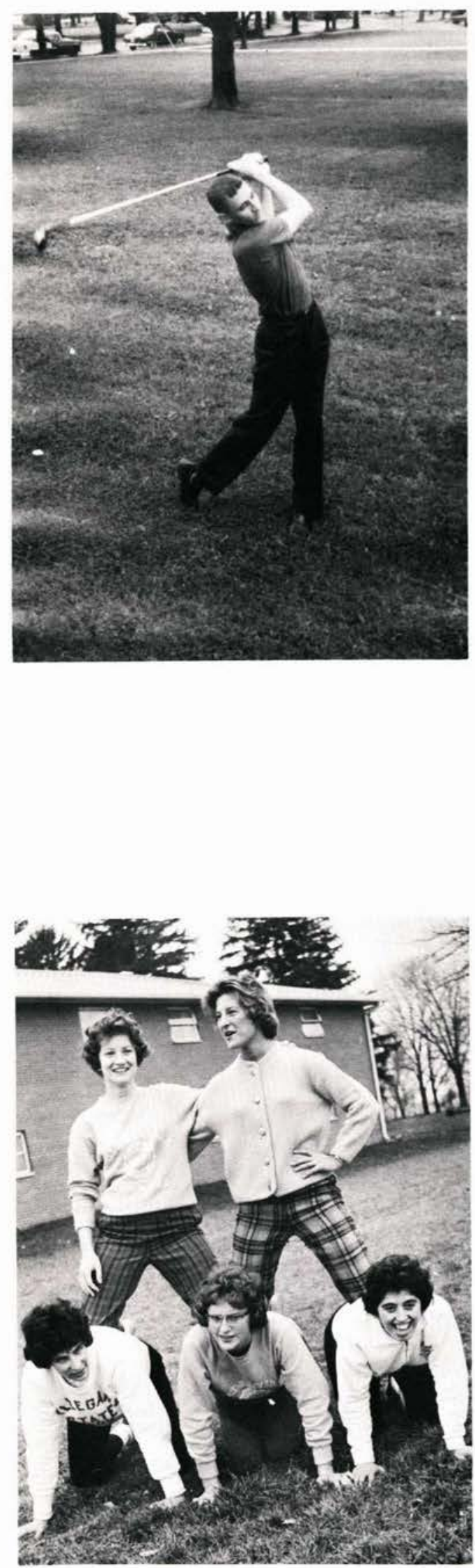


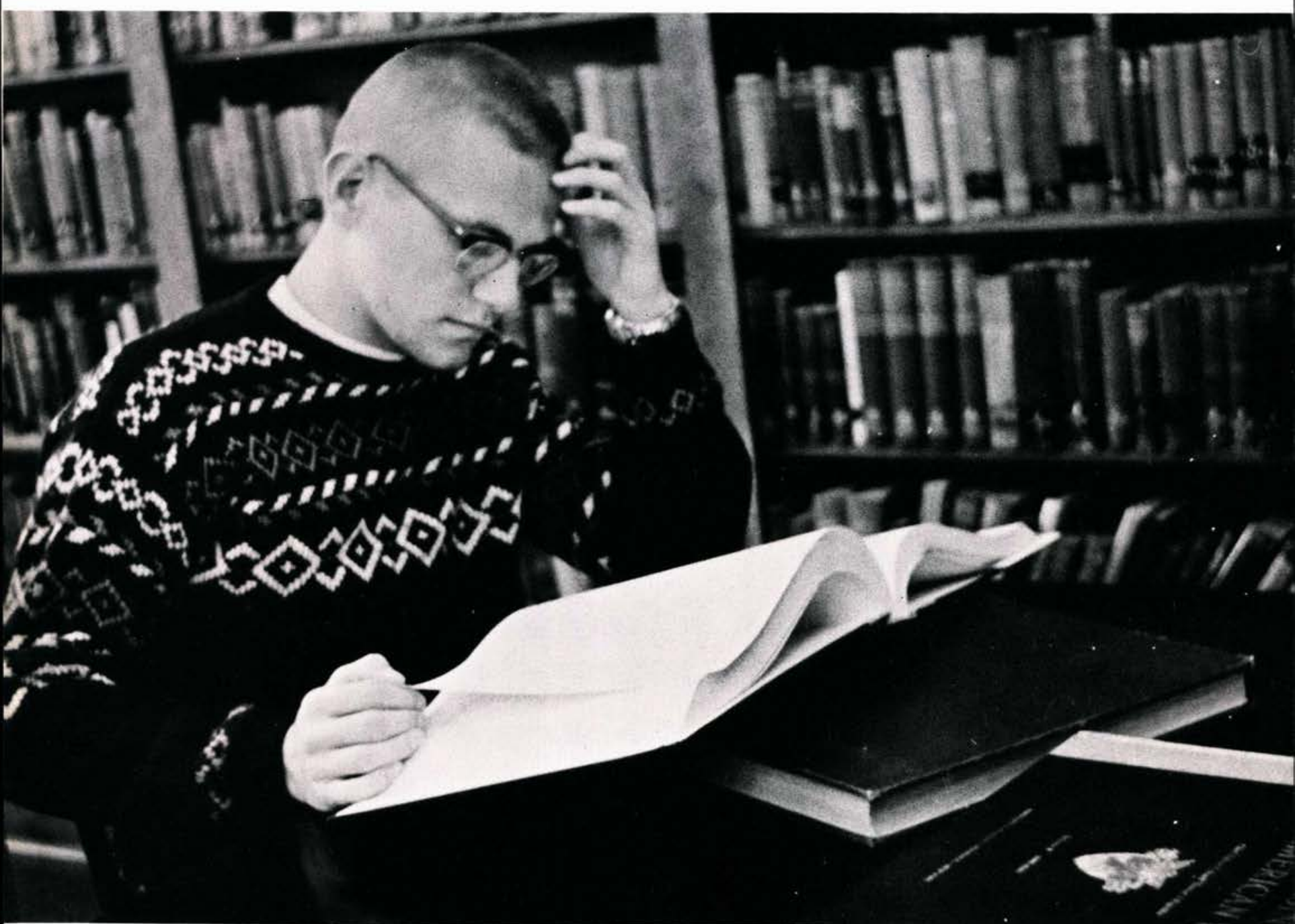

Division Of Social Sciences

History

Geography

Political Science

Sociology 


\section{History}

\section{Geography}

\section{Political Science}

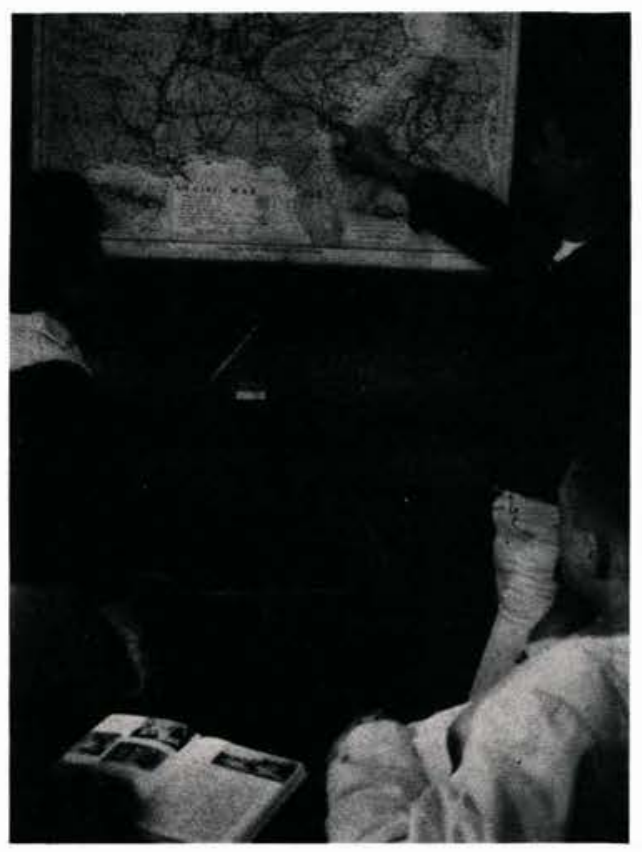

A strategic location calls for the correct approach.

The political science of the past which governs much of the modern political method enables the student to find solutions to present problems in the light of those solved in the past. The facts the student learns in history class influence the way in which he thinks, and thus the way in which he handles a problem.

Men come and go; places and dates change. But human nature remains the same, and reacts the same way to political power.
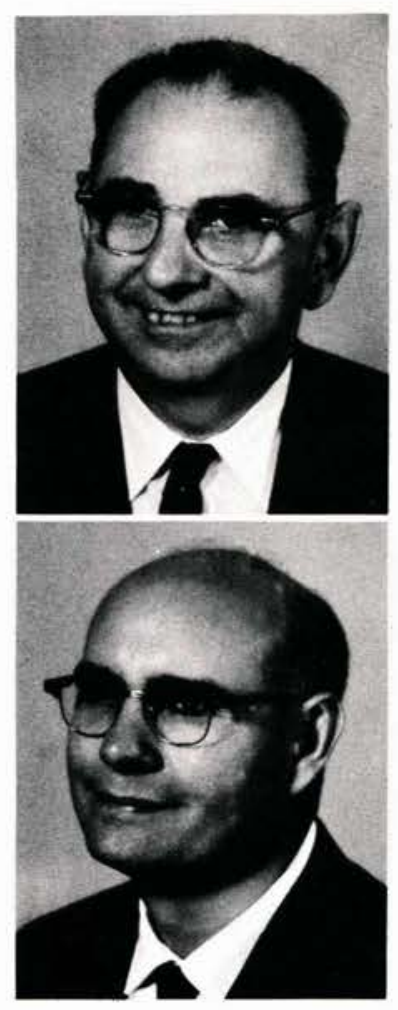


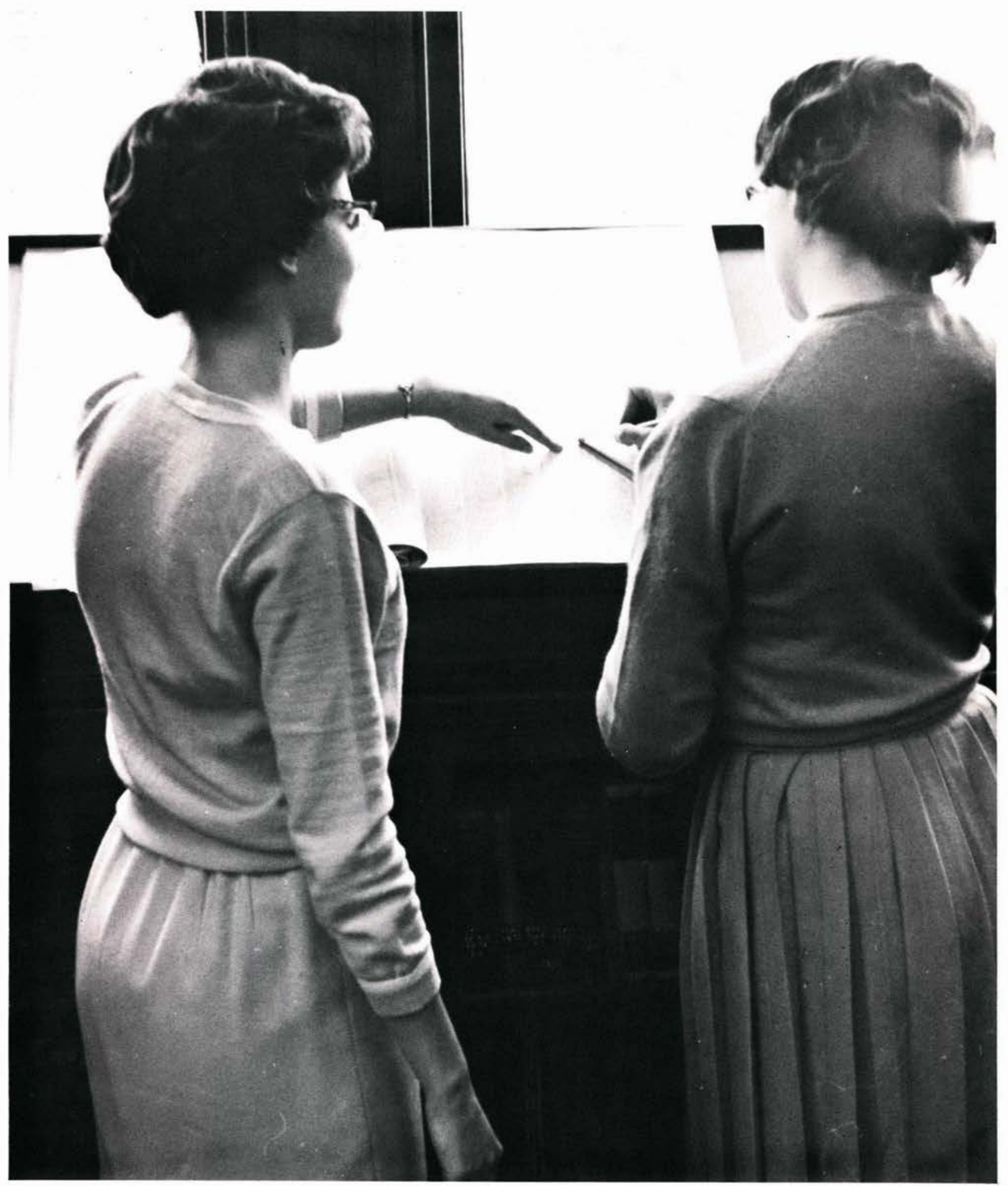

Census reports shed light on population problems. 


\section{Sociology}

"What is man, that Thou art mindful of him?" Throughout the ages this has been man's question to God - and to himself.

The record of man in his social environment is history. From it we can predict what he may do in the future as he faces various situations. Will he react ethically or unethically? Will he do that which will benefit society as a whole, or will he act purely from selfish motives?

Man exerts an influence on those in his society and on posterity. In his role as a Christian student then, he has an added responsibility to his fellow man. His goal is the understanding of man in the light of Christian ethics.

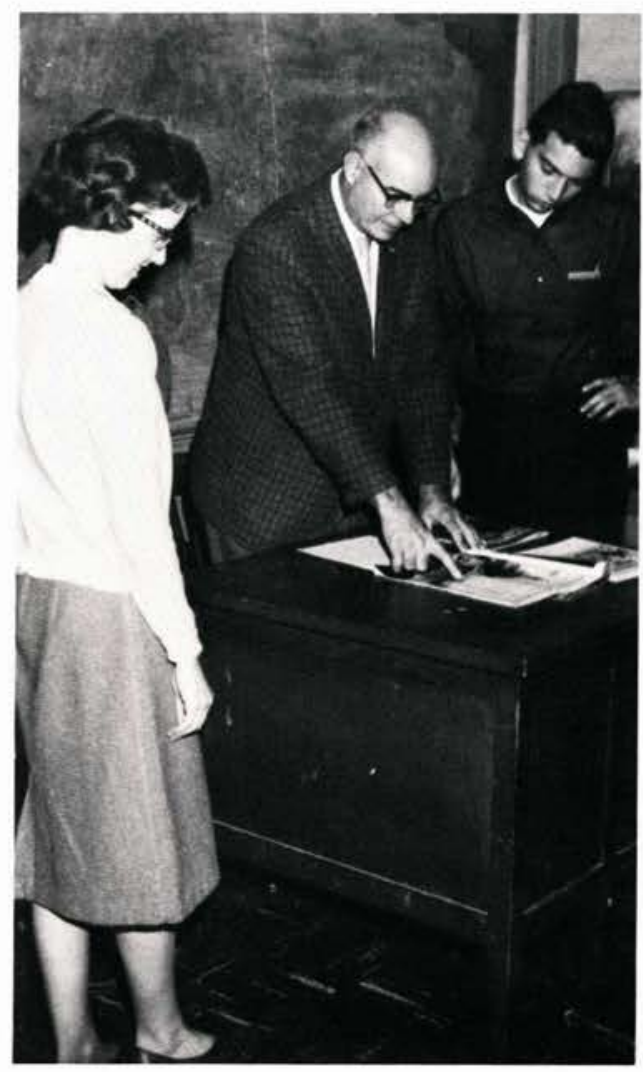

Mr. MacDonald points out some opportunities.

Cleveland McDonald, A.B., M.Litt.

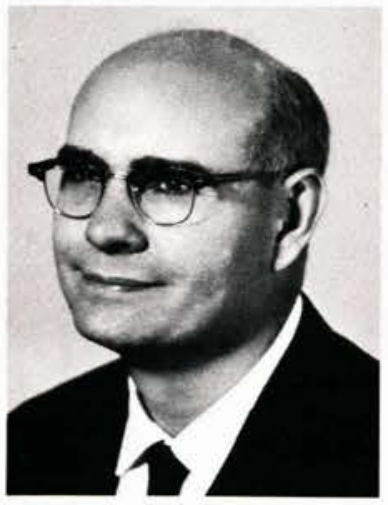

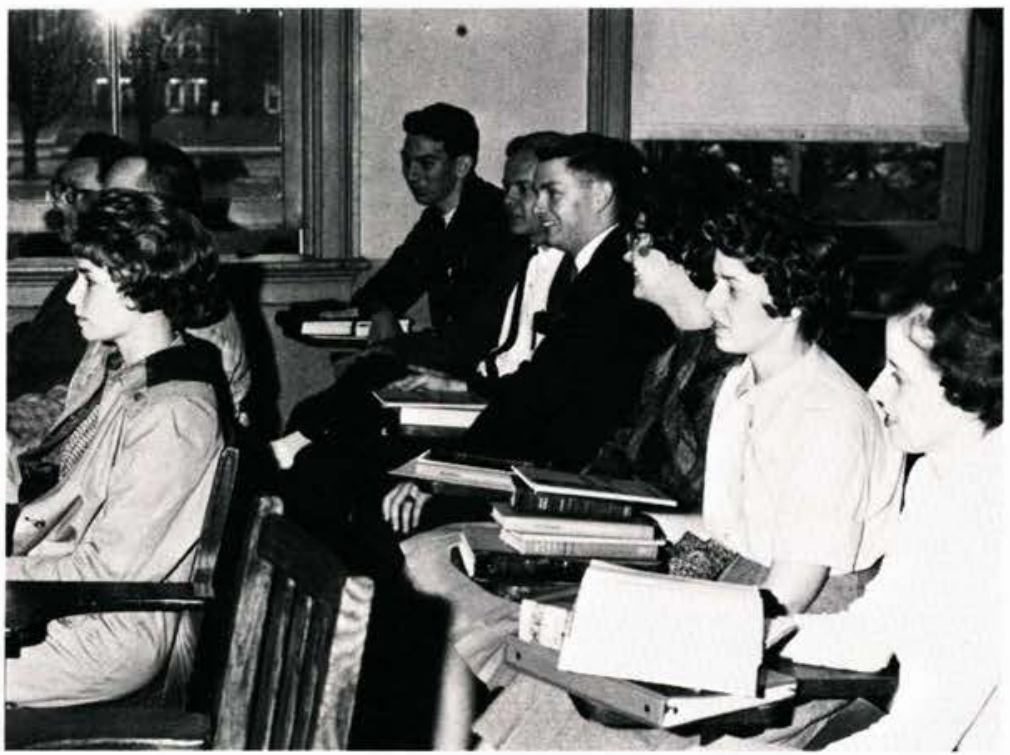

... students prepare to meet the opportunities. 


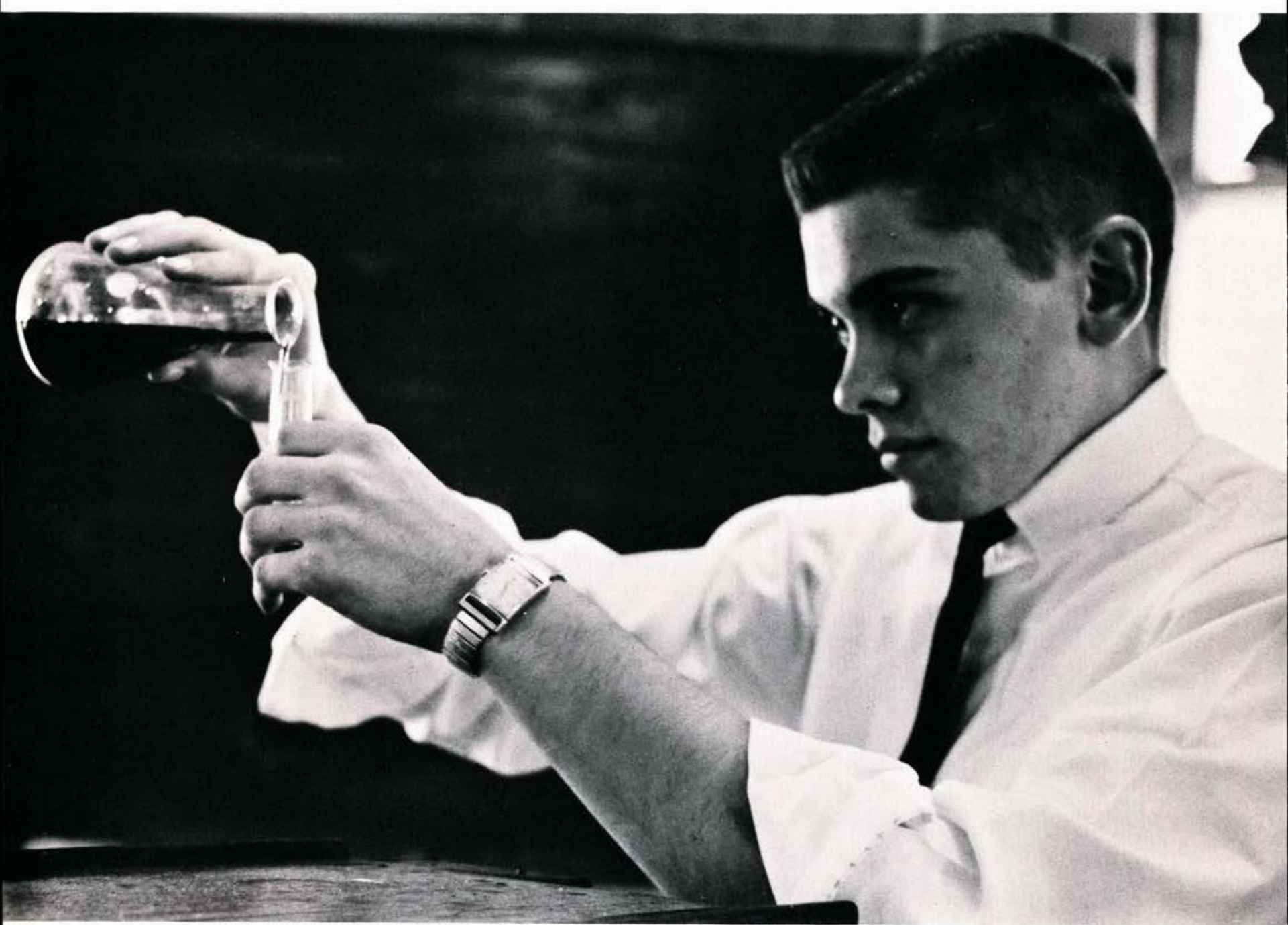

Division Of Science

Biology

Chemistry

Mathematics

Physics 


\section{Biology}

Life - plant or animal, unicellular or multicellular. Does this form of life function as simply as it appears, or is it extremely complex? The leaf is a chemical factory - photosynthesis. The structure of the human body is a masterpiece of architecture - a group of delicate and interrelated systems.

How are the emotions related to the physical aspects of life? Biology answers much of this, but leaves much unexplained.

The students in this department realize that it suggests more... a Maker.

Inspiration in the study of God's creation.

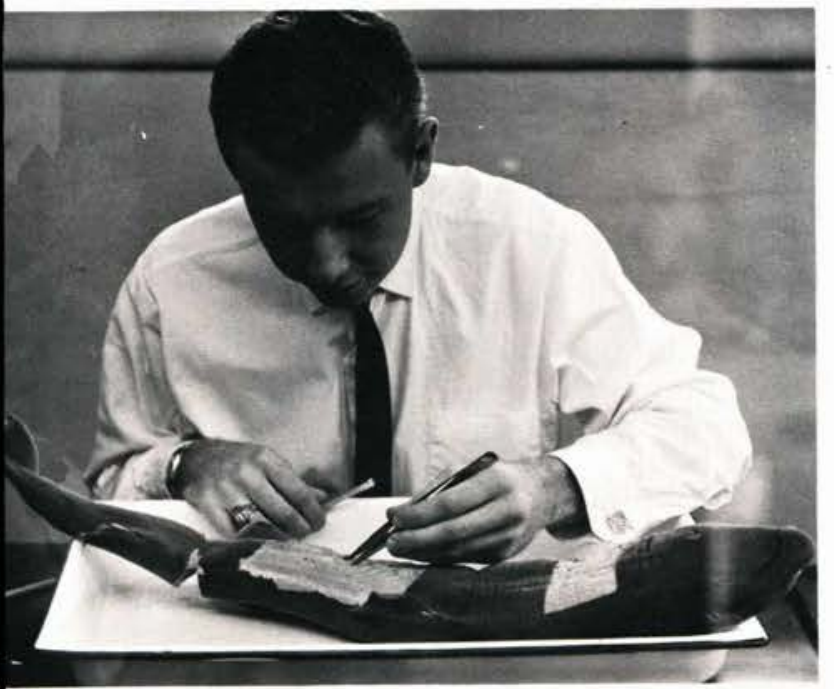

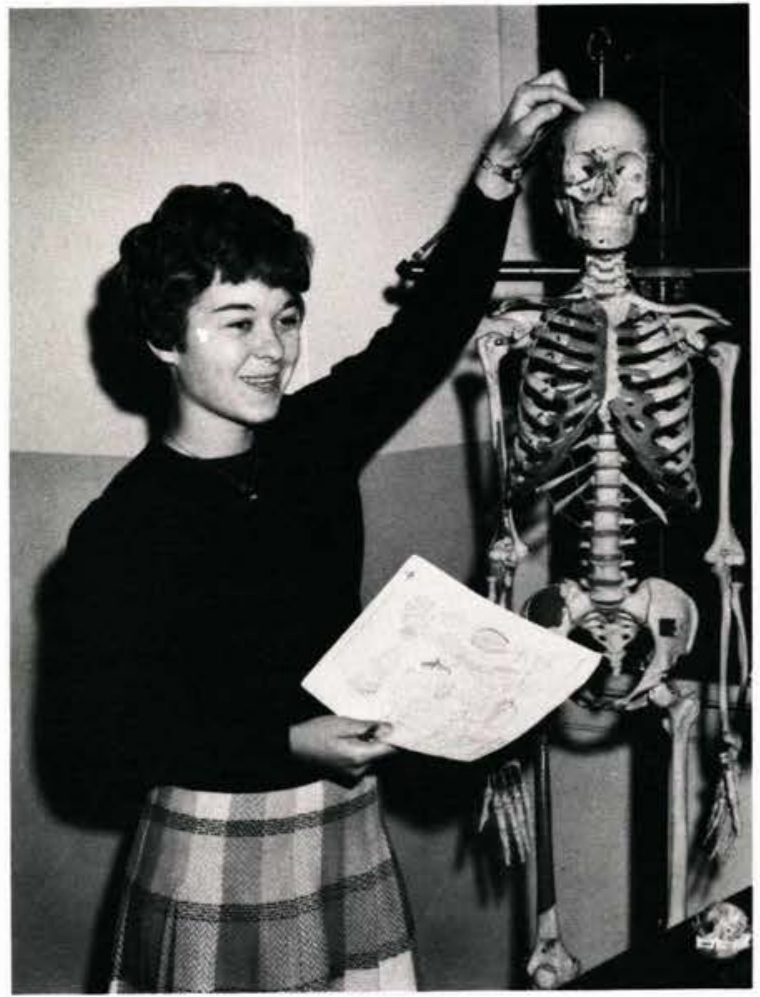

Basic structure is basic knowledge.

John Brumbaugh

A.B.

Austin Elmore

A.B.

Dale Thompson

A.B., M.S.
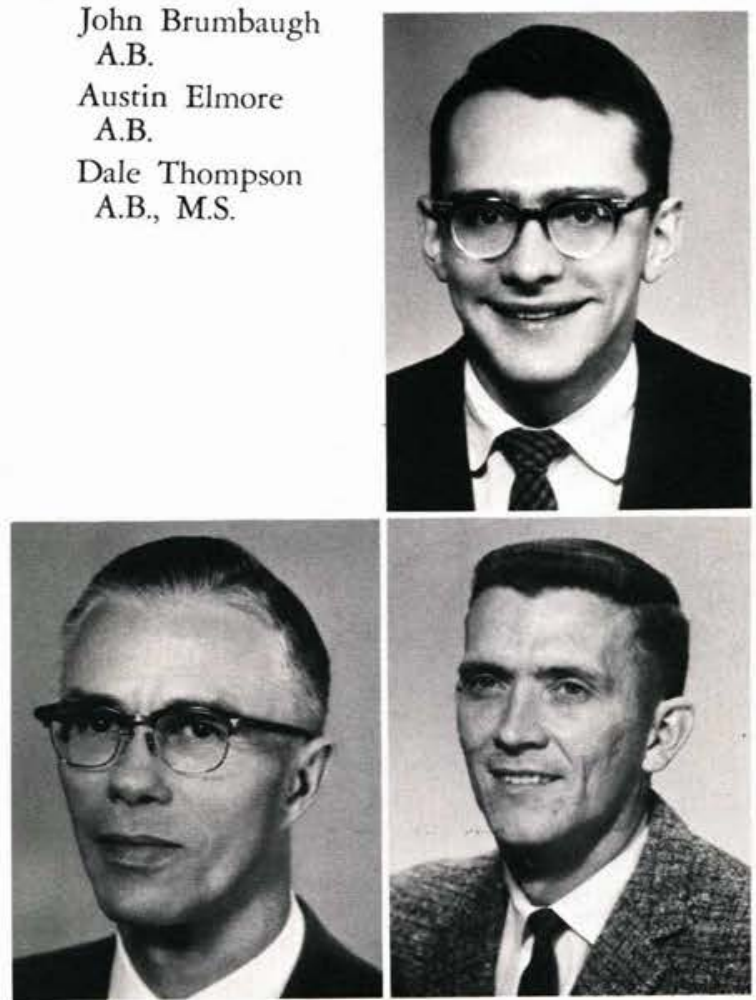

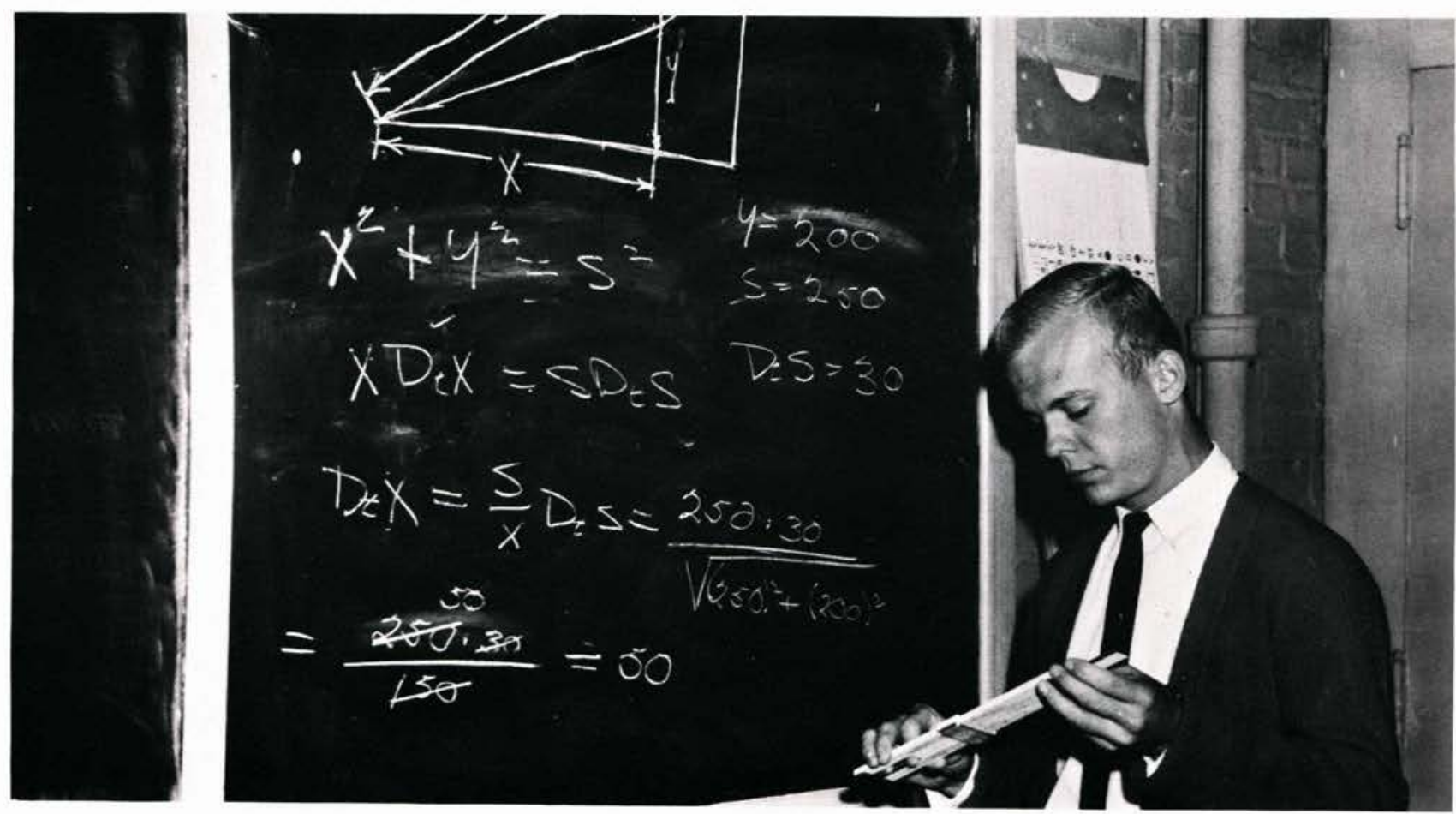

A problem solved, a point proved.

Learning - by trial and error.

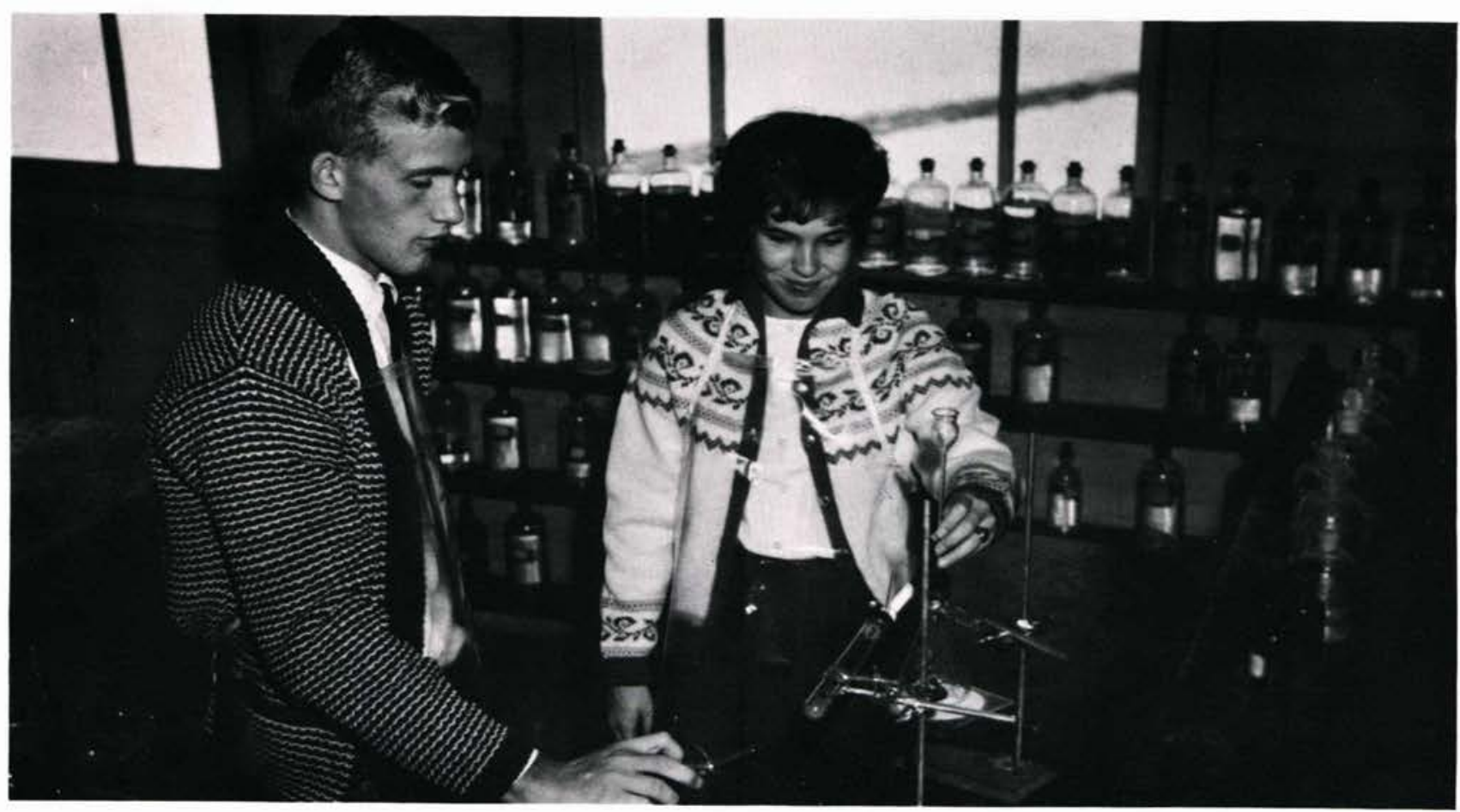




\section{Chemistry}

\section{Mathematics}

\section{Physics}

The mysterious world of the fuming liquid, the test tube, the laboratory coat, and the observing eye and steady hand of a man compose the concept of the scientist to the common man. Yet, this man studies the basic materials of our existence.

Numbers which represent the unknown factors, equations and formulae of things provide the practical application for the experiments of science. The identity of the unknown quantity is revealed by finding its relationship to the known ones.

In training to become a chemist, a mathematician, or a physicist, the Cedarville College student studies the intricate composition and functions of the universe.

Bert Frye, B.S., B.D.

Clifford Johnson, B. Ed., M. Ed., D. Ed.

Bruce Turnbull, B.S., B.D., M.S.
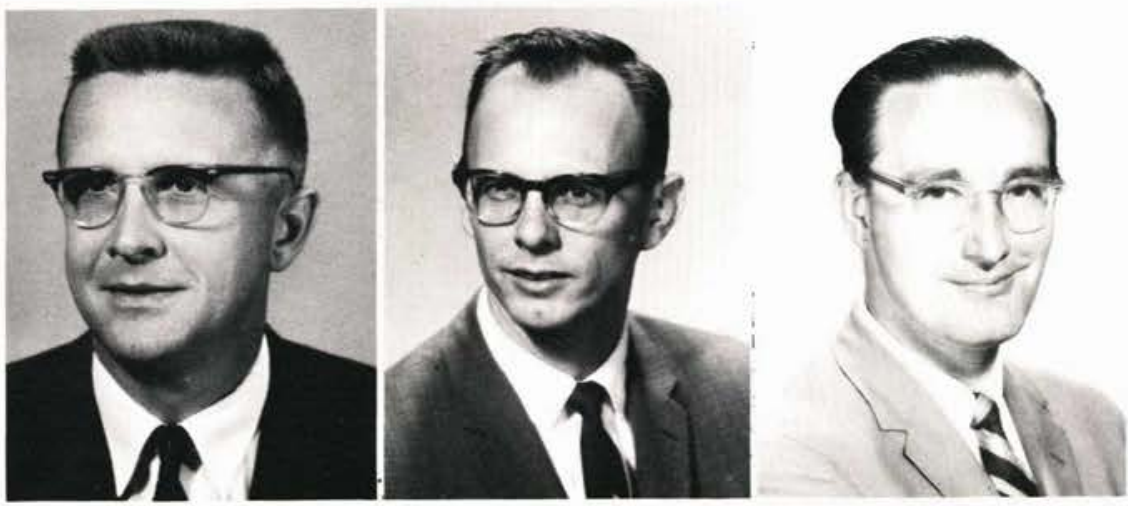

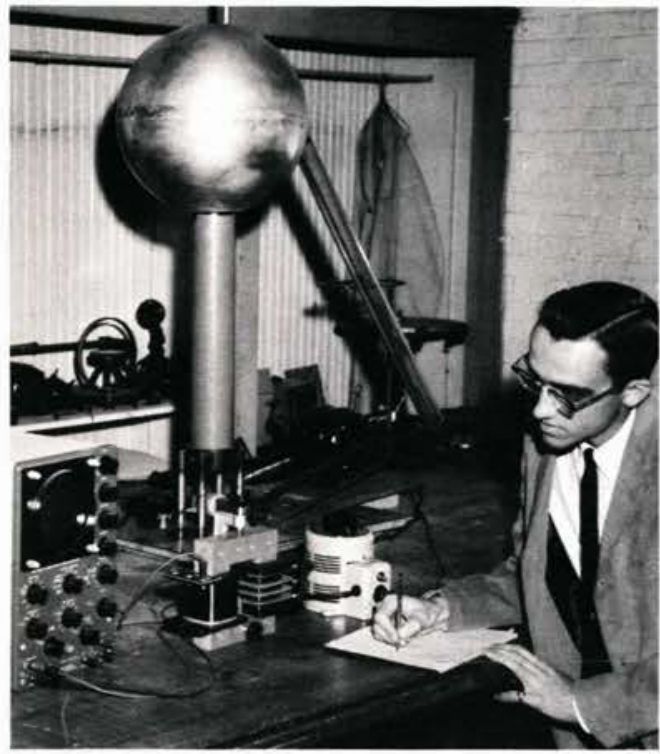

Answers through the magic of electrons.

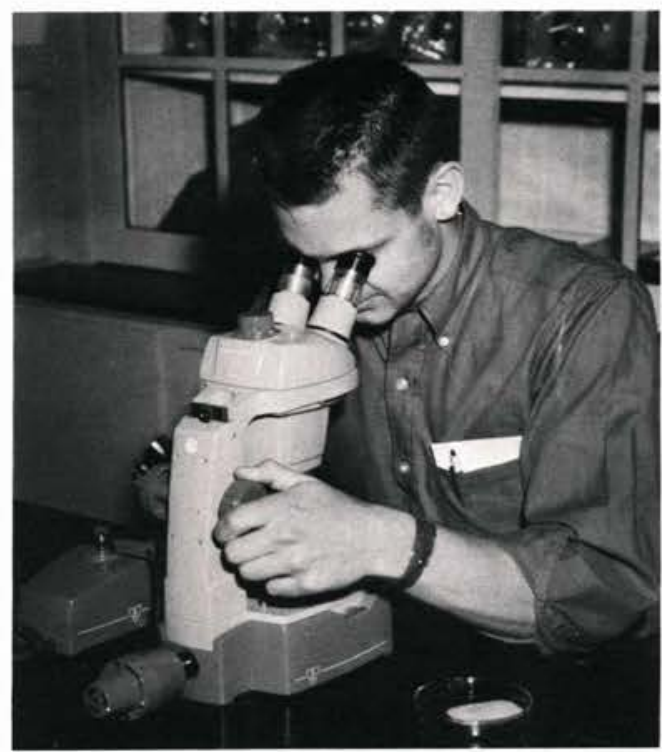

Never-ending research yields discovery. 


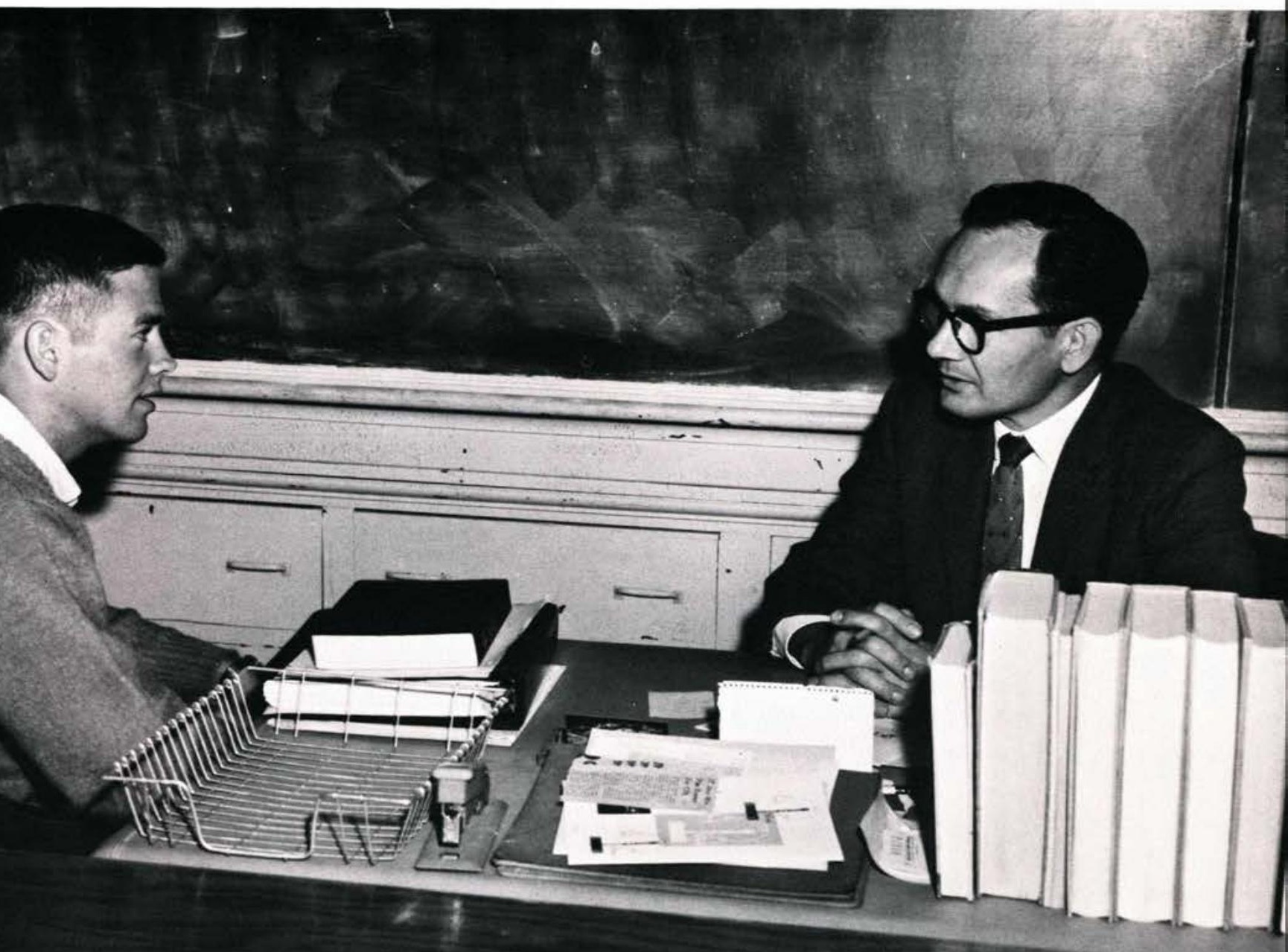

Division Of Business Administration

Accounting

General Business

Secretarial Science 


\section{Accounting}

\section{General Business}

Assets, liabilities, ledgers, balance sheets, and a host of other words compose the jargon of the business student peculiar to his field. He employs such instruments as the Monroe calculator and the adding machines, which provide shortcuts for the duties he must perform.

$\mathrm{He}$ is adequately prepared for activity in business, church leadership, a financial service to his community. He receives professional training in a Christian atmosphere for his prospective career in business.
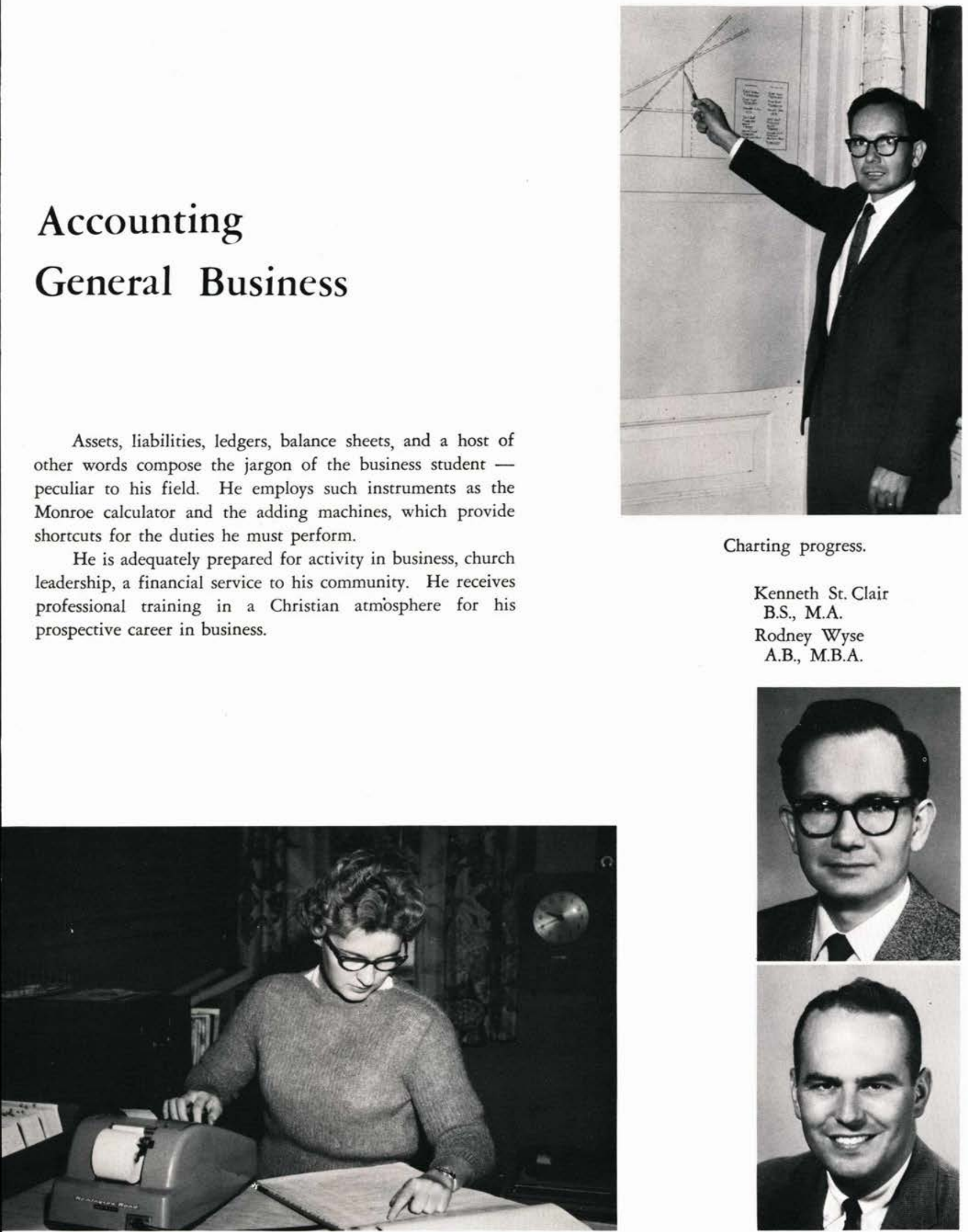

Charting progress.

Kenneth St. Clair B.S., M.A.

Rodney Wyse A.B., M.B.A.

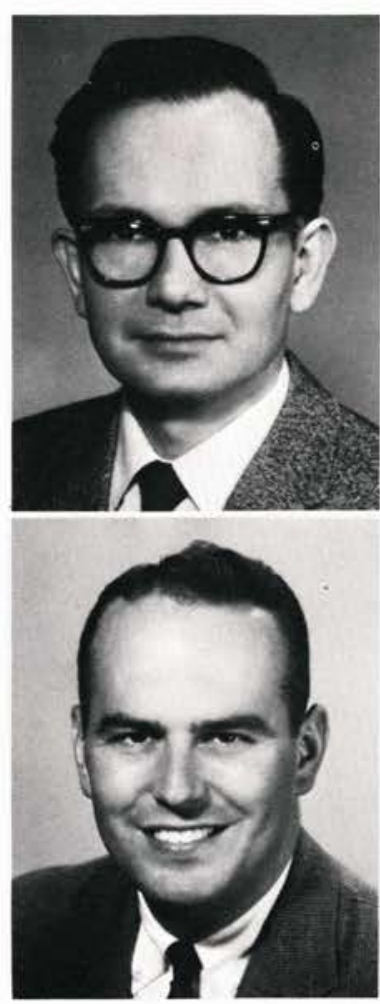

Mechanical method of checking human error. 


\section{Secretarial Science}

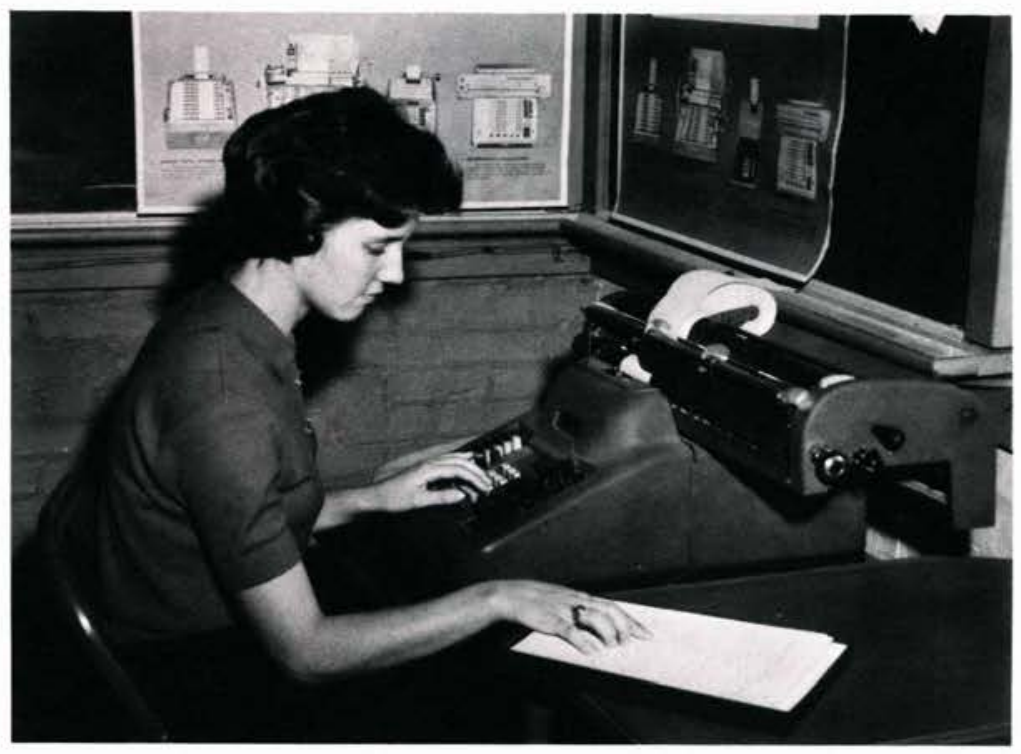

The secretarial science student upon graduation not only possesses an understanding of his field, but achieves a working knowledge and adept skill in such subjects as typing, shorthand, and business machines.

As a result of his studies in this department, he also gains the capacity to understand up-to-date business terms and language. $\mathrm{He}$ then is adequately prepared to take his place in the fast-moving world of business.

Applied learning.

Typing efficiency is speed plus accuracy.

Ardeth Webber, B.S.
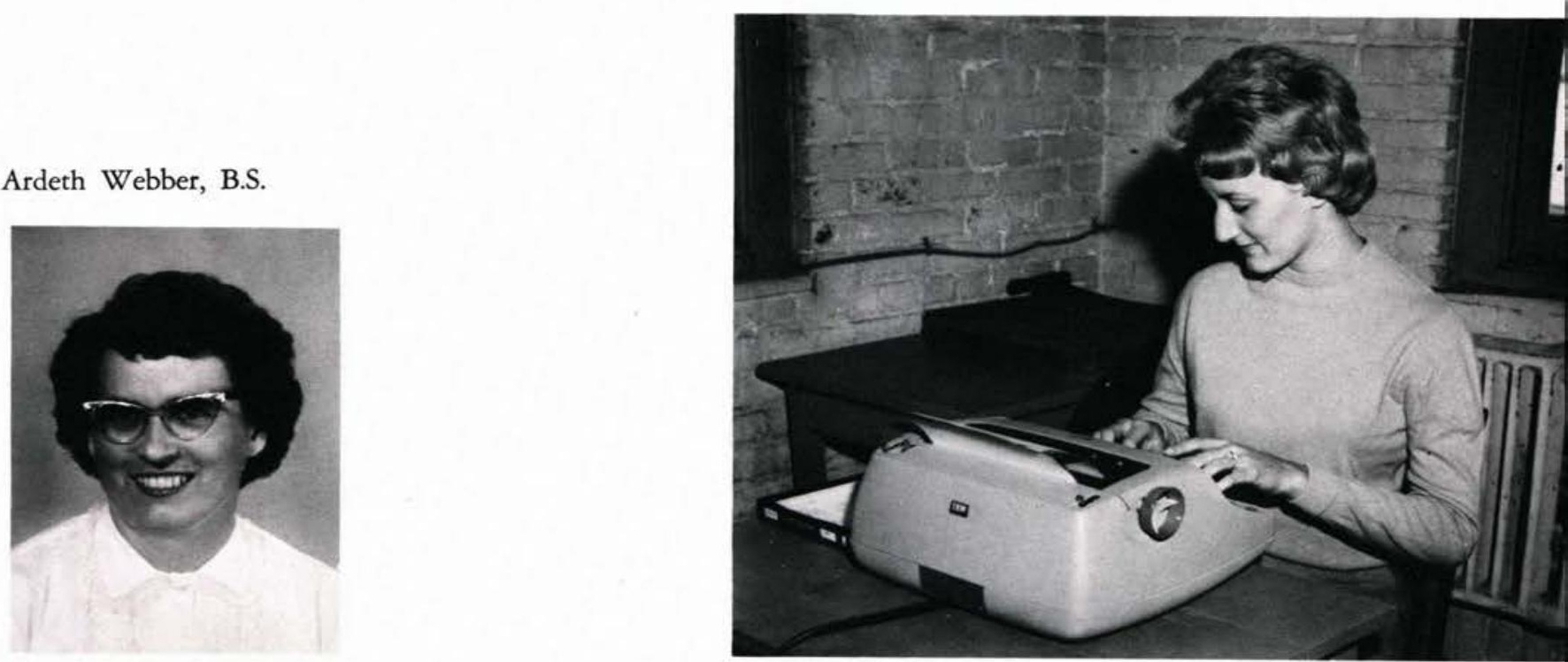


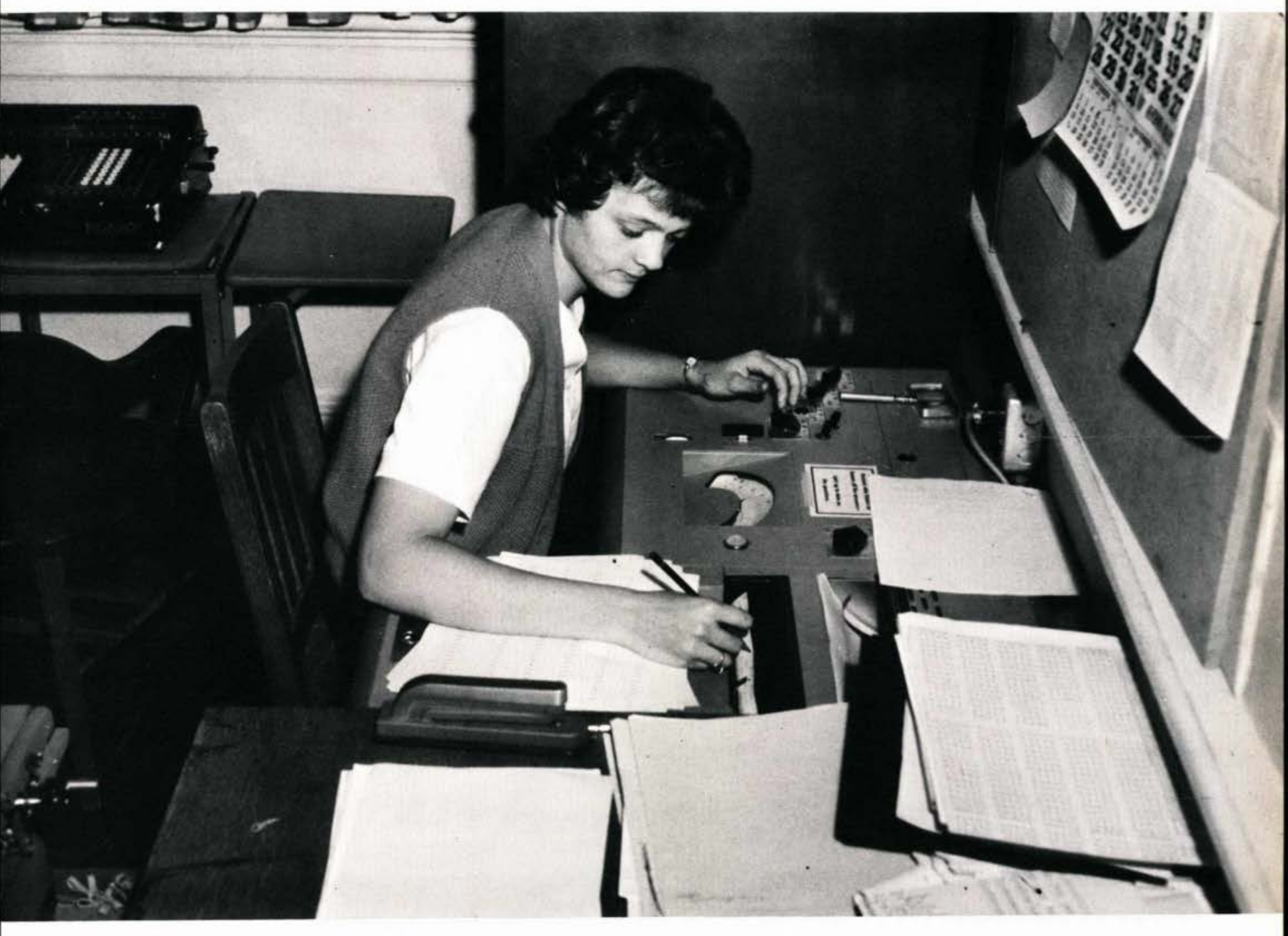

\section{Division Of}

\section{Psychology}

Psychology - the study of the man, his mind, and his soul. Why does he act and react the way he does? What are the behavorial patterns which categorize his actions? Is man's behavior controlled by instinct or reason? Where is the thin line which divides the two? Can personality intelligence, and innovations be treated experimentally?

The student who works for a degree in this field searches for these answers to these questions.
Max Dowell, B.S., M.S.

Clifford Maddox, B.S., M.A., Ph. D.
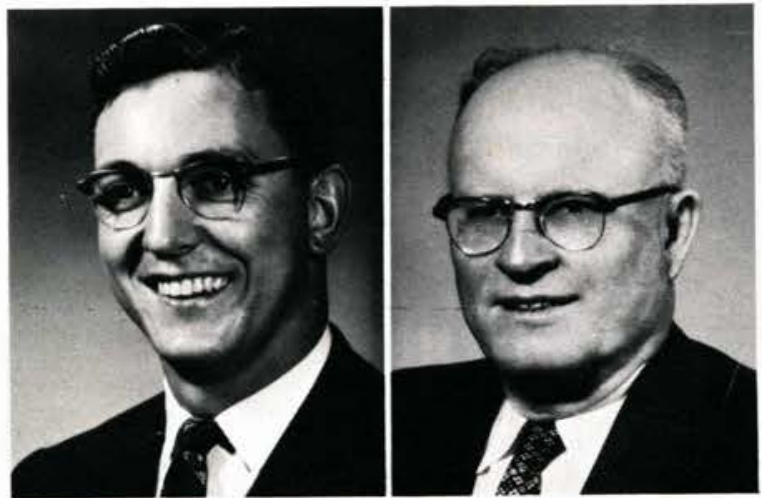
$\beta_{A}: l^{\prime}-x^{2}$

$\sin \frac{\pi}{4} x^{2} x^{2}$

sydth

s.t.

2 - से

sistih

s.

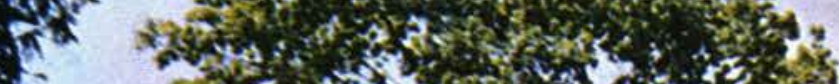

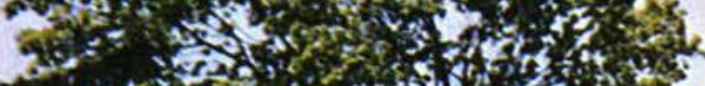

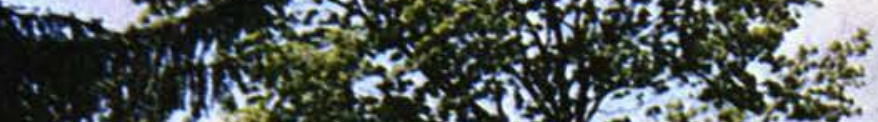

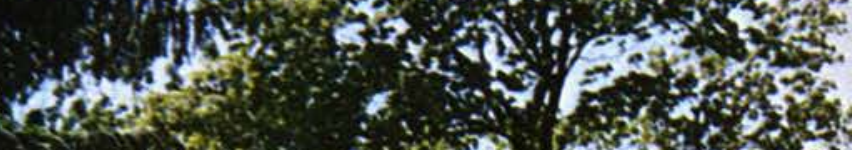

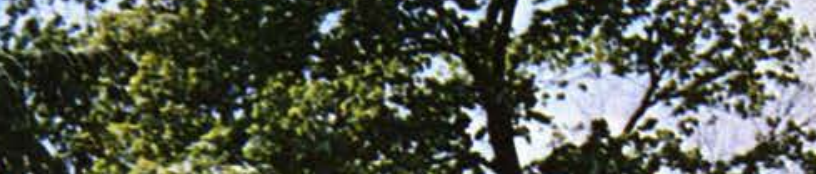
if

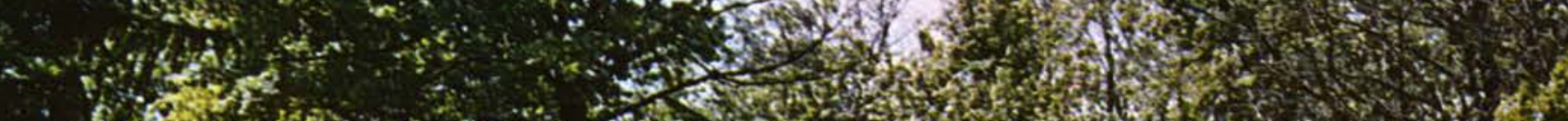

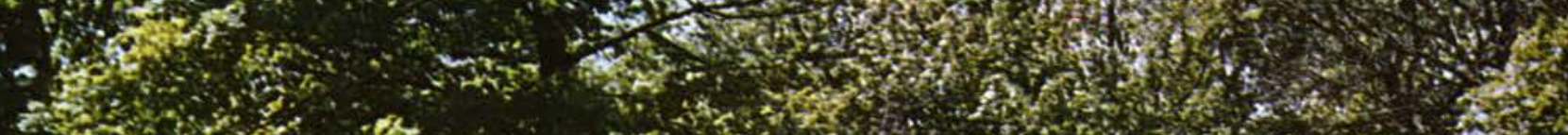

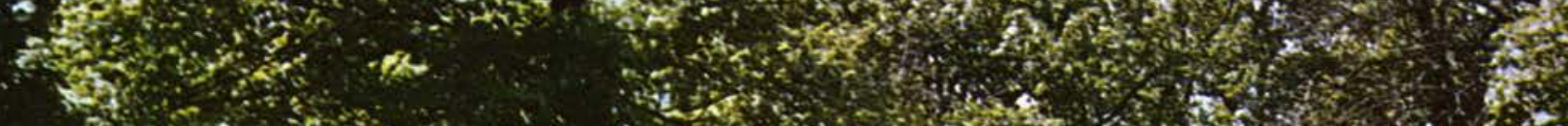

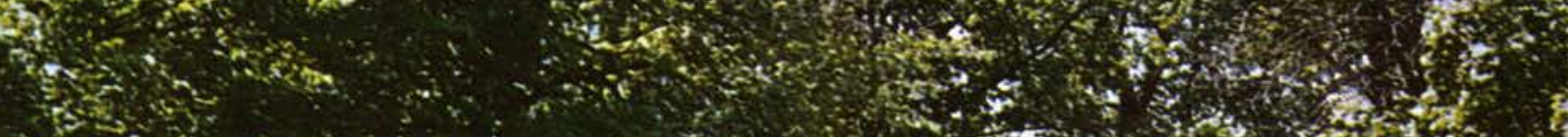

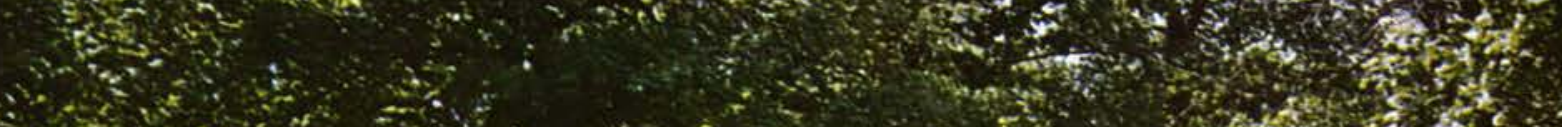

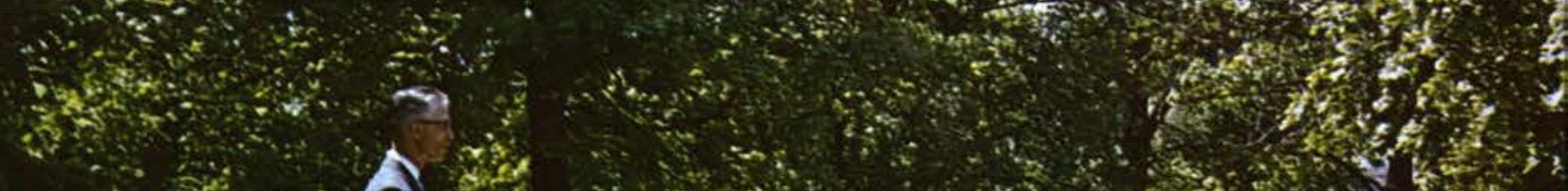
$\cos ^{2}-12 \mathrm{x}$

- 
(5)

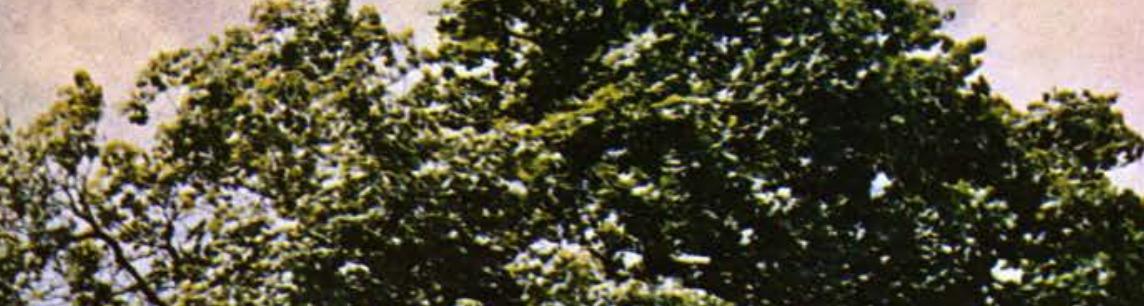

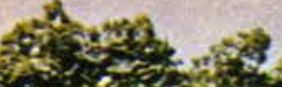

3.

(3)

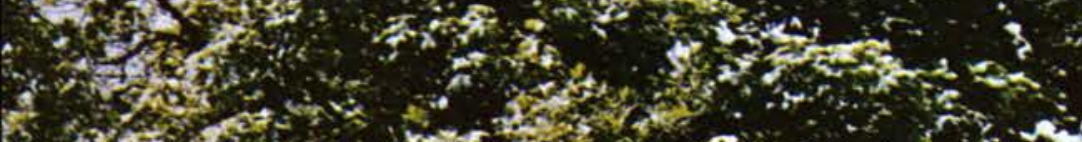

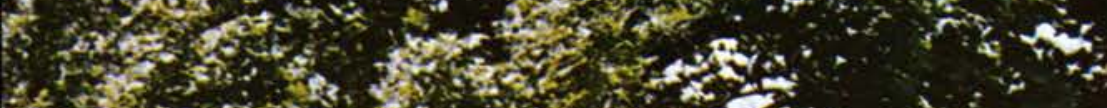

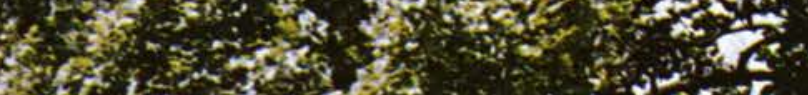

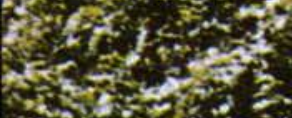
+5 है से

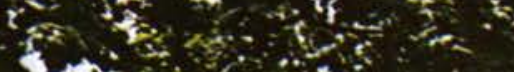
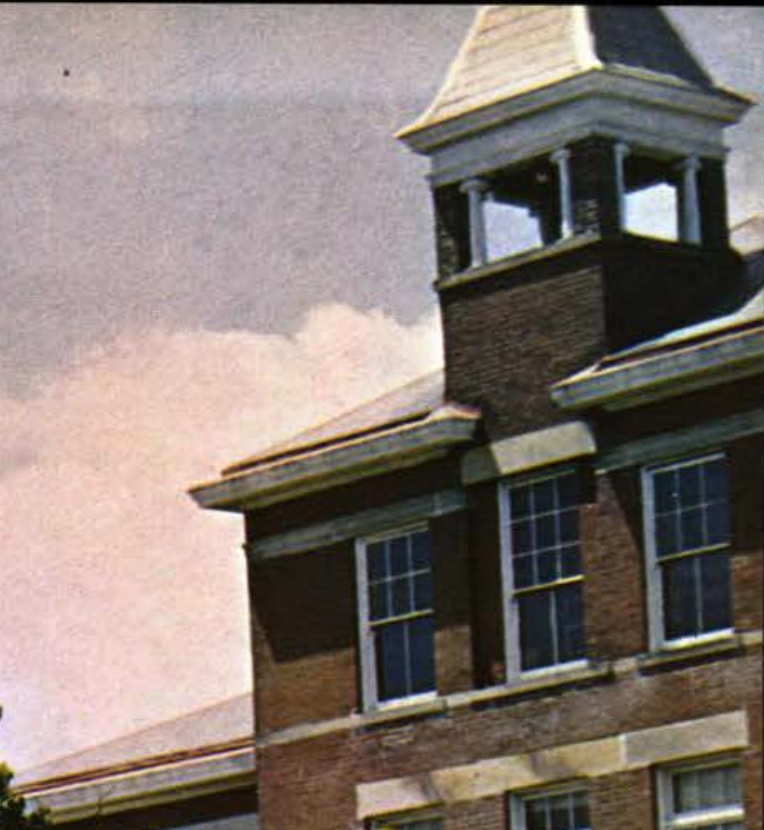
In chapel, special meetings, and in Christian service, the student is continually reminded of his responsibilities of living before others as Christ lived and of leading others to his Savior. In his efforts to do this he is constantly aware of his own inability and the limitless ability he has through the Holy Spirit. He finds fulfillment in thanksgiving and adoration of the Holy One who desires his worship.

The goal of his Christian life is not a bowed head, a harmonious voice, nor intellectual understanding. It is his effective communion with God, thanksgiving for all $\mathrm{He}$ is, and his submission to His will.

\section{Spiritual Life}

\section{Christian Service \\ Chapel \\ Special Meetings}




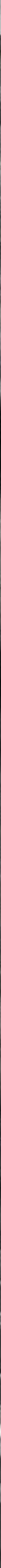




\section{Christian Service Council}

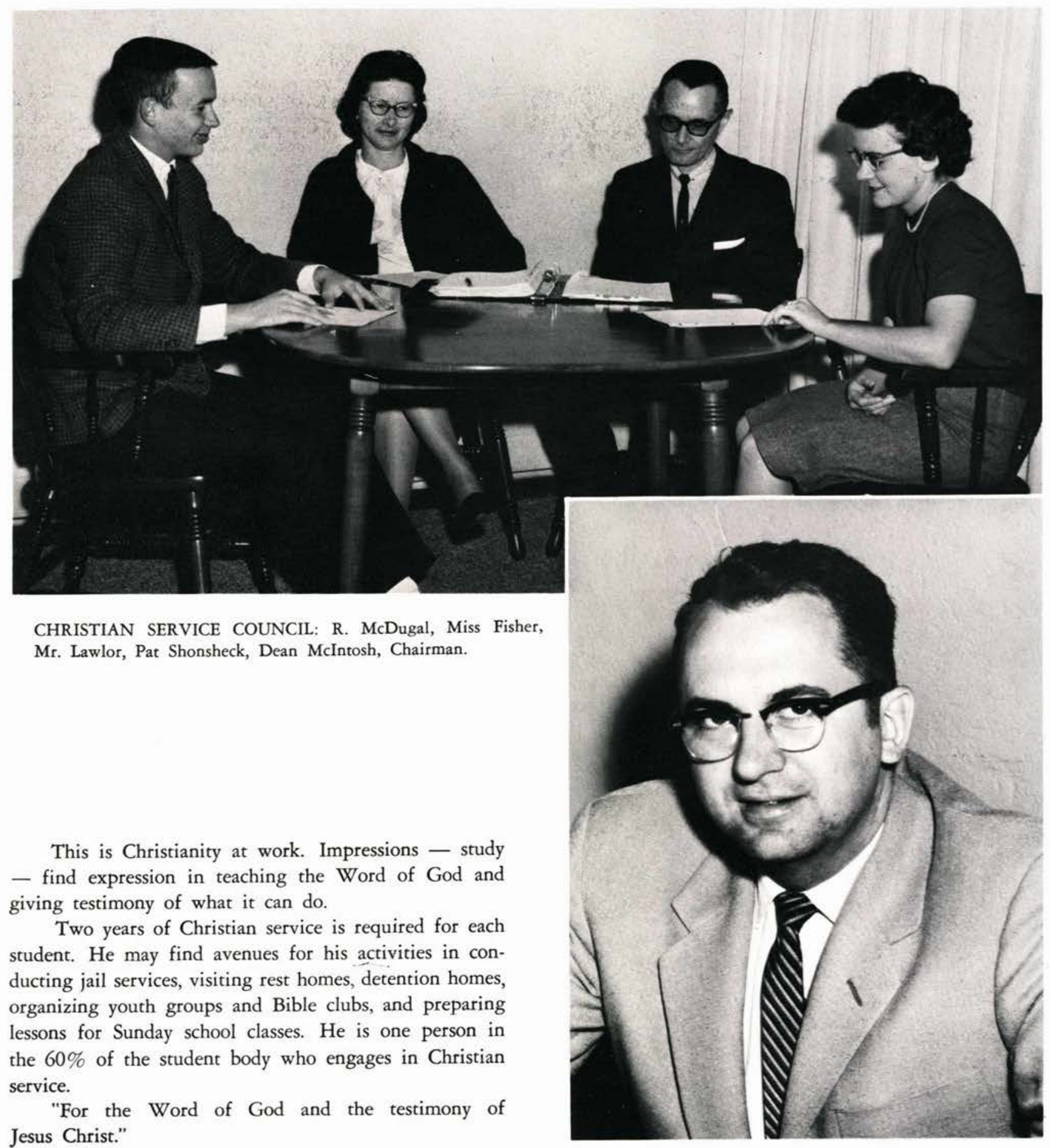




\section{Youth Workers \\ Sunday School Teachers}

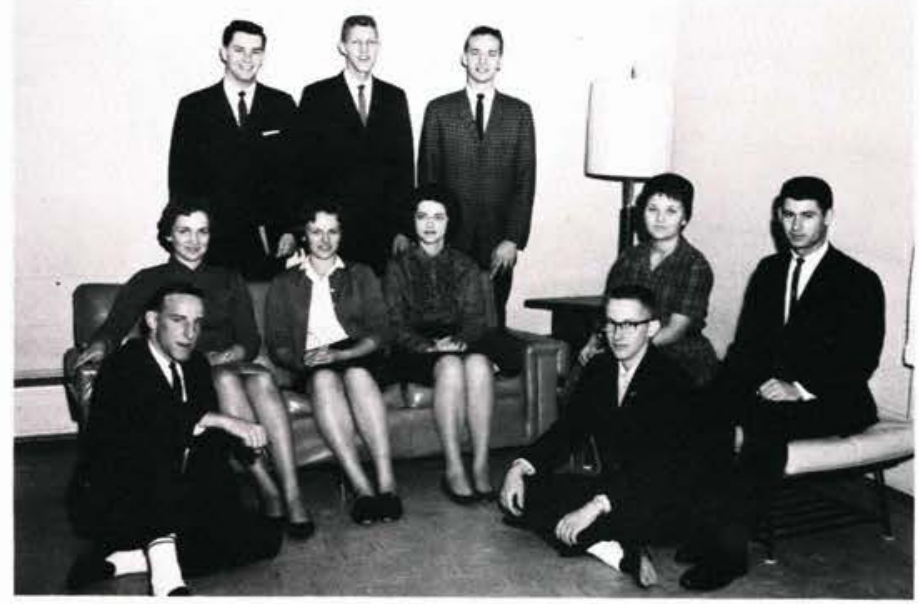

YOUTH WORKERS, Row One: D. Fetzer, D. Roost, D. Mitchell, B. Hammack, M. Karsnak, G. Griffin, S. Seevers. Row Two: R. Lamb, G. Fransted, J. Stockwell.

SUNDAY SCHOOL TEACHERS, Row One: D. Rockwell, J. Siganowich, K. Teeters. Row Two: D. Johns, P. Bird, D. Dunn, M. Greiner, A. Hoyte, A. Titus, J. Van Horn. Row Three: M. Tulloch, T. Nicklas, S. Fennell, B. McKeehan, D. Elmore, P. Nettleton, A. Patch, S. Kirisits, N. Wagner, C. Wilkins, S. Balke.
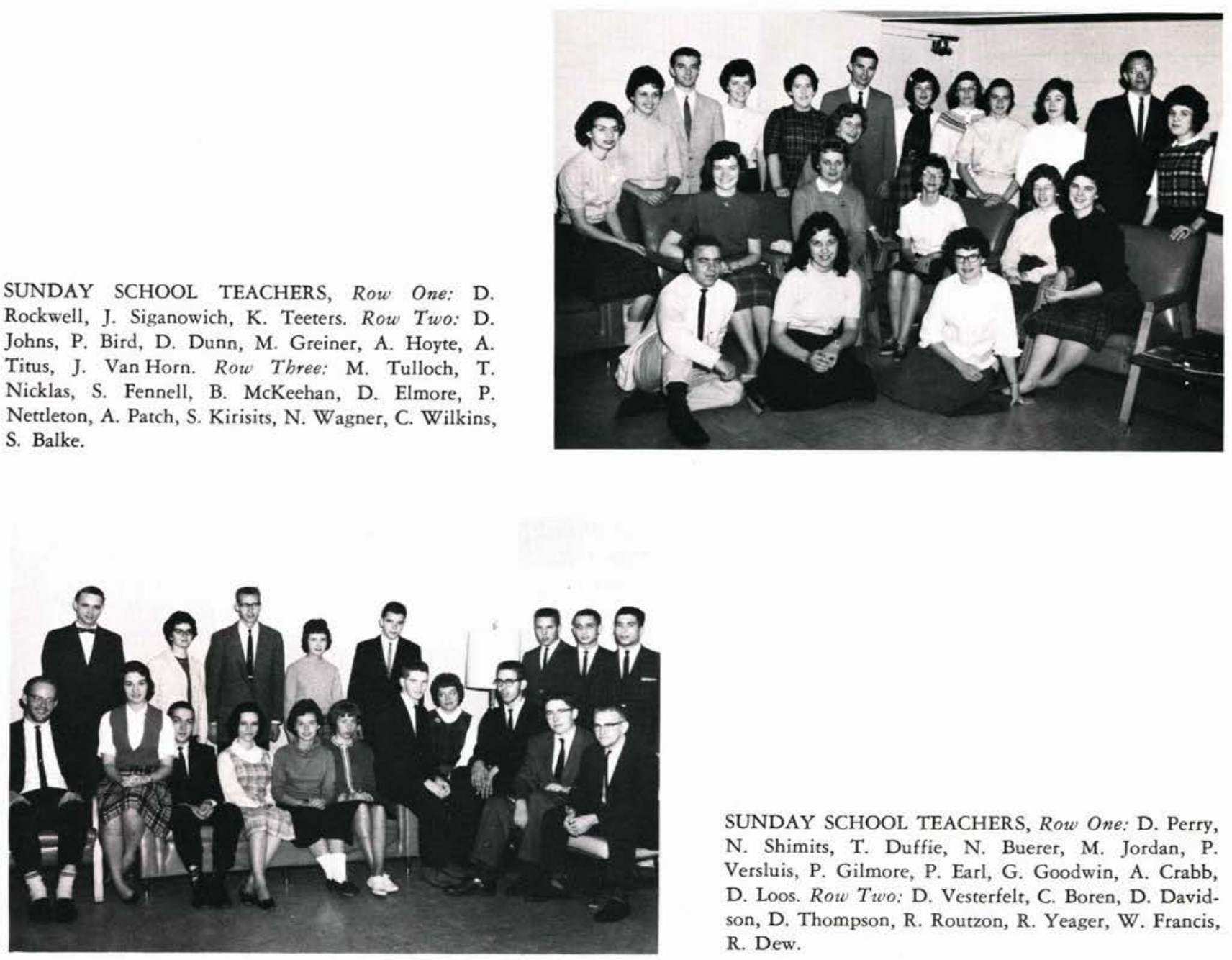

SUNDAY SCHOOL TEACHERS, Row One: D. Perry, N. Shimits, T. Duffie, N. Buerer, M. Jordan, P. Versluis, P. Gilmore, P. Earl, G. Goodwin, A. Crabb, D. Loos. Row Two: D. Vesterfelt, C. Boren, D. Davidson, D. Thompson, R. Routzon, R. Yeager, W. Francis, R. Dew. 


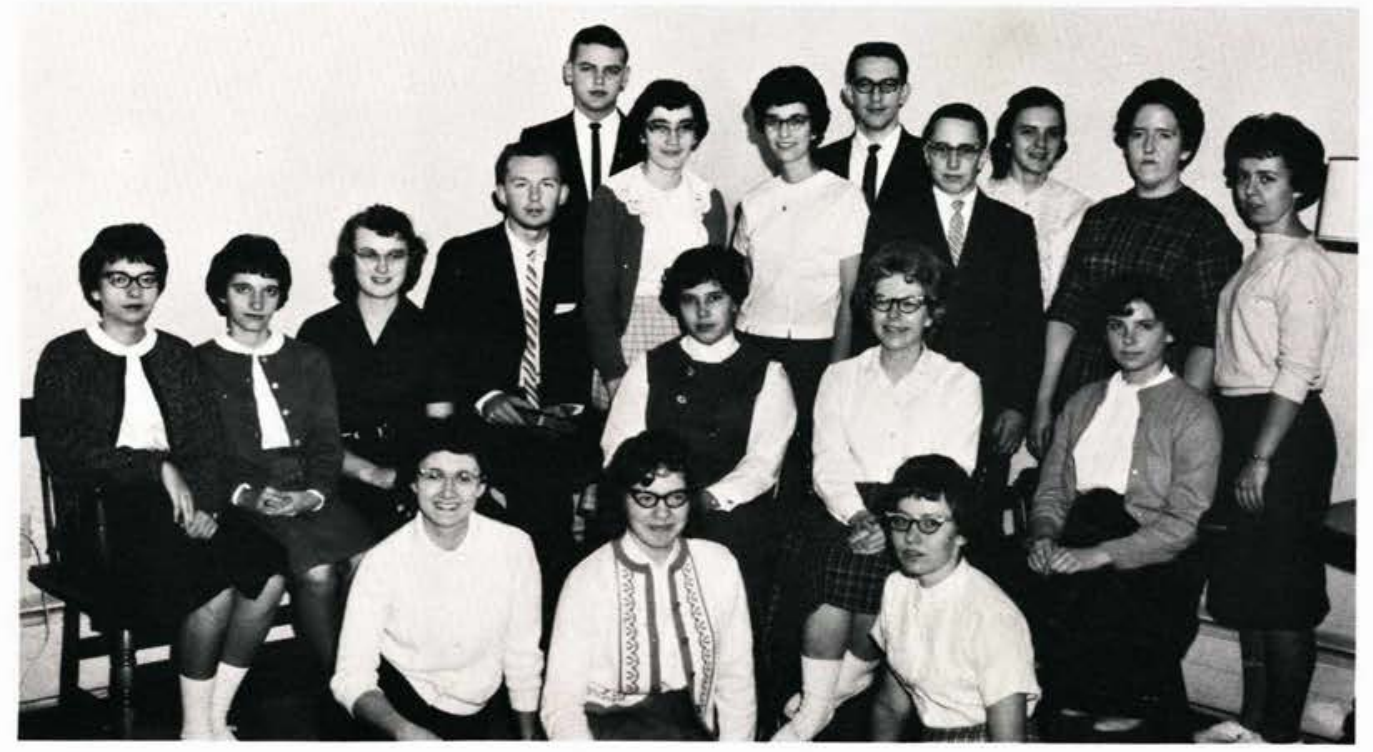

JUNIOR CHURCH DIRECTORS-Row One: C. Brown, M. Young, S. Addleman. Row Two:

G. Liechty, R. Millikin, E. Korlewitz. Row Three: P. Micka, J. Micka, M. Schmidt, P. Carlson,

G. Taylor, J. Bird, J. Humphreys, D. Rifenberick, K. Addleman, S. Kiristis, B. McKeehan,

P. Barrett.

\section{Junior Church Directors}

\section{Boys Club Leaders}

BOYS CLUBS LEADERS-Row One: R. McDugal, W. Meyers, D. Rockwell, M. Stevens. Row

Two: P. Gale, D. Prosser, D. Shue, W. Kirtland, D. Rice, L. Opitz, J. Stowell, P. Carlson.

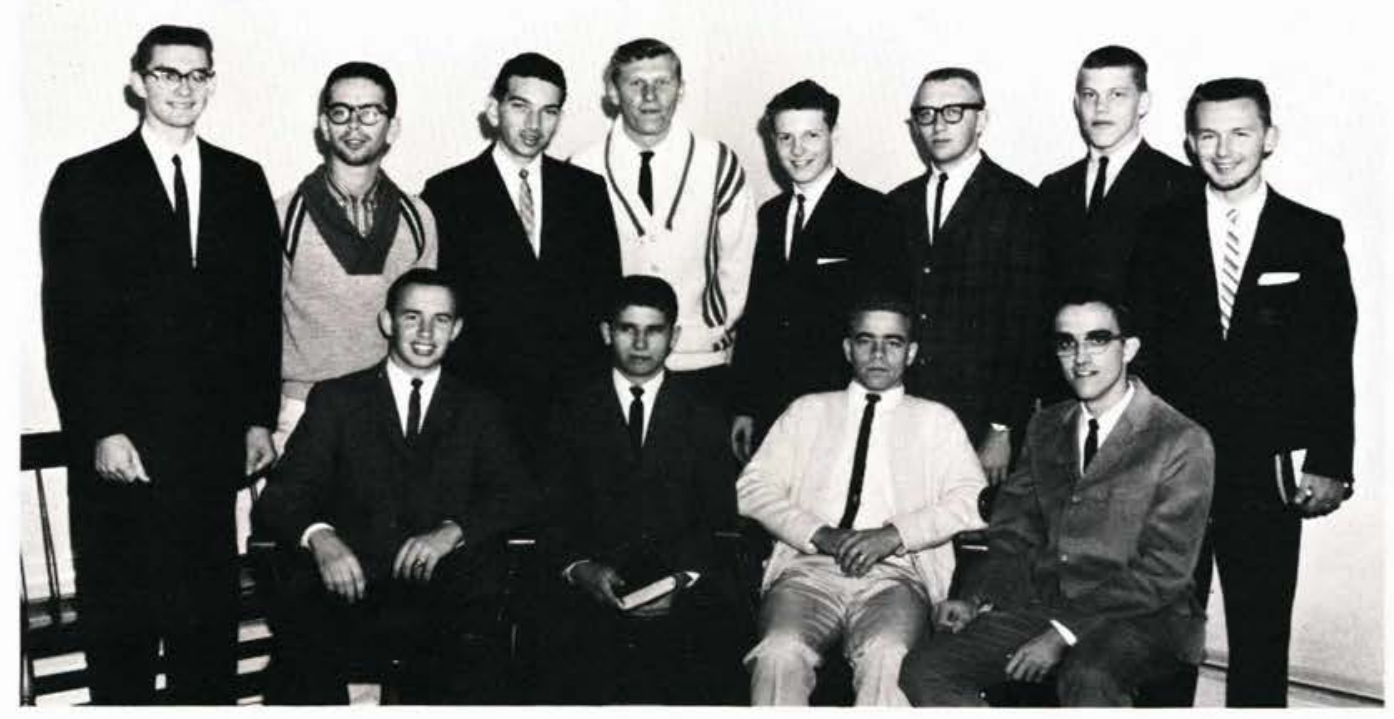




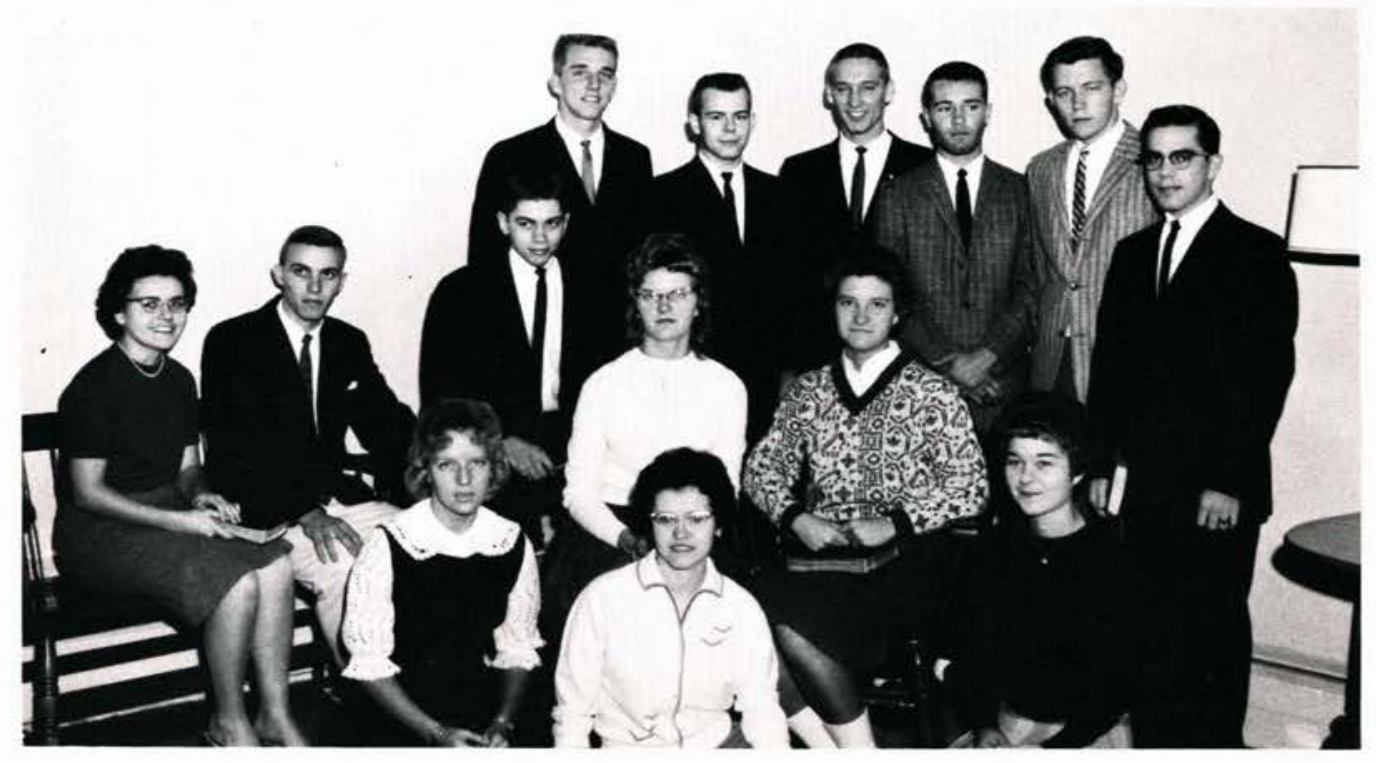

DETENTION HOME WORKERS, Row One: C. Henson, S. Ackerman, J. Dupre. Row Two: P. Schonscheck, D. Warren, M. Haseltine, J. McClintic, P. Kaster. Row Three: D. Werner, L. Czerniak, G. Culley, D. Walborn, J. Furry, D. Wilhite.

\section{Detention Home Workers}

\section{Jail Service Leaders}

JAIL SERVICE LEADERS, Row One: P. Bancroft, J. Barker, R. Butler. Row Two: L. Bayless, J. Petrie, M. Short. Row Three: S. Armitage, W. Meyers, G. Jacobs, T. Rotondi, T. Delanzo, D. Bales, M. Averitt, W. Allen, T. Ocheltree. Rou Four: T. Miller, P. Brower, J. Osborn, D. Nims, R. Davidson, D. Etner, J. Sprague.

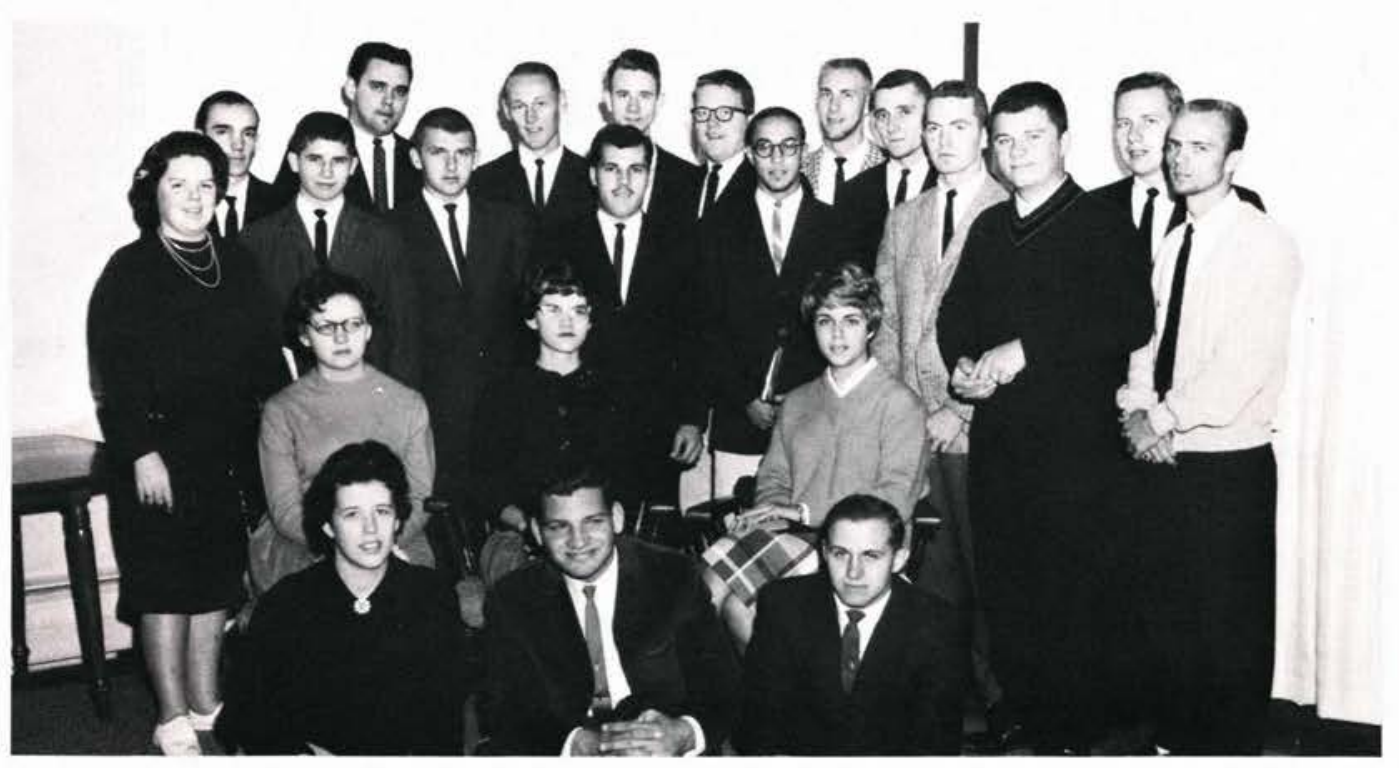




\section{Rest Homes - Street Meetings}

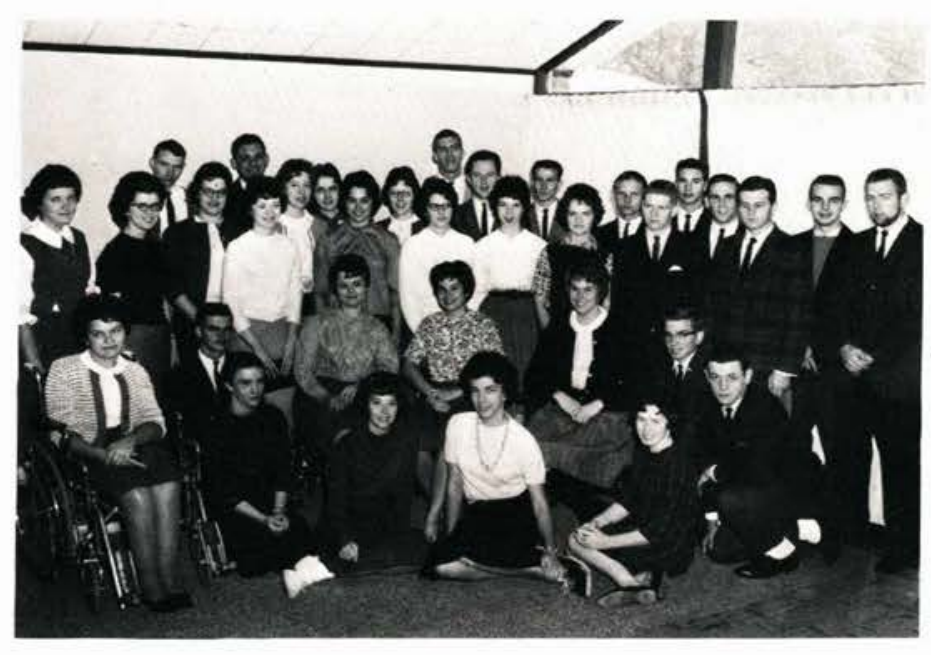

\section{Bible Clubs}

REST HOMES - Front Row: M. Brong, M. Konicek, B. Bieger, J. Addleman, G. Tullock. Second Row: R. Hoffeditz, M. Johnson, M. Bennett, P. Leunk, E. Acker. Third Row: J. Miller, J. Bryant, C. Carr, L. Sullivan, S. Gantz, M. Finley, L. Brooker, S. Wing, J. Colwell, A. McDonald, J. Bonnema, J. Hamilton. Fourth Row: D. Hoffman, J. Barker, C. Coppock, P. Albrecht, T. Shetler, B. Smith, R. Ray, D. Dean, D. Ober, D. Gordon, J. Zeigler.

STREET MEETINGS - Left to Right: D. Dunn, T. Bauer, B. Newman, P. Smith, B. Riter, D. Thorne, B. Thorne.
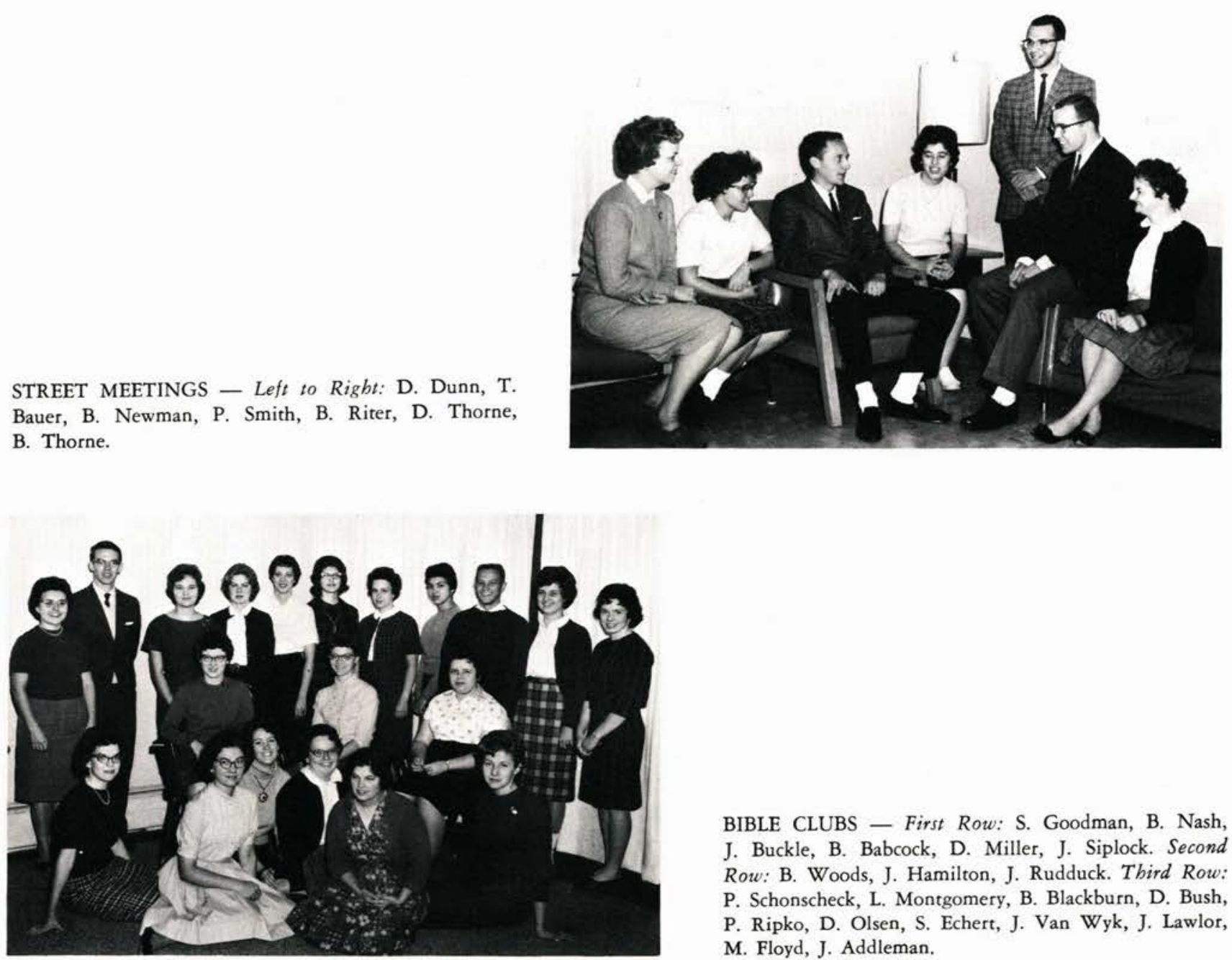

BIBLE CLUBS - First Row: S. Goodman, B. Nash, J. Buckle, B. Babcock, D. Miller, J. Siplock. Second Row: B. Woods, J. Hamilton, J. Rudduck. Third Row: P. Schonscheck, L. Montgomery, B. Blackburn, D. Bush, P. Ripko, D. Olsen, S. Echert, J. Van Wyk, J. Lawlor, M. Floyd, J. Addleman. 


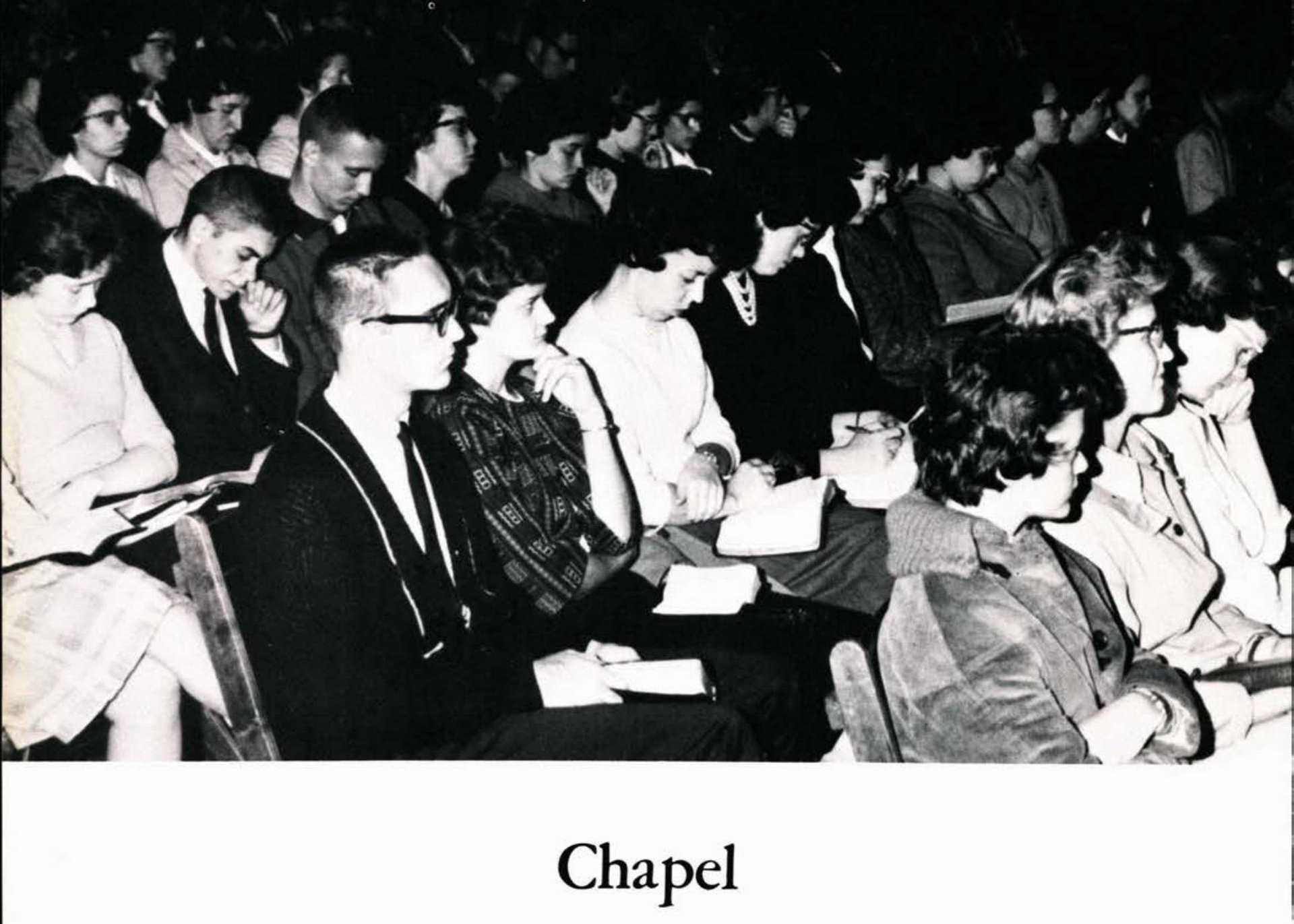


Each weekday morning at 10:00 AM, the students and faculty meet together for a time of inspiration and devotion. Due to the increase in the student body, the daily chapel service is held in the Alford Auditorium instead of Milner Chapel.

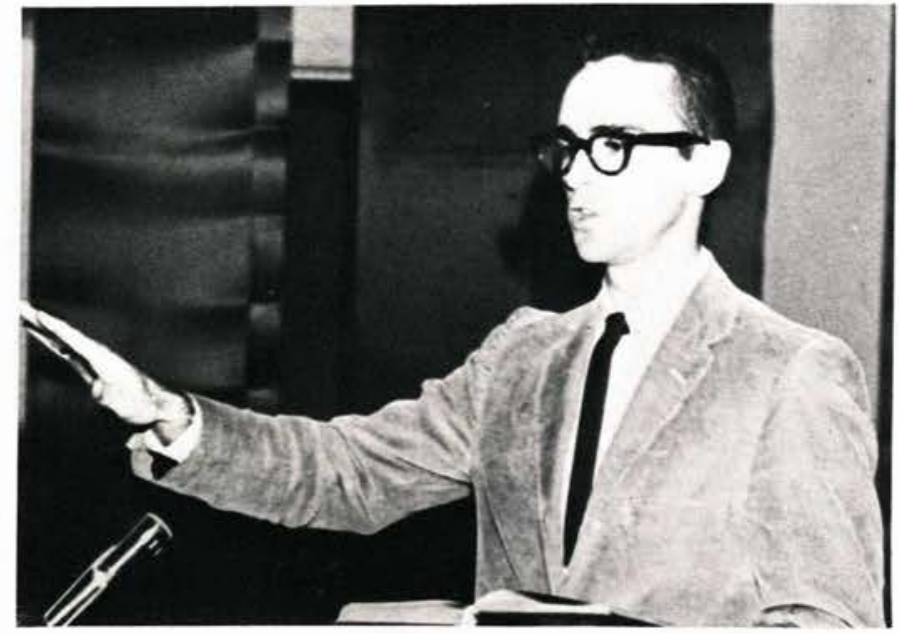

Sam Canine

John Morgan

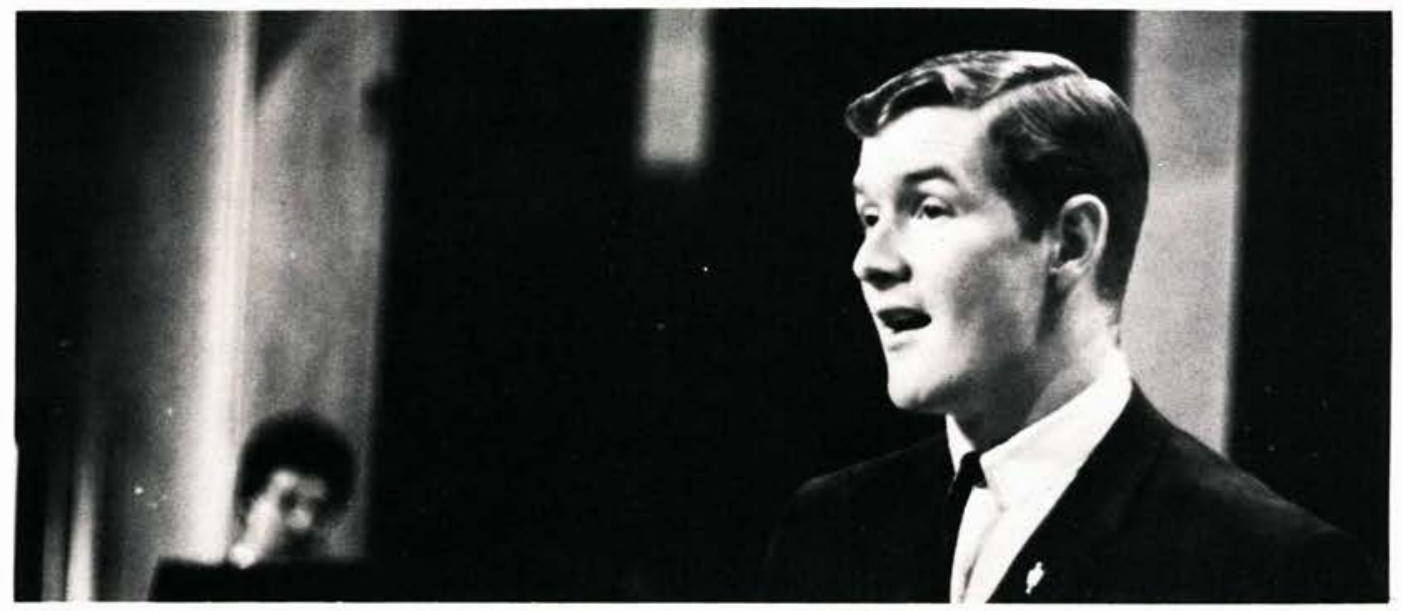




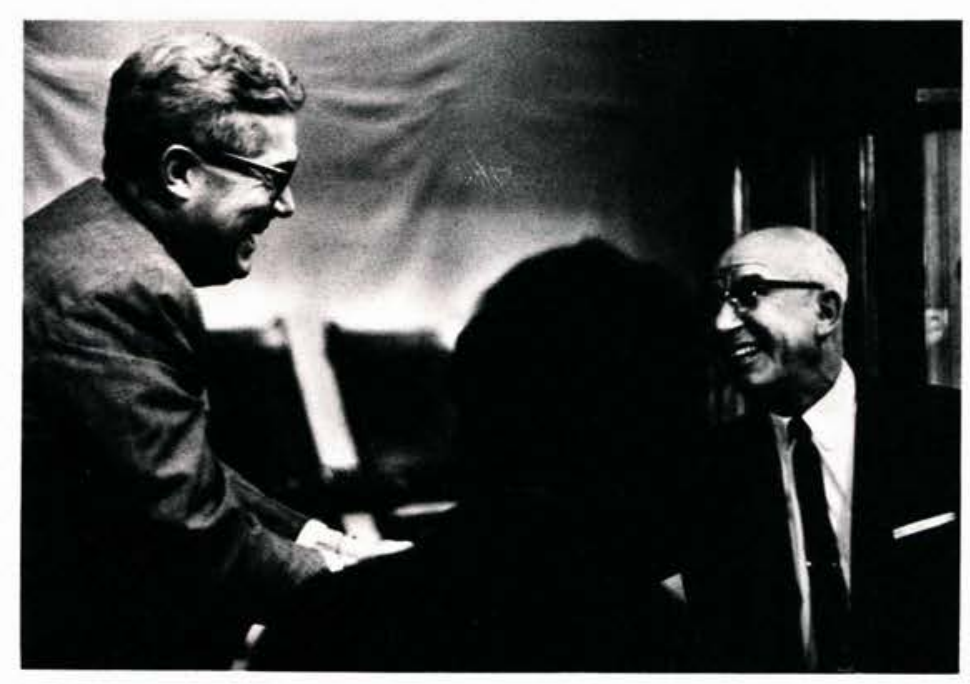

Jack Wyrtzen and Dr. Williams

Vicki Curcio, Soloist

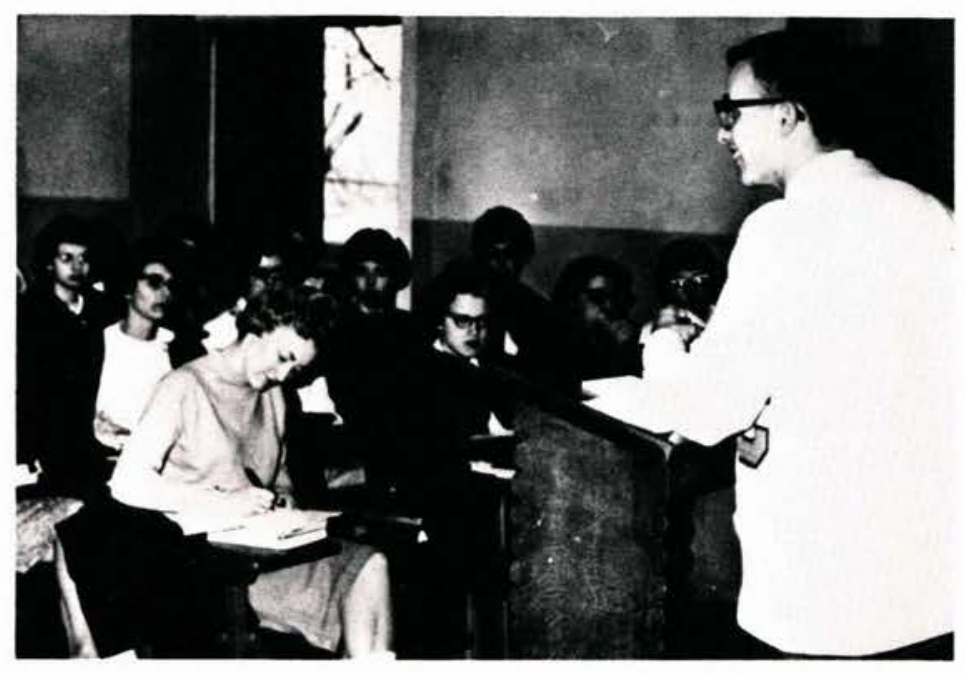

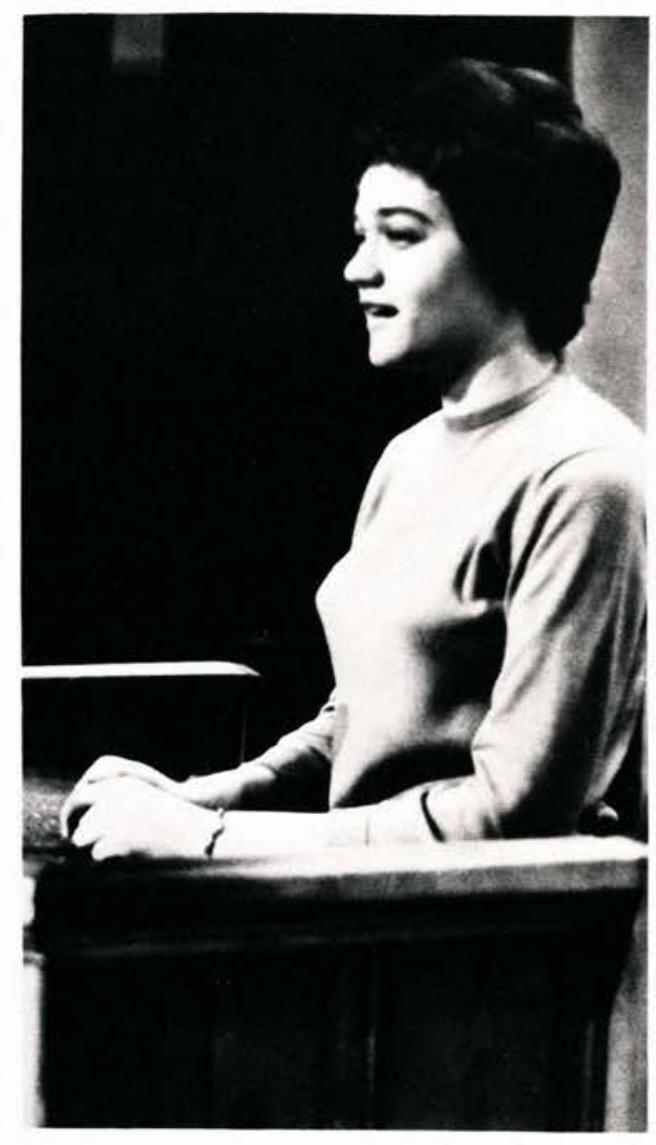

Junior Class Meeting 


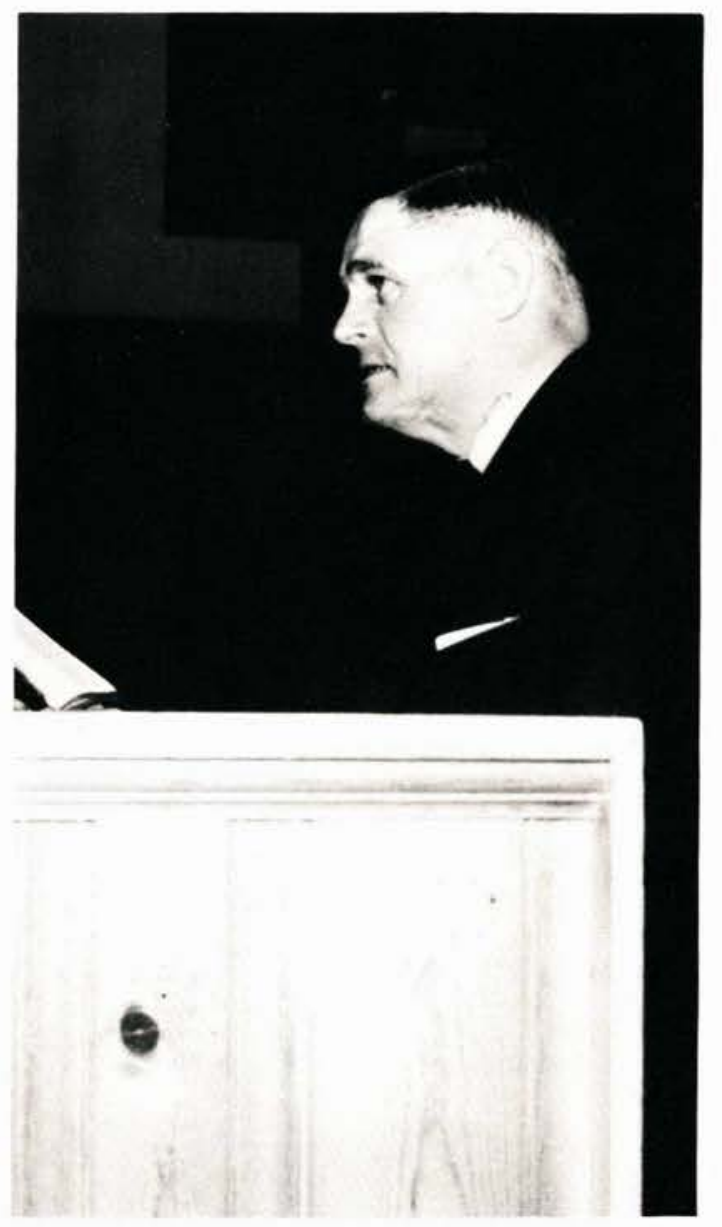

Thomas Lawrence

Christian service groups inform students of their endeavors through special chapel services. Supplementing the regular chapel services are class and faculty meetings which are divided between business and prayer.

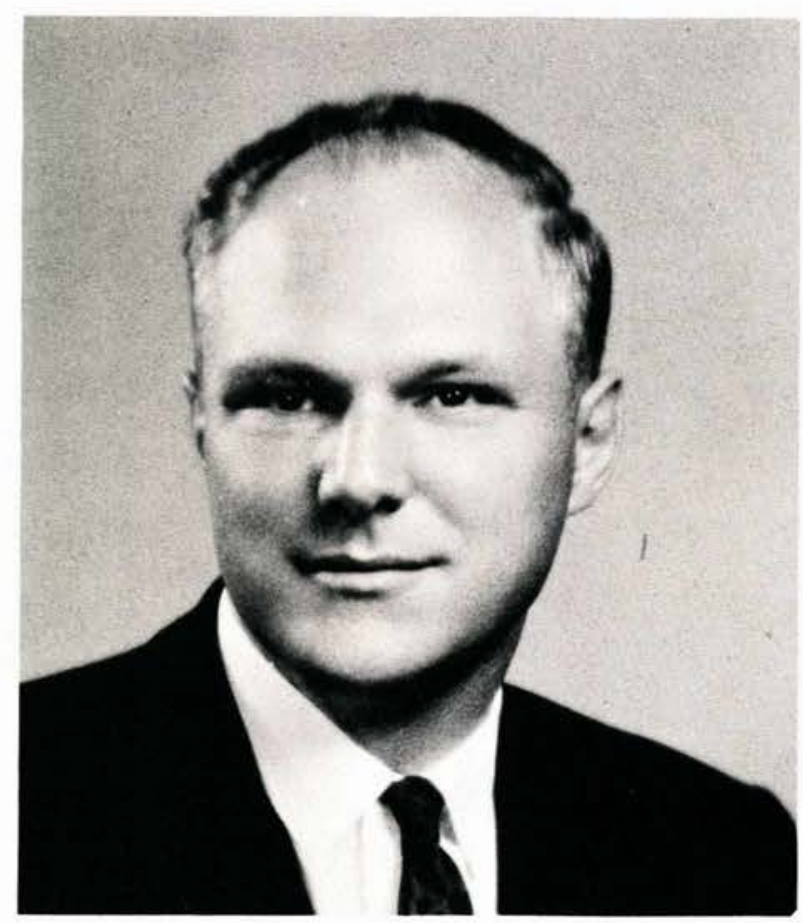

Dr. Lewis

Rev. Mr. Spiros Zodhiates

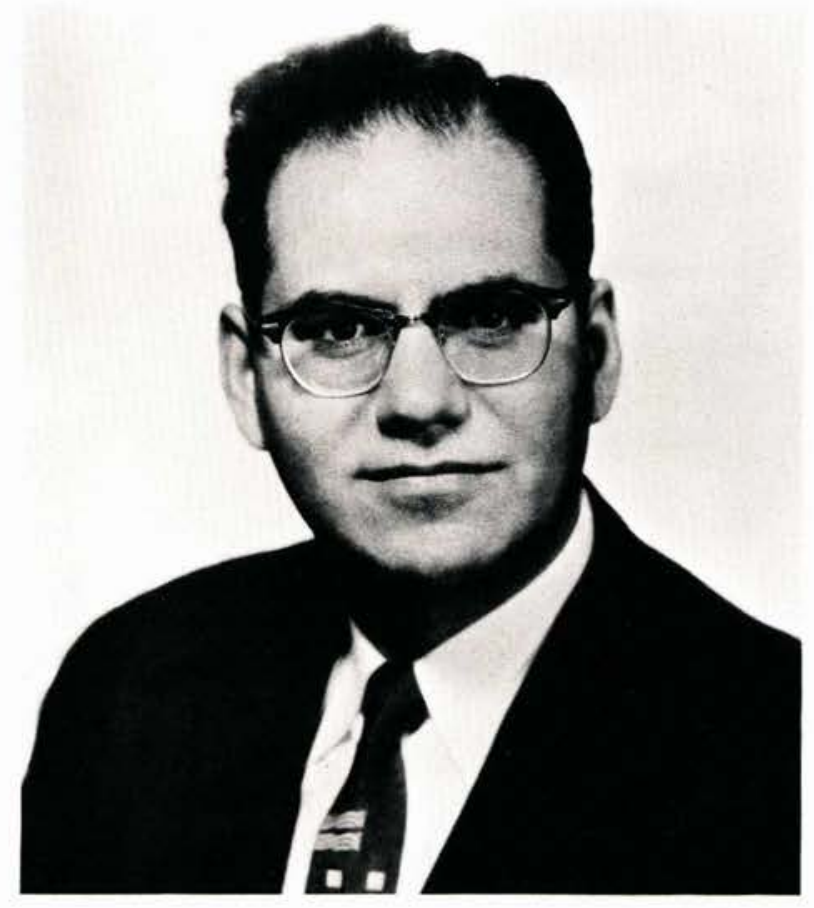




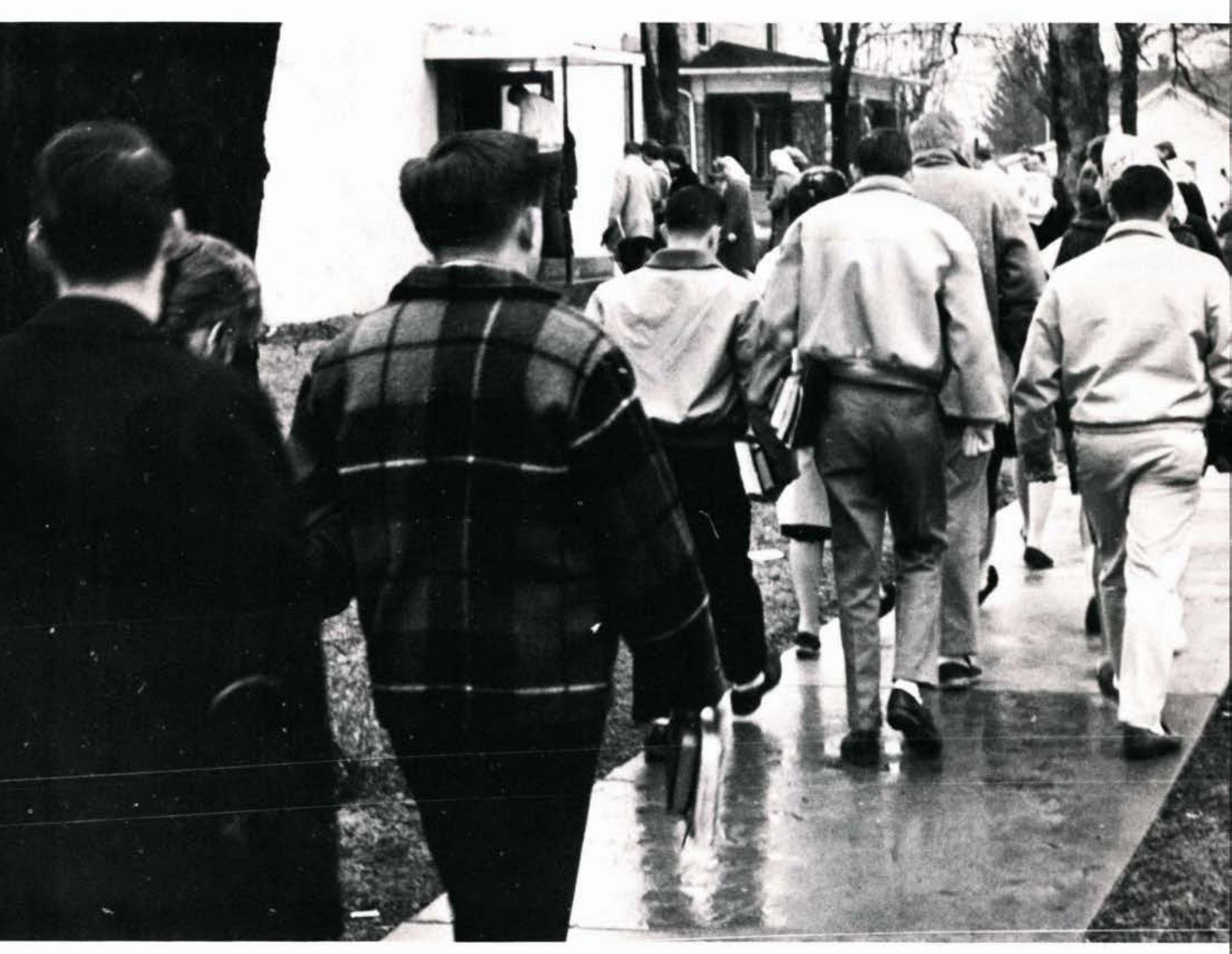

\section{Special Meetings}




\section{Special}

\section{Bible}

\section{Lectures}

Dr. John C. Whitcomb, Jr.

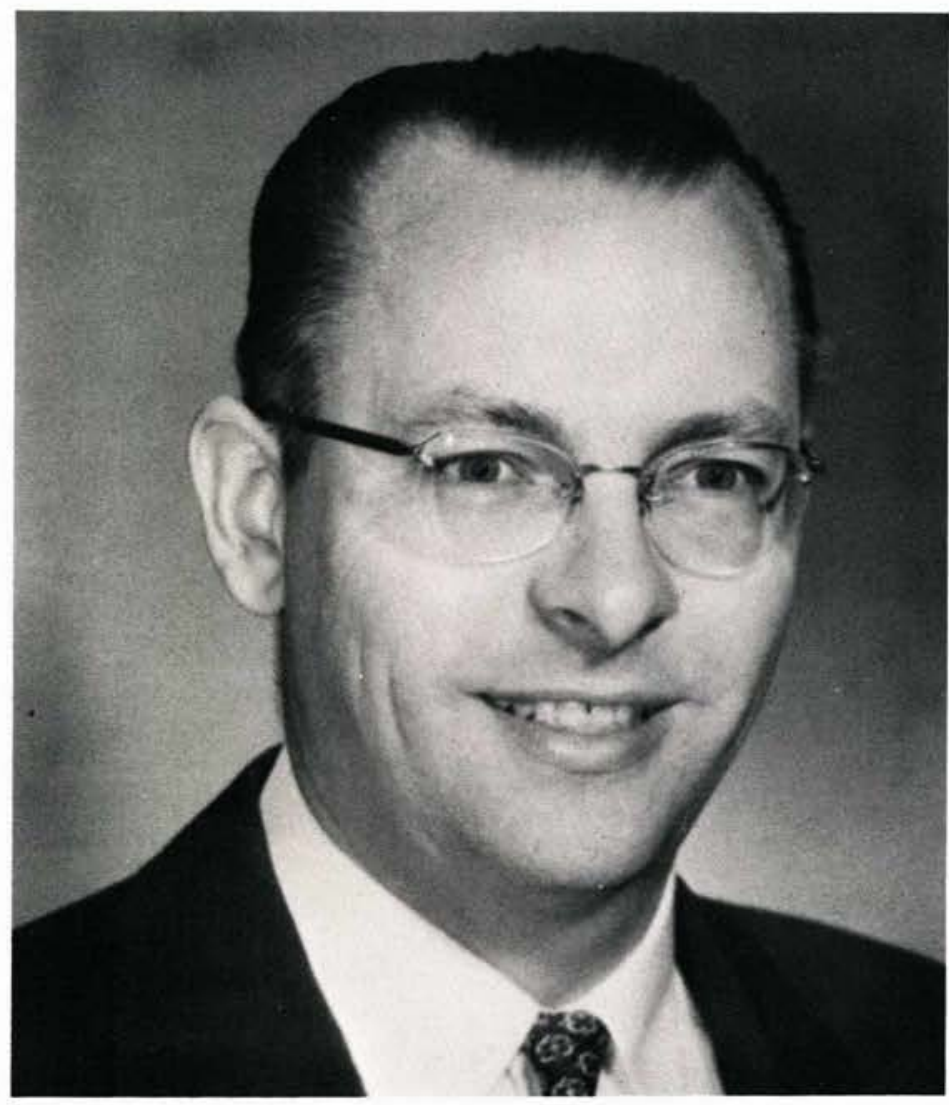

Adding to the academic and spiritual training of the students at Cedarville College were the special Bible lectures held November 7-9. The featured speaker of these meetings was Dr. John C. Whitcomb of Grace Theological Seminary, Winona Lake, Indiana. Lectures were delivered by Dr. Whitcomb at the $10 \mathrm{a} . \mathrm{m}$. chapel hour and nightly at 7:00 in the Alford Auditorium. A question and answer period followed the evening services for those who were interested. Subjects of the lectures centered around evolution, the Genesis flood, creation, science, and the Scriptures. These lectures were profitable in adding to the students' scientific background in relation to the Scriptures.

With a B.A. major in Ancient and European history, Dr. Whitcomb graduated with honors from Princeton University in 1948. After graduating in 1951 with his B.D. from Grace Theological Seminary, he then received his Th.M. in 1953 and his Th.D. in 1957. $\mathrm{He}$ is now professor of Old Testament and Hebrew at Grace Theological Seminary and serves as director of post-graduate studies there.

As a world wide traveler, Dr. Whitcomb has journeyed through the Near East and much of Western Europe. In missionary work, Dr. Whitcomb has visited mission stations in Peru and helped in establishing a church in Puerto Rico under the Foreign Missionary Society of the Brethren Church.

Dr. Whitcomb has written articles for several theological journals and Bible dictionaries. Darius the Mede: A Study in Historical Identification, a defense of the historicity and authenticity of Daniel, was authored by him. He also co-authored with Dr. Henry M. Morris The Genesis Flood: The Biblical Record and Its Scientific Implications, a defense of the universality of the flood.

Commentaries on Ezra, Nehemiah, and Esther were written by him for the Wycliffe Bible Commentary. His chronological charts are used by colleges and seminaries throughout the western hemisphere. 


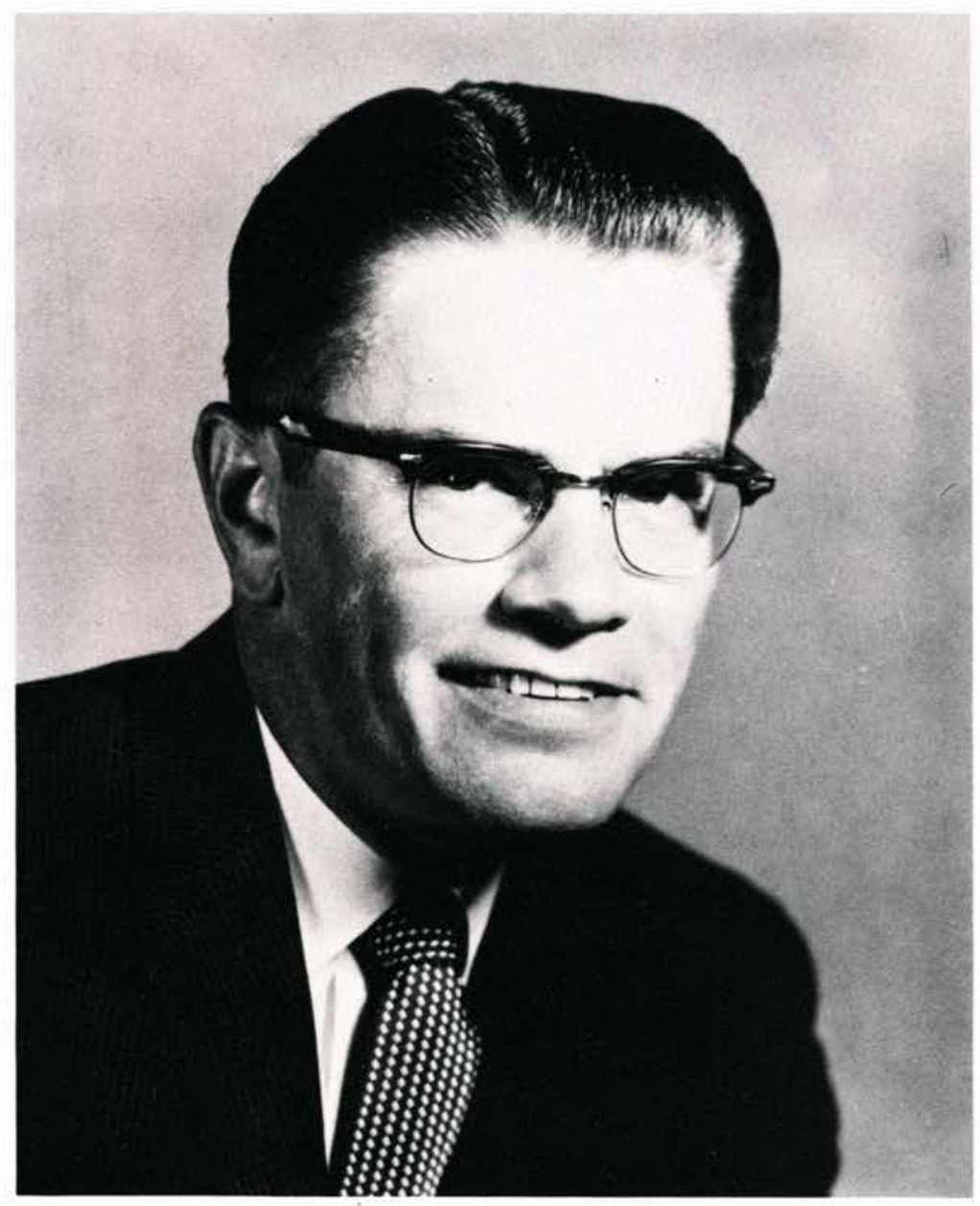

\section{Fall}

\section{Evangelistic} Services

Rev. Robert L. Sumner

Pastor

Temple Baptist Church

The speaker for the Fall Evangelistic Services (September 24-28) was the Reverend Robert Sumner, pastor of the Temple Baptist Church, Portsmouth, Ohio. Pastor Sumner began his evangelistic work in 1954 and has become quite well-known in his field.

In addition to this, he has authored numerous articles, pamphlets, and books including The Church On Fire. At present he is contributing editor of The Sword of the Lord, published by John R. Rice, and has served as associate editor of this magazine. 


\section{Spring}

\section{Bible Lectures}
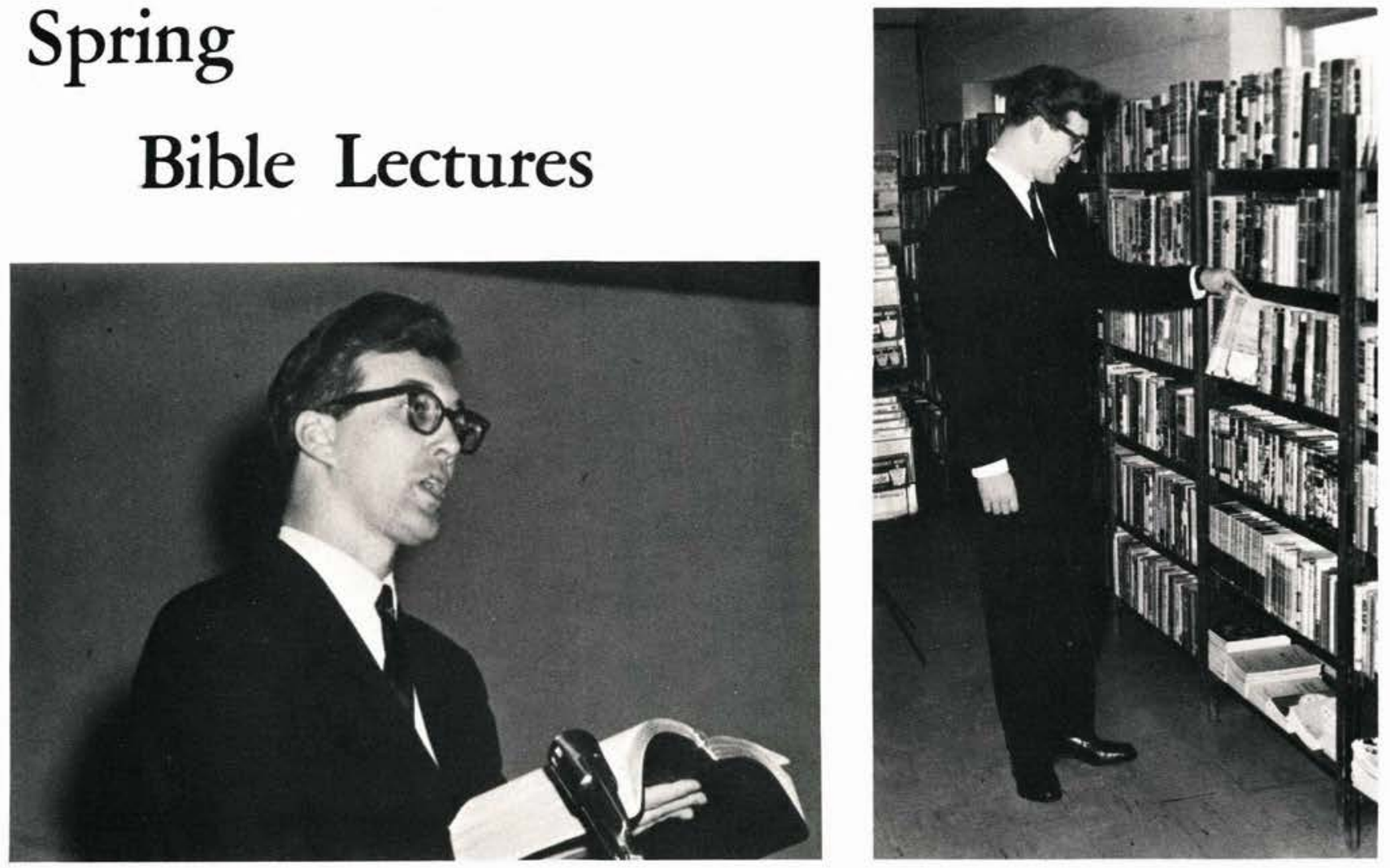

Pastor David Moore, Waterloo, Iowa, Speaker

Pastor Moore makes himself at home with us.

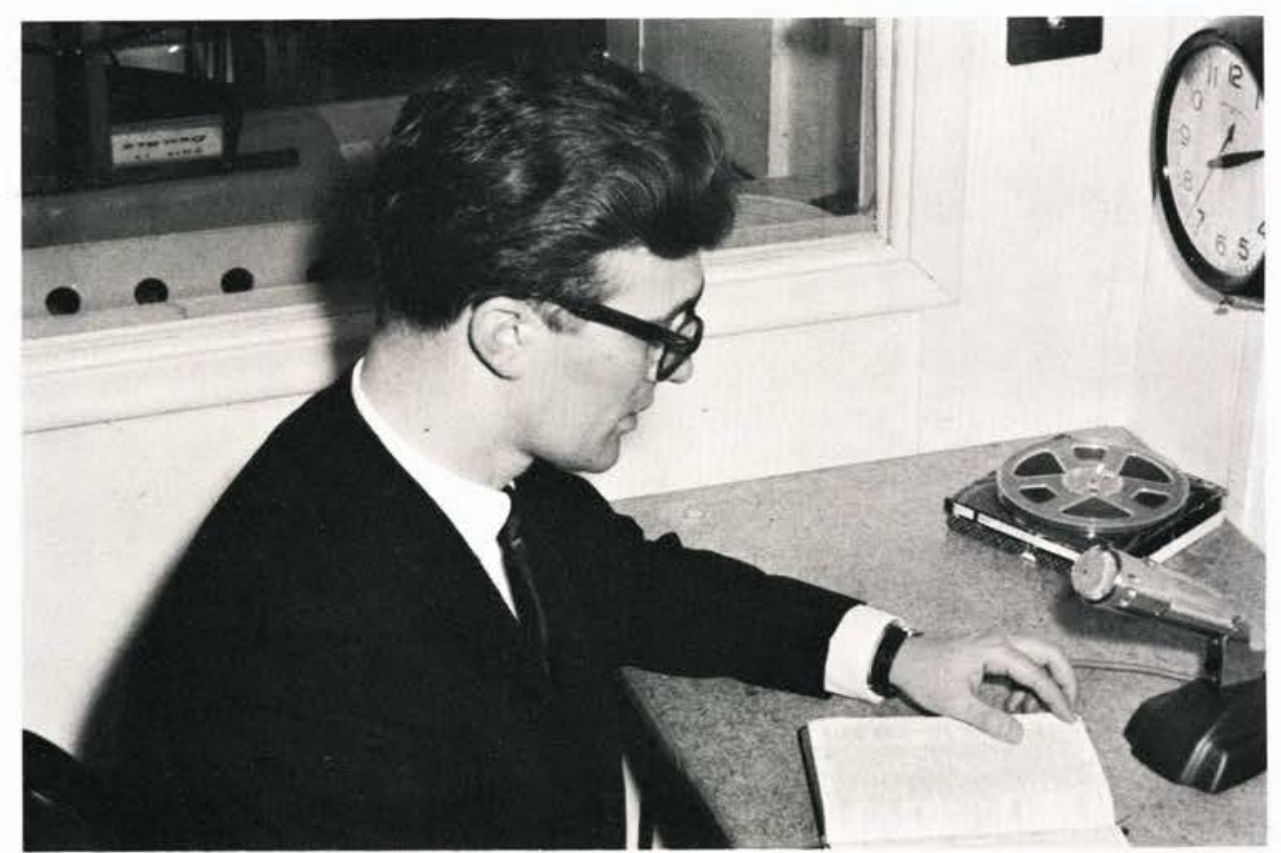

Recording some messages for future reference, Pastor Moore leaves a permanent impression with us. 


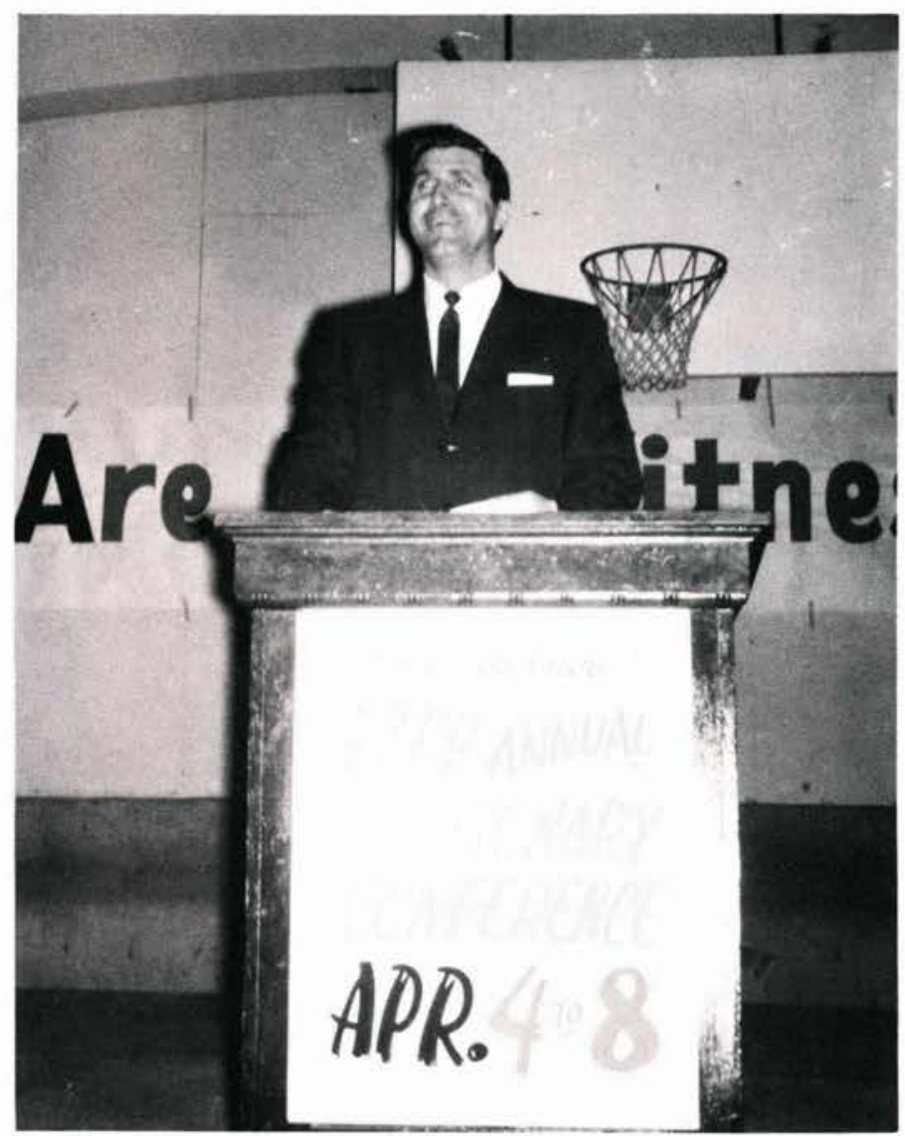

Rev. Robert Smith, Evangelical Baptist Mission

\section{Missionary \\ Conference}

"Ye are my witnesses" was the theme of the annual Missionary Conference held April 4 to 8 . The Fellowship for World Missions prayer group cooperated with the Grace Baptist Church of Cedarville in sponsoring the annual conference. It was held in the Alford Memorial auditorium for the first time this year. Featured speakers included: Rev. Blakely Rogers from Associatioin of Baptists for World Evangelism, Rev. Robert Smith from the Evangelical Baptist Mission, Rev. Emmanuel Woods from Brazil, Dr. Kenneth Good from the Fellowship of Baptists for Home Missions, Rev. Ron Meznar from Brazil, and Rev. Verne Kirby from Kentucky under Baptist Mid-Missions.

Dr. Kenneth Good from the Fellowship of Baptist for Home Missions answers a question presented by the audience.

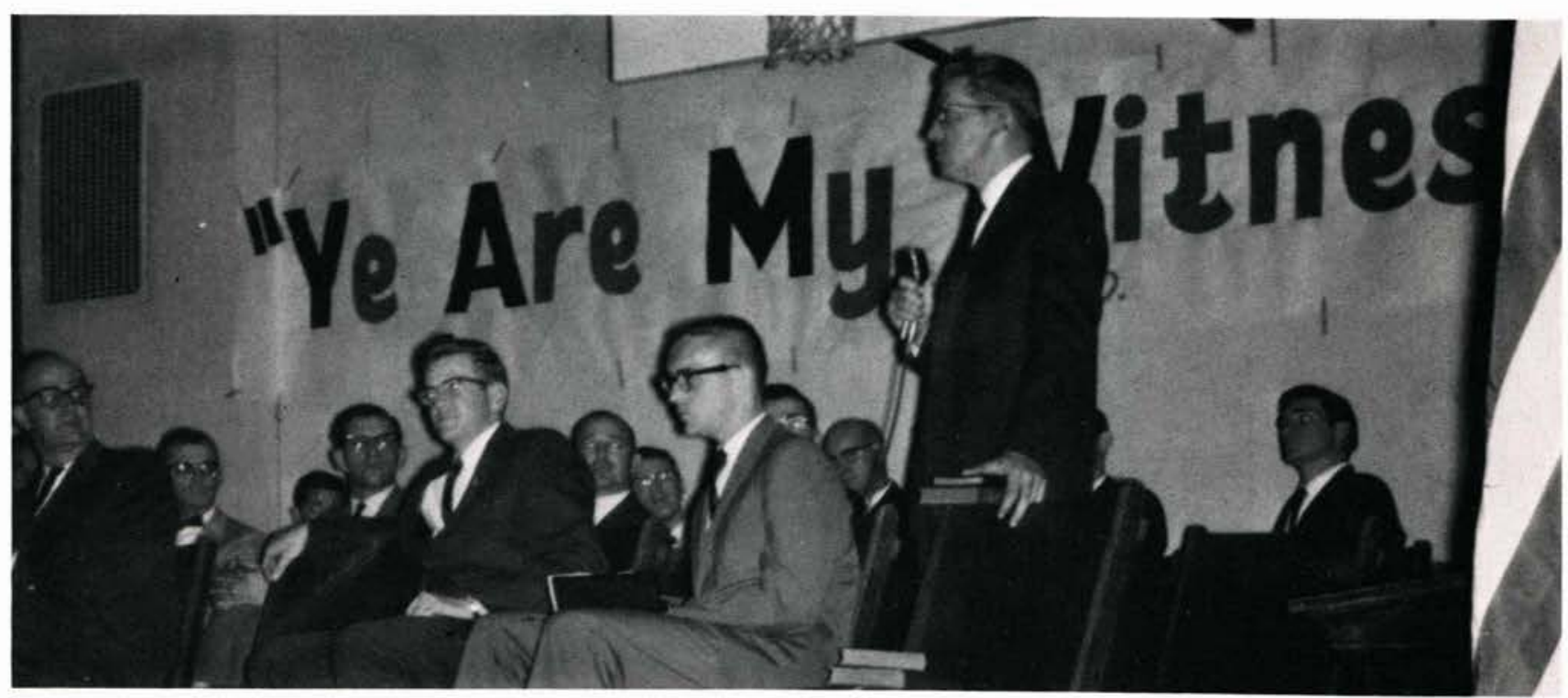




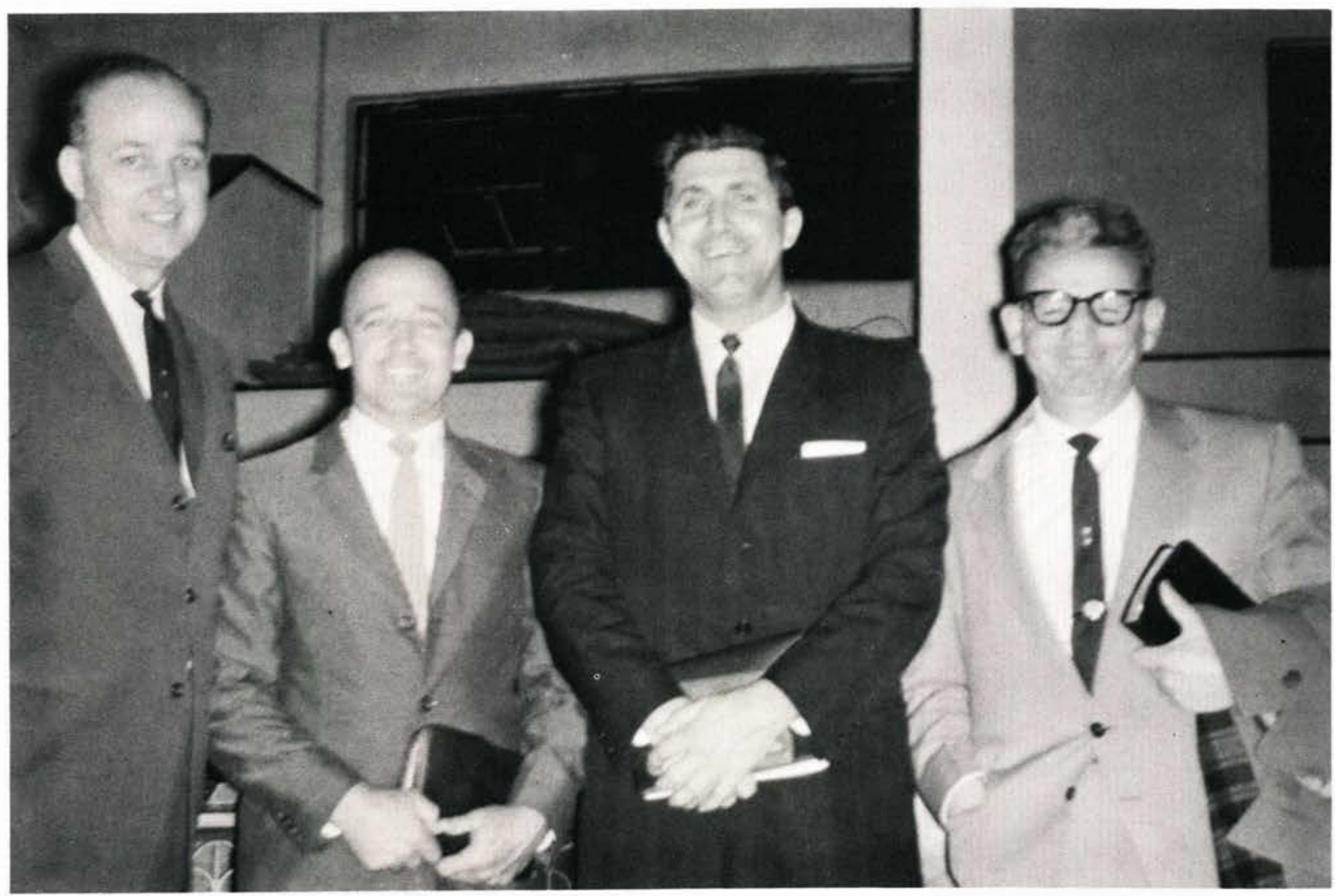

Left to right: Rev. Don Moffat, Rev. Verne Kirby, Rev. Robert Smith, Rev. Emmanuel Woods.

Rev. Verne Kirby

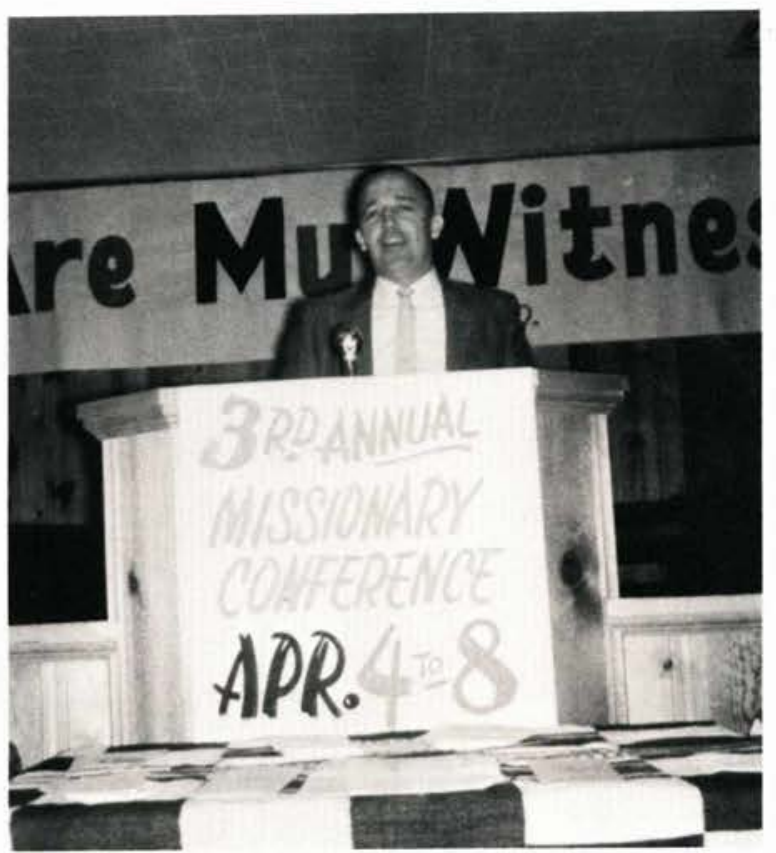

Mr. Henderson, Rev. E. Woods

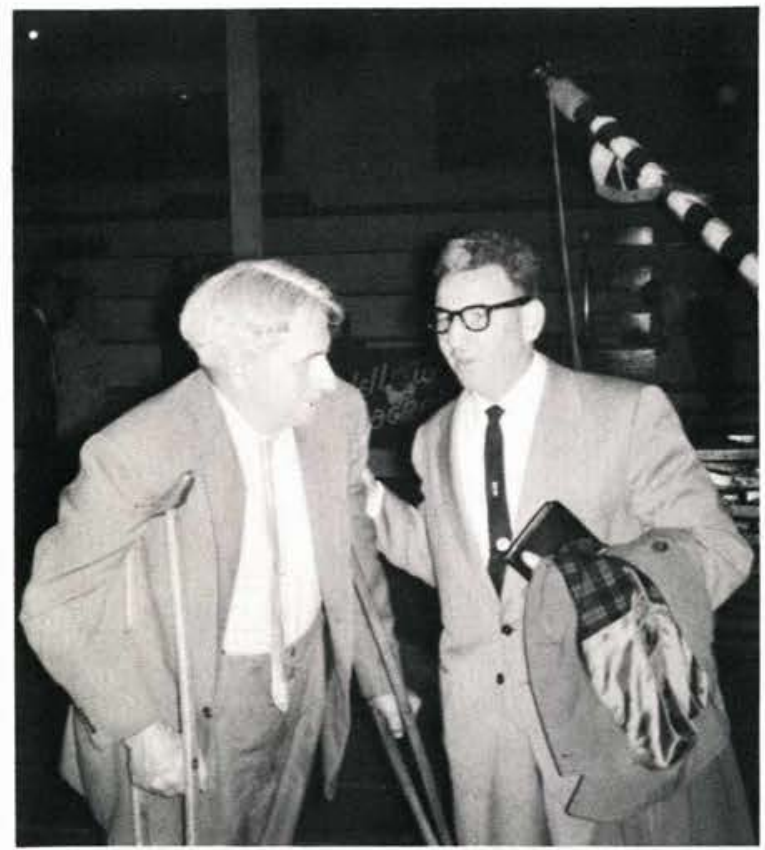


Possessing the gregarious tendencies of man, the Cedarville College student finds himself a part of a unique society. He must adjust himself to campus life, to a limited number of people, and he must choose from a certain number of activities outside the classrooms to which he will devote his extra time and energy. For some this is a job, and for others it means channeling his talents in club participation. He thus prepares for social events and in turn develops his own particular society. This leads him into a wide range of roles from a boisterous basketball game to the calm sophistication of an afternoon tea or the formality of a banquet.

But in all his activities, it is his goal to perpetuate the testimony of Jesus Christ. He seeks to personify the motto of his school through the practice of Christian ethics in every phase of his college career.

\section{Activities}

\section{Organization}


- $y^{L}$ U y 


\section{Social Committee}

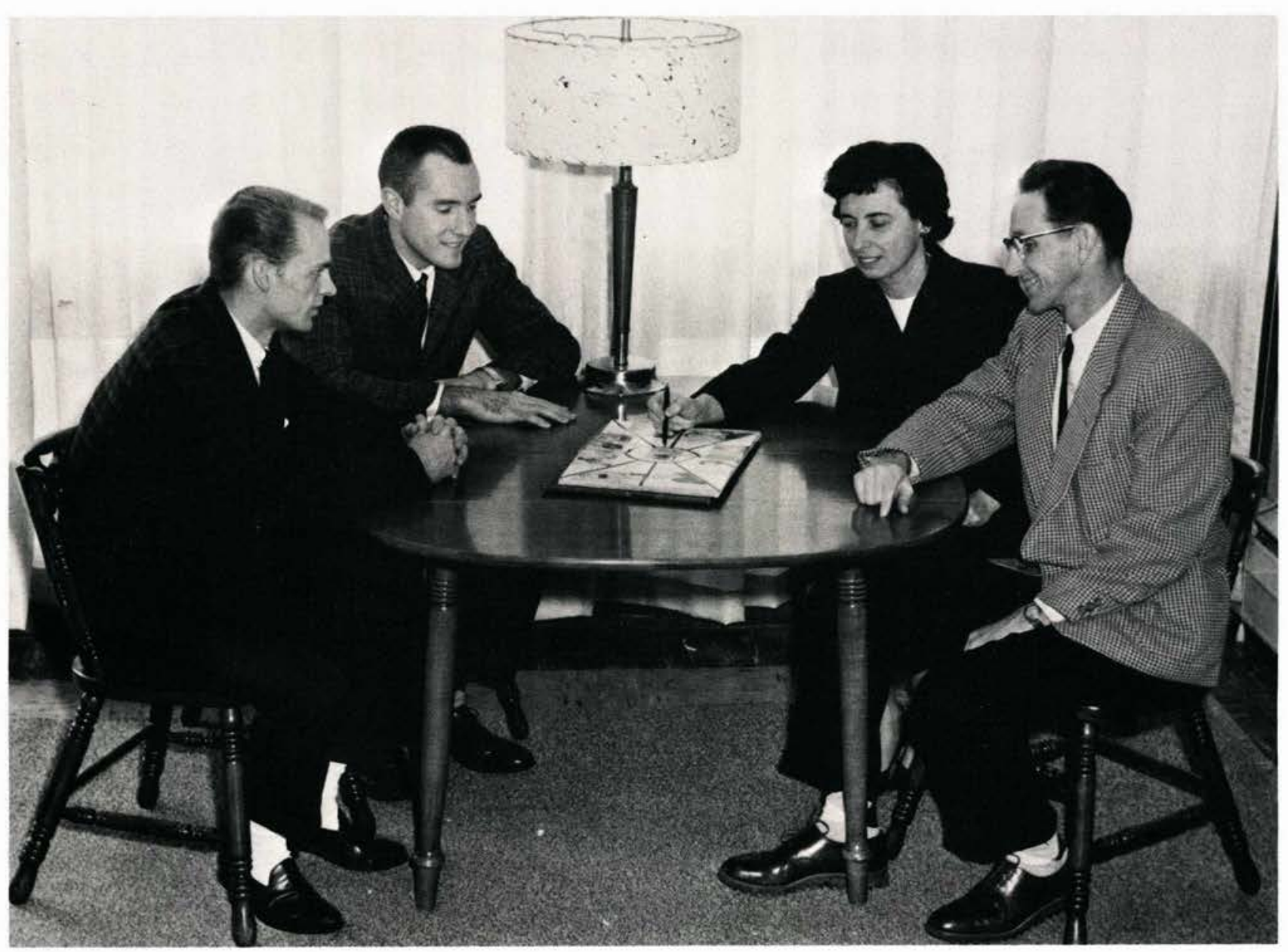

Left to Right: Ted Ocheltree, Mr. Lane Moody, Miss Joy Mackay, Mr. William Thornton. 


\section{Student Council}

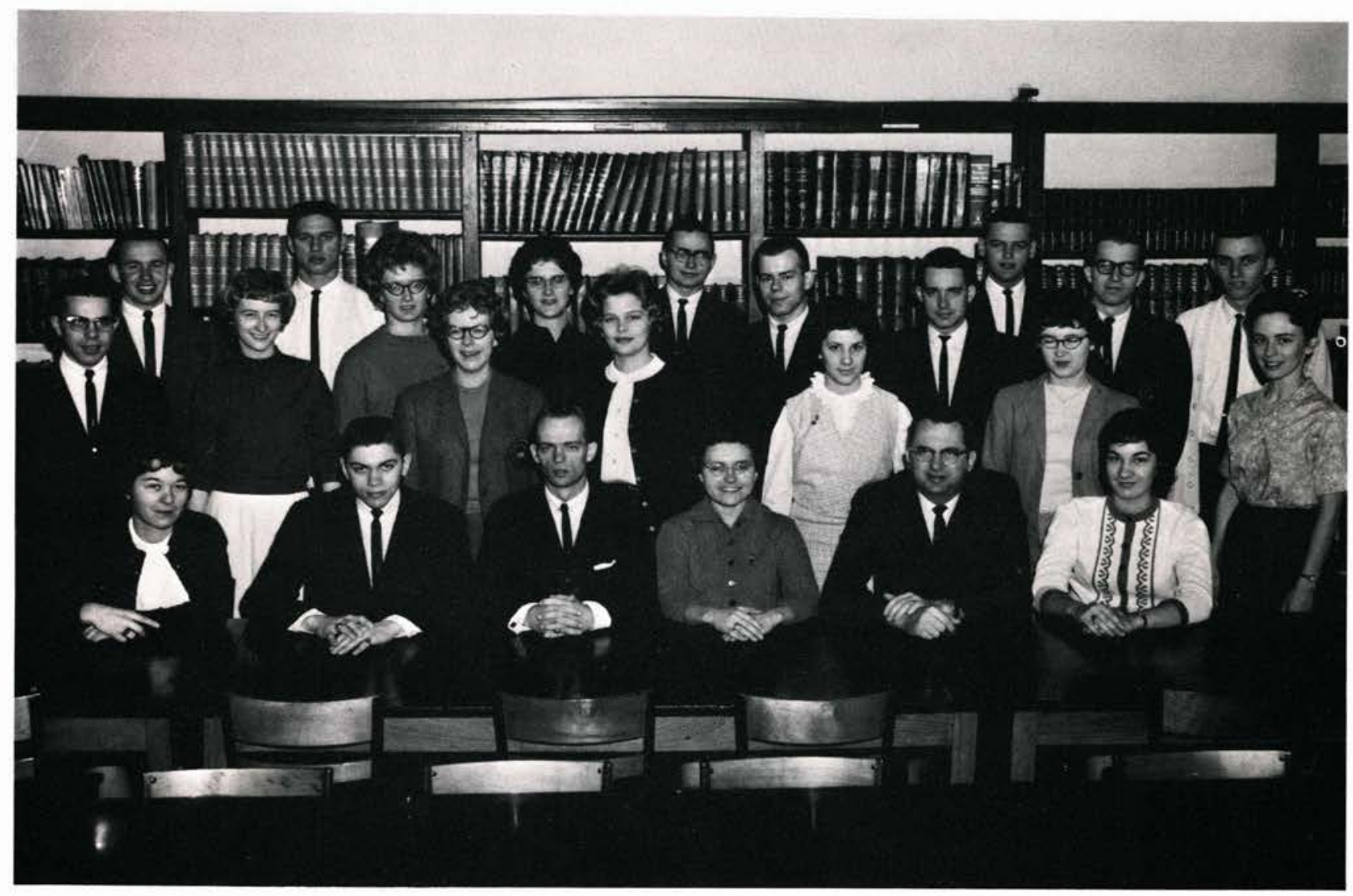

Top Row: Ron McDugle, Don Tennant, Barbara Adamson, Judy Hartzell, Paul Reno, Larry Czerniak, Don Middleton, Gordon Taylor, Ralph Werner, Dave Warren. Second Row: Dave Wilhite, LuAnn Mahanna, Rita Millikin,
Margaret Stowell, Pat Adams, Beverly Woods, Jody Ronk. Front Row: Jeannie DuPre', Mark Haseltine, Ted Ocheltree, Pat Schonscheci, Mr. McIntosh, Nancy Shimits.
As the elected representative assembly of the student body, the Student Council coordinates the student's activities with his academic life and acts as a liason between the student body and the administration.

The Council sponsors many activities during the year. Among the most important of these are the Prospective Student Days and the local Red Cross Bloodmobile visits. Under the co-chairmanship of Tom Delanzo and Ted Ocheltree, the funds from the annual student body project were donated to the college library. By vote of the student body a $\$ 2,500$ goal was set.

\section{OFFICERS}

President_____ Mark Haseltine Vice-President_____. Ted Ocheltree Secretary Treasurer Jeannie DuPre Advisor. Pat Schonscheck Richard T. McIntosh 
The result of the struggle of editors, advisor, and staff members to combine pictures, copy, and theme into a yearbook which accurately and attractively displayed Cedarville College, was truly the "Miracle," 1963. The race against time to meet deadlines, the brain-searching sessions to create balanced, unified layouts, and all the little flaws that turned up at the last minute, were soon forgotten in the rejoicing which followed the completion of the job.

Each year it is the purpose of the Miracle Staff, not only to represent the year's activities, but to continually make the presentation better. To find out how the Miracle rates with other colleges, it is submitted for judging to the Associated Collegiate Press.

\section{The Miracle}

\section{STAFF}

Editor-in-Chief________argaret Stowell Business Manager___________ois Bayless Art Editor_._._._._._._. Gordon Langeneger Copy Editor_..._._._._. Sally Bender Advertising Manager_.______._Suzanne Geyser Staff______._Ty Bryant, Ronald Moore, Joanne Hamilton, David Norris, Bonnie Hammack, Dave Blossom, Judy Neufeld.

Advisor Edward Spencer

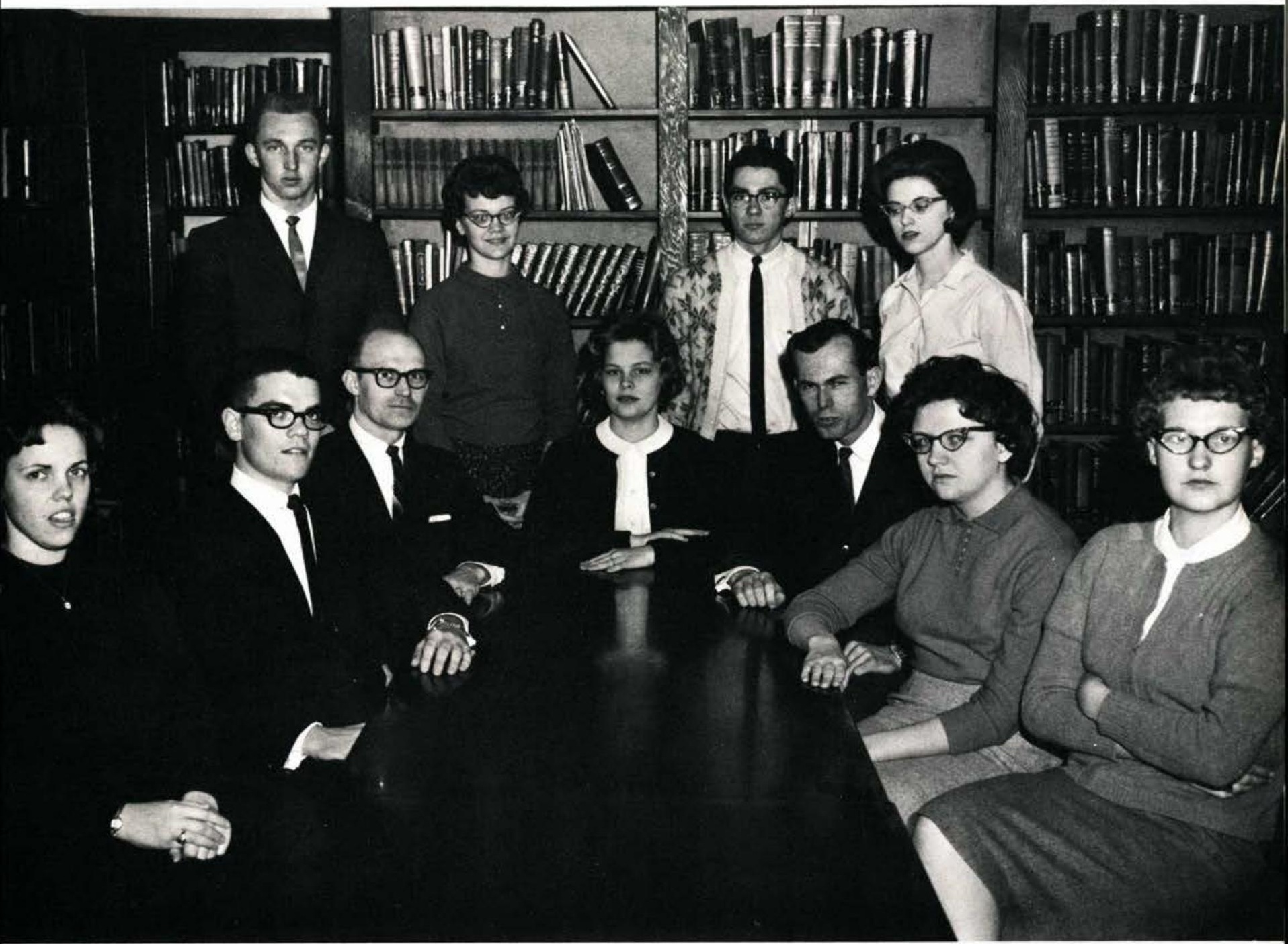

Standing: Ronald Moore, Joanne Hamilton, David Norris, Bonnie Hammack. Sitting: Sally Bender, Ty Bryant, Mr. Spencer, Margaret Stowell, Gordon Langeneger, Lois Bayless, Sue Geyser. 


\section{Alpha Chi}

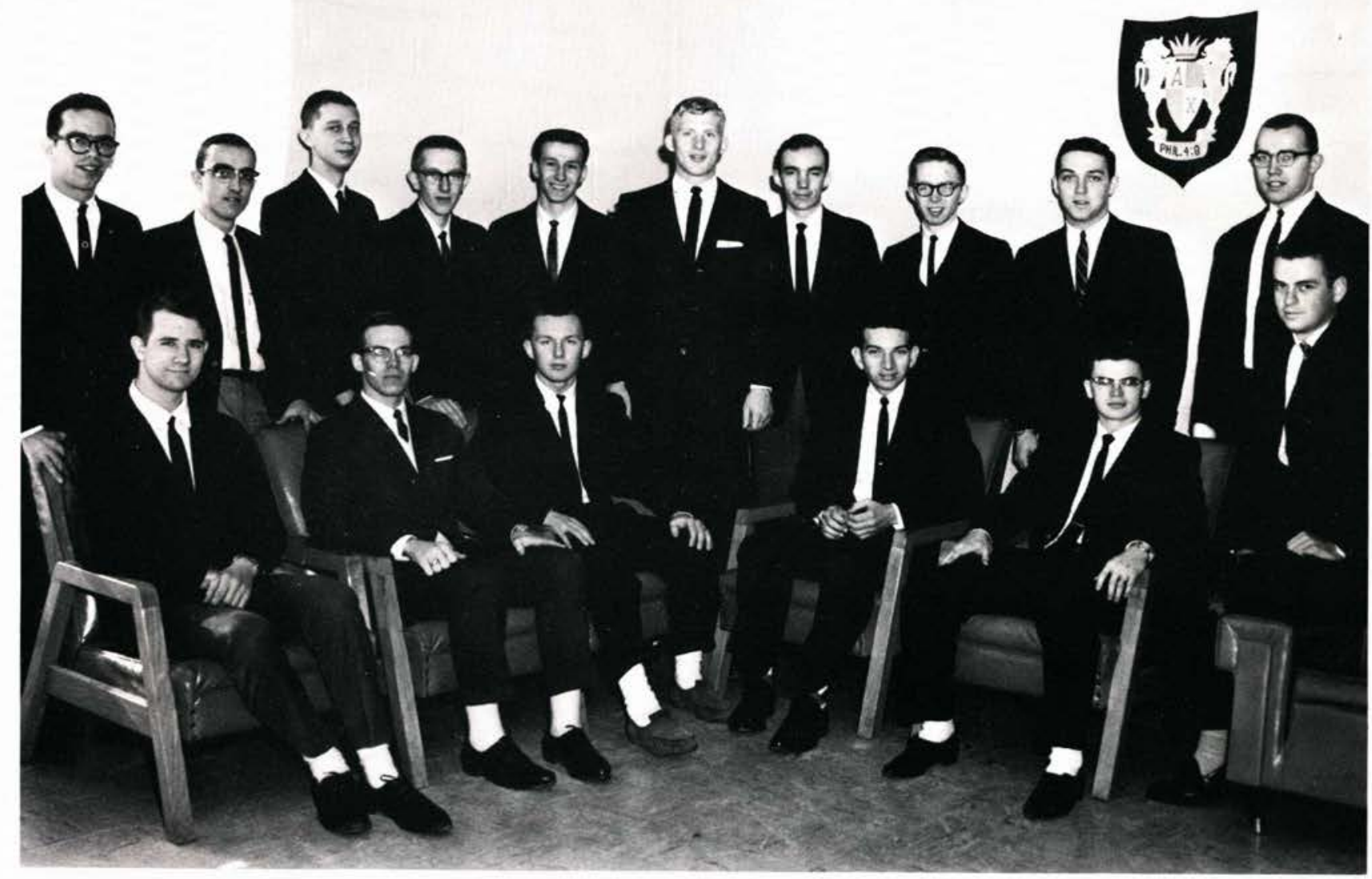

Standing: Dave Prosser, Marvin Stephens, Ray Lamb, Gordon Griffin, Ralph Pay, Val Roloff, Terry Miller, Dan Park, Tim Duffie, Dave Thorne. Sitting: Dave Nims, Larry Montgomery, Paul Carlson, Don Shue, Ray Hoffeditz, Jerry Eaton.

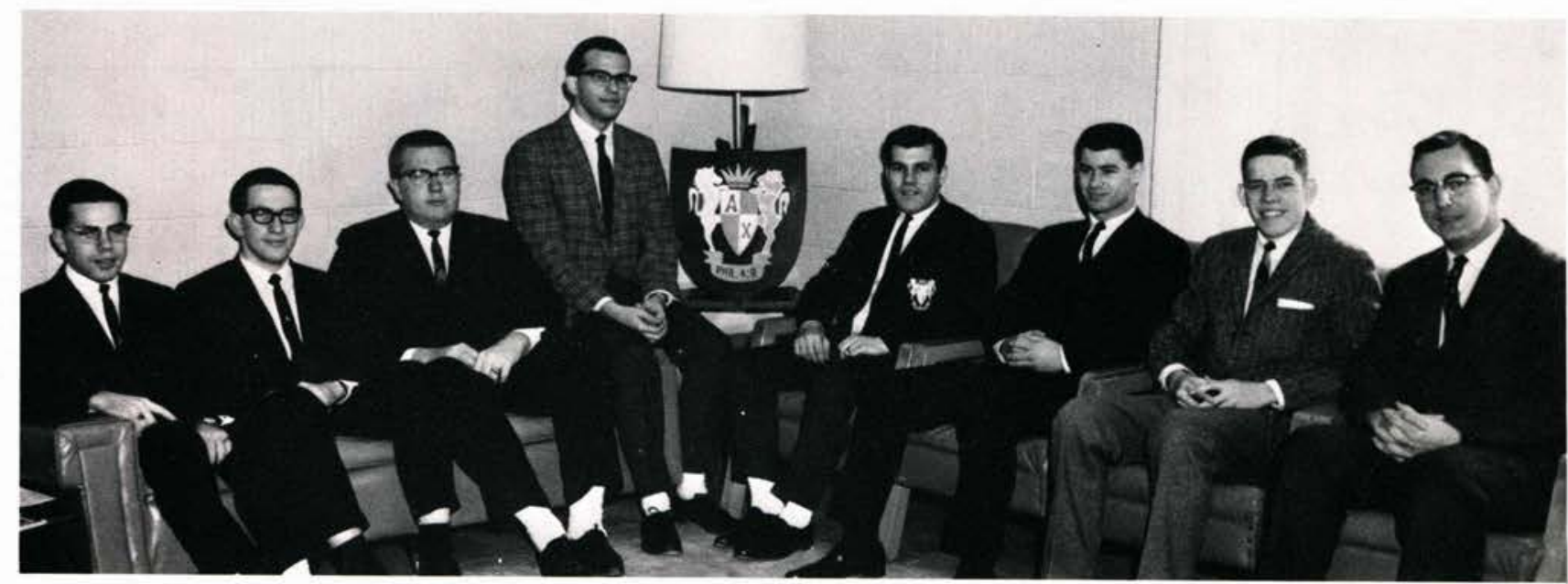

Dave Wilhite, Student Council Representative; Dave Rifenberick, Chaplain; Gary Johnson, Treasurer; Bill Riter, Secretary; Tony Rotondi, President; Stan Seevers, Vice-President; Mervin Ziegler, Parliamentarian; Max Dowell, Sponsor. 


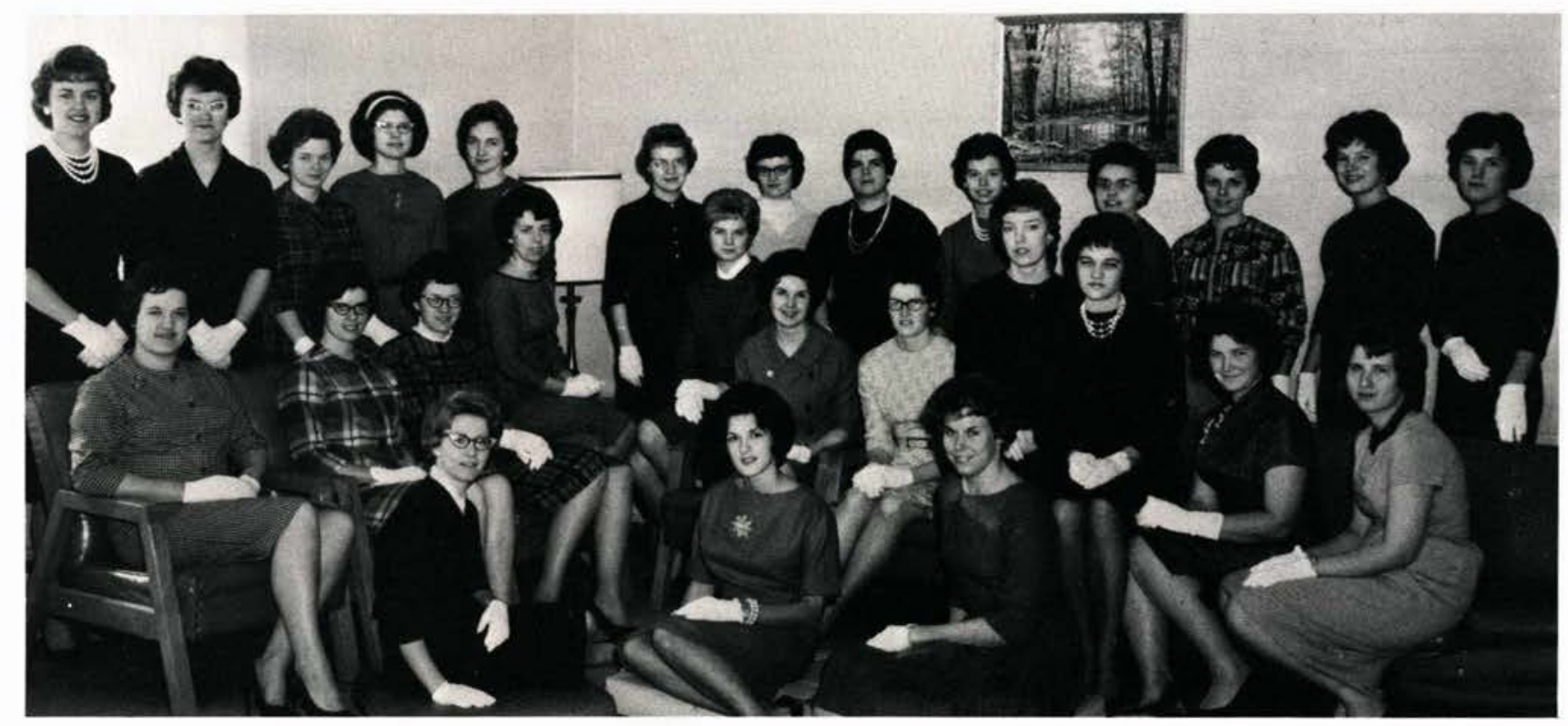

Standing: M. Goodwin, A. Oehmcke, J. Dadisman, D. Olsen, D. Roost, M. Powell, L. Varisco, K. Morgan, M. Jordan. P. Schonscheck, M. Tulloch, M. Bennett, S. Balke
Sitting: C. Carr, J. Bryant, N. Warkentin, P. Barrett, A. Whaley, M. Ballard, B. Ross, S. Gantz, V. Curcio, P. Good, K. Gildan. On Floor: S. Martin, J. Amos, P. Leunk.

\section{Gamma Chi}

Donna Johns, Program Chairman; Donna Finley, Parliamentarian; Mrs. Maddox, Sponsor; Bonnie Nash, President; Rita Millikin, Student Council Representative; Michal Geeting, Vice-President; Julie Petrie, Treasurer. Standing: Shirley Byrd, Secretary; Helen Wing, Social Chairman.

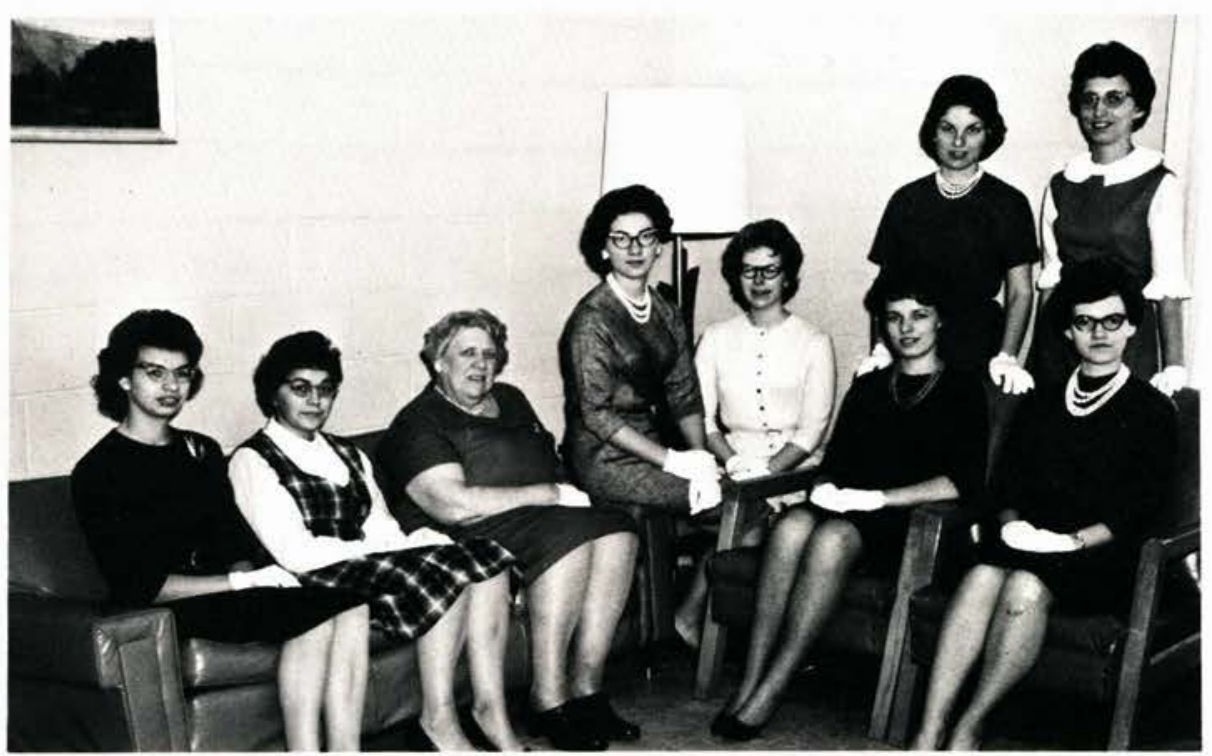

The oldest campus literary society for women is Gamma Chi - Women for Christ. Through every activity the organization seeks to stimulate growth and originality in the areas of literature, music, art, and humor. Its aim is to advocate and prepare the women of Cedarville College for participation in civic and social affairs.

In its many activities of the year, Gamma Chi sponsored notably the Valentine Banquet and the annual Faculty Christmas Banquet. 


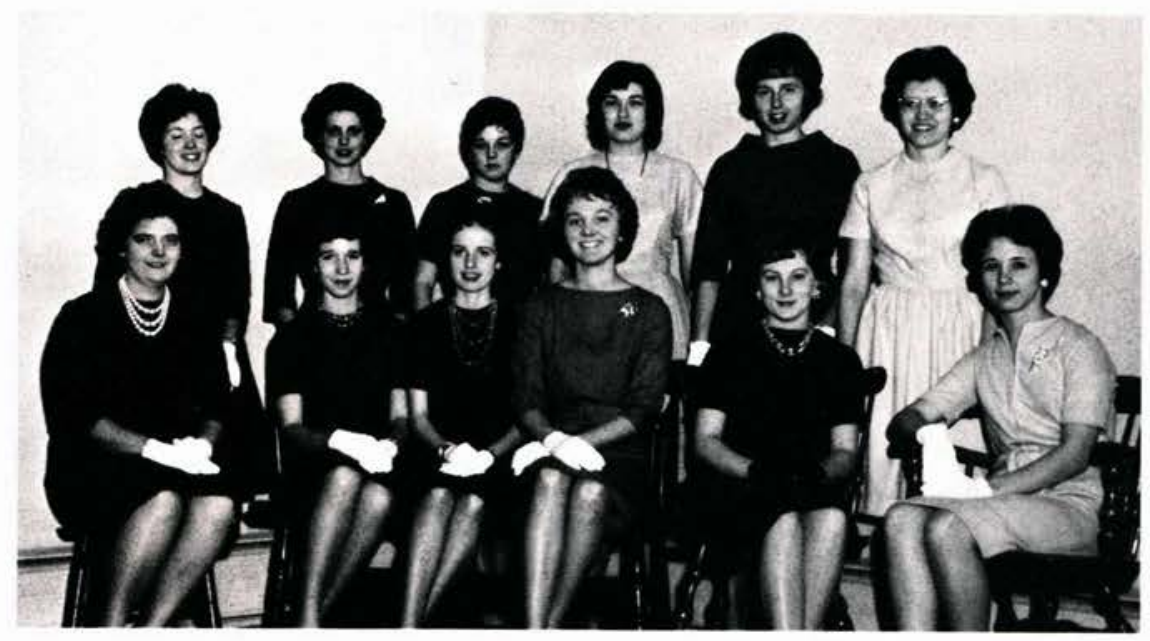

Standing: Rayna Butler, Flo Cannon, Lois Kennedy, Peggy Nettleton, Pat Versluis, Sharon Ackerman. Sitting: Loretta Cushey, Sylvia Wing, Lynne Cayton, Jean Maclaren, Joanne Neely, Sandi Welch.

\section{Kappa Delta Chi}

Kappa Delta Chi, the tiewest campus literary organization, is dedicated to developing gracious habits in its members, so that each will feel "at home' 'in any situation.

The club sponsors many activities which give a well balanced social experience to the members. Early in the fall a prospective members' tea was given. Other activities included a picnic, attendance at a Spring Bridal Show and the sponsorship of the Founder's Day Banquet.

Standing: Betty Wall, Secretary; Judy Hartzell, Student Council; Bonnie Hammack, Parliamentarian; Miss Smith, Advisor; Judy Siplock, Social Chairman; Bette Adamson, Treasurer; Lois Duddleston, Chaplain. Sitting: Pat Micka, President; Barbara Adamson, Vice-President.

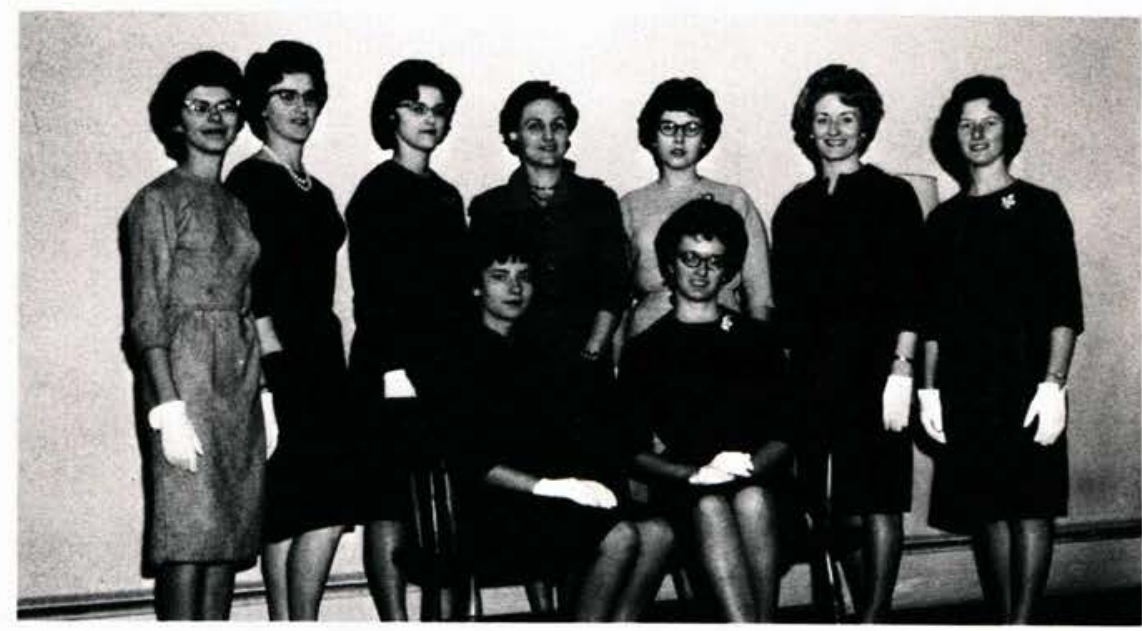




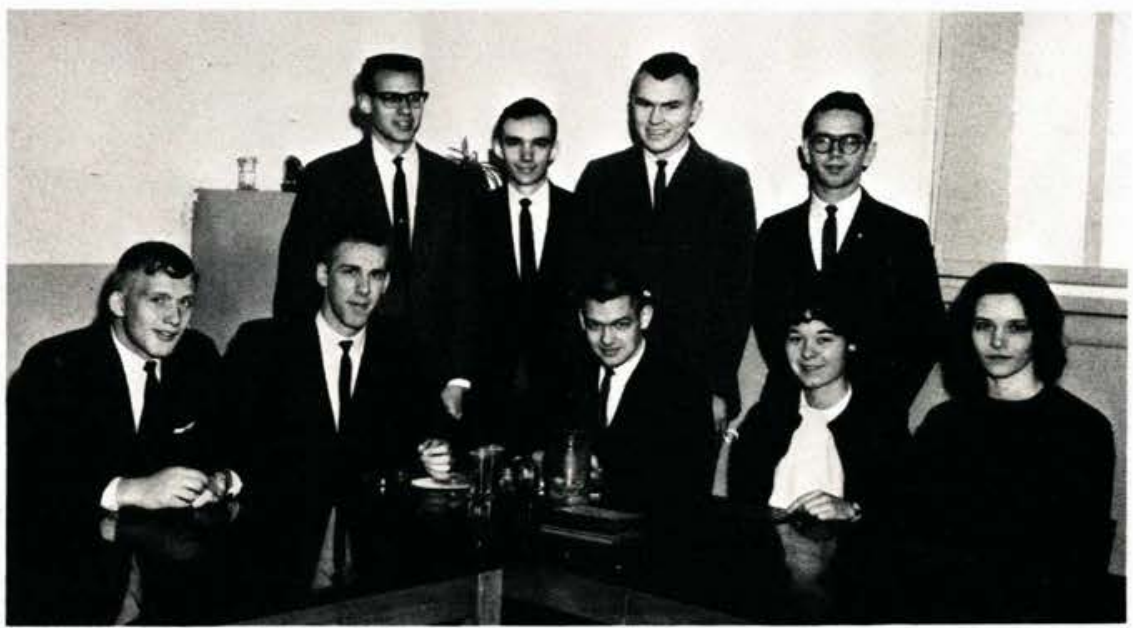

Standing: Don Davidson, Terry Miller, Charles Oehmcke, Dave Prosser. Sitting:

Val Roloff, Don Entner, Jay Moore, Jeannie DuPré, Nancy Buerer.

\section{Pi Delta}

The purpose of the Science Club is as its name, Pi Delta, suggests "prove all things." Even though its members are mostly those who are studying in the science curriculum, membership is open to all students. The students of the club converse and study to show the correlation between scientific and Scriptural truth.

Paul Reno, Student Council; Nancy Buerer, Secretary; Dave Ritenberick, Treasurer; James Furry, Vice-President; David Trumbull, President.

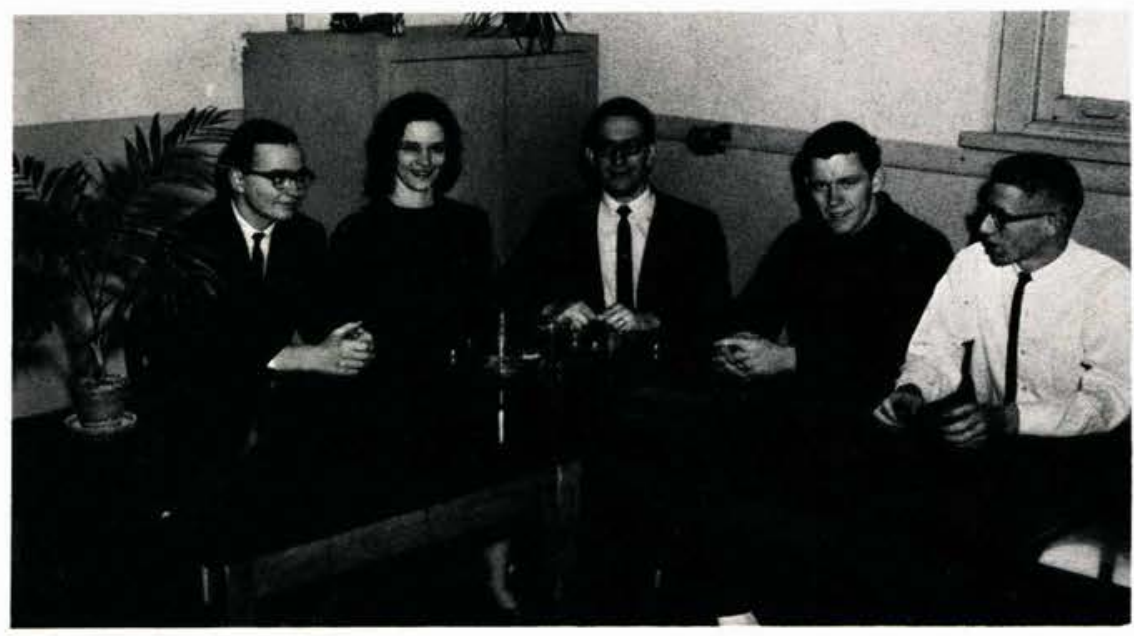




\section{Whispering Cedars}

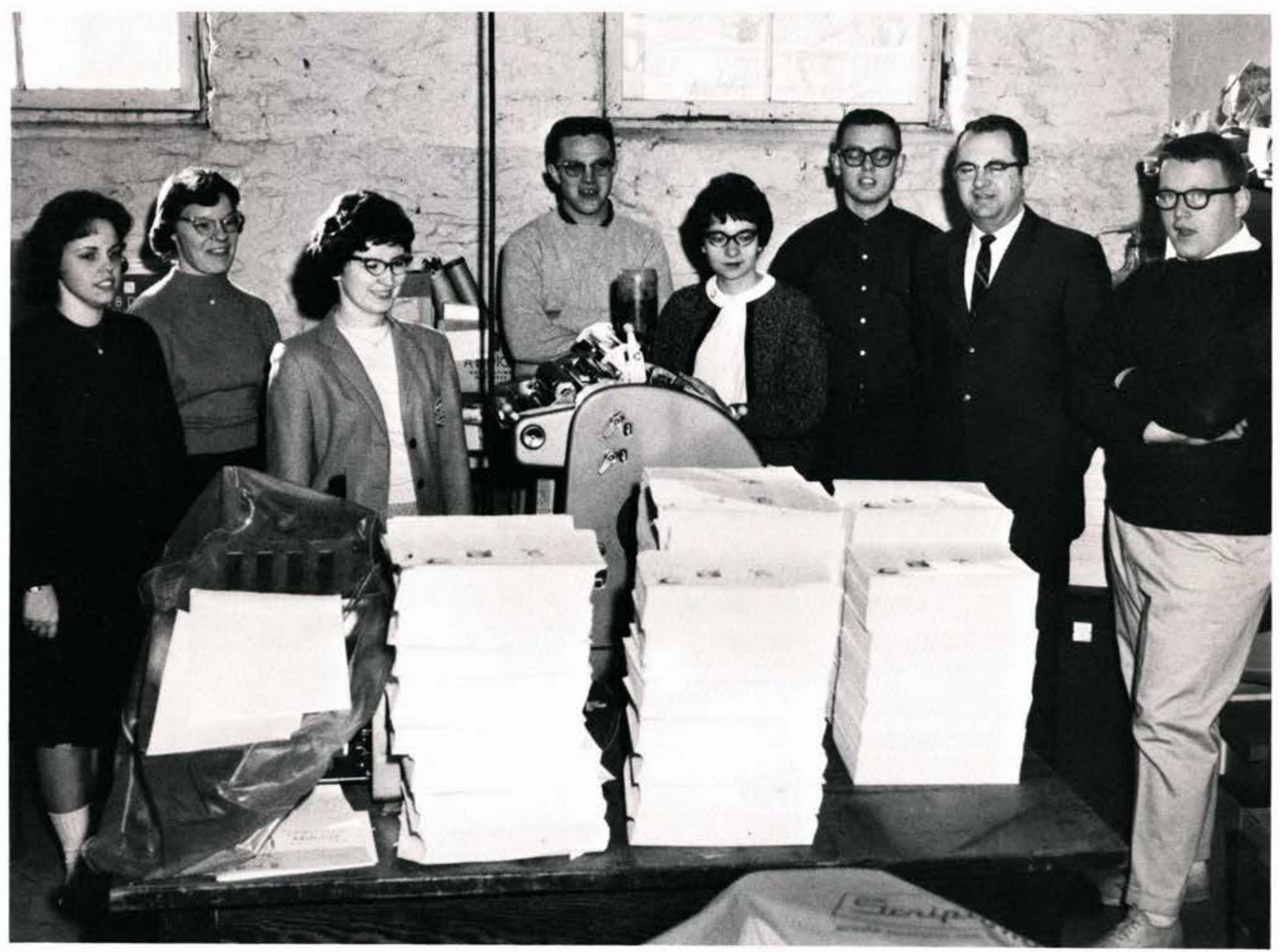

Sally Bender, Nancy Smith, Beverly Woods, Ellis Howard, Pat Micka, Bob Fidler, Robert McIntosh, Richard Davidson.

\section{Staff}

The bi-weekly publication, The Whispering Cedars was a source of information for the students. Coming activities, current campus happenings, student opinions, and a series of provocative editorials were regular features.

This year the paper was the responsibility of the Advanced Writing class, serving as a lab experience for novice journalists. As a code for publication the staff sought for punctuality, and sought to inform and educate with the best interests of the student body in mind.
Editor-in-chief-

Feature Editor

Sports Editor

Art Editor

Copyreader

Reporter-in-chief

Advertising Manager

Advisor
Beverly Woods Sally Bender Bob Fidler Rich Davidson Nancy Smith Pat Micka Ellis Howard Richard McIntosh 


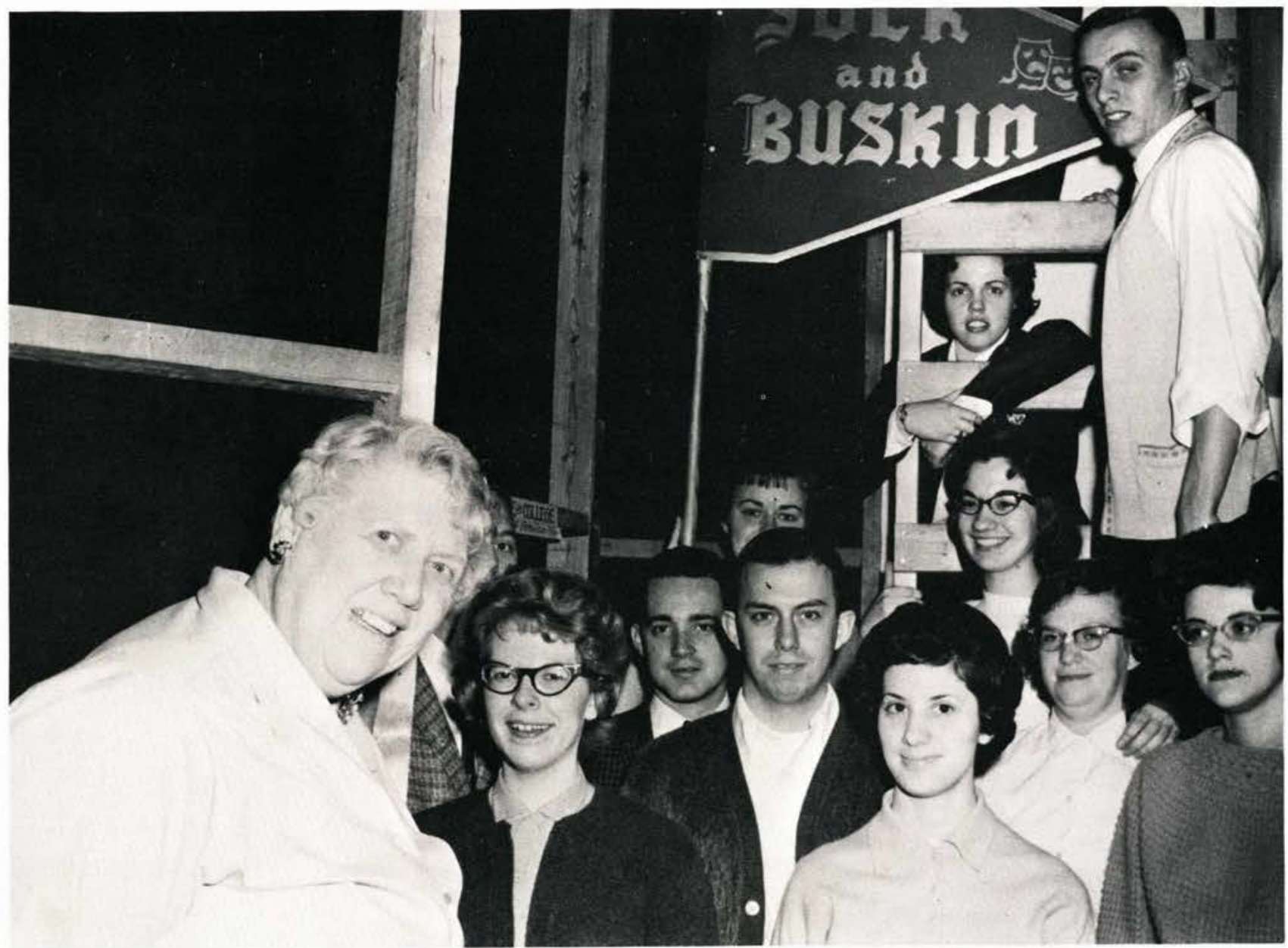

Top Row: Sally Bender, Dave Warren. Second Row: Mary Goodwin, Nancy Shimits. Third Row: Paul Gathany, Don Middleton, Don Higdon, Aloha Patch. Fourth Row: Mrs. Maddox, Rita Millikin, Pat Adams, Bonnie Hammock.

President

Vice President

Secretary

Treasurer

Historian

Student Council
Rita Millikin Don Higdon Aloha Patch Paul Gathany Sally Bender Mary Goodwin
Operating under a new point system, Sock 'n' Buskin has blossomed out into an active program in its efforts to give dramatics a prominent place on the college campus.

One of the biggest productions of the year was the Homecoming pageant, "As the Cedar Grows," in which the members of Sock ' $\mathrm{n}$ ' Buskin played an important part. They also held a ceremonial planting of a Cedar tree in order to revive a forgotten campus tradition. 


\section{Photo Club}

The photography club, Cedarville College's newest organization, held its first meeting on February 4,1963 . It then began to procure equipment to place in a long awaited darkroom. The club was formed with the intention of serving the administration, students, and the yearbook staff. The first official project was a donation to the school of any pictures that might be needed for 1963 publica-

\section{Officers}

President

Gordon Langeneger

Vice President Don Entner

Secretary-Treasurer Ron Moore tions.

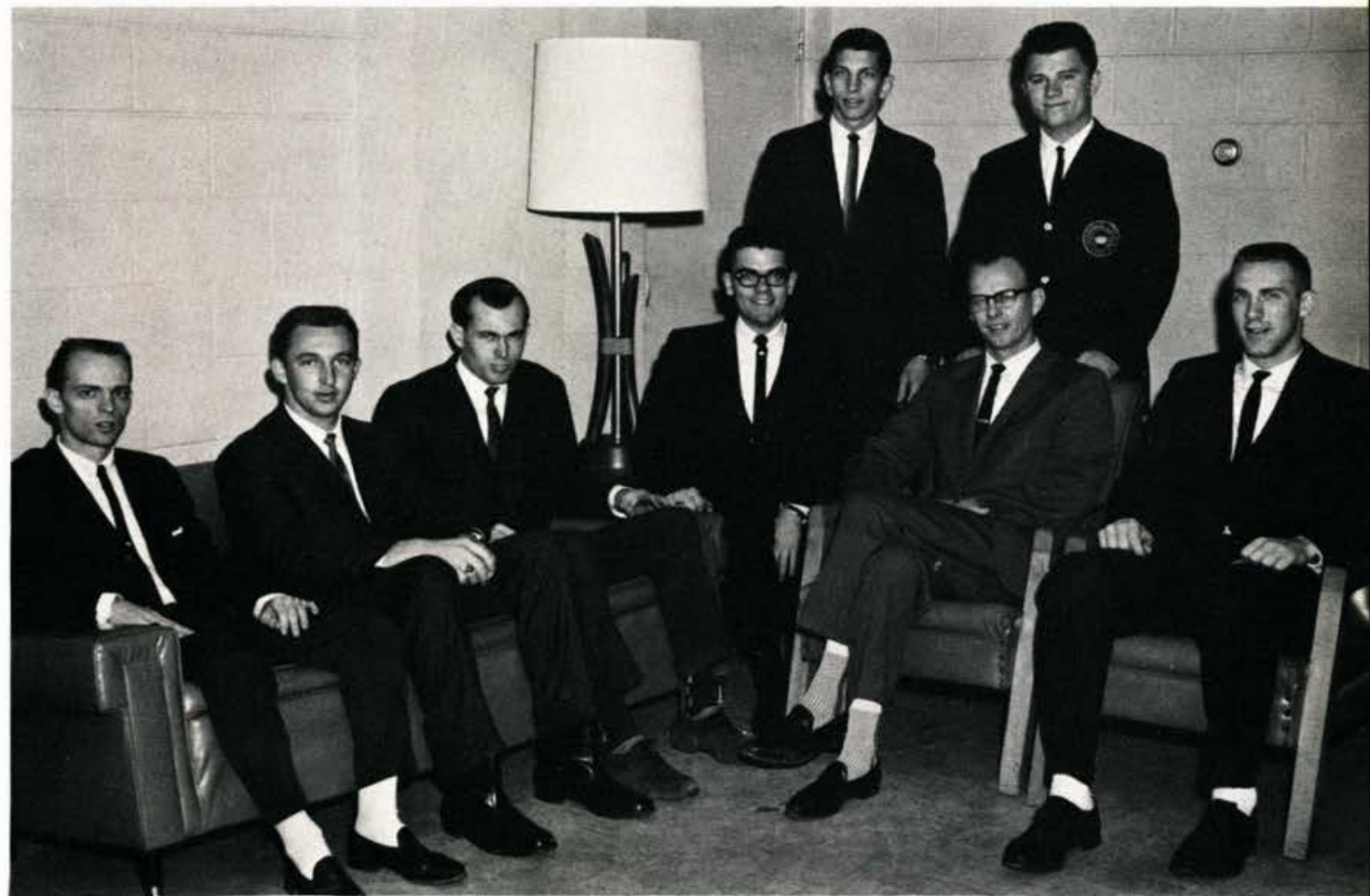

Standing: Jim Engleman, Mark Averitt. Seated: Ted Ocheltree, Ron Moore, Gordon Langeneger, Ty Bryant, Dr. Johnson, advisor; Don Entner. 


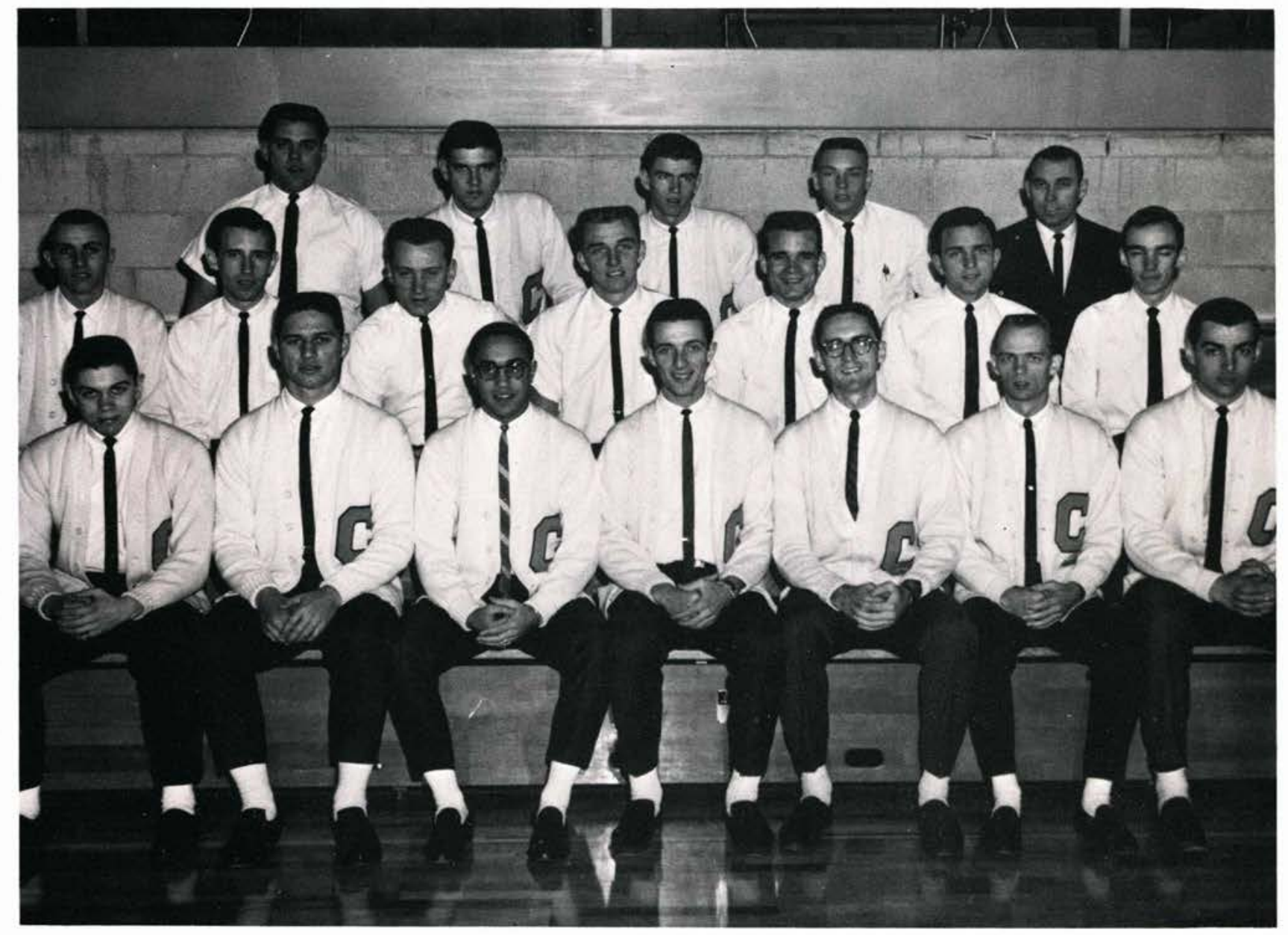

Top Row: P. Brower, G. Walthall, R. Lane, R. Davis, Don Callen. Second Row: D. Warren, D. McDonald, A. Merwald, D. Werner J. Walborn, D. Fisher, T. Miller. Front Row: M. Haseltine, D. Tennant, T. DeLanzo, N. Smith, S. Canine, T. Ocheltree, D. Jeremiah.

\section{Varsity "C"}

\section{Officers}

President Mark Haseltine

Vice-President Tom DeLanzo

Secretary Jim Sprague

A few projects sponsored by the Varsity " $\mathrm{C}$ " are Treasurer Norris Smith operating the concession stand at home games and sponAdvisor Don Callen soring the Church Basketball Tournament in March. 


\section{Pep Club}

\section{Officers}

President

Tony Rotondi

Vice-President Jay Moore

Secretary

Treasurer
The Pep Club has seen thriving growth since its inception as a campus organization three years ago. Under the direction of its officers, the Club has promoted enthusiasm among the students at both home and away basketball games, as well as pep rallies. The vocal support of this club has been a great encouragement to the basketball team, as well as giving an ample outlet for the pent-up "steam" of these basketball-minded students.
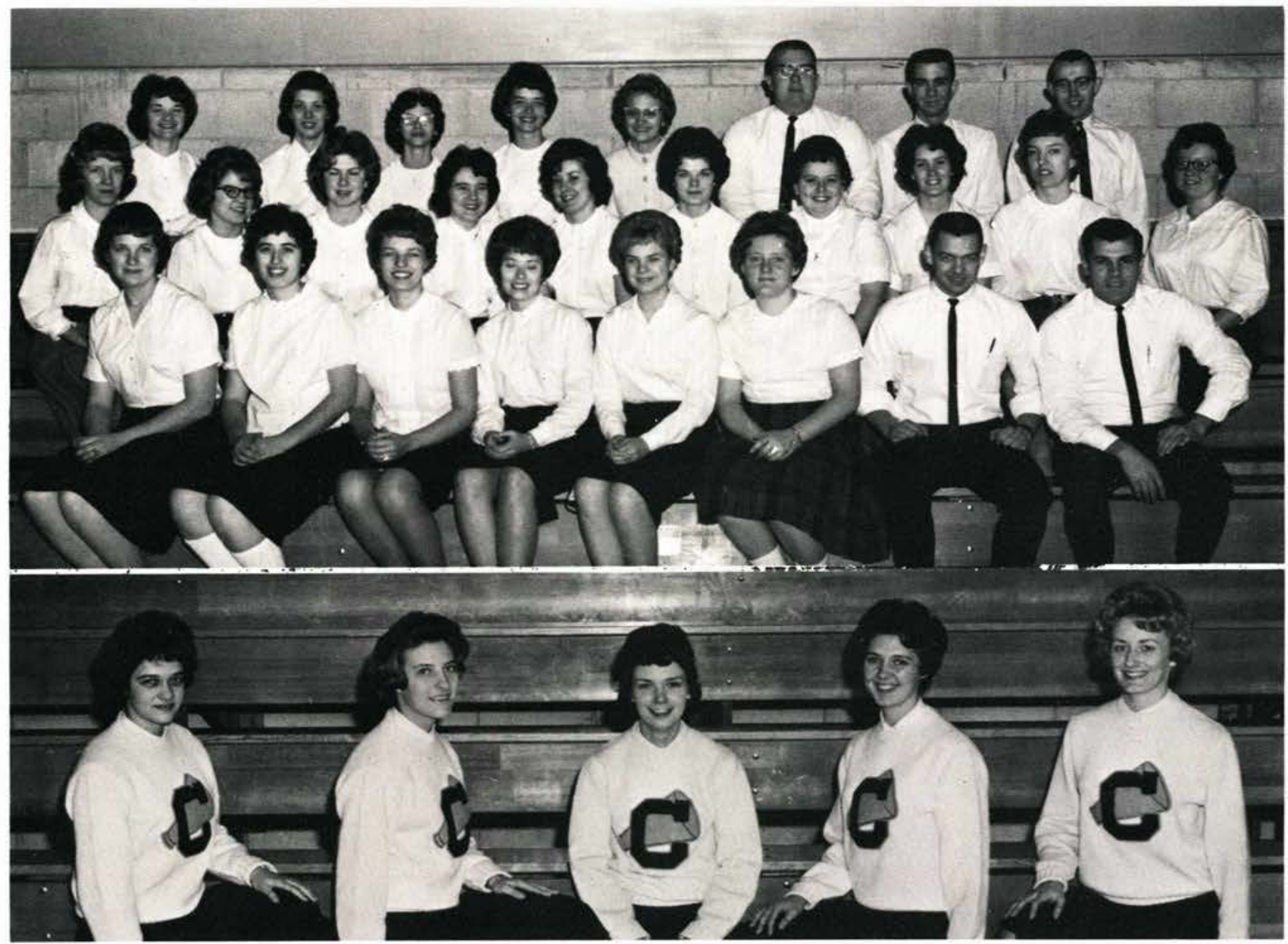

Top Row: A. Halley, P. Ripko, A. Hoyte, B. Thomson, P. Quick, G. Johnson, R. Mathis, D. Thorne. Second Row: C. Ward L. Shaw, D. Bush, J. Scholten, J. Simrell, L. Martin, B. Babcock, M. Buckle, S. Gantz, J. Gann. Front Row: J. Miller, P. Smith, M. Geeting, B. Bieger, A. Whaley, S. Lepine, J. Moore, T. Rotondi. Kneeling: V. Curcio, P. Kastor, D. Thompson, I. Lane, B. Adamson. 


\section{Modern Music Masters}

Modern Music Masters, a national organization, was organized to recognize college students who have outstanding music ability. Members are chosen on the basis of leadership, scholarship, cooperation, service and character.

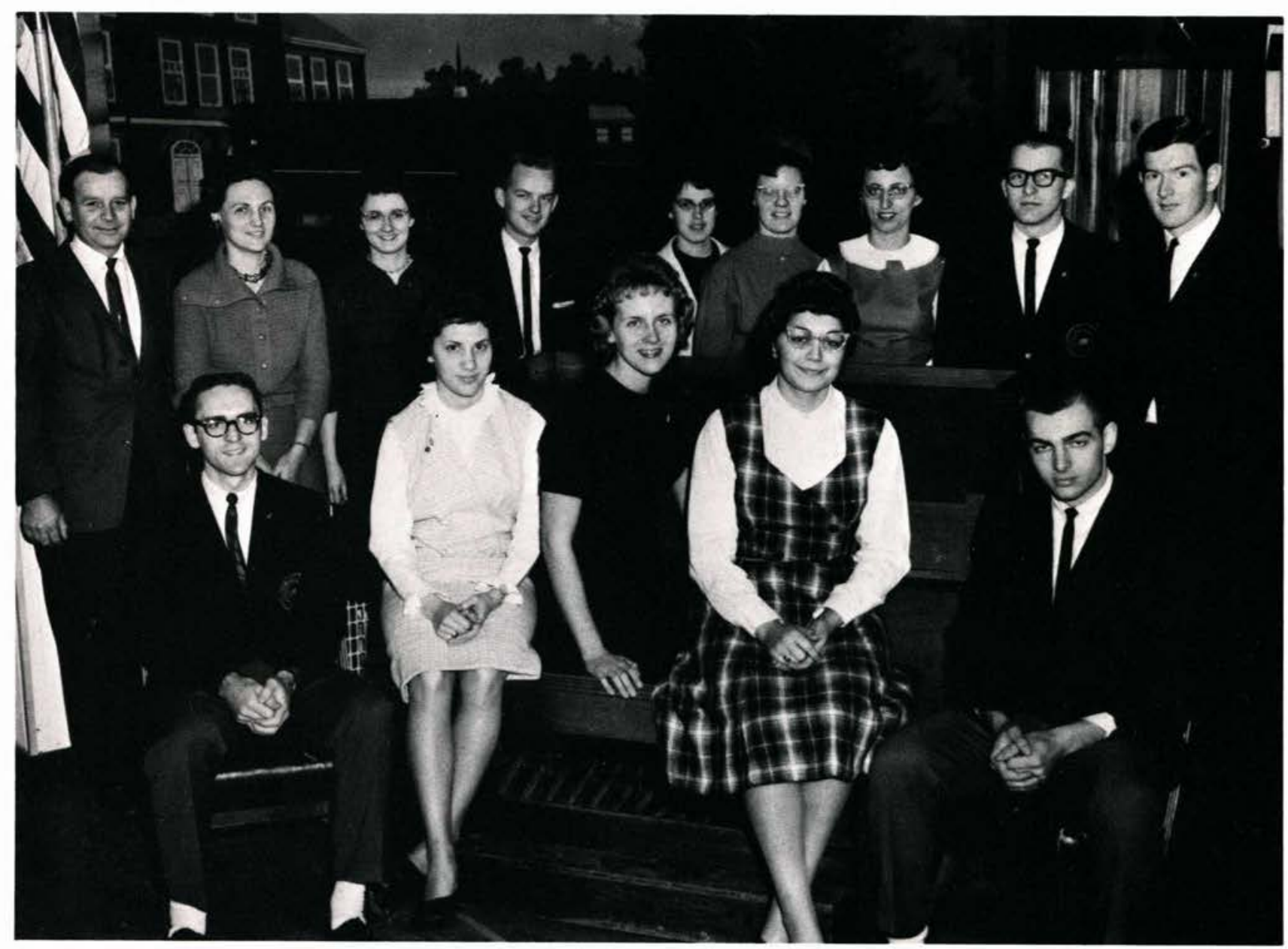

Standing: Mr. Webber, Miss Smith, advisors; Carol Brown, Bill Washburn, Elayne Howard, Nancy Smith, Helen Wing, Ralph Werner, John Morgan. Sitting: Sam Canine, President; Pat Adams, Historian; Judy Lachman, Treasurer; Donna Finley, Secretary; Dave Jeremiah, Vice-President. 


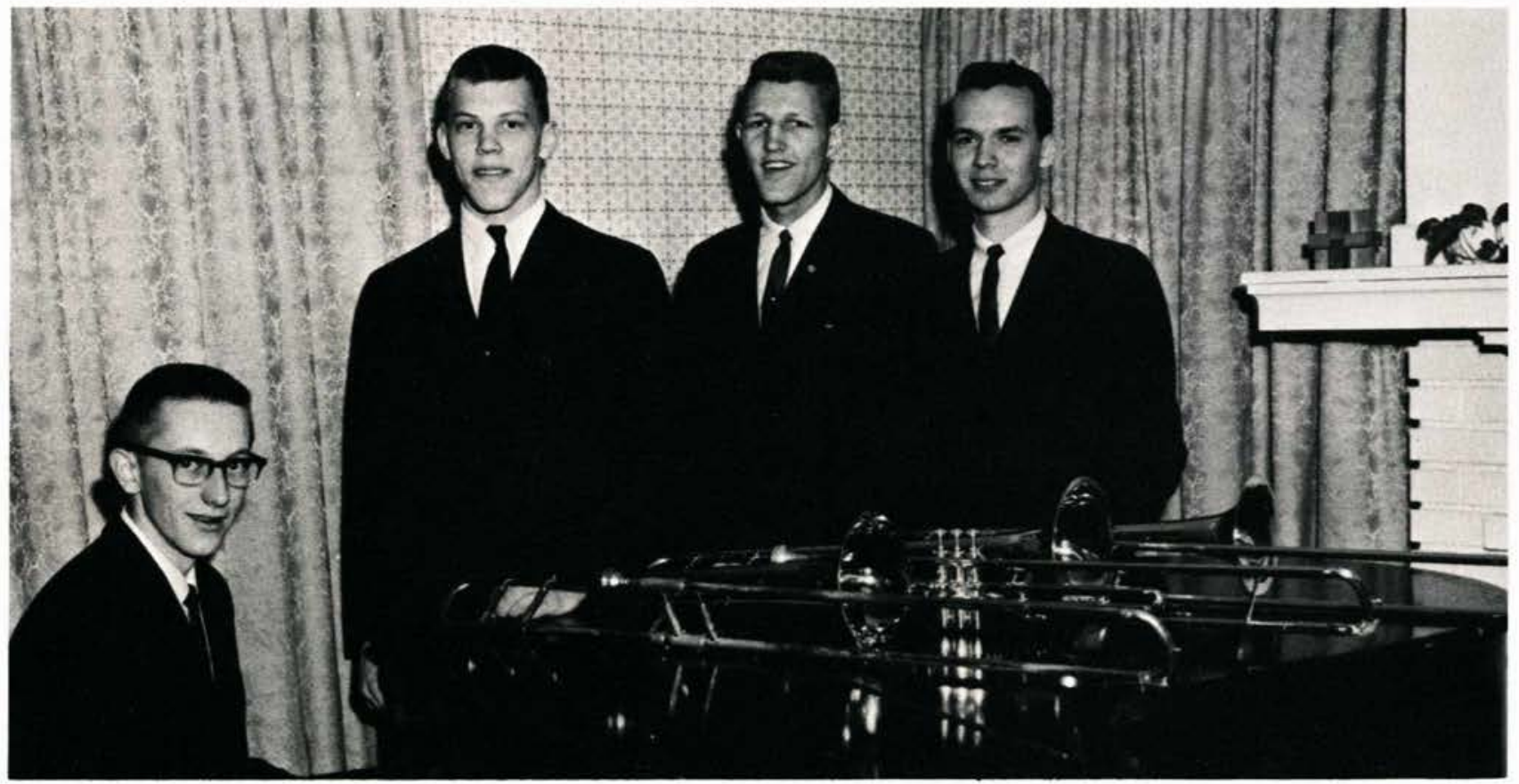

The Ambassadors : Gordon Griffin, Pianist, Joe Stowell, Gary Fransted, John Stockwell.

Traveling this summer and representing the ministry of Cedarville College are two musical groups, the Ambassadors and the Melodyaires. The trombone trio travels from Wisconsin to the East Coast. The Melodyaires also travel through the Mid-western states and conclude their tour on the West Coast.

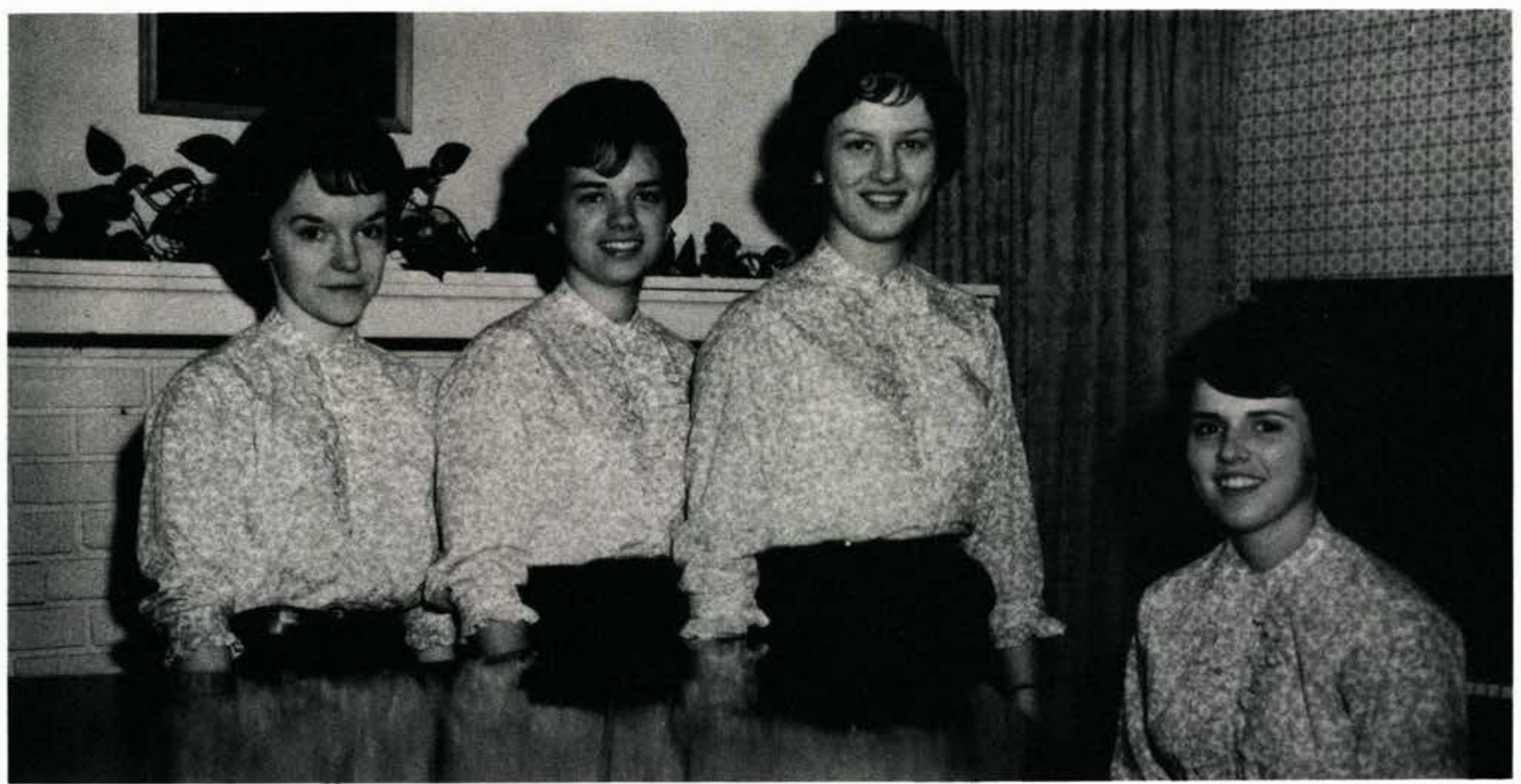

The Melody-Aires : Martha Ammons, Judy Couwenhoven, Martha Crull, Phyllis Irish, Pianist. 
Quartets And Trios

\section{Kingsmen Quartet -}

Sam Canine, Ralph Werner, Roger O'Bryon, Dave Jeremiah, Rich Davidson, pianist.

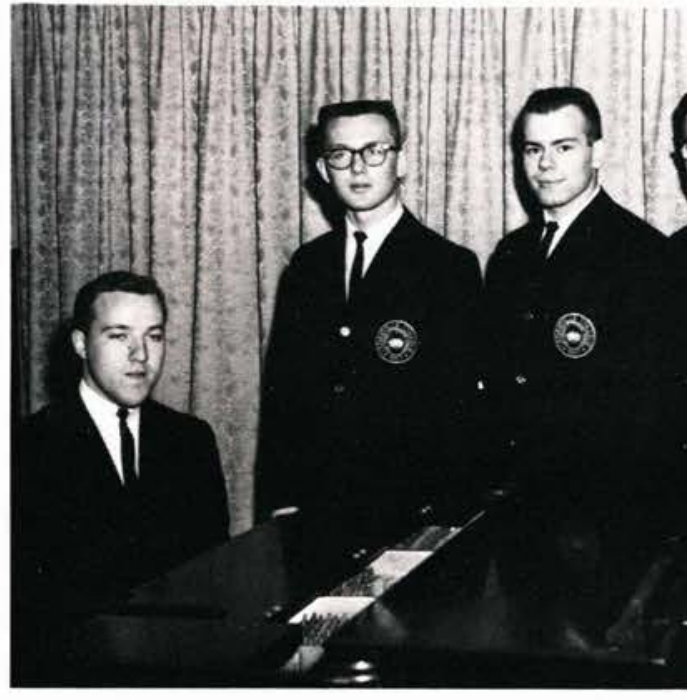

\section{Proclamators Quartet}

John Ingram, Helen Wing, pianist, Dave Perry, Dave Rifenberick, John Morgan.

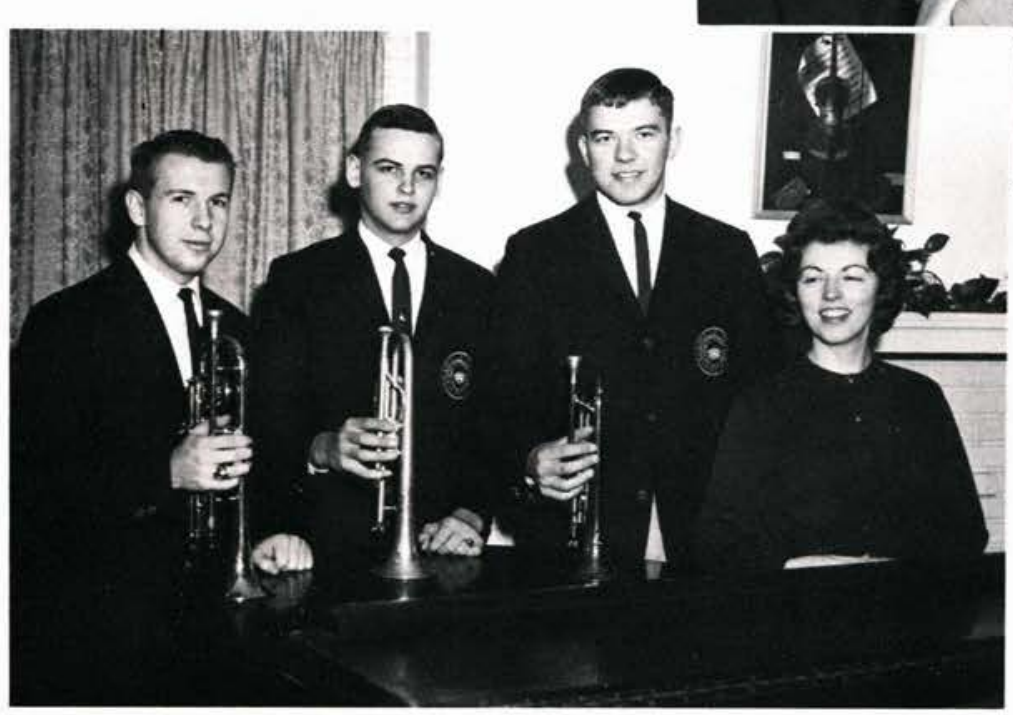

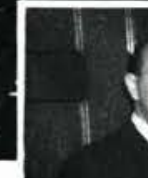

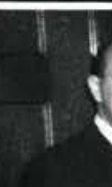

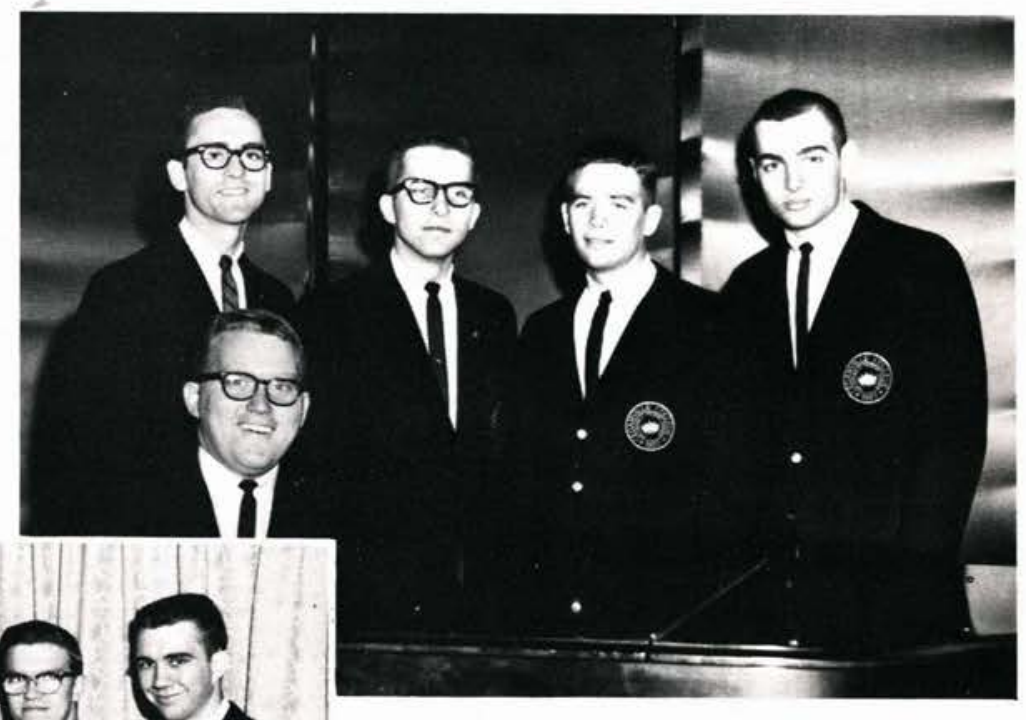

\section{Messengers Quartet -}

Paul Carlson, Larry Czerniak, Gary Harris, Ron Mathis, Ed Eastman, pianist.

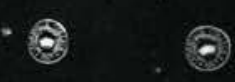




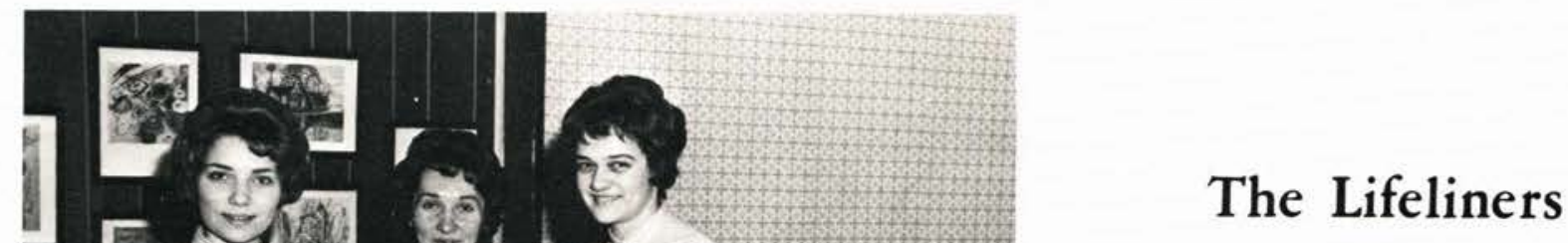

Ruth Johnson, Sharon Marks, Vickie Curcio, Shirley Byrd, pianist.

The Visionaires

Marian Rothwell, Ardith Cayton, Irene Lane, Joanne Hamilton, pianist.

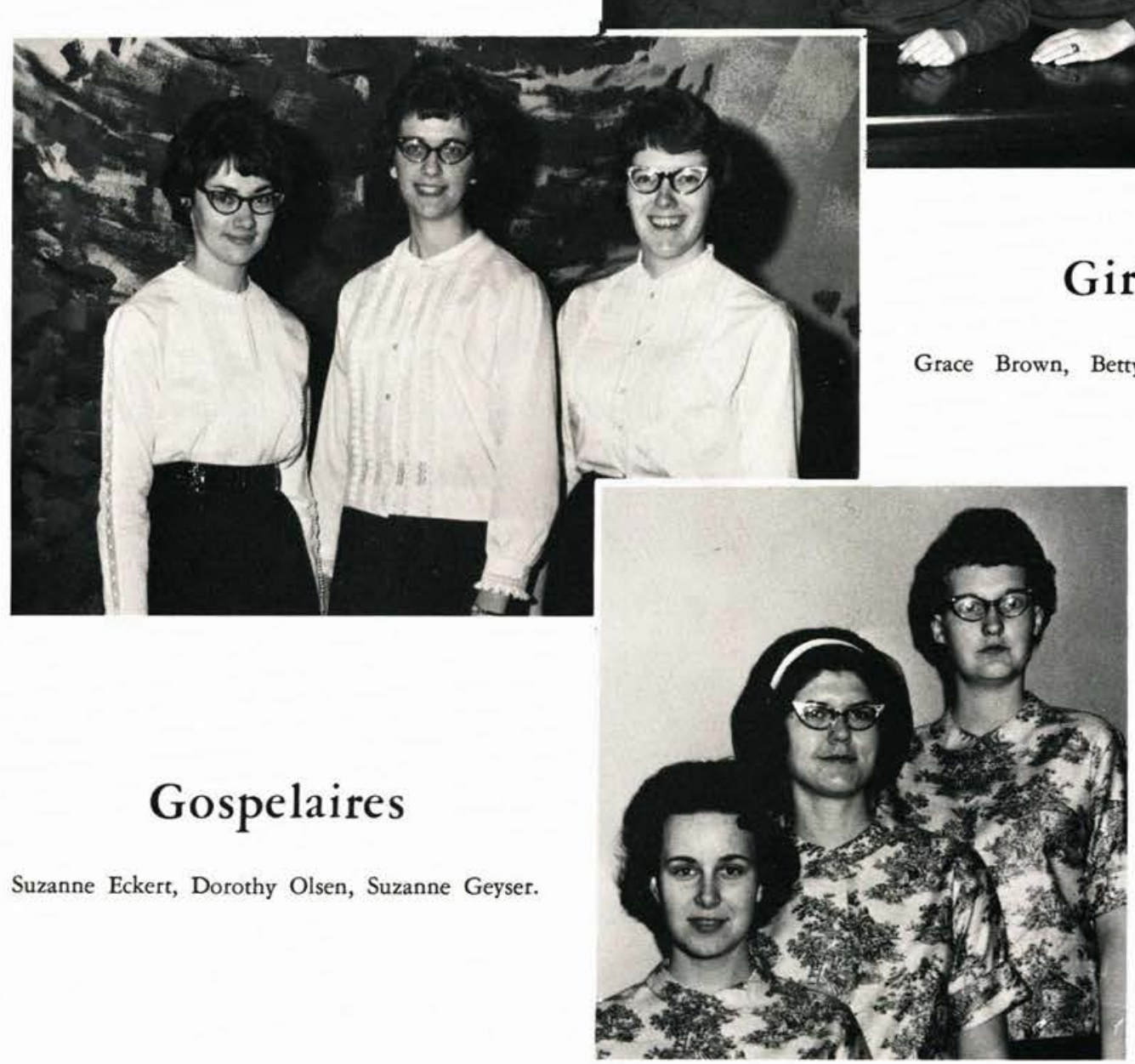




\section{College Band}

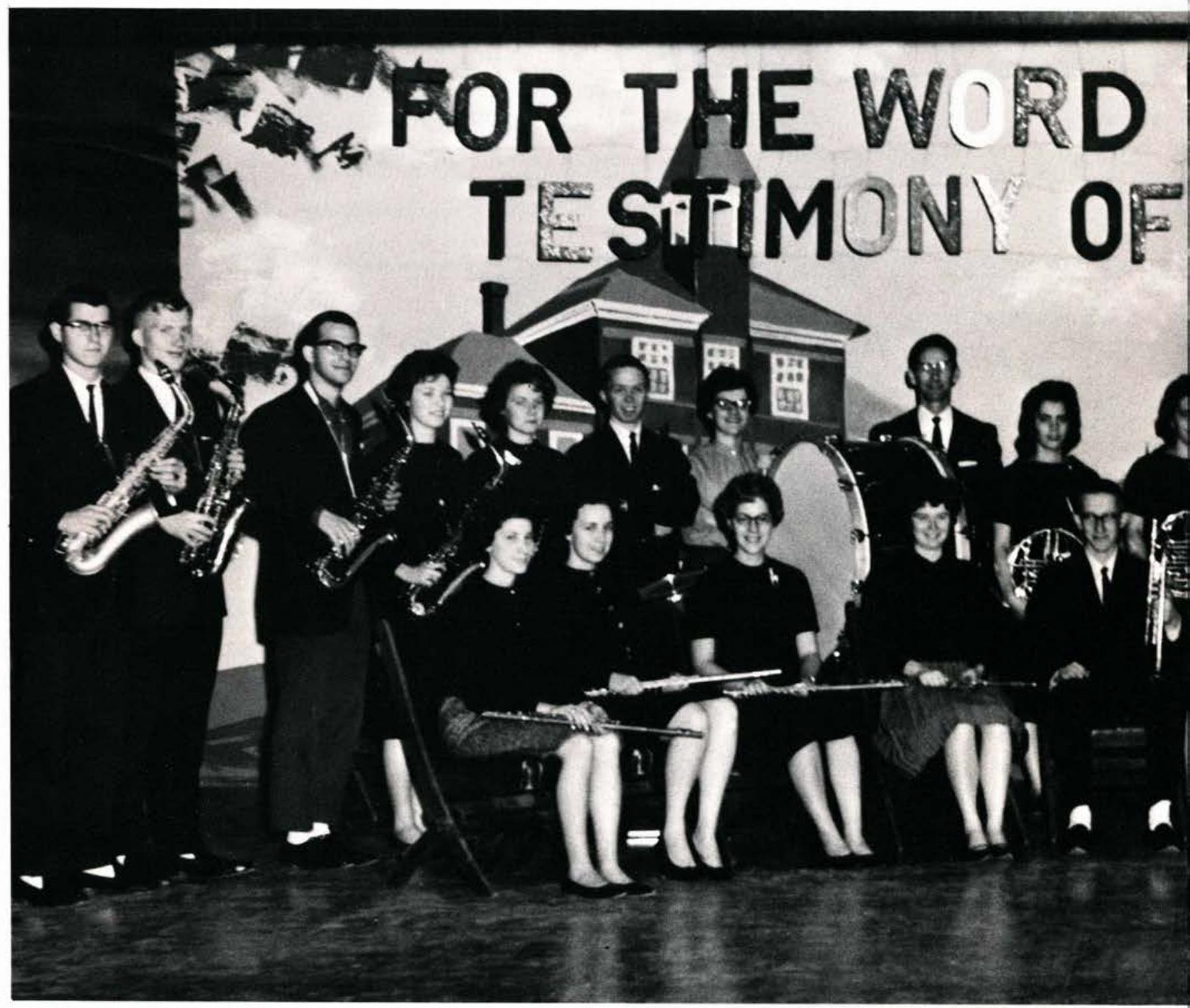

Stanaıng: B. Auffort, V. Roloff, B. Rider, L. Sullivan, V. Merryman, D. Park, J. Petrie, Mr. D. Werner, R. Werner. Sitting: P. Adams, S. Eckert, R. O'Keefe, G. Adams, G. Griffin, B. Reynolds,

\section{Officers}




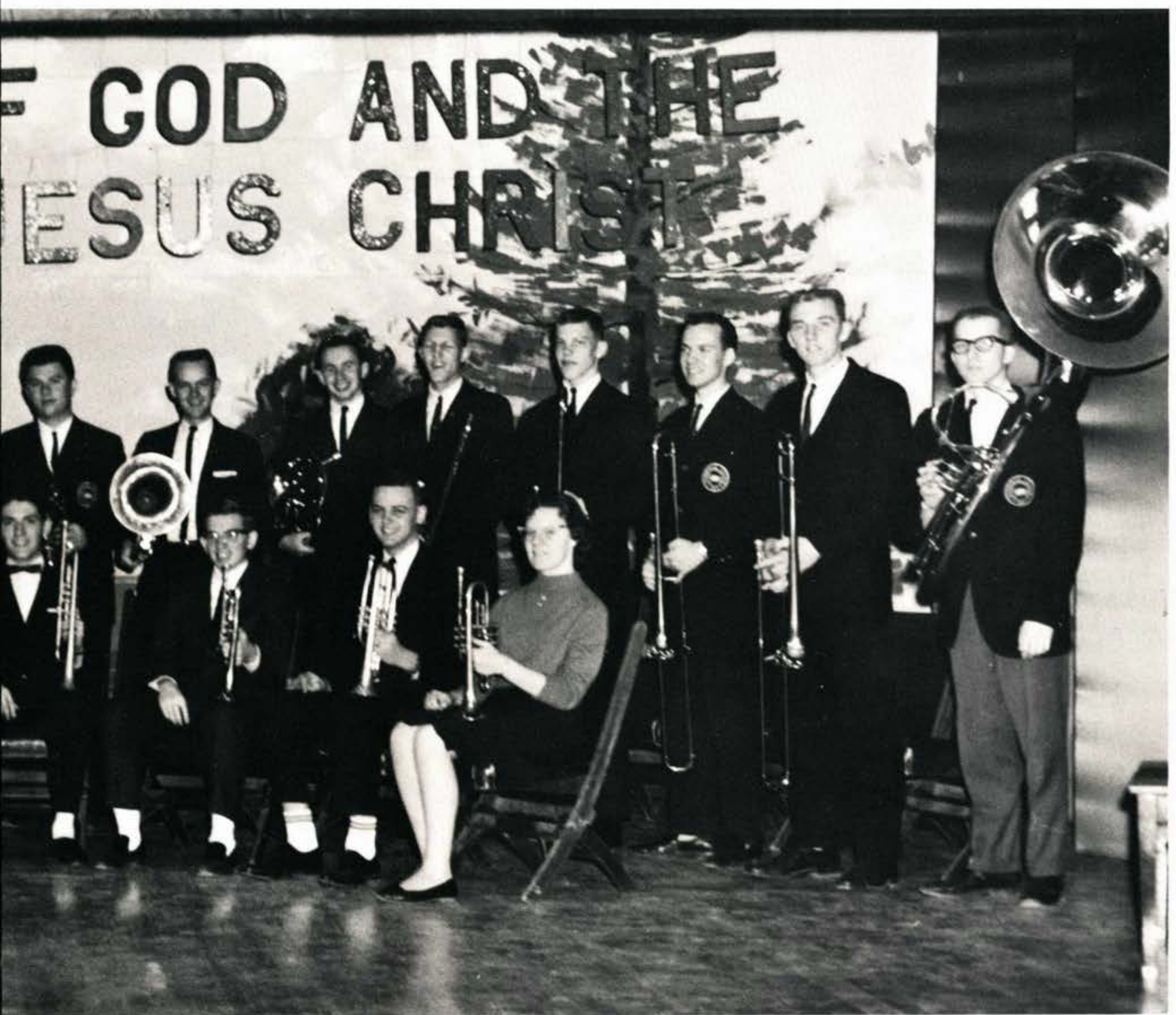

horton, E. Dudley, E. Dudley, M. Averitt, B. Washburn, R. McDugle, G. Fransted, J. Stowell, Acker, G. Taylor, N. Smith.

A welcome asset to any cheering section is the music of the Pep Band. This is a regular activity of the members of the Cedarville College Band, and can be witnessed at every home basketball game.

However, the responsibilities of the Band are not limited to this. During the past year they have displayed instrumental artistry in the Christmas Concert, and in the preparation of an early Spring Concert. 


\section{Choralaires}

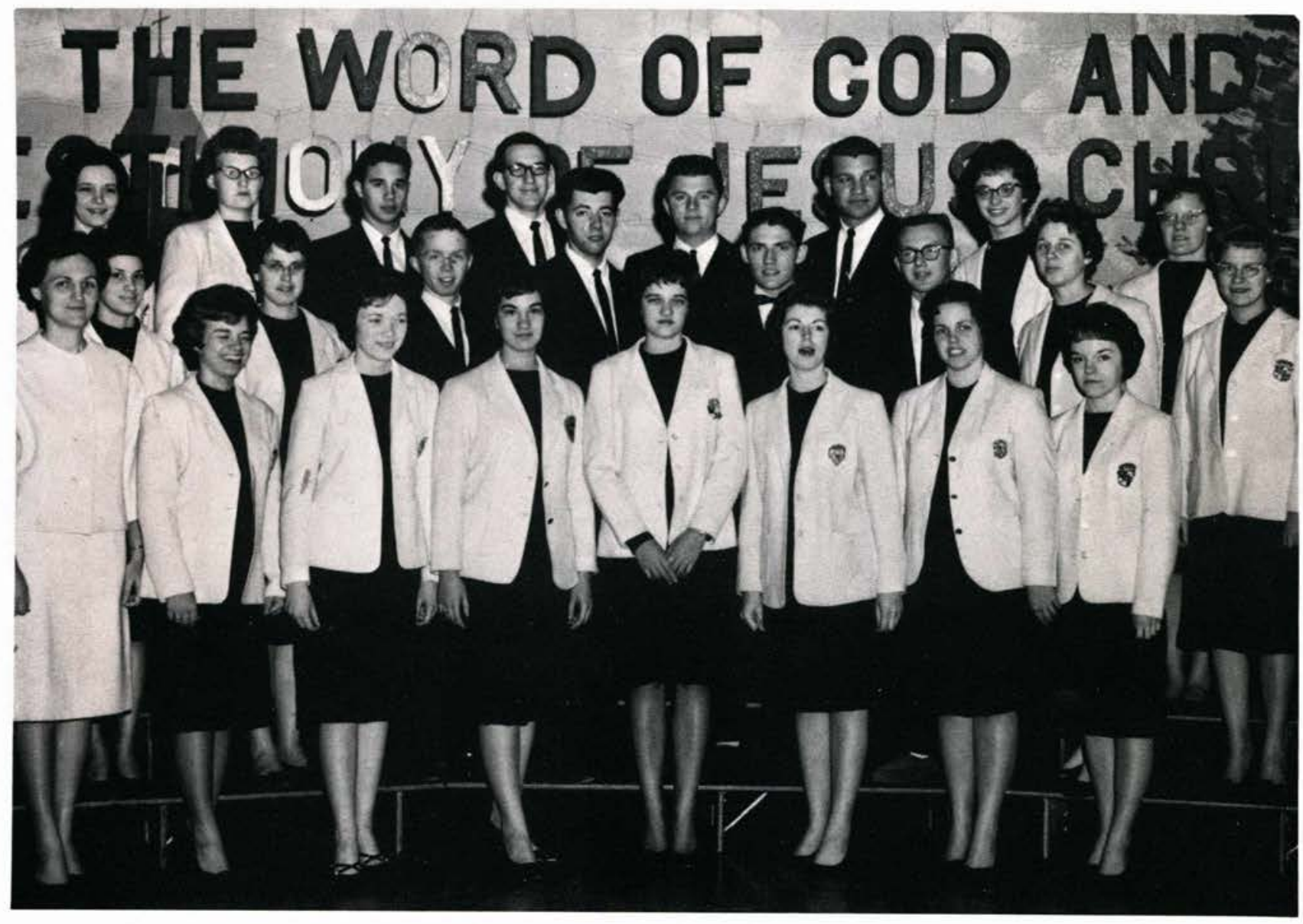

Top Row: N. Buerer, S. Geyser, D. Ober, D. Rifenberick, M. Averitt, J. Barker, E. Smelser. Second Row: P. Adams, E. Howard, D. Park, D. Jensen, B. Reynolds, P. Carlson, M. Cunningham, M. Powell. First Row: Miss Smith, J. Couwenhoven, L. Sullivan, N. Shimits, V. Curcio, J. Golden, S. Bender, M. Ammons.

The newest musical organization on campus began its second year with a performance at the Alumni-Faculty Luncheon and followed with consecutive performances at the homecoming pageant, Prospective Student's Days, and the annual Christmas Concert. Fred Waring and other arrangers are kept busy as strains of "Cool Water," "Let's Steal Away for a Holiday," "Jingle Bells," and "Nantucket" are heard floating across campus. The Choralaires have planned a performance at the Cedarville Lions Club, and a campus recital. 


\section{Chapel Choir}

\section{Officers}

President John Lawlor

Vice-President Tim Duffie

Secretary-Treasurer

Librarian
"Make a joyful noise unto the Lord - Come before His presence with singing." This has been the aim of the Chapel Choir as they have brought their musical program to area churches as well as to distant locations, including Troy, Bellfontaine, and Galion, Ohio. The immediate purpose of the Choir is the training of young people in Choral singing. Mr. George Zinn directs this Choir.

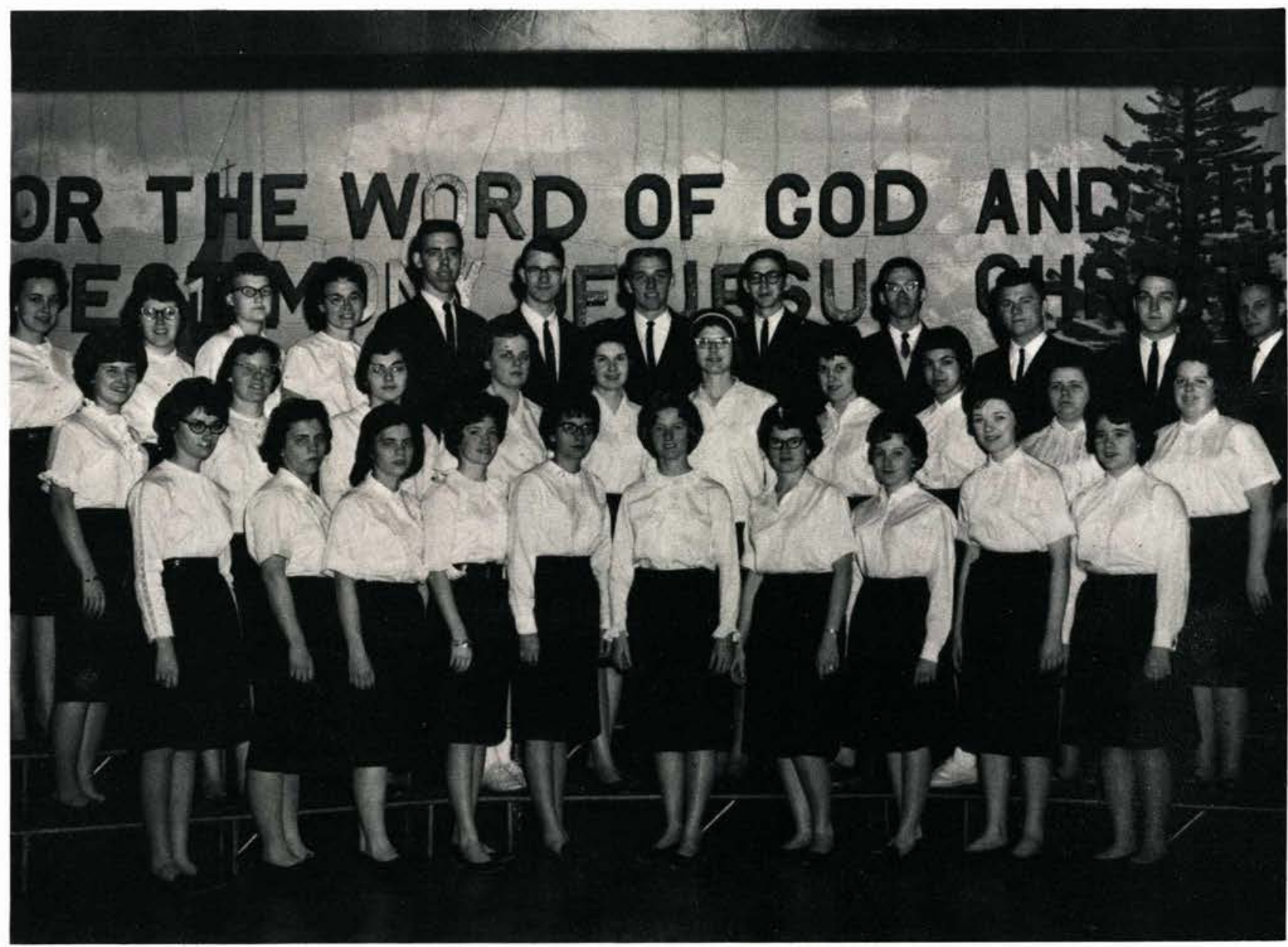

Top Row: S. Eckert, P. Albrecht, S. Geyser, J. Walborn, G. Goodwin, D. Nims, D. Werner, B. Weyhe, L. Montgomery, M. Averitt, T. Duffie, J. Lawlor. Second Row: M. Floyd, N. Smith, L. McNamara, D. Dunn, M. Ballard, D. Olsen, J. Siganowich, J. VanWyk, J. Rudduck, S. Armitage. Third Row: G. Brown, E. Dudley, E. Dudley, R. Butler, P. Micka, L. Duddleston, K. Teeters, J. Neely, L. Sullivan, J. Scholten. 


\section{College Choir}

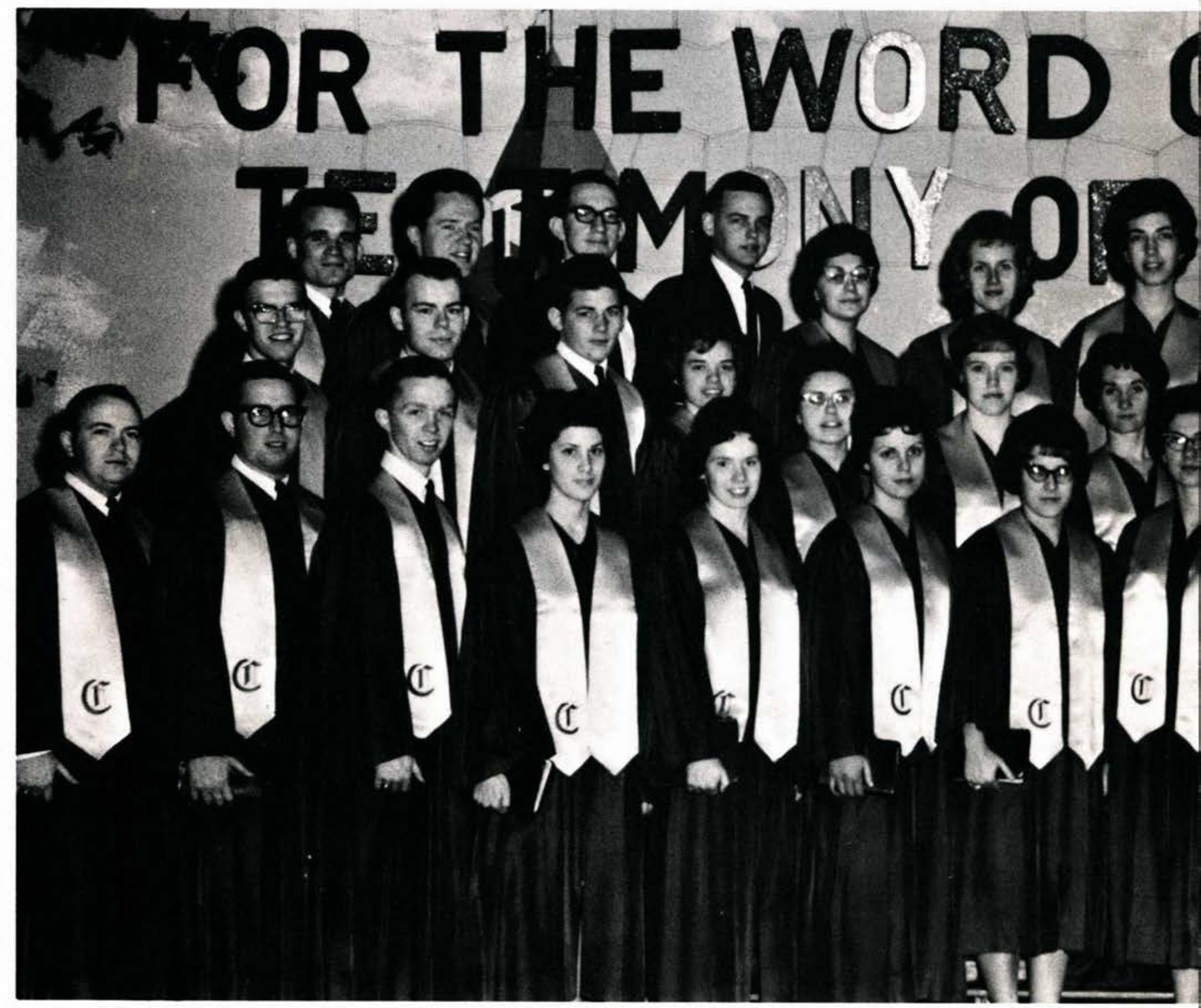

Standing: J. Walborn, B. Smith, D. Rifenberick, G. Taylor, D. Finley, J. Lachman, C. Johnson,

C. Copeland, J. Couwenhoven, P. Schonscheck, B. Miller, S. Marks, R. Johnson, H. Wing, V. Curcio, P. Olsen, D. Park, P. Adams, J. Addleman, M. Tulloch, F. Merrett, B. Nash, S. Addleman, M.

\section{Officers}

President Larry Czerniak Vice-President -John Ingram Secretary-Treasurer Donna Finley Historian Pat Adams 


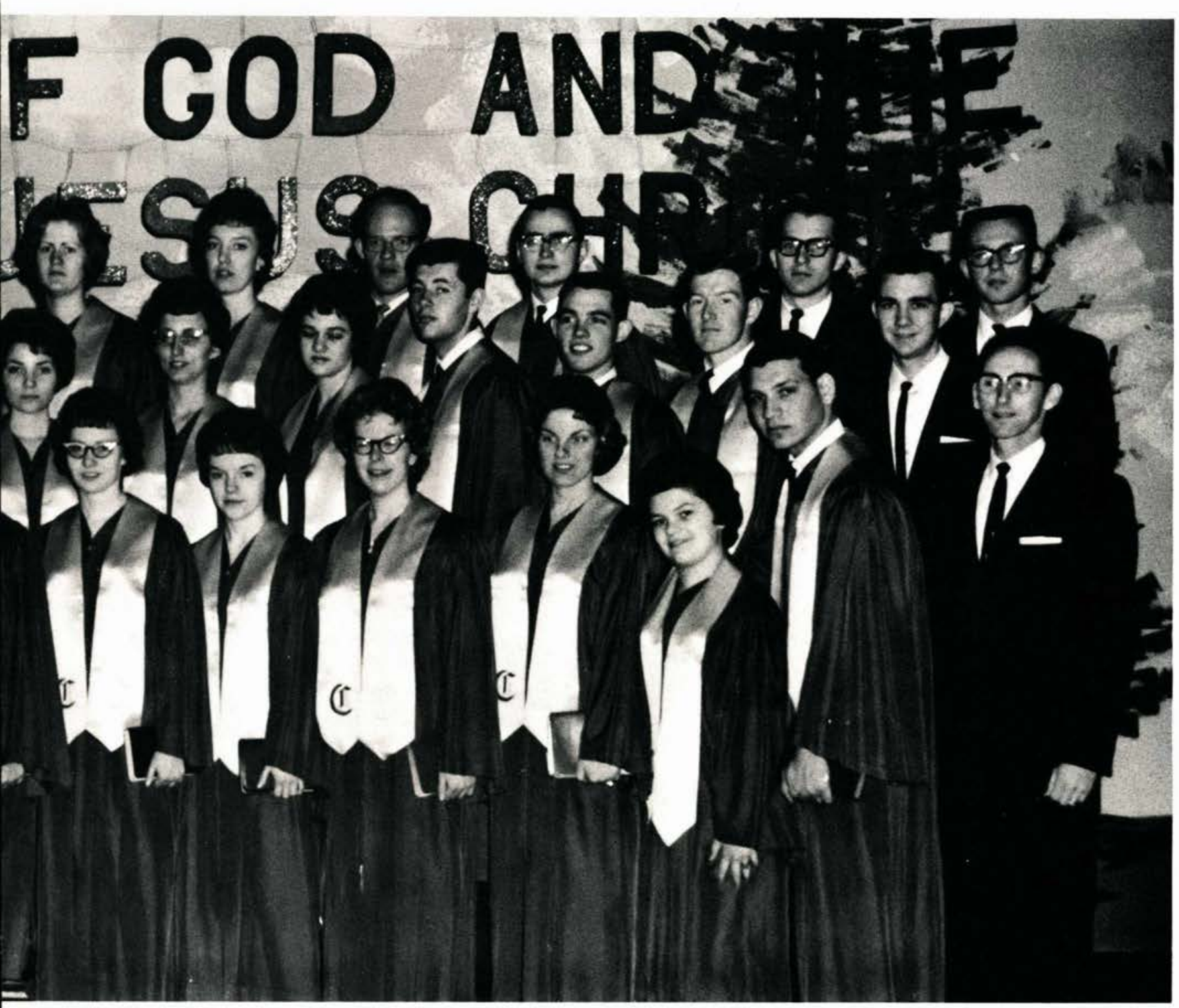

S. Brown, S. Gantz, D. Perry P. Reno, R. Werner, P. Carlson. Second Row: G. Harris, L. Czerniak, D. Jensen, M. Hollenbeck, J. Morgan, R. Mathis, Mr. Thornton, Director. Front Row: J. Ingram, Ammons, R. Millikin, S. Byrd, M. Brong, J. Barker.

The ministry of the College Choir has been extensive and effective throughout its history. Besides providing excellent opportunities for students to receive good, vocal training and experience in choral singing, it gives them a chance to present their testimonies in song for the glory of the Lord.

This year they have traveled to the Lebanon Correctional Institution, Lebanon, Ohio; to Dayton, Ohio, Covington, Kentucky, and Williamsburg, Ohio. They have done extensive recording. The Annual Spring Tour included churches in the Southern and Midwestern states 


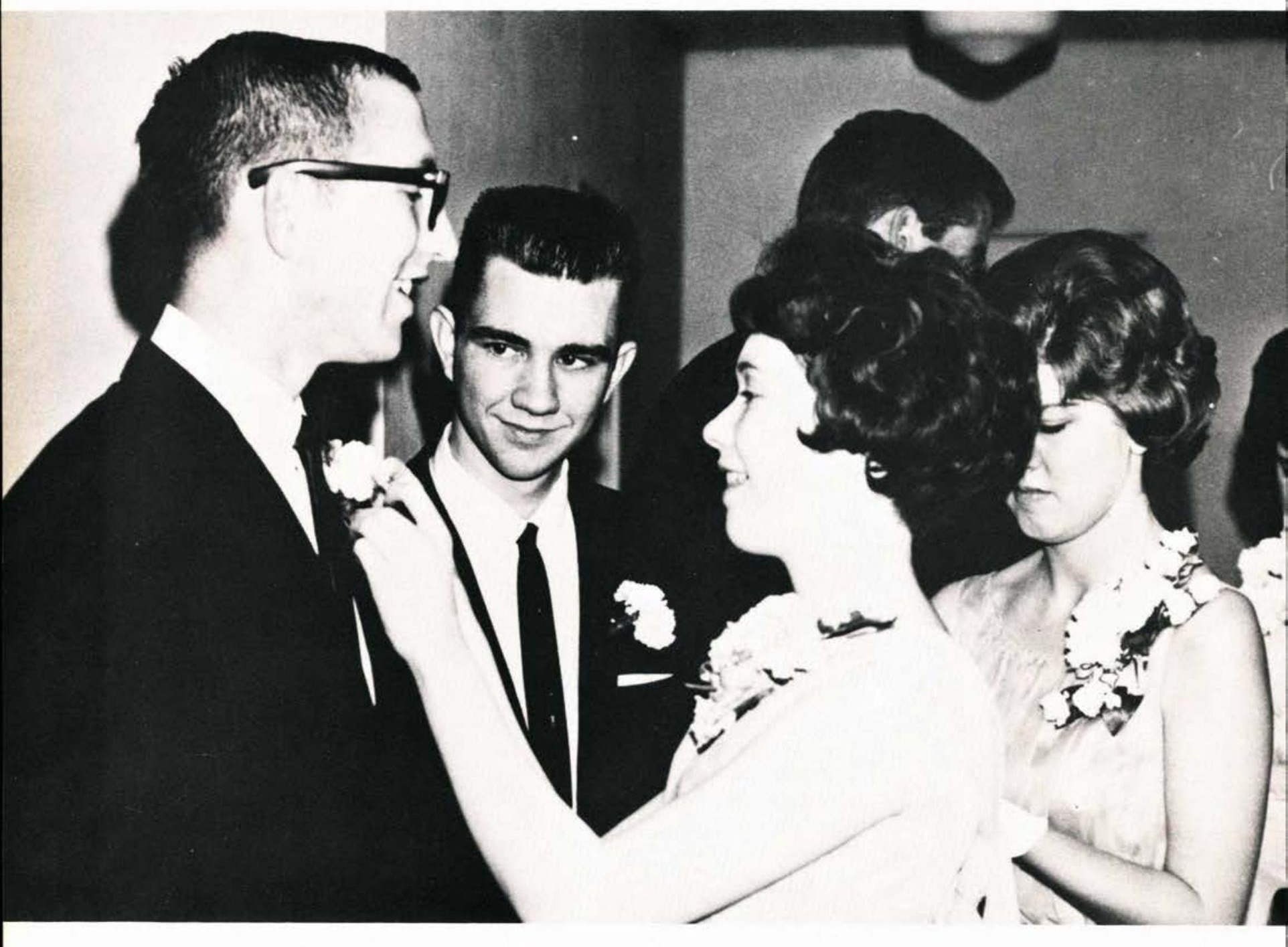

\section{Special Events}




\section{Class Of 1962}

\section{Baccalaureate}

Service

Thursday 8:00 P. M.

May 24, 1962
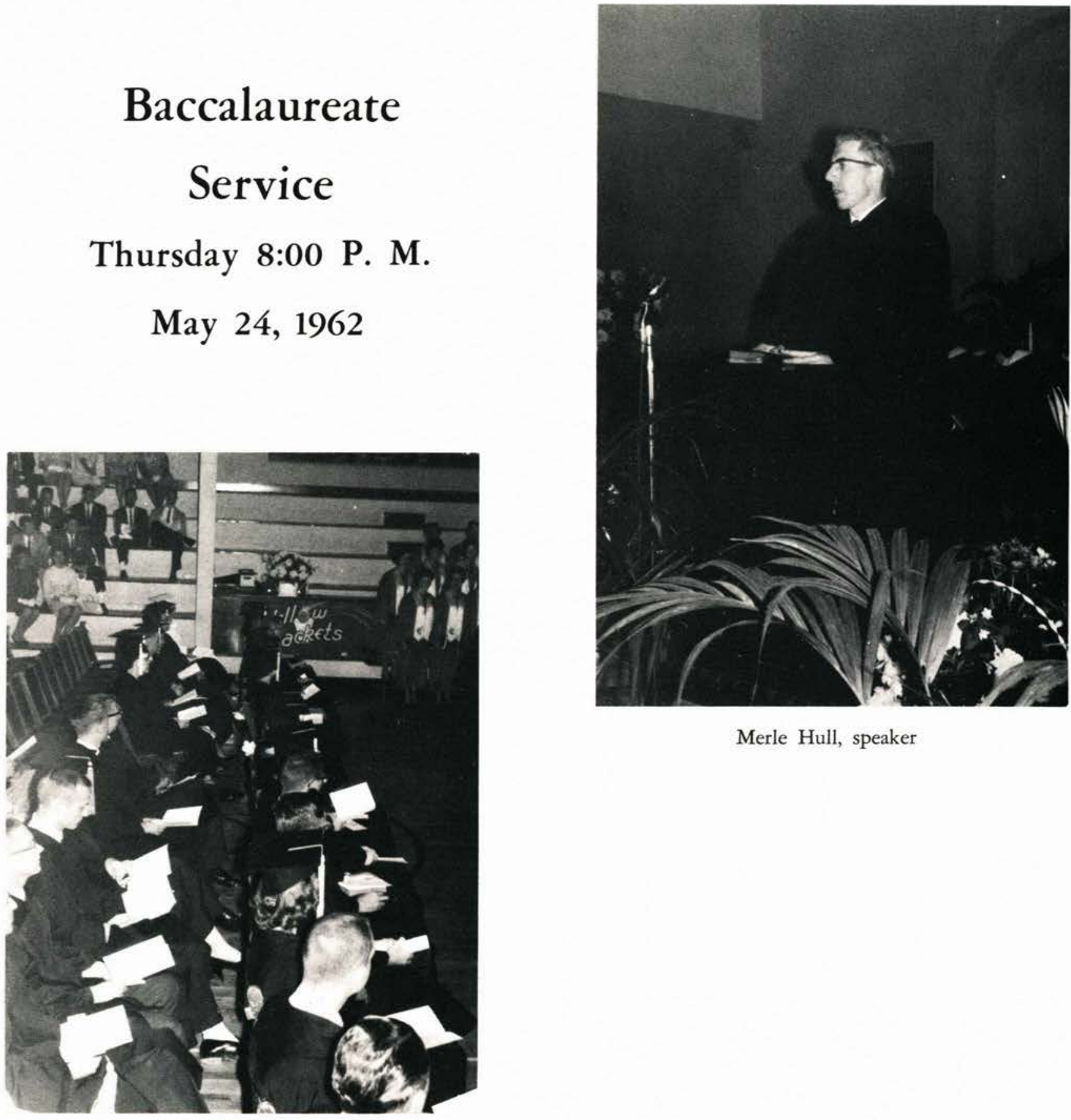

Merle Hull, speaker

The Class of 1962 receives a Spiritual charge. 


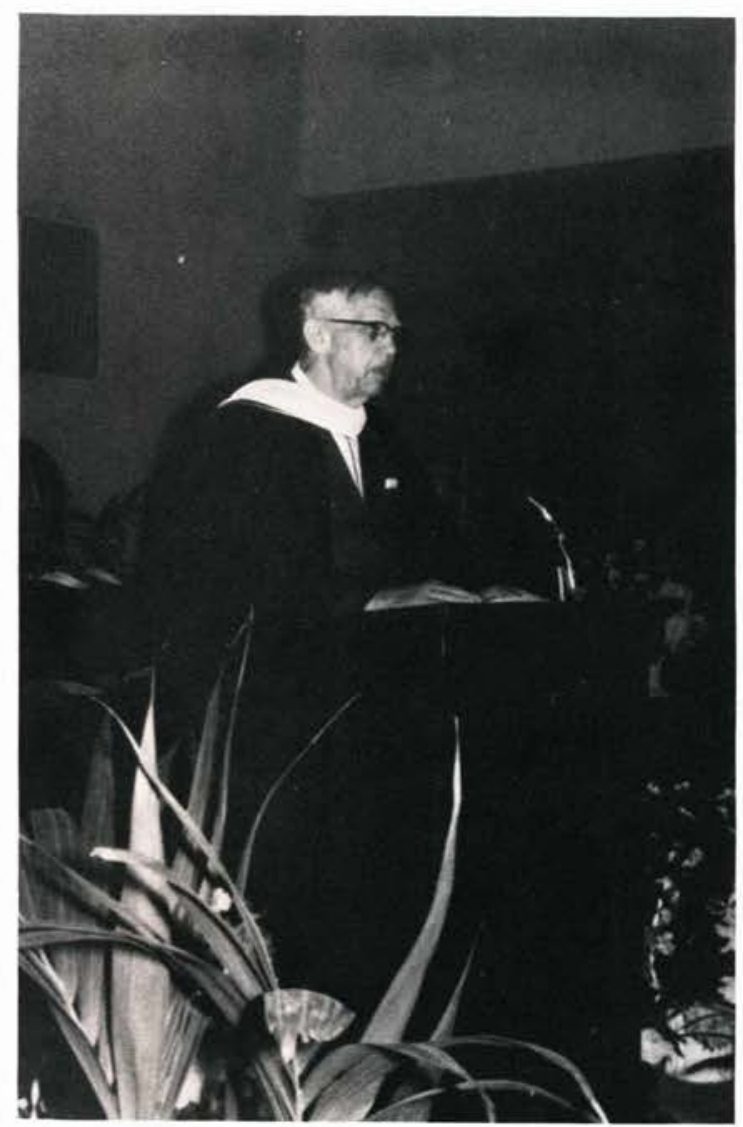

Dr. George S. Milner, Chairman of the Board, reads the announcements.

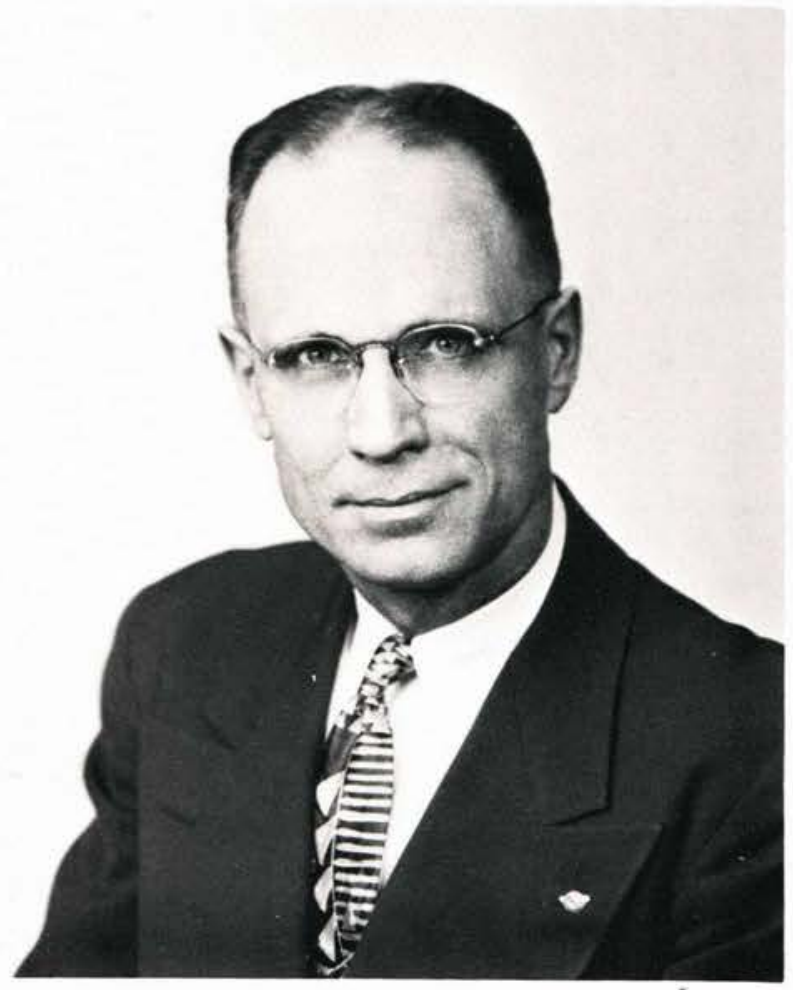

The Sixty-sixth Annual Commencement service was heralded by the familiar melody of the traditional "Pomp and Circumstance." Addressing the graduates and their guests was Dr. David Otis Fuller, noted pastor and author.

The last official ceremony of the Seniors' college career ended with the singing of the Alma Mater, "Wisdom's Dwelling" and the benediction by the President, Dr. Jeremiah.

\section{Commer}

\section{Saturday}

May 26 


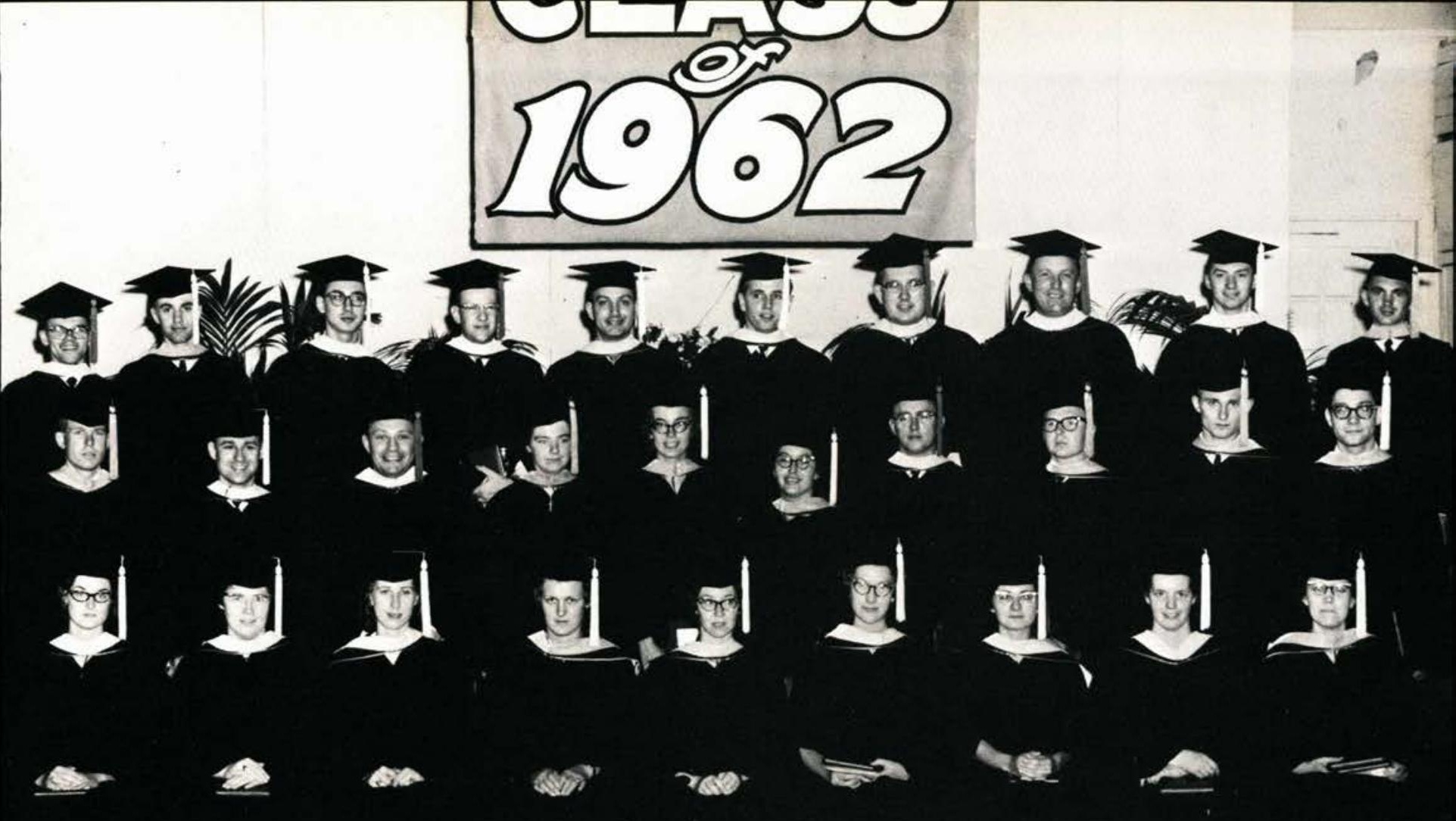

\section{CLASS OF 1962}

\section{ement}

0:00 A. M.

962

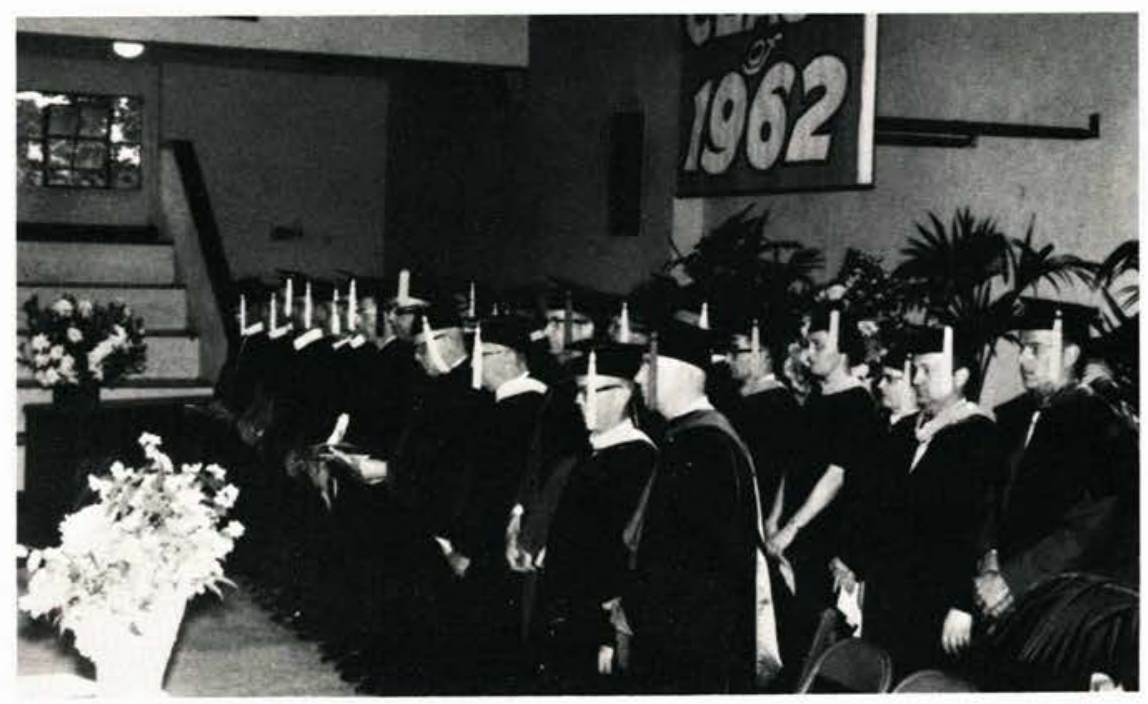

The college faculty honors the graduating class. 


\section{Spring Musical Activities}

\section{Tri M Inauguration}

Band Concert

\section{Student Recitals}

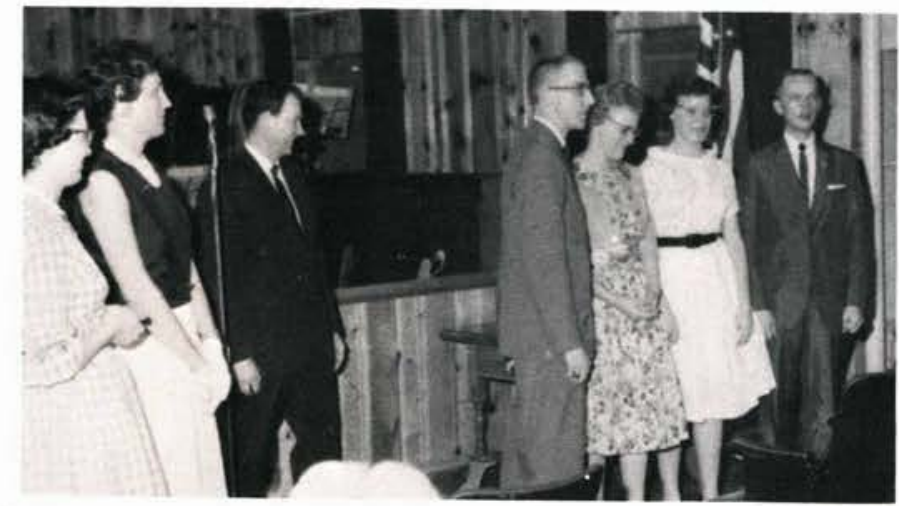

TRI M INAUGURATION: R. Werner, M. Powell, N. Smith, B. Washburn.

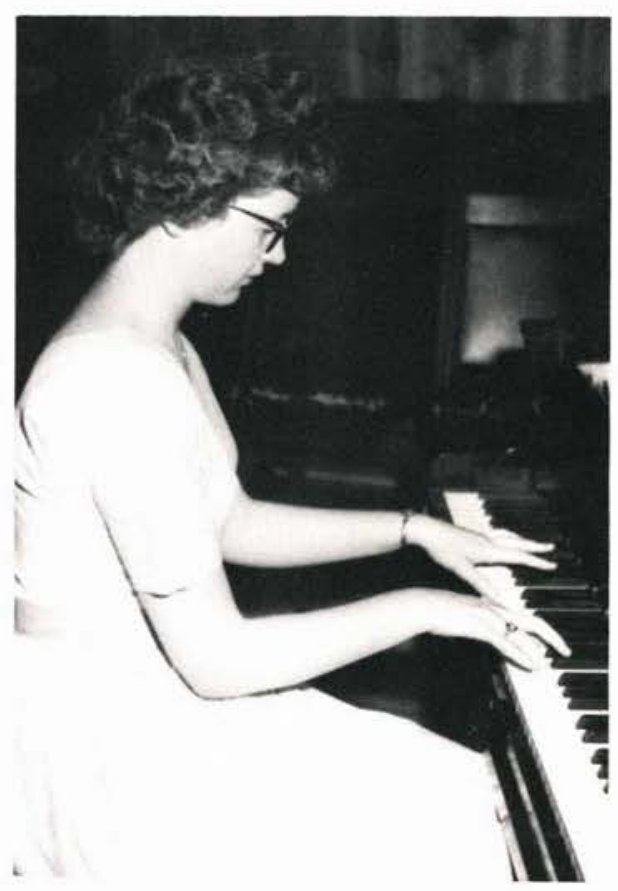

Nancy Warkentin

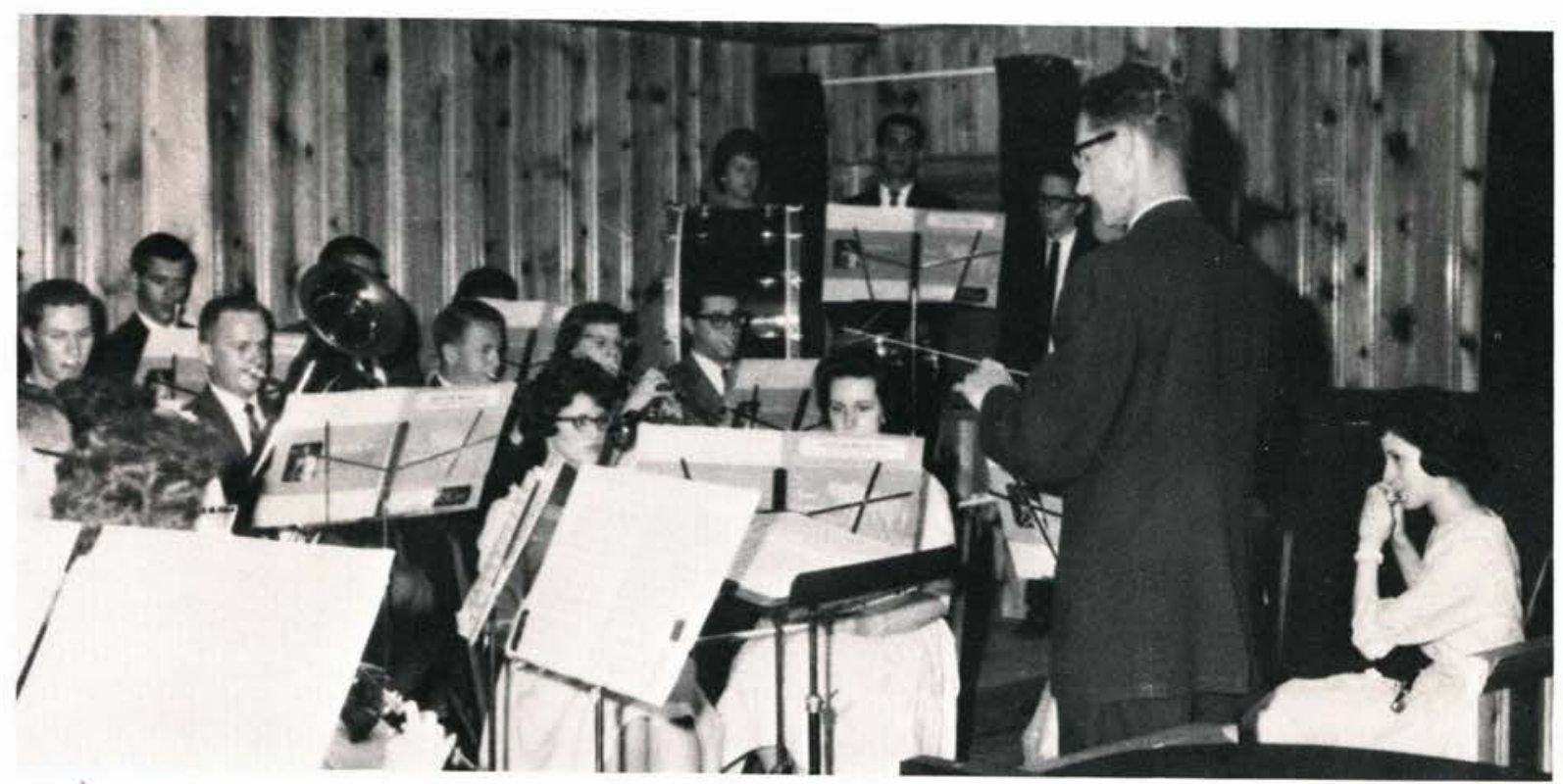

Band Concert directed by Mr. Thornton 

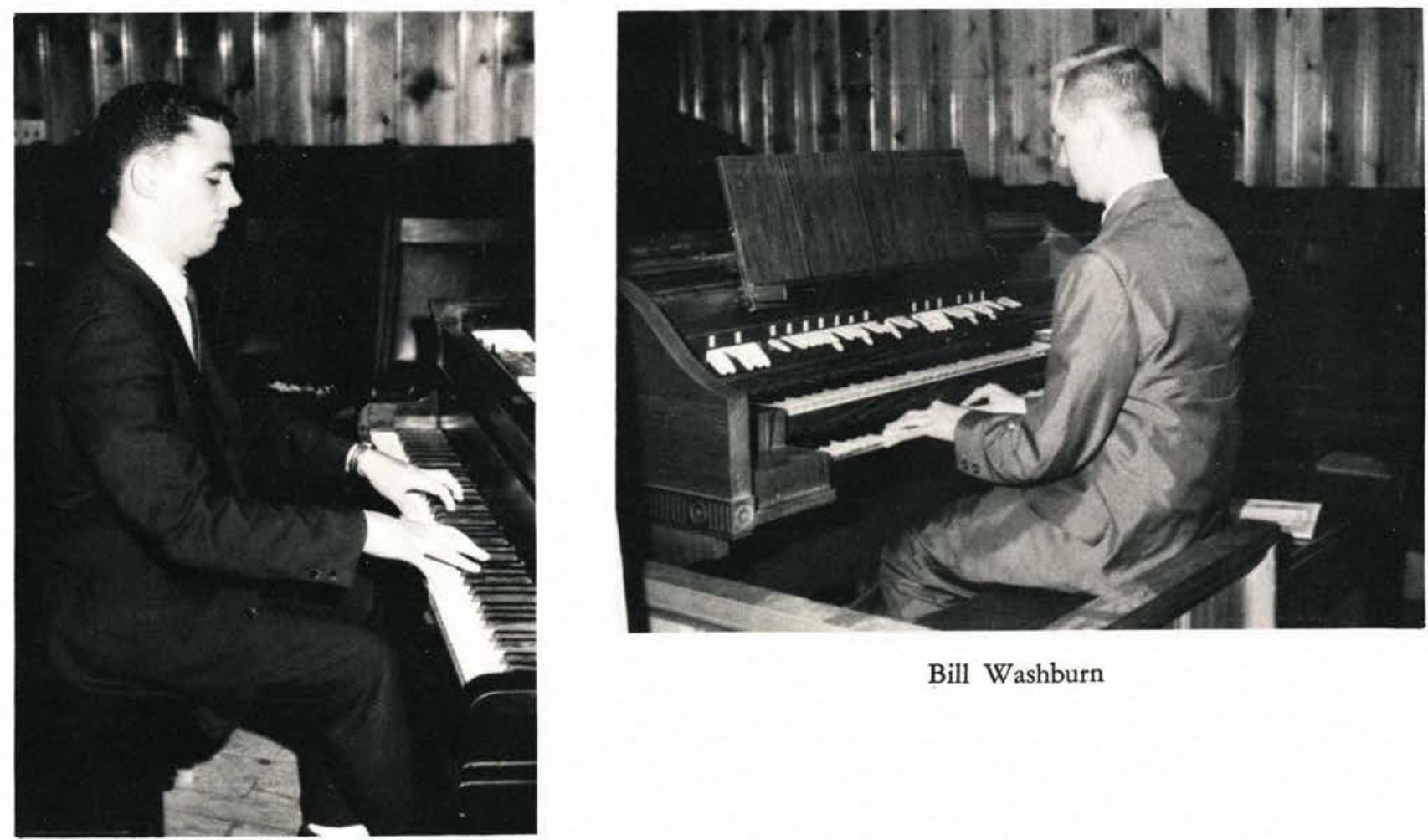

Bill Washburn

Marve Hollenbeck

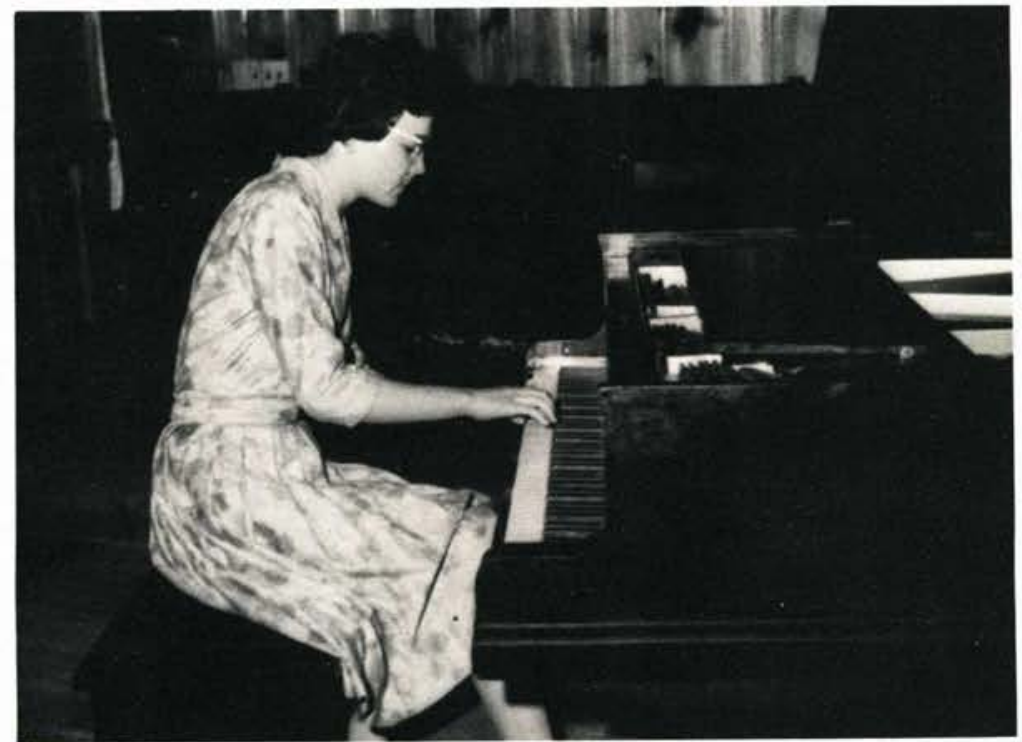

Judy Walborn

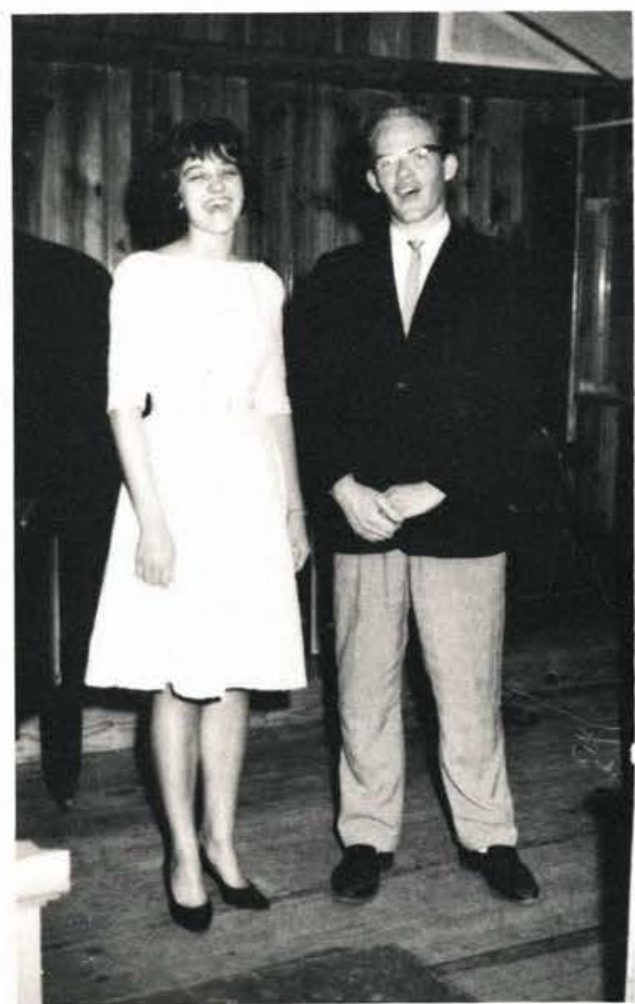

Vickie Curcio, Dave Perry 


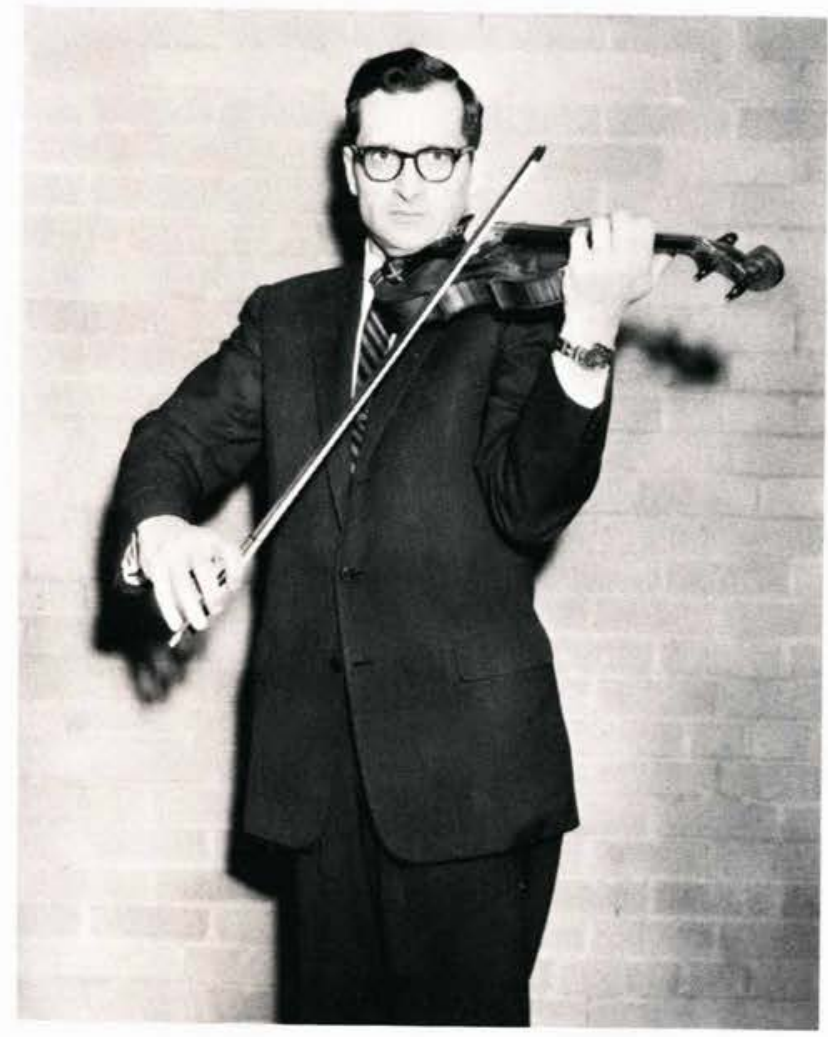

Warren Driver

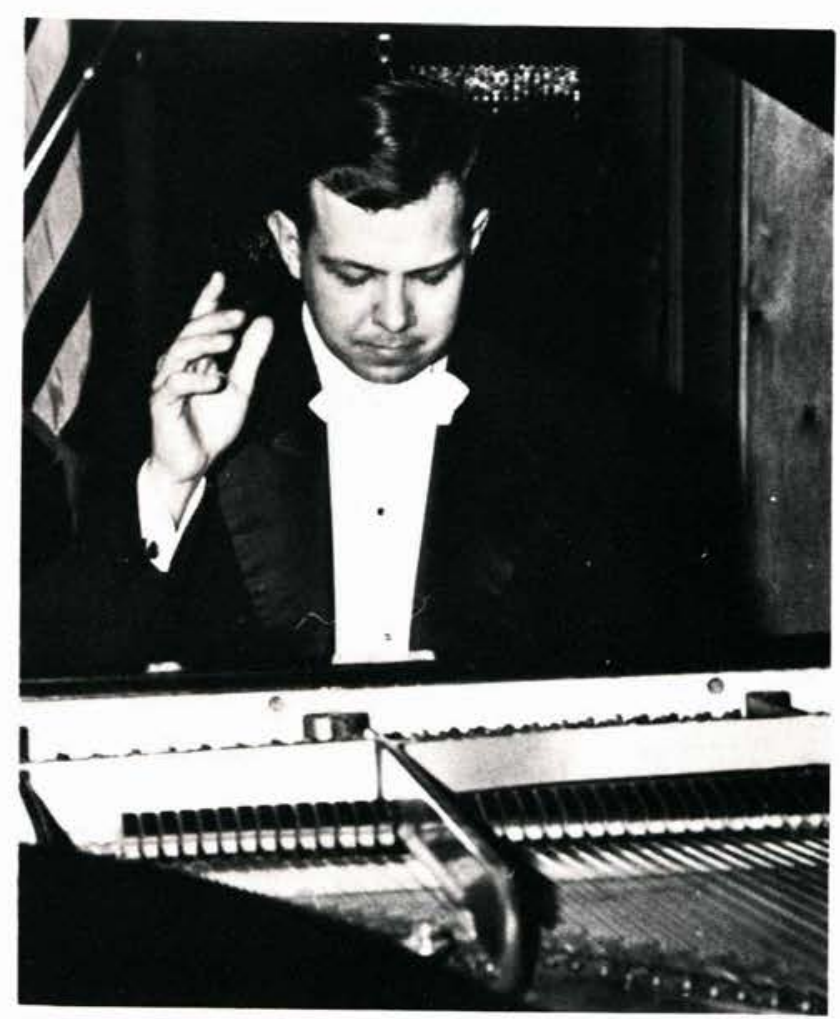

Howard Truvelle

\section{Artist}

\section{Series}

Arriving during the bustling course of every college year are those premeditated events which become the structure of our memories. Among these are evenings of aesthetic appreciation communicated to each student through the Artist Series.

The gifted hands of Howard Truvelle captivated the audience, making them one with his music. Highlighting the duopiano concert by Ruth Smith and Joseph Zimmerman was the Concerto, Op. 18, No. 2, Allegro scherzando by Rachmaninoff. Intangible moods of universal feeling were experienced as the 661st Air Force Band artistically presented songs of local color and patriotism.

Concluding the 1962-63 Artist Series, Warren Driver, concert violinist, illustrated the purpose of the Series - heights of appreciation - enlarged vision for the everyday world. 


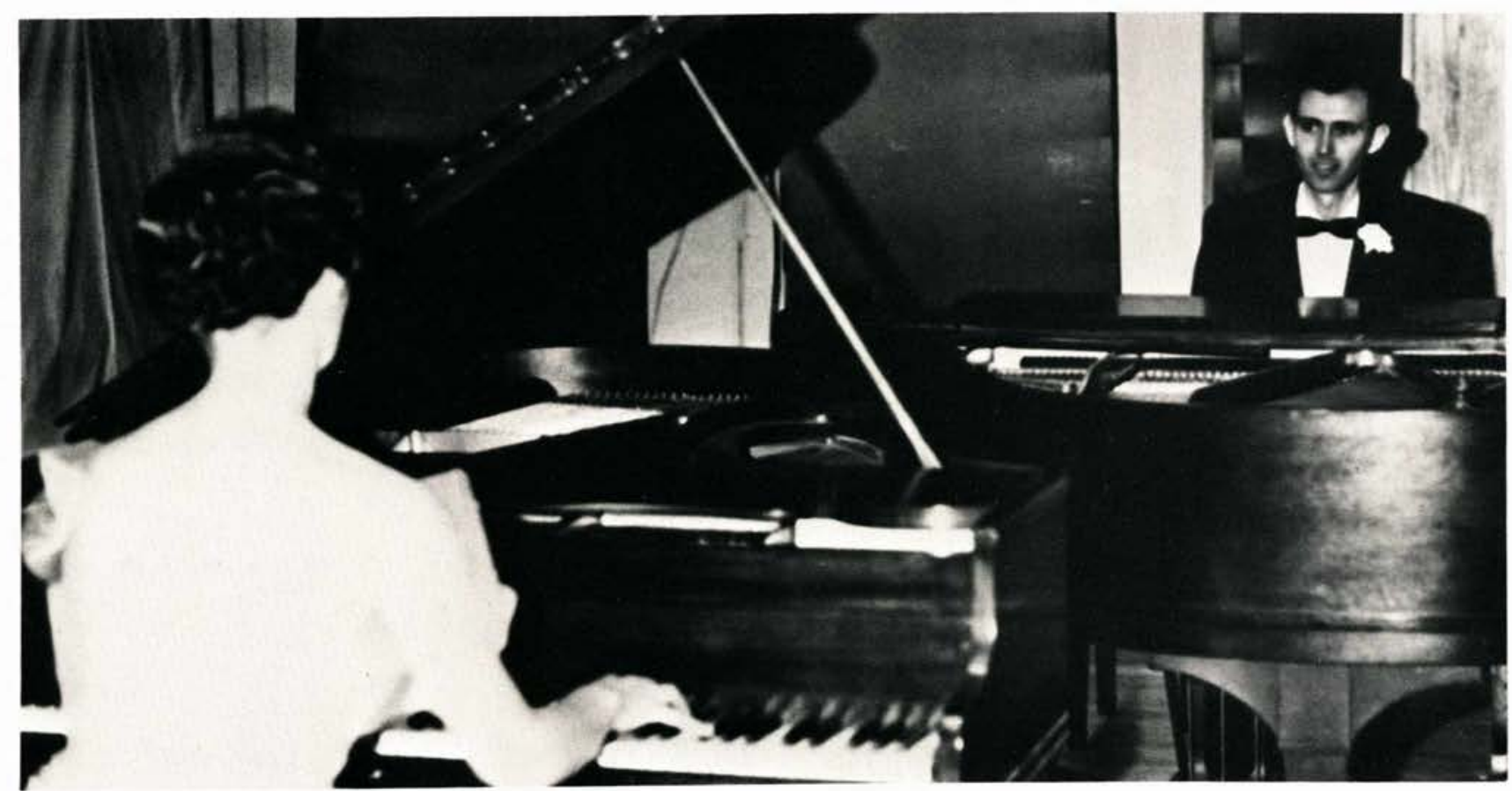

Smith-Zimmerman Piano Duo

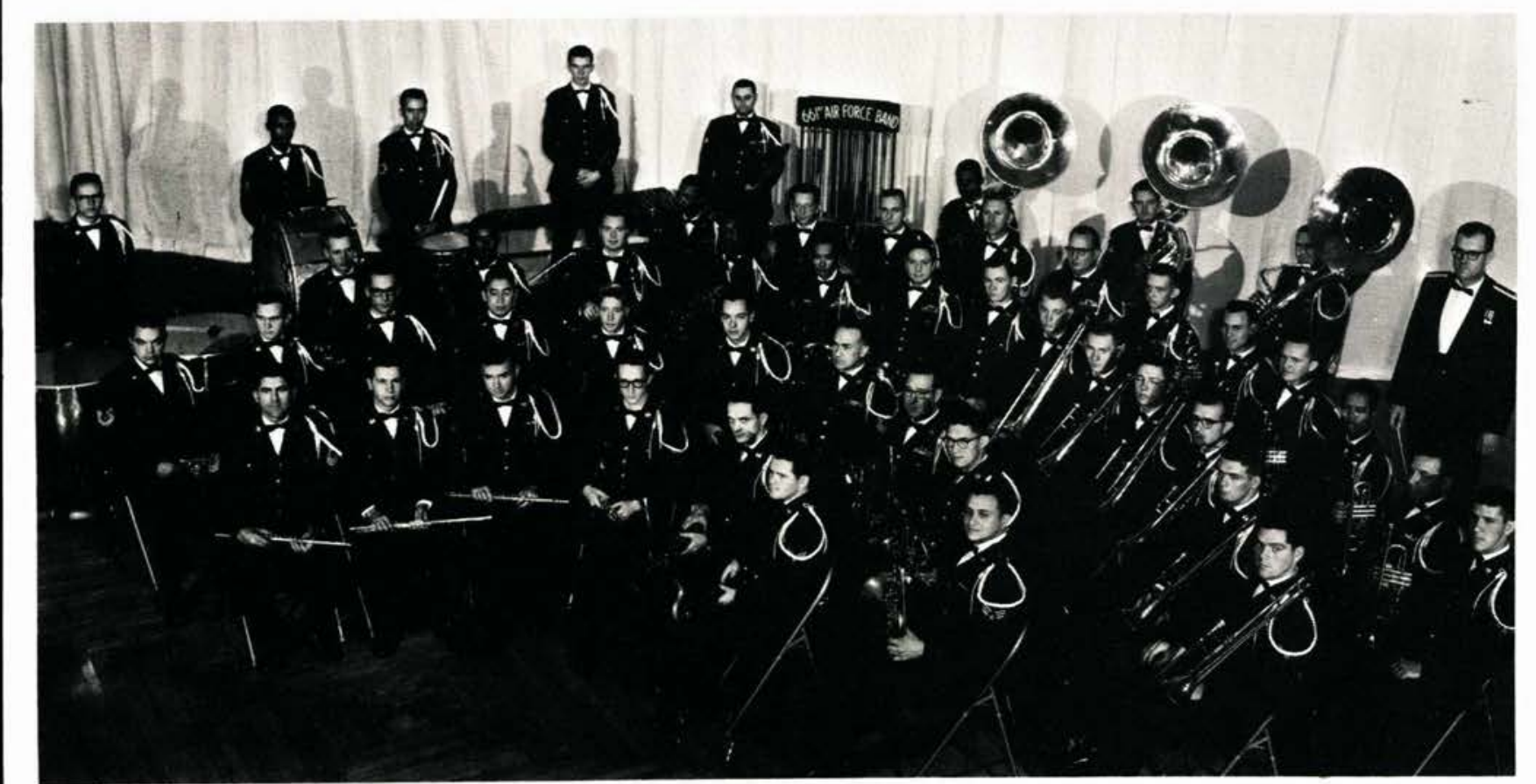

661st Air Force Band 


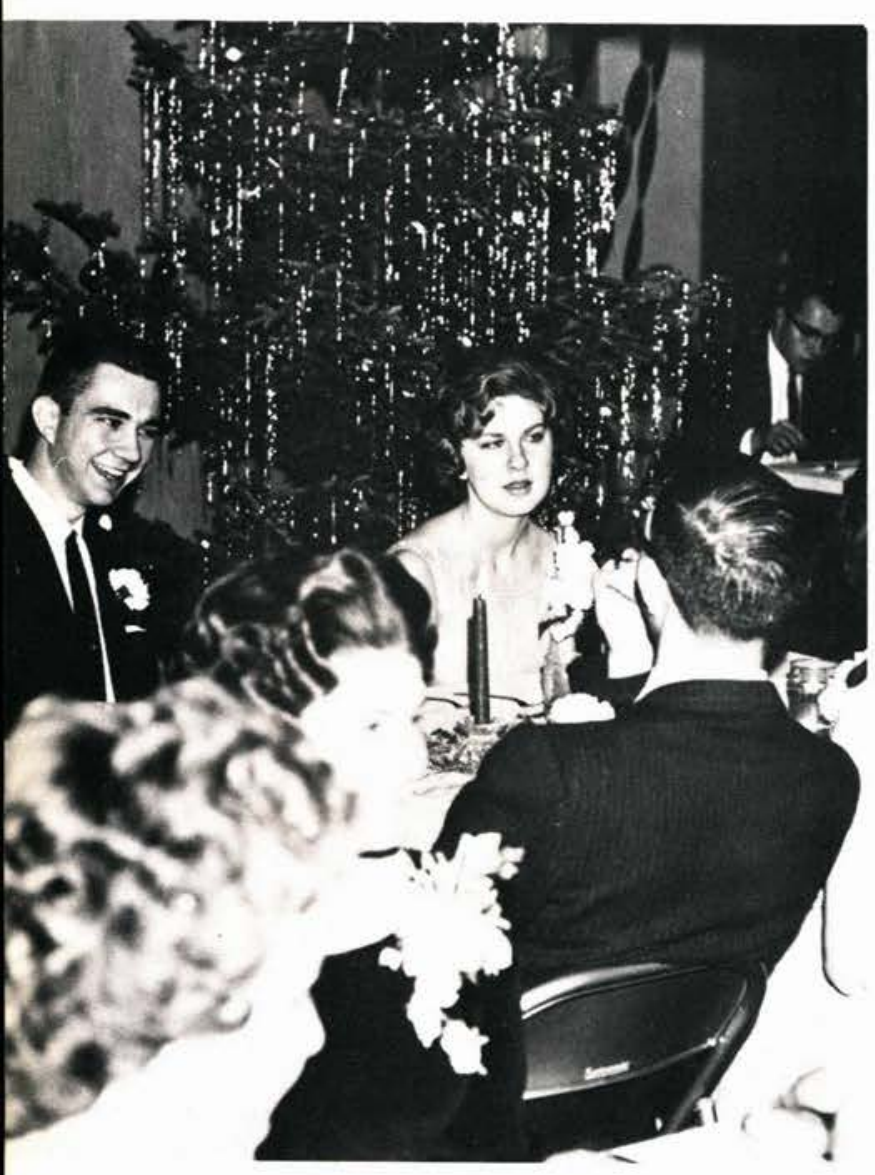

\section{Alpha Chi and}

\section{Gamma Chi Banquets}

Each year it is the responsibility of the literary societies on campus to sponsor a banquet. This year Alpha Chi sponsored the Christmas Banquet, Gamma Chi sponsored the Valentines Banquet and Kappa Delta Chi, the spring Founders Day Banquet. The Christmas Banquet with the theme "Holiday Moods," presented entertainment and speaker in the Christmas tradition. The old-fashioned theme "Grandpa Went A 'Courtin'" set the pace for a celebration of the Valentines season. Commemorating the Founders of Cedarville College, the Founders Day Banquet was an appropriate occasion during this anniversary year.

Alpha Chi Banquet

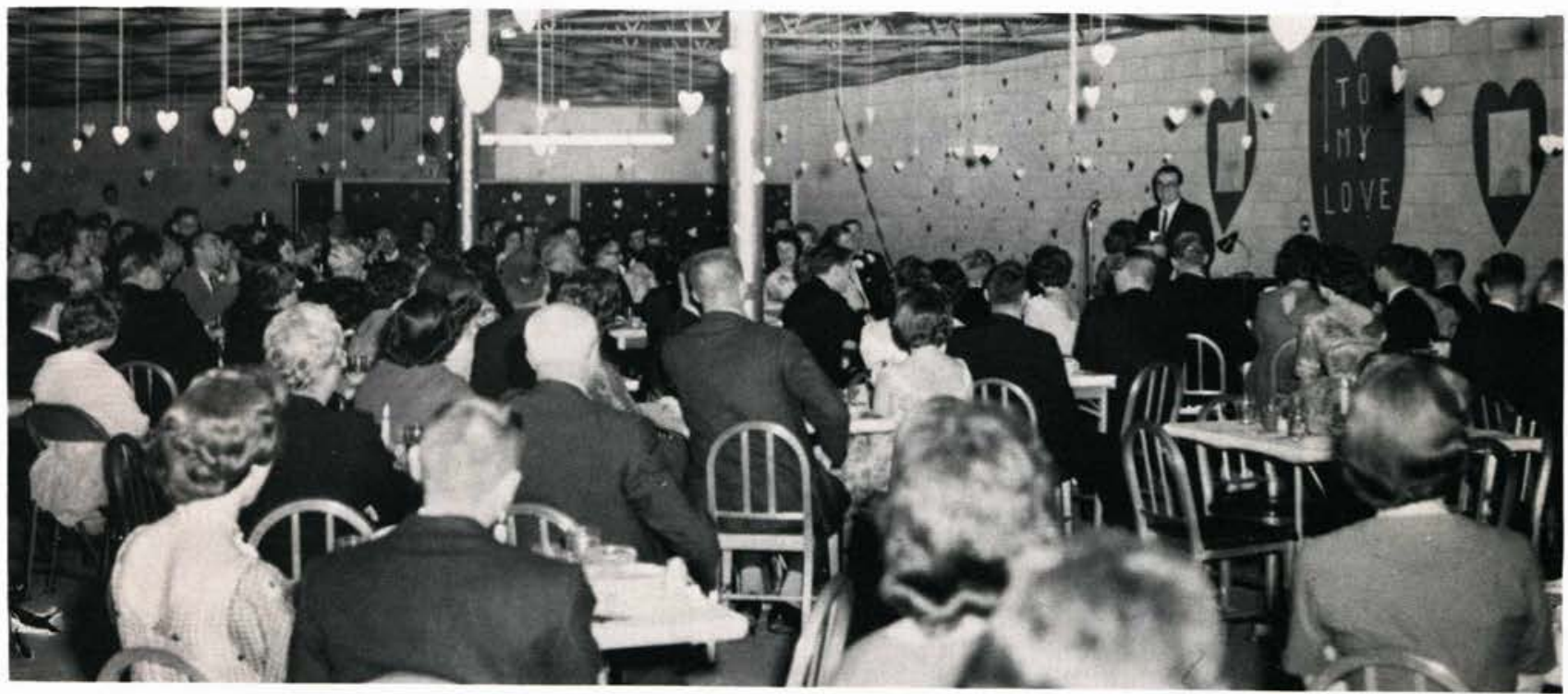

Gamma Chi Banquet was held in the banquet room of the Student Center and Mr. Robert Gromacki was the Master of Ceremonies. 


\section{Junior - Senior Banquet}

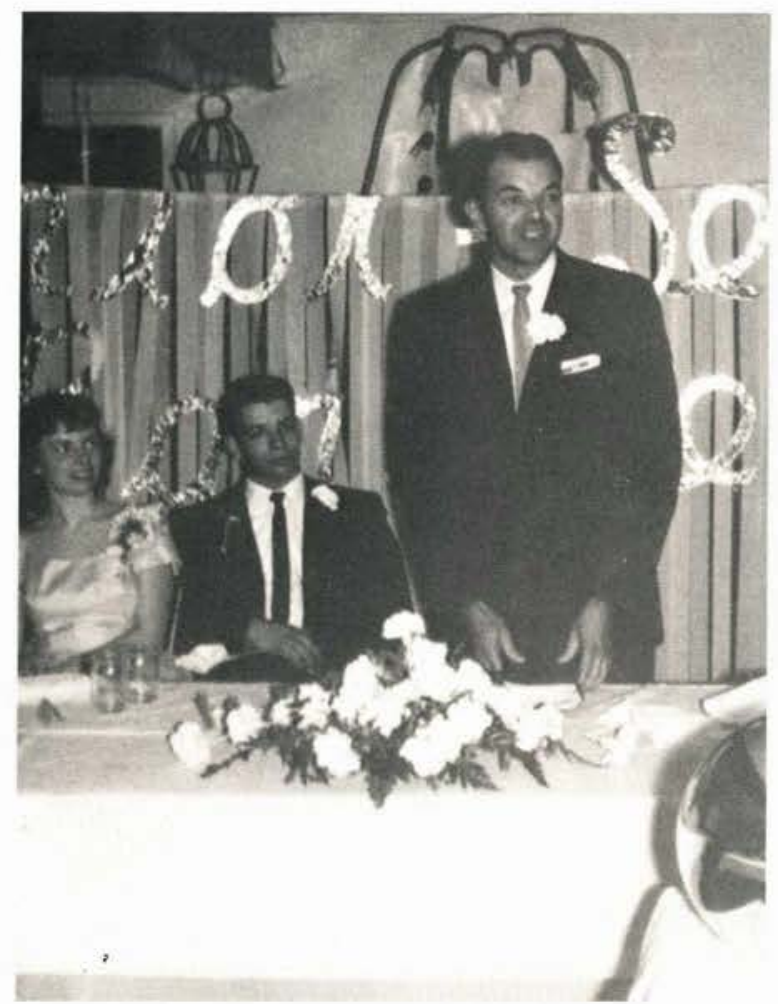

Rev. Fred Barlow, speaker.

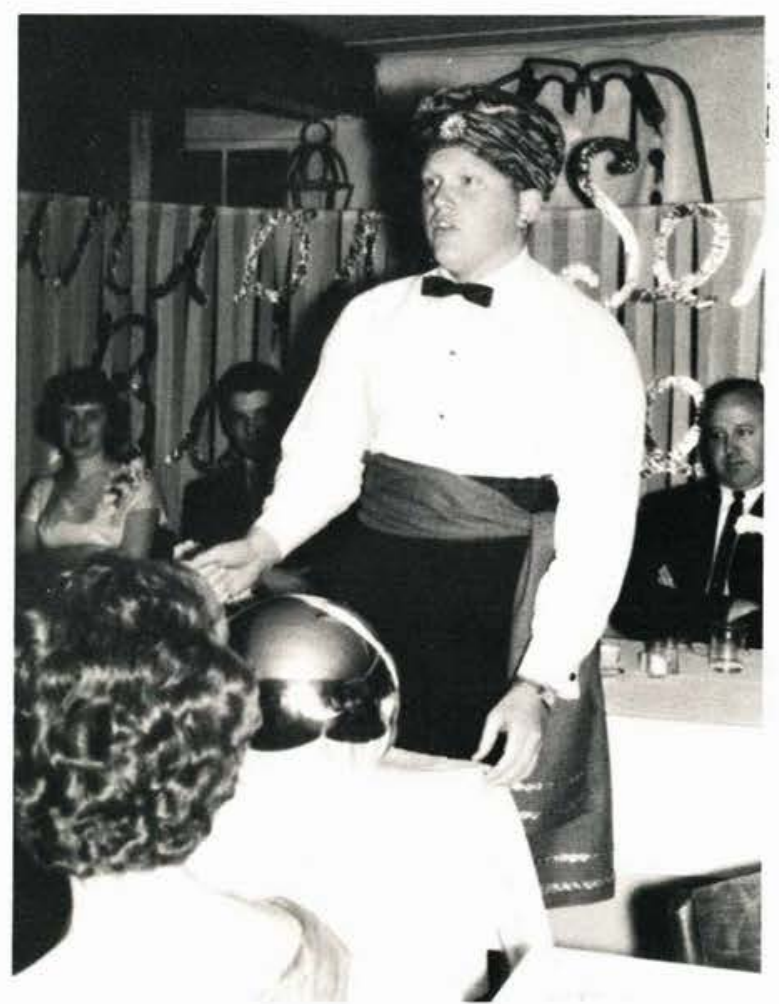

Rich Davidson gives the class prophecy.

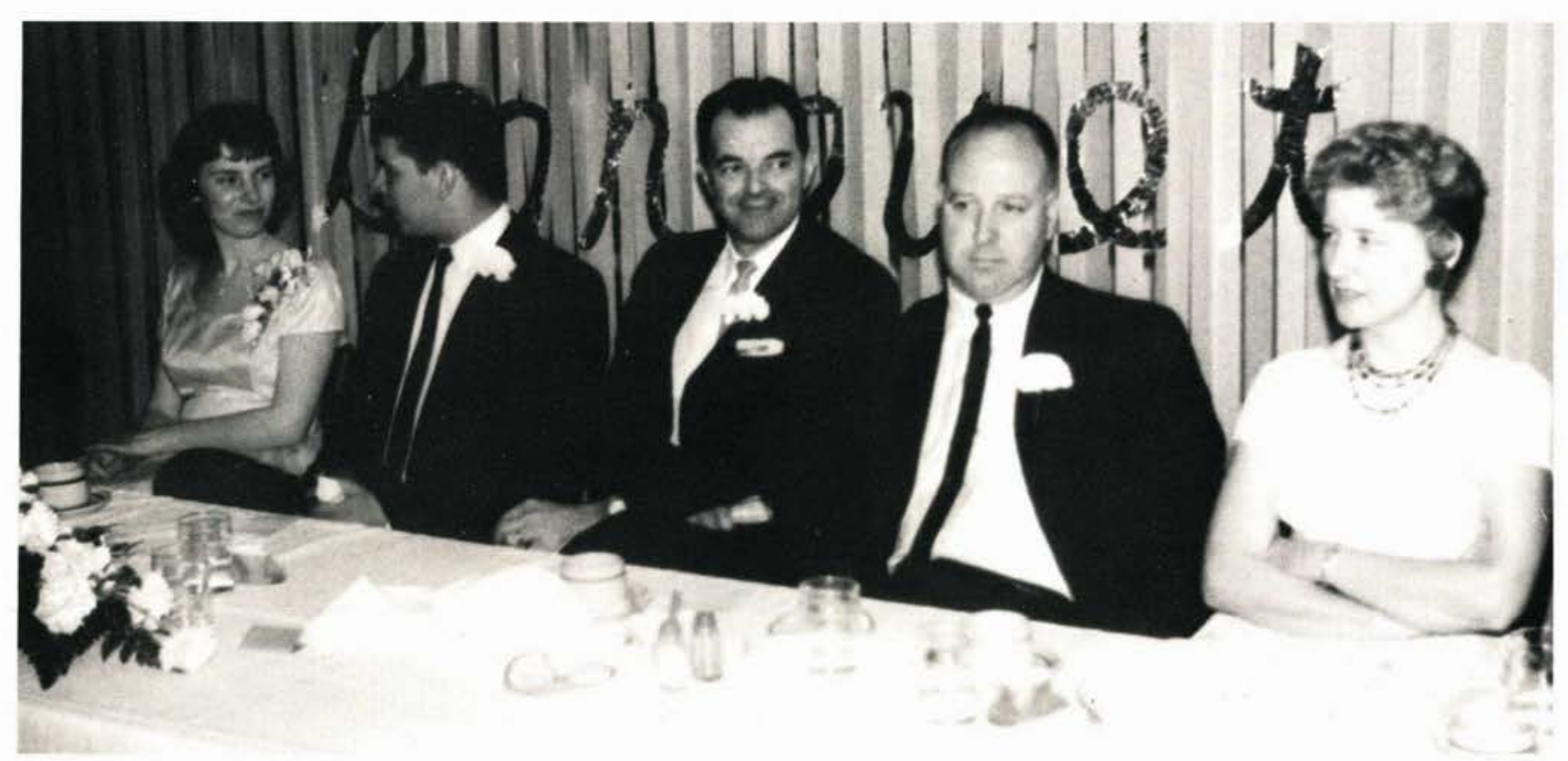

Helen Bloomenstock, Richard Bloomenstock, president; Rev. Fred Barlow, Robert Underwood, master of ceremonies; Mrs. Underwood. 


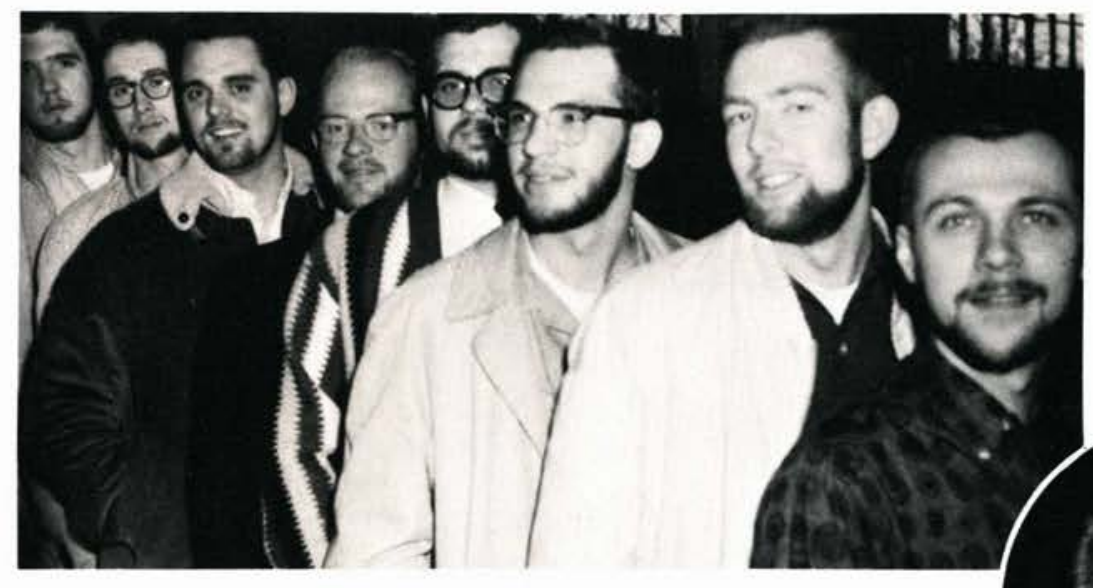

Smiling faces proudly display scratchy beards.

"Homecoming 1962," with its theme "As the Cedar Grows," was ushered in by the arrival of friends and acquaintances and the stiff competition between classes and clubs for the best Homecoming display. Novelty was provided by the men students who competed to see who could grow the "biggest and best beard the fastest," in commemoration of the college's 75 th anniversary.

In the afternoon the Alumni-Faculty luncheon was held in the dining hall, and was followed in the late afternoon hours by a football game. The activities of the day were climaxed that evening with the presentation of the pageant, "As the Cedar Grows."

Left to right: Dave Jensen, Dave Prosser, Larry Killian.

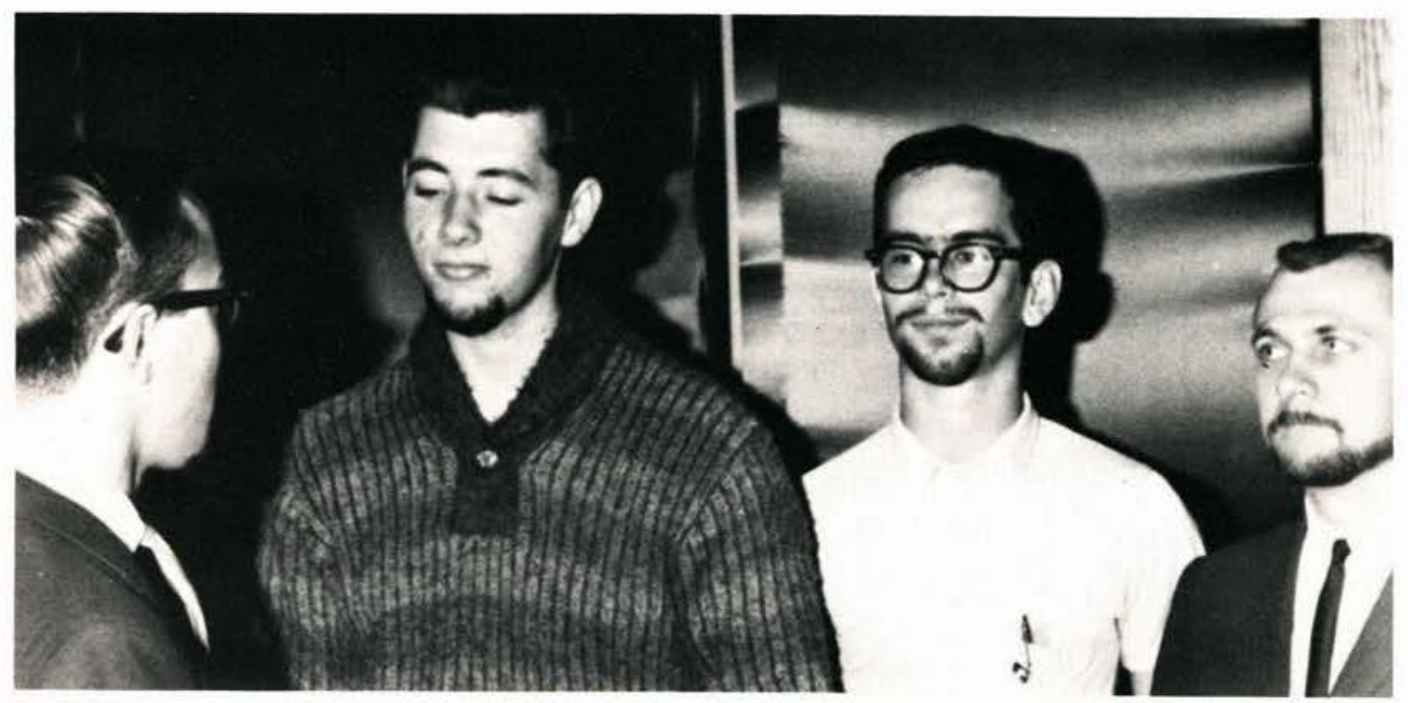




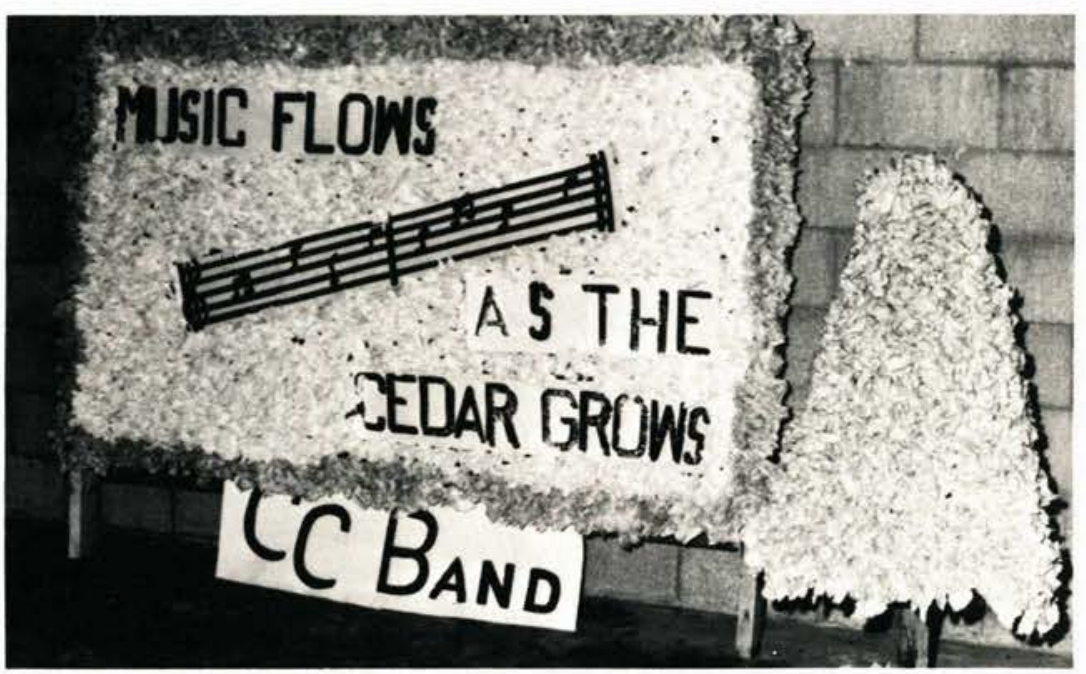

Cedarville College Band display.

\section{oming}

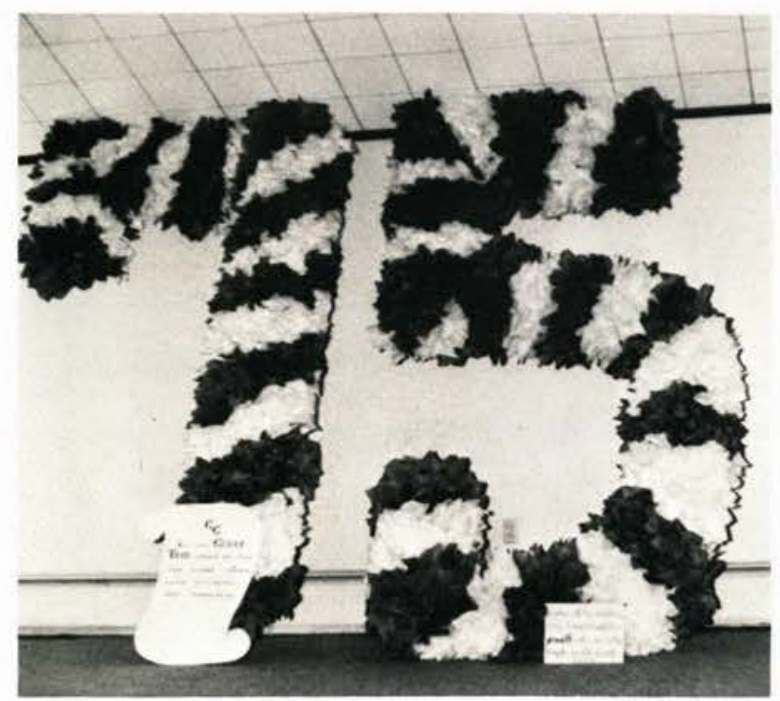

Freshman Class display.

Faith Hall display.

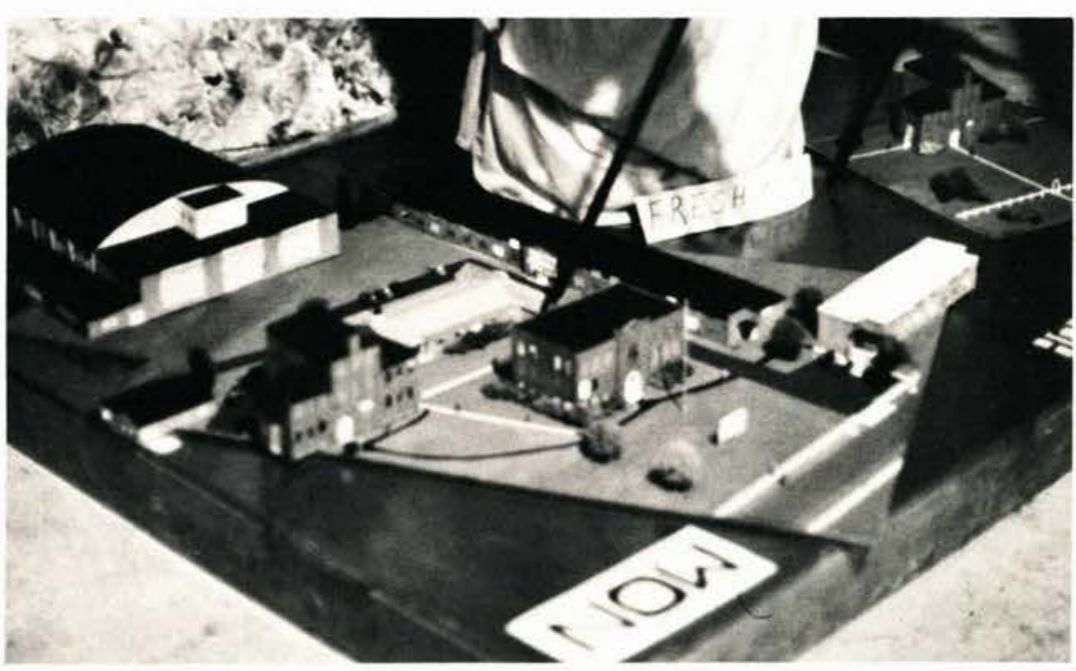



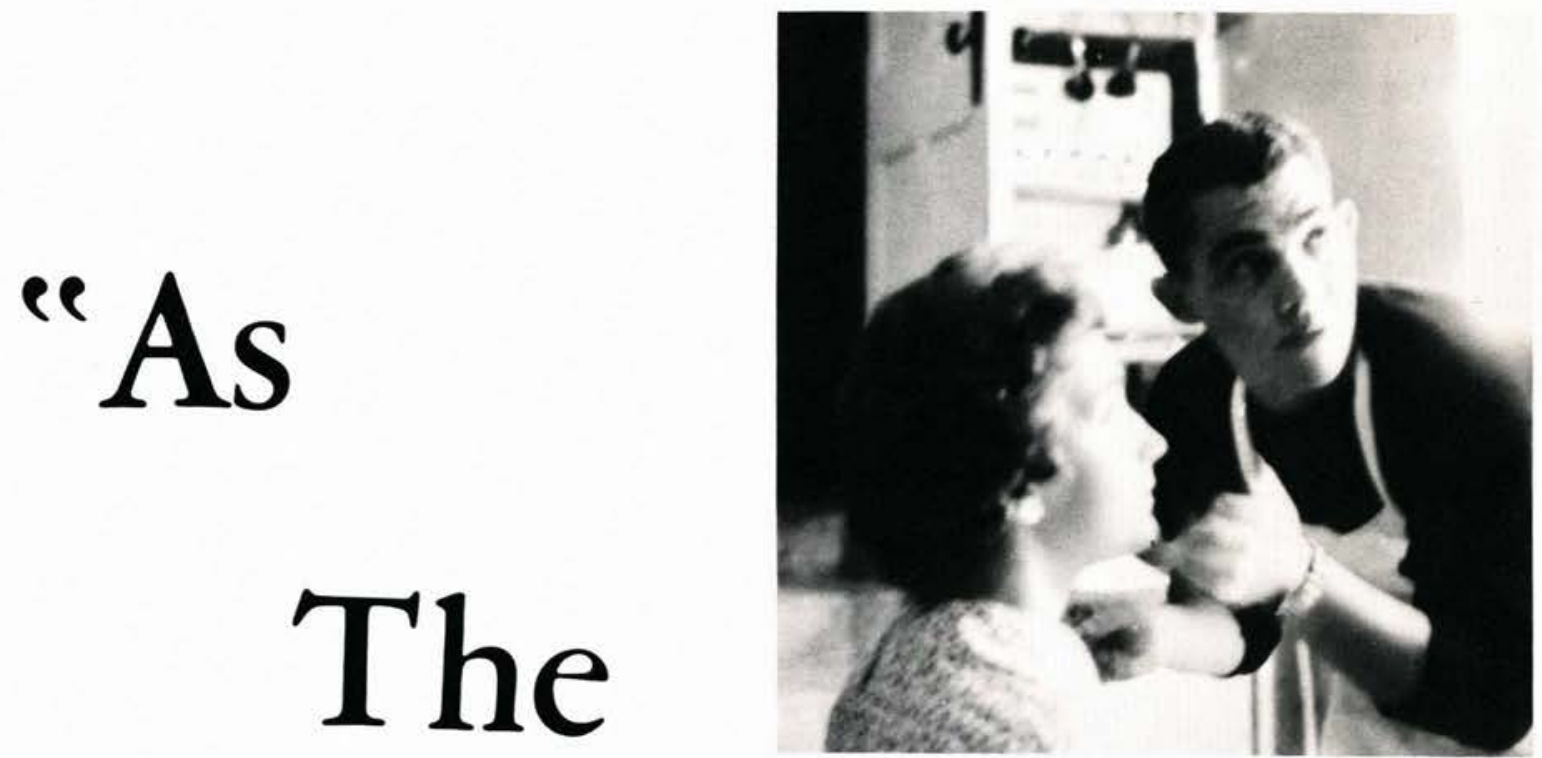

Make-up is an important part of the production.

From the first touches of make-up to the

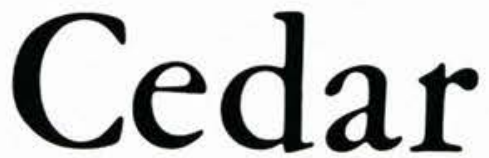
finishing touches in the last scene of dress rehearsal; the pageant "As the Cedar Grows" shaped the significant units that compose the history of Cedarville College. The traditional planting of the Cedar Tree, the signing of the deed that made the college "ours," graduation exercises, and the prominence of athletics in the social life portrayed what was and is Cedarville College.

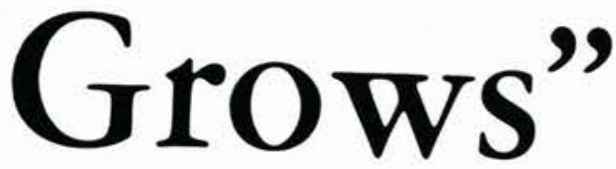

The Grand Finale.

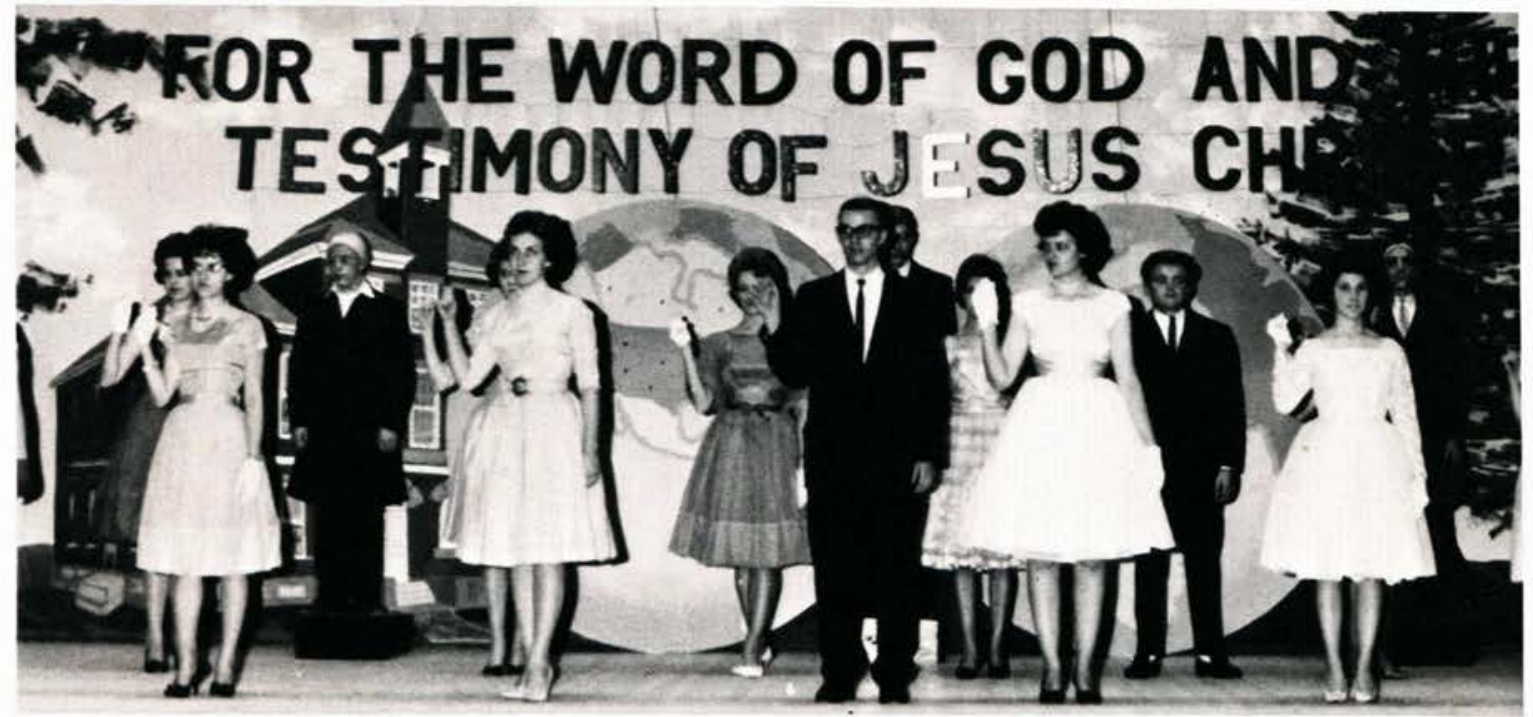




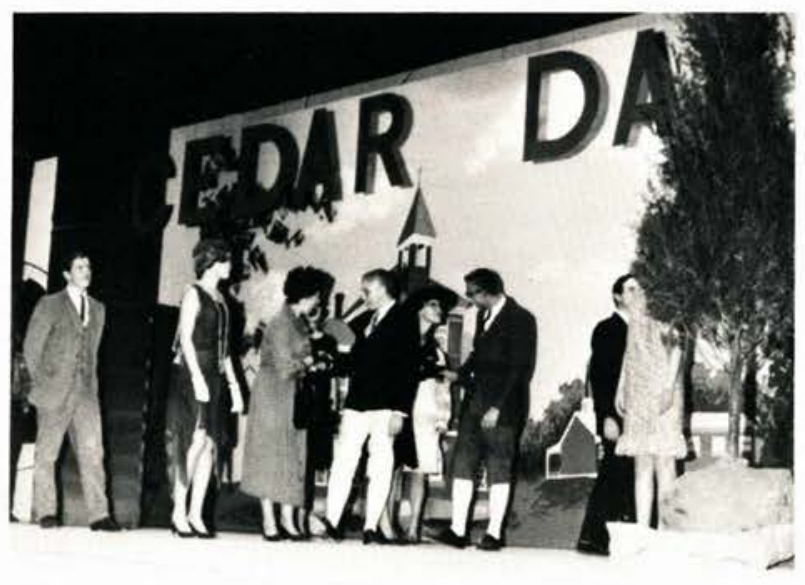

The planting of the Cedar tree.

"The Cedar Tree

With Branches Green

Entwines Our Hearts

With Grace Serene ....”

Baseball-a major sport at Cedarville.

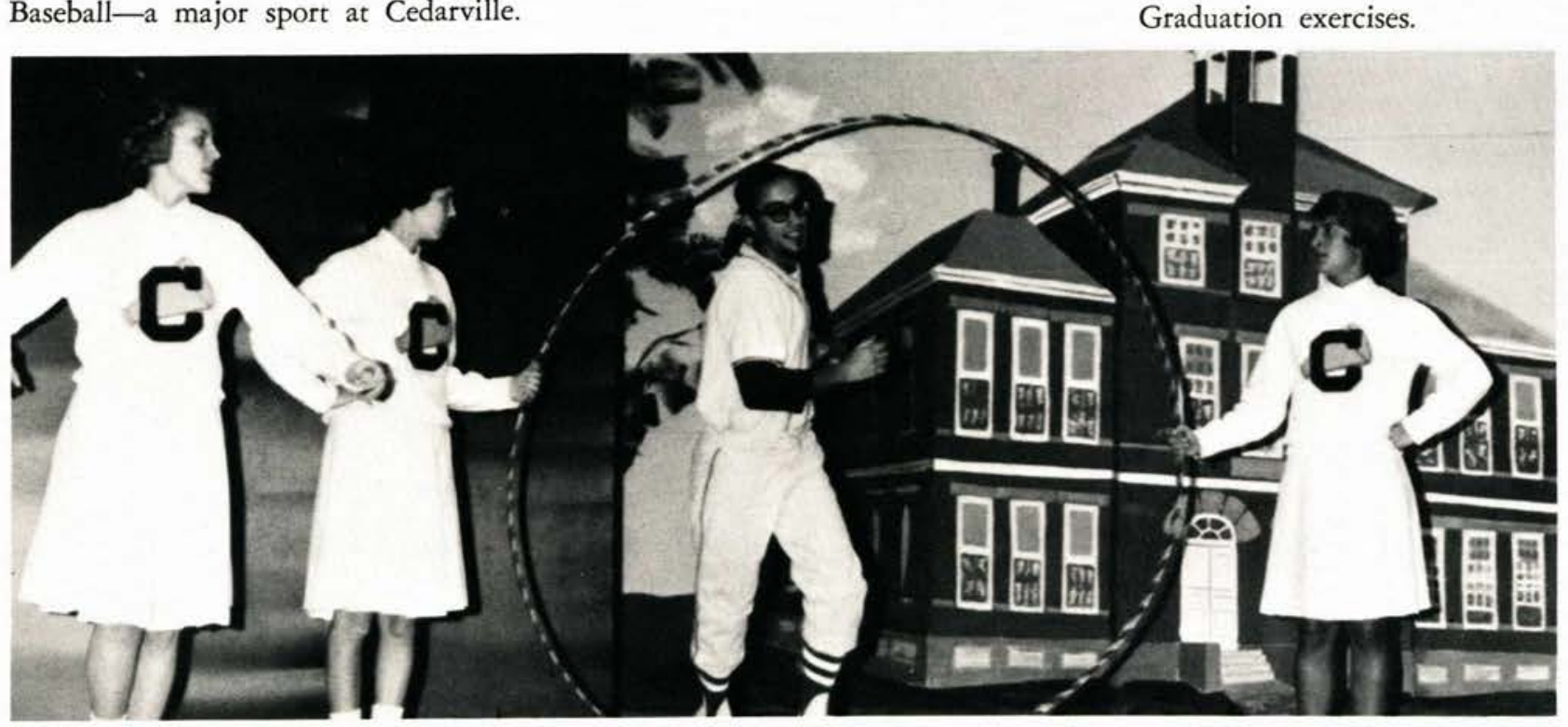


ces
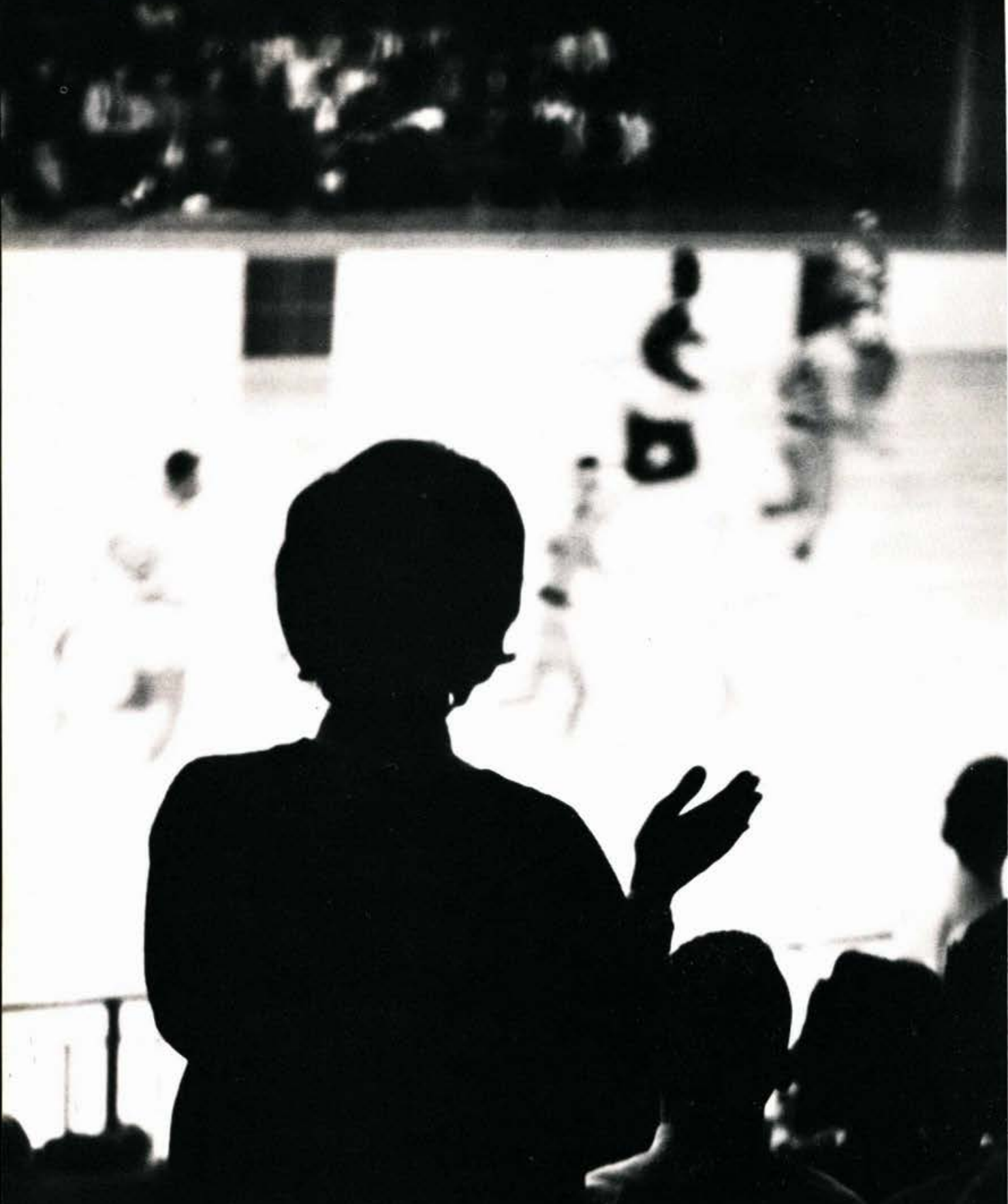
The College athletic program is supported by the trustees, faculty, and student body with great vigor. For a small school, the opponents have noted an unusually enthusiastic student-support of our team, win or lose.

Cedarville, being a Christian College, we, therefore, emphasize that our athletics adhere to Christian principles. Our primary objective is not building a great team and btilding the school's reputation as an exceptional athletic power only. Of far greater importance, whether it be intramural or inter-collegiate activities, is to develop the person into a physically sound individual better fit to fight the battle of life. To instill within the individual a determination to win is also an ardent desire of the College. Therefore, it is the sincere wish that the end result of athletics at Cedarville will be that the students learn how to win personal victories ?ven when they lose athletic contests.

\section{Athletics}

\section{Varsity Sports}

Intramurals 


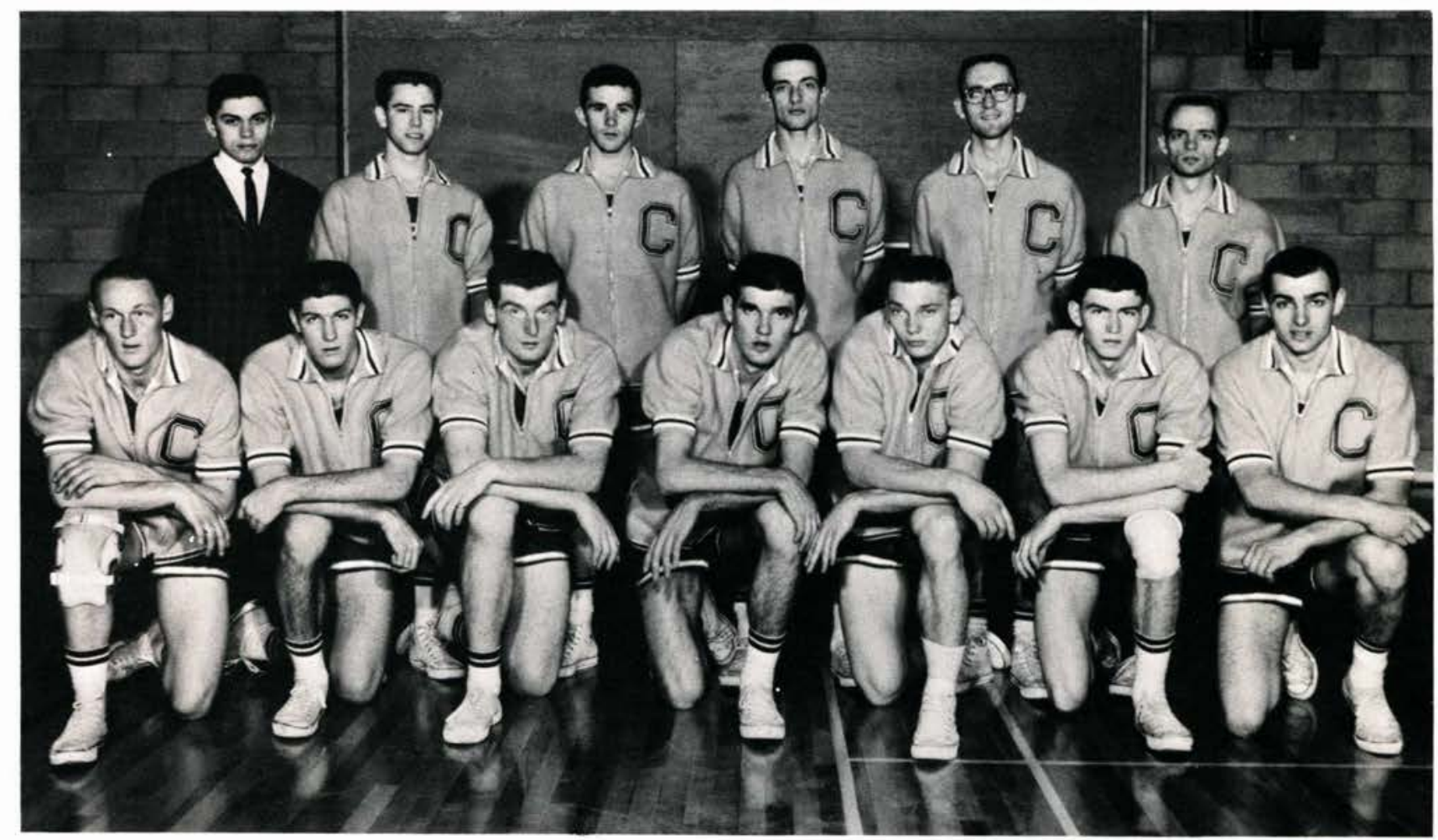

Standing: Mark Haseltine, Manager; Jerry Olson, Dick Spencer, Norris Smith, Sam Canine, Ted Ocheltree. Kneeling: Jerry Osborn, Jerry Stadt, Gary Brandes, Gary Walthall, Ray Davis, Rod Lane, Dave Jeremiah.

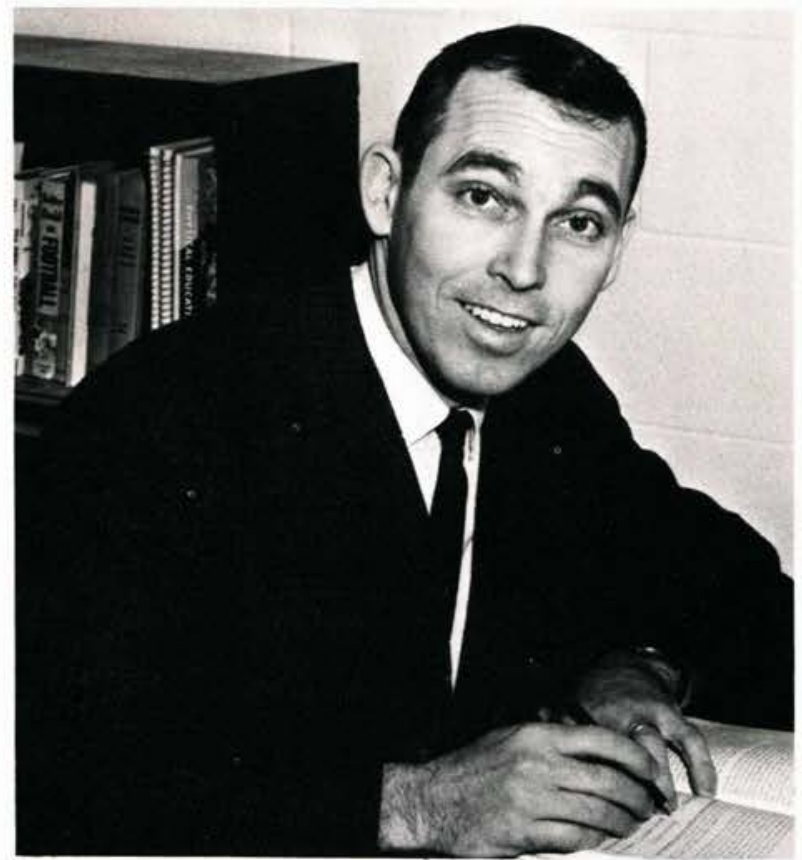

Coach Callen
Cedarville's basketball team, backed by experience, school spirit, and excellent coaching, lived up to the "Great Expectations" of its fans from the very beginning of the season. Ten returning lettermen, including all of last year's starters, were the nucleus of the Yellow Jacket cage squad which swept to a 7-game winning streak early in the season, knocking down such schools as Taylor, Indiana Tech, and Ashland and Bluffton of the Mid-Ohio League in the process. Coach Don Callan's charges also finished second in a mid-season tourney at Malone College, where star Dozier Carter was named to the all-tournament team.

Outstanding performances were recorded by Carter and Gary Walthall, who placed high among the leaders in league scoring and rebounding. Seniors Norris Smith and Dave Jeremiah backed them up with double-figure point averages each. Dick Spencer and Sam Canine shared the other guard slot throughout the season. Spencer's 41 points at Taylor proved to be the major factor in Cedarville's conquest of the Trojans. 


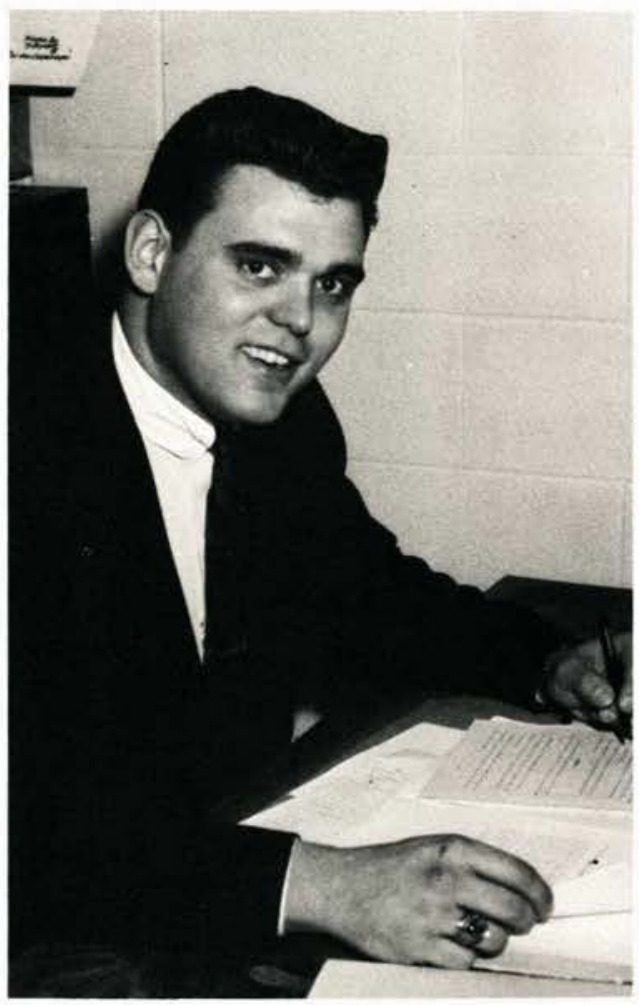

Phil Brower: Publicity Director

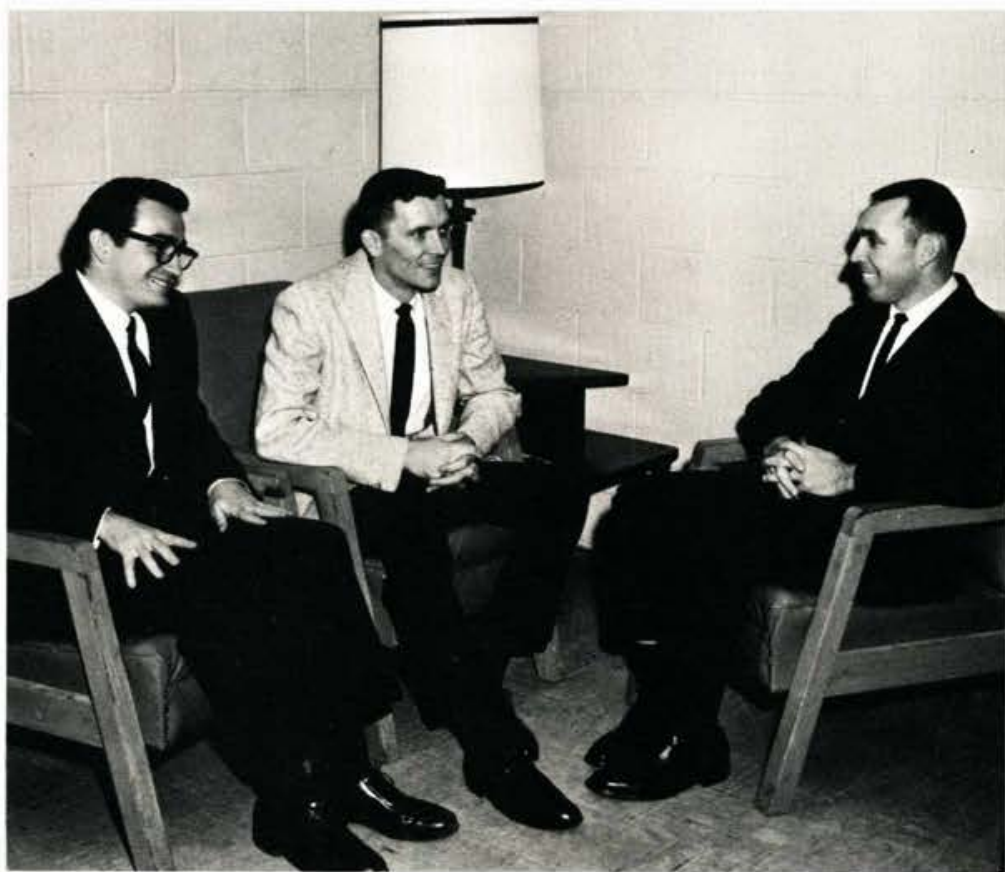

ATHLETIC COMMITTEE: Robert Gromacki, Dale Thomson, Don Callen.
Grace

Wilmington

Taylor

Rio Grande

Indiana Tech

Ashland

Berea

Oakland City

Bluffton

Wilberforce

Defiance

Defiance

Indiana Tech

Bluffton

Wilmington

Rio Grande

Central State

Ashland

Huntington

Wilberforce

Fenn

MALONE TOURNEY

Grace

Roberts Wesylyam (N.Y.)

Greenville (III.)
92

92

62

75

49

66

55

52

101

100

66

72

91

52

70

77

84

86

49

50

\section{Varsity}

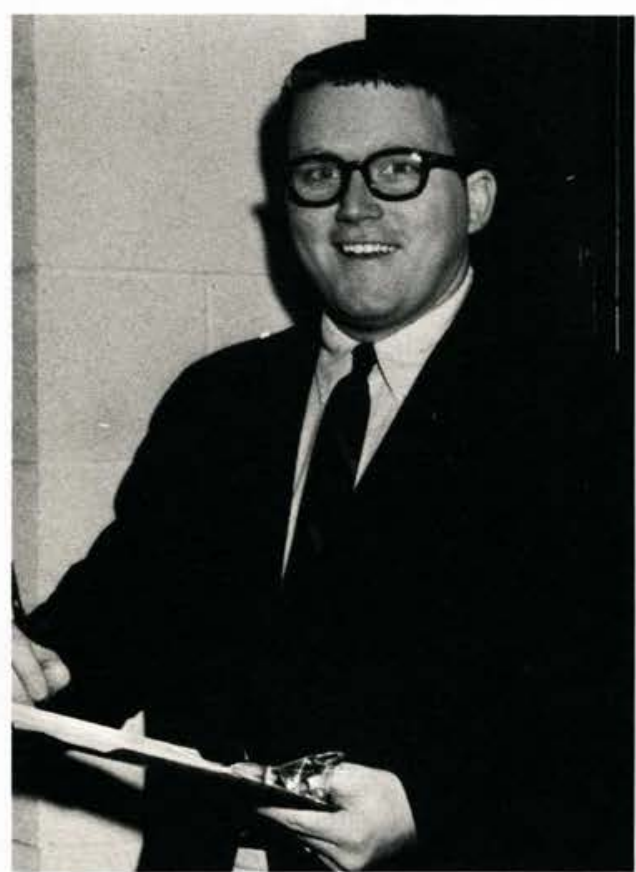

Richard Davidson: Statistician 


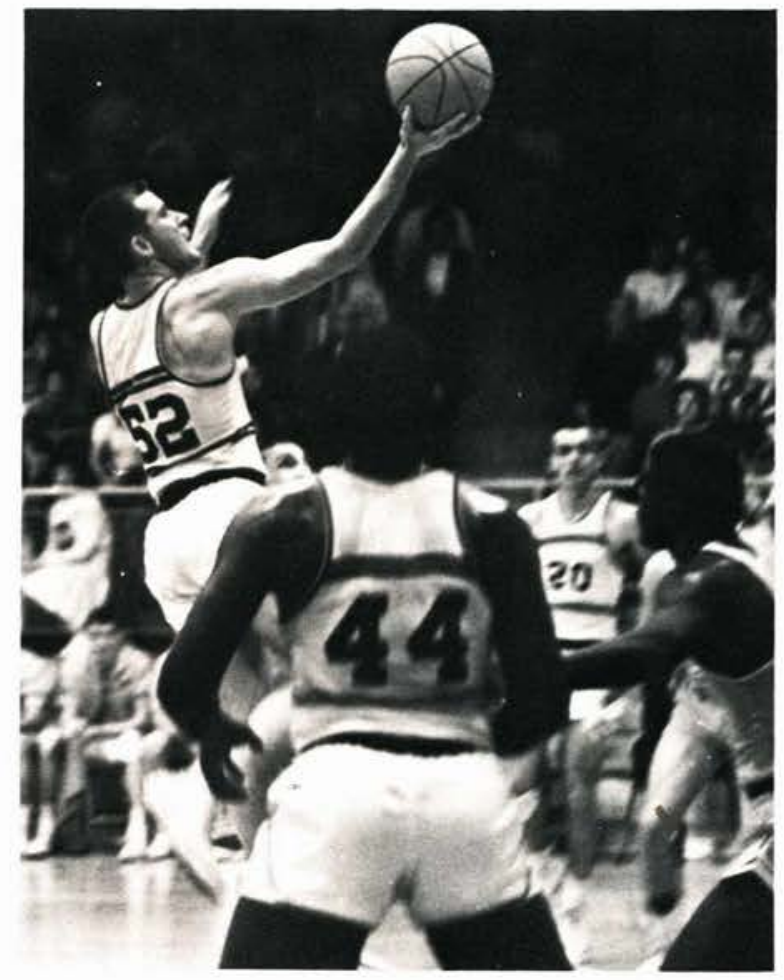

"Spence" cans one against Indiana Tech.

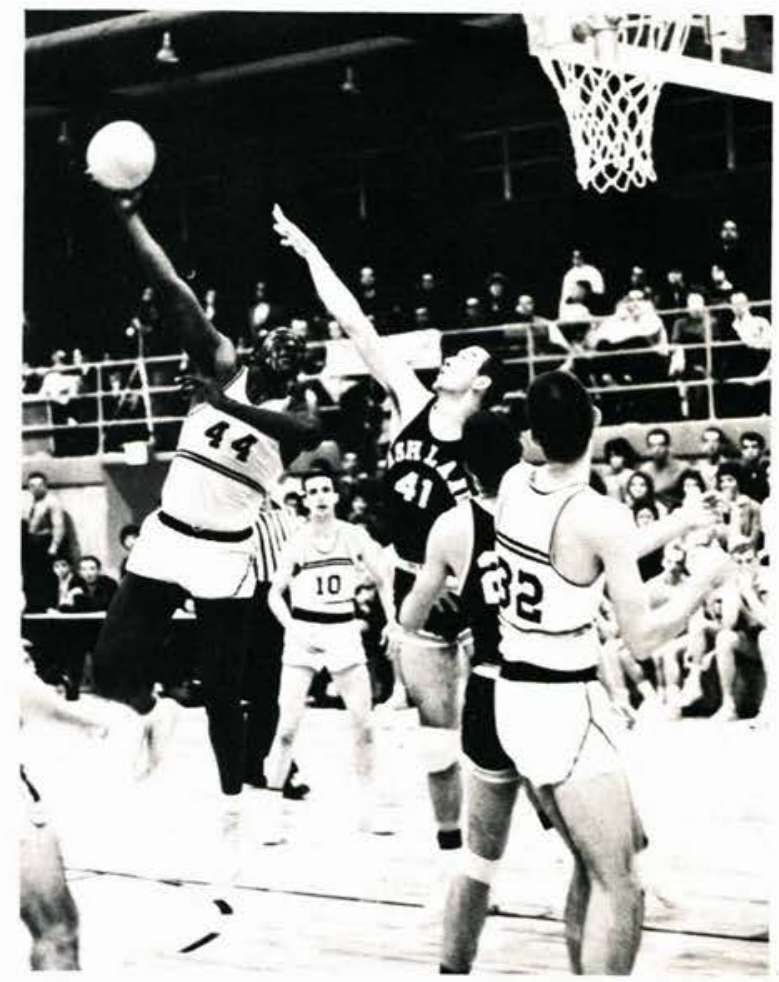

You can't stop the Carter hook.

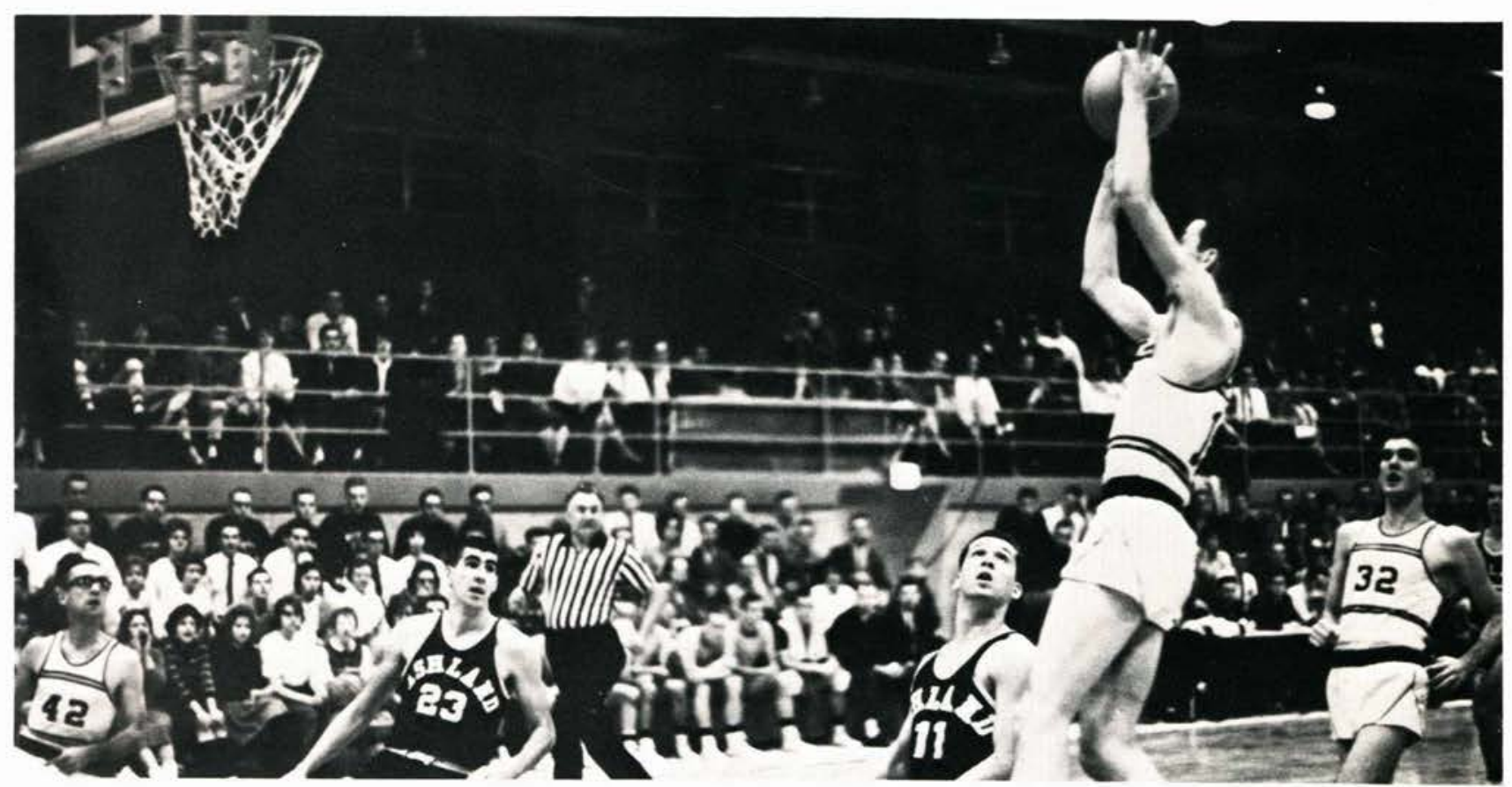

Ashland's Jim Garbash stares in unbelief as Norris Smith scoots in for another Jacket score. 


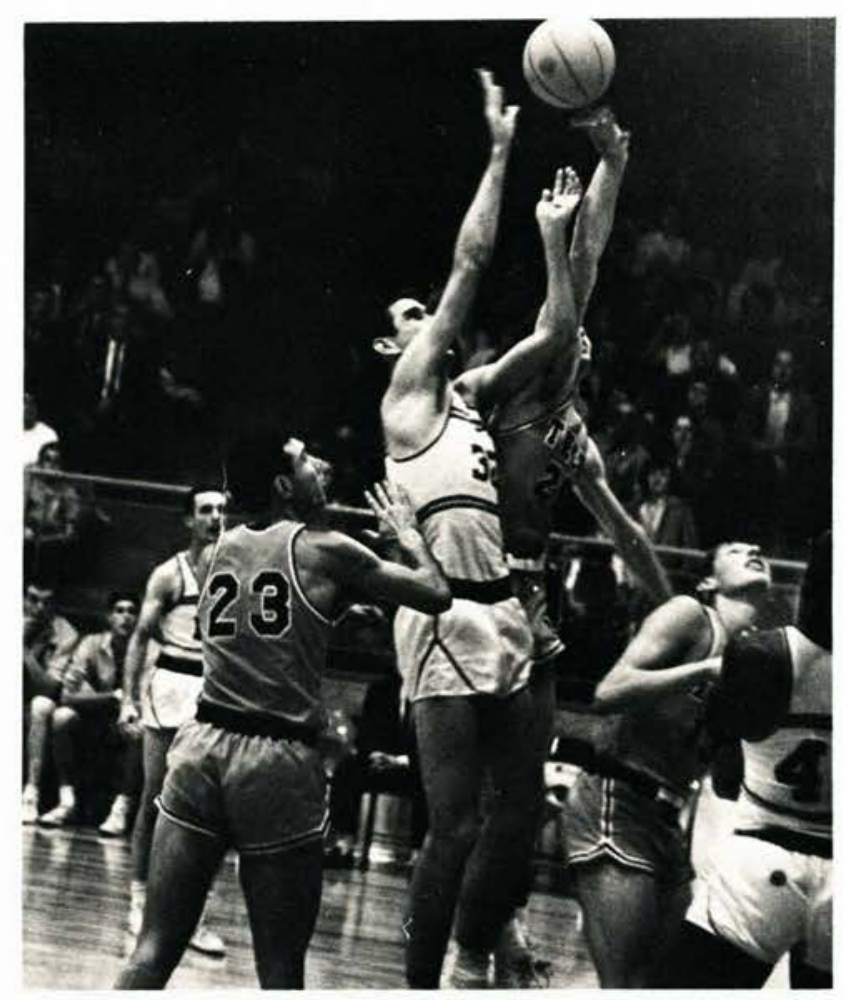

Gary Walthall bats one in against Indiana Tech.

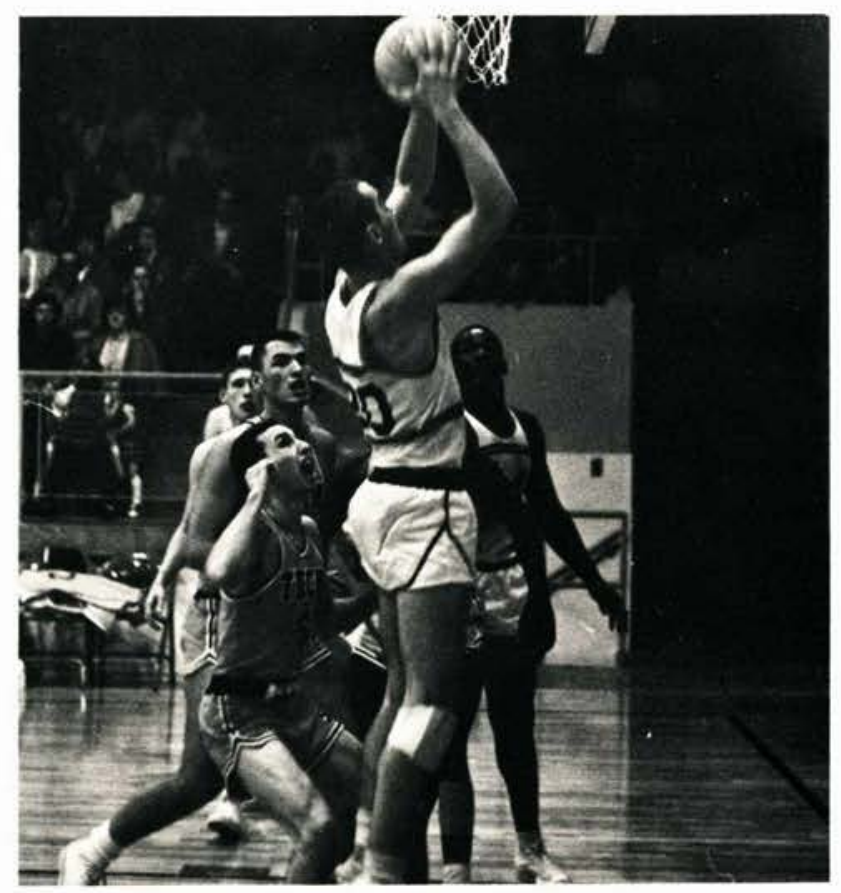

Dave Jeremiah hits for two against Warriors of Tech.

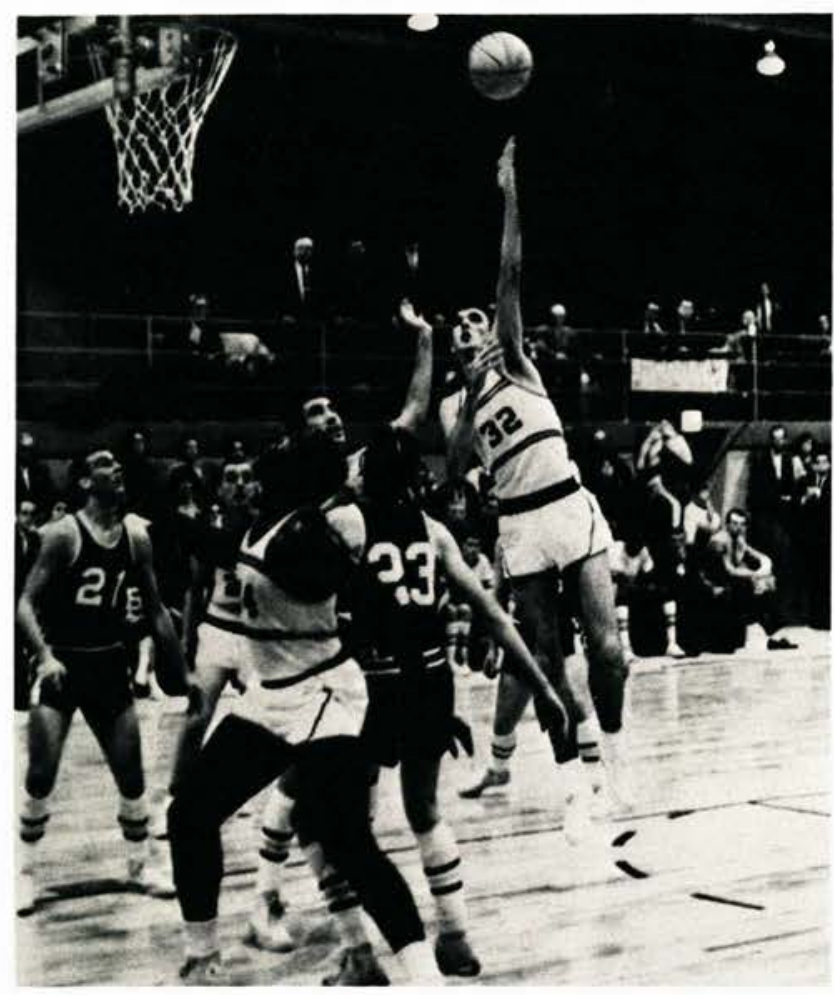

Dozier Carter and Bob Raber (23) wait for rebound.

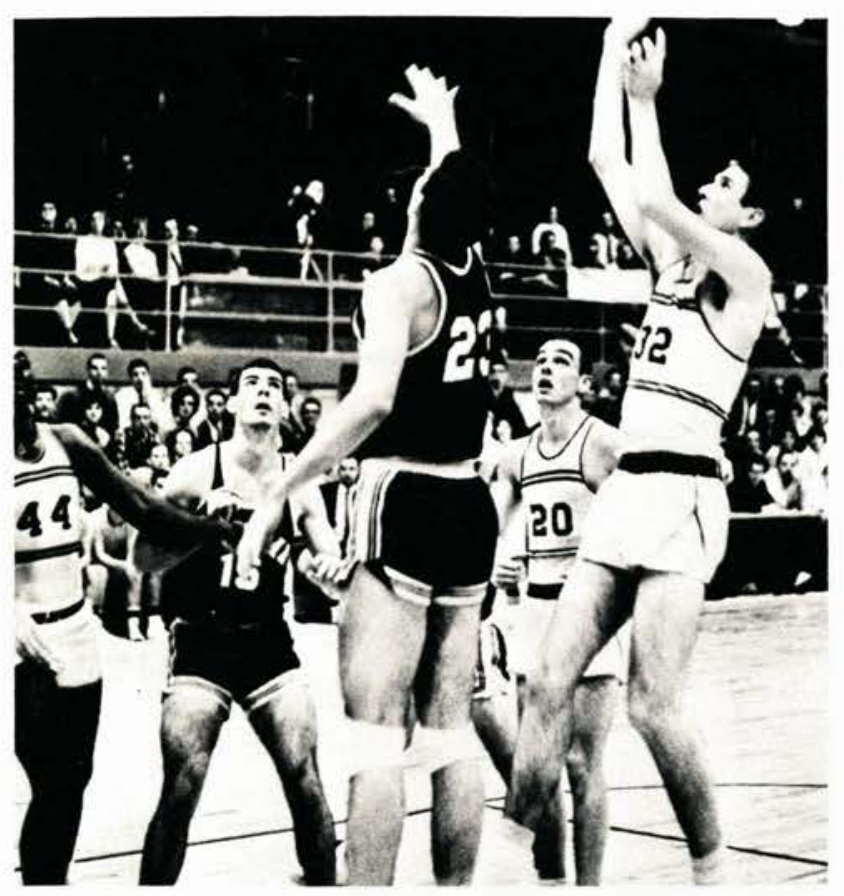

L. Augler (23) and M. McQueen (15) prepare for rebound with Carter and Jeremiah. 


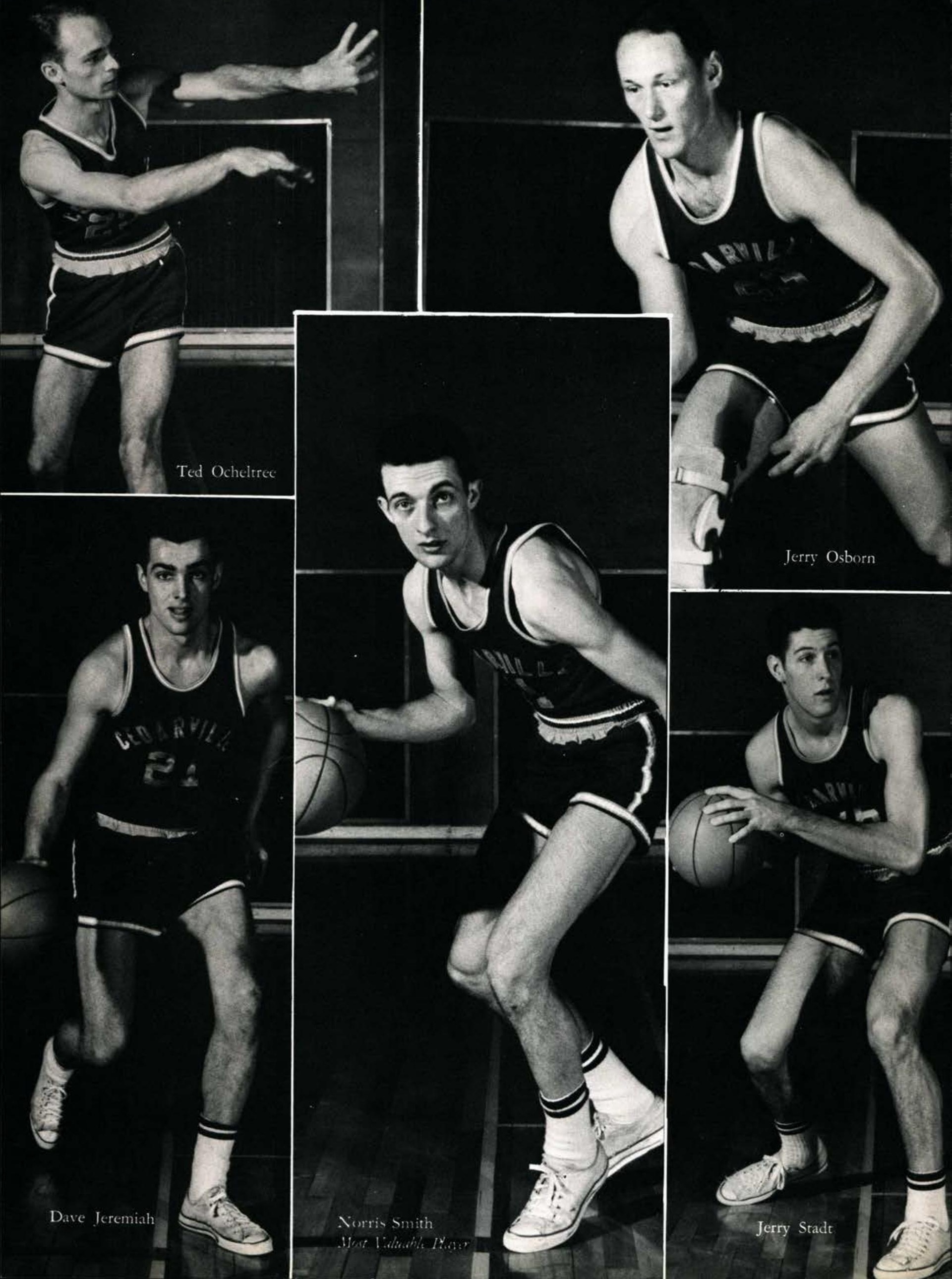




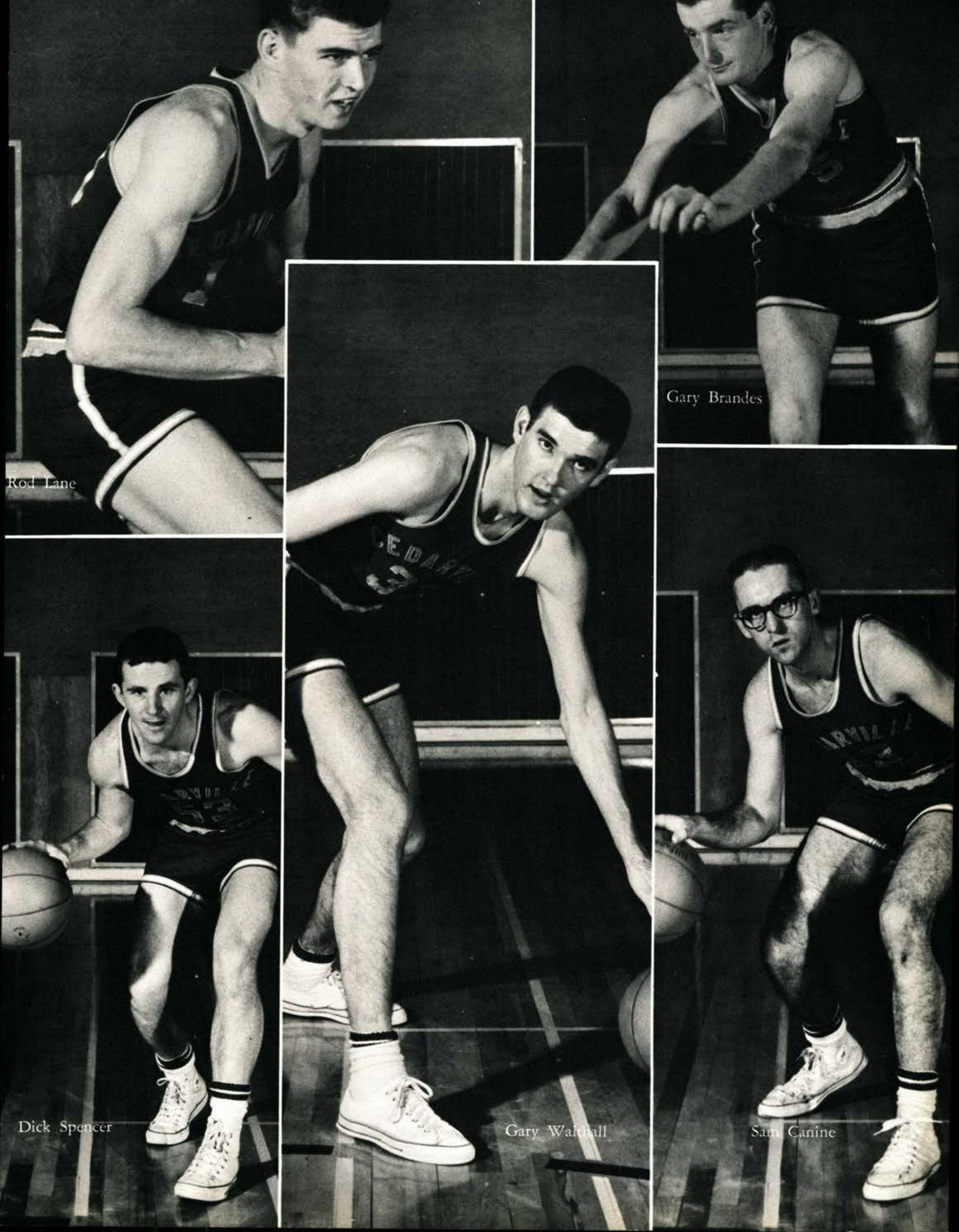




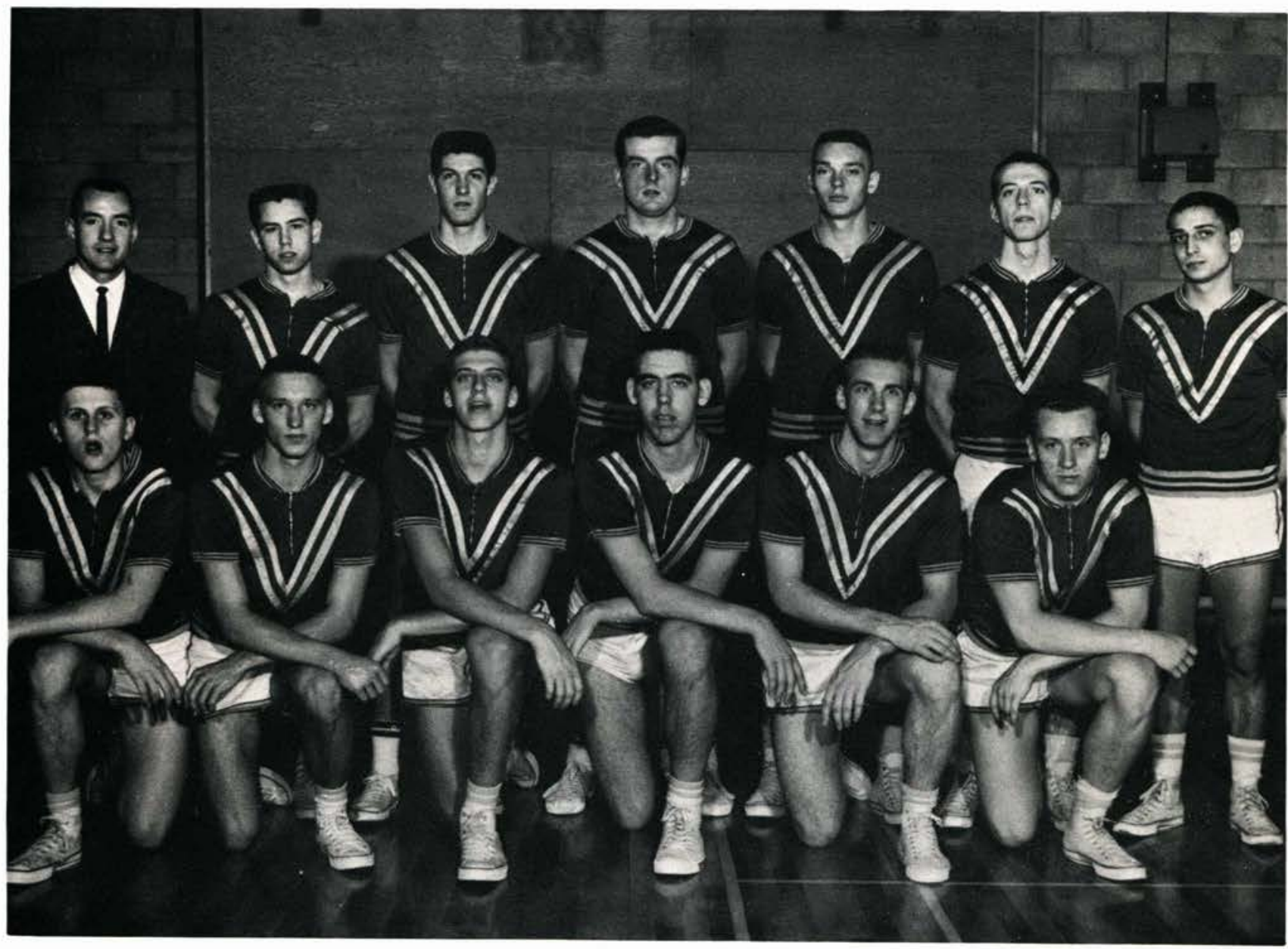

Standing: Mr. Moody, Coach; J. Olsen, J. Stadt, G. Brandes, R. Davis, L. Richardson, B. Francis. Kneeling: D. Davis, G. Culley, T. Shelter, G. Goodwin, D. Entner, A. Merwald.

Junior Varsity basketball at Cedarville provides a "training ground" for future Yellow Jacket standouts. Coach Lane Moody, himself a graduate of the Cedarville hardwoods, coached the team of freshmen and sophomores that defeated Bluffton and Defiance of the Mid-Ohio League.

Junior Varsity players showing hustle and improvement often are given a chance to break into the Varsity lineup at various times throughout the season. Playing for the J.V. squad this season were Gary Brandes, Bud Davis, Jerry Stadt, Terry Shetler, Gene Culley, Al Merwald, Jerry Olsen, Bill Francis, Larry Richardson, and Don Entner. One of the J.V. most outstanding games this year was a 67-64 overtime win over Defiance.

$\begin{aligned} \text { WE } & \\ 54 & \text { National Cash Register } \\ 94 & \text { Cedarville Merchants } \\ 100 & \text { Dayton Sanford } \\ 70 & \text { Bluffton J.V. } \\ 54 & \text { Defiance } \\ 67 & \text { Defiance } \\ 73 & \text { Bluffton } \\ 63 & \text { Central State } \\ 52 & \text { Wilmington } \\ 55 & \text { Fenn }\end{aligned}$


Long hours of practice coupled with on the job experience has characterized the job of the 1963 Cheerleading Squad. Traveling to all the away games, and participating at all the home games has provided an exceptionally busy schedule for these girls, but the leadership of the Cheerleaders' has been an encouragement to the team and a good channel for student body enthusiasm.

\section{Cheerleaders}

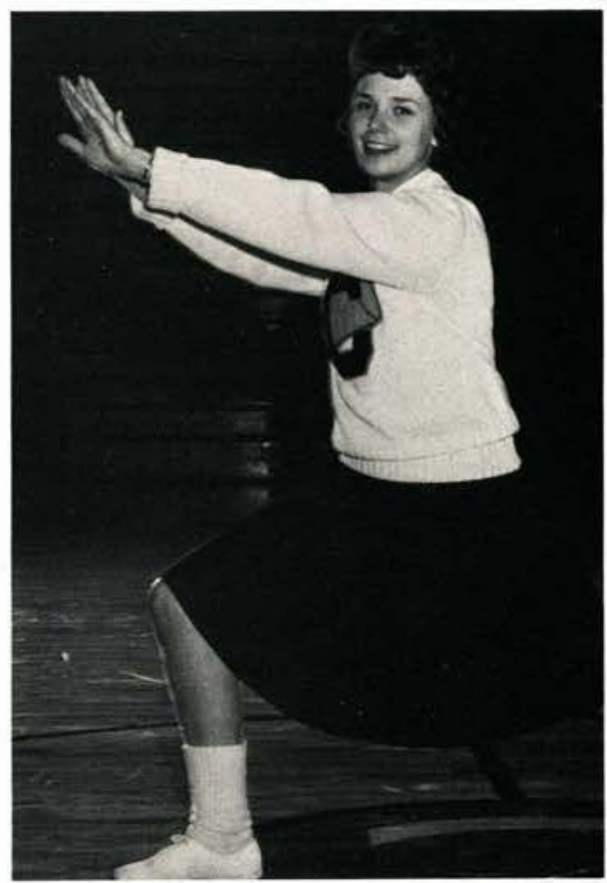

Donna Thompson, Captain

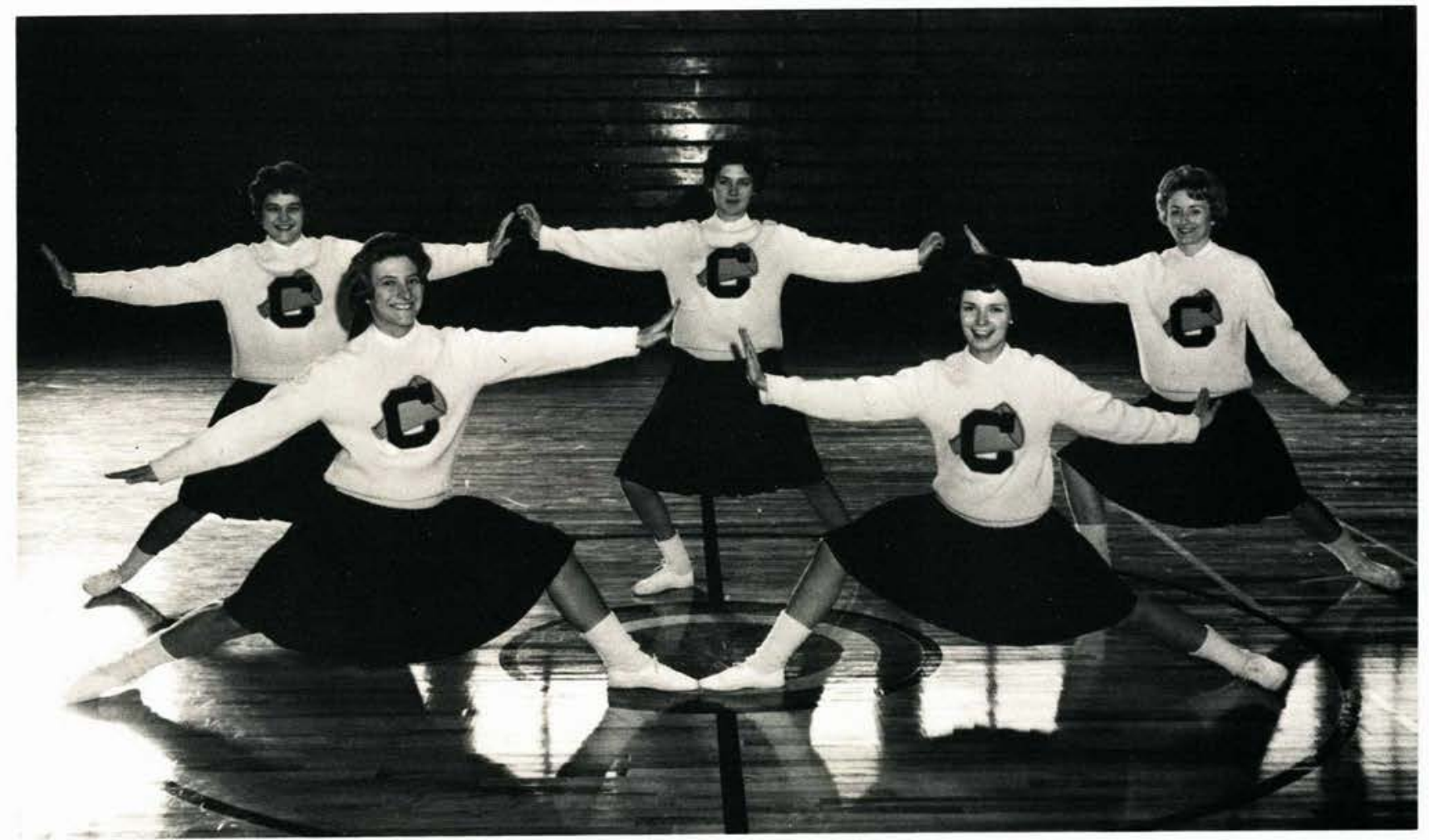

Top Row, Left to Right: Vickie Curcio, Irene Lane, Bette Adamson. Front Row: Pat Kaster, Donna Thompson. 


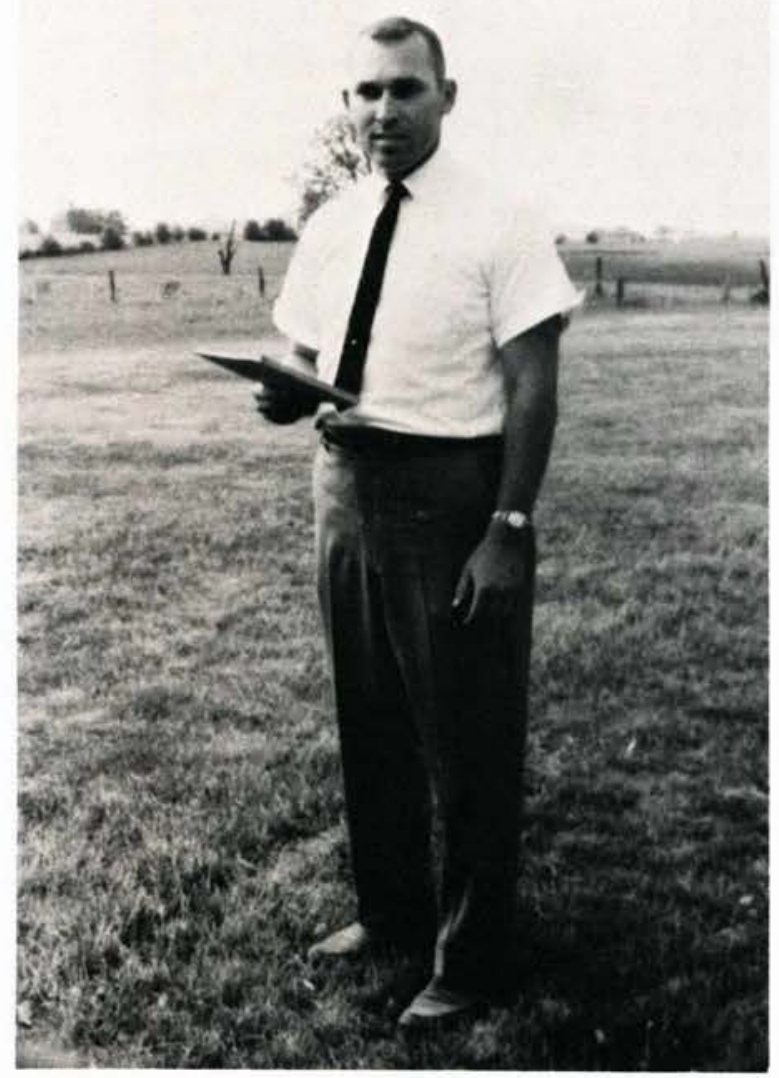

Coach Callan's Yellow Jackets opened the season with an enthusiastic determination to rise above last year. Placing 6th in the Conference, the Yellow Jackets finished with their best record of 5-12. Several home games were played at the Cedarville ball park because of the construction on the new gym on the baseball diamond. Ted Ocheltree and Tom DeLanzo, leading hitter .428 average, were co-captains of the team.

Having lost no lettermen through graduation, the team is looking forward to a greater victory this year.

Norris Smith was chosen the Most Valuable Player for the season by his teammates. "Smitty" was the winning hurler on all Yellow Jacket victories, winning 5 and dropping 5 .

Coach Callan

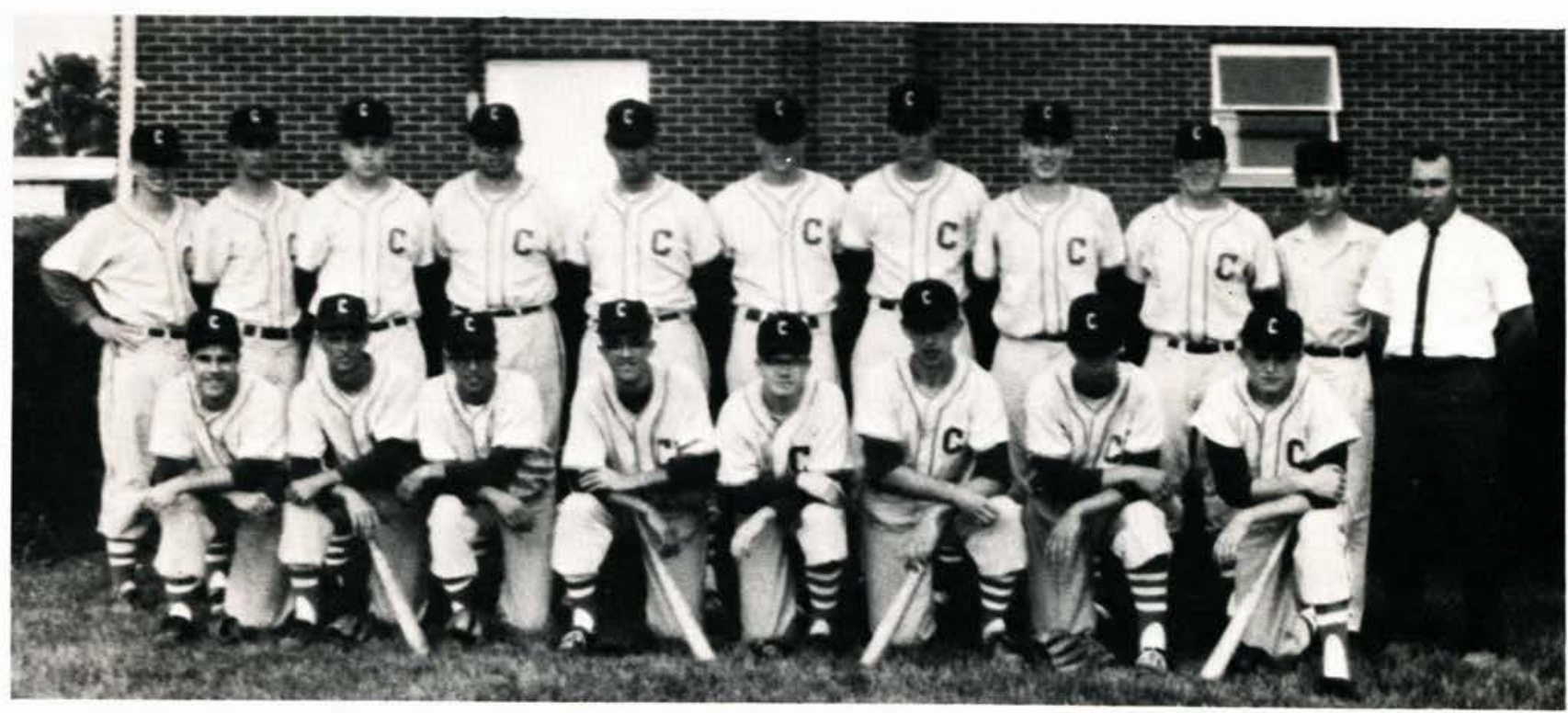

Front Row, Left to Right: Tony Rotondi, Ted Ocheltree, Tom DeLanzo, Marvin Stevens, Tom Evans, Dennis McDonald, Daniel Wood, Bud Connell. Back Row: Ron McDugle, Norris Smith, Al Merwald, John Bigelow, Dave Jensen, Rod Lane, Jerry Stadt, Larry Meek, Ed Norris, Terry Miller, Manager. 


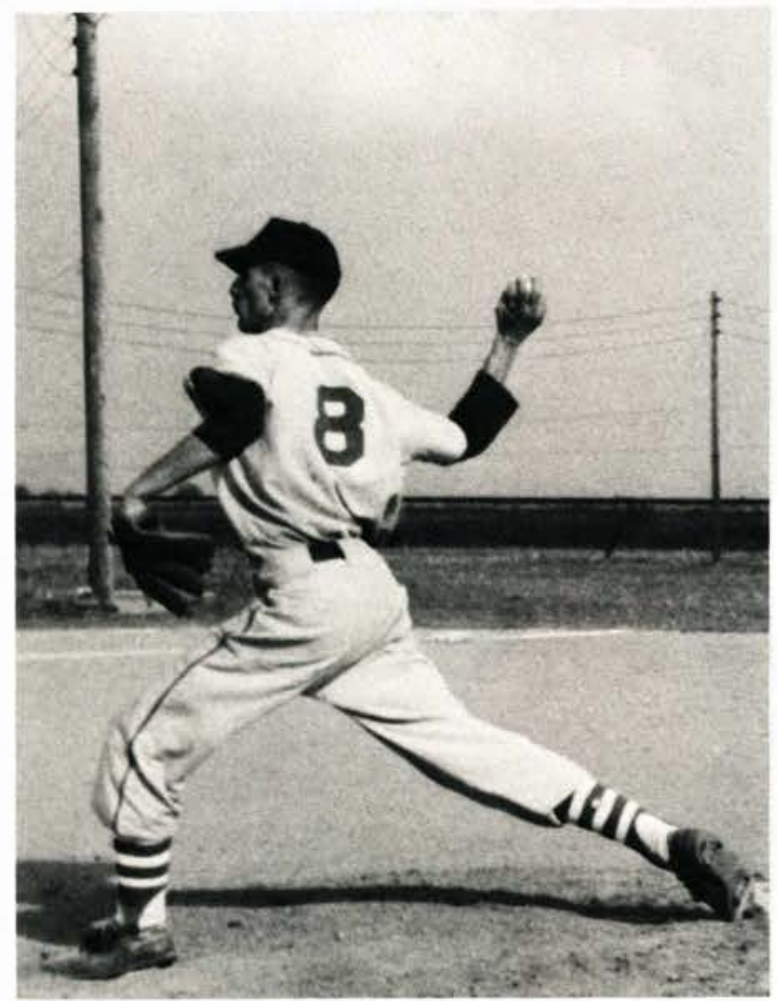

Norris Smith

Most Valuable Player

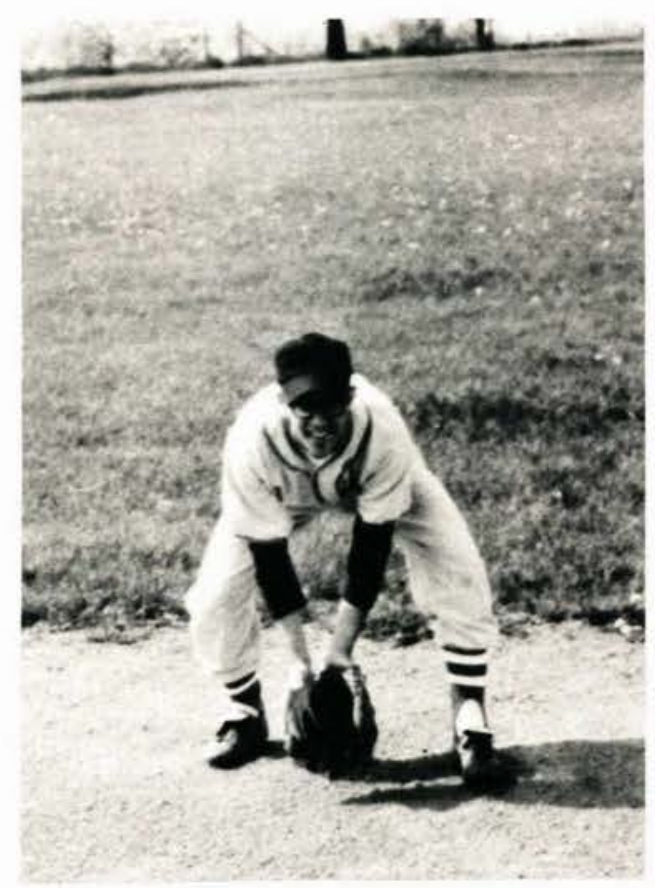

Tom DeLanzo

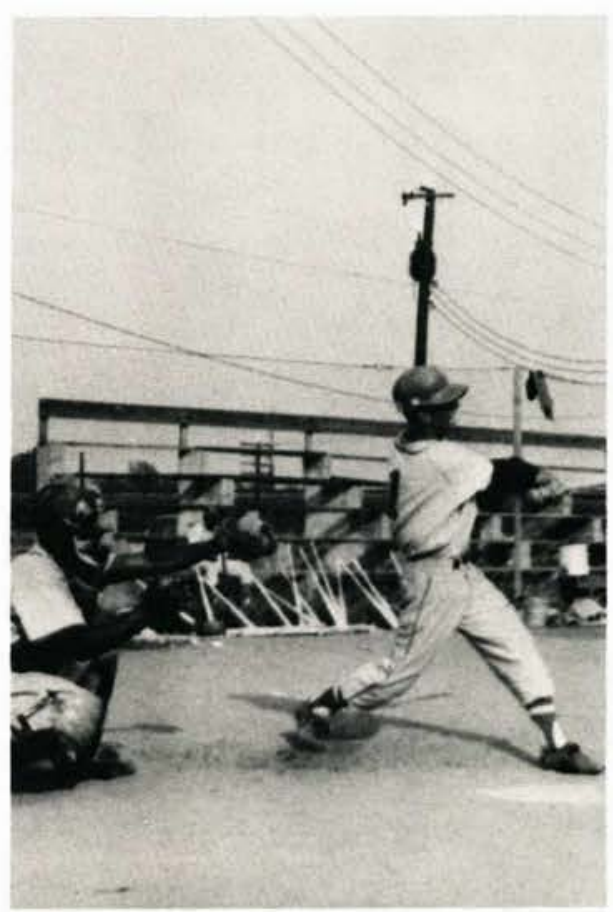

Ted Ocheltree

Leading Hitter

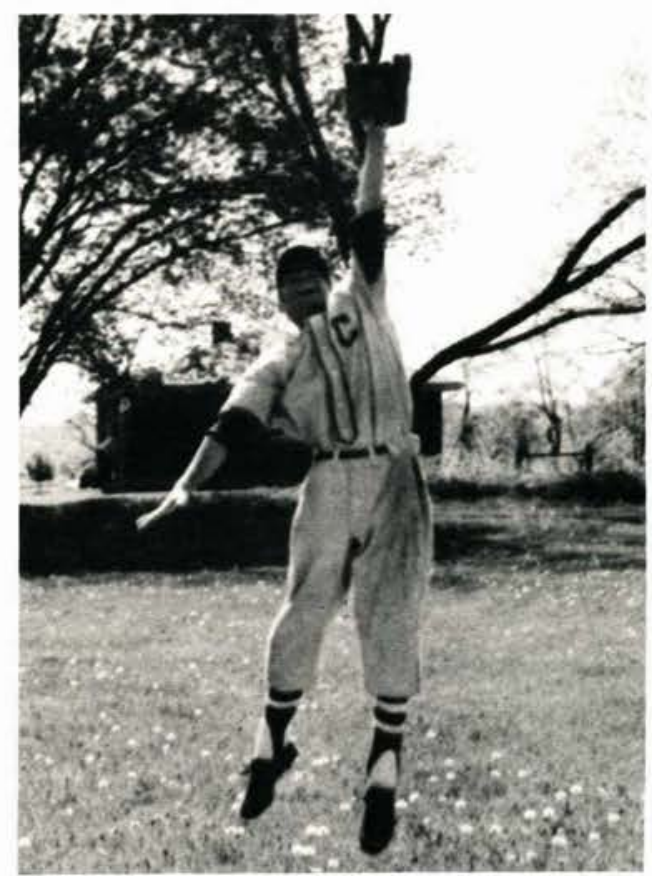

Ted Ocheltree

Co-Captain 


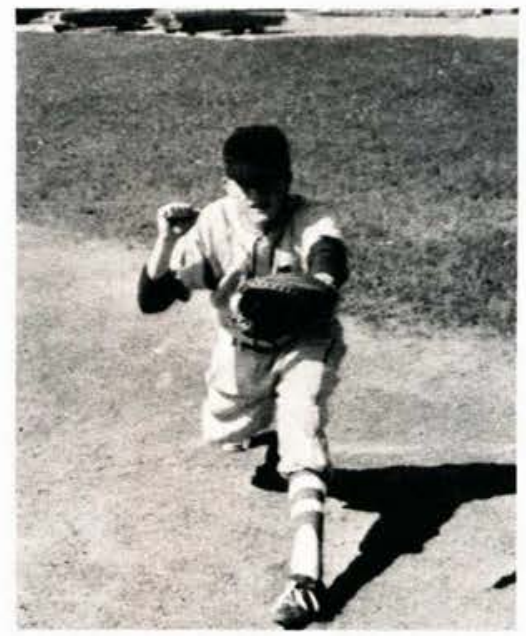

\section{Baseball}

Bud Connell, IF

Tom Evans, IF-OF
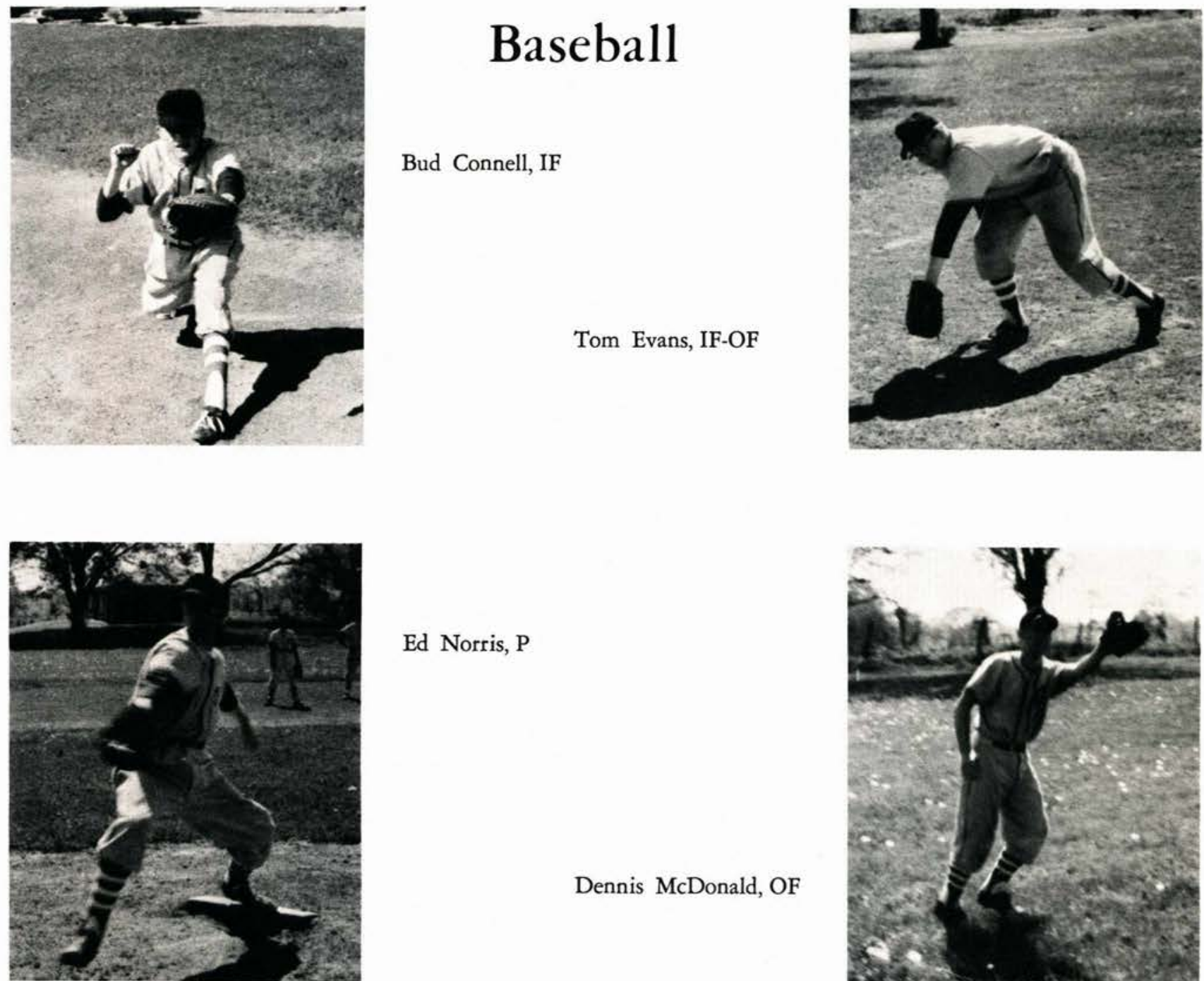

Ed Norris, $\mathrm{P}$

Dennis McDonald, OF
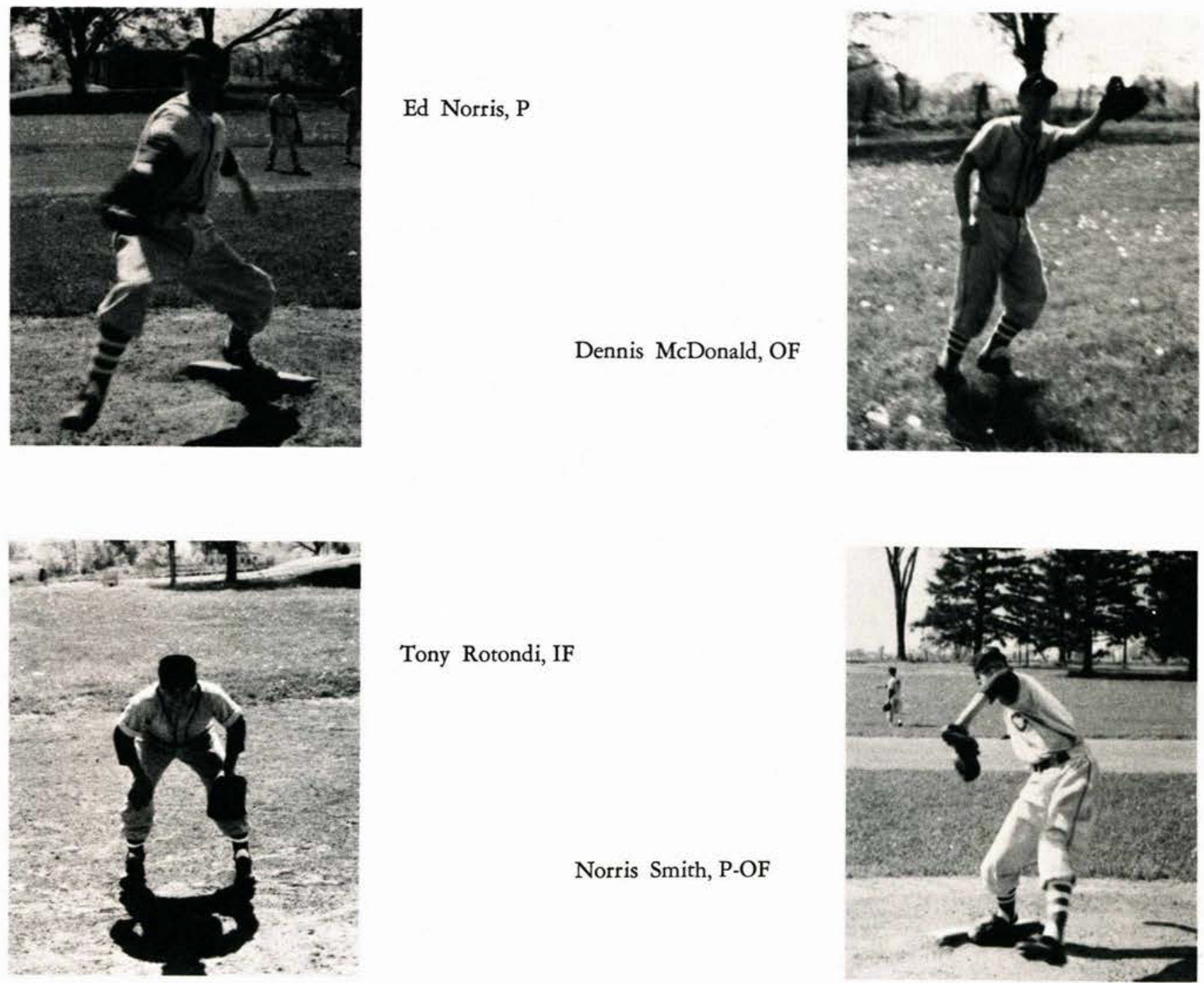

Tony Rotondi, IF

Norris Smith, P-OF 


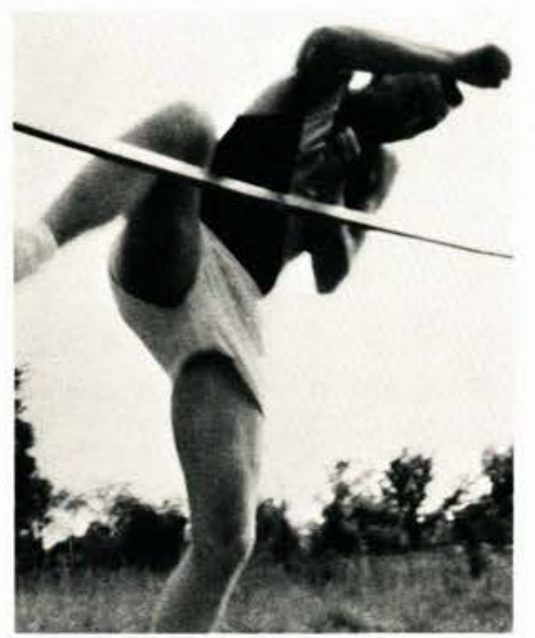

\section{Track}

Dave Werner

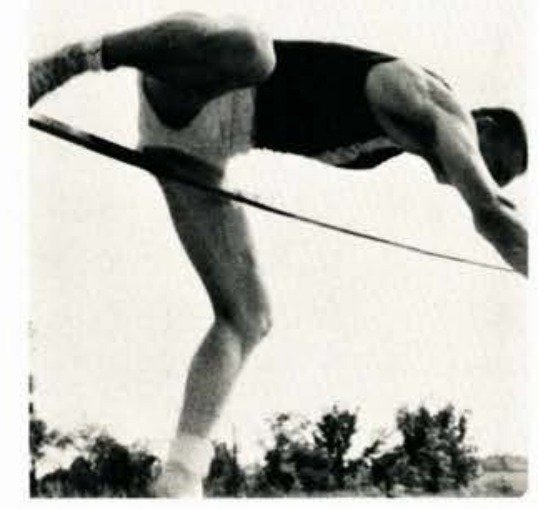

Bud Davis

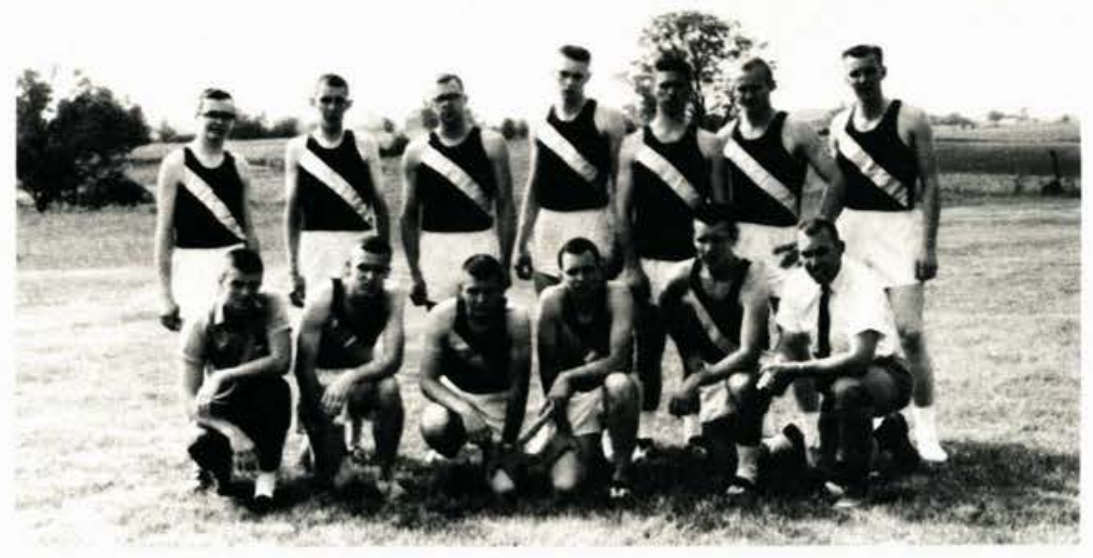

Standing: P. Reno, J. Sprague, J. Peifer, R. Davis, D. Tennant, B. Ellis, D. Werner. Kneeling: J. Eaton, D. Warren, G. Jacobs, D. Fisher, J. Walborn, Coach Callan.

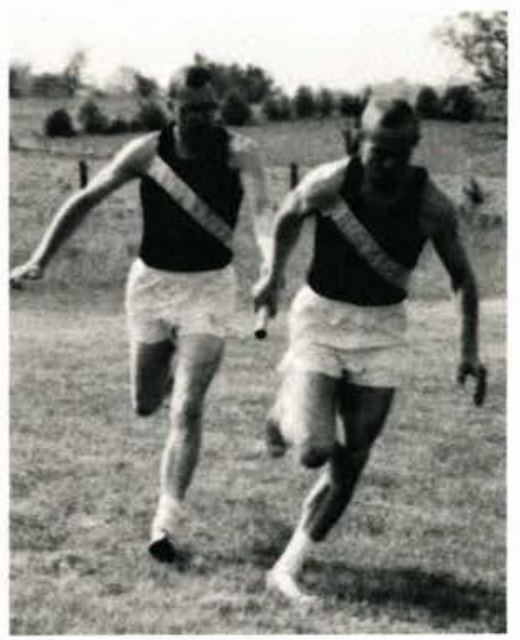

J. Peifer, B. Ellis, Captain and Assistant Coach.

Coach Callan gives Jim Sprague some pointers.

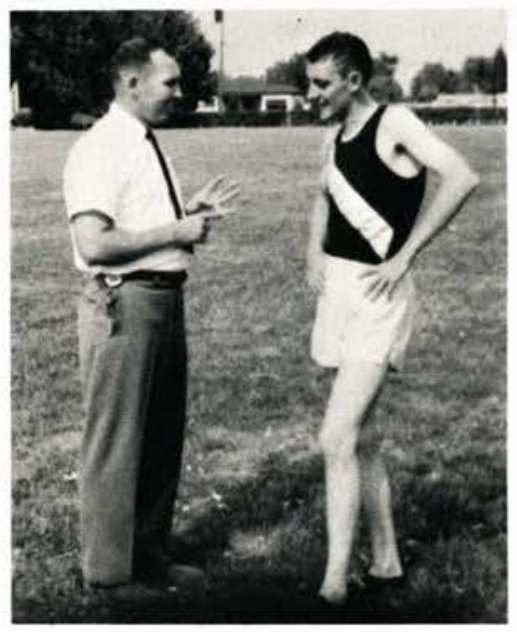

Jim Sprague, most valuable player, placed third in the All-Ohio Track meet, set a new school and Conference record of 4:25.3, won Conference onemile and two-mile race. Bud Davis and Dave Werner set a new school high jump record of 5 ' 10 " 


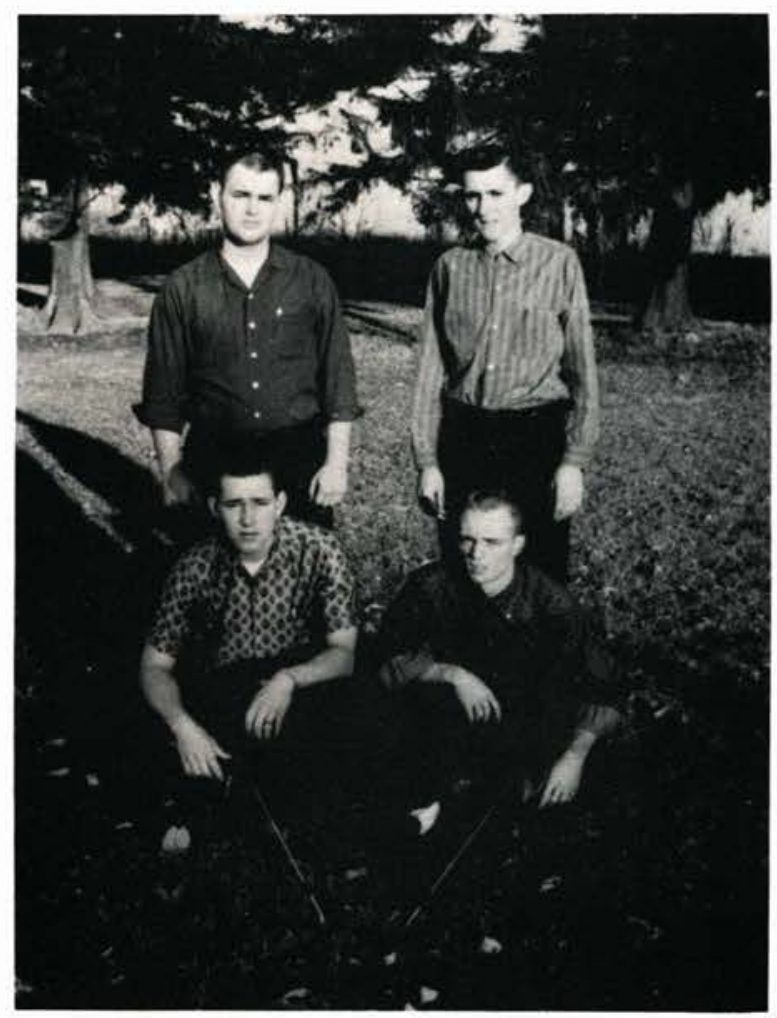

\section{Golf}

A relatively new sport on campus at Cedarville is golf. However, each year a few more golf enthusiasts are added to the team. Since all of the matches were played in an experienced Mid-Ohio League, the inexperience of the team was a major factor in their placing last in the conference.

Standing: Larry Baker, Jim Sprague. Kneeling: Steve Nimo, Ted Ocheltree.

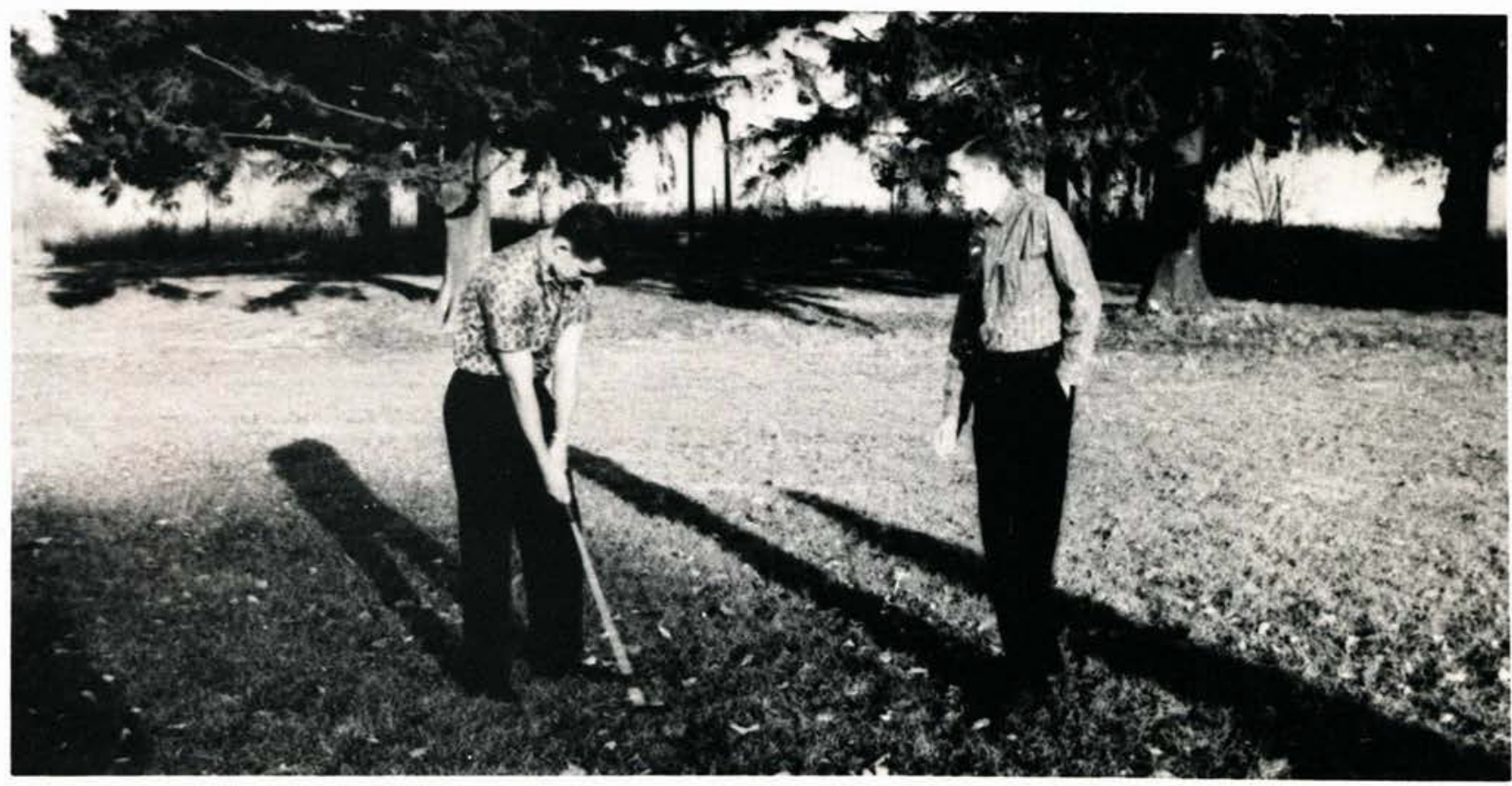

Steve Nimmo demonstrates a fine point in driving. 


\section{Tennis}

$\begin{array}{llr}\text { We } & \text { They } \\ 2 & \text { Bluffton } & 5 \\ 4 & \text { Ohio Northern } & 3 \\ 5 & \text { Ashland } & 2 \\ 6 & \text { Defiance } & 1 \\ 5 & \text { Wilmington } & 2 \\ 3 & \text { Ohio Northern } & 4 \\ 2 & \text { Central State } & 5\end{array}$

Third place in the Mid-Ohio League

Tournament

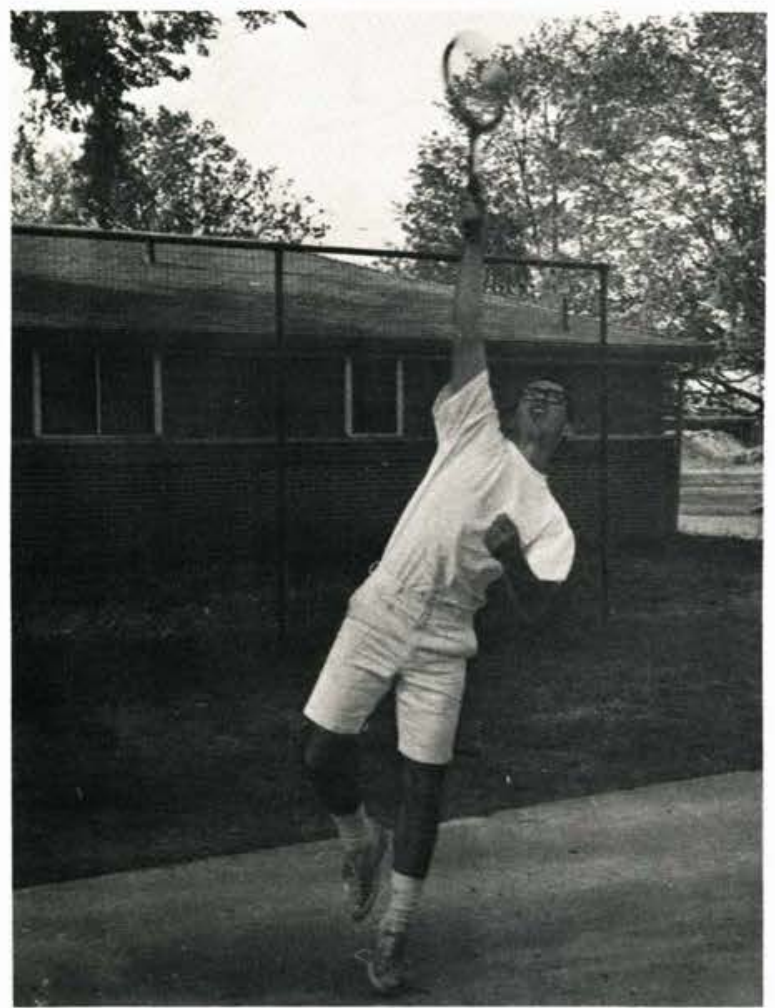

Bill Elder

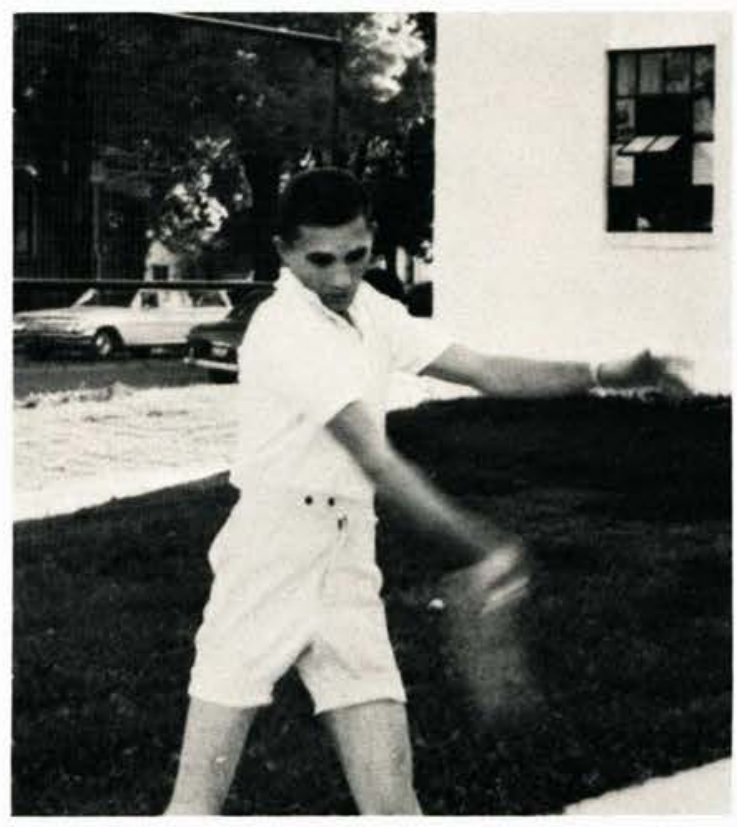

Fred Wolfe

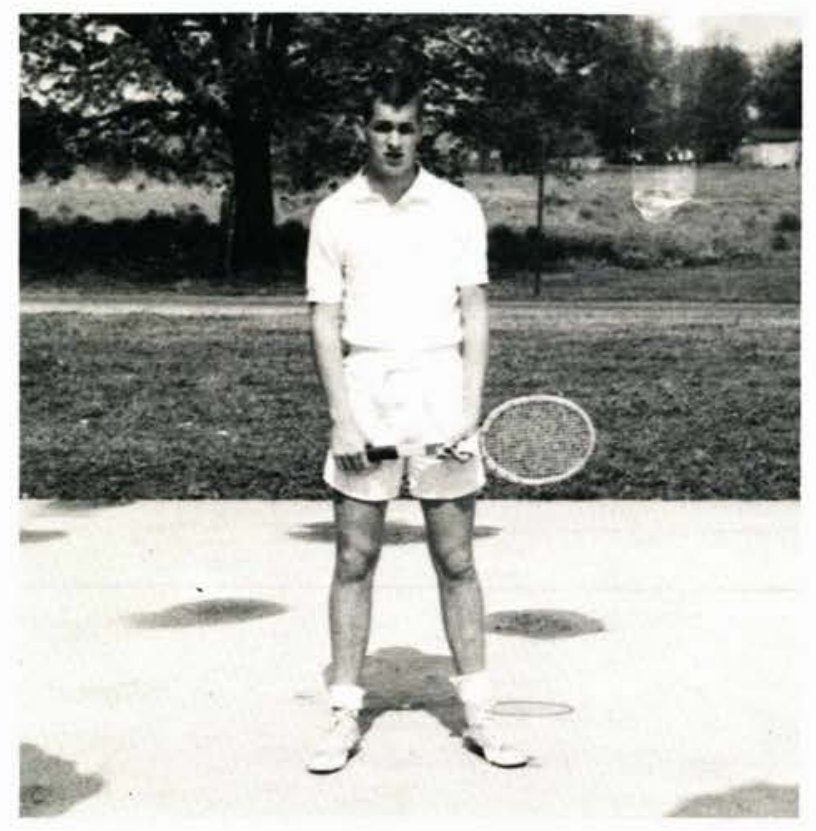

Bob Auffort 


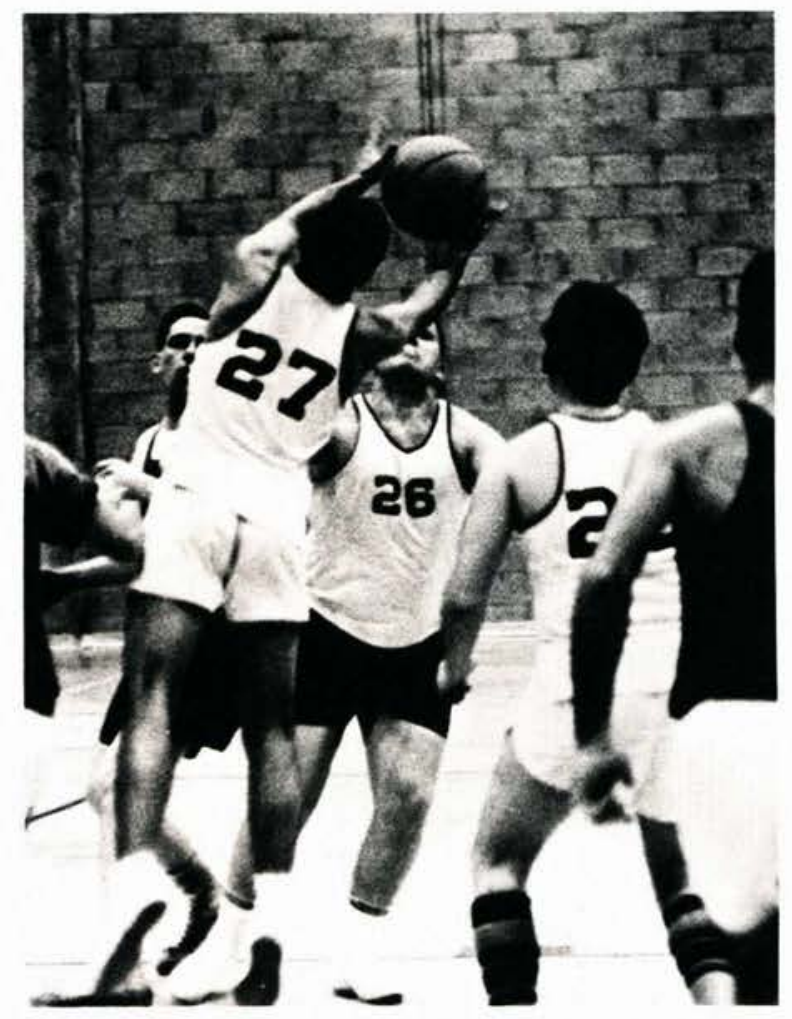

Tom DeLanzo claims the ball.

D. Jeremiah, T. Ocheltree, D. Wood, E. Norris.

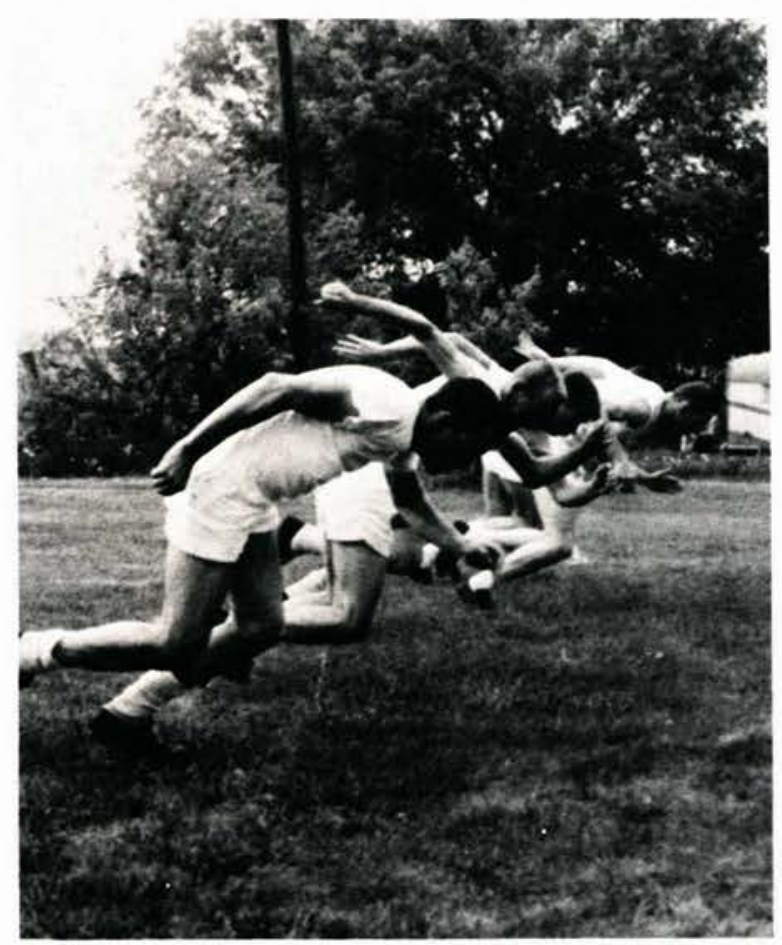

\section{Intramural}

\section{Sports}

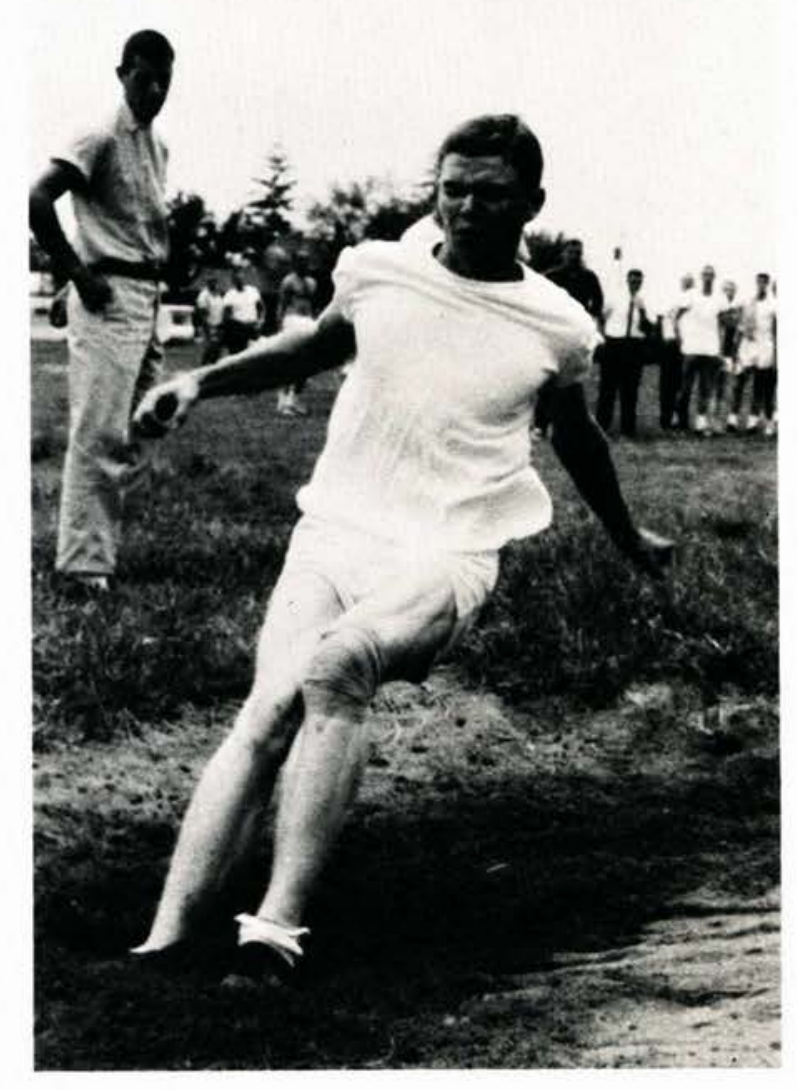

Rod Lane 
The Intramural Football All-Stars, replacing the annual Alumni-Varsity basketball contest, met and defeated the Bookstore Champions 33-19 on Homecoming Day. Leading the All-Stars was Sticka's quarterback Roger O'Bryon and end Tom DeLanzo. Chosen by the players themselves, Tom DeLanzo was given the Most Valuable Player Trophy. His pass receiving and running led Sticka to a second place finish in the intramural football standings and was a major factor in the All-Stars victory.

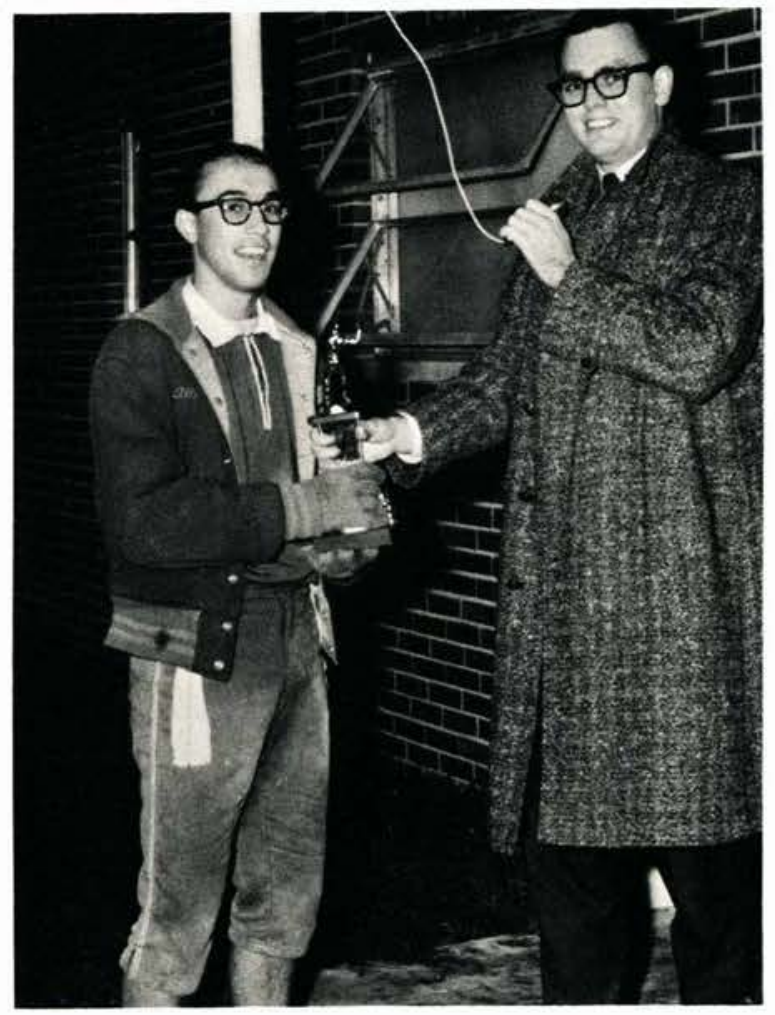

Tom DeLanzo wins the MVP award.
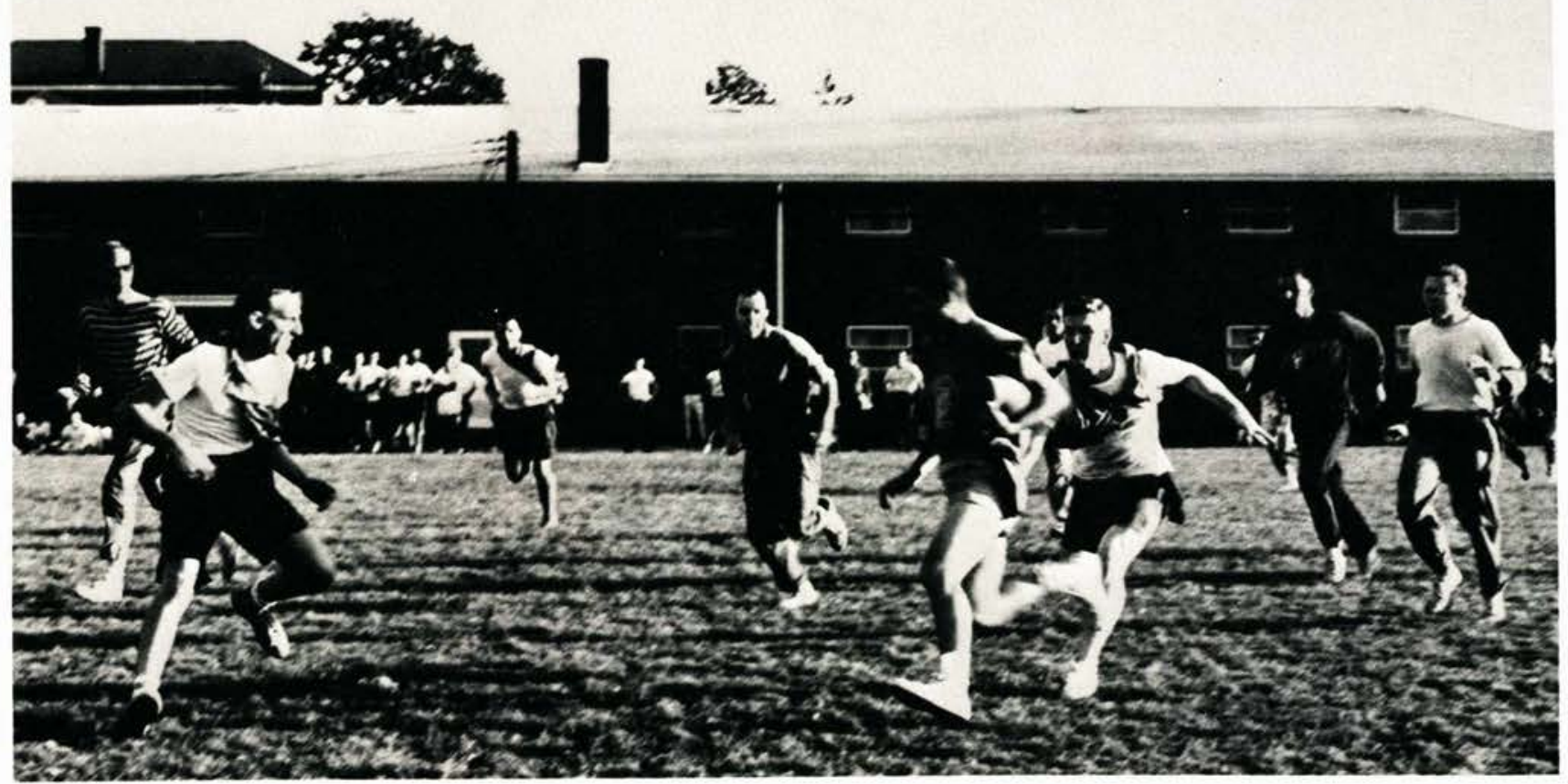

The "Bethel Boys" pressure Bookstore's Art Thompson. 


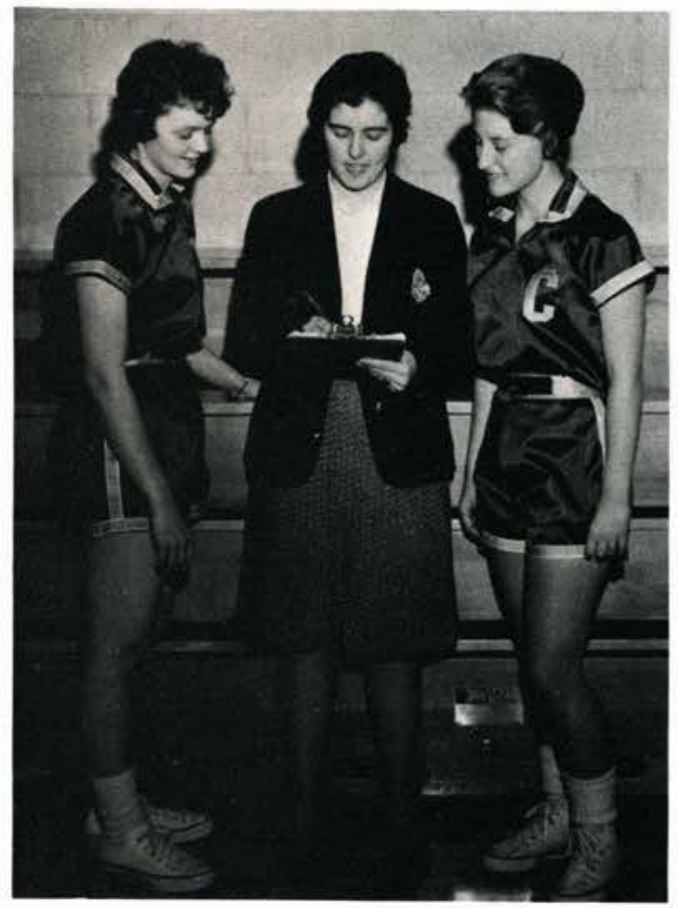

The thrill and excitement of a new experience came to the girls of Cedarville College in the form of an organized, intercollegiate basketball team. With two practices a week and ten games during February and March, the team members kept up a swift pace. A most welcome addition to the appearance of the team was the arrival of blue and gold uniforms.

The second semester of 1961 brought in the spring weather and brought out the girls to play intramural softball. Teams formed from Faith Hall, New Girls Dorm and Off-campus Students participated in the afternoon hours for the Campus Championship. The team from Faith Hall captured the title after a season of stiff competition.

\section{Intercollegiate}

\section{Basketball}

Co-captains Maryalyce Jeremiah and Pat Kastor check the line-up with Coach Kearney.

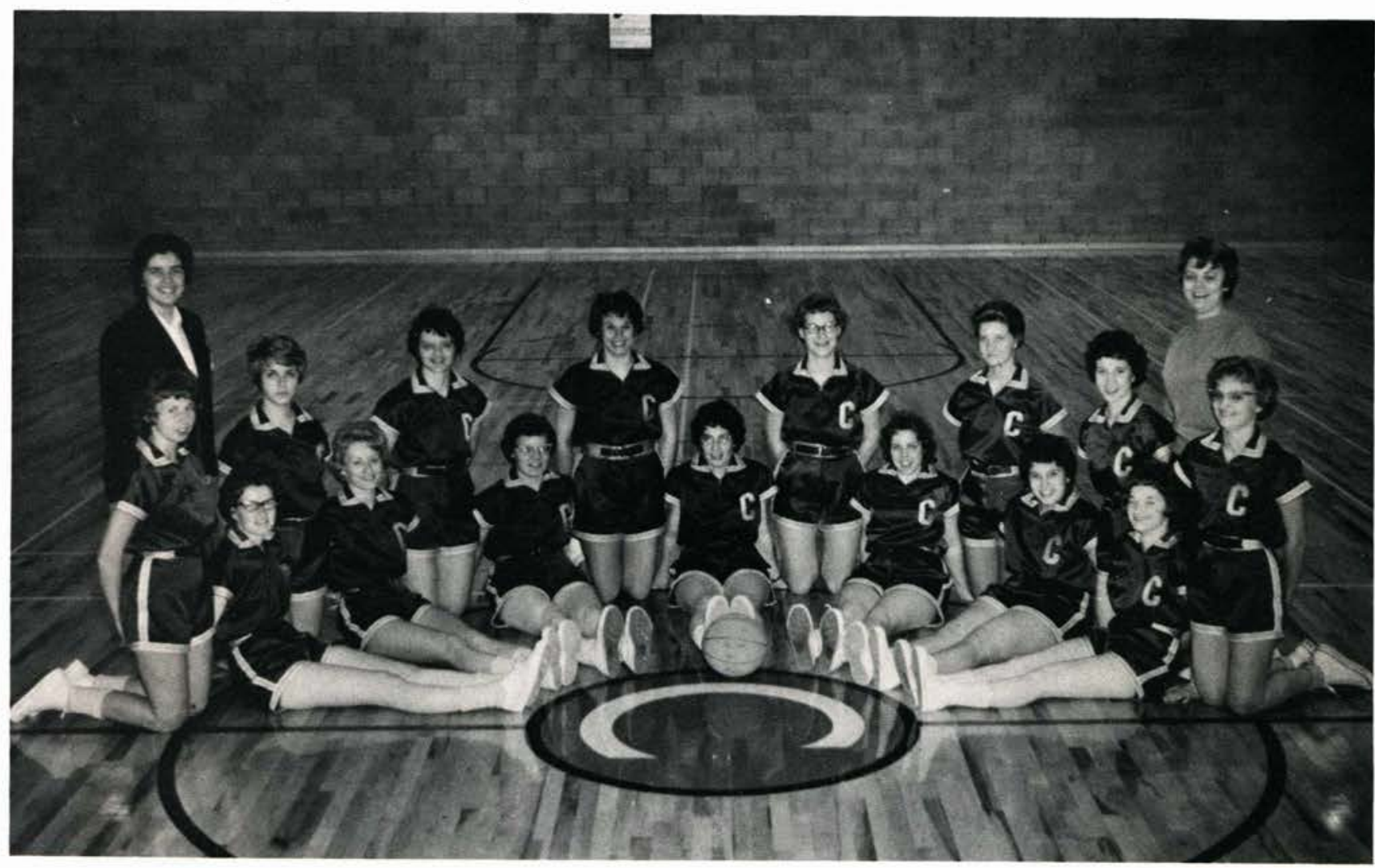

Seated: B. Ross, B. Adamson, N. Smith, S. Johns, S. Bender, G. Leichty, A. Halley. Kneeling: P. Versluis, M. Short, M. Jeremiah, P. Leunk, S. Geyser, P. Kaster, S. Wing, P. Quick. Coach: Miss June Kearney; Manager: Margaret Johnston. 


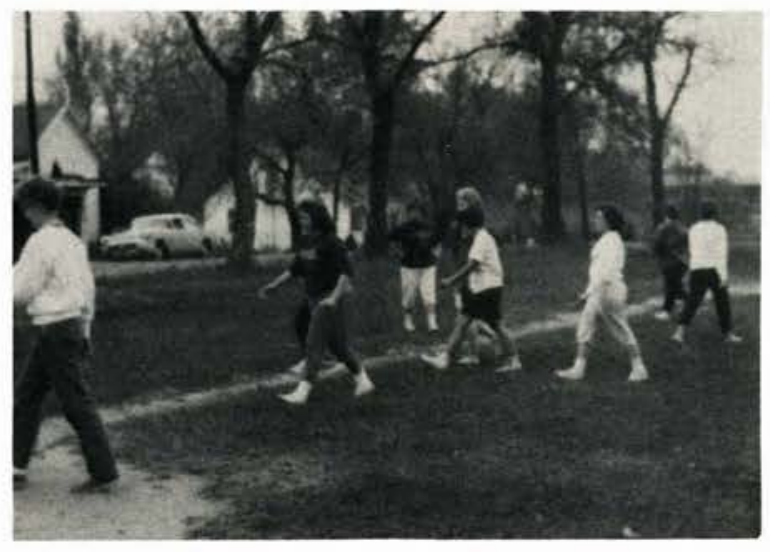

Leaving the field in determination

\section{Girls}

\section{Softball}

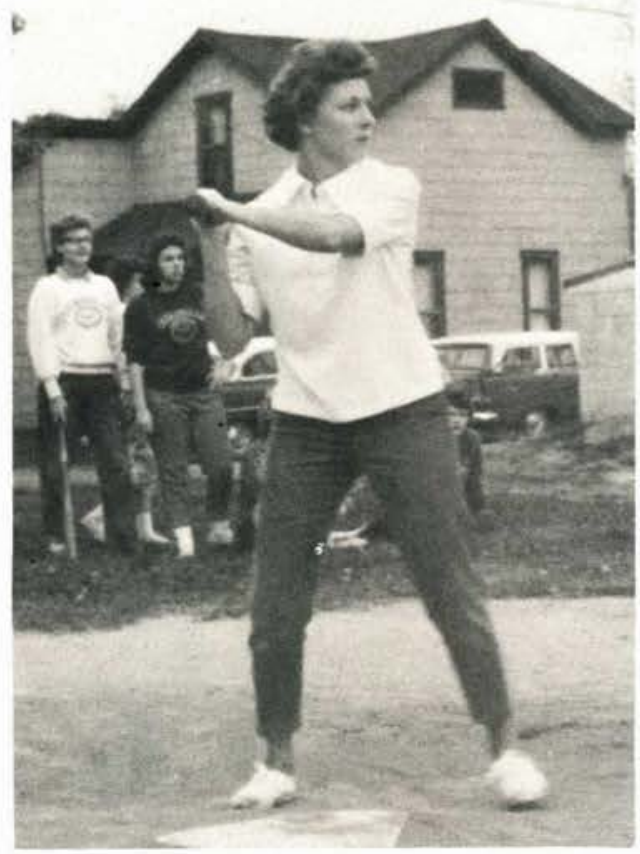

Tense expectation - Shall I or shall I not?

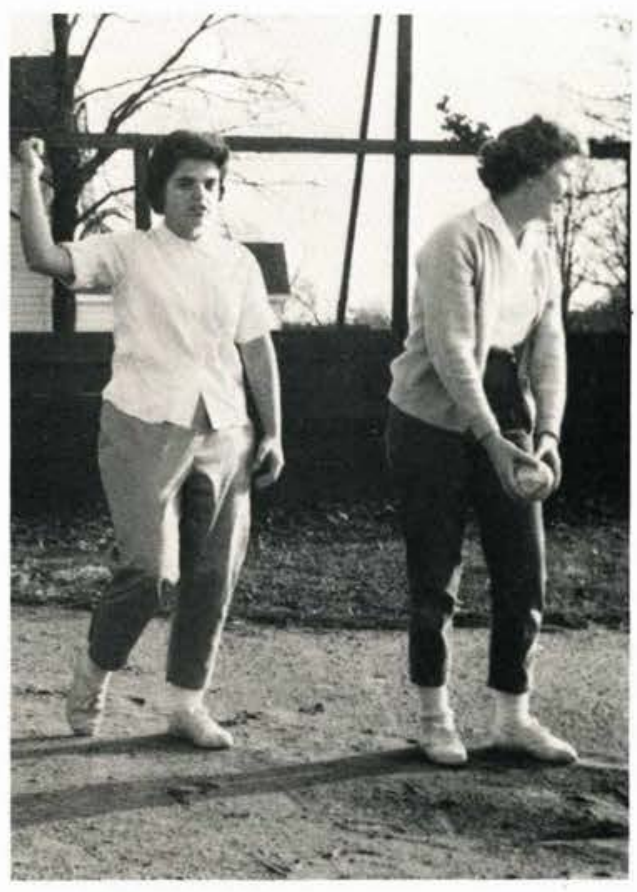

The official is always right

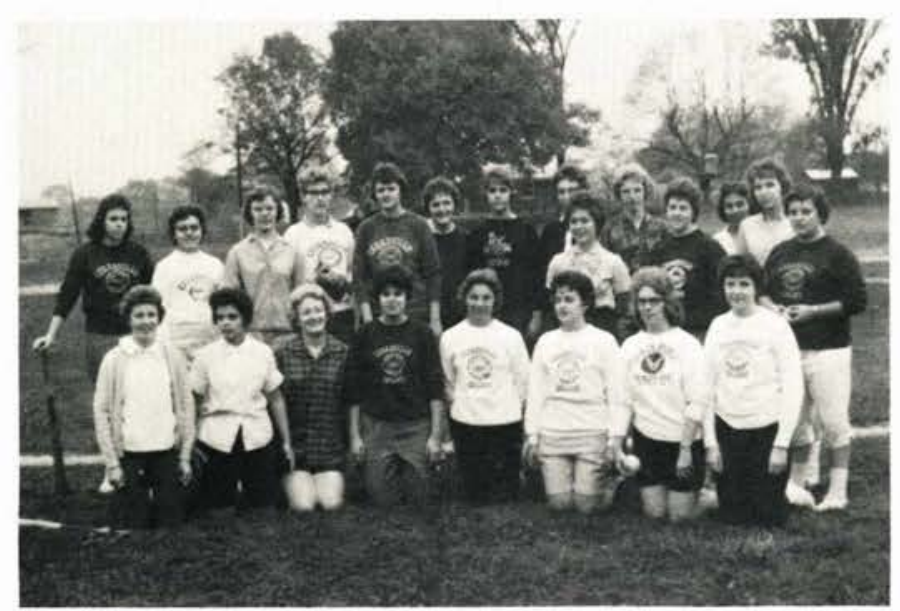

Top Row: S. Bender, P. Shonscheck, N. Smith, S. Geyser, M. Jeremiah, B. Unzicker, M. Short, H. Wing, J. DuPree, S. Dyda, E. Himsel, J. Newfeld, M. Taylor, G. Brooks. Second Row: E. Price, J. McClish, B. Adamson, S. Fulhart, S. Byrd, F. Doctor, C. Ward, J. Miller. 
What would a college be without students? A name? A group of students? Empty traditions? With students there is life, a vibrant society, a world of problems, solutions, studies and activities.

The students support teams, participate in debates, work on newspapers and yearbooks in order to promote their ideas or to improve their school. Beneath the stream of competition and complaints there runs a deeper current of loyalty and devotion that is steady and evident when put to the test. 


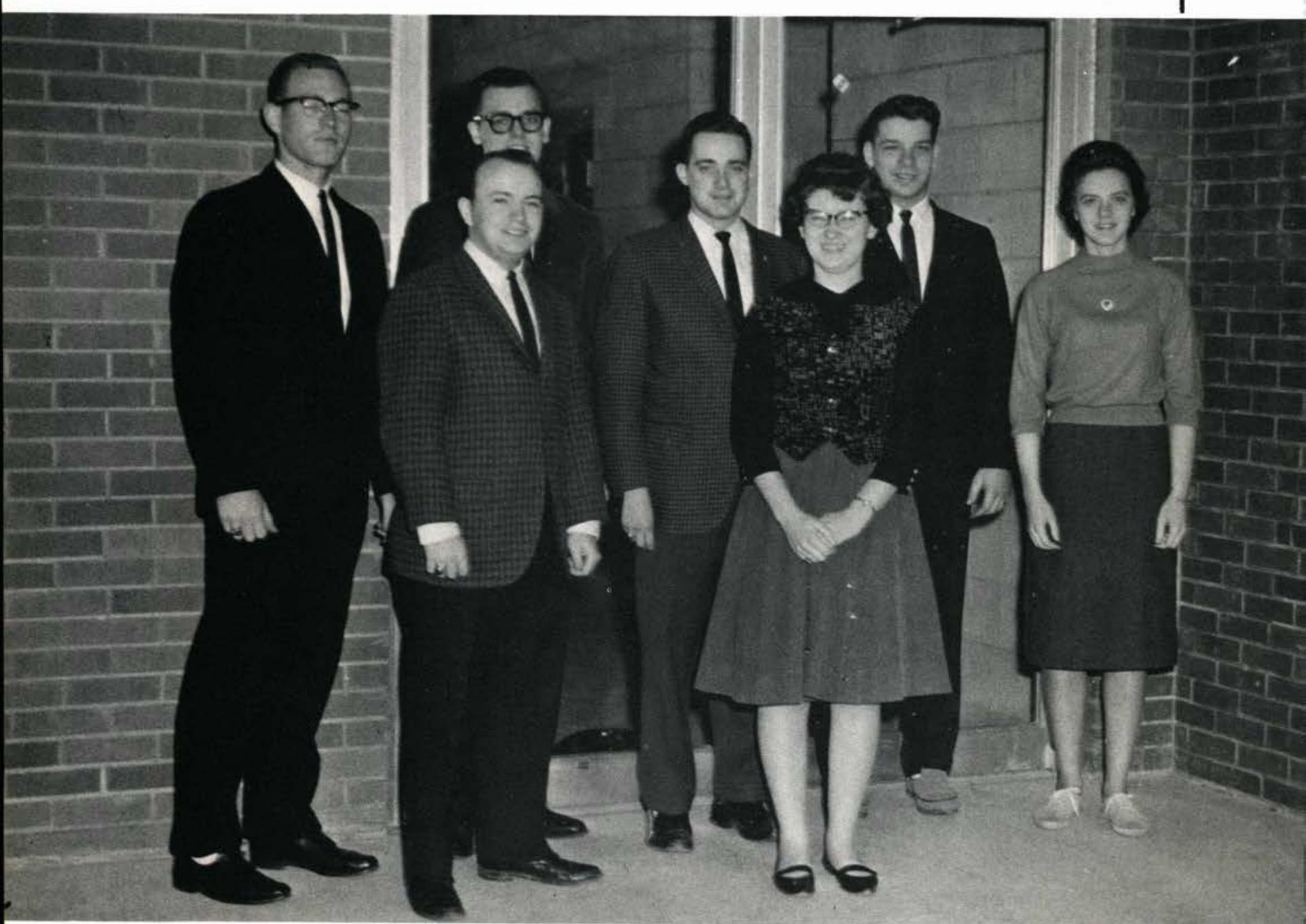

\section{Seniors}

\section{Class Officers}

President

Vice-President

Secretary

Treasurer

Advisor
Richard Blumenstock John Ingram Beverly Woods William Warfield Kenneth St. Clair 


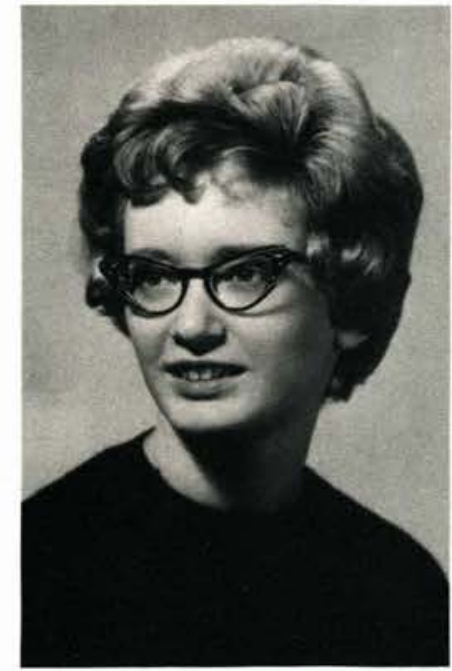

Barbara Adamson

Perry, Iowa

First Baptist Church B.S., Secretarial Science Baptist Bible Seminary '59. 60, Central State College '62. 63: Student Council 4; Gamma Chi 2; Whispering Cedars Staff 4; Basketball Team 2, 3; Kappa Delta Chi 3, 4, VicePresident 4

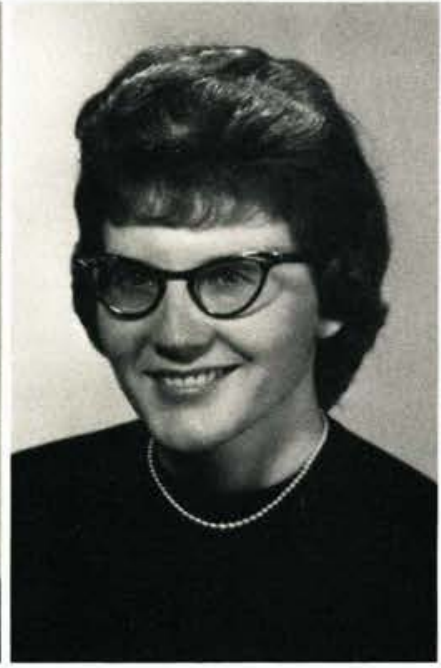

Rosa Lee Albrecht LaPaz, Indiana

Calvary Baptist Church B.A., Elementary Education - Moody Bible Institute Graduate '59, Central State College 61-63; Student Council 2; Gamma Chi 2, 3 , Vice-President 3; Whispering Cedars Staff 2; Fellowship for World Missions 2, 3, 4, Secretary-Treasurer 3; Dorm Counsellor 3; Kappa Delta Chi 4; Pi Delta 3.

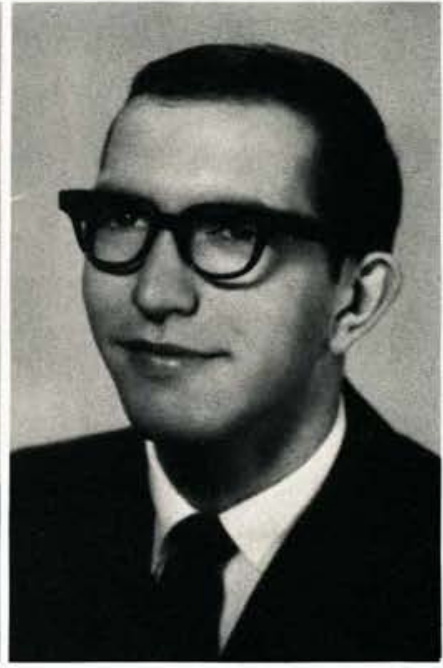

Robert A. Baldock

Rochester, Minnesota First Baptist Church B.S., Business Administration - Illinois Institute of Technology '58:'61; Homecoming Play Sound Engineer 4; Future Pastors 3; Pep Club 3, 4.

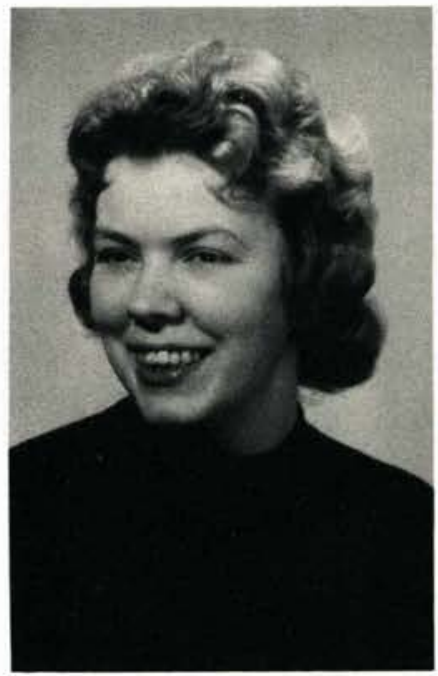

Irene Marie Benson

Gary, Indiana

Central Baptist Church

B.A., Social Science - Central State '61-63; Gamma Chi 2; Pep Club 2; Fellowship for World Missions 1, 2,3 .

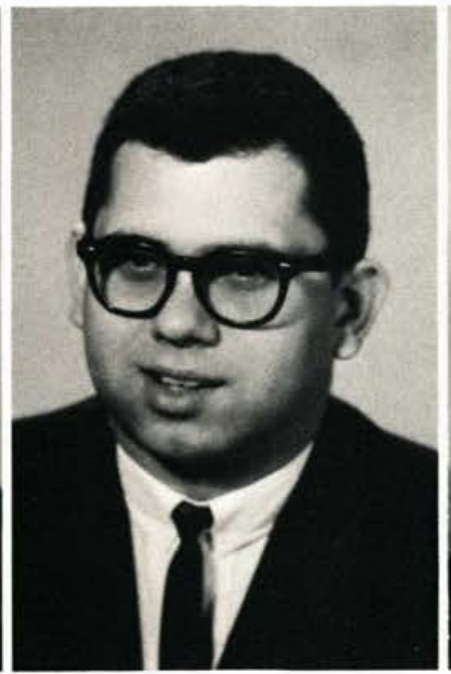

John R. Bigelow

Detroit, Michigan West Chicago Baptist B.A., Bible - Shelton 57. '58; Baseball 3, 4; J.V. Basketball 3; Chapel Choir 2.

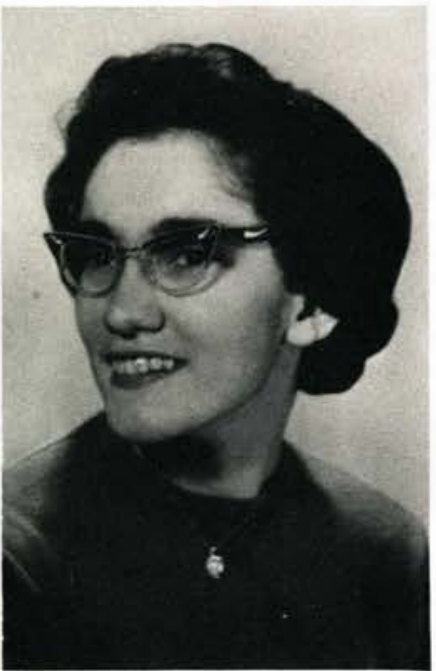

Julia E. Bird

Saline, Michigan York Baptist Church, Milan, Micbigan

B.S., Christian Education Gamma Chi 1, 2; Fellowship for World Missions 1, 2. 


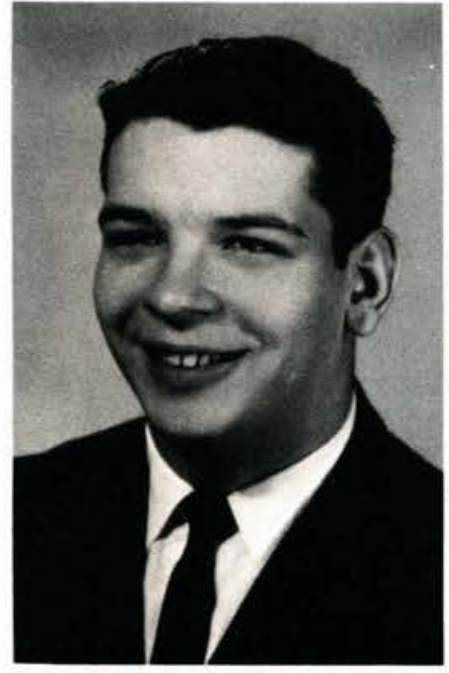

Richard Blumenstock

Teaneck, New Jersey

First Baptist Church.

Hackensack, New Jersey B.A., Bible - Class President 3, 4; Alpha Chi 1, 2, 3, Secretary 2 .

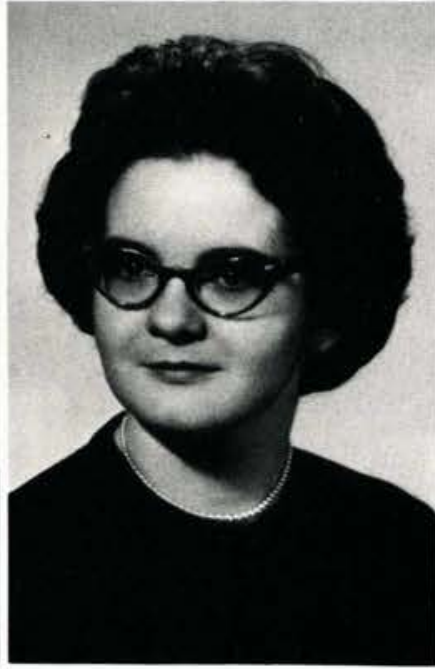

Carole Ann Boren

Niles, Ohio

First Baptist Church

B.A., Social Studies - Student Council 2, 3, Treasurer

3; Band 1, 2, 3, 4, Librarian

2; Clarinet Trio 3.

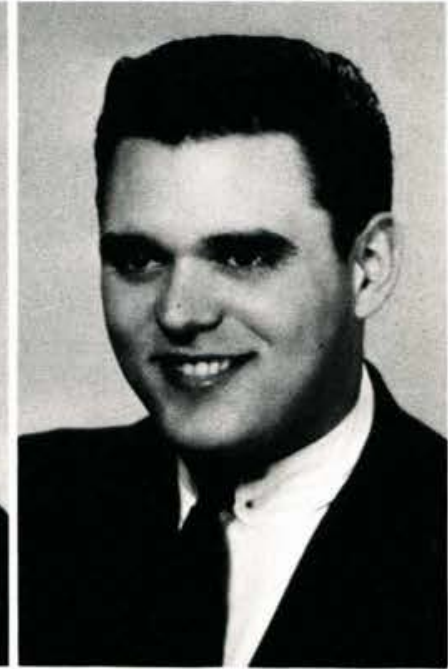

Philip Mark Brower

Rockford, Michigan

Rockford First Baptist Church B.S., Business - Varsity " $\mathrm{C}$ " 3, 4; Basketball Team 1; Choir 2; Small Music Group 1; Athletic Publicity Director 3, 4 .

\section{Seniors}

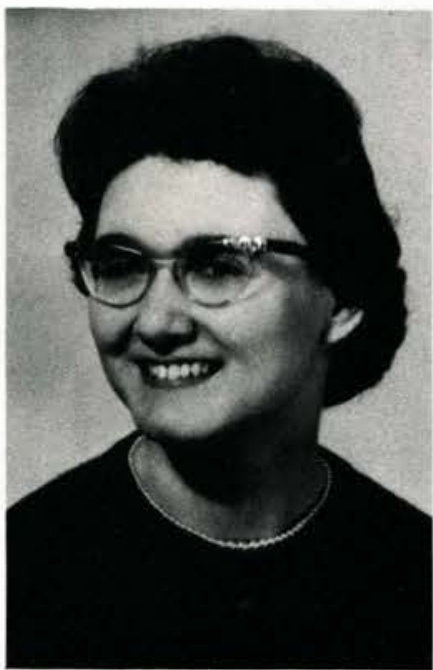

Carol Ann Brown Sycamore, Ohio

Tiffin Calvary Baptist Church B.S., Christian Education Student Government 1; Gamma Chi 2; Fellowship for World Missions 1, 2, 3; College Choir 1, 2, 3; Music Masters 2, 3, 4, Vice-President 3; Small Music Groups $1,2$.

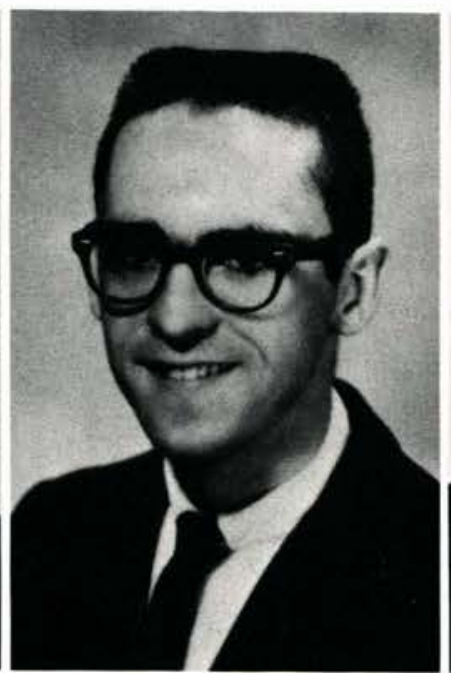

Sam Canine

Blanchester, Ohio

First Baptist Church

A.B., Bible - Class Parliamentarian 3; Student Council 2, 3; Varsity "C" 2, 3, 4, Chaplain 4; Basketball Team 1, 2, 4; Choir 1, 2; Band 1, 2; Music Masters 2, 3, 4, President 3, 4; Men's Quartet $1,2,3,4$.

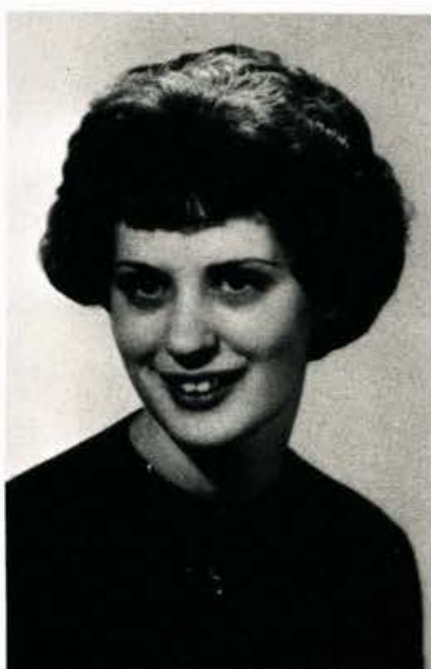

Flo Cannon

Decatur, Georgia Second Avenue Baptist Church

A.B., English - Central State '60-'63; Gamma Chi 1. Whisper Cedars Staff 3; FWM 1, 2; Kappa Delta Chi 3, 4; J.V. Cheerleader $1,2$. 


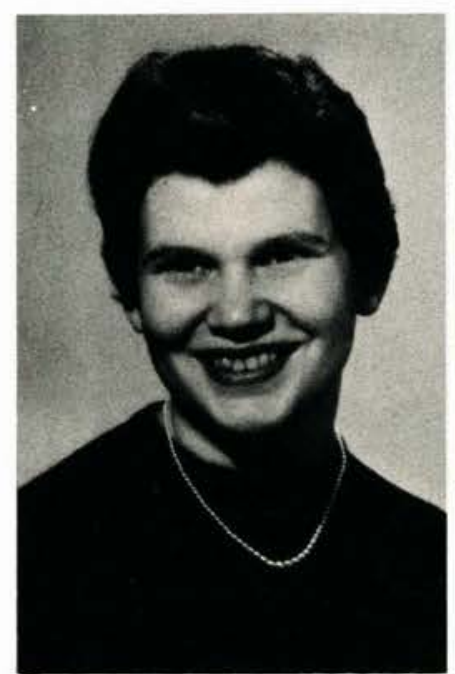

Alberta Graham Carr

Hayward, California Grace Baptist Church, Cedarville, Obio

A.B., Social Science - Central State '62:63; Student Council 1; Gamma Chi 2, 3; Whispering Cedars 2, 3; Basketball Team 1, 2, 3; Choir 1, 2, 3; Trio 2; Cheerleaders 2; Student Wives 3, 4 .

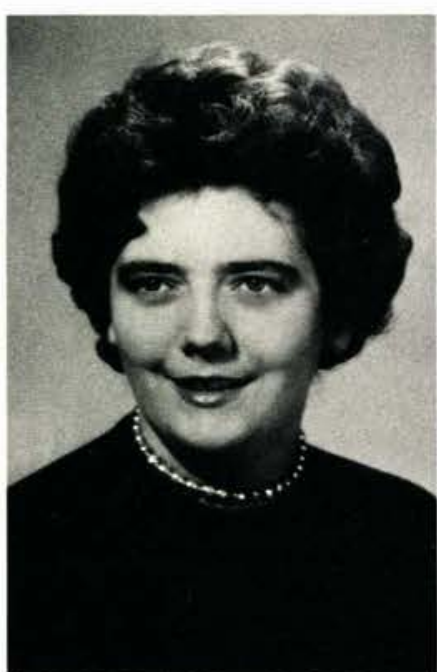

Loretta M. Cushey

Butler, Pennsylvania First Baptist Church

B.A., Elementary Education - Central State College '6163; Homecoming Play 1, 2; Basketball Team 1; Kappa Delta Chi 3, 4 .

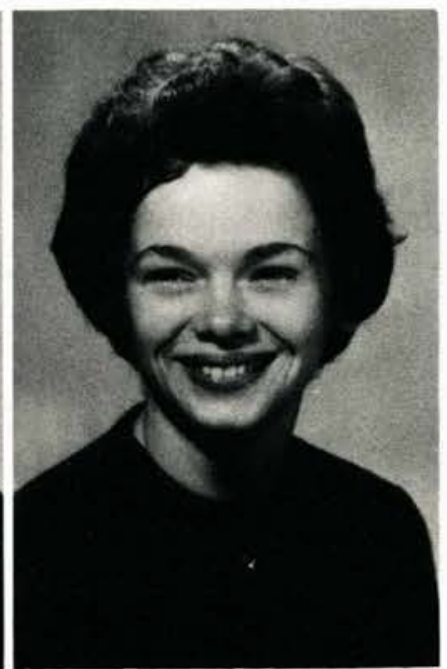

Judith Dadisman

Warren, Ohio

North Mar Christian and Missionary Alliance Church B.A., Elementary Education - Central State College '61'63; Gamma Chi 3, 4; Chapel Choir 1.

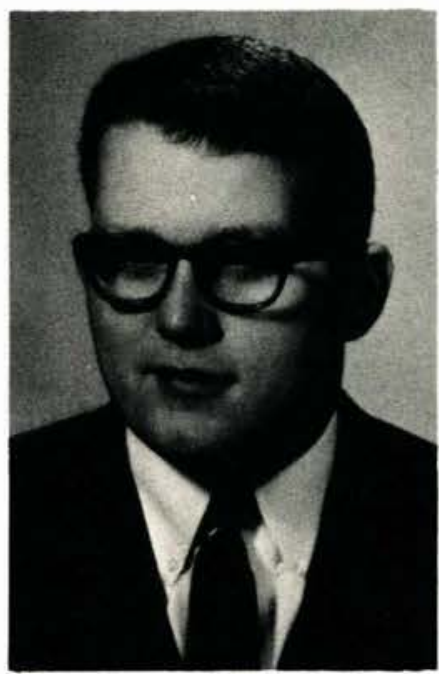

Richard Lawrence Davidson

Harvey, Illinois First Baptist Church B.A., English - Homecoming Play 1, 3; Yearbook Staff 3; Whispering Cedars Staff 4; Choir 2. 3; Small Music Group 2, 3, 4; Statistician 3,4 .

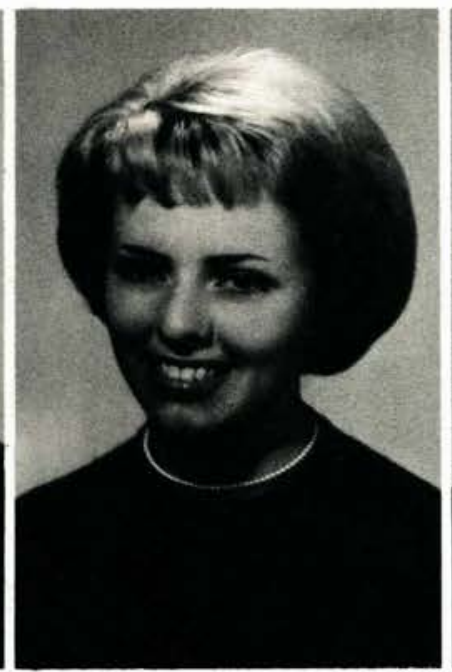

Donna Lee Davis

Detroit, Michigan West Chicago Baptist Church B.A., Social Science - Shelton College '58:'60, University of Detroit '60:'61, Central State College '62-63; Kappa Delta Chi Secretary 3.

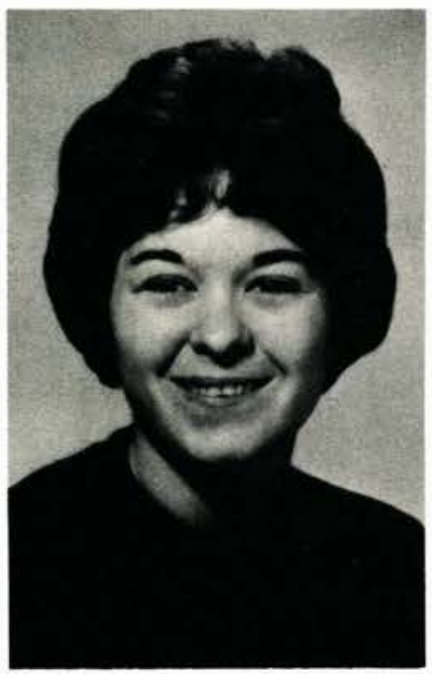

Jeannie DuPre Washington, D. C. Capitol Baptist Church B.S., Biology - Maryland University (Summer) '62; Student Council Secretary. 3, 4; Gamma Chi 1; Sock 'n Buskin 4; Homecoming Play 2, 3, 4; Fellowship for World Missions 2; $\mathrm{Pi}$ Delta 3, 4, Secretary 3; Dorm President 4; Dorm Counsellor 4 . 


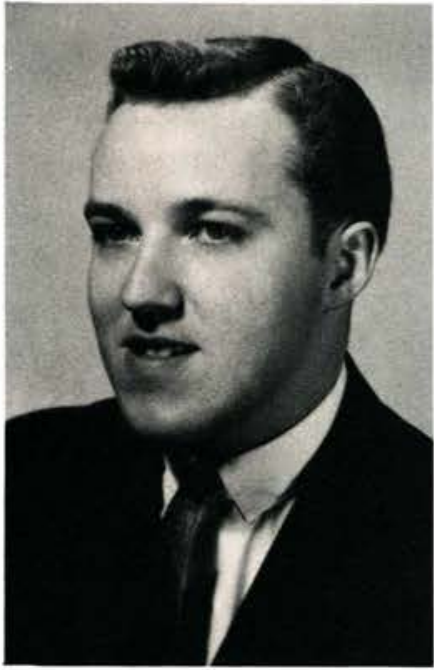

Edward Lee Eastman

Wiscasset, Maine Bible Baptist Church

B.A., Social Studies - Central State College '61:63; Fellowship for World Missions 3; Basketball Team 1; Tennis Team 4; Band 1; Small Music Group 1, 4 .

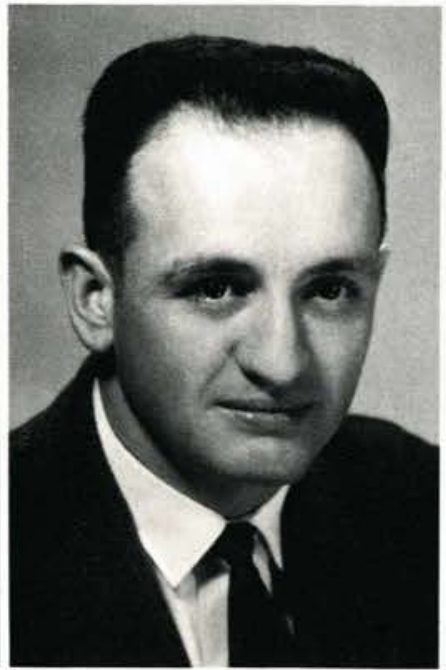

Leon E. Farnsworth

Jerome, Michigan North Adams Baptist Church A.B., Social Studies - Fellowship for World Missions $1,2$.

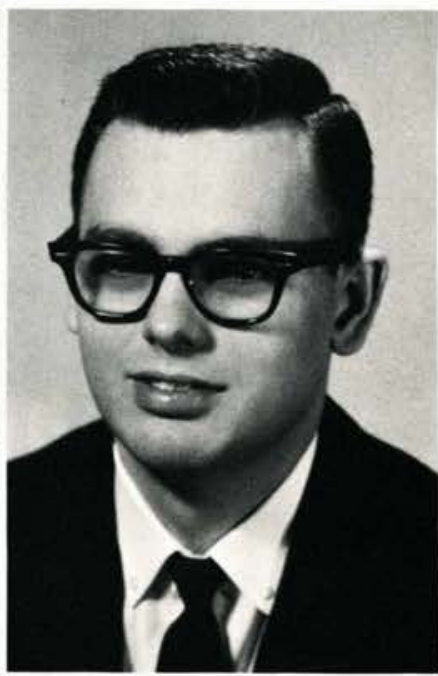

Robert Bruce Fidler

Gary, Indiana

Glen Park Baptist Church

B.A., English - Class Social Chairman 4; Yearbook Staff Sports Editor 3; Whispering Staff Sports Editor 4; Baseball Team 2; WCDR-FM Staff 4 .

\section{Seniors}

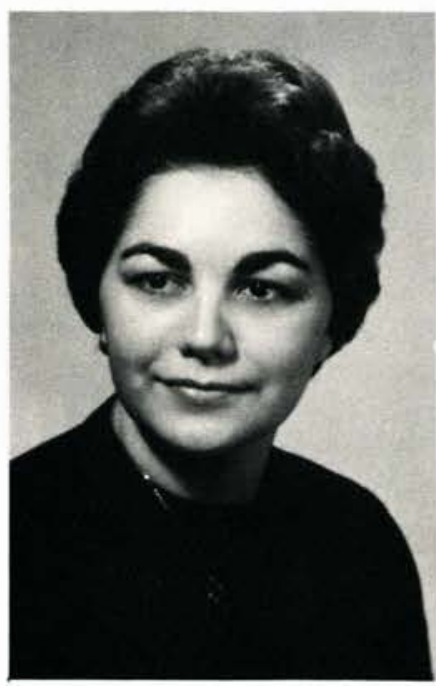

Donna Jean Finley

Faribault, Minnesota

First Baptist Church

B.A., History - Gamma Chi 1, 2, 3, 4, Treasurer 3, Parliamentarian 4; Homecoming Play 4; Choir 1, 2, 3, 4, Secretary-Treasurer 3, 4; Music Masters 2, 3, 4, Historian 3, Secretary 4; Ladies Trio 1, 2; Mixed Quartet 3; Ladies Duet

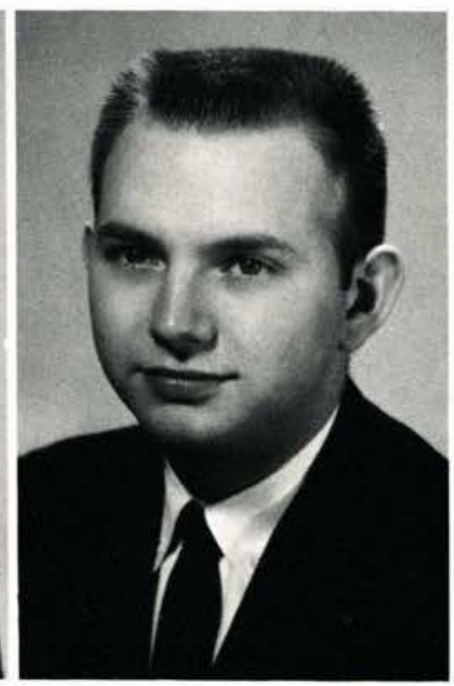

Paul H. Gathany

Highland, Indiana

Calvary Baptist Cburch B.A., Speech - Alpha Chi 1, 2, 3, Parliamentarian 3: Sock 'n Buskin 2, 3, 4, Treasurer 4; Homecoming Play 1, 2, 3, 4, Technical Director 3, 4; Band 1; WCDR-FM Announcer and Chief Engineer 4.

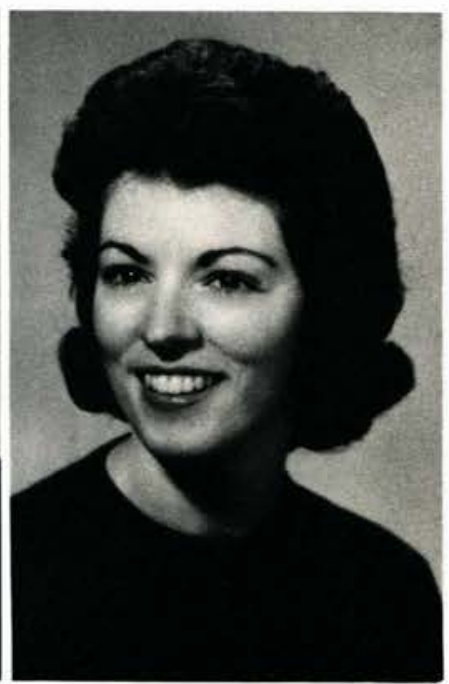

June Ellen Golden Stanton, Michigan First Baptist Church B.A., Music - Grand Rapids Baptist Bible College; Class Social Chairman 1; Choir 1. 2; Band 1; Small Music Groups 1, 2, 3, 4; Dorm President 4. 


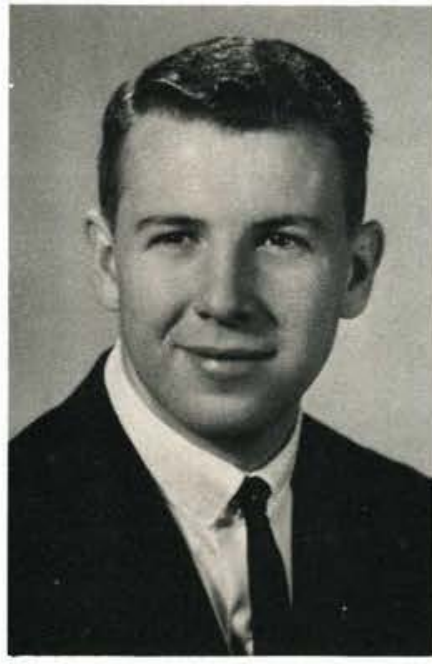

Phil Grant

East Moline, Illinois Third Street Baptist Church B.S., Biological Science Student Council 2; Homecoming Play 4; Band 1, 2, 3, Vice-President 3, Stude n t Council 2; Small Music Group 1, 3 .

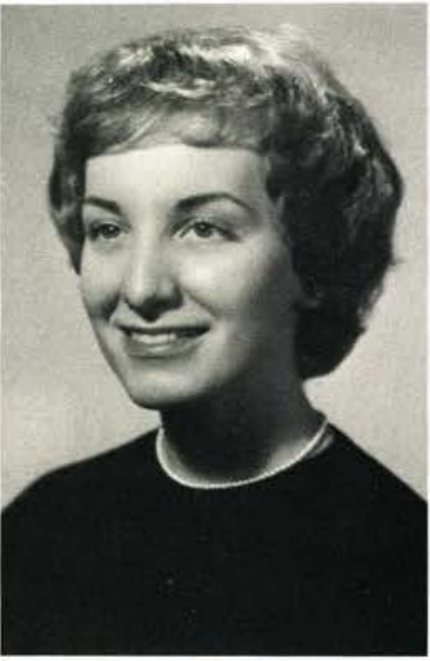

Cheryl Ann Harris

Cleveland Heights, Ohio Cedarbill Baptist Church B.S., Business Administration - Bob Jones University ' 59 62.

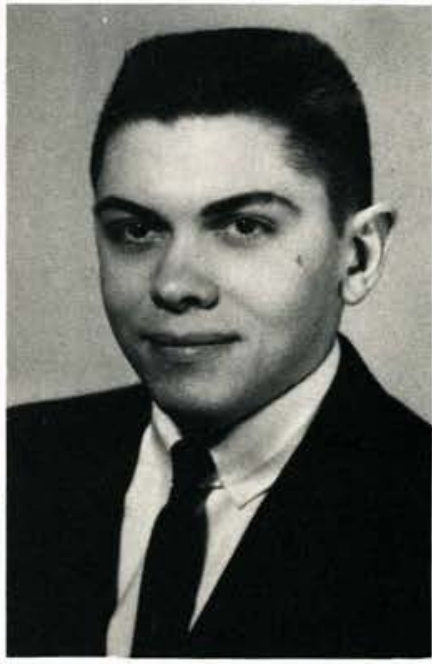

Mark Haseltine

East Butler, Pennsylvania First Baptist Church Central State College '62; Class Treasurer 1, 2, 3; Student Council 3, 4, President 4; Discipline Committee 4; Alpha Chi 1, 2, 3, Vice-President 2, Student Council Representative 3; Homecoming Play 4; Fellowship for World Missions 1, 2; Varsity "C" 2, 3, 4, President 3, 4; Basketball Team Manager 2, 3, 4; Baseball Team 1, 2; Sigma Eta $\mathrm{Pi}$

President 4; College Social Committee 3.

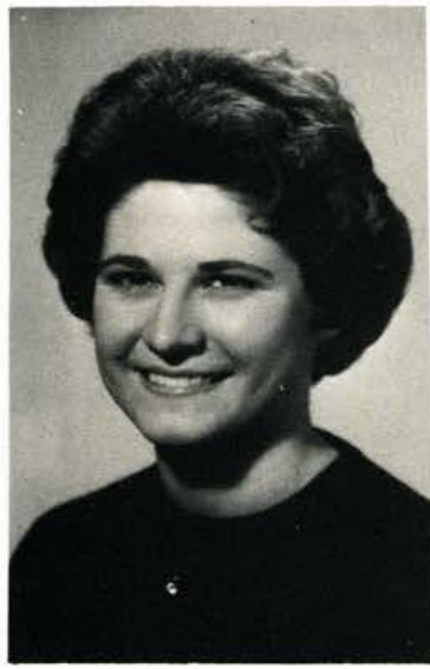

Carole Hell

Gladwin, Michigan Skeels Baptist Church B.S., Christian College Trinity College '58.'59; Class Social Chairman 4; Gamma Chi 2; Fellowship for World Missions 4; Choir 1; Small Music Group 1; Kappa Delta Chi Parliamentarian 4

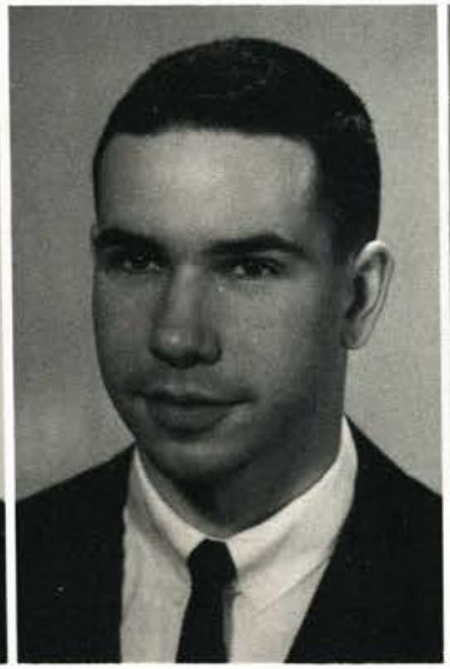

Larry S. Helmick

Traverse City, Michigan Immanuel Baptist Church B.S., Physical Science - Central State College '61-'63; Alpha Chi 2; Fellowship for World Missions 2; Chapel Choir 2.

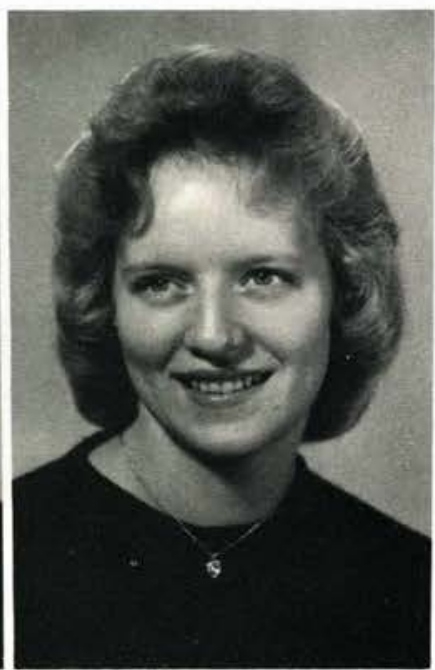

Carol Henson

St. Louis, Missouri Lackland Road Baptist Church B.S., Christian Education Gamma Chi 1; Choir 1, 2; Pep Club 3. 


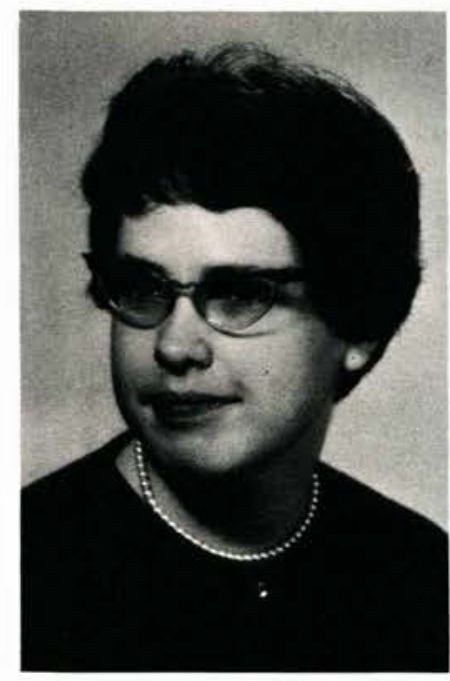

Elayne M. Howard

Chicago, Illinois

Belden Avenue Baptist Church B.S., Christian Education Homecoming Play 3; Choir $1,2,3$, Secretary 2; Music Masters 2, 3, 4, Secretary 3; Small Music Group 2, 3; Choralaires Secretary 3. 4.

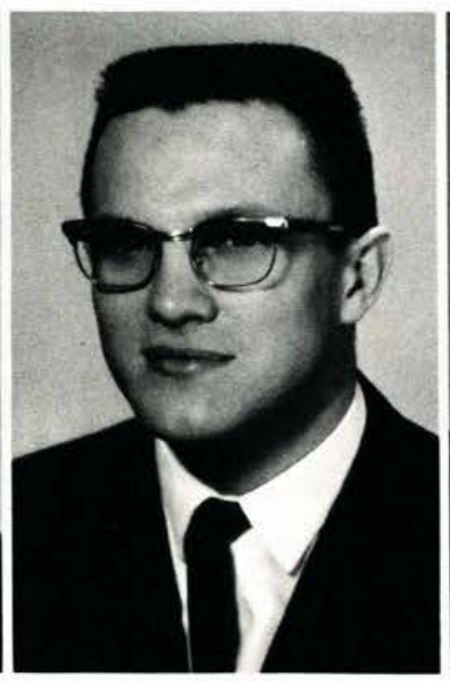

Ellis M. Howard

Williamston, Michigan First Baptist Church B.A., English - Midwestern Baptist Seminary and College '58-'59; Alpha Chi 2; Whispering Cedars Staff 4; Chapel Choir 2.

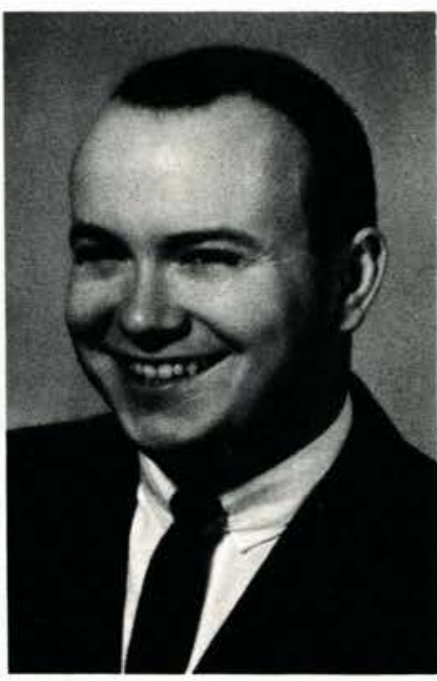

John R. Ingram

Columbus, Ohio

Immanuel Baptist Church

Class Vice-President 4; Alpha

Chi 1; Homecoming Play 2; Choir 1, 2, 3, 4; Quartet 4 .

\section{Seniors}

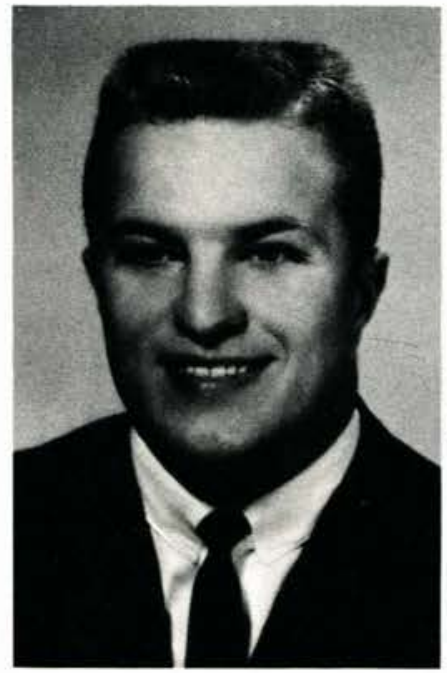

Lynn E. Jefson

Forest City, Iowa Calvary Baptist Church B.S., Business Administration - Class Social Chairman 3; Class Parliamentarian 4; Student Council 3; Basketball Team 1; Choir Manager 1, 2, 3; Quartet 1, 2, 3.

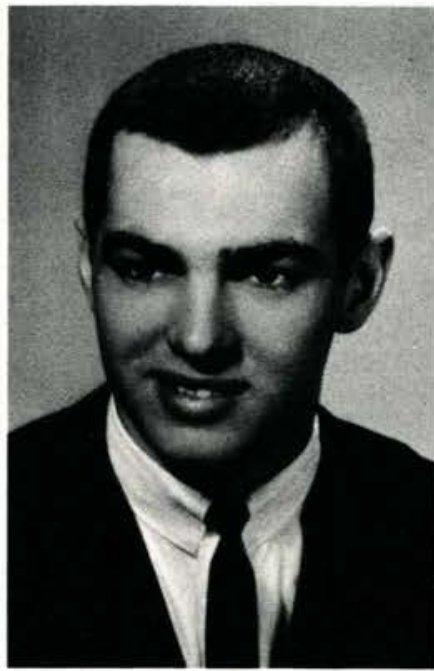

Dave Jeremiah

Cedarville, Ohio Grace Baptist Church B.A., Bible - Varsity " $\mathrm{C}$ " 1, 2, 3, 4, Chaplain 3; Basketball Team $1,2,3,4$, CoCaptain 3, 4; Choir 1, 2, 3, President 3; Band 1, 2, President 2; Music Masters 2, 3, 4 , Vice-President 4; Quartet 1, 2, 3, 4; WCDR-FM Manager 4 .

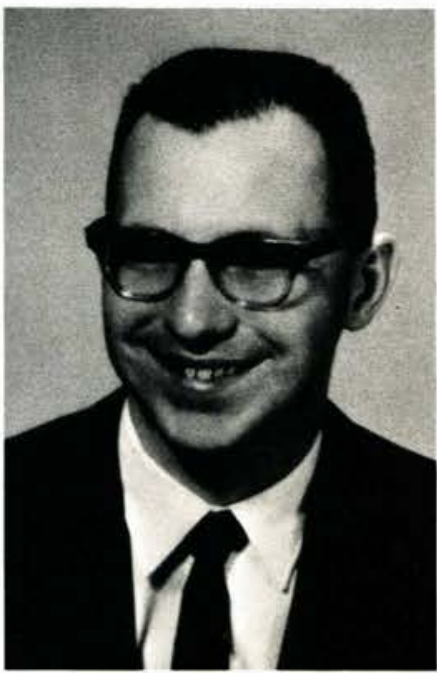

Donald C. Johnson

Kennedy, New York Kennedy Baptist Cburch B.S., Christian Education Buffalo Bible Institute ' 58 . '61. 


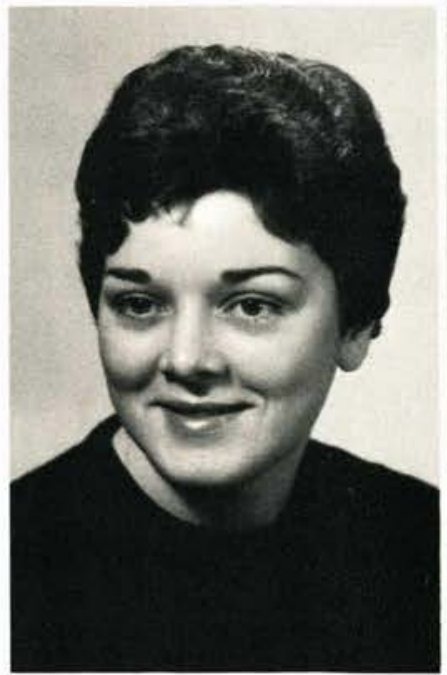

Lois Ruth Kennedy

Pleasantville, New Jersey Chelsea Baptist Church. Atlantic City, New Jersey. B.A., Elementary Education - Houghton College '58-'60, Central State College '62-'63; Class Social Chairman 2; Band 1, 2; Kappa Delta Chi 3, 4 .

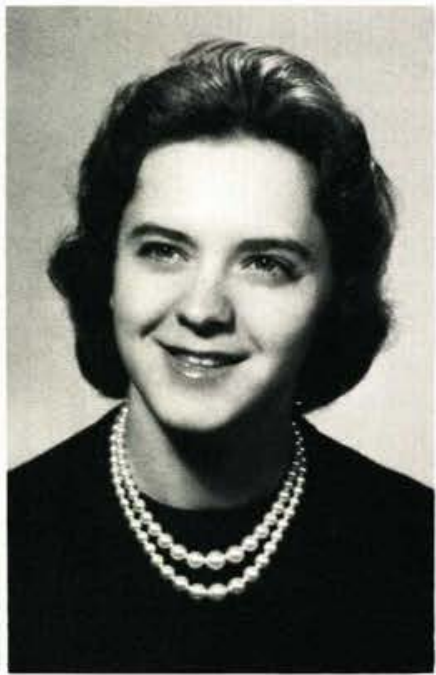

Sandra Jeanine Kirisits

Derby, New York

B.A., Christian Education Huntington College '59:'62; Class Social Chairman 4; Fellowship for World Missions 3,4 .

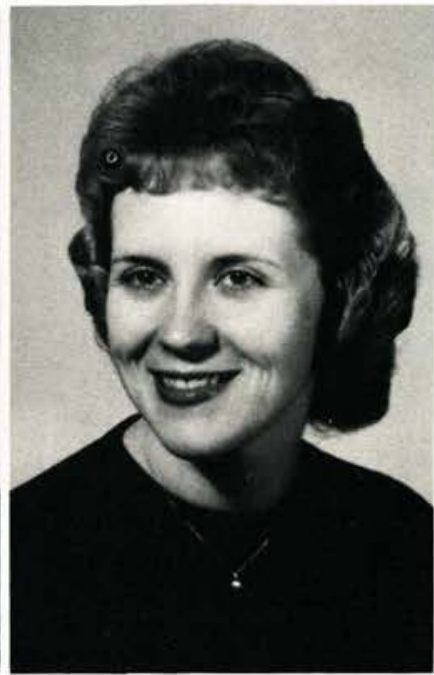

Judy Ann Lachman Lorain, Ohio

Penfield Junction Baptist Cburch

B.A., Music - Central State College '62-'63; Gamma Chi 1, 2, Parliamentarian 2; Homecoming Play 1, 4; Choir 1, 2. 3, 4, Librarian 3, Student Director 3, 4; Music Masters 2, 3, 4, Treasurer 3 .

4; Ladies Quartet 1; Ladies Duet 4; Varsity Cheerleader 2, 3; Dorm Treasurer 3; Dorm Counselor 4.

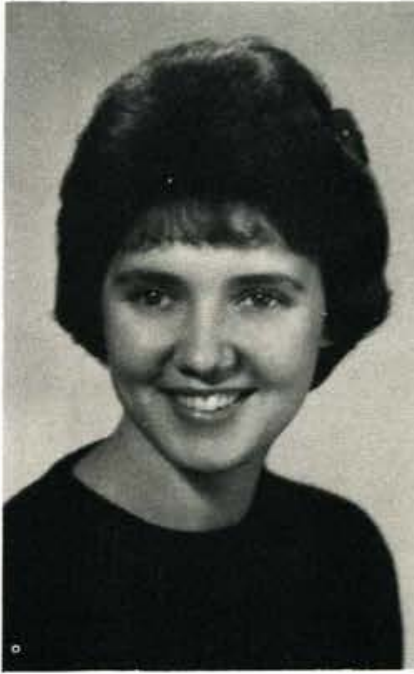

Irene Lane

Loveland, Ohio

Newtown Baptist Church

B.S., Secretarial Science -

Sue Bennett College '58:'6C, Central State 62-63; Gamma Chi 3, 4; Homecoming Play 4; Ladies Trio 4; Cheerleader 1. $2,3,4$.

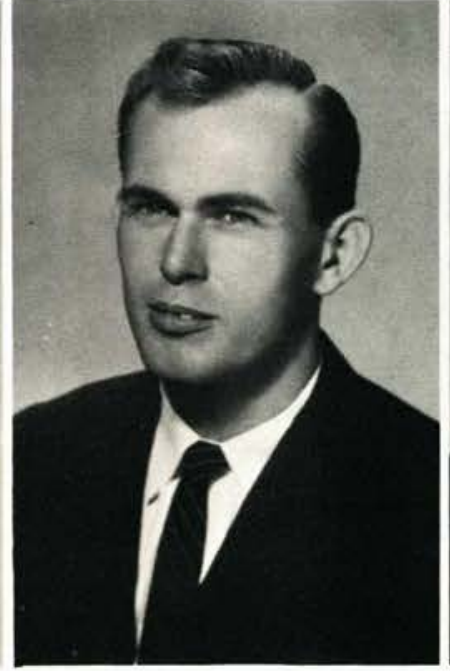

Gordon Langeneger Port Jefferson, New York Calvary Baptist Church B.A., Art - Shelton College '60-'61; Hofstra College '61; Yearbook Staff Art Editor 3; Photo Club President 4.

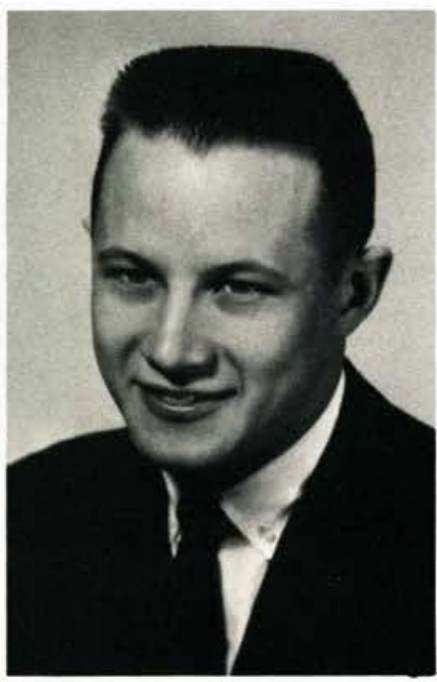

John Irving Lawlor Cedarville, Ohio

Grace Baptist Church B.A., Bible - Class Chaplain 4; Student Council 1, 2, 3, Vice-President 3; Alpha Chi 1, 2, Parliamentarian 2; Homecoming Play 1; Chapel Choir President 1, 4; WCDRFM Staff 4. 


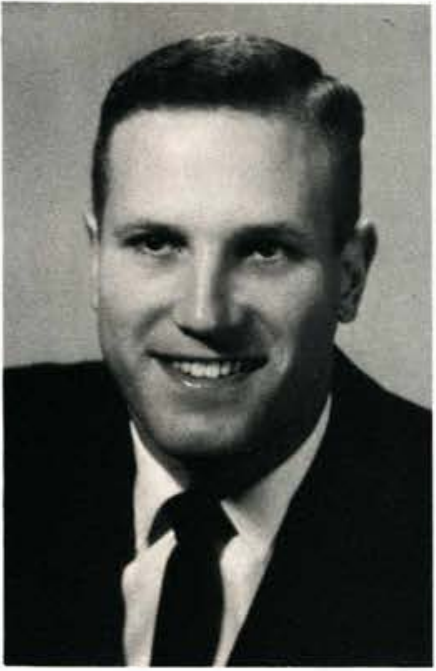

William Logsiger

Saginaw, Michigan

Immanuel Baptist Church

B.A., Biblical Education -

Prairie Bible Institute Graduate '61; WCDR-FM 4.

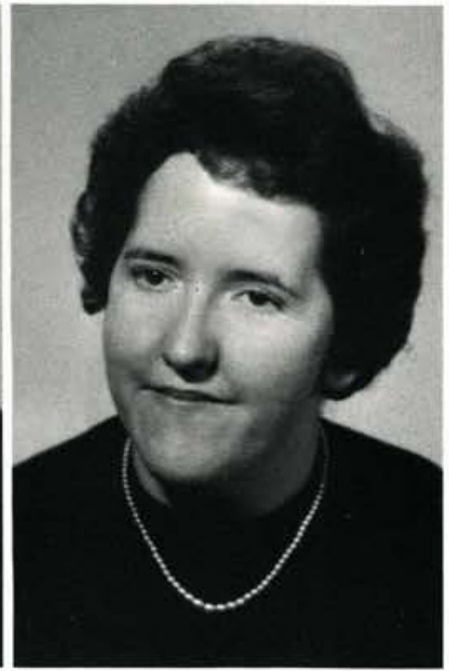

Betty Anne McKeehan

Chevrolet, Kentucky

First Baptist Church, Galion, Obio

B.S., Christian Education Whispering Cedars Staff 1, 2; Fellowship for World Missions 3,4

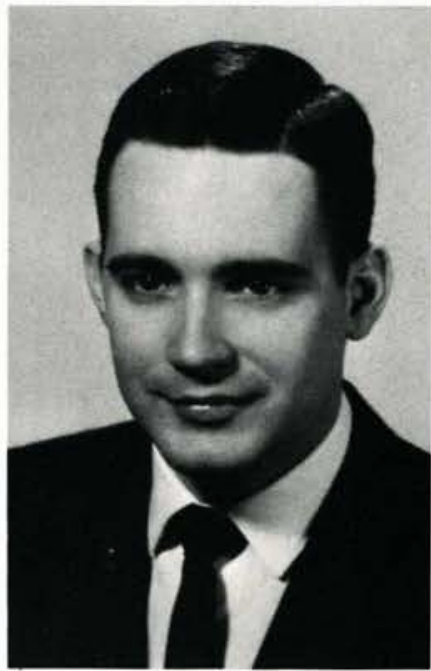

Donnell Lee Middleton

Middletown Township,

Lima, Pennsylvania

North Chester Baptist Church

Chester, Pennsylvania

B.A., Bible - Northern Bap-

tist Theological Seminary

(Correspondence); Stude n t Council 4; Alpha Chi 1, 2; Sock 'n Buskin 4; Fellowship for World Missions 1, 2, 3; Future Pastors Fellowship 2,

\section{Seniors}

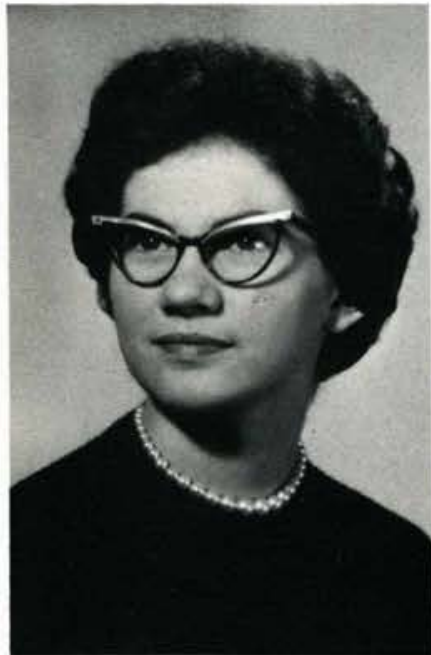

Bonnie Mae Nash Midland, Michigan Calvary Baptist Church B.A., History - Student Council 2, 3; Gamma Chi $1,2,3,4$, Student Council Representative 2, 3, President 4; Fellowship for World Missions 1, 2, 3, 4; College Choir 1, 2, 3, 4; Dorm Counselor $2,3,4$.

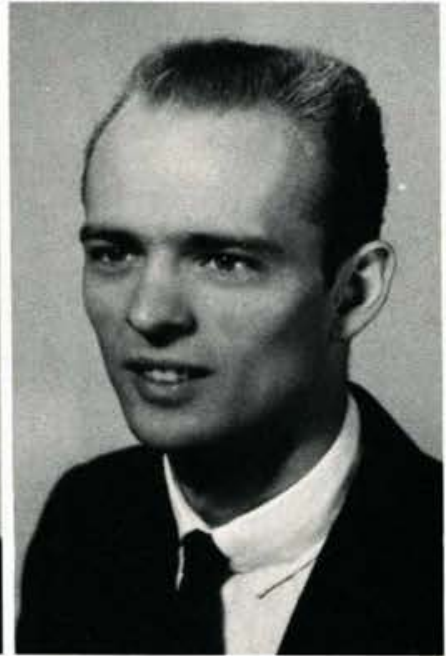

Ted Ocheltree St. Albans, West Virginia Randolph Street Baptist Church

B.A., Business Adminstration - Class Vice-President 3; Student Council 3, 4, Vice-President 4; Homecoming Play 4; Fellowship for World Missions 1; Varsity "C" Business Manager 2, 3, 4; Basketball Team 1, 2, 3, 4, Student Council Representative 3 ; Baseball Team 1, 2, 3, 4, Captain 3, 4; Dorm Counselor 3,4 .

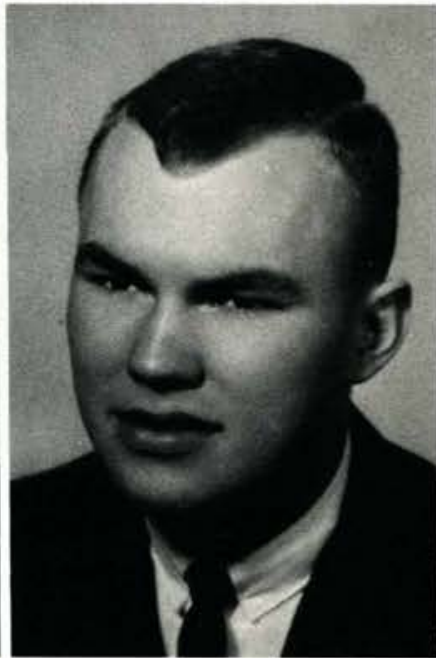

Charles Oehmcke

Wauwatosa, Wisconsin Garfield Avenue Baptist Cburch

B.S., Biology - University of Wisconsin-Milwaukee ' 59 . 61; Alpha Chi 3; Pi Delta 4; Sigma Eta Pi Secretary 4. 


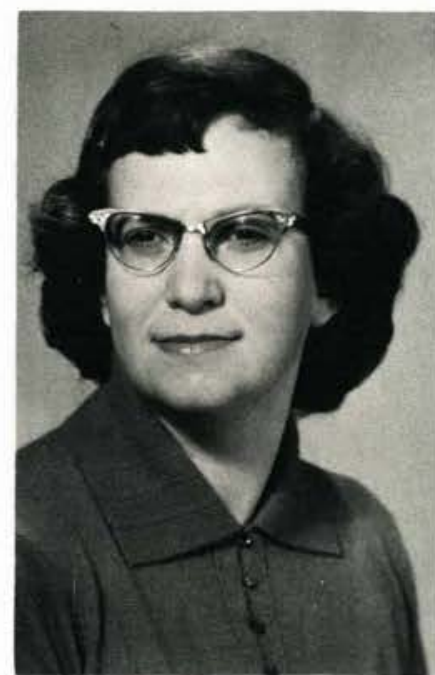

Aloha Patch

Austin, Minnesota

Grace Baptist Church, Cedarville, Obio B.S., Science - Gamma Chi 1, 2, Social Chairman 2; Sock 'n Buskin 3, 4, Secretary 4; Homecoming Play 1, 2, 3, 4; Chapel Choir 1; Pi Delta 3.

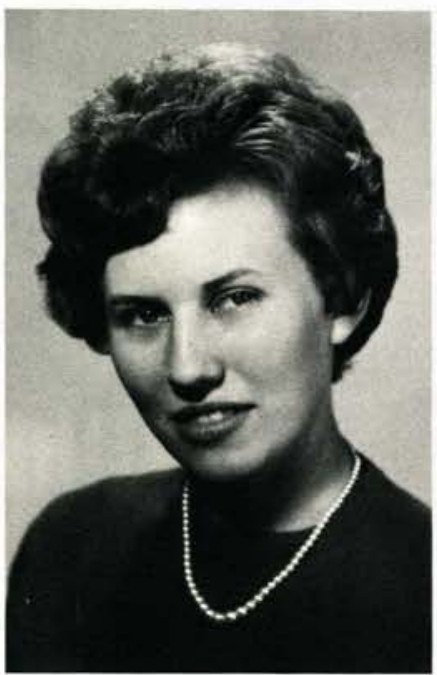

Clara Ellen Quiter

Bronson, Michigan Allen Baptist Church

B.A., Elementary Education - Central State College '60. 63; Fellowship for World Missions 1; Kappa Delta Chi 3, 4 .

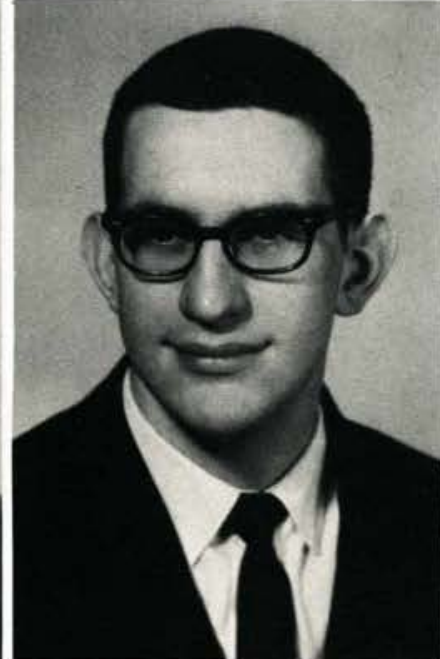

David Harold Rifenberick Spartansburg, Pennsylvania First Baptist Church

B.A., Chemistry - Temple University '59-60; Alpha Chi Chaplain 4; Fellowship for World Missions 3, 4, President 4; Choir 2, 4; Small Music Groups 4; Pi Delta Treasurer 3,4 .

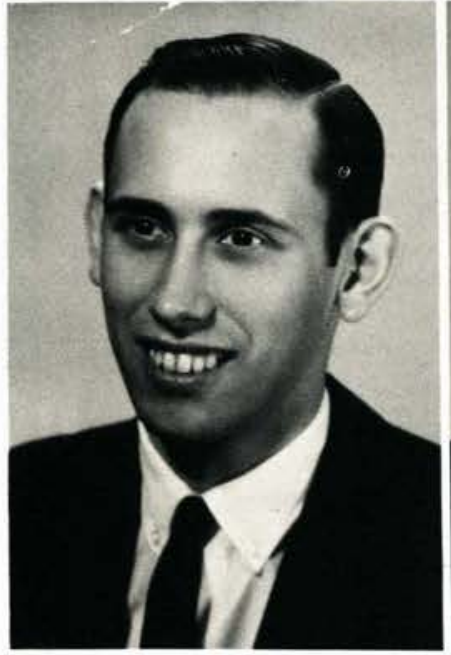

Lauren $\mathrm{H}$. Schenck

Cedarville, Ohio

Calvary Baptist Church B.A., Bible - Class Chaplain 3; Fellowship for World Missions 1, 2, 3, 4, President 3.

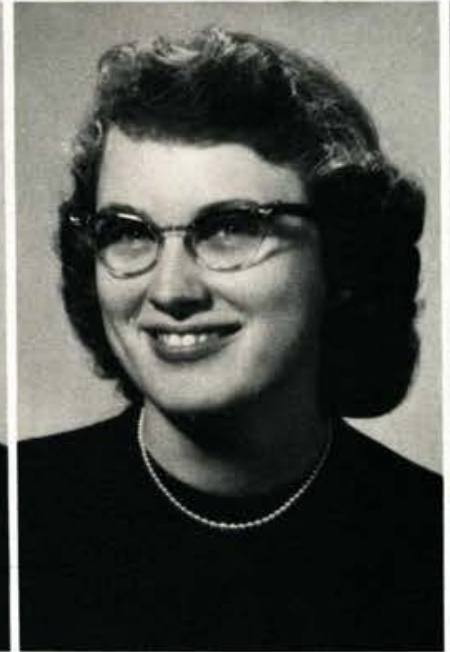

Mollie Jeanne Schmitt Hillsdale, Michigan North Adams Baptist Cburch A.B., Christian Education Huntington College '59-'61; Fellowship for World Missions 3, 4, Secretary-Treasurer 4.

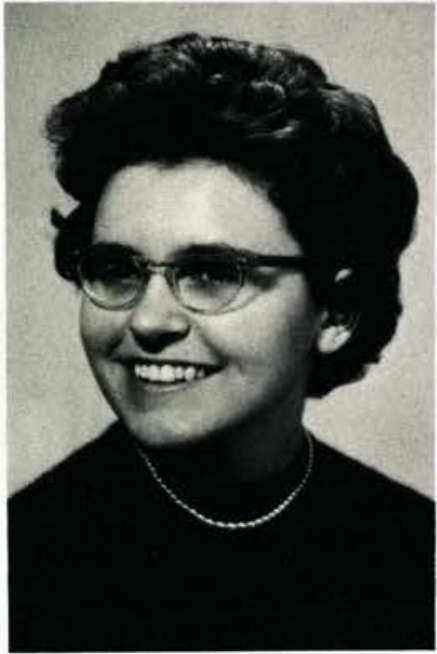

Patricia Thelma

Schonscheck

Allen Park, Michigan Evangel Baptist Church, Taylor, Michigan

B.A., Social Studies - Central State College '62:'63; Class Student Council Representative 3, 4, Treasurer 4; Discipline Committee 4; Gamma Chi 4; Sock 'n Buskin 3, 4; Yearbook Staff 3;

Choir 1, 3, 4 . 


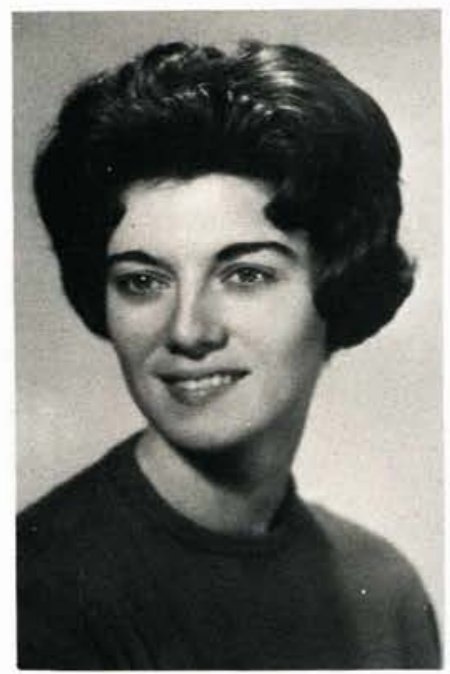

Catherine E. Shelton Howell, Michigan Grace Baptist, Cedarville Obio B.A., Social Science - Secretary 2; Fellowship for World Missions 1, 2, 3, 4; Girl's Basketball 1.

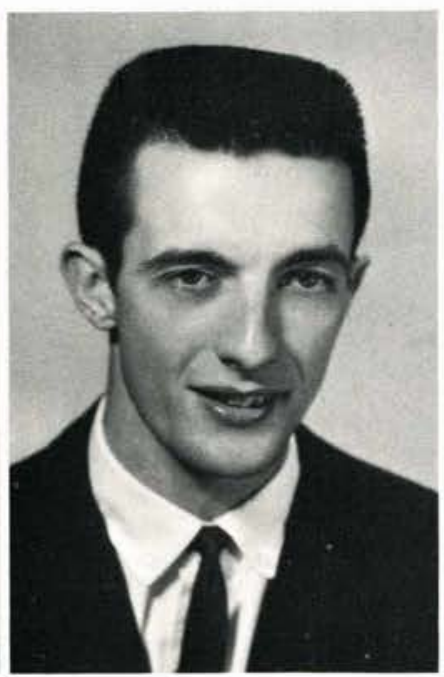

Norris H. Smith

Kirkersville, Ohio Bible Mission Baptist Church B.A., Physical Education Homecoming Play 1, 4; Varsity "C" 1, 2, 3, 4, Treasurer 2, 3, 4; Basketball Team 1, 2, 3, 4, Co-Captain 3, 4; Baseball Team 1, 2, 3, 4; Choir 1; Band 1; Small Music Group 1; Dorm Counselor 3, 4.

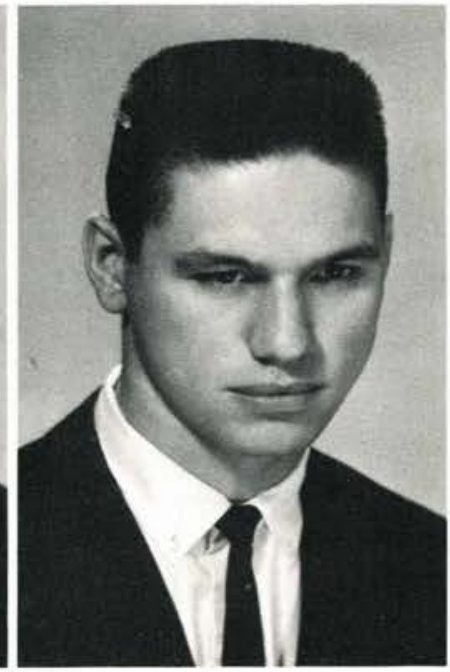

Donley Ray Tennant

Bellefontaine, Ohio First Regular Baptist Church B.A., History - Central State College (Part Time) '61:'63; Student Council 3; Alpha Chi 1, 2; Varsity "C" 2, 3, 4; Student Council Representative 4; Basketball Team 1; Track 2, 3, 4 .

\section{Seniors}

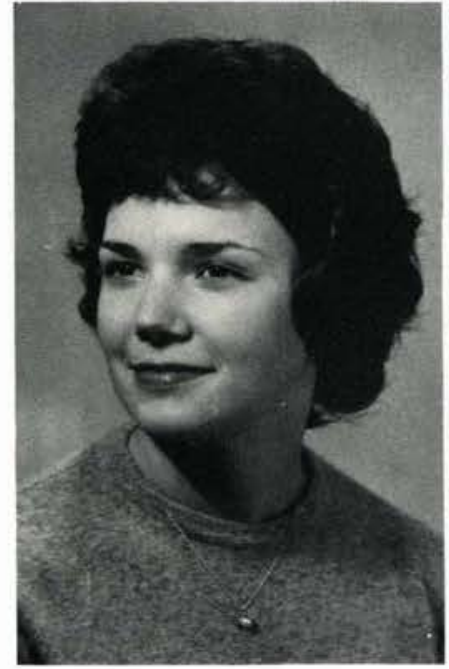

Donna M. Thompson Bedford, Ohio

North Solon Baptist Church B.S., Business Education Central State College '61:'63; Gamma Chi 2; Homecoming Play 4; Choir 1, 2, 3; Kappa Delta Chi Vice-President 3: Varsity Cheerleader 1, 2, 3, 4, Captain 3, 4; Pep Club 2, 3,4 .

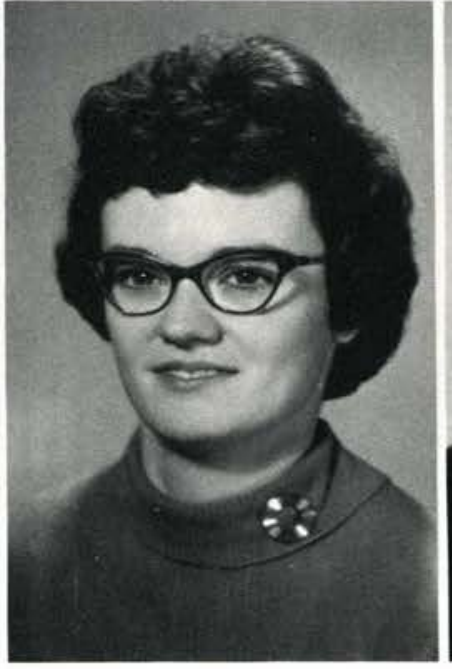

Louise Maxine Varisco

Strongsville, Ohio Beebetown, Ohio B.S., Secretarial Science Gamma Chi 1, 2, 4, Treasurer 2; Chapel Choir 1.

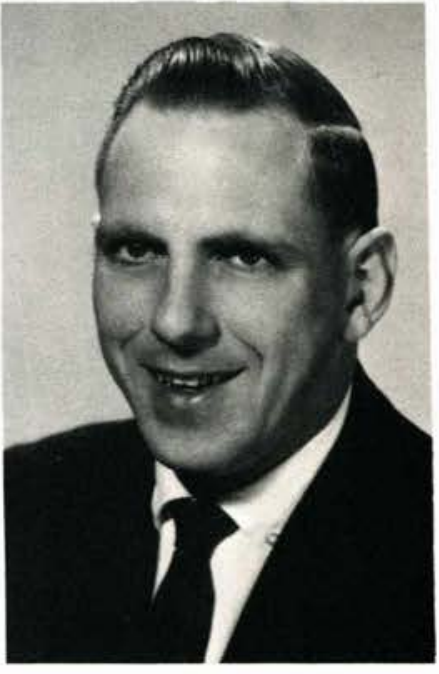

Gerald Wagnitz Wauseon, Ohio First Baptist Church B.A., Bible - Fe!llowship for World Missions 1, 2, 3, VicePresident 3; Future Pastors Fellowship 2, 3, President 3. 


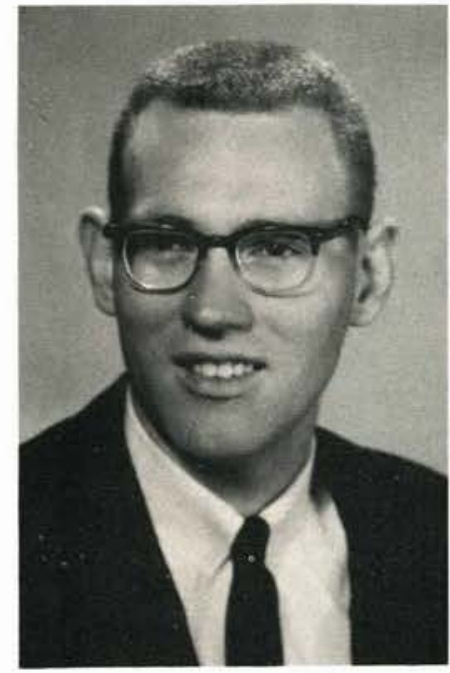

William W. Warfield

Elmhurst, Illinois

Grace Baptist,

Lombard, Illinois

B.S., Accounting - Treasure

4.

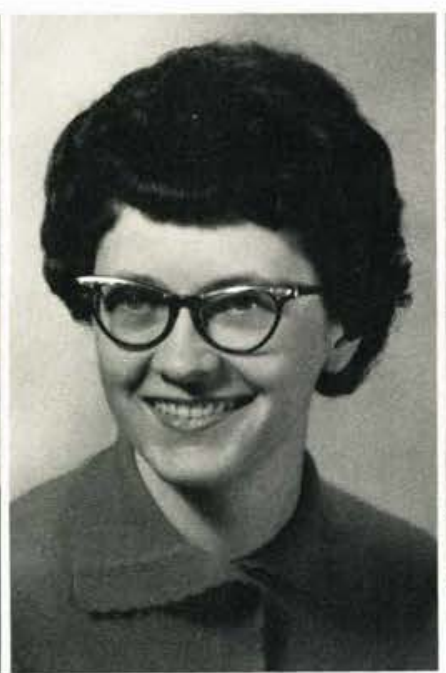

Nancy Jean Warkentin Waverly, Iowa

W alnut Street Baptist Church Waterloo, Iowa

B.A., Music - Wartburg-College (Summer School); Class Secretary 1, 2; Gamma Chi 1. 2, 4; Choir 1, 2; Dorm Counselor 3, 4 .

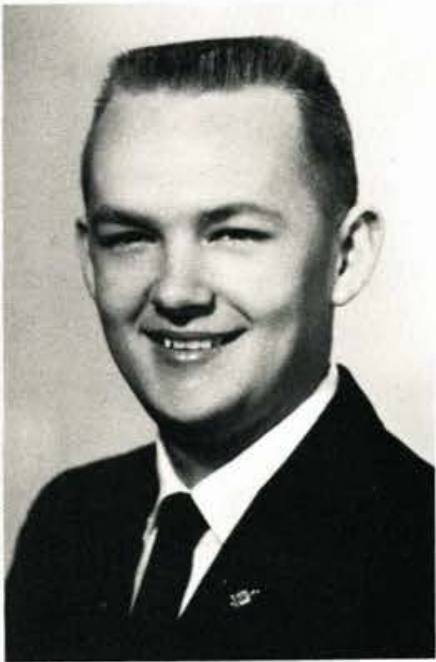

William J. Washburn Xenia, Ohio

First Reformed Church B.Mus., Music - Chapel Choir 2, 3, Vice-President 3; Band 2, 3, 4, Vice-President 4; Music Masters 4.

\section{Not Pictured}

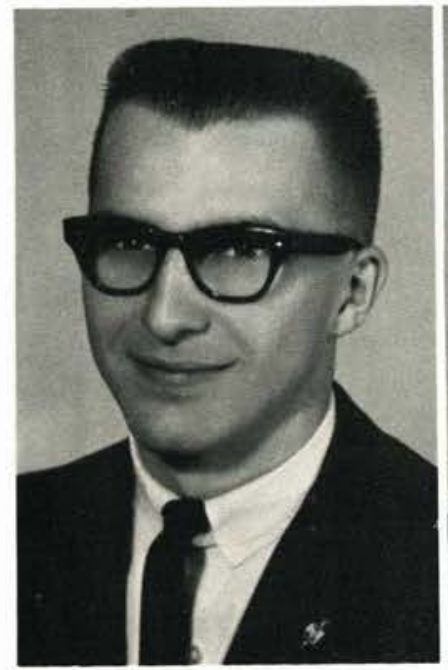

Ralph M. Werner, Jr.

Columbia Falls, Montana First Baptist Church

B.A., Music - Student Council 4; College Choir 1, 2, 3, 4, Vice-President 4; Band 1, 2 , 3, 4, President 4; Music Masters 3, 4; Student Council Representative 4; Small Music Group 1, 2, 3, 4; Dorm Counselor 4 .

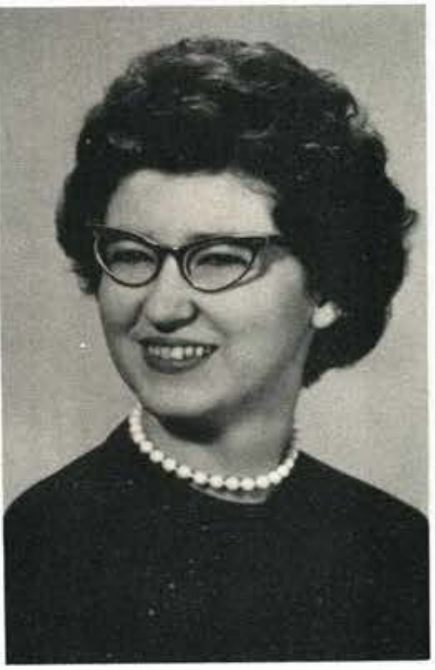

Beverly Ann Woods Fostoria, Ohio Fostoria Baptist Church

B.A., Secretarial Science Class Secretary 3, 4; Student Council 4; Homecoming Play 4; Yearbook Staff 2, 3; Whispering Cedars Staff 1, 2 , 4 .

\section{A. Lee Bennett \\ Freeport, Pennsylvania Calvary Baptist Church}

B.A., History - Moody Bible Institute (Correspondence) '56.'57; Northern Theological Seminary (Correspondence) '60; Central State '61-'62; Ohio State University (Correspondence) '62; College Choir 1; Homecoming Play 2.

\section{Richard Lee Bresson}

Tippecanoe, Indiana

Mentone Baptist Church, Mentone, Indiana B.A., Psychology - Wheaton College '59-'60.

\section{Don E. Hall}

Susquehanna, Pennsylvania Little White Church, Conklin, N.Y. B.S., Christian Education - Practical Bible Training School, Graduate '50; Baptist Bible Seminary '50-'51; Northern Baptist Theological Seminary (Correspondence) ' 51 ; Missionary to Ghana and Nigeria, West Africa, 1953-. 


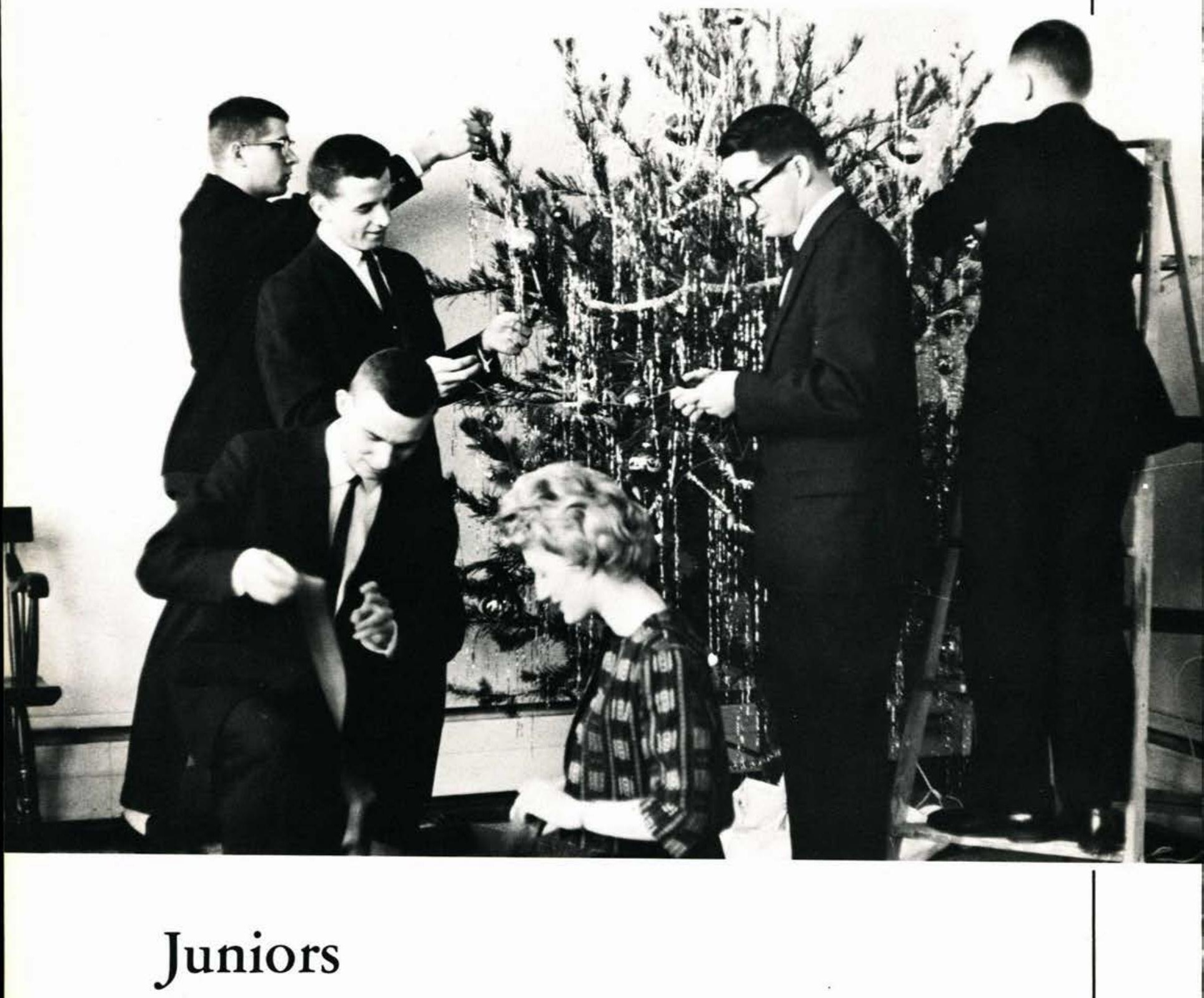

\section{Class Officers}

President Dave Warren

Vice-President Norman Nicklas Secretary Bette Adamson Treasurer Robert Auffort Advisor Mr. Gromachi 


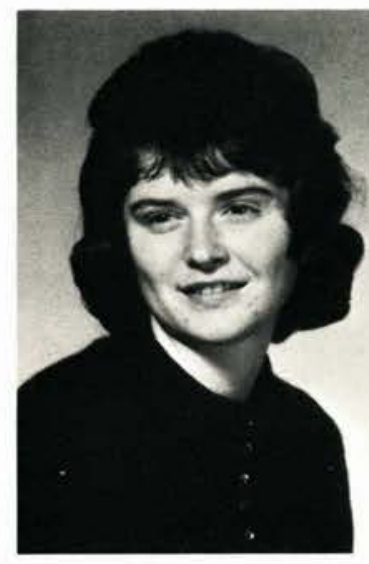

GLADYS ADAMS

Hazel Park, Michigan

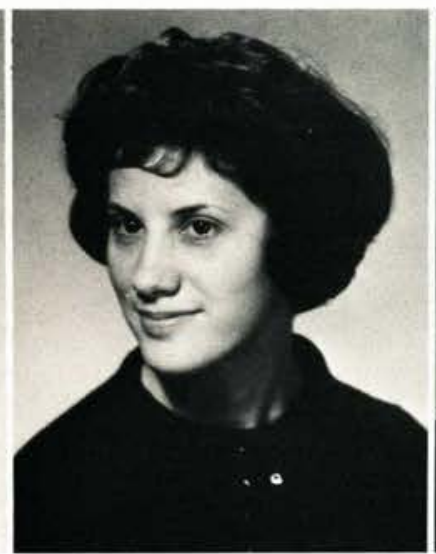

PATRICIA ADAMS

Silvis, Illinois

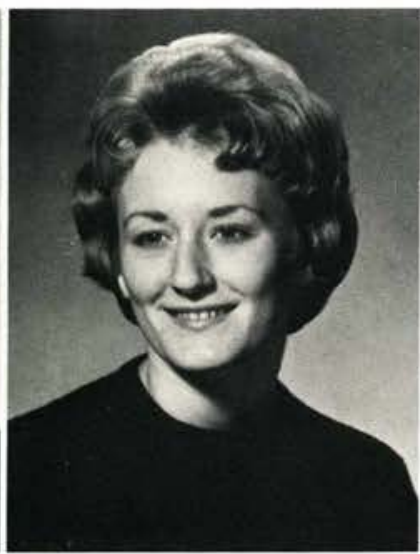

BETTE ADAMSON

Perry, Iowa

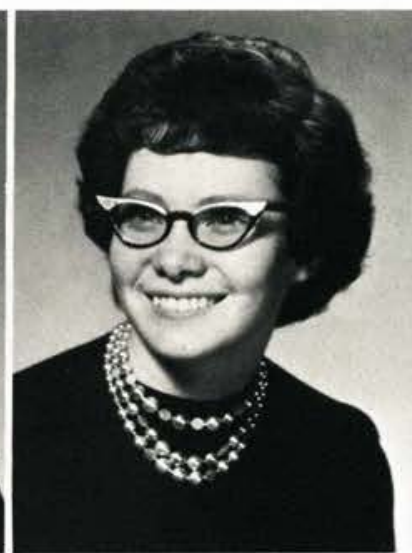

SHARON ADDLEMAN

Hillsdale, Michigan
ROBERT AUFFORT

Collingswood, New Jersey

SALLY BENDER

Clendenin, West Virginia
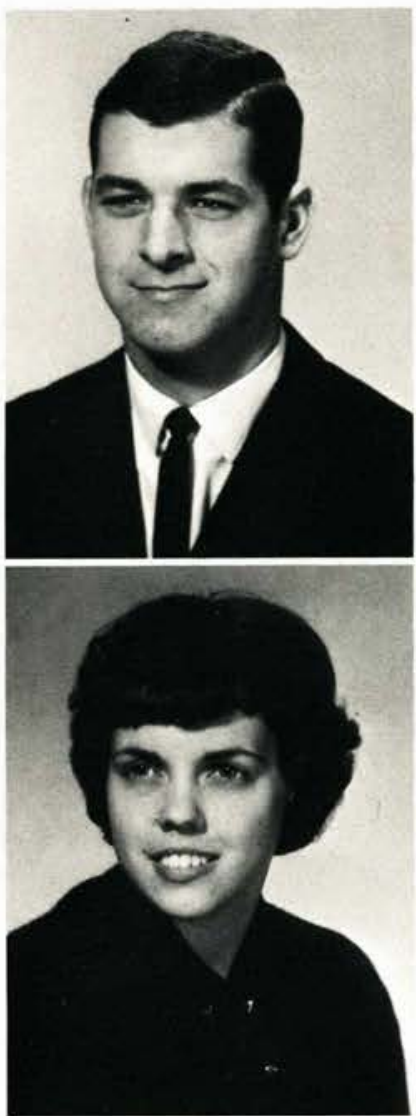

LAWRENCE BAKER

Taylor, Michigan

BARBARA BLACKBURN

Elora, Tennessee
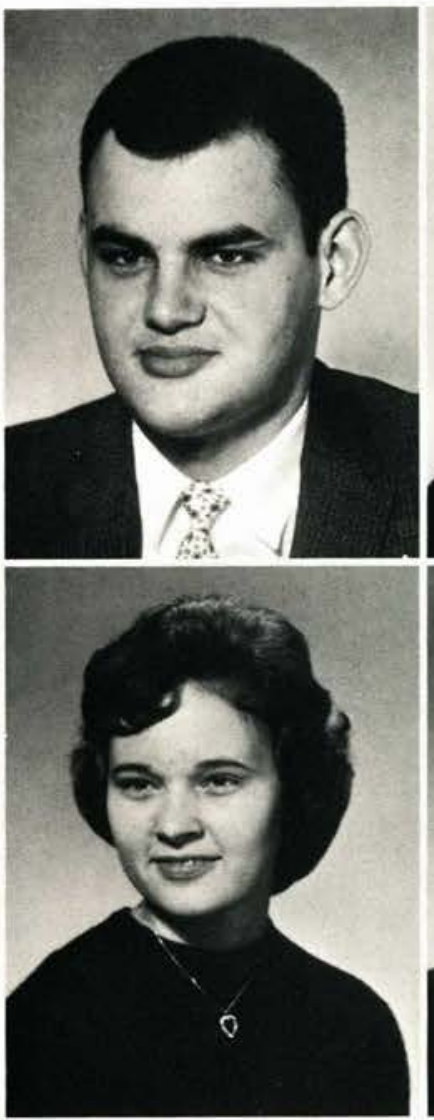

PAT BARRETT

Muscatine, Iowa

DAVID BLOSSOM

Vassar, Michigan
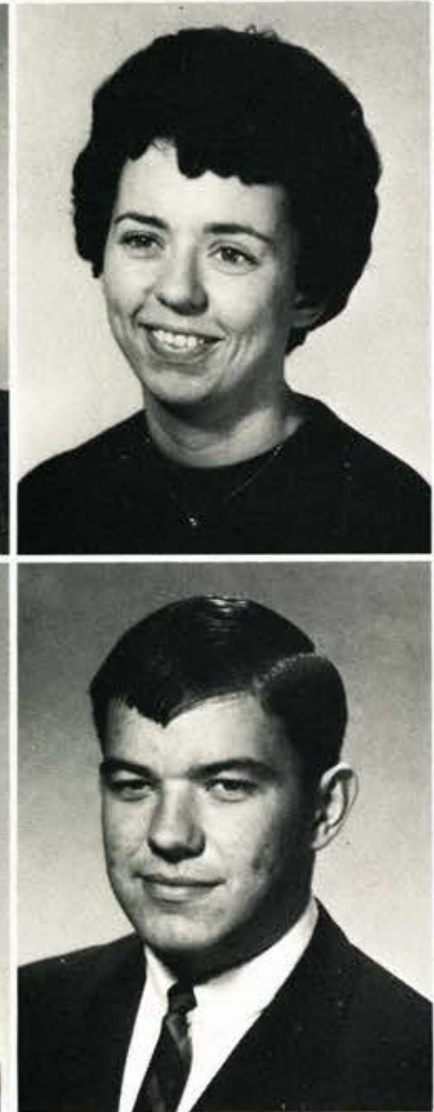

LOIS BAYLESS

Yuma, Arizona

TOM BROWN

Eagle Grove, Iowa
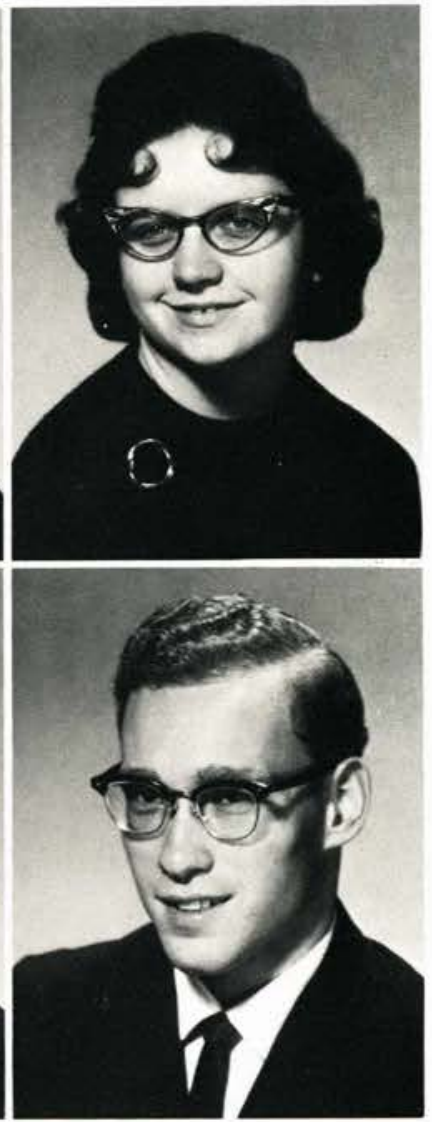


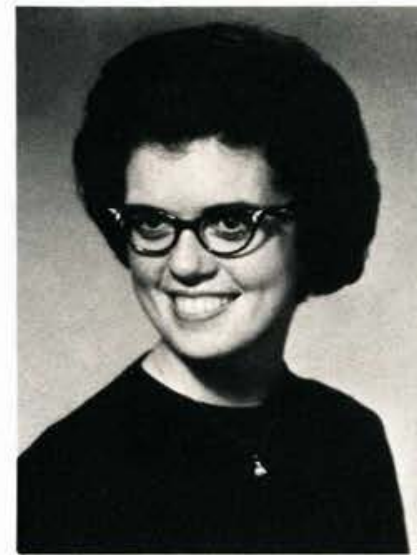

JOAN BRYANT

Akron, Ohio

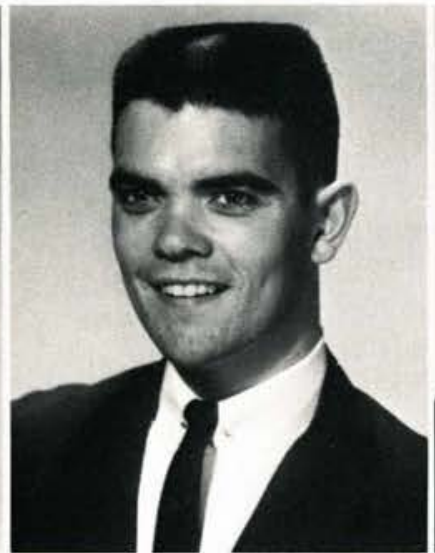

TYRONE BRYANT Akron, Ohio

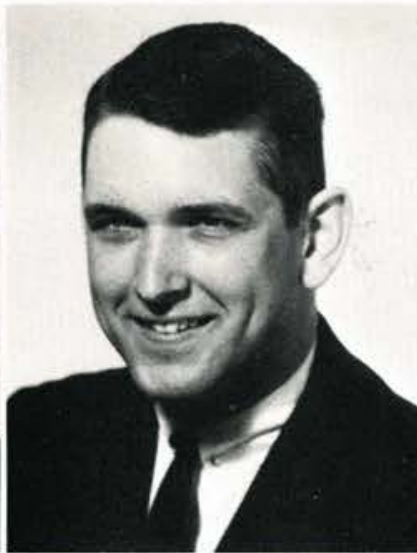

PHIL BUCHANAN

Glasgow, West Virginia

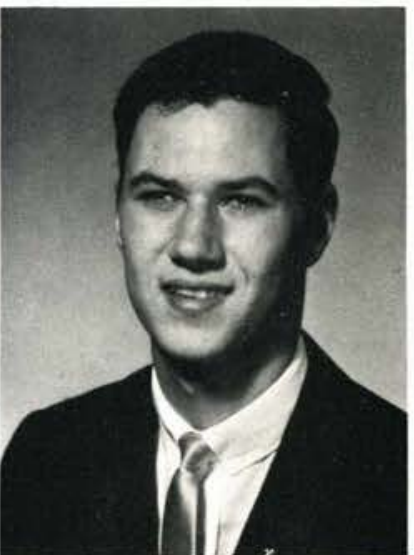

GORDON CHITTY

Xenia, Ohio

\section{Juniors}

HANK COOK

Flint, Michigan

LOIS DUDDLESTON

Decatur, Illinois
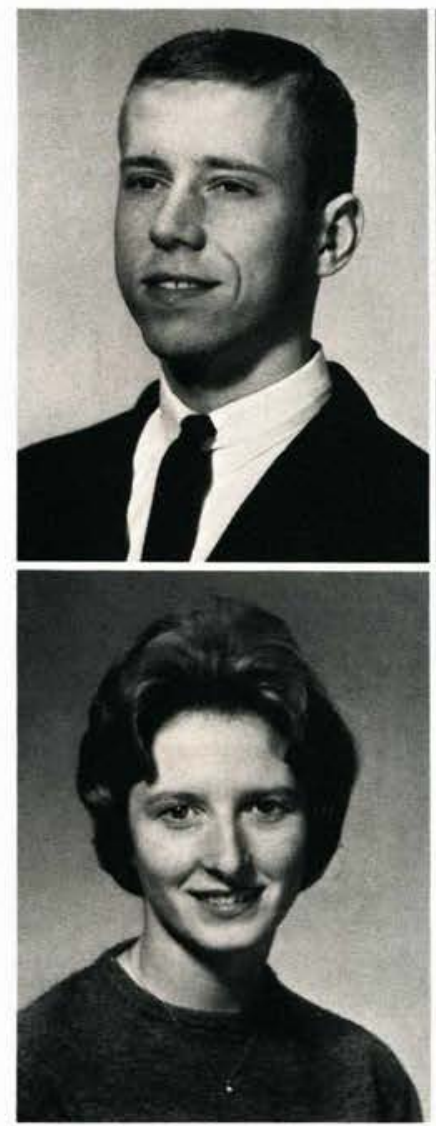

LARRY CZERNIAK

Hammond, Indiana

ROBERT EDWARDS

Cedarville, Ohio
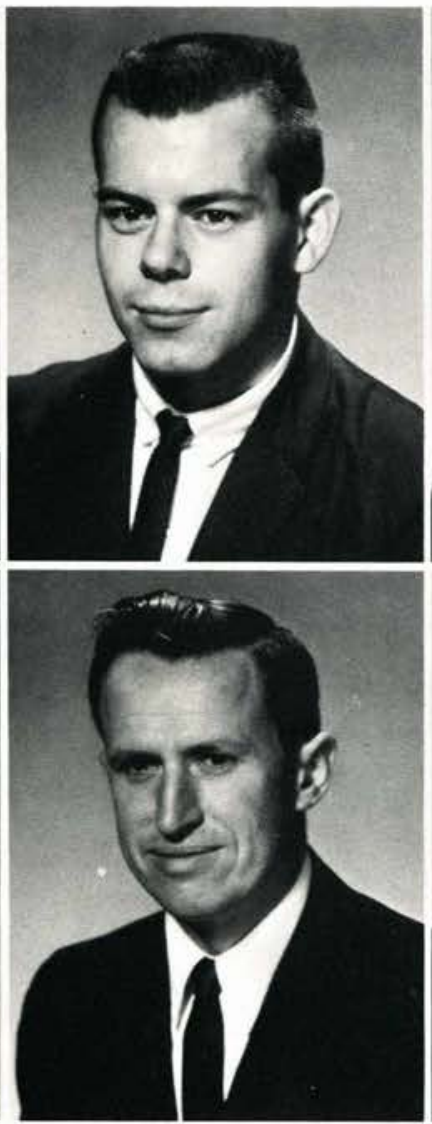

HOWARD DAY

Portsmouth, Ohio

TOM EVANS

Columbus, Ohio

\section{TOM DELANZO}

New Castle, Pennsylvania

DAVID FETZER

Cleveland Heights, Ohio
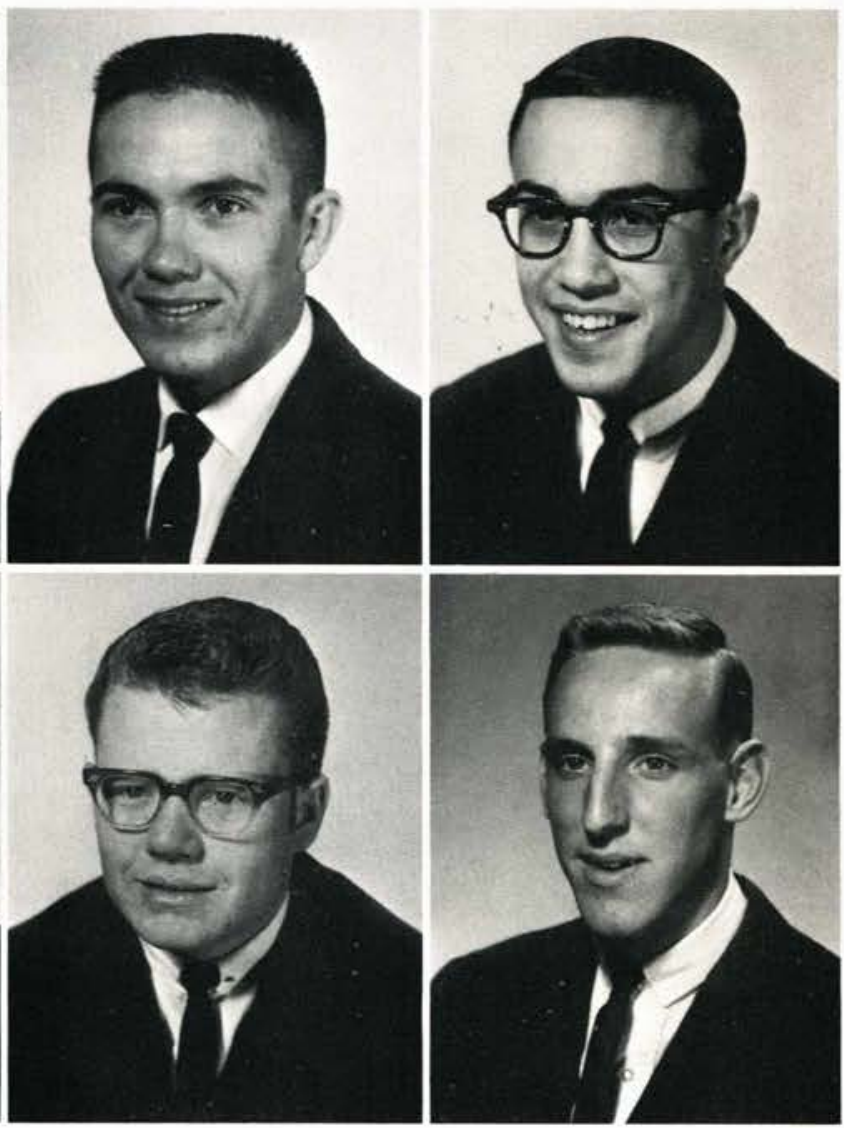


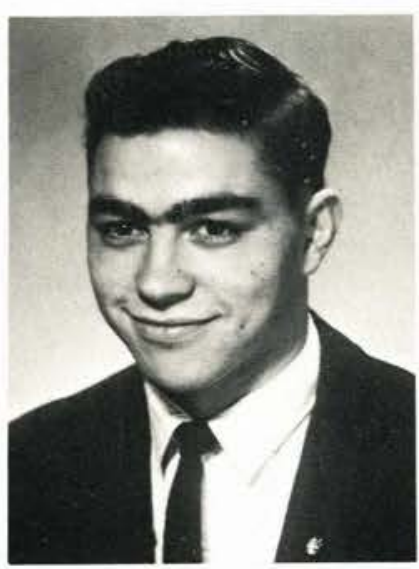

GORDON FINLEY

Faribault, Minnesota

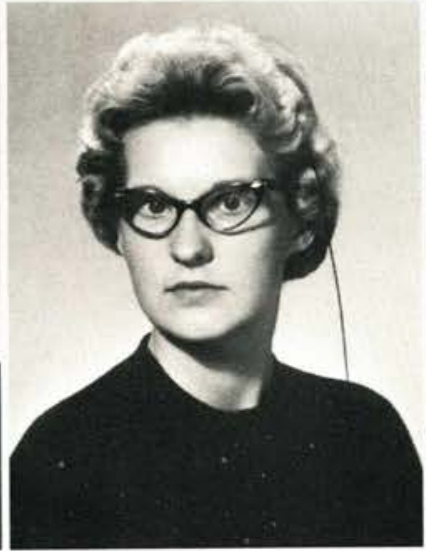

SUZANNE GEYSER

Berea, Ohio

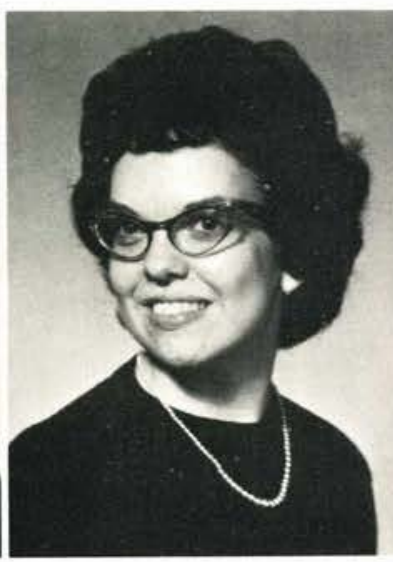

SHIRLEY GOODMAN Mentone, Indiana

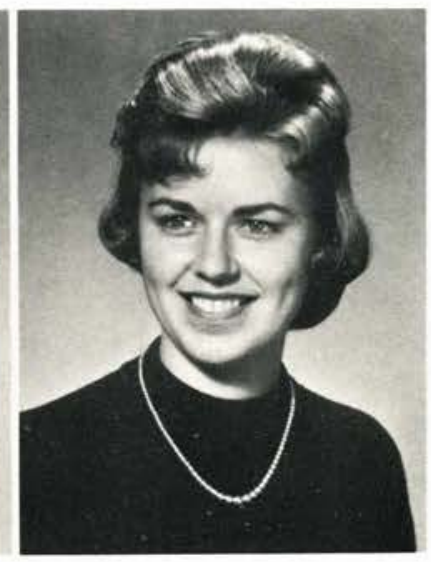

MARY GOODWIN

Oak Forest, Illinois
JAMES GRAFTON

Worthington, Pennsylvania

ELAINE HIRSCHY

Evans City, Pennsylvania
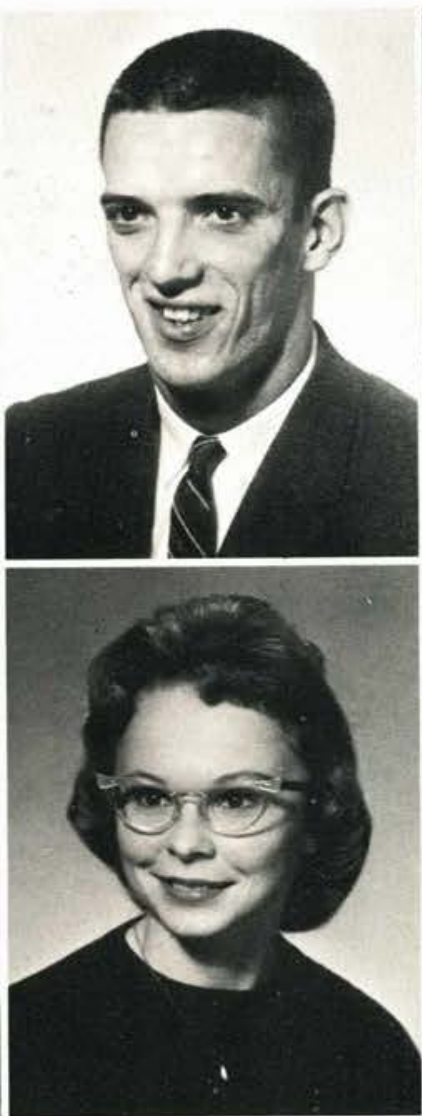

PHILLIP GRISSO

Springfield, Ohio

JUDITH HUMPHREYS

Findlay, Ohio
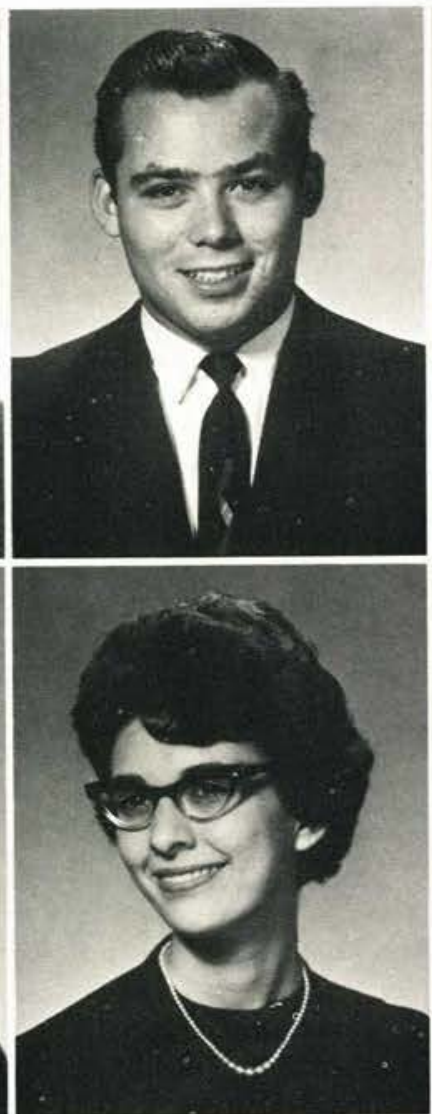

JAMES HAMILTON

Wilmington, Delaware

BONNIE JACKSON

Utica, Ohio
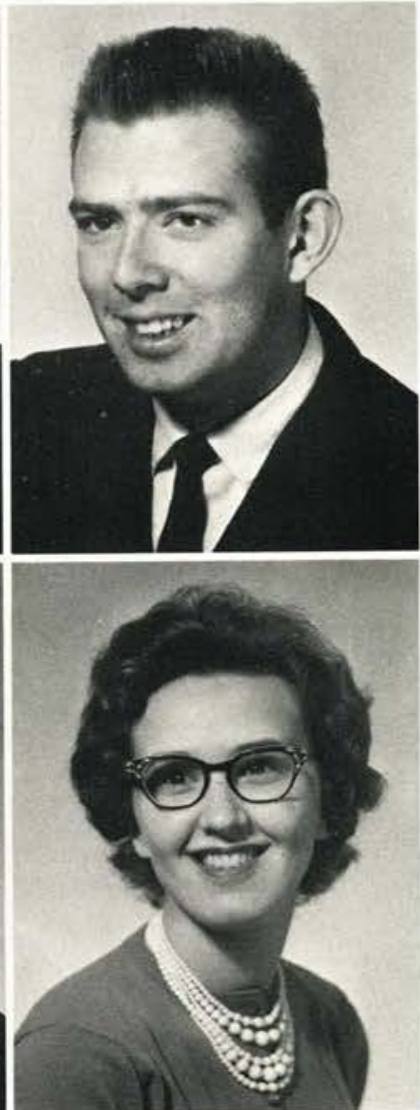

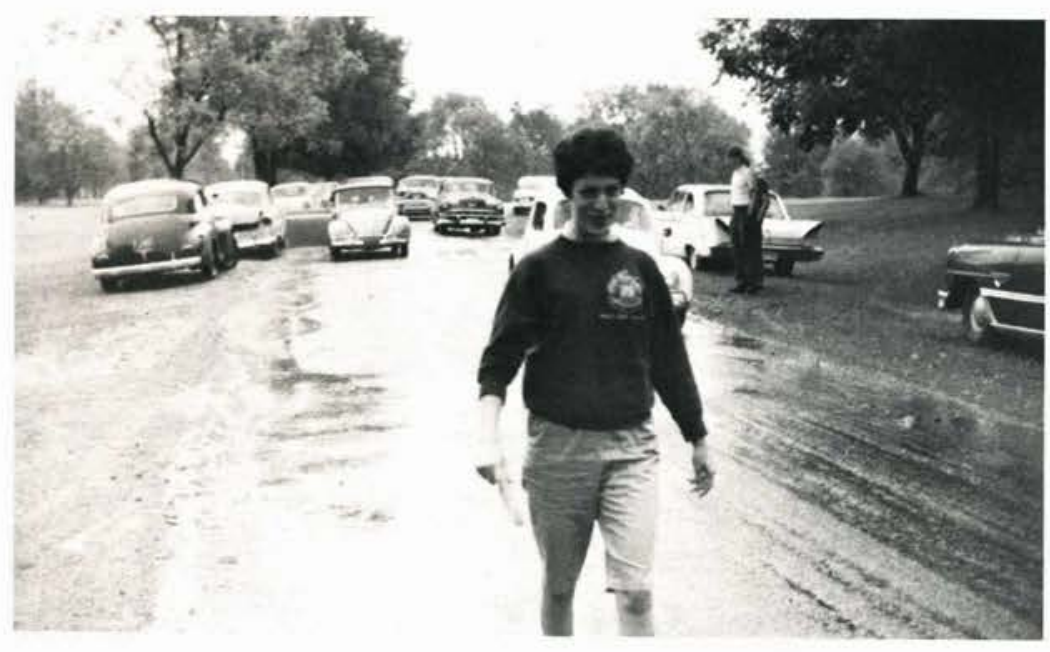

Rain did not stop Judy Leiby from enjoying the All-School picnic held at the John Bryan Park.

\section{Juniors}

GARY JACOBS

Bay City, Michigan

MARIAN KARSNAK

Novelty, Ohio
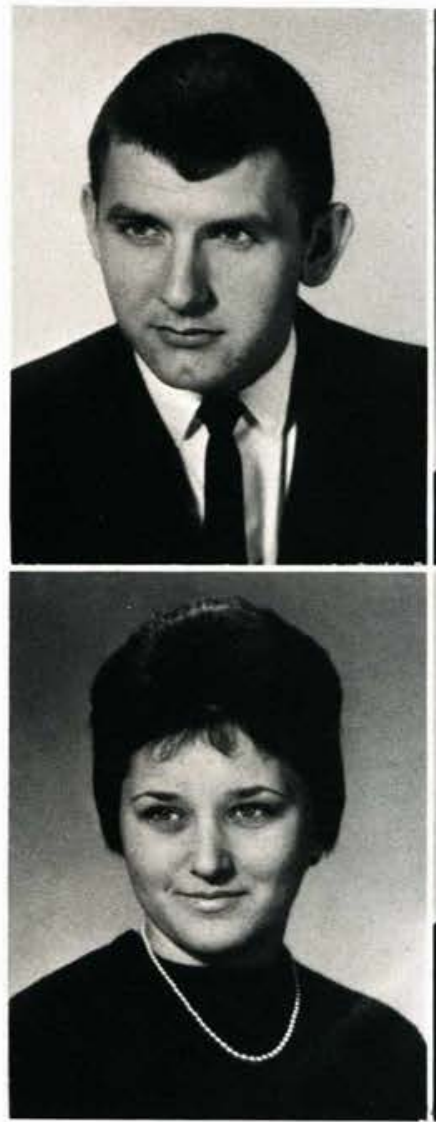

DONNA JOHNS

Mercer, Pennsylvania

LARRY KILLIAN

Shickshinny, Pennsylvania
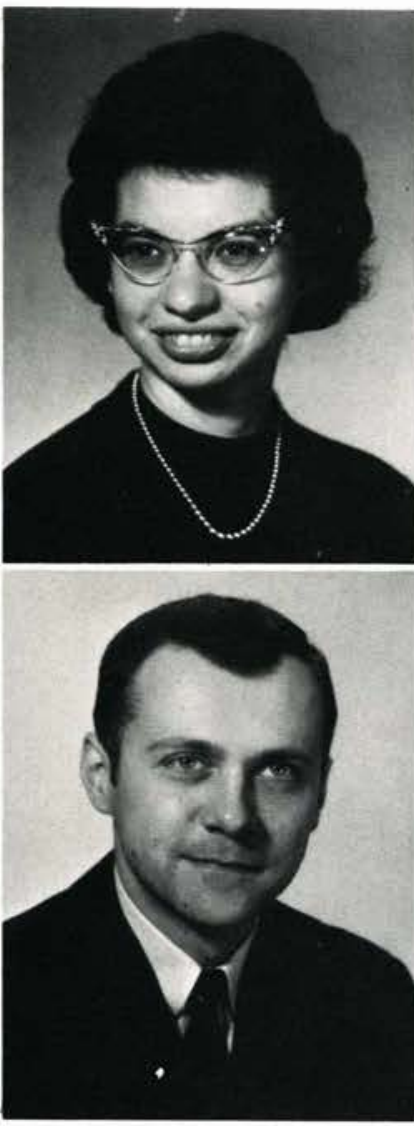

EUNICE JOHNSON (no picture) Cedarville, Ohio

RODNEY LANE

Midland, Ohio
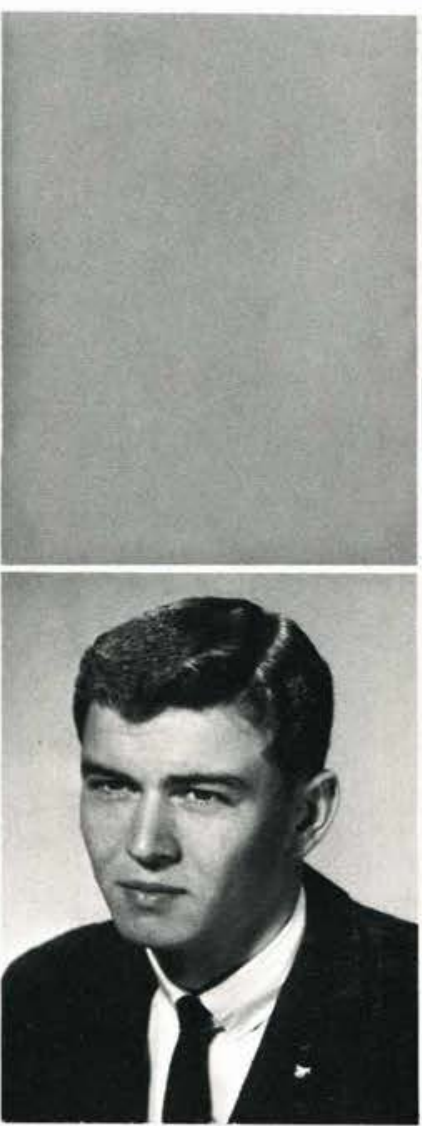

GARY JOHNSON

Silvis, Illinois

BLAIR MAIERS

Mayville, Michigan
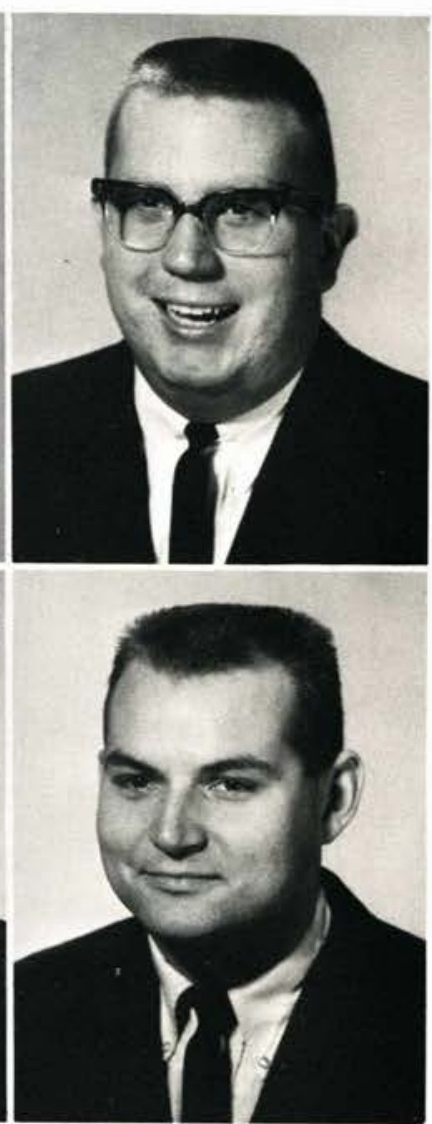


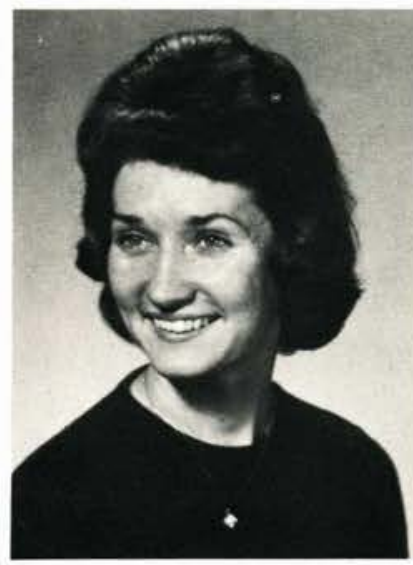

SHARON MARKS

Newberry, Michigan

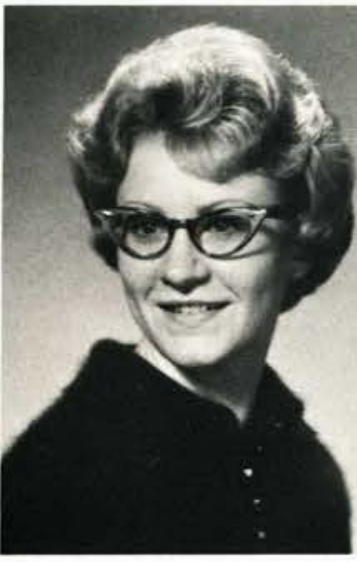

SHERYL MARTIN

Fort Wayne, Indiana

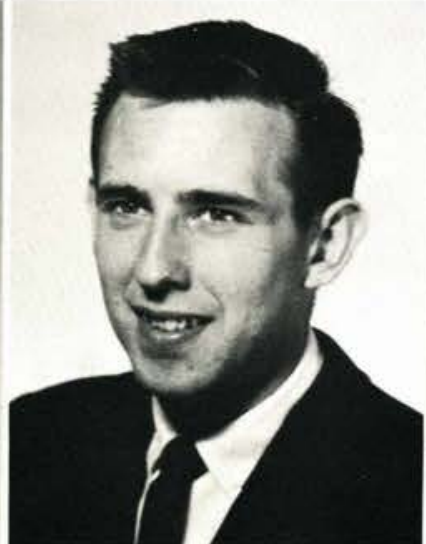

DENNIS MCDONALD

Lake Orion, Michigan

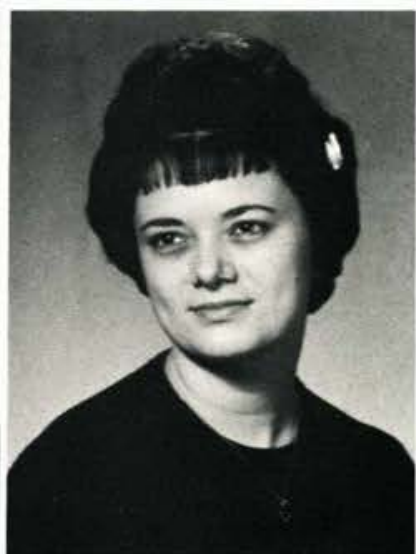

JUDITH MICHAELS Northfield, Ohio
RON MICK

Cedarville, Ohio

JAY MOORE

Verona, Wisconsin
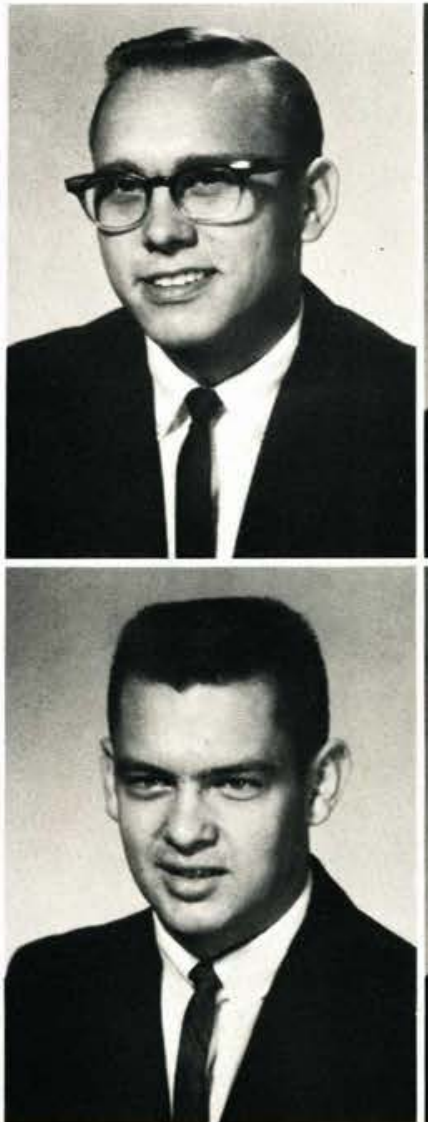

PATRICIA MICKA

Ridgefield Park, New Jersey JOHN MORGAN

Dysart, Iowa
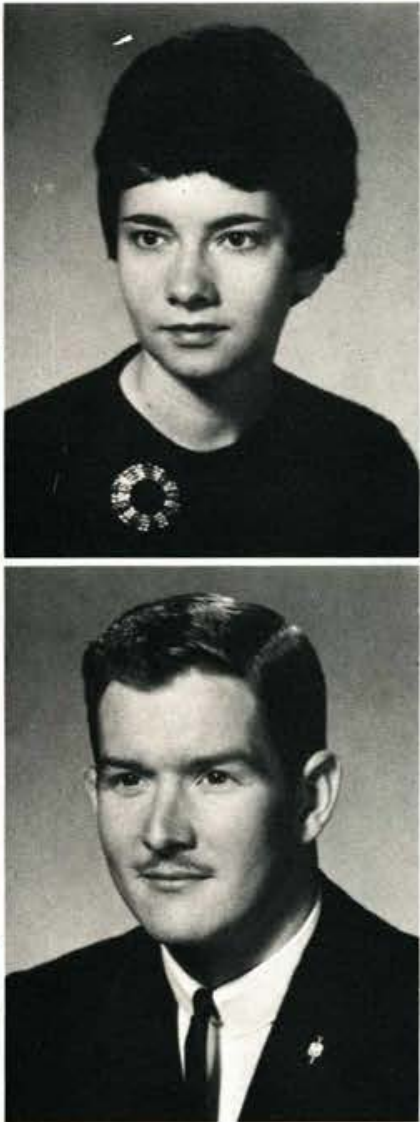

RITA MILLIKIN

Kalkaska, Michigan

JUDITH NEUFELD

Callaway, Nebraska
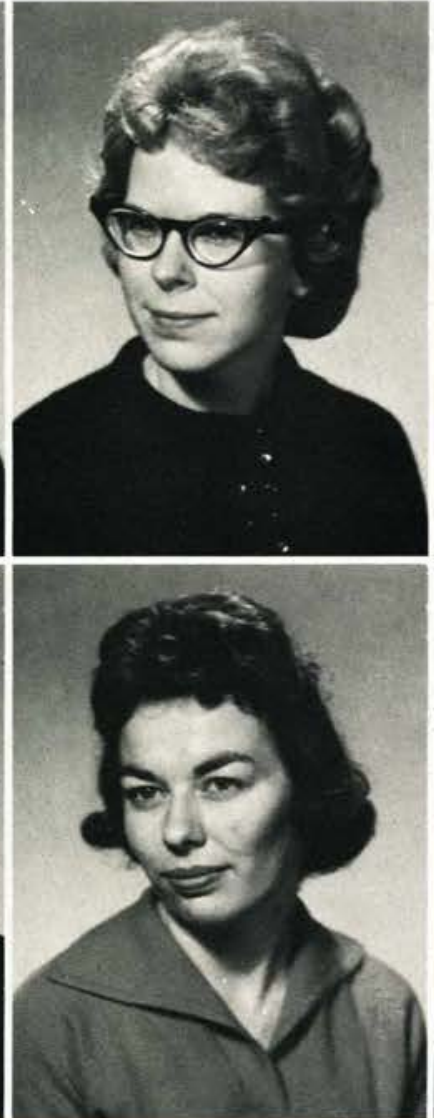

DAVID MILLS

Xenia, Ohio

NORMAN NICKLAS

Callery, Pennsylvania
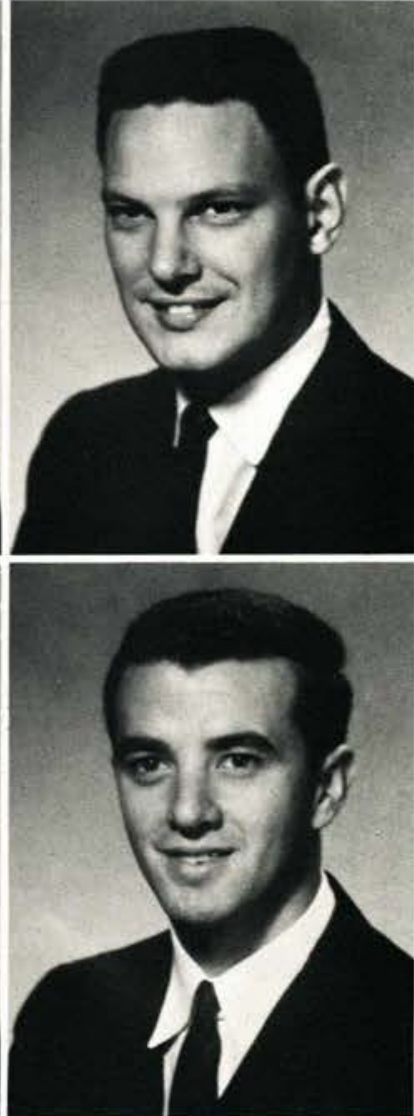


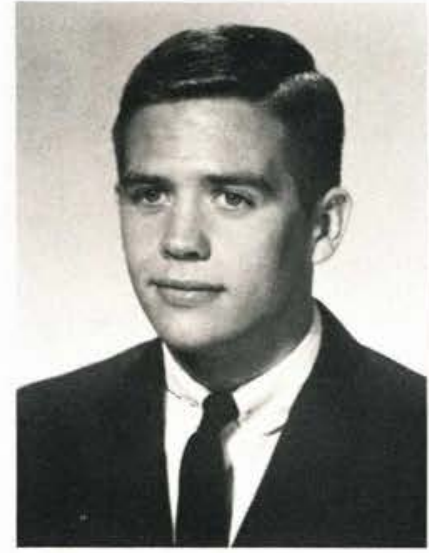

ROGER O'BRYON

Eldora, Iowa

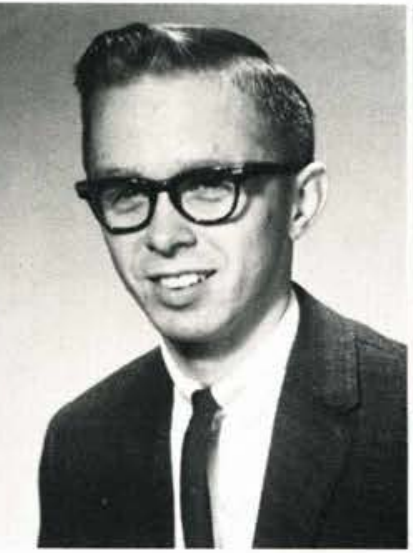

DAN PARK

Vassar, Michigan

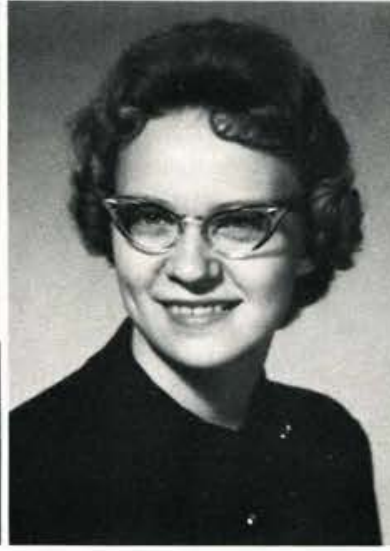

MARY ELLEN POWELI Renfrew, Pennsylvania

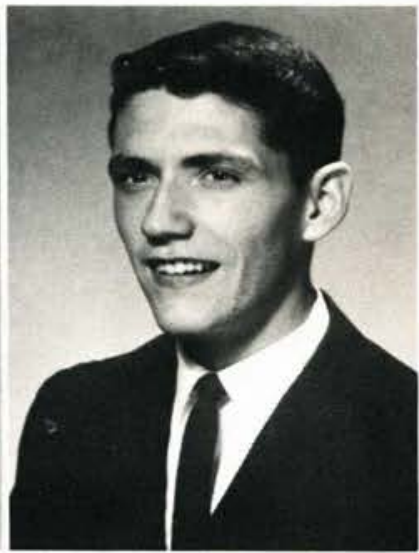

ROBERT REYNOLDS Xenia, Ohio

\section{Juniors}

WILLIAM RITER

Deerfield, Illinois

STANLEY SEEVERS

Galena, Ohio
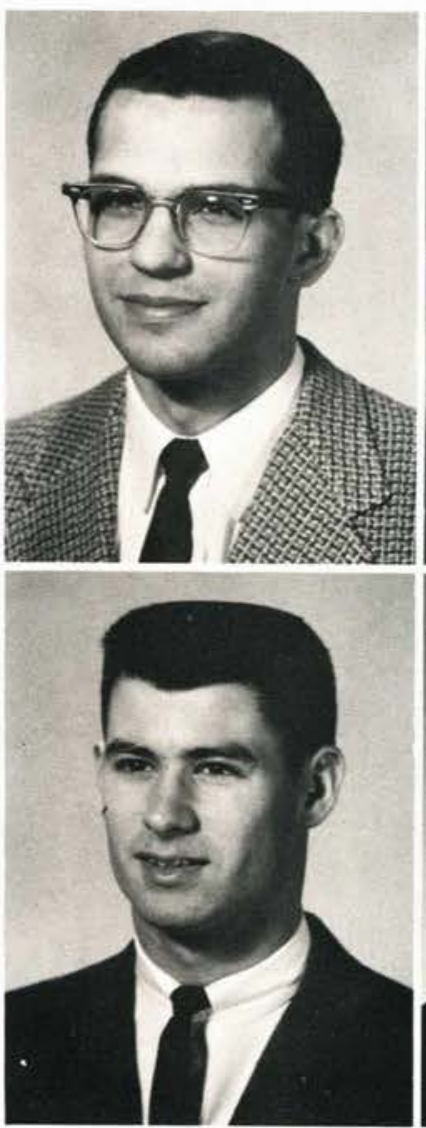

MARIAN ROTHWELL Oakland, New Jersey

NANCY SHIMITS

East Cleveland, Ohio
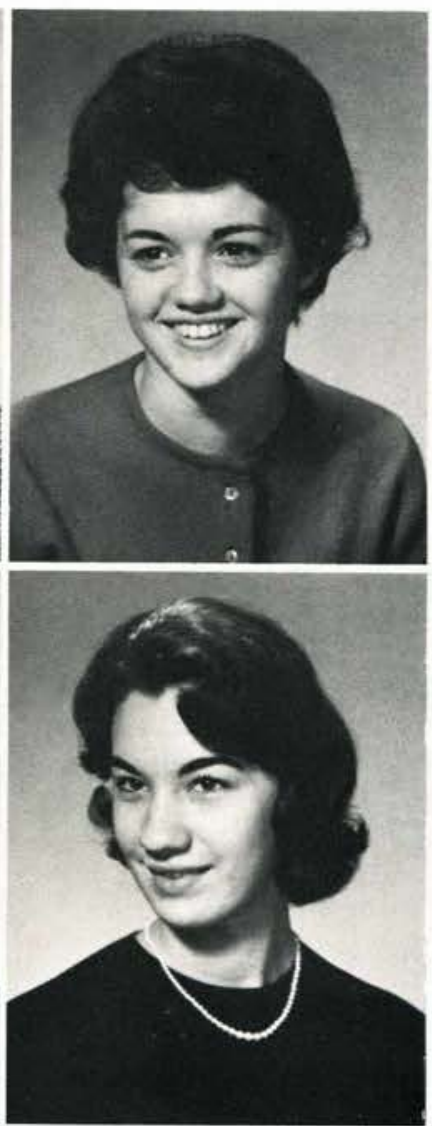

TONY ROTONDI

Teaneck, New Jersey

FRED SHUGAR

Plymouth, Pennsylvania
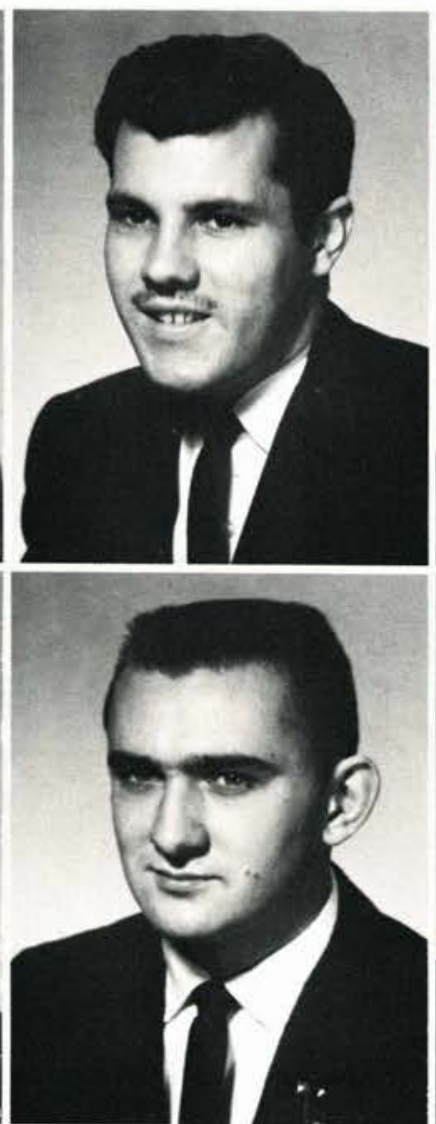

CHESTER RUSSELI

Cedarville, Ohio

JUDITH SIPLOCK

Chesterland, Ohio
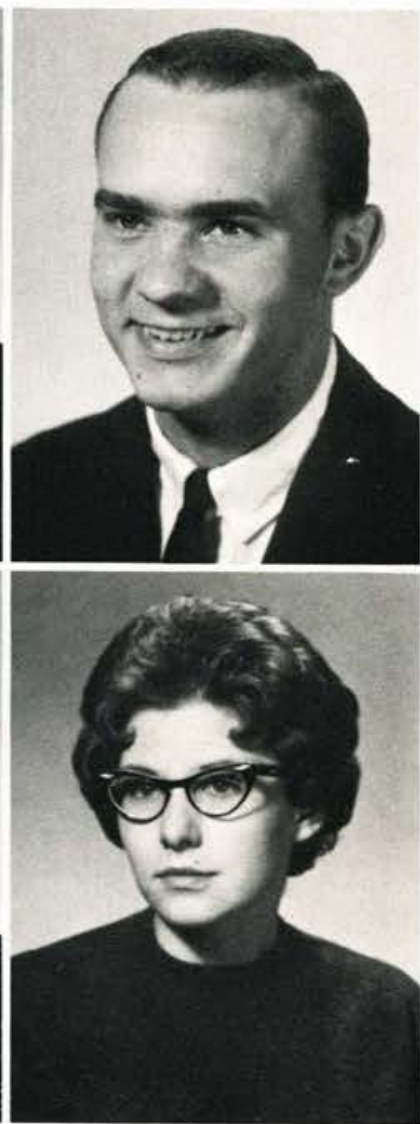

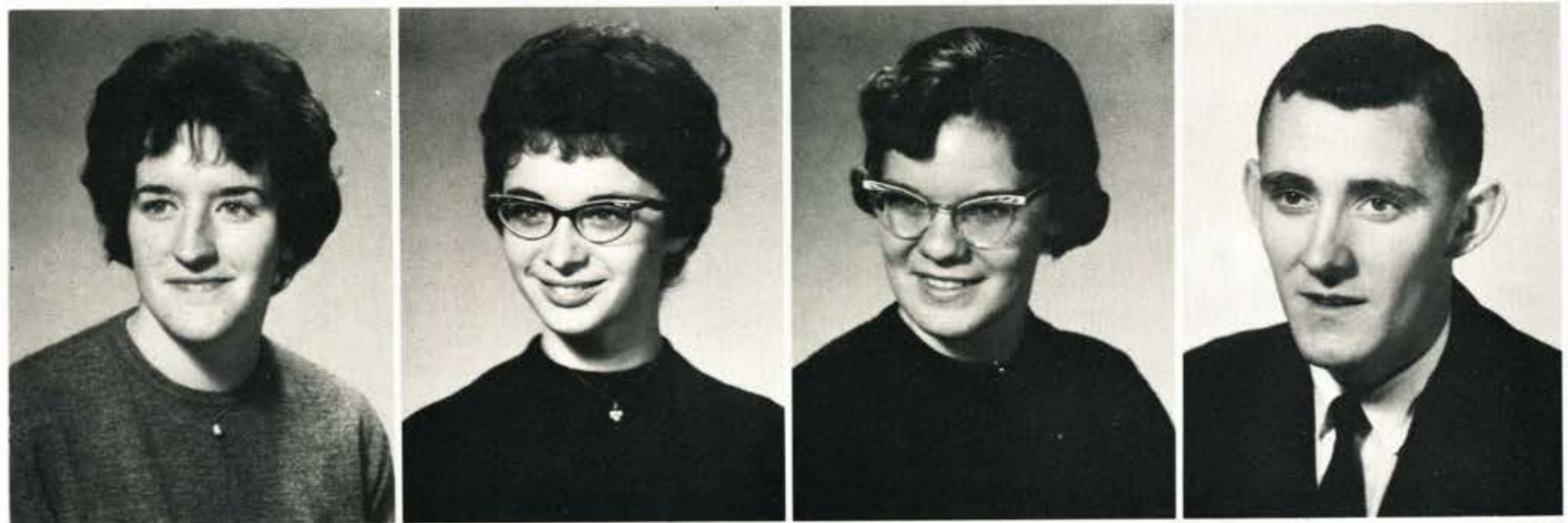

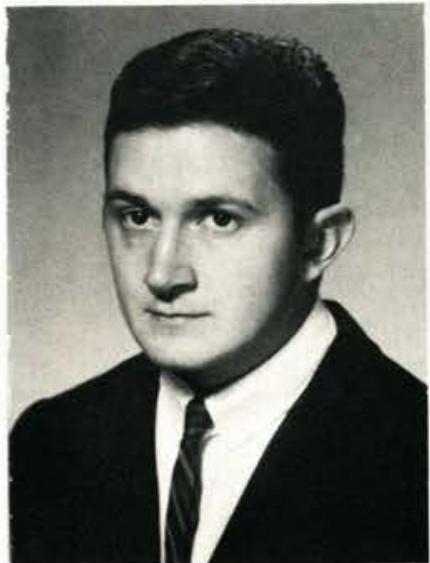

BARBARA SLAVENS

Crawfordsville, Indiana

GERALD STAFFORD

Baltimore, Maryland

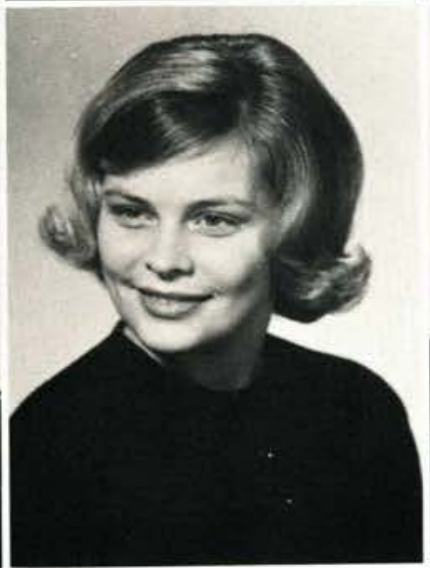

ELEANOR SMELSER

Medina, Ohio

MARGARET STOWELL

Hackensack, New Jersey

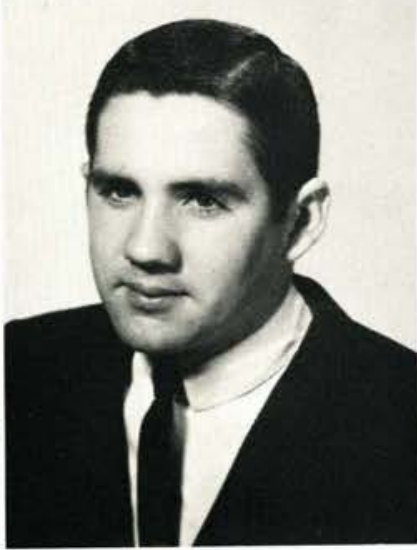

NANCY SMITH

Kirkersville, Ohio

KEN SWIGART

Dexter, Iowa

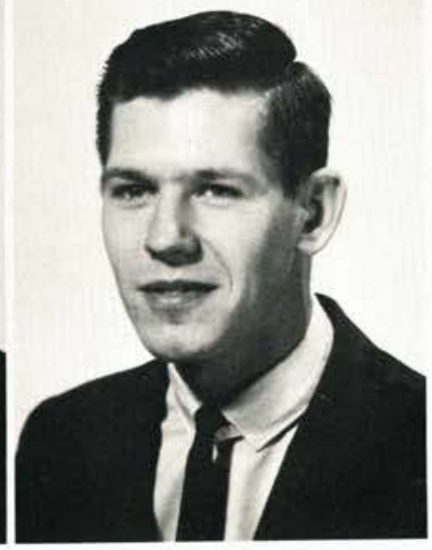

JAMES SPRAGUE

South Lyon, Michigan

DAVID TAYLOR

Blanchester, Ohio

\section{Juniors}

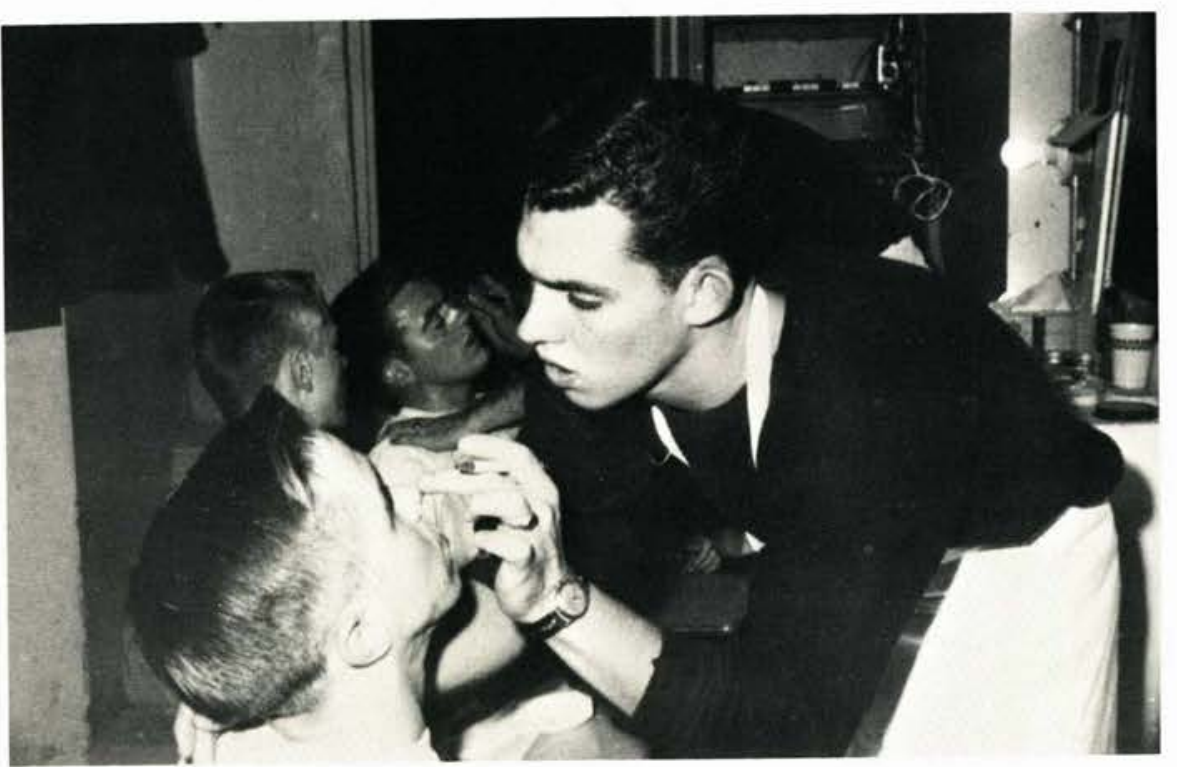

Dan Parks will have a professional make-up job if Marv's look of concentration is any indication. 


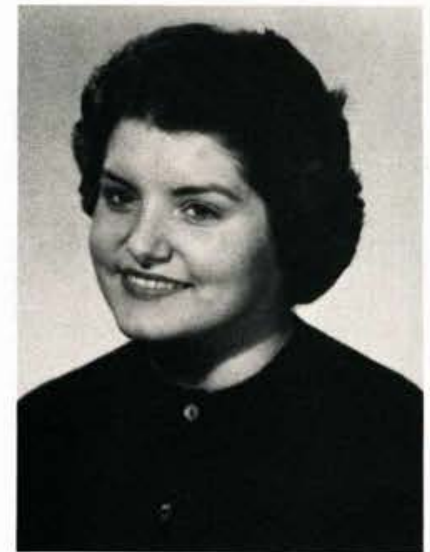

PATRICIA TERRY

Ypsilanti, Michigan

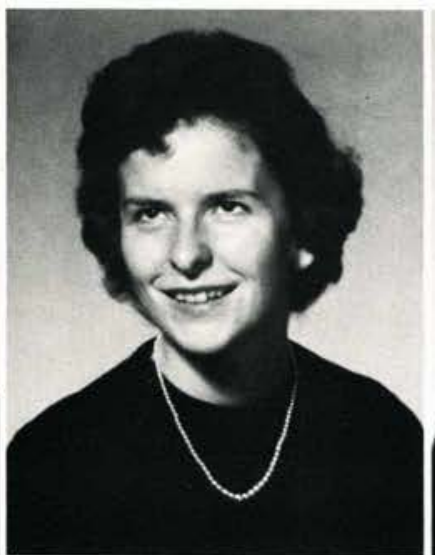

EVELYN THOMS

Sylvania, Ohio

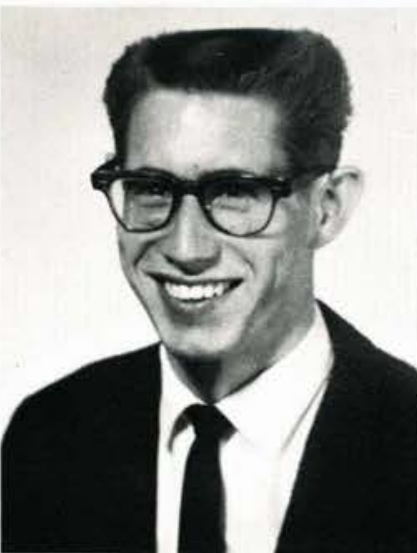

DAVID TRUMBULL

LeVale, Maryland

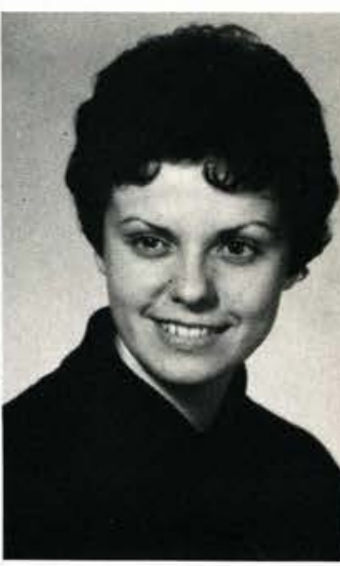

MARILYN TULLOCH

Omer, Michigan

\section{Juniors}

DAVID VESTERFELT

Delavan, Wisconsin

BETTY WALL

Decatur, Illinois
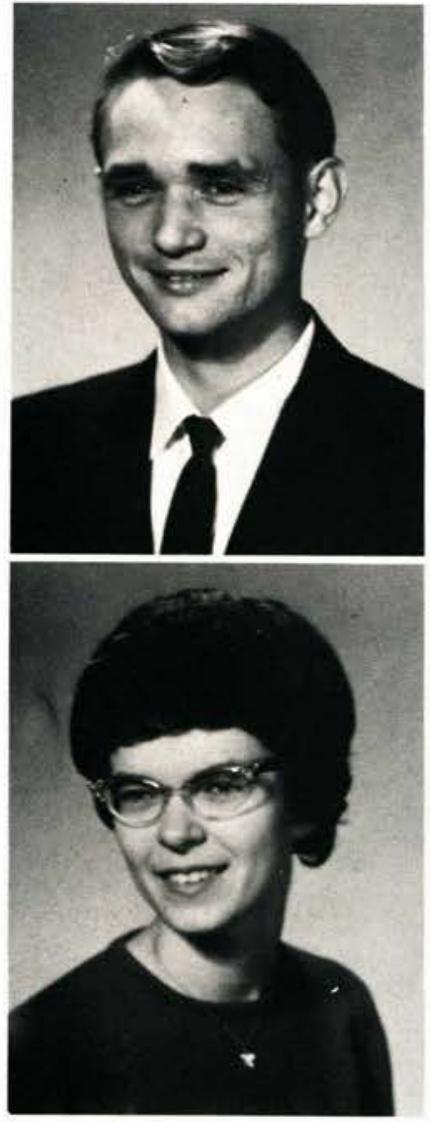

JUDITH WALBORN

East Cleveland, Ohio

GARY WALTHALL

Xenia, Ohio
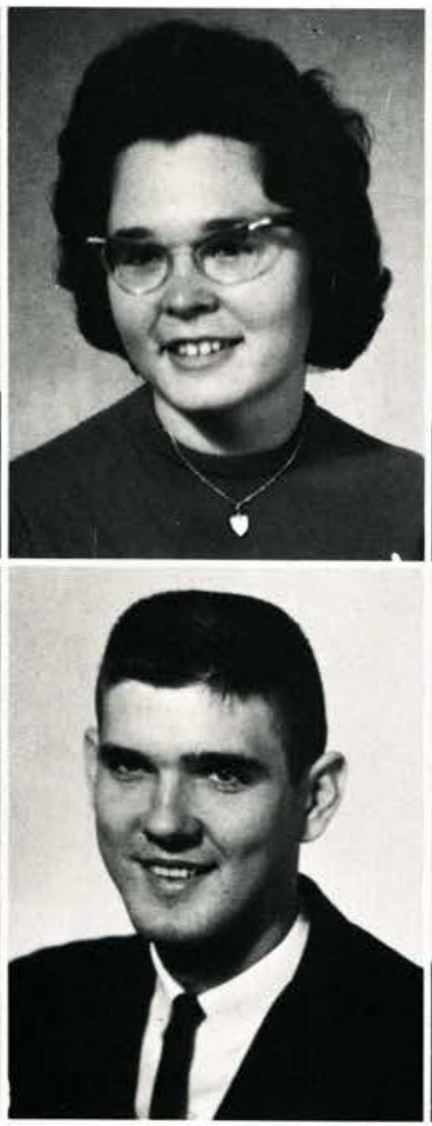

JAMES WALKER

Soap Lake, Washington

DAVID WARREN

Taylor, Michigan
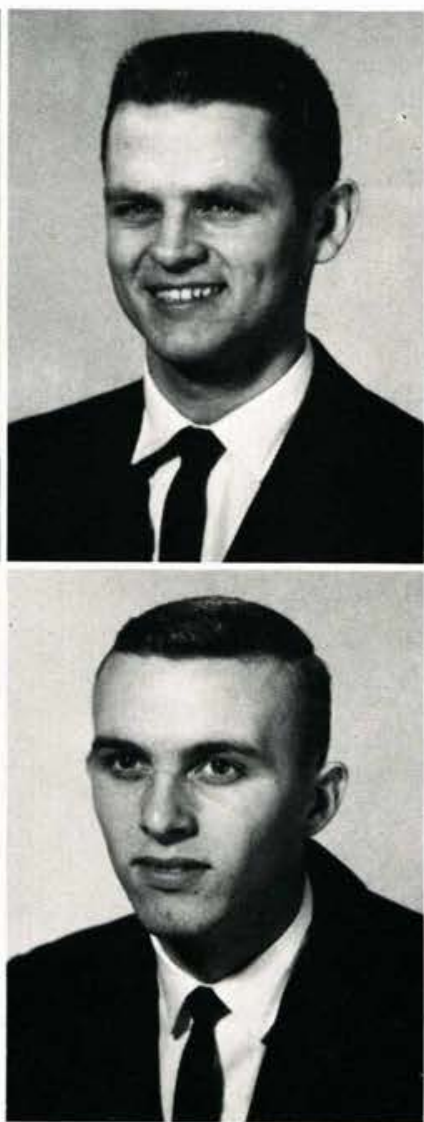

ROOSEVELT WALKER Cedarville, Ohio

SANDI WELCH

Bellbrook, Ohio
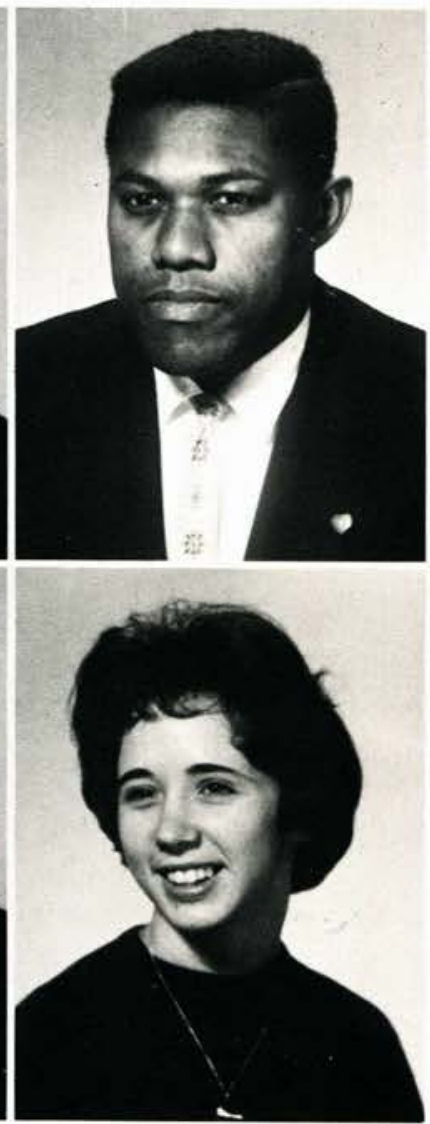


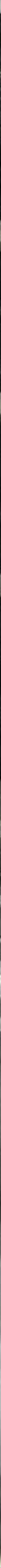


SHARON ACKERMAN, Frankfort, Michigan. ROSS ADAMS, Akron, Ohio. JANICE ADDLEMAN, Hillsdale, Michigan. KATHLEEN ALBERTER, Johnstown, Pennsylvania.
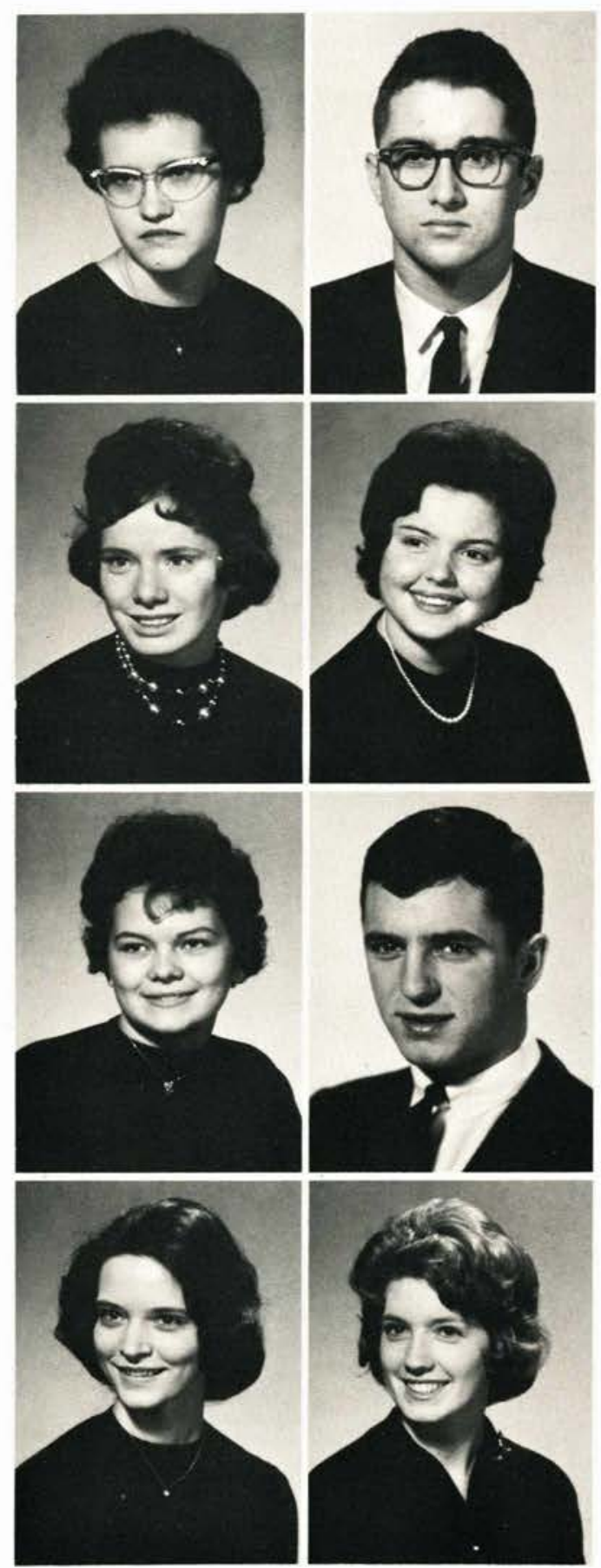

MARY BRONG, Clear Lake, Iowa. PAUL BROWER, Rockford, Michigan. NANCY BUERER, Mandaluvong, Rizal, P.I. RAYNA BUTLER, Corning, New York.
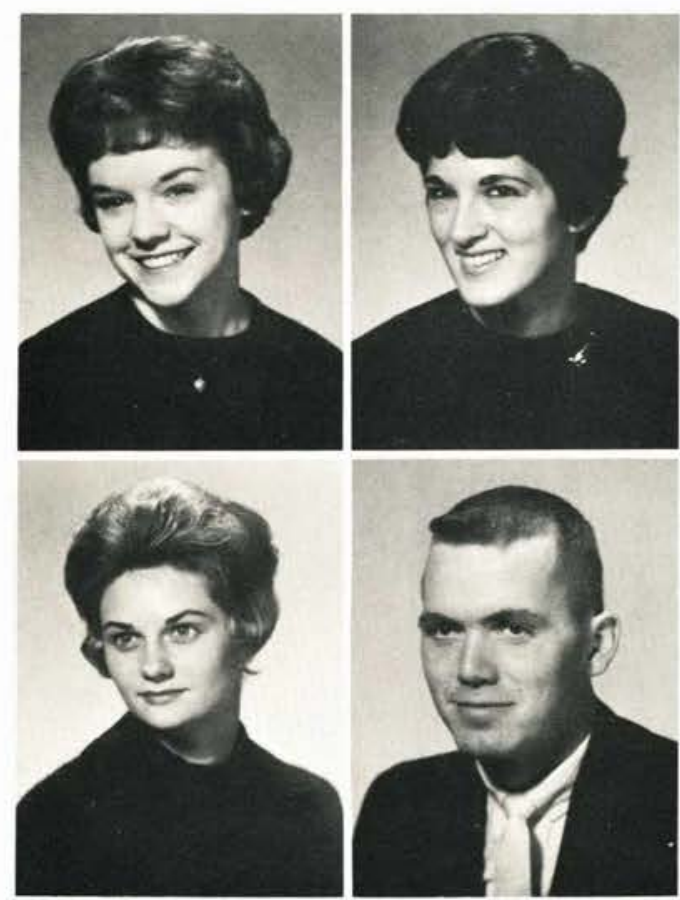

MARTHA AMMONS, Gardena, California. JANICE AMOS, Wickliffe, Ohio. CINDA ATKINSON, Kokomo, Indiana. DUANE BALES, Pana, Illinois.

SARAH BALKE, Hinckley, Ohio. SUZANNE BARTHELD, Valley Stream, New York. LARRY BEARD, Mayville, Michigan. GARY BRANDES, Buffalo, New York.
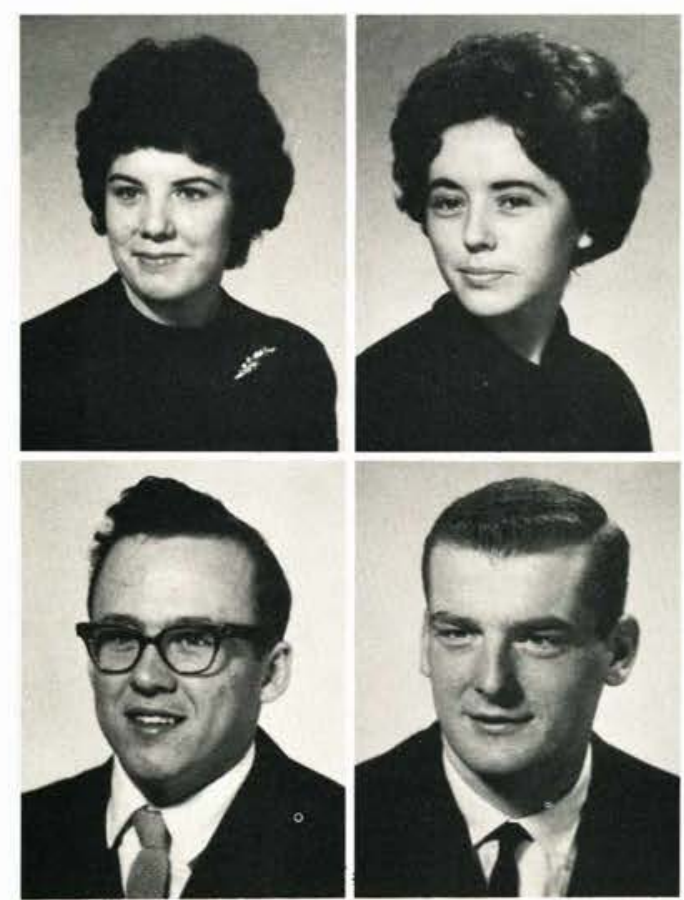

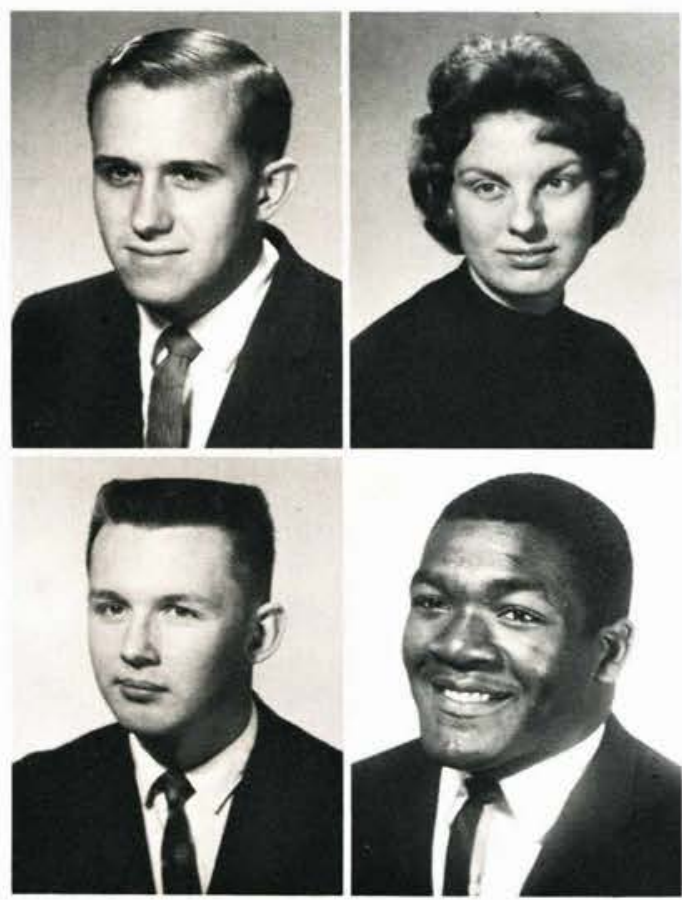

RONALD BUTLER, Toledo, Ohio. SHIRLEY BYRD, Hammond, Indiana. PAUL CARLSON, Gary, Indiana. DOZIER CARTER, Portsmouth, Ohio.
ARDITH CAYTON, Milwaukee, Wisconsin. LYNNE CAYTON, Shorewood, Wisconsin. CAROLYN COPPOCK, Xenia, Ohio. JUDY COUWENHOVEN, Harvey, Illinois.
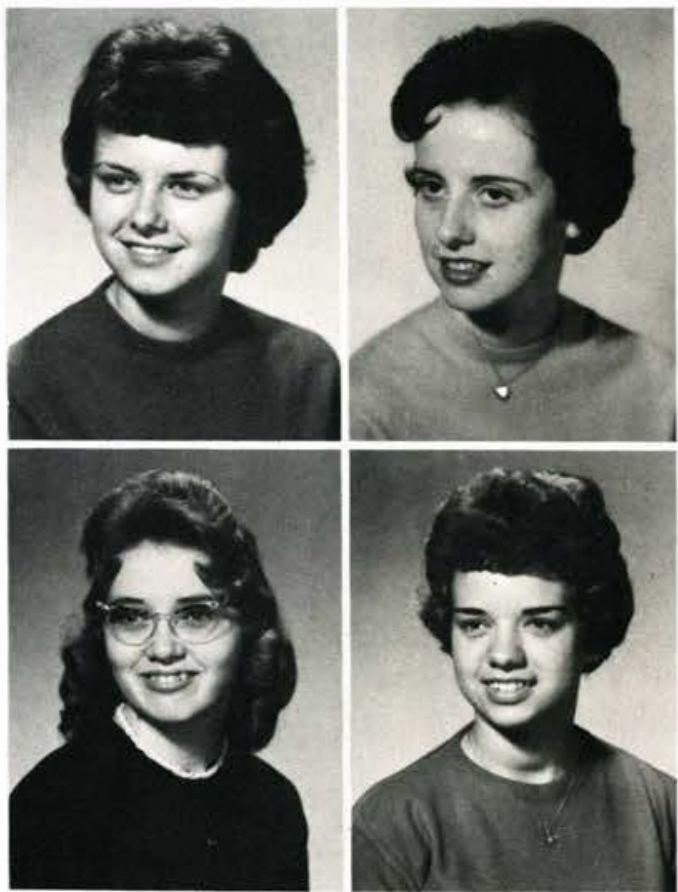

\section{Sophomores}

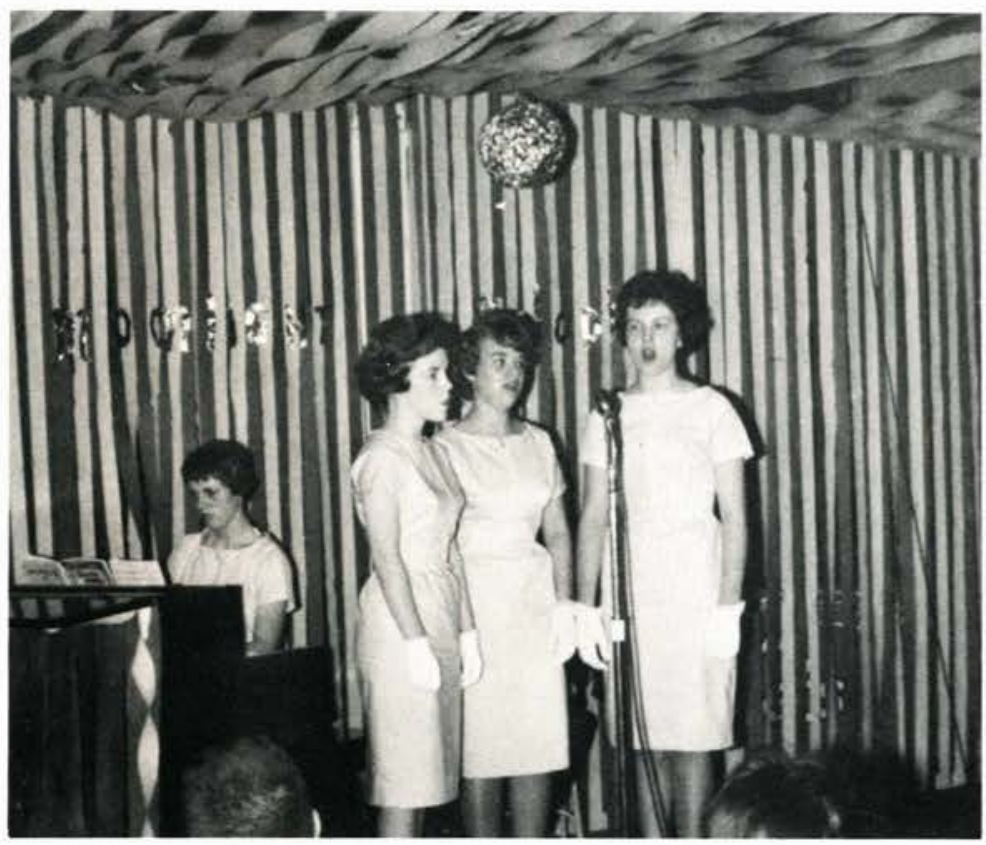

The Melody-Aires Trio-Phyllis Irish, pianist; Martha Ammons, Judy Couwenhoven, Martha Crull provide special music for an all-school party. 
ALVAH CRABB, Kewanna, Indiana. MARTHA CRULL, Howe, Indiana. MARY CUNNINGHAM, Bradenton, Florida. VICKIE CURCIO, Portsmouth, Ohio.
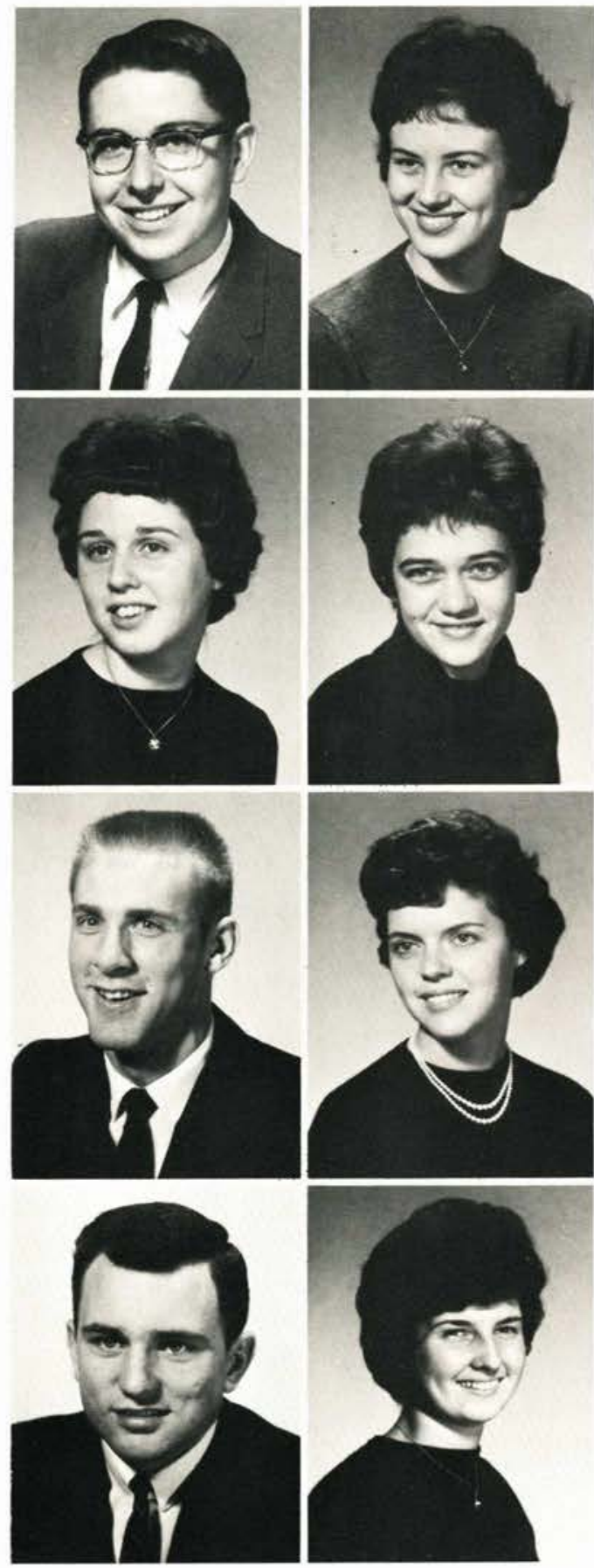

DONALD ENTNER, Dunkirk, Indiana. SUZANNE FENNELL, Sturgis, Michigan. DAVID FISHER, Dayton, Ohio. MARY ELLEN FLOYD, Galion, Ohio.

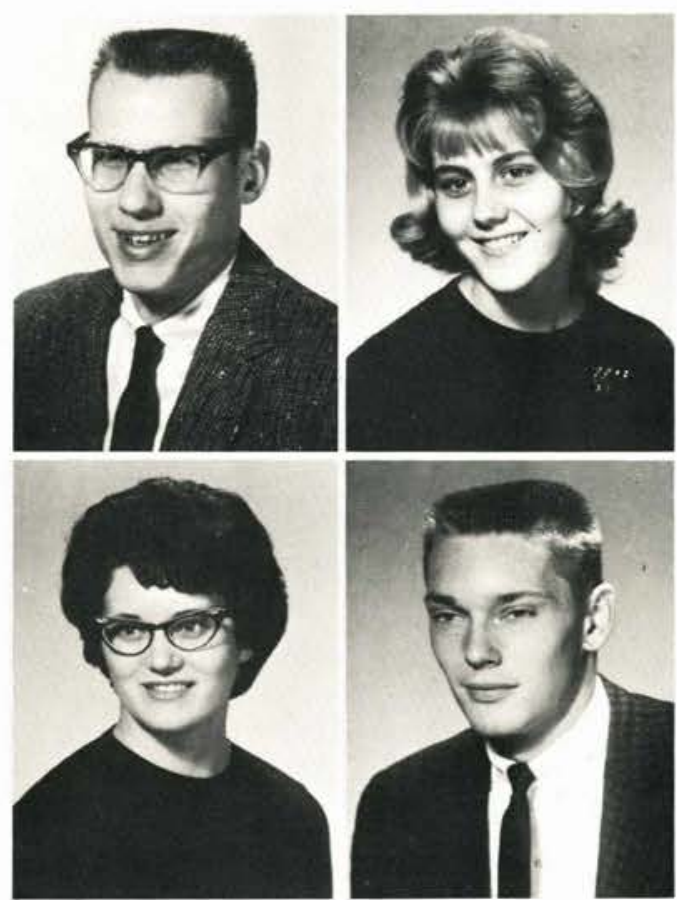

DON DAVIDSON, Brookfield, Wisconsin. CAROL DAVIS, Spenard, Alaska. JANICE DAVIS, Mentone, Indiana. RAY DAVIS, Sherman, New York.

FAY DOCTOR, Ellsworth, Michigan. JERRY EATON, Rochester, Indiana. SUSANNE ECKERT, Berea, Ohio. DAVID ELMORE, Cedarville, Ohio.
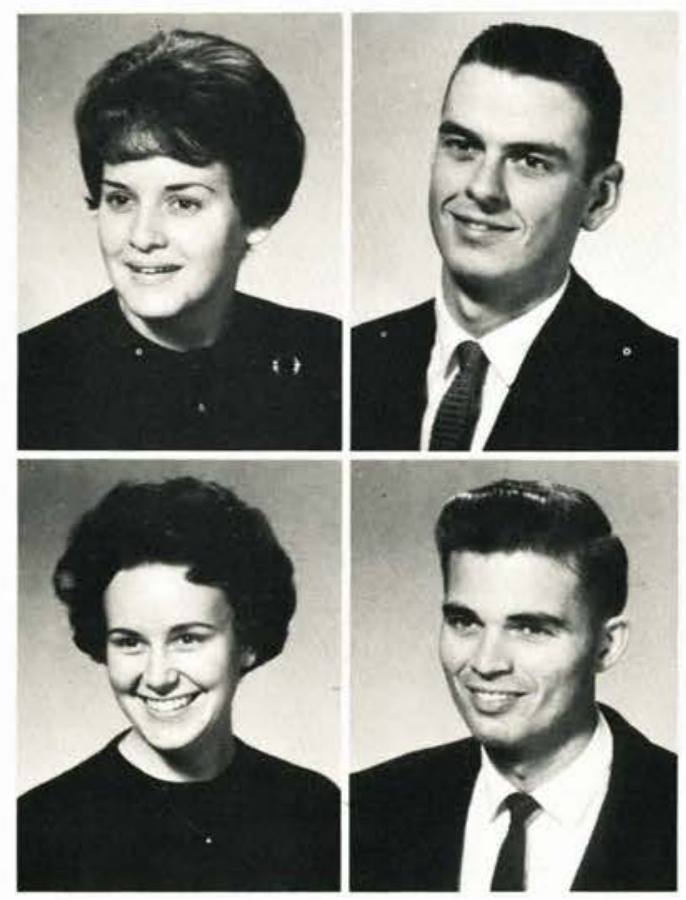

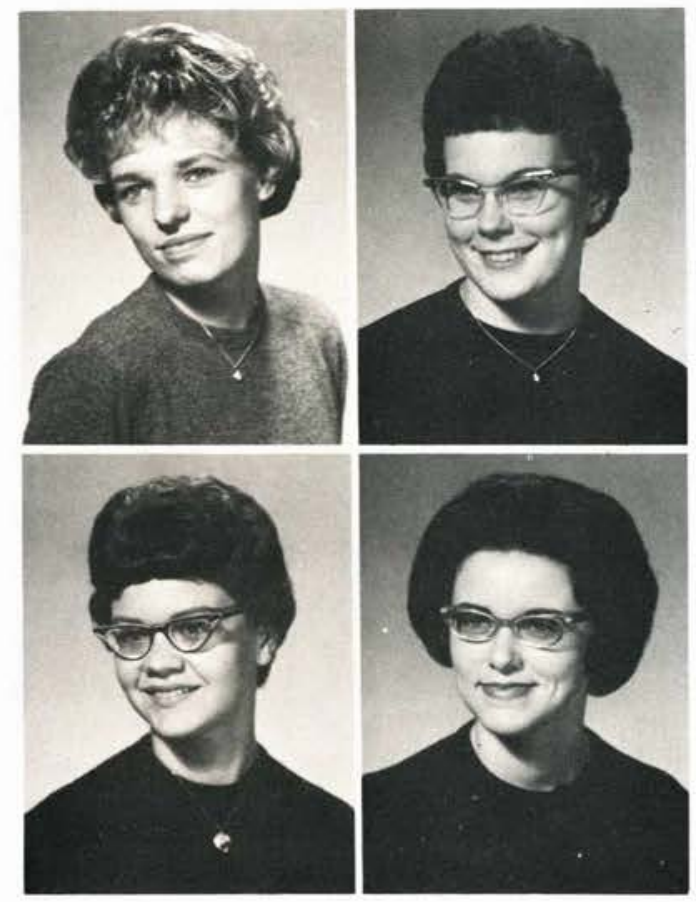

MICHAL GEETING, Wheaton, Illinois. GAYLE GORDON, Connersville, Indiana. JOANNE HAMILTON, Alton, Illinois. BONITA HAMMACK, Niles, Ohio.

PHYLLIS IRISH, Gary, Indiana. DAVID JENSEN, Wellington, Ohio. MARYALYCE JEREMIAH, Cedarville, Ohio. PAUL JODRY, Stryker, Ohio.
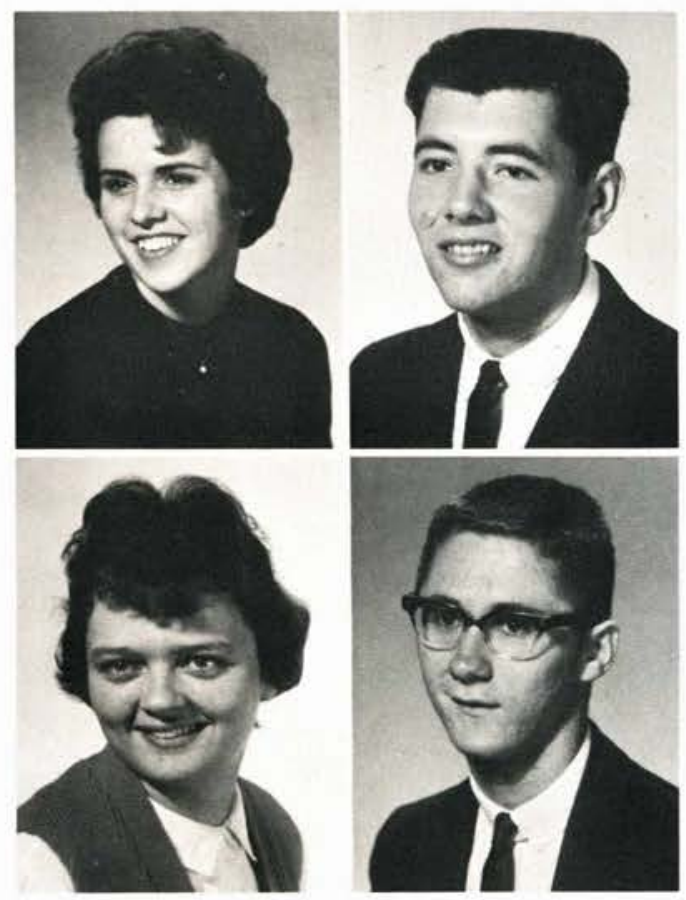

JUDITH HARTZELL, Butler, Pennsylvania. DON HIGDON, Glen Burnie, Maryland. RAYMOND HOFFEDITZ, Linton, Indiana. MARVIN HOLLENBECK, Marlette, Michigan.
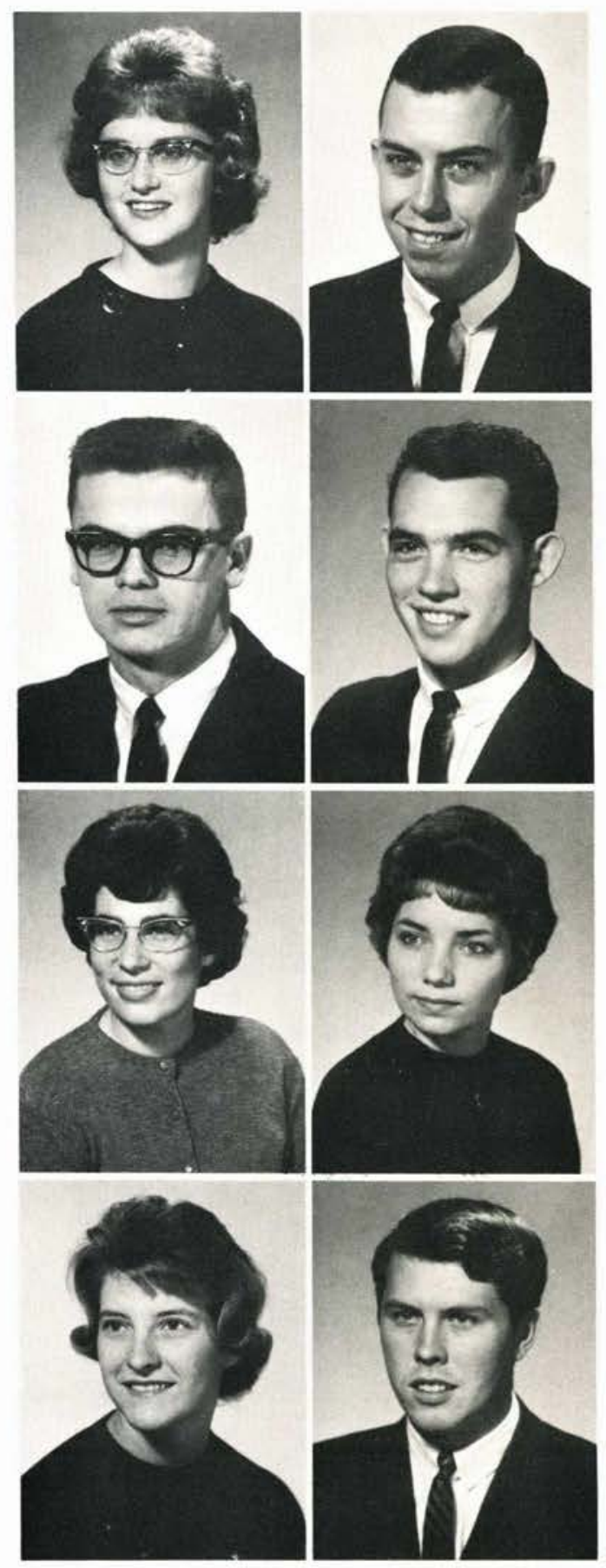

SUSAN JOHNS, East Randolph, New York. RUTH JOHNSON, Portsmouth, Ohio. PATRICIA KASTER, Ventura, Iowa. MICHAEL KELLOGG, Detroit, Michigan. 
NANCY KETTELL, Falls, Pennsylvania. LARRY LAMB, Cincinnati, Ohio. RAY LAMB, Crawfordsvile, Indiana. DOROTHY LIGHTLY, Austin, Minnesota.
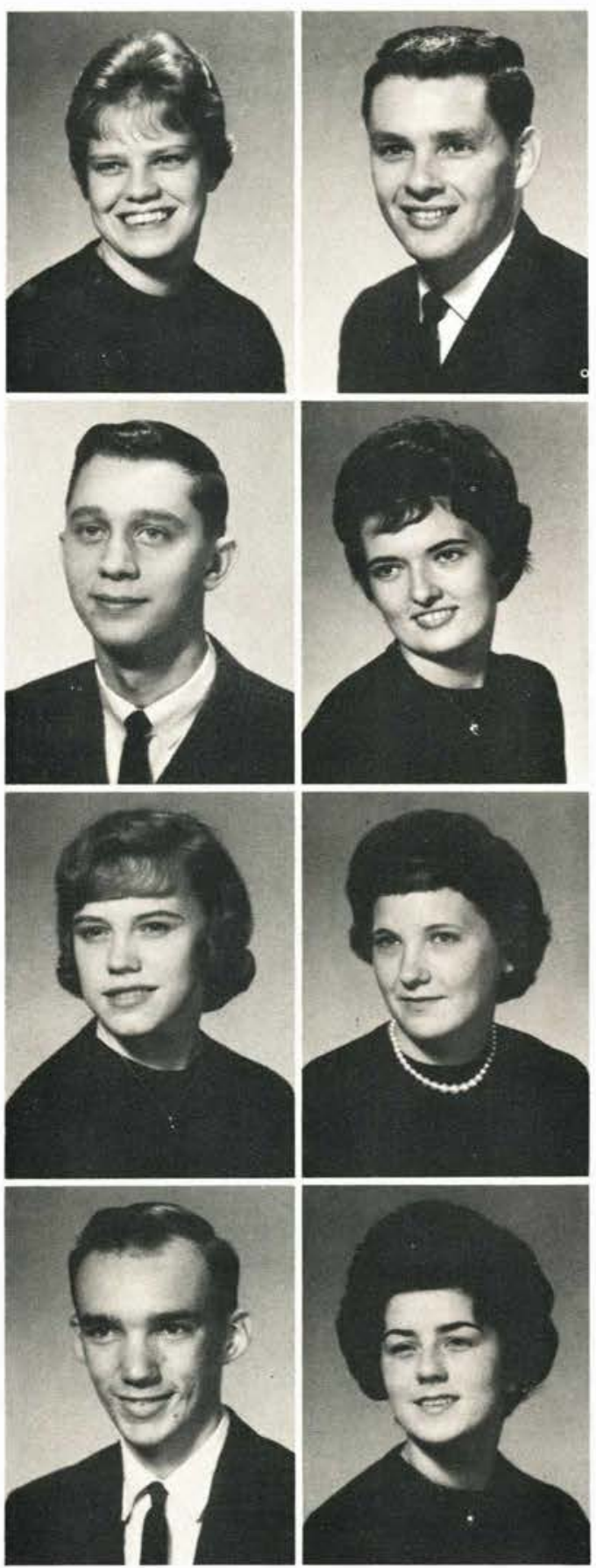

BARBARA MILLER, Ypsilanti, Michigan. JANET MILLER, Medina, Ohio. TERRY MILLER, Elyria, Ohio. MARTHA MOTTS, Northfield, Ohio.
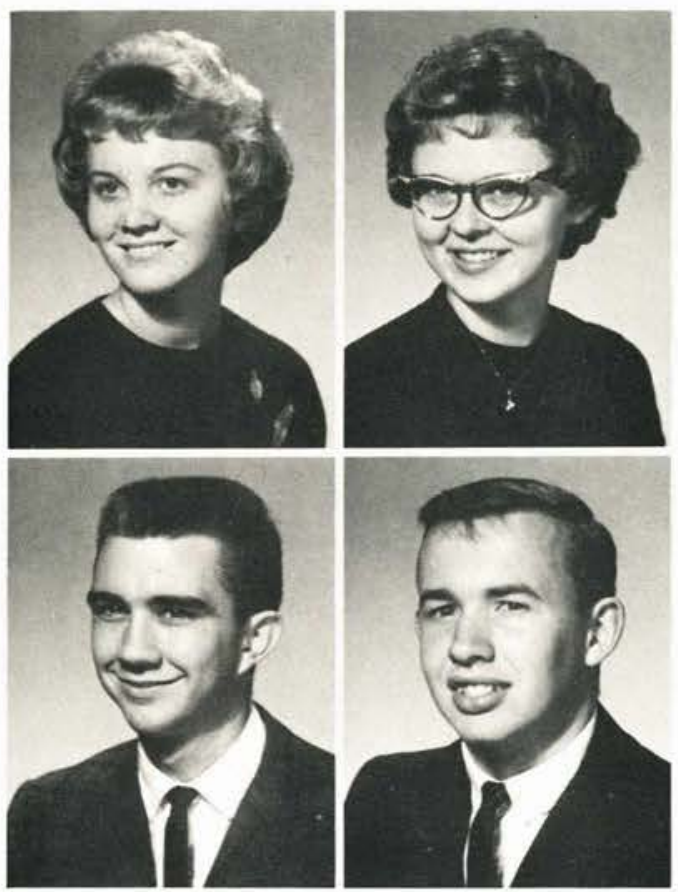

JEAN MACLAREN, Harpster, Ohio. SUSAN MARTIN, Bronson, Michigan. RON MATHIS, Cedarville, Ohio. RON McDUGLE, Pontiac, Illinois.

LEEANN McNAMARA, Meadville, Pennsylvania. LARRY MEEK, Urbana, Ohio. AL MERWALD, Portage, Indiana. HELEN MESHEW, Jackson, Michigan.
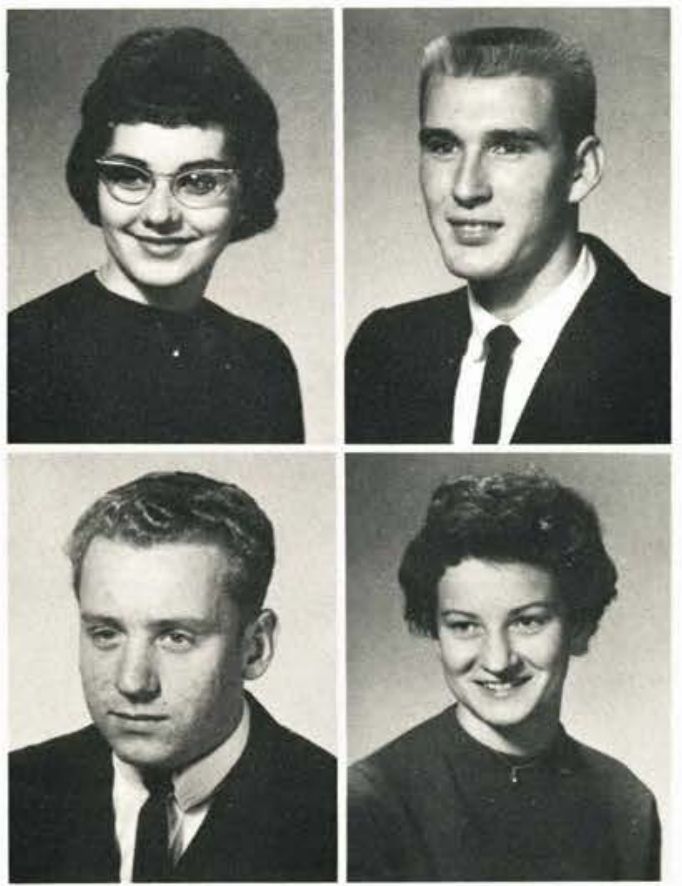

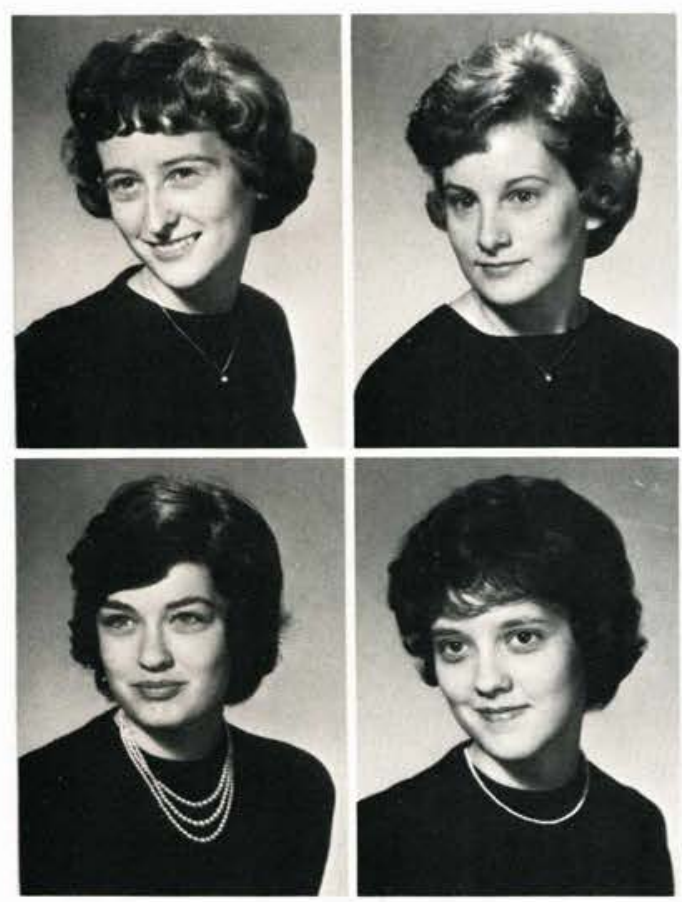

LUANN MUNDHENK, Pitsburg, Ohio. JOANNE NEELY, Gary, Indiana. PEGGY NETTLETON, Longmeadow, Massachusetts. SUE NEWCOMER, Medina, Ohio.

JERRY OSBORN, Midland, Ohio. JOE OSBORNE, Wheeleesburg, Ohio. DENNIS PEARCE, Stanwood, Washington. DAVID PERRY, Cedarville, Ohio.
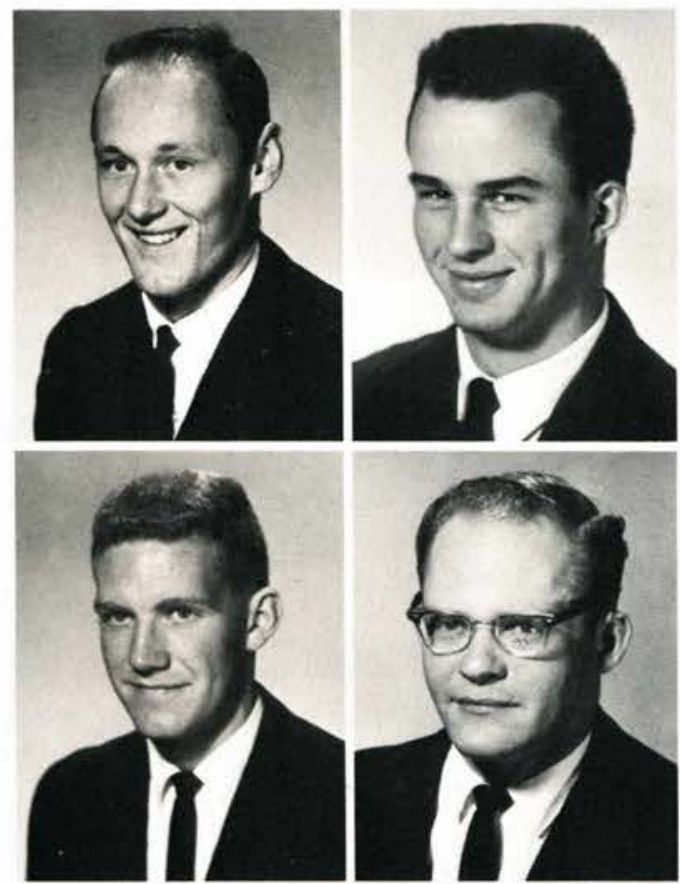

ROBERT NEWMAN, Hawthorne, New Jersey. DAVID NORRIS, Rochester, Indiana. ARLENE OEHMCKE, Wauwatosa, Wisconsin. PHILIP OLSEN, Lapeer, Michigan.
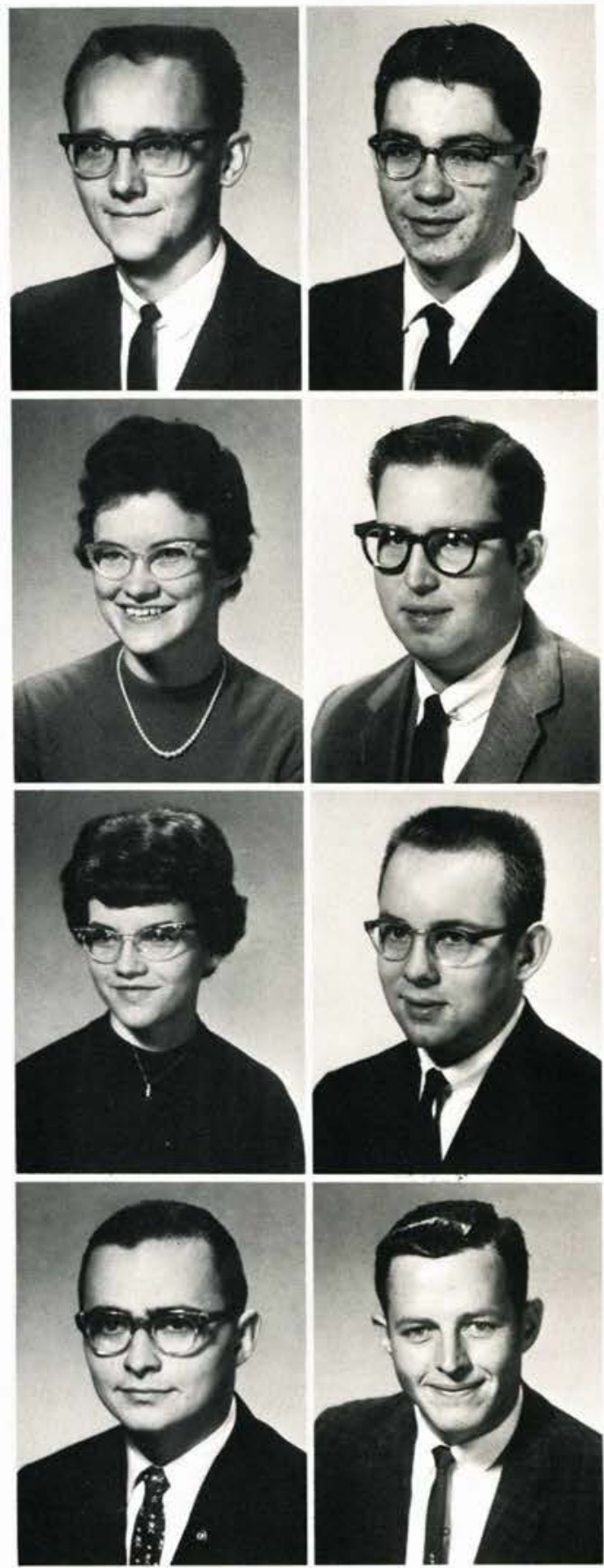

JULIANN PETRIE, Highland, Michigan. EUGENE REAM, Brookfield, Wisconsin. PAUL RENO, Cedarville, Ohio. RICHARD RICH, St. Louis, Michigan. 
VAL ROLOFF, Charles City, Iowa. DONNA ROOST, Reading, Michigan. NANCY SCHUT, Grand Rapids, Michigan. MICHAEL SHINGLETON, Indianapolis, Indiana.
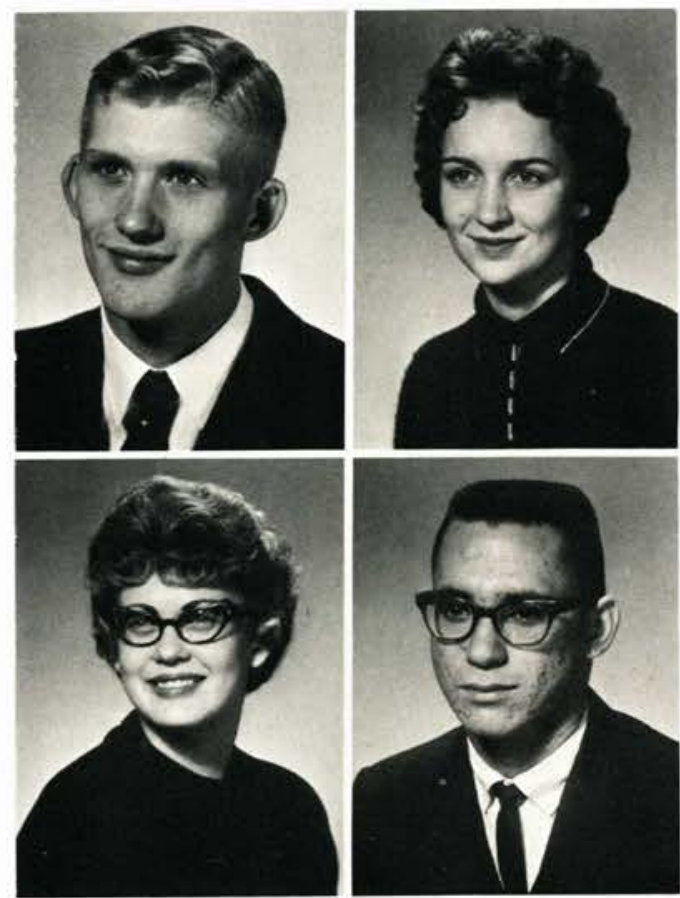
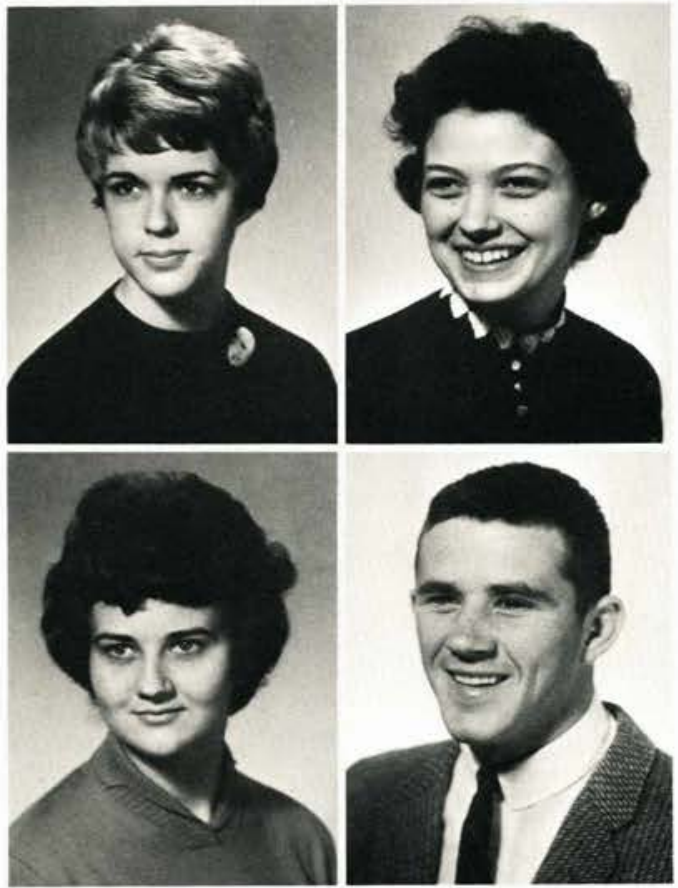

MARTHA SHORT, Winterset, Iowa. JACQUELYN SIDLE, Bellefontaine, Ohio. LINDA SKEIE, Ames, Iowa. RICHARD SPENCER, Portsmouth, Ohio.
The first snow of the season makes the familiar walk from the Ad Building to Milner Hall more pleasant. 

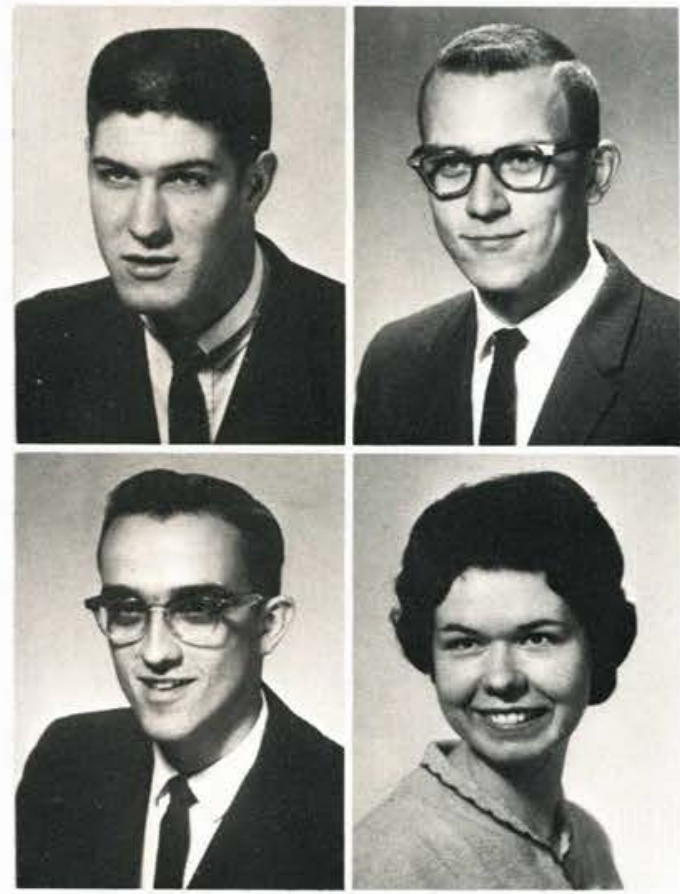

JERRY STADT, Deerfield, Illinois. DAN STEPHENS, Lebanon, Indiana. MARVIN STEPHENS, Grand Rapids, Michigan. SYLVIA SURBER, Springfield, Ohio.
DANIEL THOMAS, Dayton, Ohio. BARBARA THORNE, Medford, New Jersey. DAVID THORNE, Medford, New Jersey. ANNA TITUS, Crawfordsville, Indiana.
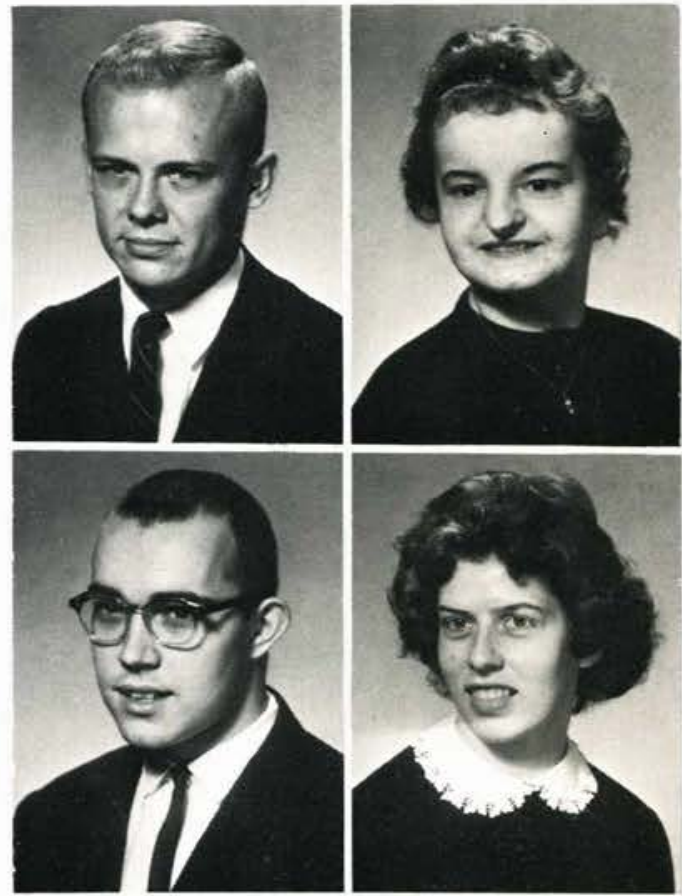

\section{Sophomores}

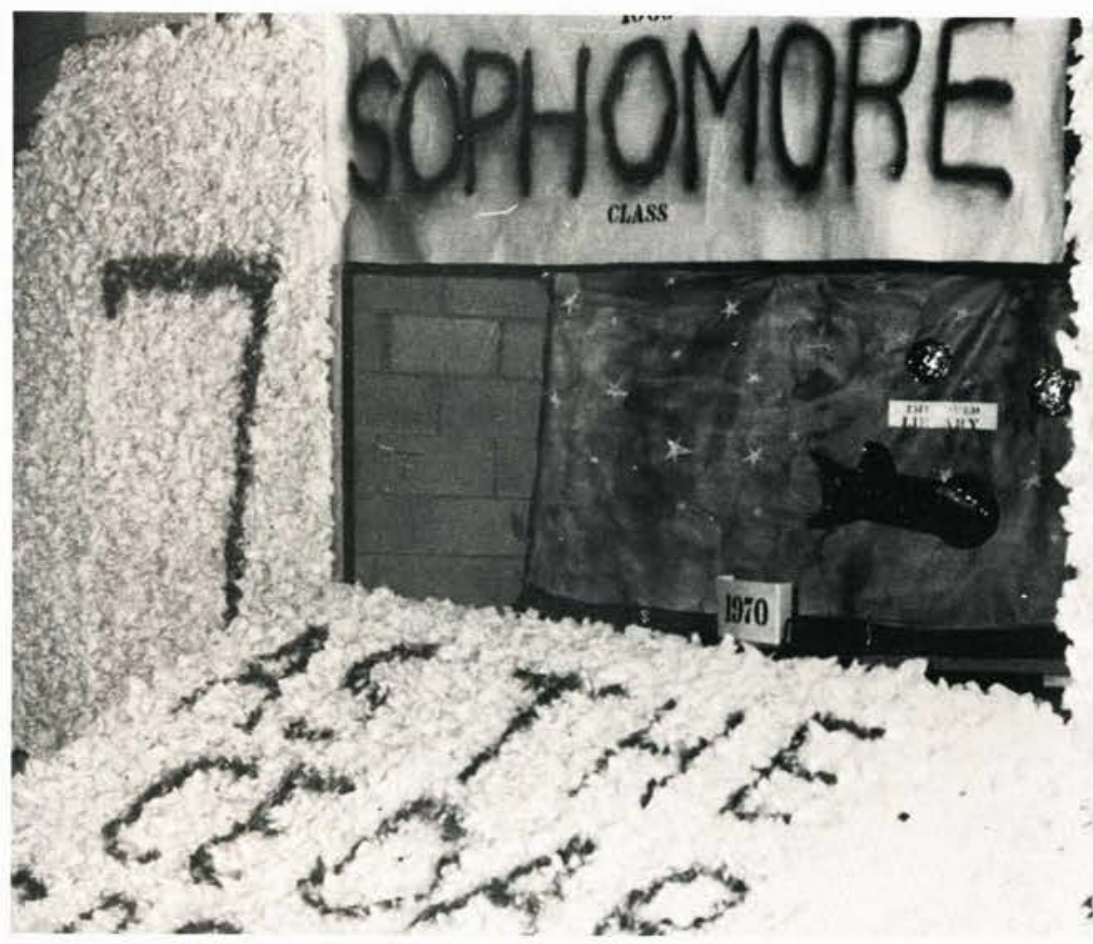

After many long hours of work on their homecoming display, the Sophomores felt that the time was well spent as they received the first prize for the "best class display." 
JANET TREMBA, Youngstown, Ohio. BRIAN TWIEST, Grand Rapids, Michigan. PATRICIA VERSLUIS, Grand Rapids, Michigan. JON WALBORN, Cleveland, Ohio.
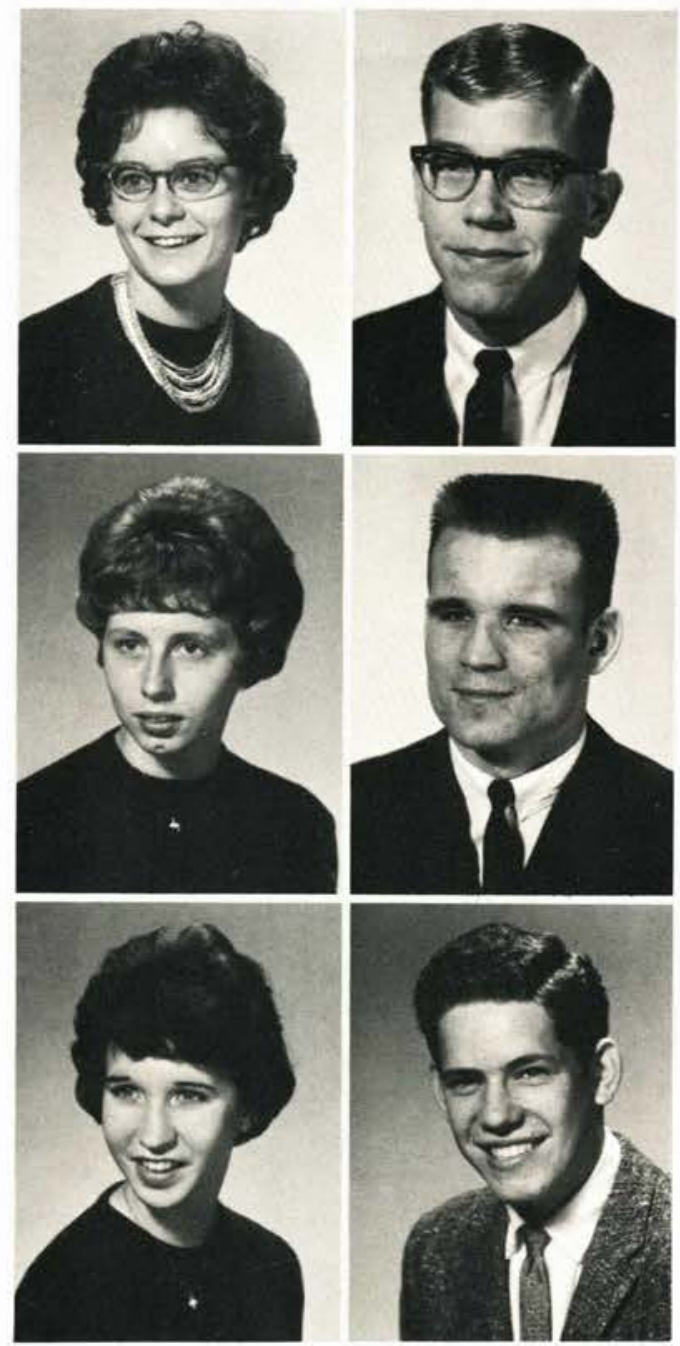

SYLVIA WING, West Winfield, New York. MERVIN ZIEGLER, Cochabamba, Bolivia.
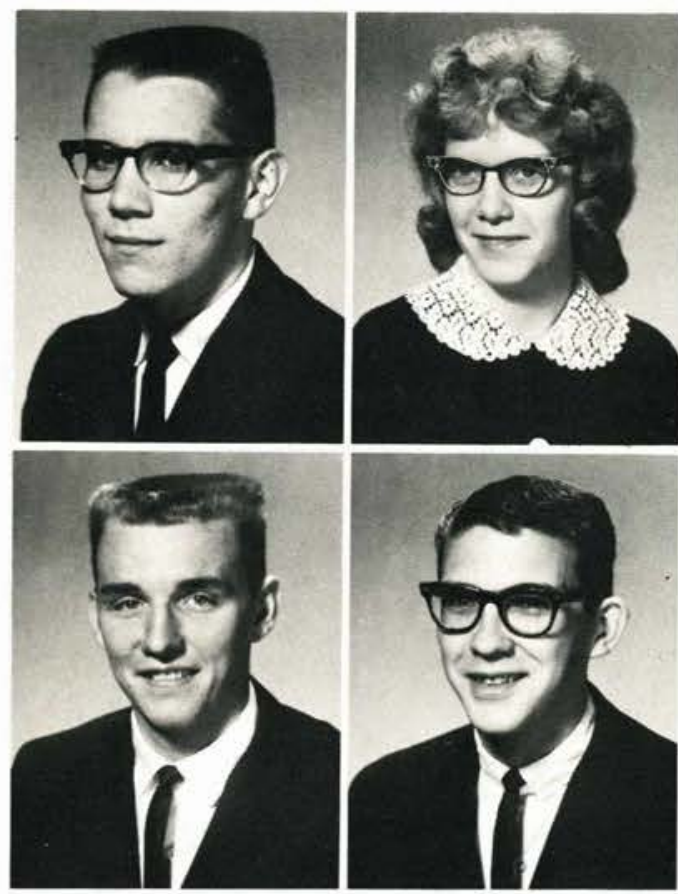

EUGENE WALLIS, Thurston, Ohio. CORNELIA WARD, Collins, Ohio. DAVID WERNER, Columbia Falls, Montana. BRADLEY WEYHE, Olean, New York.

GERALDINE WICKELL, Canton, Missouri. DAVID WILHITE, Corwith, Iowa. JANEEN WILLIAMS, Greenfield, Indiana. HELEN WING, Grand Rapids, Michigan.
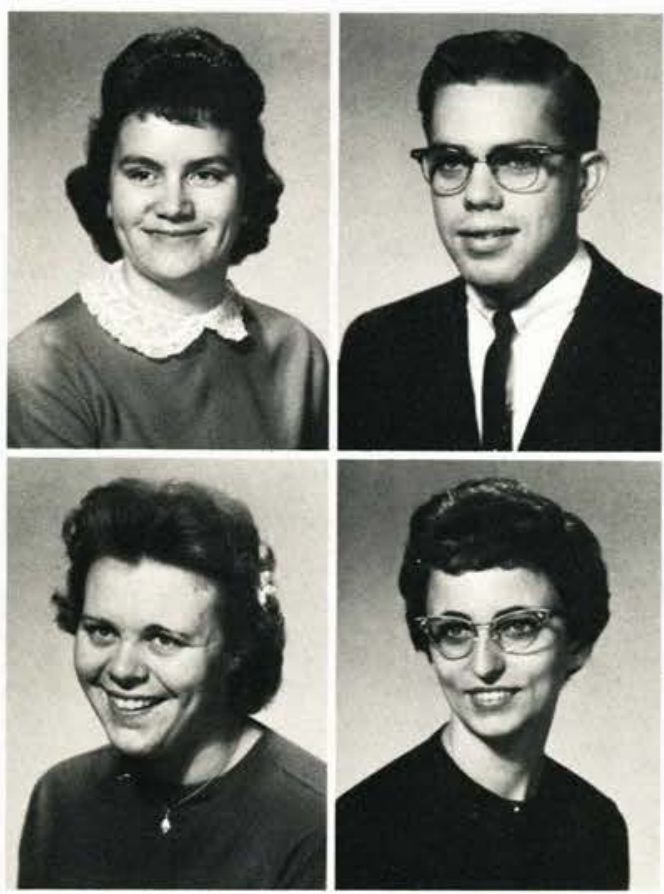


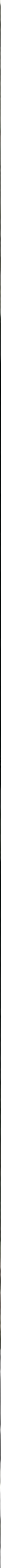


ELTON ACKER

Randolph, New York

KEITH ADDLEMAN

Hillsdale, Michigan

PEGGY ALBRECHT

Lakeville, Indiana

WALTER ALLEN

South Bend, Indiana
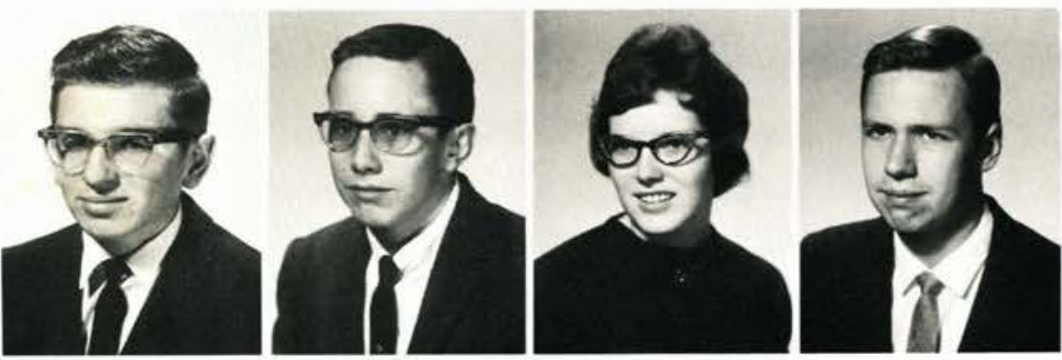
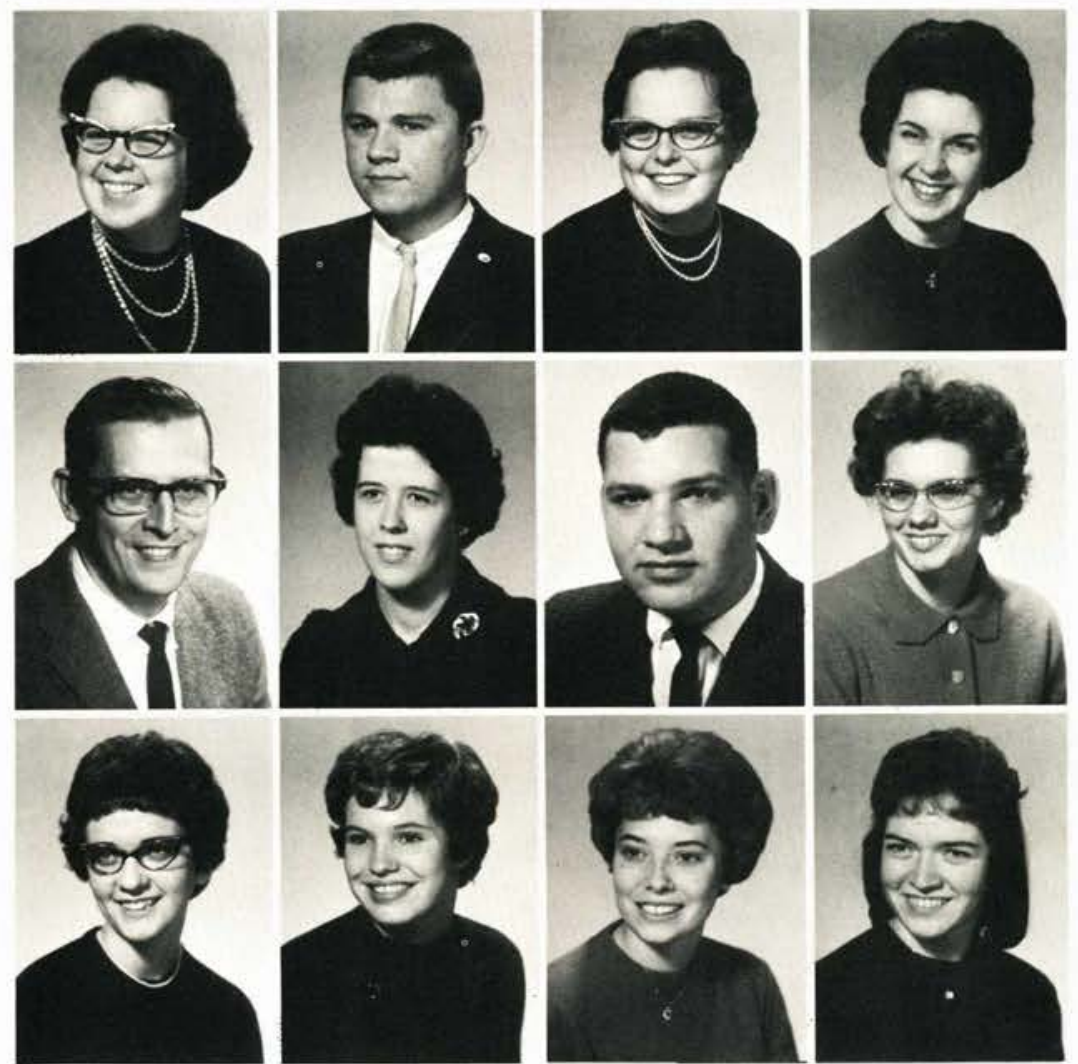

SHARON ARMITAGE

Holland, New York

MARK AVERITT

Sauk Village, Illinois

BARBARA BABCOCK

Northbrook, Illinois

MONA BALLARD

Belleville, Michigan

JERALD BAKER

Fairborn, Ohio

PHYLLIS BANCROFT

Adrian, Michigan

JON BARKER

Highland, Indiana

TERRI BAUER

Beech Grove, Indiana

\section{BETTY BEIKERT}

Butler, Pennsylvania

MARTHA BENNETT

Cleveland Heights, Ohio

BARBARA BIEGER

Lincoln, Nebraska

PATRICIA BIRD

Saline, Michigan
BENJAMIN BOND

Marlette, Michigan

JAN BONNEMA

Painesville, Ohio

RUTH ANN BOONSTRA

Garfield, New Jersey

LOIS BROOKER

Sebring, Florida
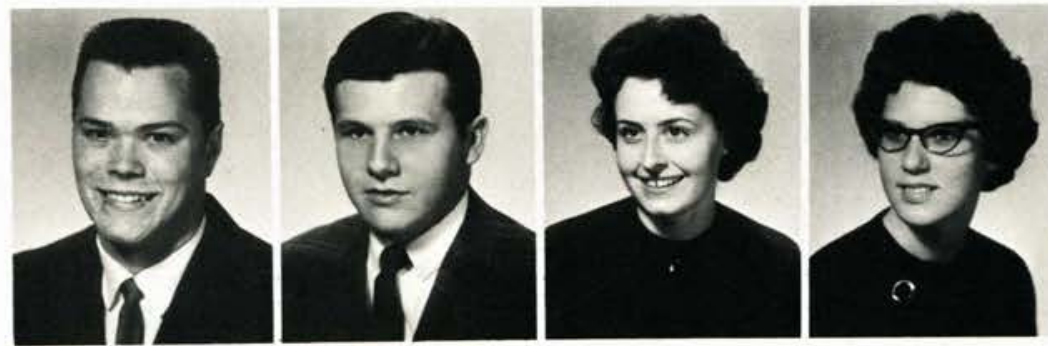

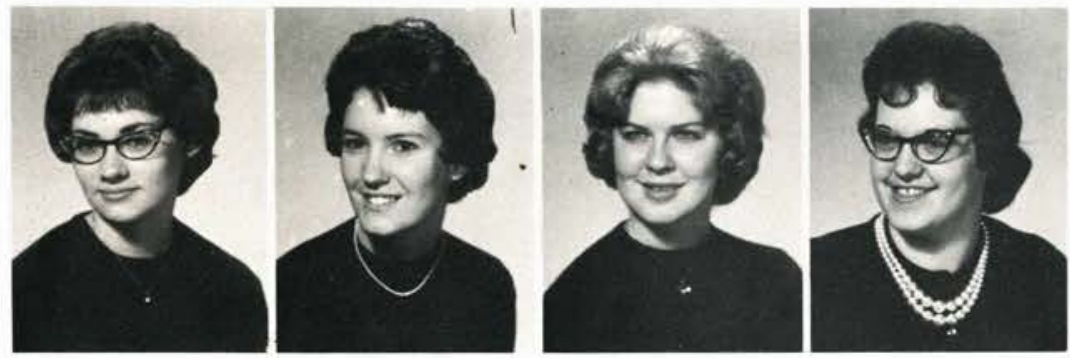

\author{
GRACE BROWN \\ Holly, Michigan \\ MARIAN BUCKLE \\ Lock Haven, Pennsylvania \\ DORINDA BUSH \\ Cuyahoga Falls, Ohio \\ CAROL CARR \\ Gerry, New York
}

\title{
Freshmen
}

JANET COLWELL

New Bethlehem, Pennsylvania CHESTER COPELAND

Dayton, Ohio

BARBARA CROWN

Creston, Iowa

GENE CULLEY

Kalamazoo, Michigan

\section{DONALD DEAN}

Federal Way, Washington

RONALD DEW

Willowick, Ohio

PHILLIP DOAN

Caldwell, Ohio

EDITH DUDLEY

Port Allegany, Pennsylvania

\section{EUNICE DUDLEY}

Port Allegany, Pennsylvania

TIMOTHY DUFFIE

West Alexandria, Ohio

DAMARIS DUNN

Euclid, Ohio

PAMELA EARL

Hasbrouck Heights, New Jersey
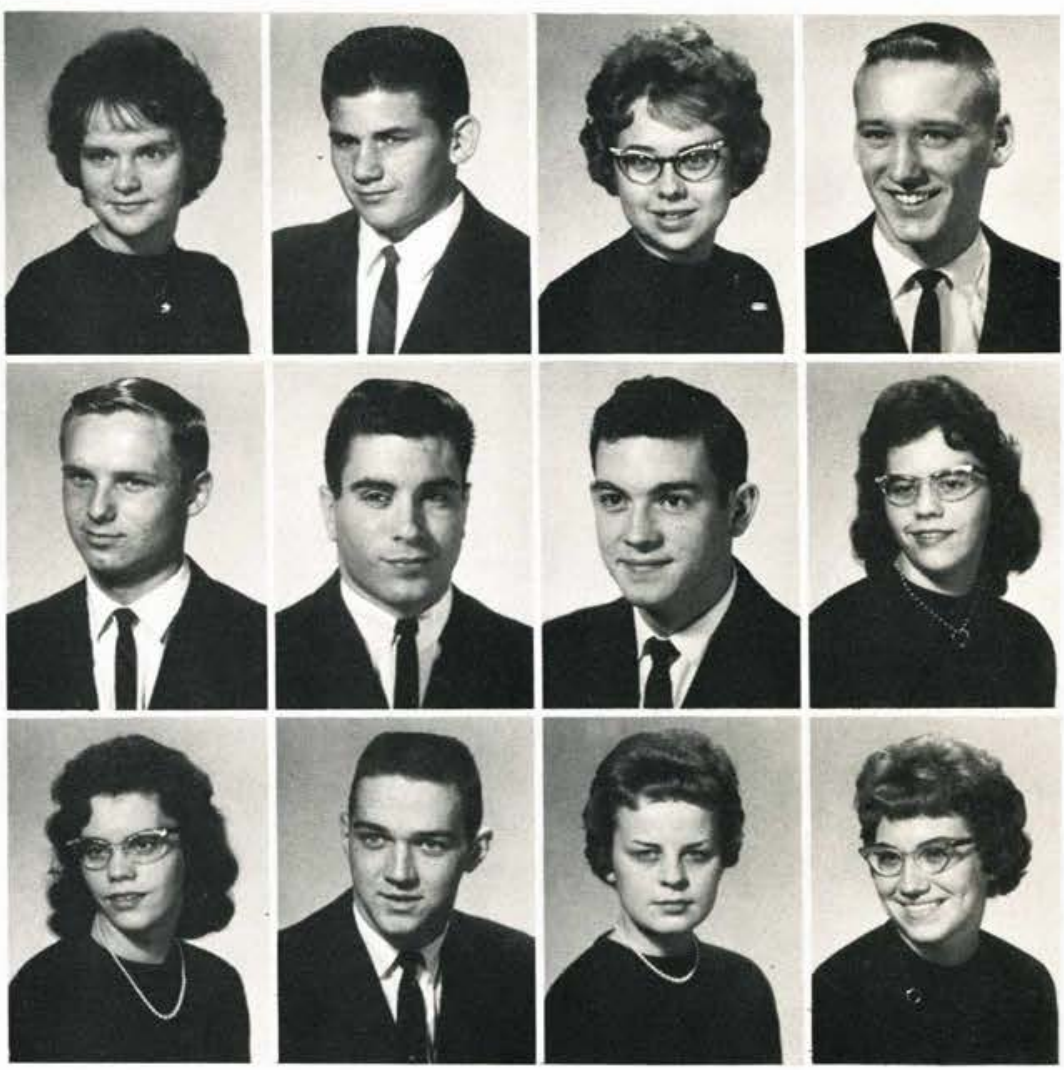
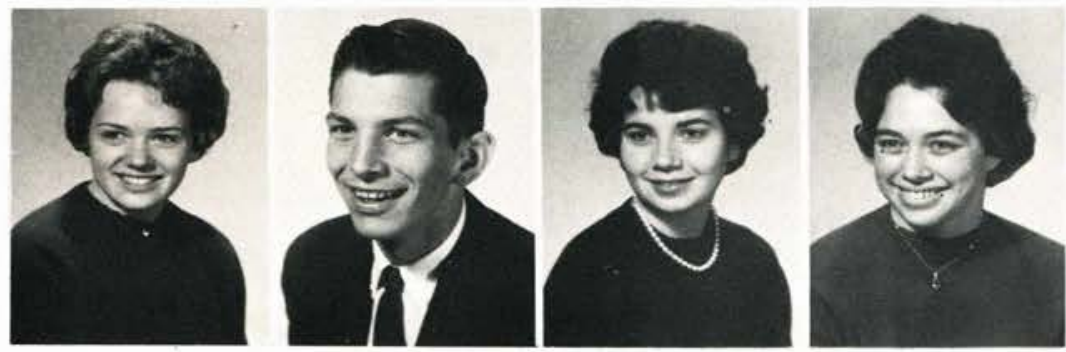

JANICE EMERSON

Brooklyn, Michigan

JAMES ENGELMANN

Flint, Michigan

MIRIAM FARROW

Cleveland Heights, Ohio

MAXINE FINLEY

Faribault, Michigan 
MILDRED FISHER

Dayton, Ohio

LORIS FOX

Cedarville, Ohio

WILLIAM FRANCIS

Kouts, Indiana

GARY FRANSTED

Jackson, Michigan
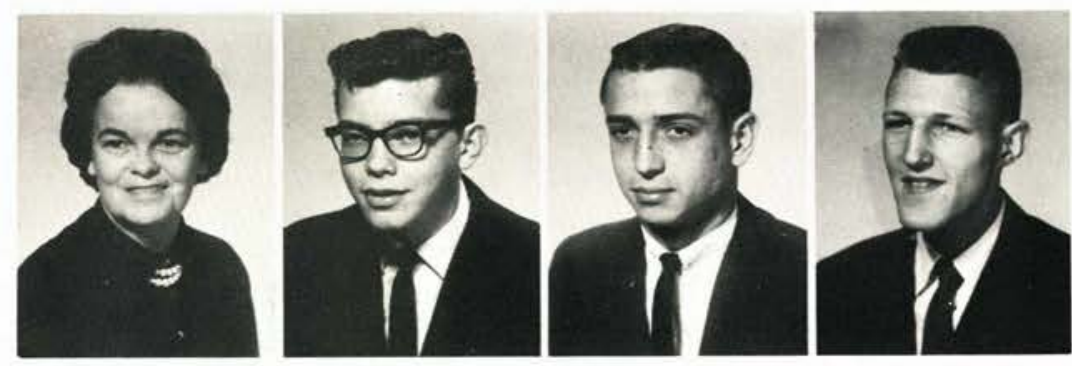
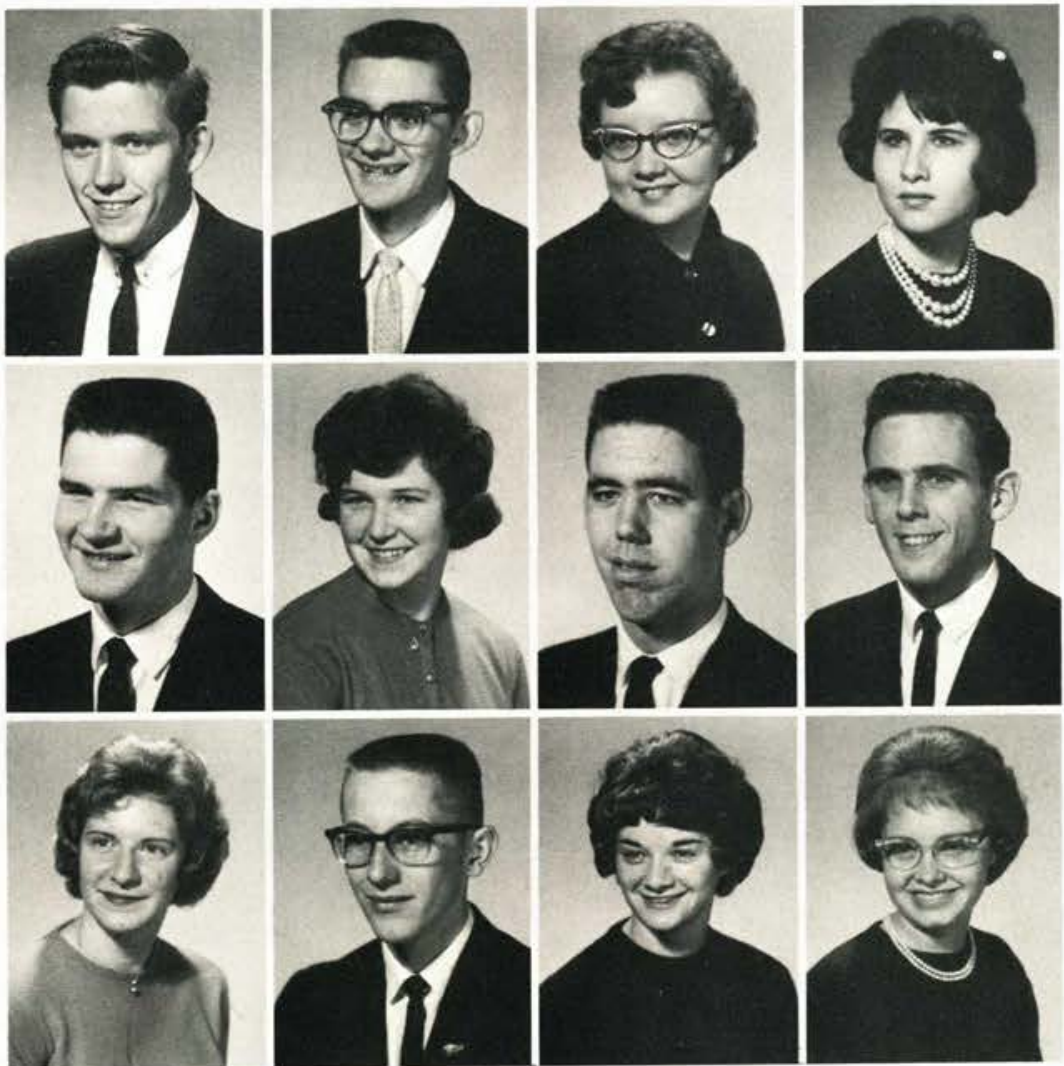

JAMES FURRY

Gary, Indiana

PAUL GALE

Cedarville, Ohio

JOYCE GANN

Jackson, Michigan

KATHLEEN GILDAN

Elyria, Ohio

PHILIP GILMORE

Trenton, Michigan

PATRICIA GOOD

Eggertsville, New York

GEORGE GOODWIN

Oak Forest, Illinois

DAVID GORDON

Connersville, Indiana

MIRIAM GREINER

Wellington, Ohio

GORDON GRIFFIN

Lincoln, Nebraska

ANNE HALLEY

Columbus, Ohio

JANET HANLON

Ypsilanti, Michigan

GARY HARRIS

Beech Grove, Indiana

SALLEY HAYES

Mannington, West Virginia

LINDA HEALY

Moscow, Iowa

SHERRILL HES

Port Norris, New Jersey
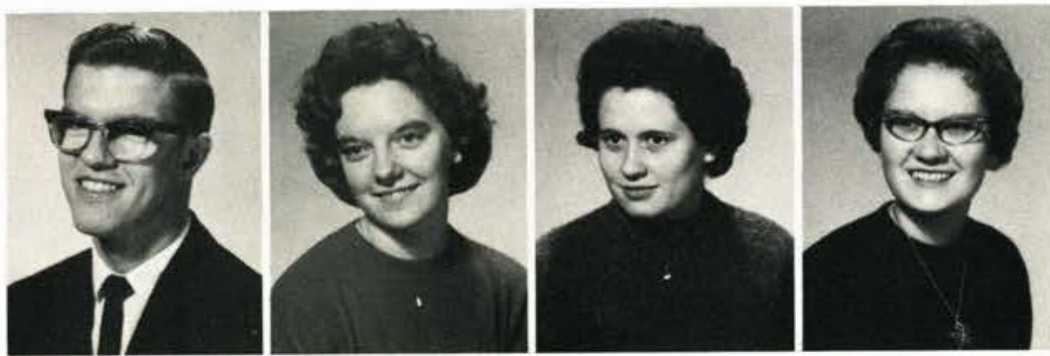

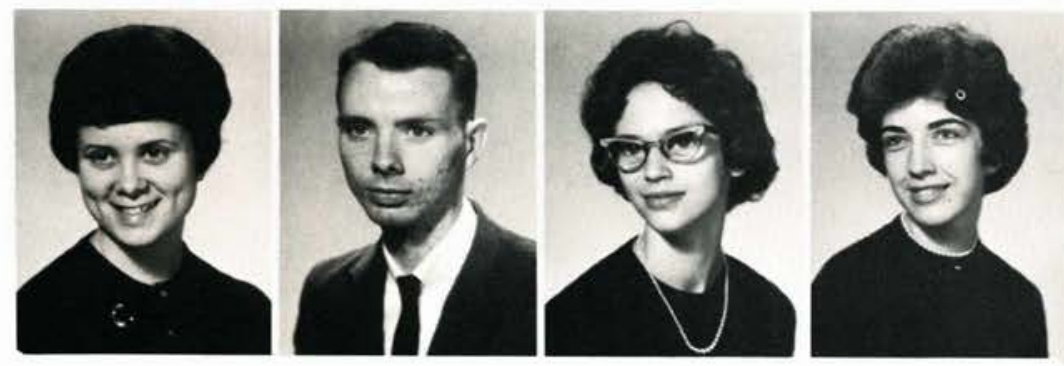

\section{LINDA HILLIKER \\ Wellington, Ohio \\ DAVID HOFFMAN}

Marlette, Michigan

ARLENE HOYTE

Whitney Point, New York

CHARIS JOHNSON

Olean, New York

\section{Freshmen}

MEDORA JORDAN

Richmond, Virginia

WILBUR KIRTLAND

Valencia, Venezuela

MARYLEA KONICEK

Traer, Iowa

ELAINE KORLEWITZ

Johnstown, Pennsylvania

DEEANN LAWRENCE Tifflin, Ohio

SUZANNE LEPINE

Buffalo, New York

POLLY LEUNK

Shaker Heights, Ohio

GRETCHEN LIECHTY

Hobart, Indiana

DAVID LOOS

Mishawaka, Indiana

CHARLOTTE LYME Sidney, Ohio

AL MACDONALD

Cement City, Michigan

LUANN MAHANNA

Columbus, Ohio
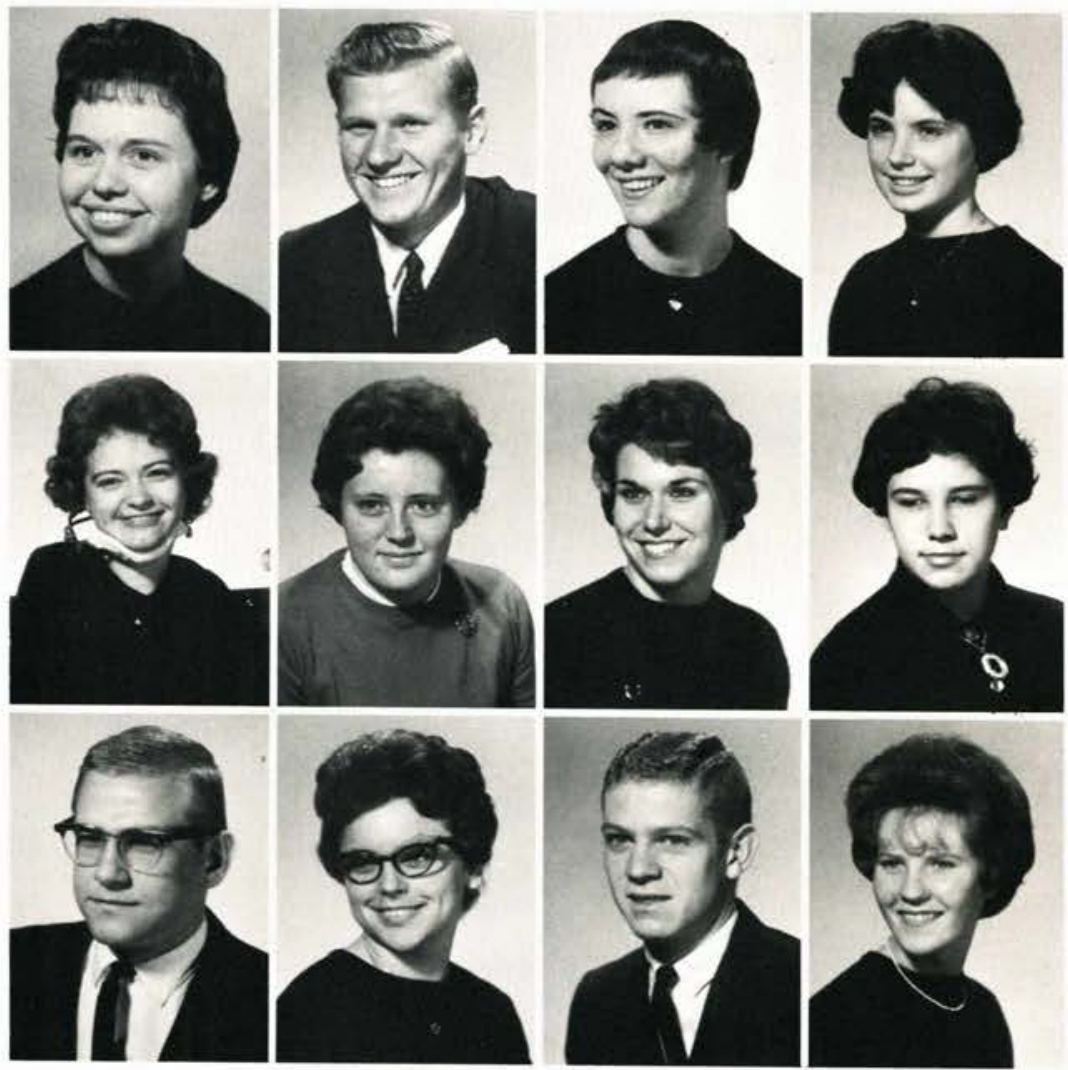
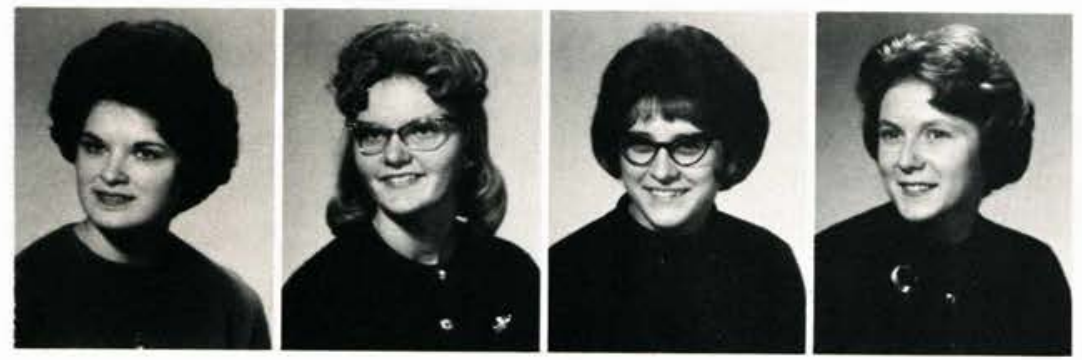

LINDA MARTIN

Mishawaka, Indiana

JUDITH McCLINTIC

Shepherd, Michigan

FRANCES MERRETT

Indianapolis, Indiana

VALERIE MERRYMAN

West Englewood, New Jersey 
WILLIAM MEYERS

Omaha, Nebraska

JOYCE MICKA

Ridgefield Park, New Jersey

DIANE MILLER

Lowellville, Ohio

DAWN MITCHELL

Pontiac, Michigan
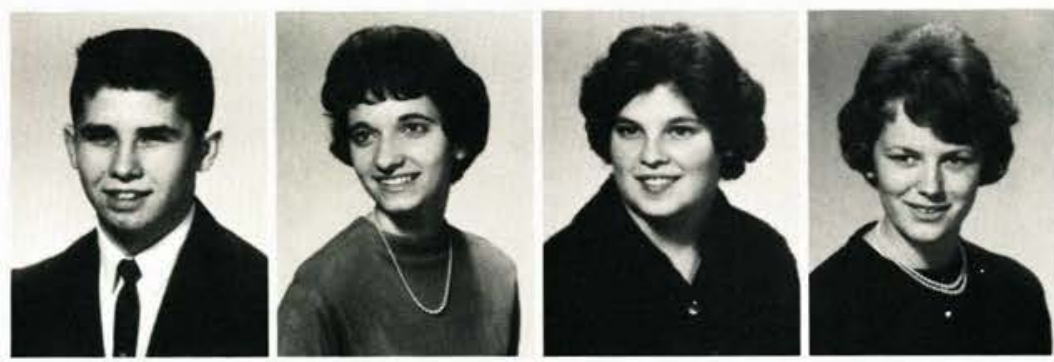
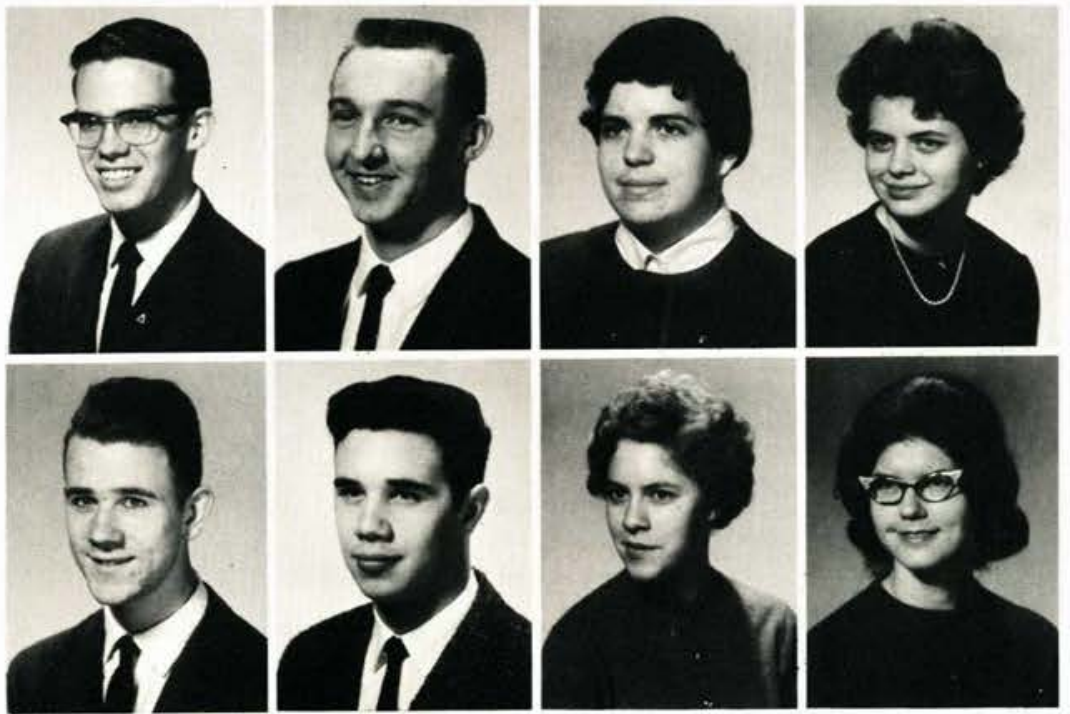

LARRY MONTGOMERY

Columbus, Ohio

RONALD MOORE

Ypsilanti, Michigan

KATHLEEN MORGAN

Vernon, Pennsylvania

LOIS MORRELL

Bedford, Ohio

DAVID NIMS

Keene, New Hampshire

DENNIS OBER

Ankeny, Iowa

REBECCA O'KEEFE

Parma, Ohio

DOROTHY OLSEN

Berea, Ohio
Registration presents a frustrating experience to Ruth Ann even before classes begin.

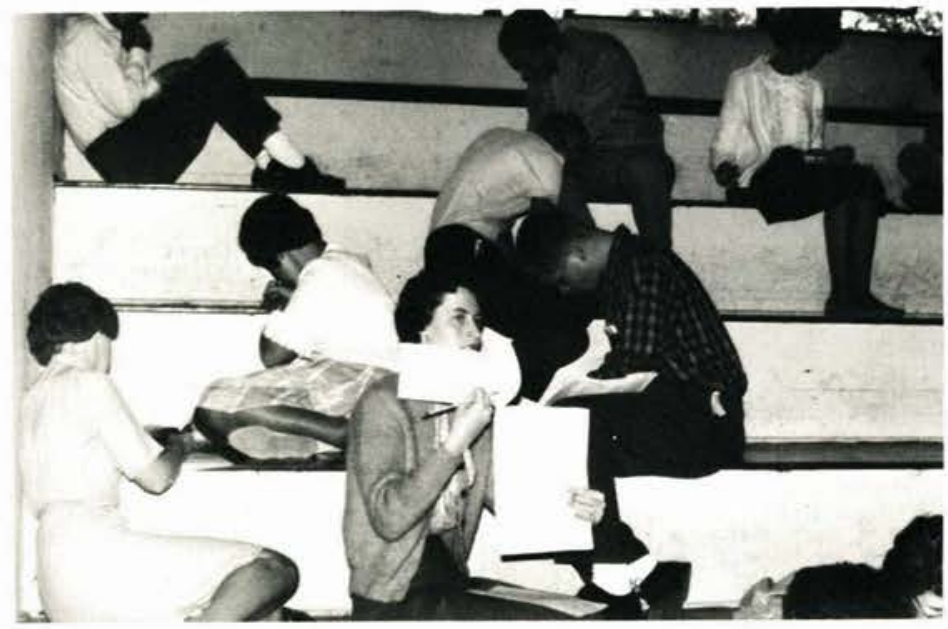



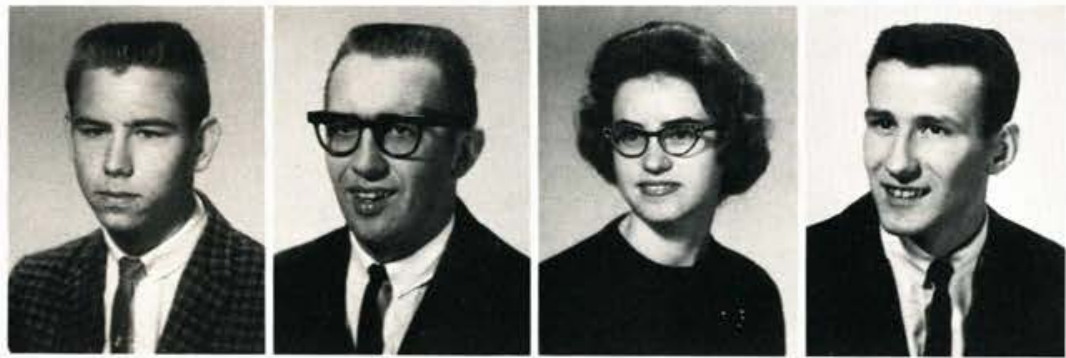

JERRY OLSEN

Rochester, Michigan

LARRY OPITZ

Plymouth, Indiana

SHIRLEY OTTO

Rolfe, Iowa

RALPH PAY

Brecksville, Ohio

\section{Freshmen}

RONALD PEARSON

Indianapolis, Indiana

BYRON PEASLEY

Westerville, Ohio

DOROTHY PELKE

Gary, Indiana

EUGENE PRATHER

Loveland, Ohio

DAVID PROSSER

Warren, Ohio

PATRICIA QUICK

Ankeny, Iowa

ROY RAMSEY

Blanchester, Ohio

DAVID RICE

Randolph, New York

LAWRENCE RICHARDSON

Livonia, Michigan

PHYLLIS RIPKO

Garfield Heights, Ohio

DENNIS ROCKWELL

Indianapolis, Indiana

NANCY RODENBERG

Belleville, Michigan
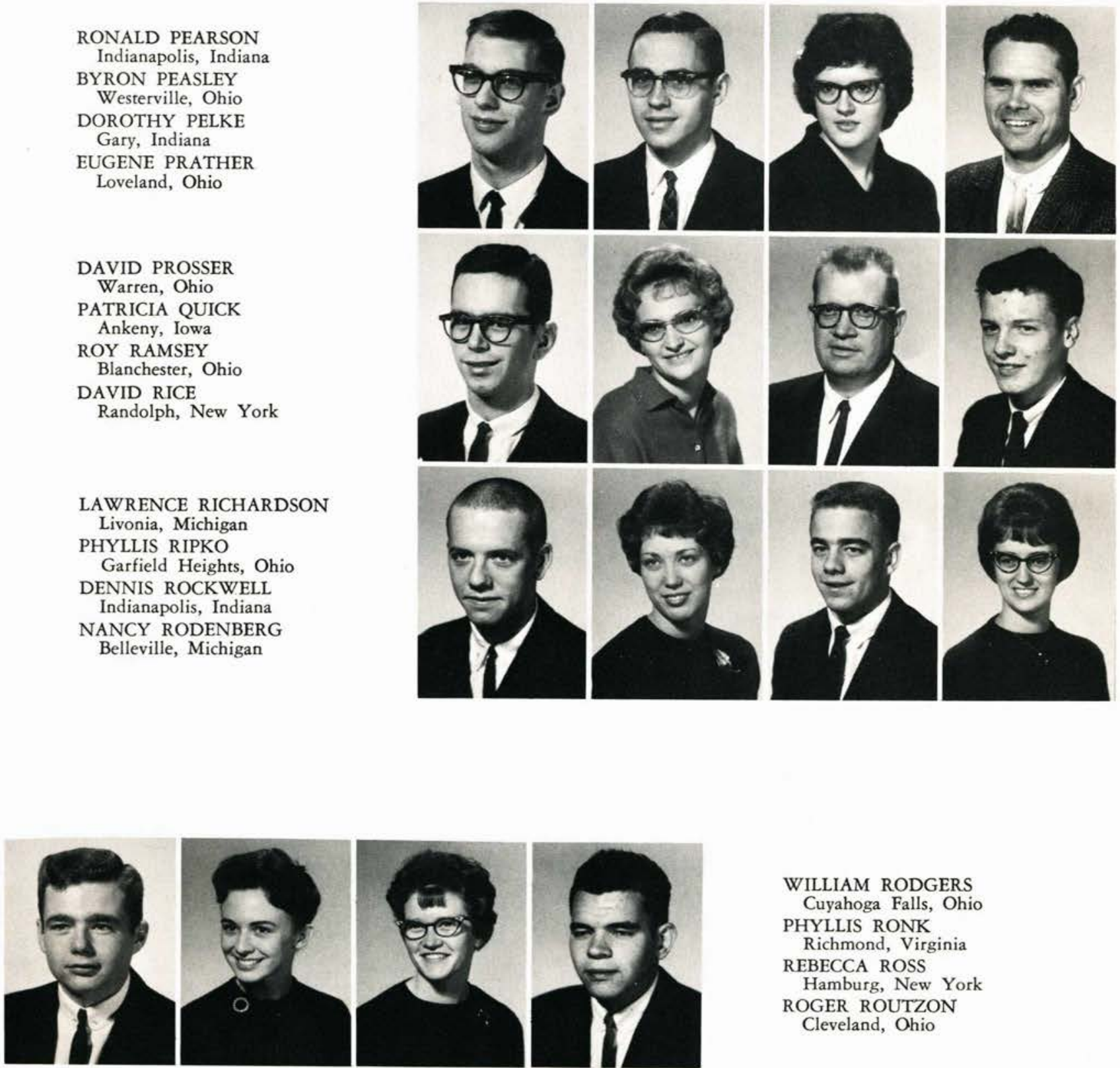

WILLIAM RODGERS

Cuyahoga Falls, Ohio

PHYLLIS RONK

Richmond, Virginia

REBECCA ROSS

Hamburg, New York

ROGER ROUTZON

Cleveland, Ohio 
JOYCE RUDDUCK

Waterloo, Iowa

CAROL JEAN SCHOLTEN

Columbus, Ohio

LAVONNE SHAW

Cherry Hill, New Jersey

TERRY SHETLER

Covington, Kentucky
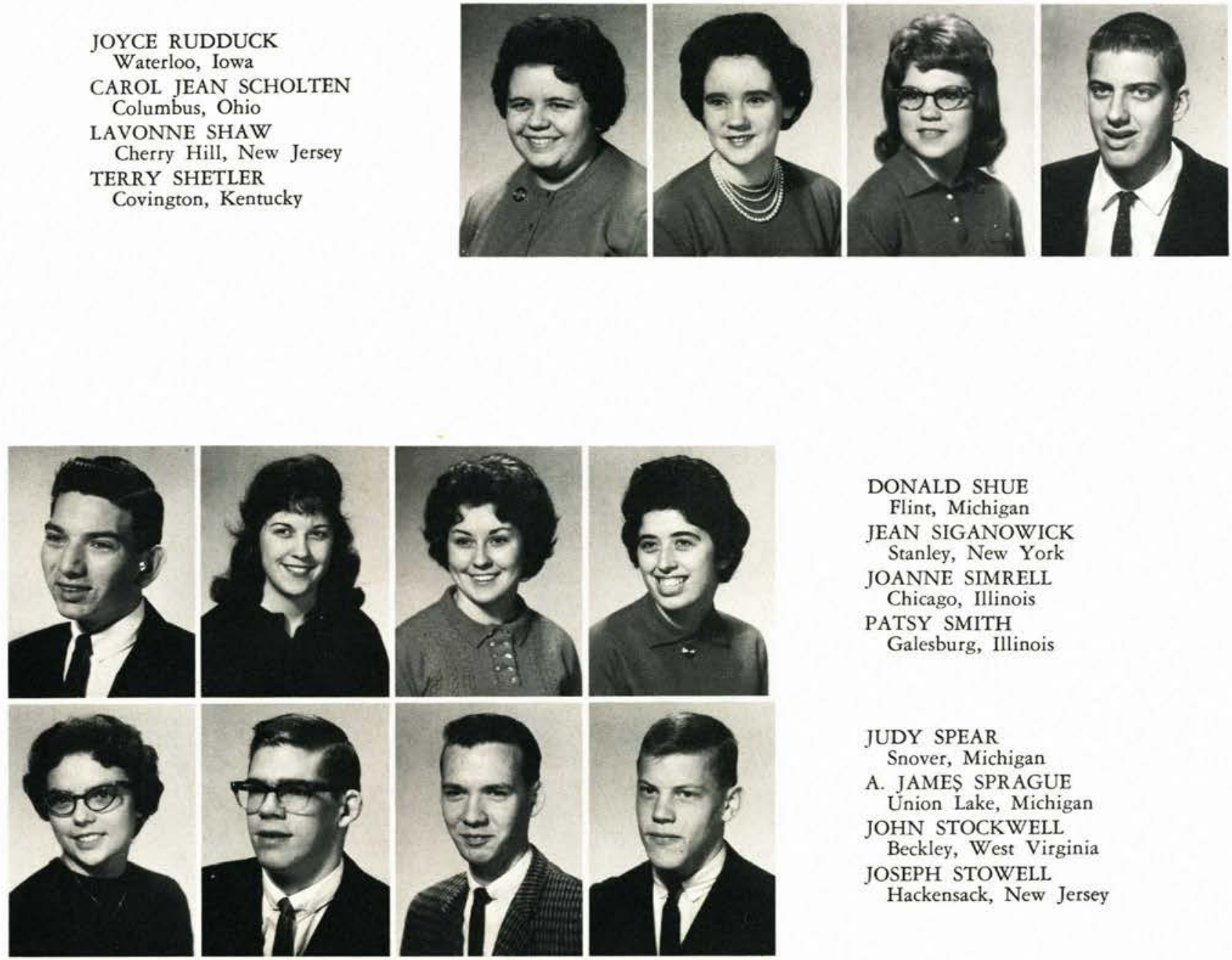

DONALD SHUE

Flint, Michigan

JEAN SIGANOWICK

Stanley, New York

JOANNE SIMRELL

Chicago, Illinois

PATSY SMITH

Galesburg, Illinois
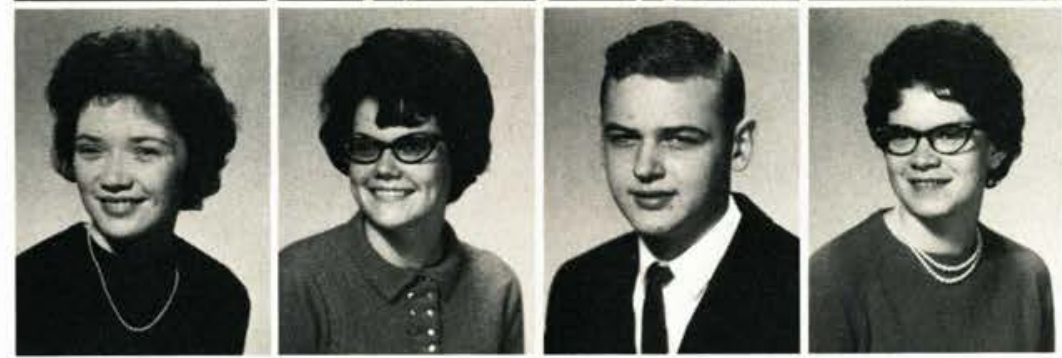

LETHA SULLIVAN

Warren, Ohio

LORETTA TAULBEE

Lennon, Michigan

GORDON TAYLOR

Steamboat Rock, Iowa

KATHLEEN TEETERS

Fayette, Ohio

UDY SPEAR
Snover, Michigan

A. JAMES SPRAGUE

JOHN STOCKWELL

JOSEPH STOWELL

Hackensack, New Jersey

BETH THOMSON

Miami, Florida

GEORGE TULLOCH

Omer, Michigan

DAVID VANDERGROUND

Cleveland, Ohio

JANICE VAN HORN

Plainfield, Illinois
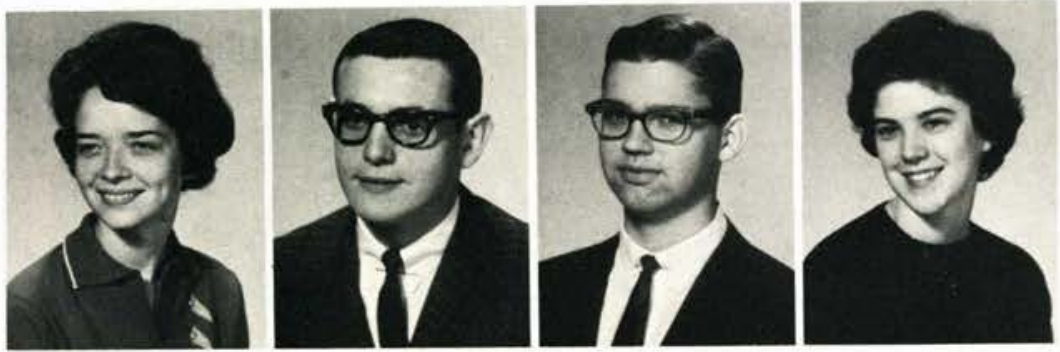

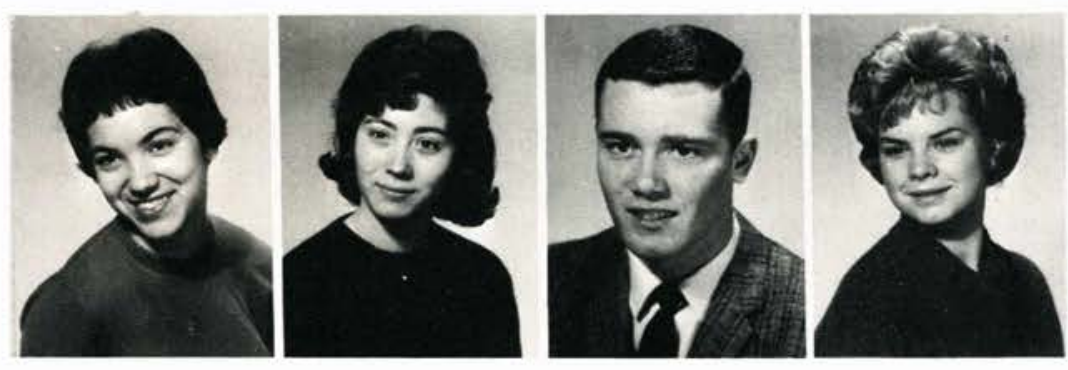

\section{JANICE VAN WYK}

Monroe, Iowa

NANCY WAGNER

St. Clair, Michigan

DAVID WALBORN

Wauseon, Ohio

ANNETTE WHALEY

Granada Hills, California

\section{Freshmen}

CHARLES WILKINS Davton, Ohio

GARY WILKINSON

Cuyahoga Falls, Ohio

CAROLE WRIGHT

Columbus, Ohio

ROBERT YEAGER

Gladwin, Michigan

MAXINE YOUNG

Pleasant, Michigan

JAMES ZEIGLER

Buffalo, New York
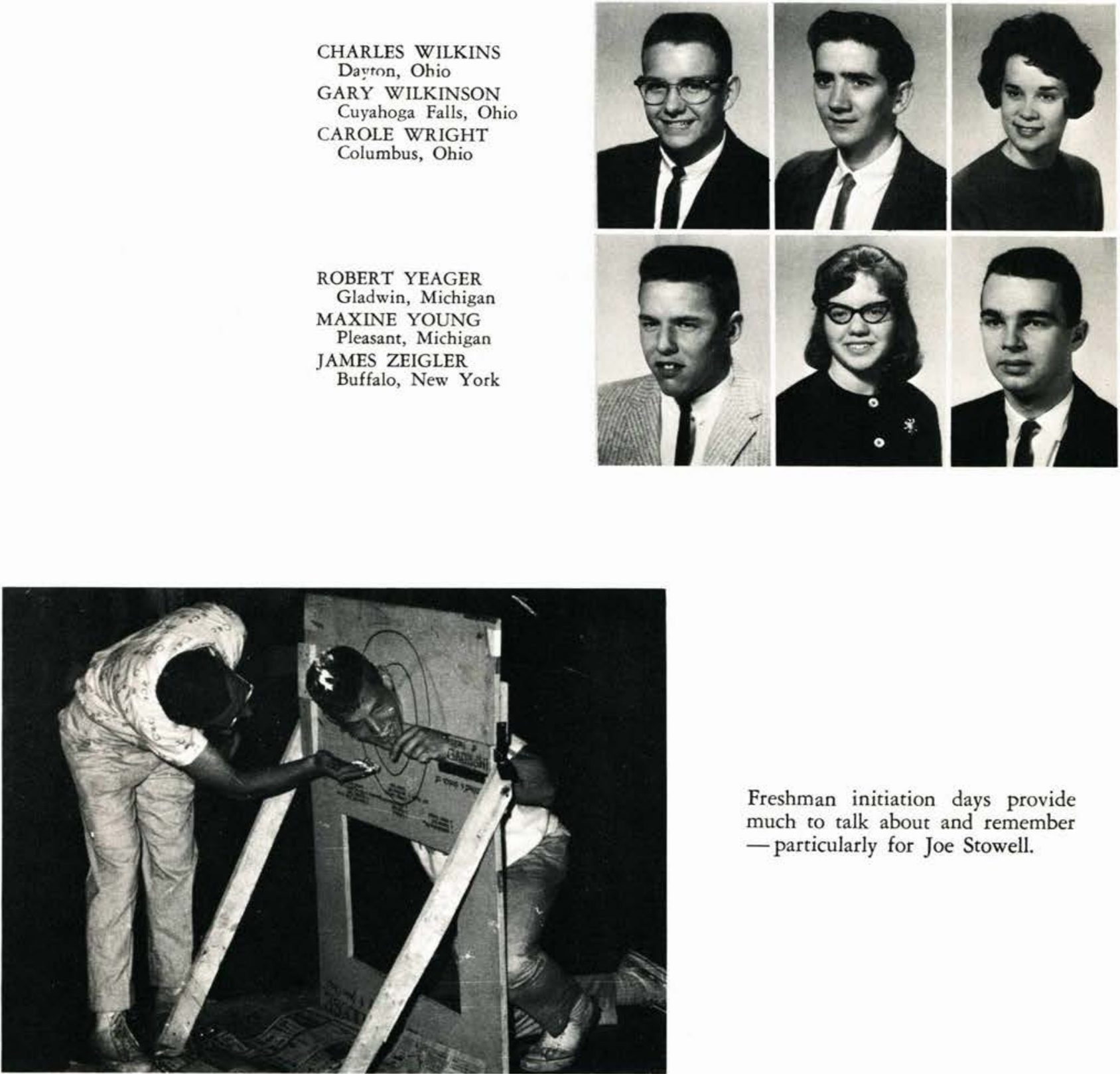

Freshman initiation days provide much to talk about and remember - particularly for Joe Stowell. 


\section{Second Semester Students}

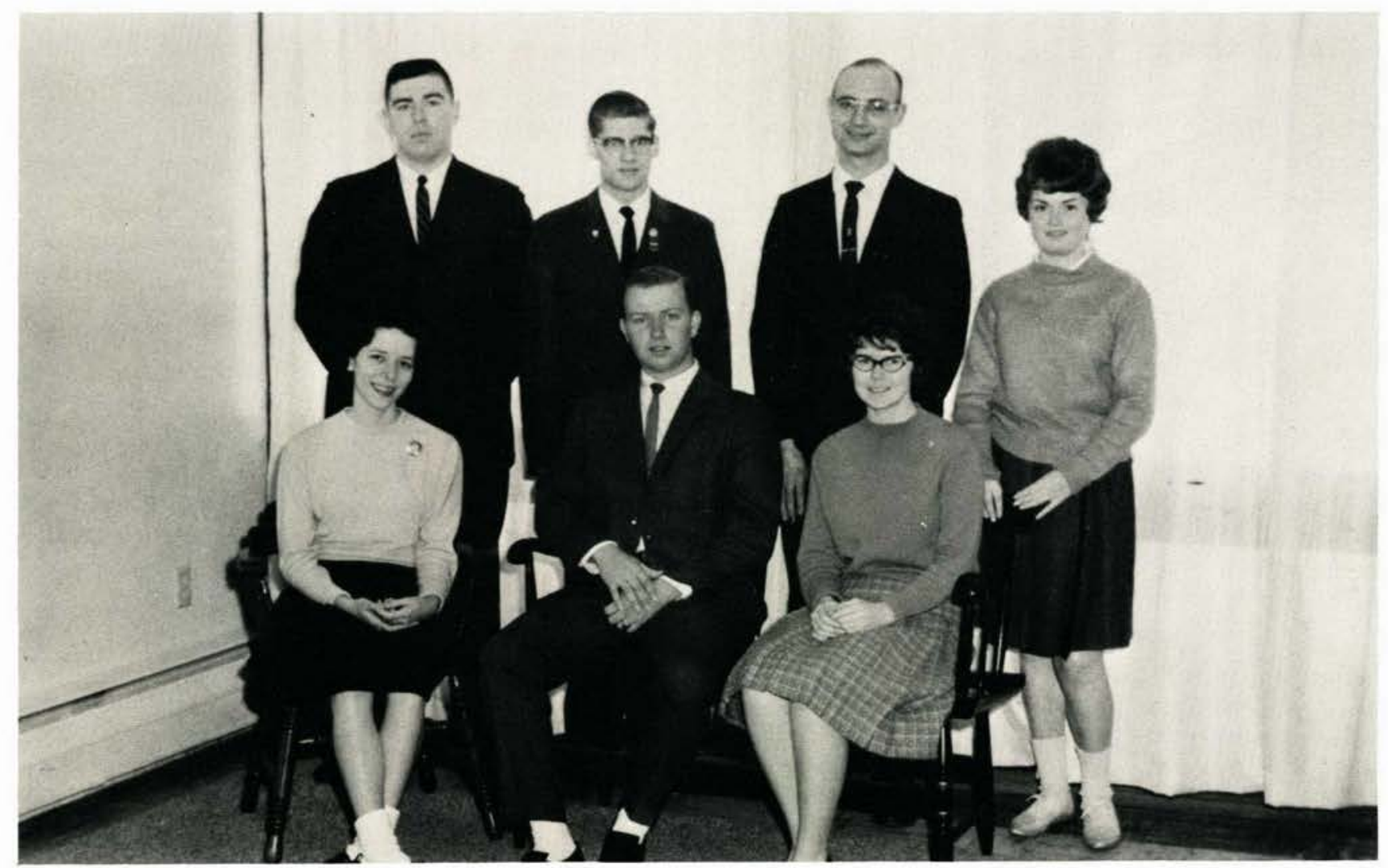

Standing, Left to Right: G. Hensley, Junior; G. Ford, Freshman; V. Boozel, Junior; S. Kidder, Junior. Seated: P. Buerer, Senior; L. Lane, Sophomore; M. Blann, Junior.

\section{Not Pictured}

Lee Bennett

Beverly Foulkrod

Thomas Foulkrod

Richard Harper

James Joiner

Dennis Kerchner

Clifford Lones
Senior Special Student Special Student Junior Junior Freshman Senior

David McDonald
Barbara McIntosh
Stephen Nimmo
James Rivers
Barbara Tennant
Stephen Tennant
Lynn Tice




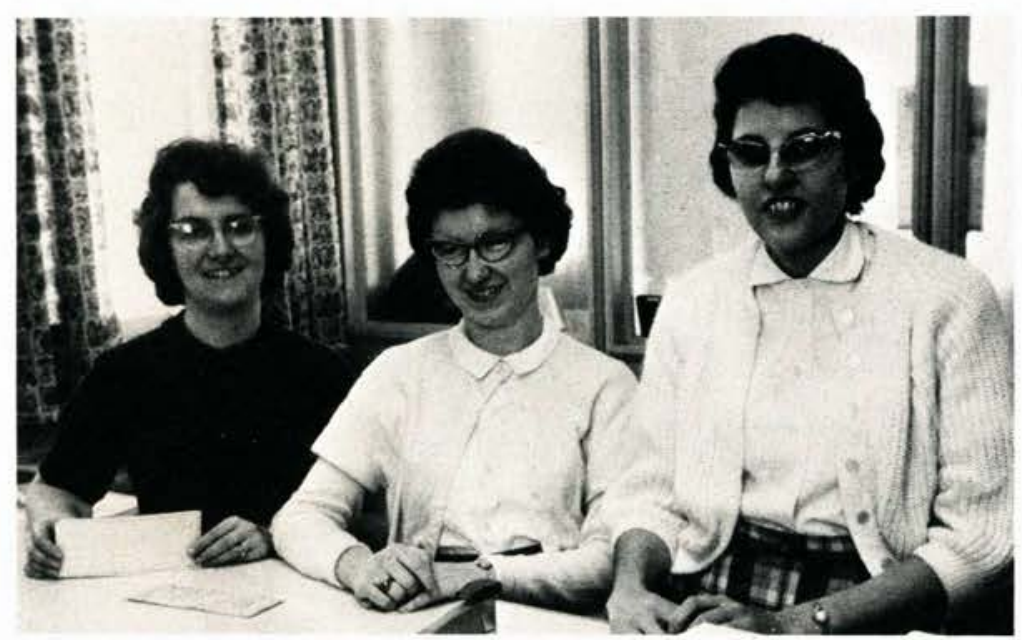

The never ceasing task of writing receipts, banking the money received from gifts and monthly support of our churches, making up the monthly pay roll, and many other duties take place in the business office. Students assist by answering the switchboard, making up the daily cash report, and processing the current invoices.

Mrs. Kathy Dempsey, Secretary to the Registrar; Beverly Woods, Secretary to the Academic Dean; Margaret Spaulding, Secretary to the Presidnet.

\section{Office Staff}
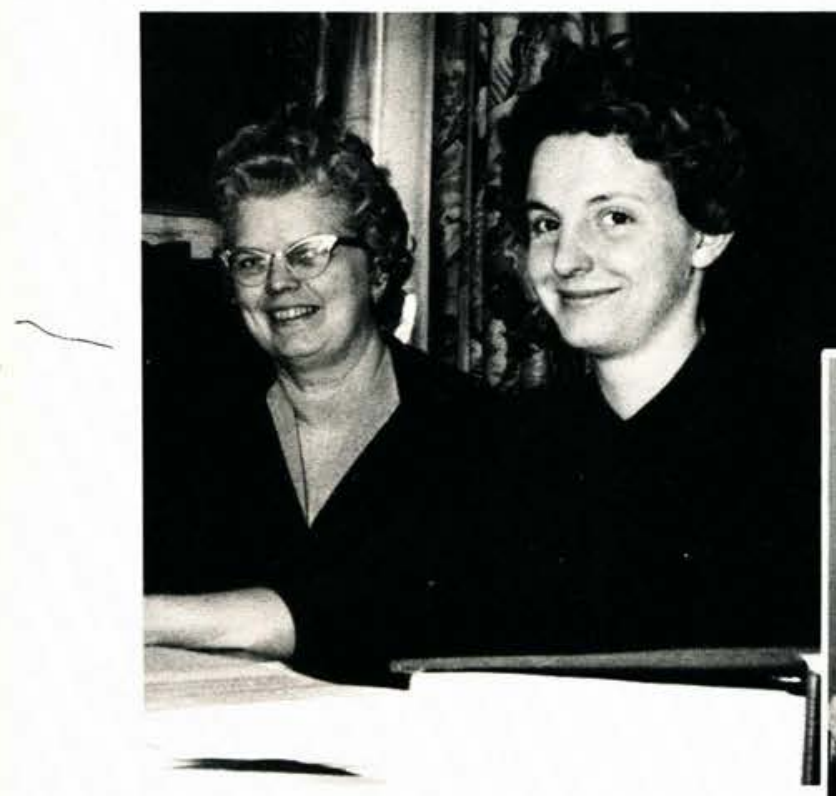

Anne Halley, Sheryl Martin, Donna Johns

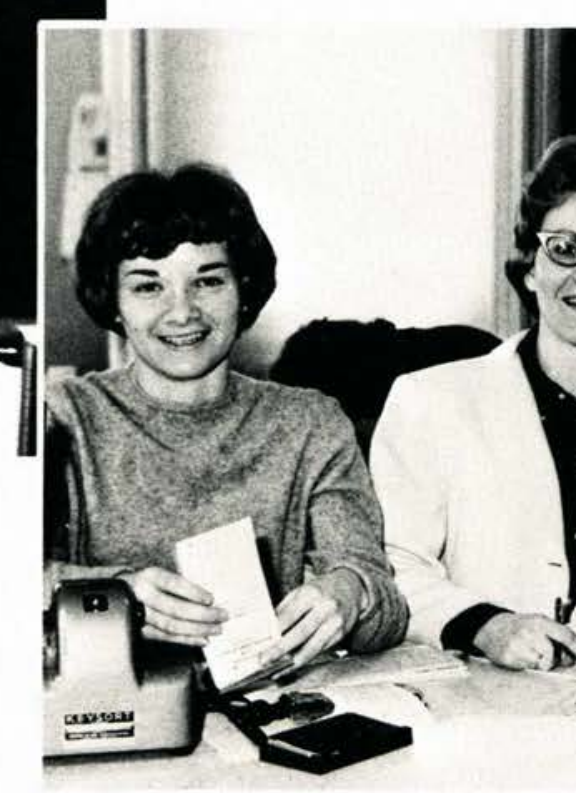

Mrs. Elmore, Cashier

Mrs. Elinor Marshall, Bookkeeper

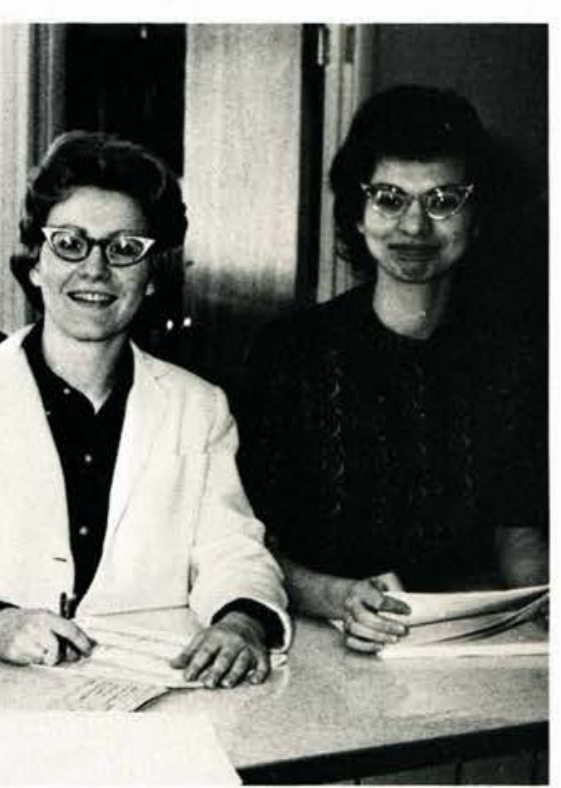


The current alumni project is to acquire one thousand volumes in addition to those bought from the regularly budgeted funds of the college. The student body also voted to give a part of their project funds to the library.

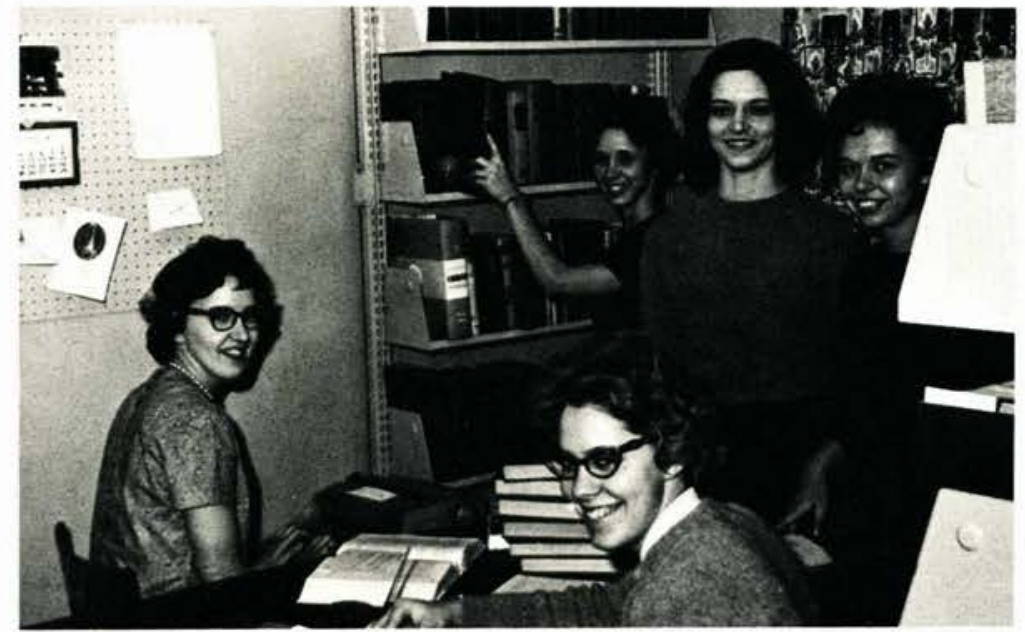

GROUP OF GIRLS - Left to Right: R. O'Keefe, B. Jackson, S. Welch, N. Buerer, M. Jordan.

\section{Library Staff}

Mrs. Alberta Chaffe, Head Librarian
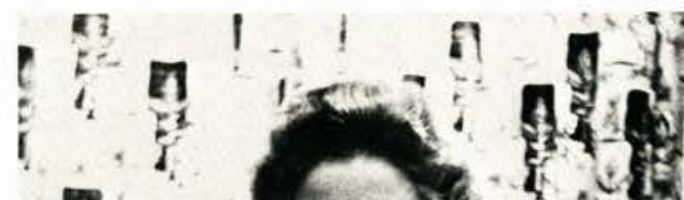

\section{a.}

$$
1 \%
$$
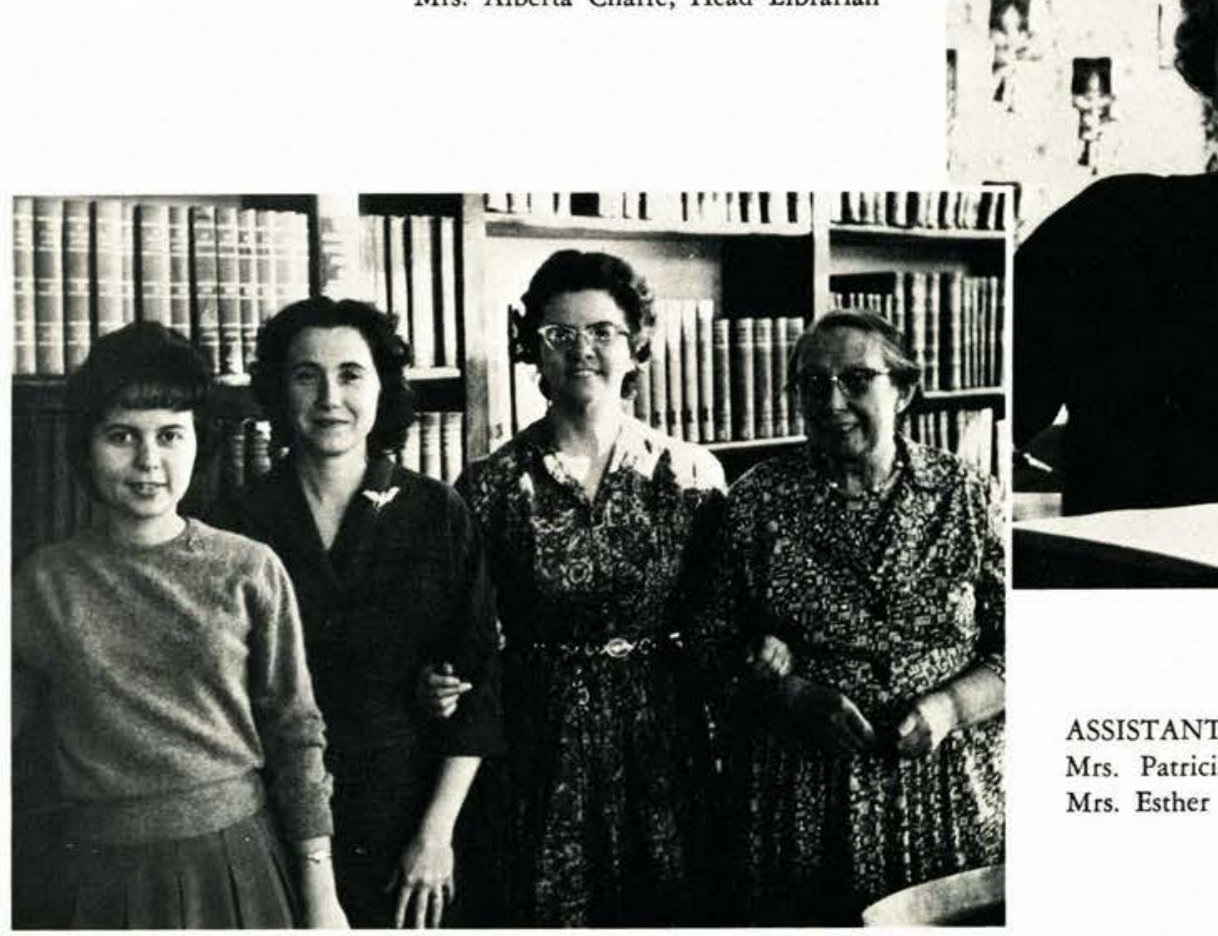

ASSISTANTS - Left to Right: Elaine Jordan, Mrs. Patricia Thornton, Mrs. Virginia Russell, Mrs. Esther Ruder. 
In addition to the daily preparation of food for the student body, the cafeteria staff provides a candlelight buffet style dinner at Thanksgiving and Christmas. This year hostesses have been added to the staff to seat guests and remove student trays.
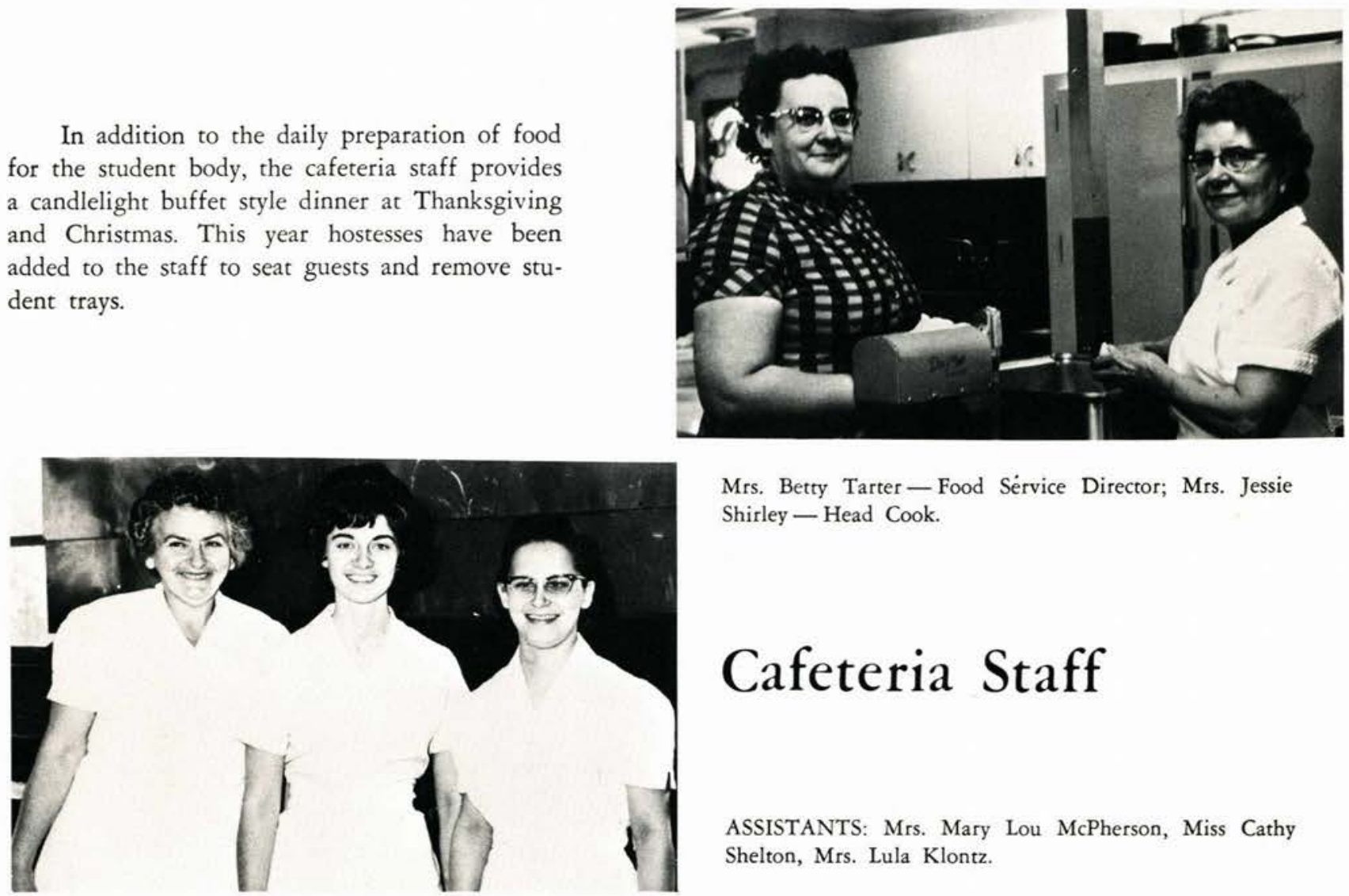

Mrs. Betty Tarter - Food Sérvice Director; Mrs. Jessie Shirley - Head Cook.

\section{Cafeteria Staff}

ASSISTANTS: Mrs. Mary Lou McPherson, Miss Cathy Shelton, Mrs. Lula Klontz.

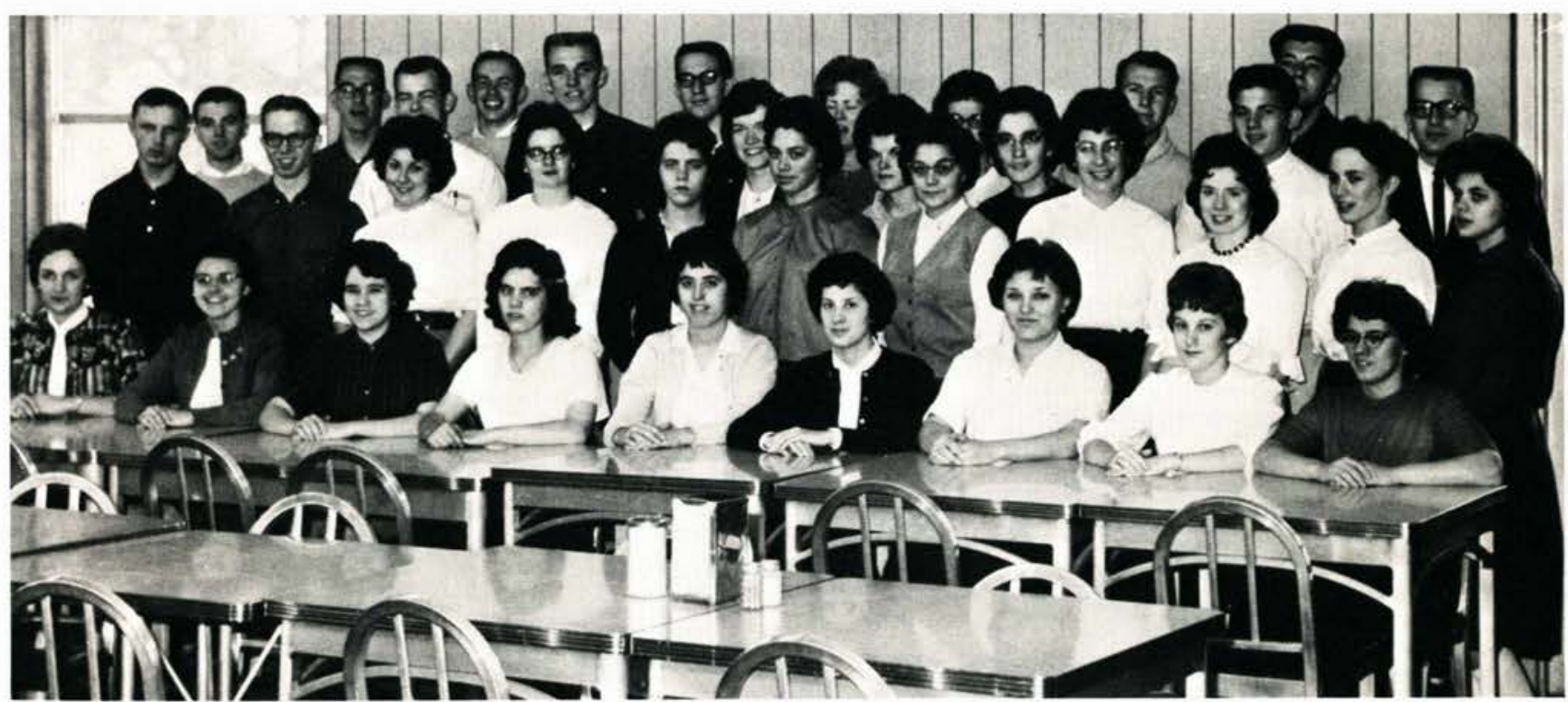

Front Row, Left to Right: D. Roost, P. Schonscheck, J. Scholten, E. Dudley, P. Smith, P. Adams, M. Karsnak, J. Neely, T. Bauer. Second Row: D. Dean, D. Parks, J. Simrell, C. Boren, E. Dudley, M. Finley, D. Finley, S. Johns, J.
Addleman, P. Ronk, L. Morrell. Third Row: N. Nicklas, M. Shingleton, L Czerniak, R. McDugle, D. Werner, D. Rifenberick, P. Bird, S. Brown, L. Martin, S. Bender, J. Bird, P. Grant, C. Copeland, D. Jensen, R. Werner. 


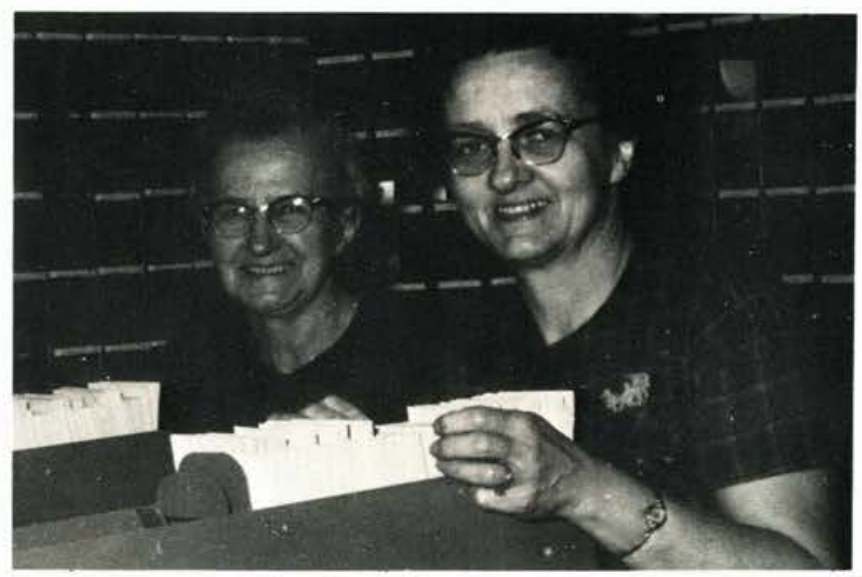

\section{Publications}

Mrs. Underwood, Manager of College Post Office

Mrs. Jeremiah, Publications

Phil Gilmore, Donna Thompson, Anne Halley

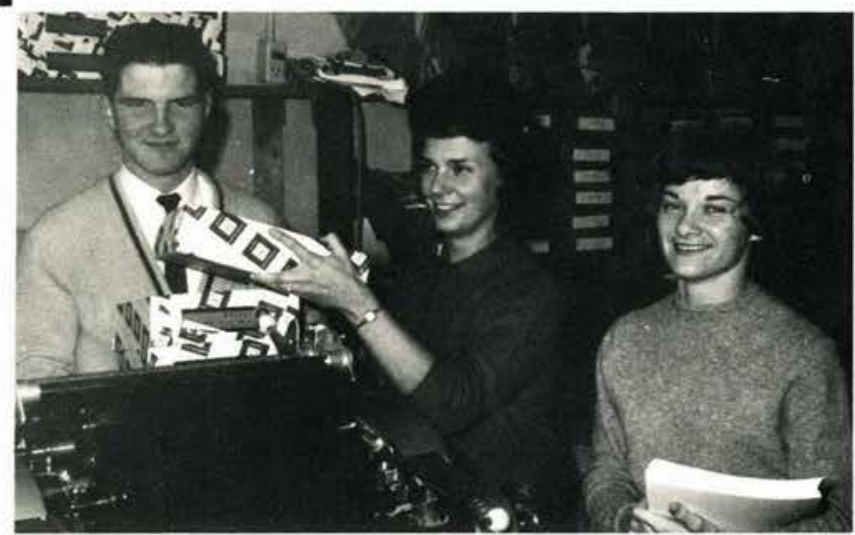

\section{Bookstore Staff}

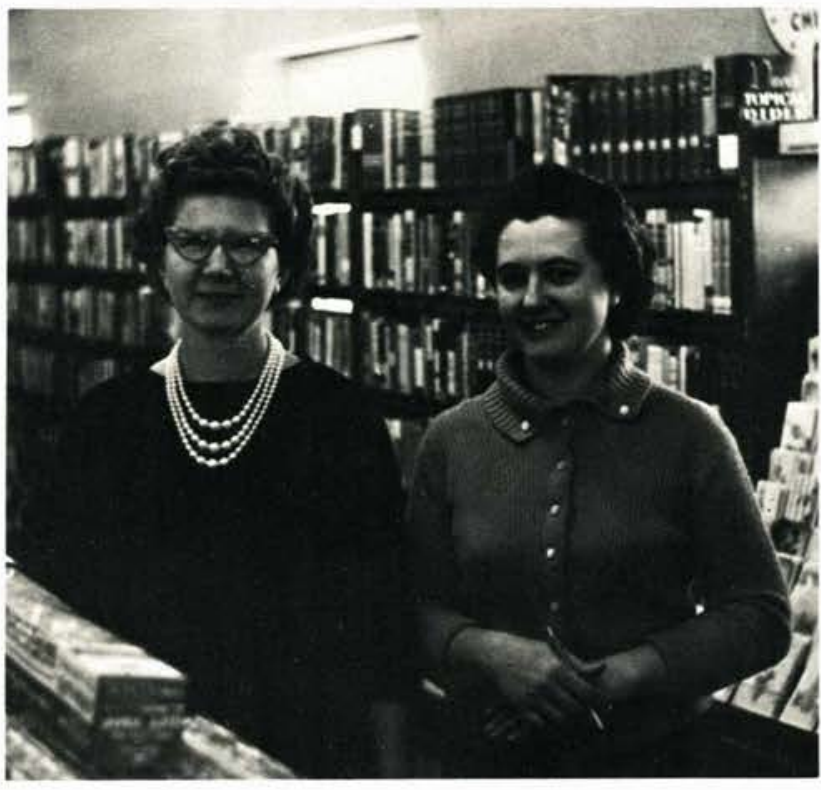

BOOKSTORE: Miss Bernice Mick, Manager; Mrs. Harmon Bergen, Assistant.

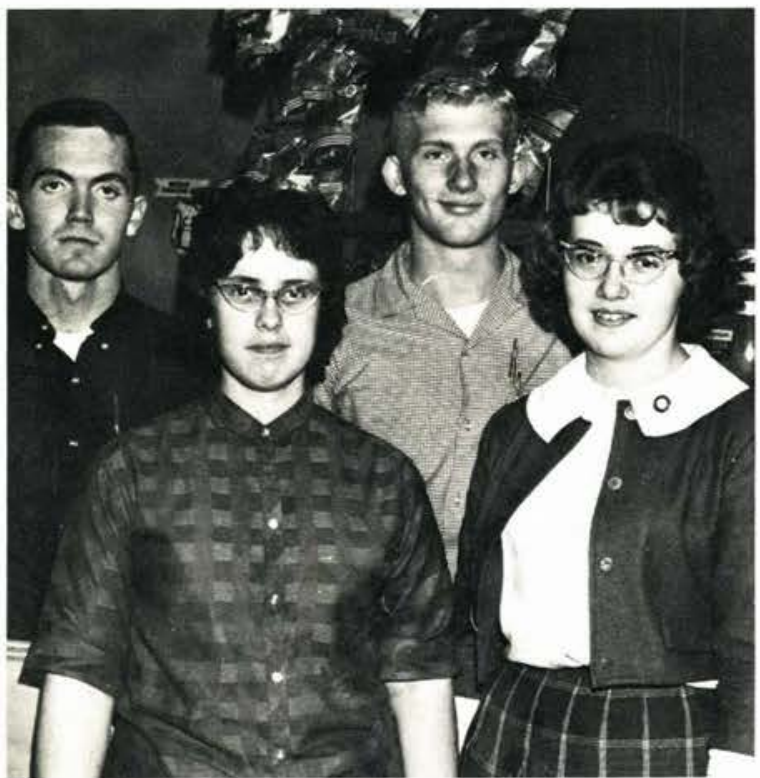

Front Row: E. Howard, C. Coppock. Second Row: D. Bales, V. Roloff. 


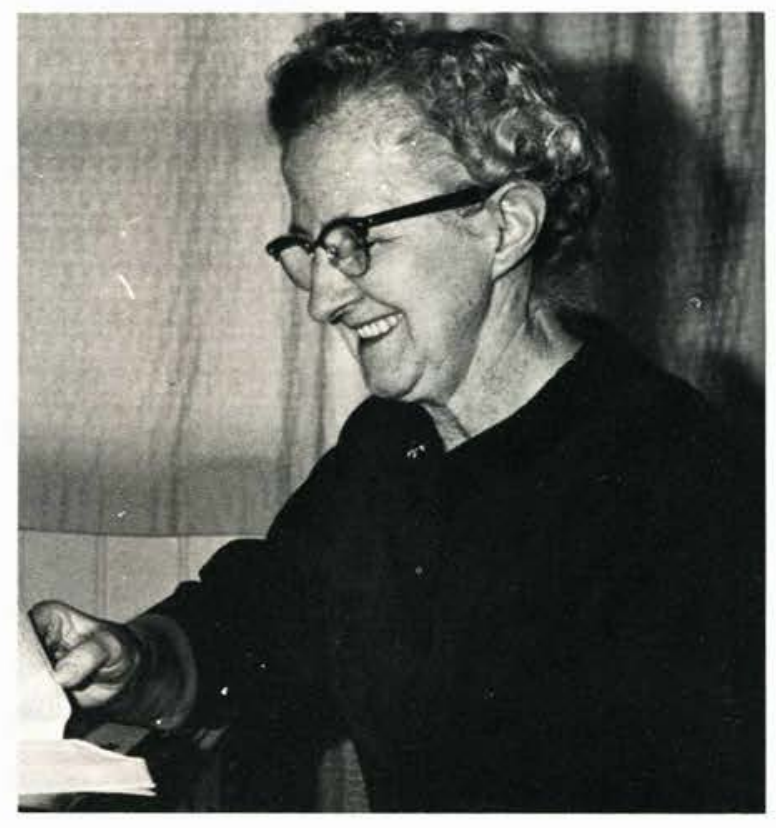

Mrs. Ruth Underwood, Dorm Mother

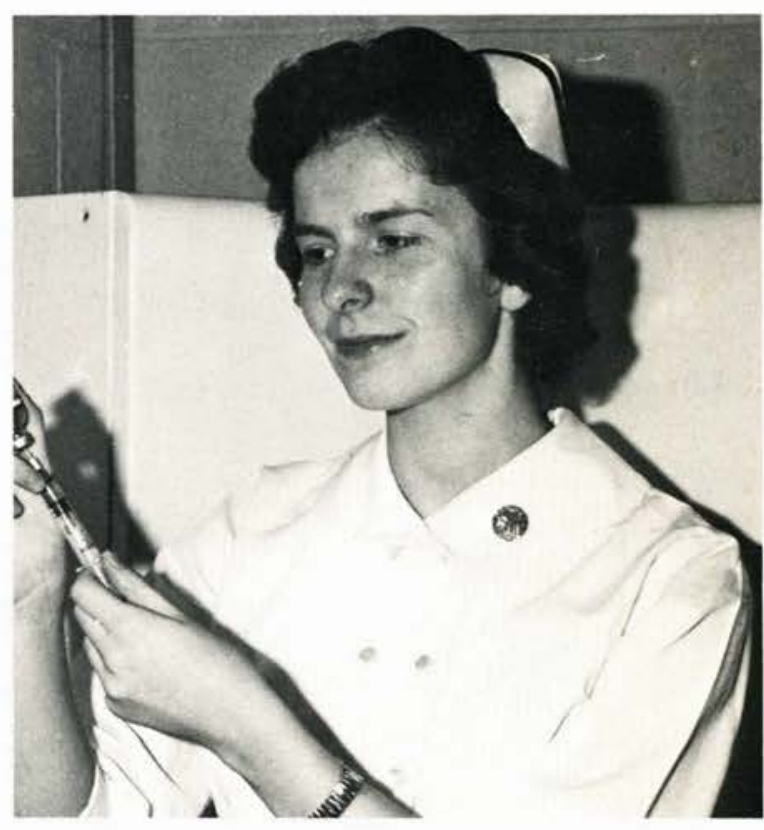

Evelyn Thoms, Nurse

\section{Residence Staff}

Living in the girls' new dorm, Mrs. Underwood serves as house-mother to the girls and oversees the dorm conduct of all the girls there. She also serves on the college discipline committee. Counselors and monitors govern the other dormitories on campus. Staff members keep the dormitories clean. Evelyn Thoms, the school nurse, provides medical care to the students.

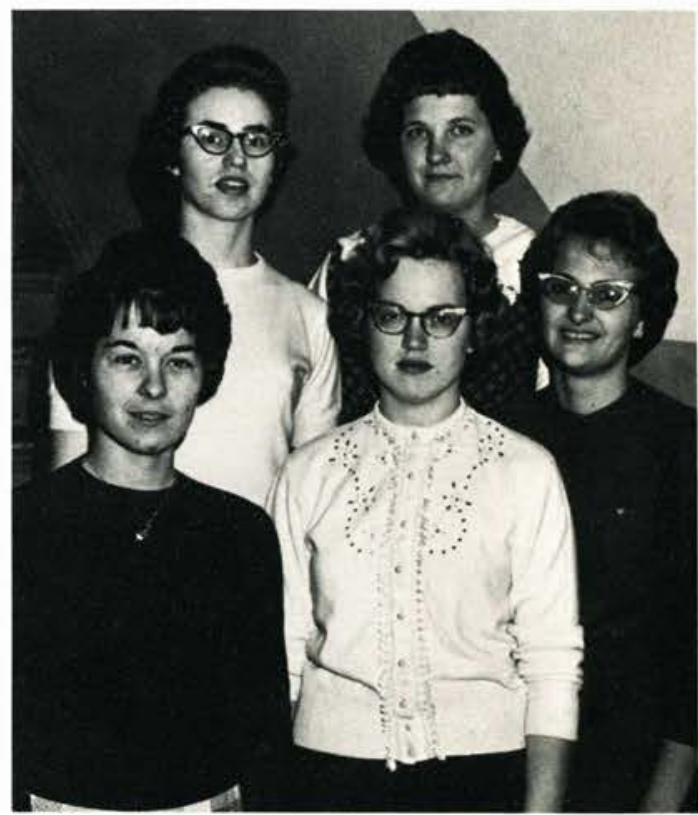

Front Row. Left to Right: J. DuPre, C. Gorthey, P. Quick. Second Row: S. Otto, J. Miller. 


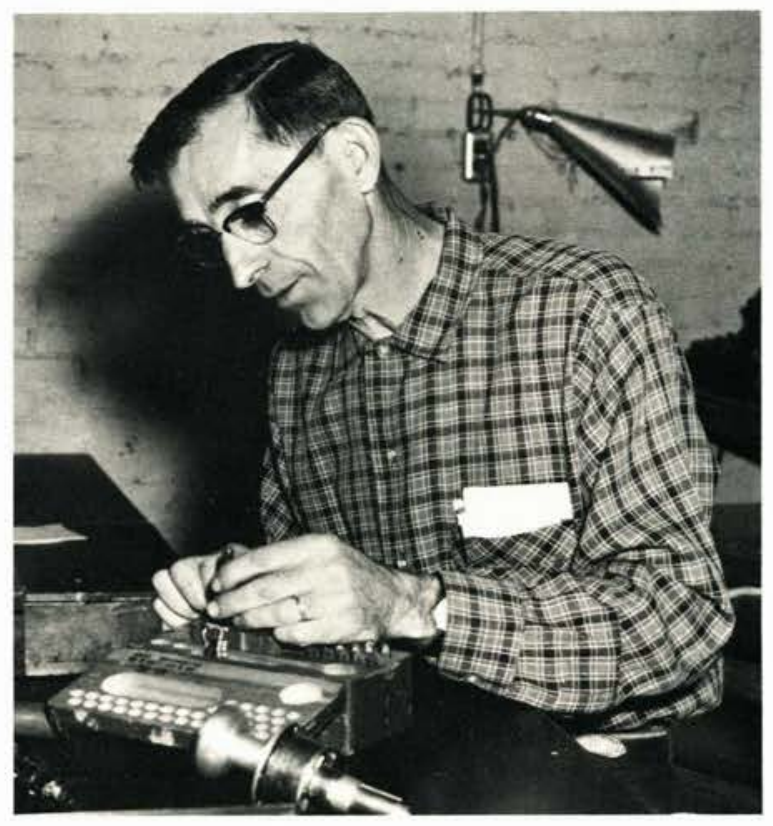

Gerald "Pop" Marshall

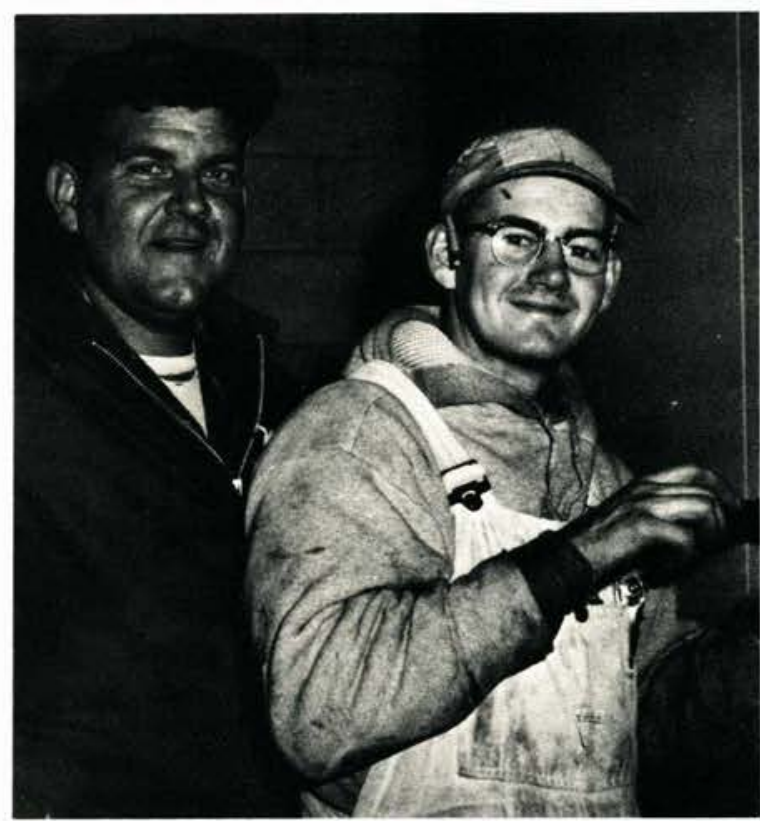

Charles Tarter, Tom Folkrod

\section{Maintenance}

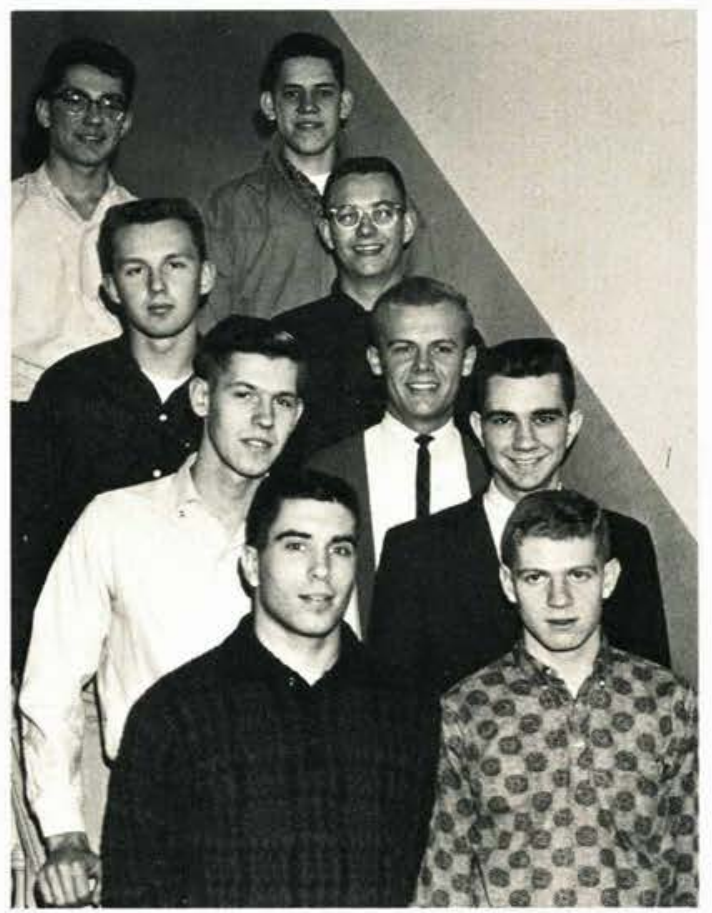

Top Row, Left to Right: D. Norris, M. Ziegler. Second Row: P. Carlson, C. Wilkins. Third Row: D. Taylor, D. Thomas, R. Mathis. Fourth Row: R. Dew, A. Macdonald.
Not only during the school year but also during the summer months the Maintenance Department is kept busy remodeling, repairing, and painting present buildings. Students find employment on the staff by keeping the buildings and campus clean. 
$b_{1}+x_{2}$

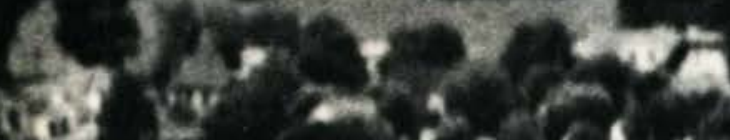

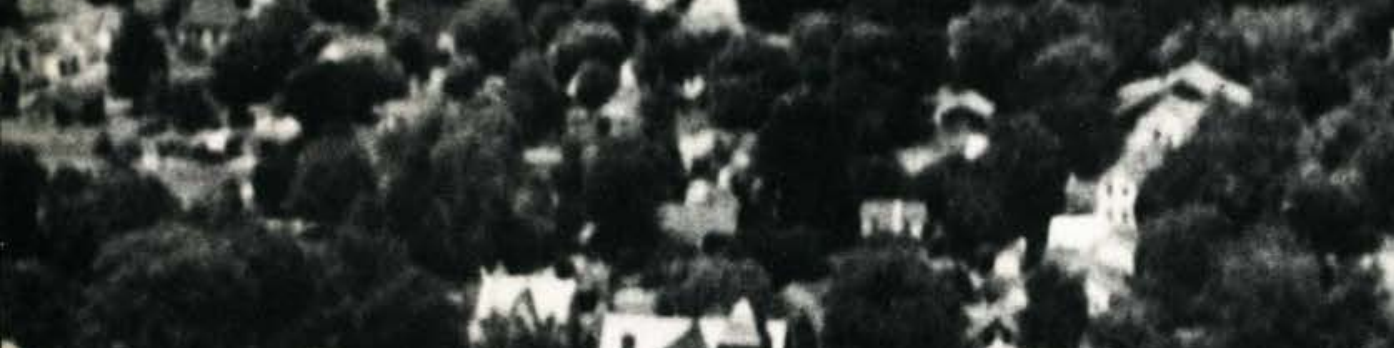

a 5

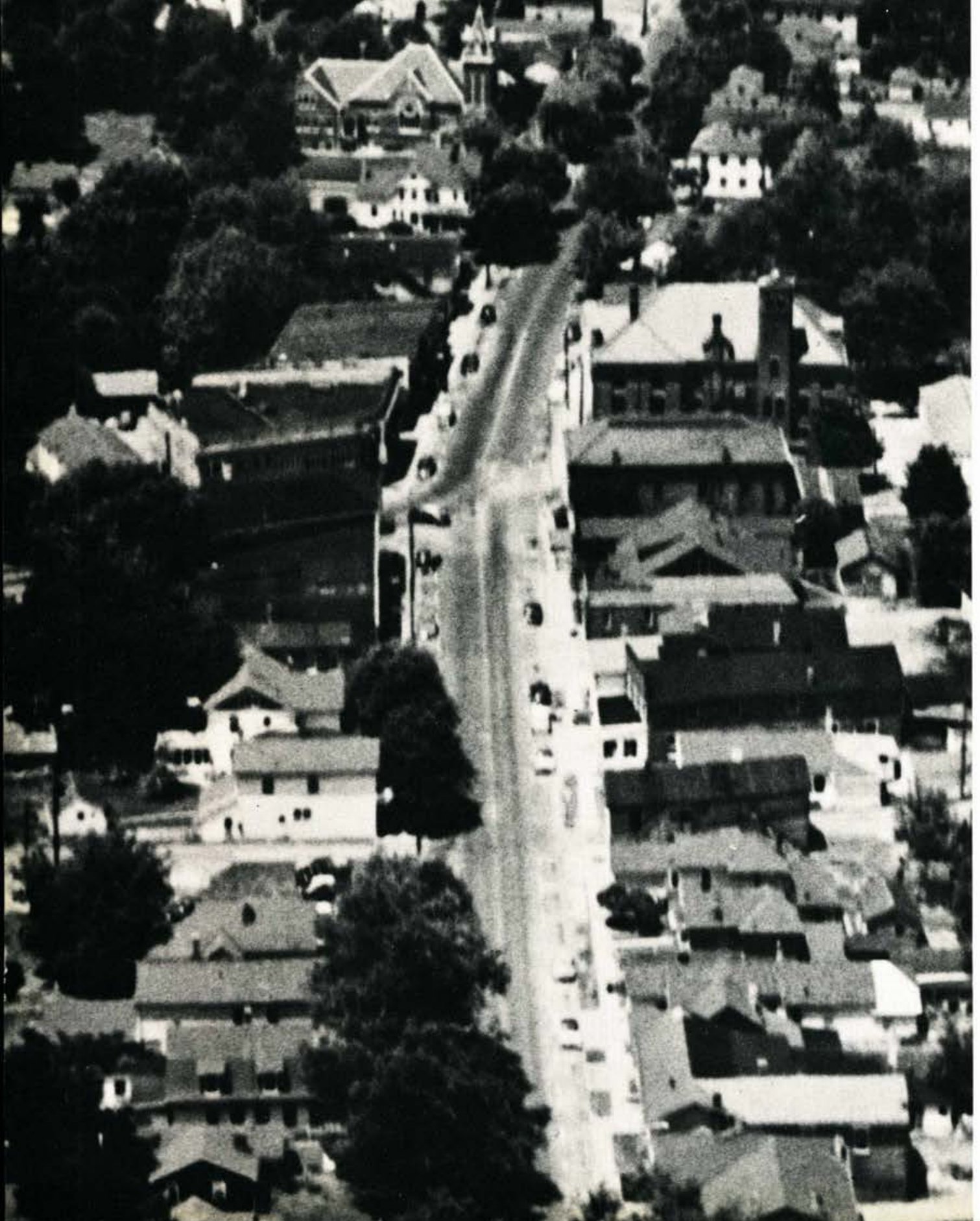


The patrons who readily and faithfully support Cedarville College in its program are those to whom a great deal of our appreciation is directed.

We are indebted to the churches across the nation and their members who have supported the college with their gifts and prayers.

Our gratitude extends also to the community of Cedarville, to those who have shown a friendly and active interest in the functions of the college, and to the local business establishments for their willingness and co-operation.

\section{Patrons}

individuals . . . businesses . . . community . . churches . . . supplying an essential need for Cedarville College. 


\section{FIRST BAPTIST CHURCH}

Third Avenue at Locust Street

Gallipois, Ohio

Rev. Howard G. Young, D.D., Pastor

Mr. Wm. G. Beverage, B.R.E., Min. C. Ed. and Mus.

"In the HEART of the City

with the City on its HEART"

"Not Forsaking the Assembling of Ourselves Together"

You Are Cordially Invited to Attend Our:

Bible School at 9:30 A.M.

Morning Worship at 10:30 A.M.

Young People's Meeting at 6:30 P.M.

Evangel Hour Service at 7:30 P.M.

Prayer Meeting Wednesday 7:30 P.M.

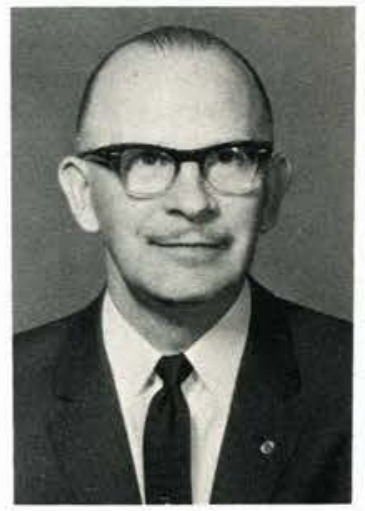

We Preach Christ Crucified, Risen and Coming Again!

\section{CENTRAL BAPTIST CHURCH}

529 Jefferson Street

"In the heart of Gary with Gary on its Heart" Gary, Indiana
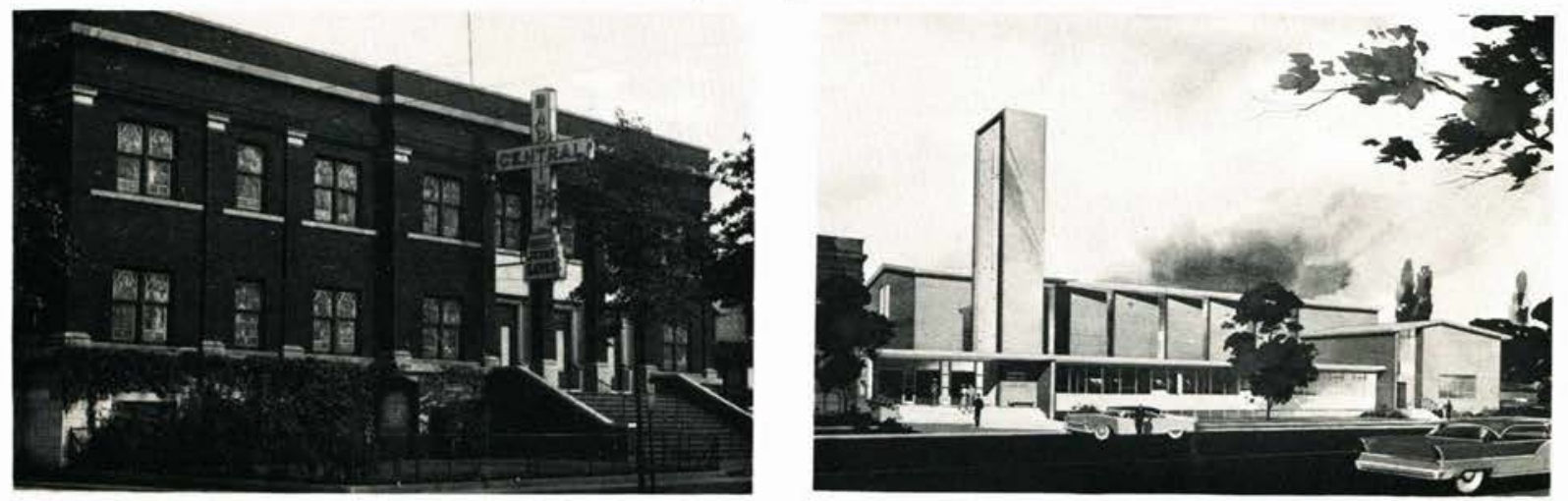

Central Yesterday

Central Tomorrow

\section{Congratulations, '63 Graduates}

Attending Cedarville

from Central:

Paul Carlson

Phyliss Irish

Steve Boalt, B. Mus.

Joanne Neely

Minister of Youth and Music

Al Merwald

Mr. and Mrs. Jim Joiner 
Congratulations from:

\section{THE FIRST BAPTIST $\mathrm{CHURCH}$}

\section{Elkhart, Indiana}

Rev. Hugh T. Hall, D.D., Pastor Rev. Marvin Kanengieter, Youth Pastor A Fundamental, Bible-believing Church in the

Band Instrument Capital of the World.

\section{FIRST BAPTIST CHURCH OF PARMA}

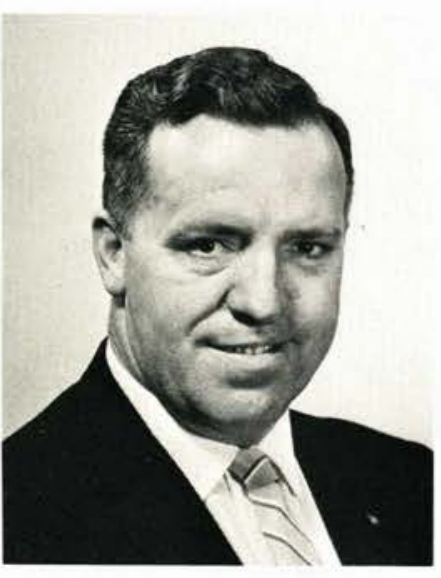

Pastor Elliott

"A Positive Ministry for a Bewildered Age"
5994 Ridge Road

Parma 29, Ohio

Preaching Services

Every Lord's Day

11:00 a.m. and

7:30 p.m.

\section{Congratulations and the Lord's Blessing Upon You, Class of 1963}

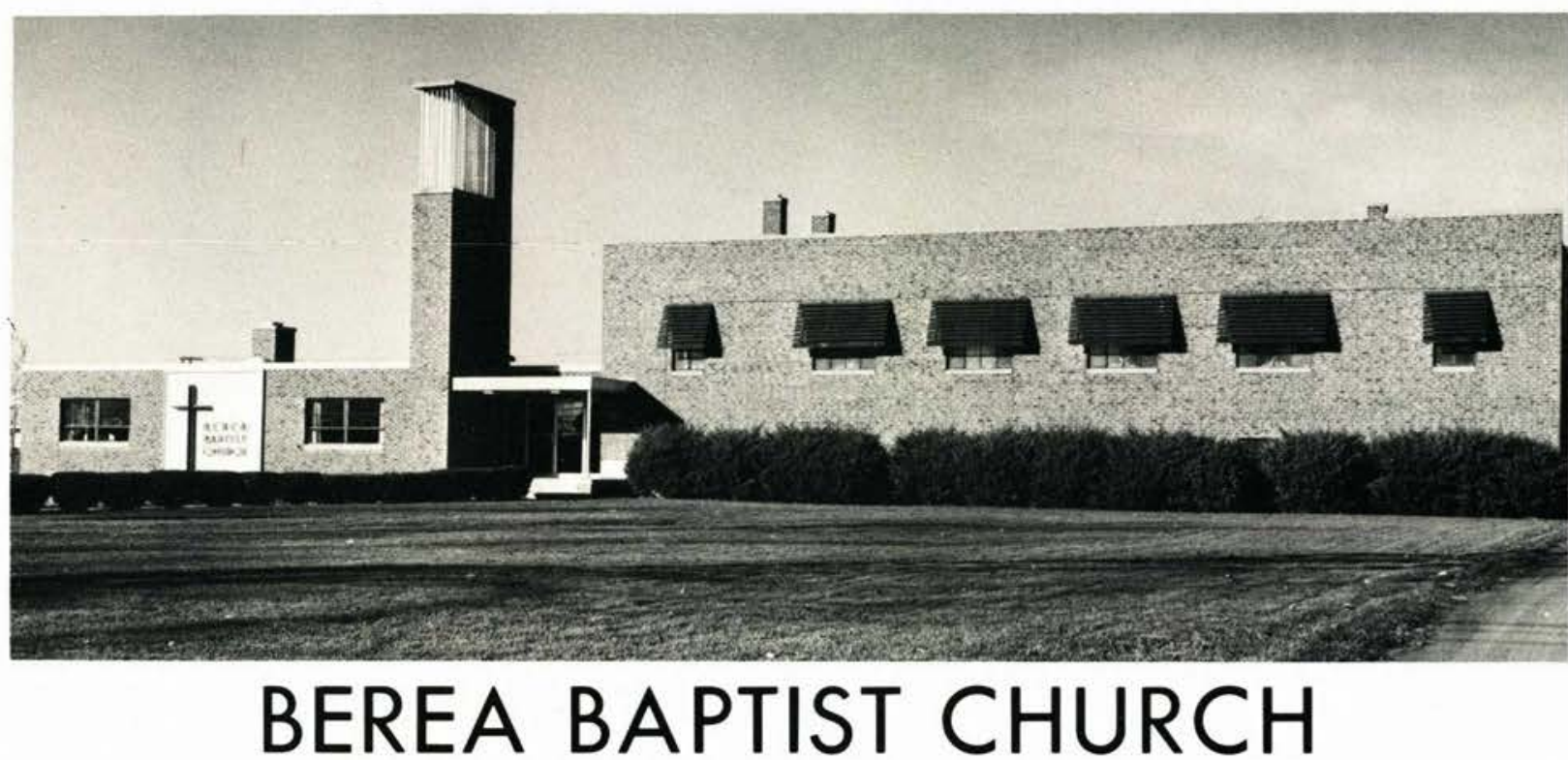

250 West St., Berea, Ohio

NURSERY

FACILITIES
You Are Cordially Invited to Attend Our:

Bible School at

Morning Worship at

Youth Hour at

Evening Worship at

and Wednesday P
Earl V. Willetts, Pastor 9:30 A.M. 10:45 A.M. 6:30 P.M. 7:30 P.M.

AMPLE

PARKING

In Fellowship with the General Association of Regular Baptist Churches 
FIRST BAPTIST

CHURCH

Main at Lawrence Mishawka, Indiana

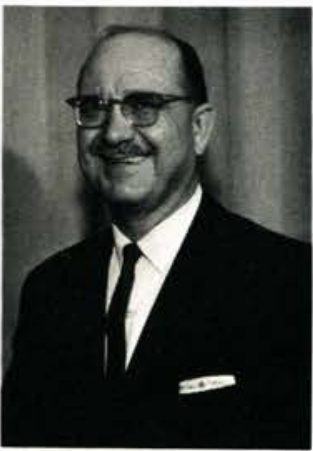

Rev. Roy G. Hamman Pastor

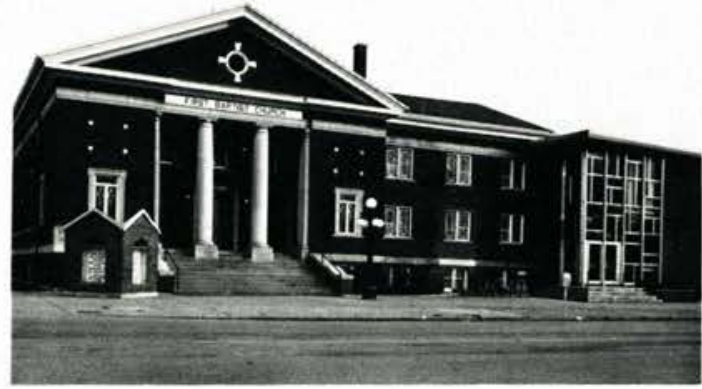

Sunday School 9:25 am.

Morning Worship 10:30 a.m.

5 Youth Groups 6:30 p.m.

Evening Service 7:30 p.m.

Wed. Victory Hour 7:30 p.m.

8 Graded Choirs 8:30 p.m.

"Radio and Telephone Ministries"
"The Bible as it is for men as they are."

THURS. VISITATION

6 P.M.

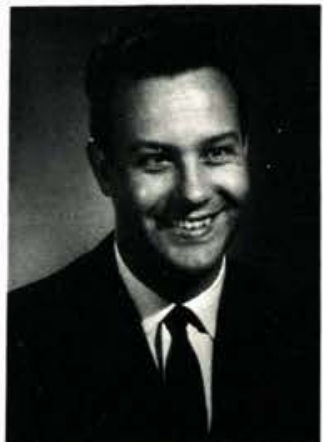

Rev. Robert C. Messner Education, Music and Youth

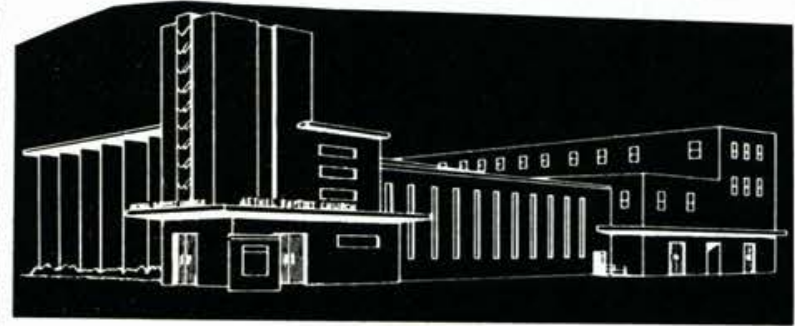

\section{A CHRIST-CENTERED PROGRAM}

- Teaching the Whole Bible Graded Sunday School for All Ages

- Preaching the Gospel of Christ Worship Services, Gospel Hours

- Practicing the Power of the Gospel Midweek Praise and Prayer Hour

- Promoting the Universal Gospel Appeal Worldwide Missionary Program

- Preparing for a Life of Usefulness Youth Training and Activities
You Are Always Welcome at the

\section{GRANDVIEW}

\section{PARK BAPTIST CHURCH}

1701 E. 33rd Street Des Moines 17, lowa

Carl E. Elgena, D.D., Pastor

Jack Payne, B. Mus.

Minister of Music and Youth

Regular Services for Each Lord's Day

\section{GRACE BAPTIST CHURCH}

Salem and Elliot Street Springfield, Mass.

Bible School-9:30 A.M.

Morning Worship-10:30 A.M.

Youth Hour-6:00 P.M.

Evening Service-7:00 P.M.

Mid-Week Service-Wednesday at 7:30 P.M.

David Nettleton, Pastor

"Holding forth the word of life." 


\section{FIRST REFORMED CHURCH}

Detroit and Church Streets

$$
\text { Xenia, Ohio }
$$

Russell Mayer, Pastor

\section{FIRST BAPTIST CHURCH}

Medina, Ohio

Just Off Square on W. Liberty

$$
\text { Invites You: }
$$

Bible School 9:45-Worship 10:55

Youth Groups 6:00 (June, July, Aug.) 6:30

Evening 7:00 (June, July, Aug.) 7.30

Prayer Meeting, Wednesday 7:30

R. Kenneth Smelser, Pastor

\section{We Desire the Lord's Blessing for the Graduates of 1963}

Calvary Baptist Church

Cresaptown, Maryland

Pastor Harold Allen

First Baptist Church of Milford

Corner of 601 Union and Detroit Sts.

Milford, Michigan

\section{Emmanuel Baptist Church}

Marion, Ohio

Dr. Clement E. Hershey

\section{Windsor Village Baptist Church}

2151 N. Kitley Avenue

Indianapolis 18, Indiana

\section{First Baptist Church}

518 North Street

Caldwell, Ohio
The First Baptist Church

114 W. Walnut Street

Galion, Ohio

Calvary Baptist Church

Forest City, lowa

Dr. M. K. Hotcum

\section{First Baptist Church}

Harrison, Michigan

Rev. Donald Chapel

Mt. Tabor Baptist Church

Rt. 3, Box 282

Beckley, West Virginia

Tuma-Mesa Baptist Church

24th Street at Carole Ave.

Yuma, Arizona 


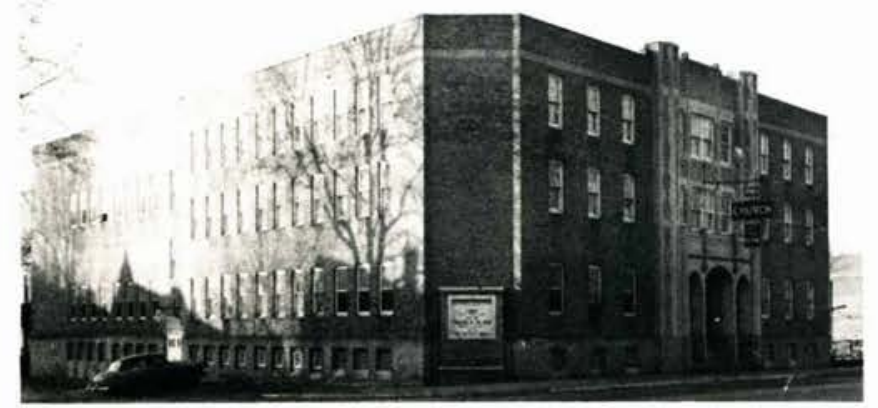

Sincere

Best Wishes

to the Class of ' 63

\section{TEMPLE BAPTIST CHURCH}

\section{Portsmouth, Ohio}

Rev. Robert L. Sumner, Pastor

Rev. Thomas D. Bunyan, Minister of Music

Rev. Billy Carl Rice, Minister of Visitation

\section{Sunday Services}

9:15 A. M. Bible School

10:30 A. M. Morning Worship

Broadcast over WNXT, Portsmouth (1260 on your dial)

5:30 P. M. Broadcast over WPKO, Waverly, Ohio

6:30 P.M. Youth Groups

7:30 P.M. Evening Service

9:30 P.M. Delayed broadcast of evening service over WNXT, Portsmouth

"TIMELY TRUTHS FOR TRYING TIMES"

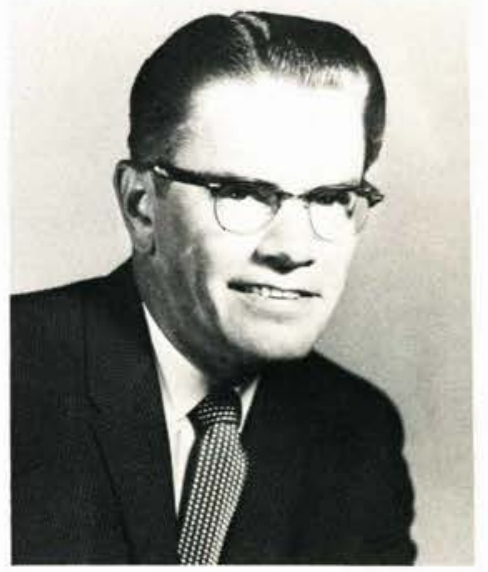

TEACHING AND PREACHING THE WHOLE WORD OF GOD Calvary Baptist Church - Covington, Ky.

Warren W. Wiersbe, Pastor

"All Scripture is given by inspiration of God, and is profitable..."

II Tim. 3:16

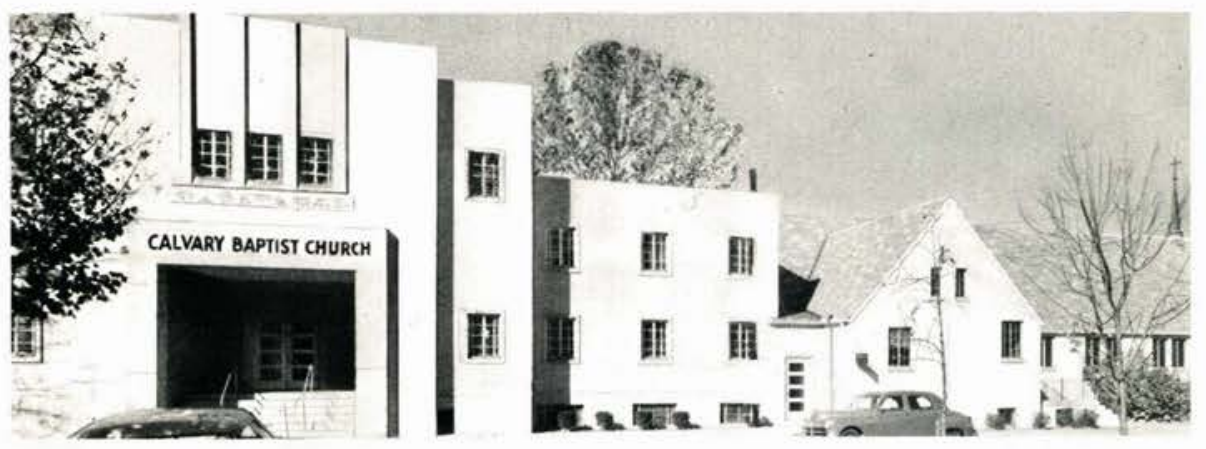

* Home of "The Whole Bible Study Course" founded by Dr. D. B. Eastep, for 35 years pastor of Calvary Baptist Church.

* Home of the Calvary Book Room, distributors of dependable Bible study literature, and publishers of exclusive titles by Arthur Pink, D. B. Eastep, and A. C. Dixon.

* Home of the Calvary Bible School, where, Sunday by Sunday, the whole Word of God is taught book by book and chapter by chapter, over a period of seven years.

For a free book list and information about "The Whole Bible Study Course," write

\section{CALVARY BAPTIST CHURCH}

Latonia Station - Covington, Kentucky

"The church with a heart . . in the heart of Latonia"
"Man sholl not live by bread alone, but by every word that proceedeth out of the mouth of God."

Mt. $4: 4$ 


\section{CALVARY BAPTIST $\mathrm{CHURCH}$}

Oaklawn at Davis

Ypsilanti, Michigan

M. Donald Currey, Pastor 12 S. Summit

9:45 A. M. Sunday School

11:00 A. M. Worship Service

11:00 A. M. Primary Church

6:30 P. M. Training Union

7:30 P. M. Good News Service

7:30 P. M. Prayer Service, Wednesday

In Fellowship with GARBCC, ICCC, ACCC

\section{CEDAR HILL \\ BAPTIST CHURCH}

12601 Cedar Road

Cleveland, Ohio

Rev. John G. Balyo, Pastor

CHRIST CENTERED, BIBLE BASED, LIFE RELATED

Attending Cedarville from Cedar Hill

$\begin{array}{ll}\begin{array}{l}\text { Janice Amos } \\ \text { Martha Bennett }\end{array} & \begin{array}{l}\text { Steve Nimmo } \\ \text { Phyllis Ripko } \\ \text { Mirian Farrow }\end{array} \\ \begin{array}{l}\text { Jon Walborn } \\ \text { David Fetzer }\end{array} & \text { Judy Walborn } \\ \text { Polly Leunk } & \\ \text { ON THE AIR EVERY SUNDAY } \\ \text { 8:30 A.M., WGAR, } 1220 \text { kc A.M. } \\ \text { 99.5 Meg. FM } \\ \text { 7:30 P.M., WDOK, } 1260 \text { kc A.M. }\end{array}$

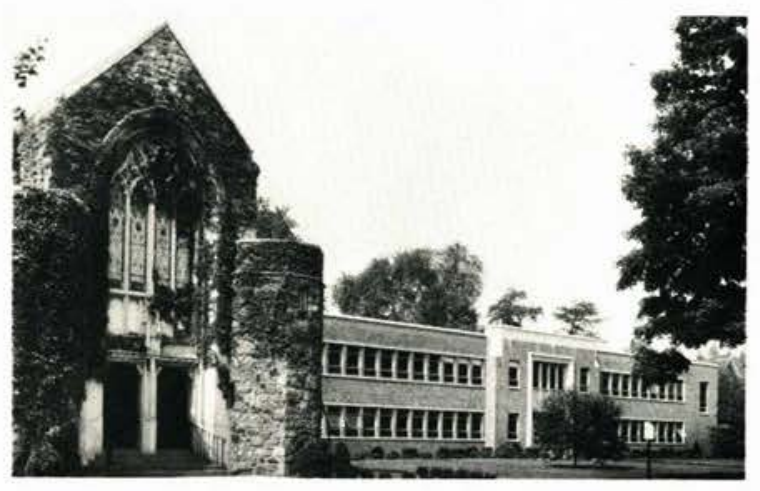

\section{FIRST BAPTIST \\ $\mathrm{CHURCH}$}

Anderson Park

Hackensack, N. J.

Joseph M. Stowell, M.A., D.D., Pastor

Charles S. Wilkes, M.S., Minister of Music

Warren E. Simmons, B.R.E.,

Christian Ed. Director

We Believe God Has a Great Future for Cedarville

\section{CLINTONVILLE BAPTIST CHURCH}

35 Oakland Park Avenue

Columbus 14, Ohio

Founded on THE WORD OF GOD Grounded in THE WORD ǪF GOD Bounded in THE WORD OF GOD Glenn H. Davis, Pastor 
Congratulations to the Class of ' 63

\section{CEDARVILLE COLLEGE BOOK STORE}

Student Supply Center

Bernice Mick, Manager

\section{STEAMBURG UNION CHURCH}

Steamburg, New York

Rev. Harley E. Acker, Pastor

\section{STANDISH \\ BAPTIST CHURCH}

Standish, Michigan

109 N Grove

Rev. Eugene Bragg, Pastor

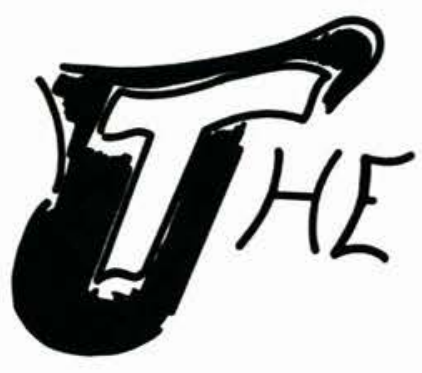

STUDENTS'

$\mathrm{CHURCH}$ SERVICES

Church Worship 8:30 and 11:00 A.M. Evangelistic Hour 7:30 P.M.

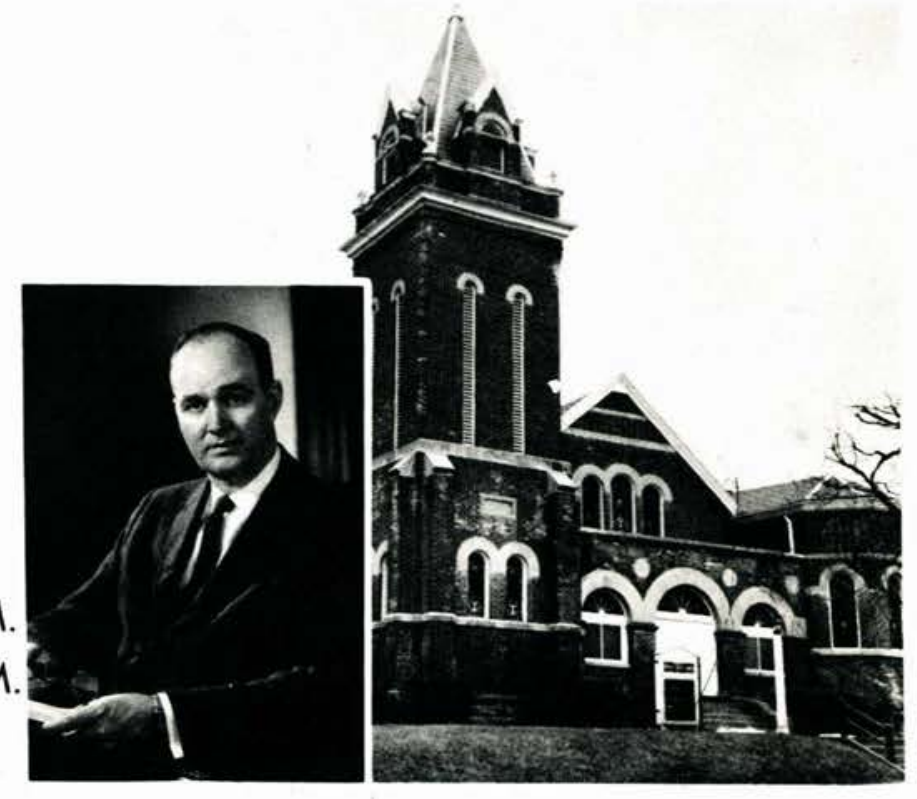

\section{GRACE BAPTIST CHURCH}

Cedarville, Ohio 


\section{CONGRATULATIONS TO THE CLASS OF '63}

Ray Cox Insurance

127 E. Main

Xenia_-DR. 2-7666

Montgomery Ward

$45 \mathrm{E}$. Main

Complete Department Store

\section{Corner Pharmacy}

Detroit and Main

"Three Decades of Service"

\section{Reece Paint and Wallpaper}

Co.

36 E. Main Street

Xenia, Ohio

\section{Eichmans Appliance}

52 W. Main Street

Xenia, Ohio

Nilson-Bone Florists

44 W. Main Street

DR. 2-4211

\section{Main Auto Supply}

28 W. Main Street

"Everything for the Car and Home"

Sherwin-Williams Co.

10 North Detroit Street

"Free Delivery"

\section{Xenia School and Office} Supply

35 Greene Street

Dollar Value

33 Green Street-Xenia

6 Washington-Jamestown

\section{Cedar Cliff Beauty Salon}

19 S. Main Street

Cedarville, Ohio
Rogers Jewelry

22 S. Detroit

DR. 2-7681

The Card Shop

Hallmark Cards and Gifts

5 E. Main Street

Del'Abar Hardware

"The Hardware Center of Xenia"

24 S. Detroit Street

Xenia Area Chamber of Commerce

Your Partner in Business

Wishes Your Success

Cherry's Furnishings

36 W. Main Street

372-3579

\section{Hurley's Florists}

21 Green Street

372-8871

\section{Seifert Sohio Station}

Detroit and Market Sts.

Xenia, Ohio

Ehrhart Sports Center

42 West Main Street, Xenia

DR. 2-2301

Band Box Music Store

31 W. Main Street

Xenia - Fairborn

\section{Modern Shoe Repair Shop \\ 25 W. Main \\ Xenia, Ohio}

\section{Book and Bible Supply}

53 South Detroit Street
Chics Barber Shop

Cedarville, Ohio

Central Barber Shop

31 E. Main

Jerry - Gary — Phil

I. T. Pizza House

122 E. Main

Pizza As You Like It

Daum and Son

120 S. Detroit Street

DR. 2-5231

Anchor Paint Store

$33 \mathrm{~W}$. Main

Xenia, DR. 2-0785

\section{Camera Shop}

22 W. Main

\section{Xenia Gazette}

"Growing with All Green County"

Geyers Restaurant

15 W. Main St.

Xenia, Ohio

Tiffany Jewelry Store

65 Detroit Street

Hamilton, Bulova, Craton Watches

\section{Home Furniture}

52 E. Main

Xenia, Ohio

Braun's Jeweler's

Registered Jeweler

Xenia, Ohio

Dutch Oven Bakery

30 N. Detroit

"Baked Today and Sold Today" 


\section{HADDON HEIGHTS BAPTIST CHURCH}

Third and Station Aves.

Haddon Heights, New Jersey

"Holding Forth the Word of Life"

Rev. Kenneth W. Masteller, Pastor

Laurence E. Smith, Minister of Christian Education

Sunday

-Weekly Schedule of Events-

9:45 A.M.-Bible School (Departmentalized and Graded for AII)

11:00 A.M.-Morning Worship Service

6:30 P.M.-Six Thriving Youth Groups Convene

7:30 P.M.-Gospel Service

Monday

7:45 P.M.-Visitation Program

Wednesday

8:00 P.M.-Prayer Meetings (Youth and Adults)

\section{Friday}

7:30 P.M.-Fun Night for Youth

Saturday

All Day Recreation Program in Recreation Room

\section{EUCLID-NOTTINGHAM BAPTIST CHURCH}

God's Choicest Blessings

on Each of You from the

18901 Lake Shore Boulevard

Euclid 19, Ohio

Rev. George E. Huffman, Pastor

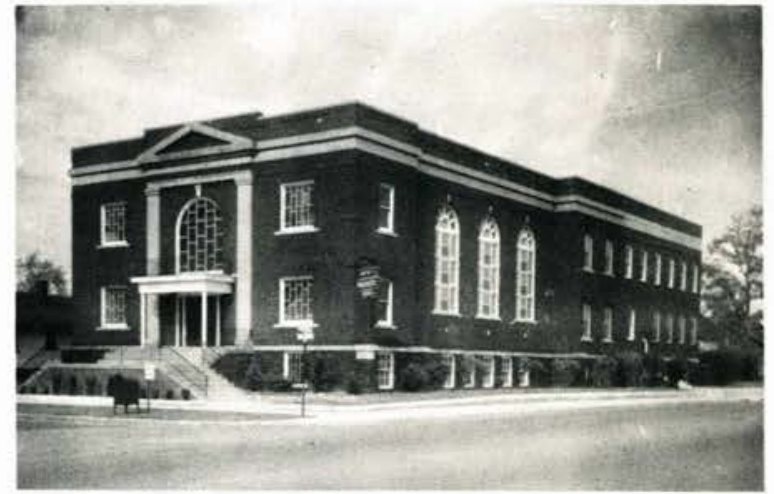

\section{RIVERSIDE BAPTIST CHURCH}

Decatur, Illinois

George A. Bates, Pastor Helen Lapp, Pastor's Secretary Dale Williams, Youth Director

"As my Father hath taught me, I speak these things ... for I do always those things that please Him."

Jesus Christ 


\section{THE CRITERION}

Xenia, Ohio

Men's Clothing and Furnishings

Varsity Town - Arrow - MacGregor

Freeman - Palm Beach — Stetson

\section{HOAK'S GREENHOUSE}

Greenhouses and Nursery

Fairborn, Ohio

FLOWERS FOR ALL OCCASIONS

Phone $87-8621$ or $87-8453$
Follow College Activities

on Your Campus Station

WCDR-FM

$88.1 \mathrm{mc}$.

Cedarville, Ohio

David Jeremiah, Station Manager

Paul Gathany, Chief Engineer

\section{IRVIN DAIRY ISLE}

North Main St.

Ice Cream

Sandwiches

Sodas
Cedarville, Ohio Soft Drinks Candy Sundaes

\section{CONGRATULATIONS TO THE \\ CLASS OF 1963}

FROM

THE

\section{MIRACLE STAFF}


FIRST BAPTIST

\section{$\mathrm{CHURCH}$}

221 Newcastle Street

Butler, Pennsylvania

RALPH O. BURNS, Pastor

The Church Home of Four Cedarville Students

\section{IMMANUEL BAPTIST CHURCH}

3417 Palmetto at Derrer Road Columbus, Ohio

WILLIAM A. BROCK, Pastor

\section{BLESSED HOPE BAPTIST CHURCH}

315 S. Kensington Place Springfield, Ohio

Glenn Greenwood Pastor

\section{SUNDAY SERVICES}

9:30 Sunday School

10:45 Morning Worship

6:15 Youth Groups

7:15 Evening Service

Midweek Prayer Hour-

Wednesday, 7:30

RADIO MINISTRY

7:30-8:00 Sunday Evening WIZE-1340 kc.

6:45-7:00 P.M., Mon. thru Fri.

WEEC-FM- $100.7 \mathrm{mg}$.

7:30 P.M., Mon. thru Fri.

WCDR-FM-88.1 $\mathrm{mg}$.

BROWN STREET BAPTIST CHURCH

3125 Brown Street Alton, III.

BIBLE-believed CHRIST-centered MISSION-minded

Gaylard S. Hamilton, Pastor

Bible School

Worship

Training Union

Evening Service

Wednesday Prayer

CONGRATULATIONS

$A N D$

GOD'S RICH BLESSINGS UPON YOU

FROM

\section{FIRST BAPTIST CHURCH \\ 120 Main Street}

Hamburg, New York 


\section{CONGRATULATIONS}

TO THE

CLASS

of 163

FROM

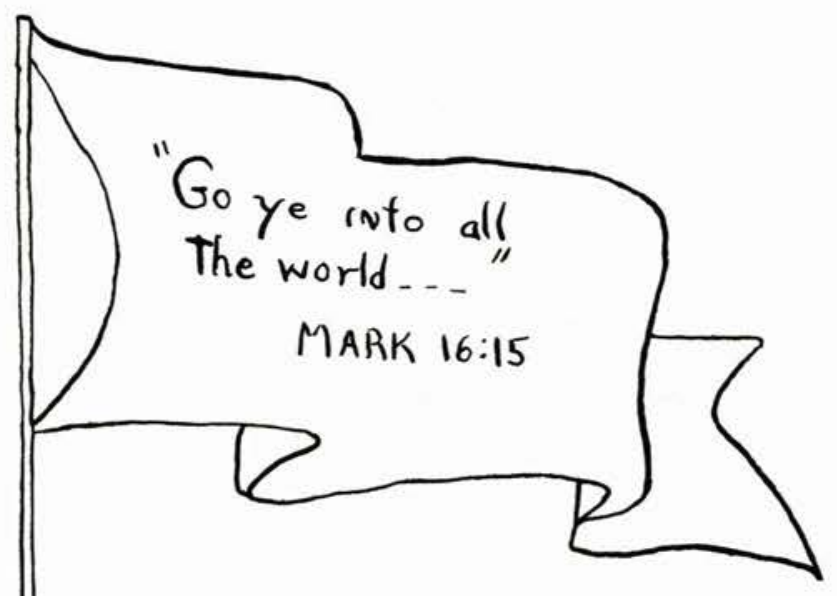

THE CLASS 


\section{CONGRATULATIONS \\ CLASS OF 1963 \\ CEDARVILLE COLLEGE ALUMNI \\ ASSOCIATION}

\section{PORTRAITS - WEDDINGS \\ GROUPS \\ ART COX \\ STUDIOS}

210 Weaver St., Xenia, Ohio

DR 2-1241

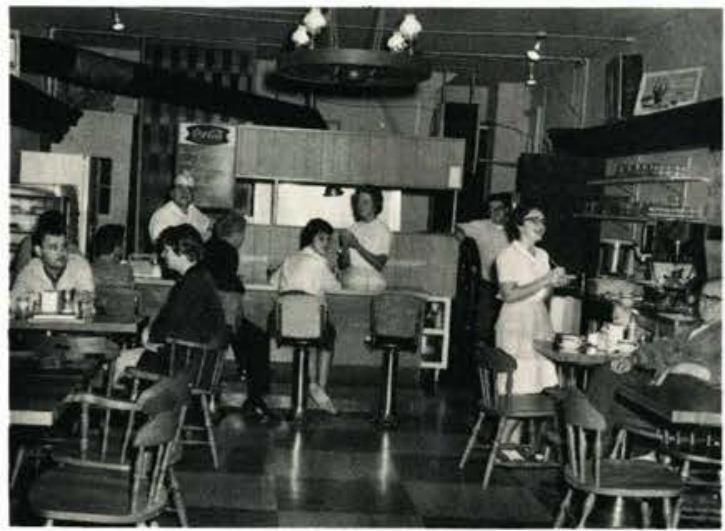

\section{BIG WHEEL RESTAURANT}

N. Main

Cedarville, Ohio

Phone: 766-5220

"Enjoy your food in the rustic atmosphere of the BIG WHEEL." 


\section{HARNER'S \\ CEDARVILLE MARKET}

Compliments of

CEDARVILLE HARDWARE

Progressive Hardware Service

Cedarville, Ohio

Phone 766-1941

Your GE Appliance Dealer

Meats

Produce

Groceries

Phone 766-1201

Cedarville, Ohio

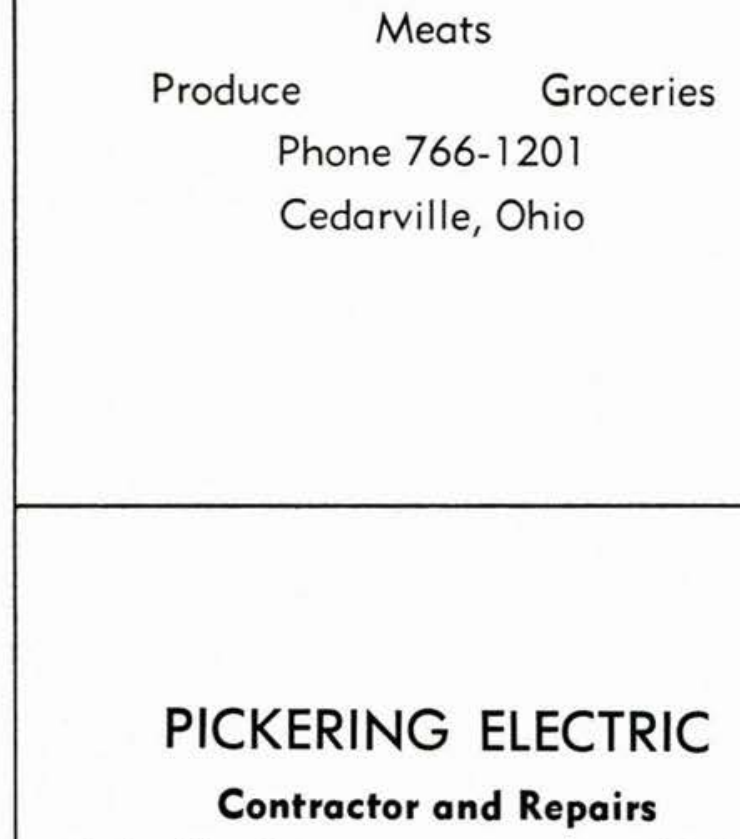

Cedarville, Ohio

$766-5191$

\section{"JAMES" REXALL STORE}

Cedarville, Ohio

42 N. Main

Phone: 766-1771

\section{CEDARVILLE}

\section{VARIETY STORE}

Berkshire Hose

Forget-Me-Not Cards and Wrapping

N. Main Street

Phone: 766-5126

\section{CEDARVILLE}

\section{FEED \& GRAIN}

Grain, Feed, Seed, Coal, Salt,

Wool, Fertilizer,

Builders' Supplies and Fencing

Cedarville, Ohio

Phone: 766-2021

\section{LEACH QUICK WASH}

\author{
Self-Service \\ 24-Hour Service \\ Cedarville, Ohio
}

E. Xenia St.

Behind Firehouse

Phone: 766-5186 


\section{NOW! \\ Enjoy the Finest \\ in Dairy Products . . . Produced \\ in Springfield's Most Modern Self-Serve \\ Home-Owned Dairy!}

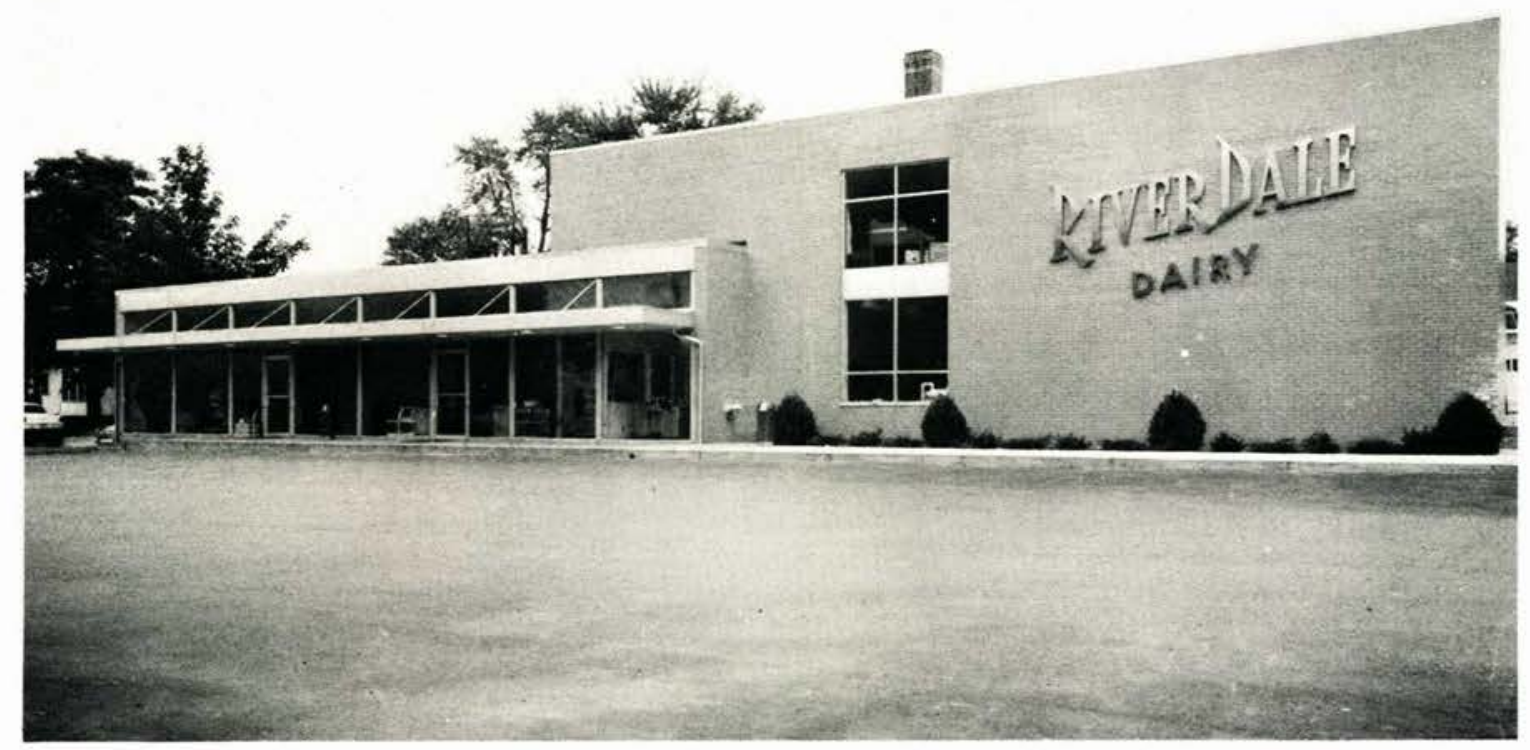

BUT WHERE YOU SAVE

Springfield's Home-Owned, Home-Operated

\section{PARTY SLICES}

Corner Selma Road and Oak Street

Open Daily 8 A.M. till 9 P.M. Plenty of Parking Space 


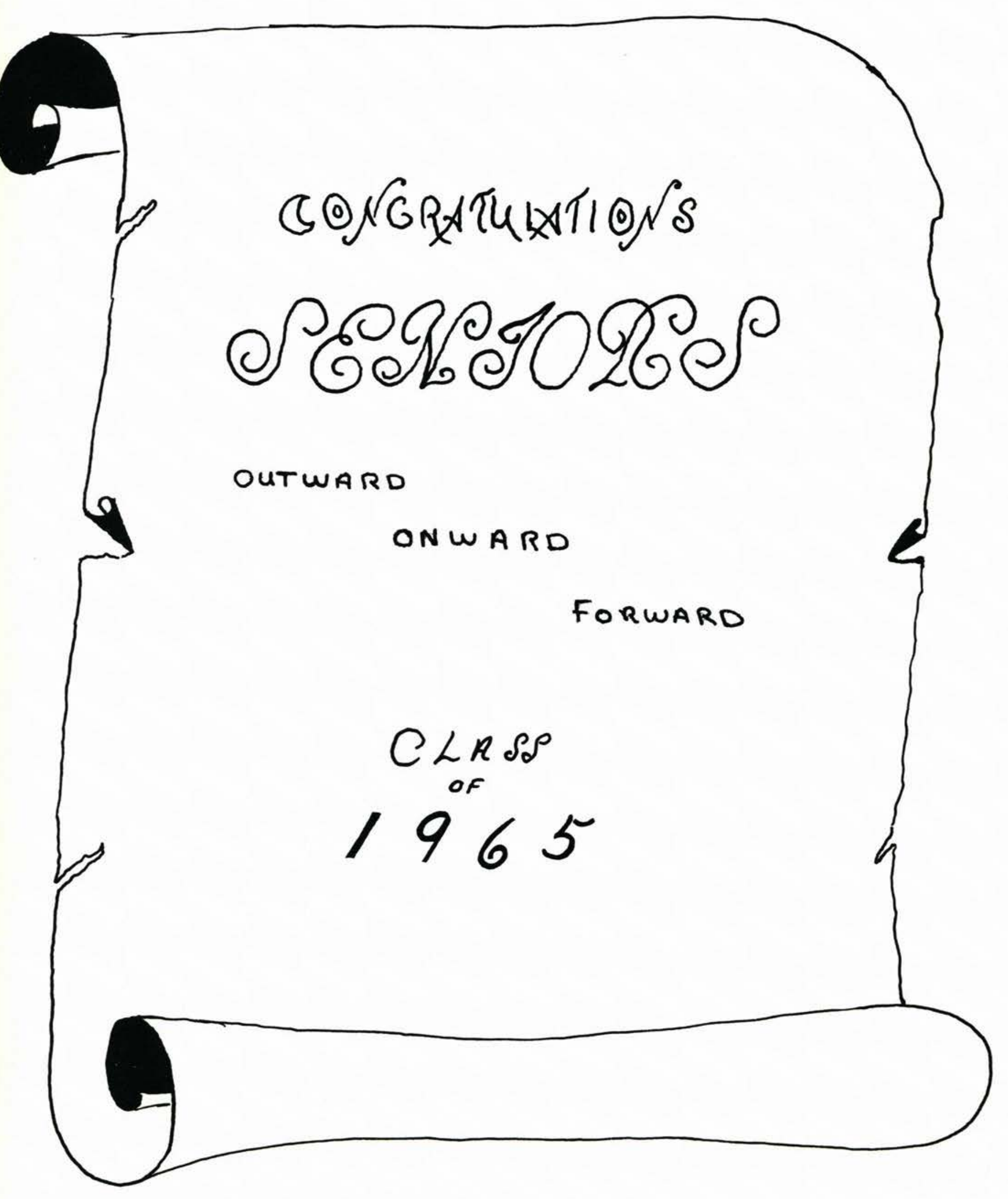




\begin{tabular}{|c|c|}
\hline $\begin{array}{c}\text { CHAPLIN CLEANERS } \\
\text { Laundry Service } \\
\text { Cleaning } \\
\text { Shoe Repair } \\
\text { Phone } 766-3871 \\
\text { Cedarville, Ohio }\end{array}$ & $\begin{array}{c}\text { CONGRATULATIONS } \\
\text { CLASS OF } 1963 \\
\text { FROM THE } \\
\text { CEDARVILLE COLLEGE } \\
\text { DINING HALL }\end{array}$ \\
\hline $\begin{array}{c}\text { BEAL'S } \\
\text { DEPARTMENT STORE } \\
\text { Clothing and Shoes } \\
\text { S. Main } \\
\text { Phone } 766-5362 \\
\text { Cedarville, Ohio }\end{array}$ & $\begin{array}{c}\text { RANDALL \& STORMONT, } \\
\text { INC. } \\
\text { Purina Chows } \\
\text { and Health Aids } \\
\text { Phone 766-1031 } \\
\text { Cedarville, Ohio }\end{array}$ \\
\hline \multicolumn{2}{|c|}{ COMPLIMENTS } \\
\hline Yellow Springs, Ohio & Cedarville, Ohio \\
\hline
\end{tabular}




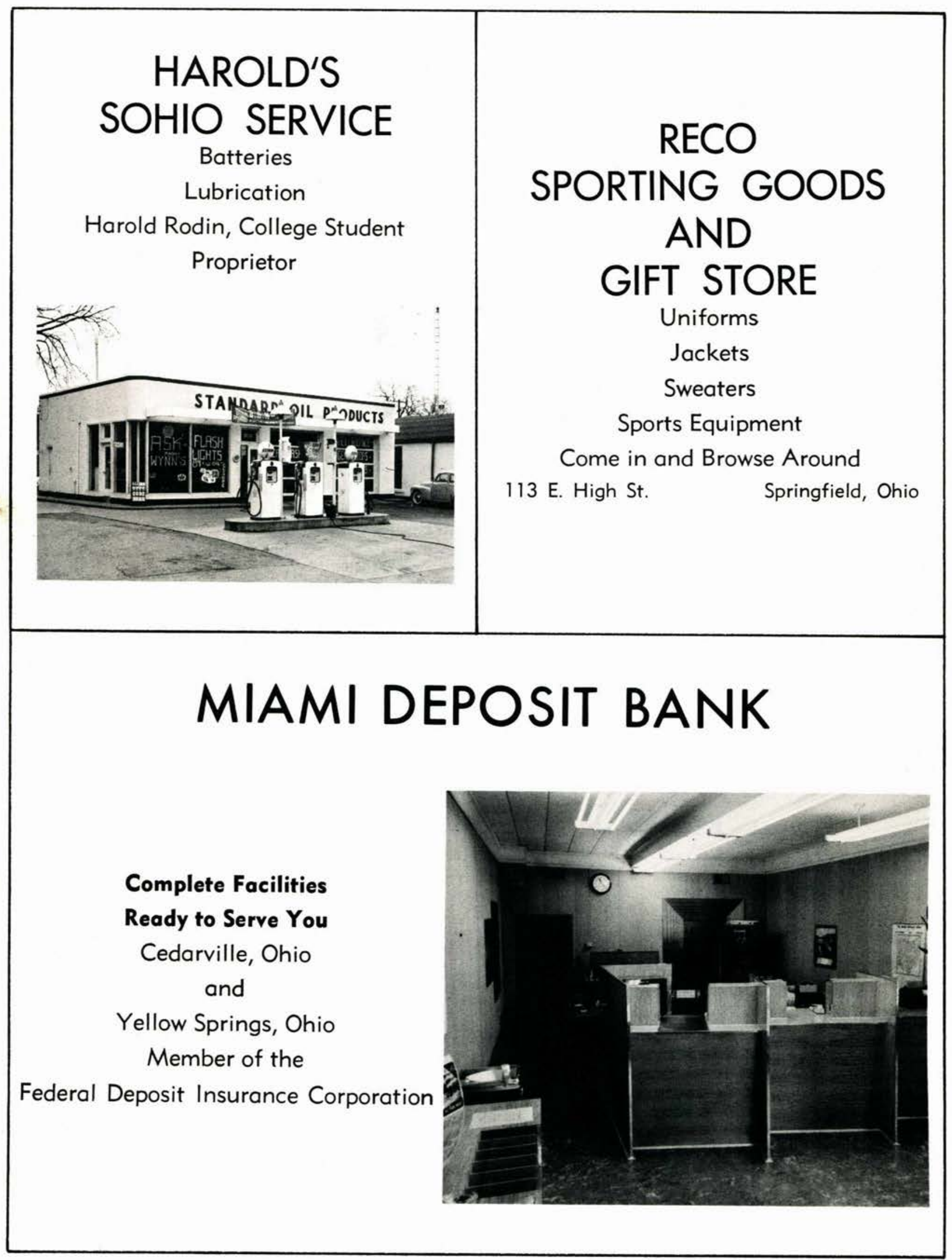


In Appreciation

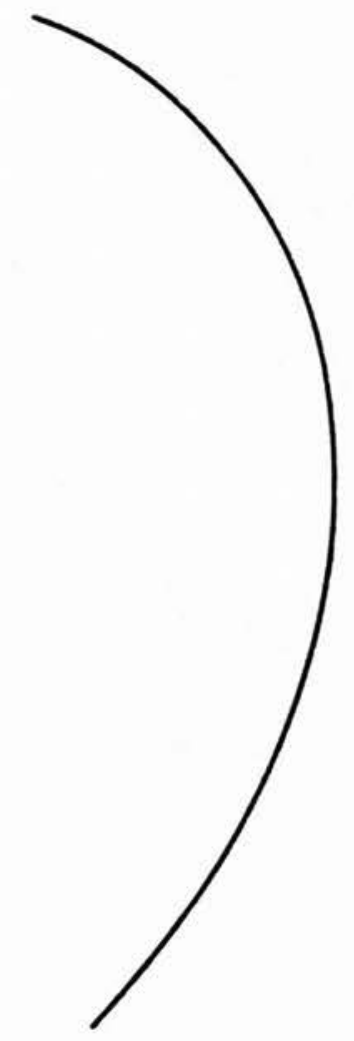

\section{Local Patrons}

Art Cox Studios

Inter-Collegiate Press

Fellowshiping Churches
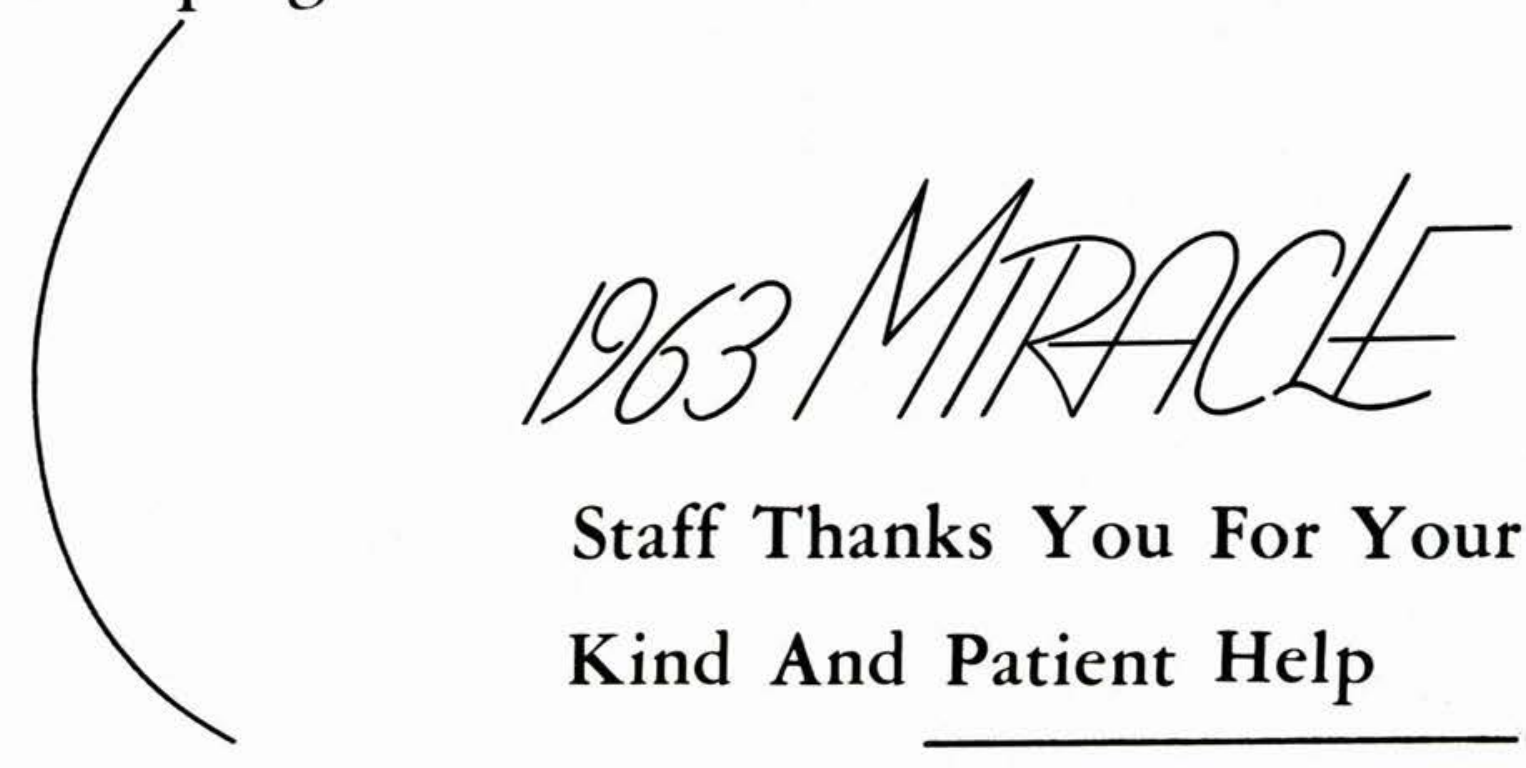

Staff Thanks You For Your Kind And Patient Help 


\section{Index}

Acker, Elton - 65, 97, 98, 171

Ackerman, Sharon - 64, 84, 161

Adams, Gladys - 97, 151

Adams, Patricia - 80, 87, 92, 97, 99, 101, 151,182

Adams, Ross - 161

Adamson, Barbara - 80, 84, 139

Adamson, Bette - 84, 91, 125, 134, 135, 150151

Addleman, Janice - 65, 88, 101, 161

Addleman, Keith - 171

Addleman, Sharon - 88, 101, 151, 182

Alberter, Kathleen - 161

Albrecht, Peggy - 65, 95, 98, 171

Albrecht, Rosalee - 139

Allen, Walter - 64, 171

Ammons, Martha - 93, 99, 101, 161, 174

Amos, Janice - 83, 161

Armitage, Sharon - 64, 98, 171

Atkinson, Cinda - 161

Auffort, Robert - 96, 131, 150, 151

Averitt, Mark - 64, 89, 96, 98, 99, 171

Babcock, Barbara - 65, 91, 171

Baker, Jerald - 171

Baker, Lawerence - 130, 151

Baldock, Robert - 139

Bales, Duane - 64, 161, 183

Balke, Sarah - 62, 161

Ballard, Mona - 83, 98, 171

Bancroft, Phyllis - 64, 171

Barker, Jon - 64, 65, 99, 101, 163, 171

Barrett, Pat - 83, 151

Bartheld, Suzanne - 161

BARTHLOMEW, Mr. Raymond - 35

Bauer, Terri - 65, 171, 182

Bayless, Lois - 64, 81, 151

Beard, Larry - 161

Beikert, Betty - 95, 171

Bender, Sally - 81, 86, 87, 99, 134, 135, 151, 182

Bennett, Lee

Bennett, Martha - 65, 83, 171

BERGEN, Mrs. Harmon - 183

BERGEN, Mr. Harmon - 36

Benson, Irene - 139

Biddle, Allen

Bieger, Barbara - 65, 91, 171

Bigelow, John - 126, 139

Bird, Julia - 139, 182

Bird, Patricia - 62, 171, 182

Blackburn, Barbara - 65, 151

Blann, Mary - 179

Blossom, David — 94, 151

Blumenstock, Richard - 111, 138, 140

Bond, Benjamin - 183

Bonnema, Jan - 65, 183

Boonstra, Ruth Ann - 183, 187

Boren, Carole - 62, 140, 182

Boozel, Veo - 179

Brandes, Gary - 118, 123, 161

Bresson, Richard

Brong, Mary - 65, 101, 161

Brooker, Lois - 65, 183
Brower, Paul - 161

Brower, Phil - 64, 90, 119, 140

Brown, Carol - 92, 100, 140

Brown, Grace - 94, 98, 172

Brown, Tom - 151, 182

Brown, Sharon

Bryant, Joan - 65, 83, 152

Bryant, Tyrone - 81, 89, 152

Buchanan, Phil - 152

Buckle, Marian - 65, 91, 172

Buerer, Nancy - 62, 85, 99, 161, 181

Buerer, Peggy - 179

Bush, Dorinda - 64, 91, 172

Butler, Rayna - 64, 98, 161

Butler, Ronald - 162

Byrd, Shirley - 83, 88, 95, 101, 135, 162

CALLEN, Mr. Donald - 43, 90, 118, 119, 126,129

Canine, Sam - 67, 90, 92, 94, 118, 123, 140

Cannon, Flora - 84, 140

Carlson Paul - 82, 94, 99, 100, 162, 184

Carr, Alberta - 141

Carr, Carol - 65, 83, 172

Carter, Dozier - 120, 121, 162

Cayton, Ardith - 95, 162

Cayton, Lynne - 84, 162

CHAFFE, Mrs. Alberta -181

Chamberlain, Jesse

Chandler, Will

Chitty, Gordin - 152

Cochran, David

Colwell, Janet - 65, 172

Connell, Edsel - 126, 128

Cook, Henry - 152

Copeland, Chester - 100,172, 182

Coppock, Carolyn - 65, 162, 183

Coppock, Paul

Corbin, Darlene

Couwenhoven, Judy - 93, 99, 100, 162

Crabb, Alvah - 62, 163

Crown, Barbara - 172

Crull, Martha - 93, 163, 175

Culley, Eugene - 64, 88, 172

Cunningham, Mary - 99, 163

Curcio, Vickie - 68, 83, 91, 95, 99, 100, $107,125,163$

Cushey, Loretta - 84, 141

Czerniak, Larry - 64, 80, 94, 100, 152, 182

Dadisman, Judith - 83, 141

Davidson, Don - 62, 85, 163

Davidson, Rich - 64, 86, 94, 111, 119, 141

Davis, Carol - 163

Davis, Daniel

Davis, Donna - 141

Davis, Janice - 163

Davis, Ray - 90, 118, 129, 163

Day, Howard - 152

Dean, Donald - 65, 172, 182

DeLanzo, Tom - 64, 90, 126, 127, 132, $133,143,152$

DEMPSEY, Mrs. Kathy - 35, 180

Dempsey, Timothy

Dew, Ronald - 62, 172, 185
Doan, Phillip - 172

Doctor, Fay - 135, 163

DOWELL, Mr. Max - 55, 82

Duddleston, Lois - 84, 98, 152

Dudley, Edith - 96, 98, 172, 182

Dudley, Eunice - 96, 98, 172, 182

Duffie, Timothy - 62, 82, 98, 172

Dunn, Damaris - 63, 65, 98, 172

DuPre' Jeannie - 64, 80, 85, 135, 141, 184

Earl, Pamela - 62, 172

Eastman, Ed - 94, 142

Eaton, Jerry - 82, 129, 163

Eckert, Susanne - 65, 95, 97, 98, 163

Edwards, Robert - 152

Ehnis, Mary Ann

ELMORE, Mrs. Austin - 180

ELMORE, Mr. Austin - 49, 160

Elmore, David - 62, 163

Elmore, Marcia

Emerson, Janice - 172

Engelmann, James - 89, 172

England, Ronald

Entner, Donald - 64, 85, 89, 160, 163

Evans, Tom - 126, 128, 152

Farnsworth, Leon - 142

Farrow, Miriam - 172

Fennell, Suzanne - 62, 160, 163

Fetzer, David - 62, 152

Fidler, Robert - 86, 142

Finley, Donna - 83, 92, 100, 142, 182

Finley, Gordon - 153

Finley, Maxine - 65, 88, 172, 182

Fisher, David - 90, 129, 163

FISHER, Miss Jean - 31, 61, 173

Fisher, Mildred - 173

Floyd, Mary Ellen — 65, 98, 163

Ford, George - 179

Foulkrod, Beverly

Foulkrod, Thomas - 185

Fox, Loris - 173

Francis, William - 62, 173

Fransted, Gary - 62, 88, 93, 96, 173

FRYE, Mr. Bert - 51

Furry, James - 64, 85, 173

Gale, Paul - 173

GALE, Mr. Ralph - 45

Gann, Joyce - 91, 173

Gantz, Sharon - 65, 83, 91, 100

Gathany, Paul - 80, 87, 142

Geeting, Michal - 83, 91, 164

Geyser, Suzanne - 81, 95, 98, 99, 134, 135, 153

Gildan, Kathleen - 83, 173

Gilmore, Philip - 62, 173, 183

Golden, June - 94, 99, 142

Good, Patricia - 83, 88, 173

Goodman, Shirley - 65, 153

Goodwin, George - 62, 98, 173

Goodwin, Mary - 83, 87, 153

Gordon, David - 65, 173

Gordon, Gayle - 164

Gorthey, Carol - 153, 184

Grafton, James - 153 
Grant, Phil - 94, 143, 182

Greiner, Miriam - 62, 173

Griffin, Gordon - 62, 82, 88, 93, 97, 173

Grisso, Philip - 153

GROMACKI, Mr. Robert - 33, 119, 150

Hall, Donald E.

Halley, Anne - 91, 134, 170, 173, 180, 183

Hamilton, James - 65, 153

Hamilton, Joanne - 65, 81, 95, 164

Hammack, Bonita - 62, 81, 84, 87, 164

Hamman David - 153

Hanlon, Janet - 173

Harben, Richard

Harris, Cheryl - 143

Harris, Gary - 94, 100, 173

Hartsell, Jeanne

Hartzell, Judith - 84, 90, 164

Haseltine, Mark - 64, 80, 90, 118, 143

Hayes, Sally - 173

Healy, Linda - 173

Hell, Carole - 143

Helmick, Larry - 143

Hensley, Gary - 179

Henson, Carol - 64, 143

Hes, Sherrill - 173

Higdon, Don - 87, 164

Hilliker, Linda - 174

Hirschy, Elaine - 153

Hoffeditz, Raymond - 65, 82, 164

Hoffman, David - 65, 174

Hollenbeck, Marvin - 100, 107, 164

Howard, Elayne - 92, 99, 144, 183

Howard, Ellis - 86, 144

Hoyte, Arlene - 62, 91, 174

Humphreys, Judith - 153

Ingram, John - 94, 101, 138, 144

Irish, Phyllis - 93, 164, 174

Jackson, Bonnie - 81, 88, 153

Jacobs, Gary - 64, 129, 154

Jefson, Lynn - 144

Jensen, David - 99, 100, 112, 126, 164, 182

Jeremiah, David - 90, 92, 94, 118, 121, $122,132,134,144$

JEREMIAH, Mrs. J. -183

JEREMIAH, Dr. James - 12, 15, 33, 67

Jeremiah, Maryalyce - 134, 135, 164

Jodry, Paul - 164

Johns, Donna - 62, 83, 154, 180

Johns, Susan - 134, 164, 182

Johnson, Charis - 100, 170, 174, 186

JOHNSON, Dr. Clifford - 14, 51, 89

Johnson, Donald - 144

Johnson, Eunice

Johnson, Gary - 82, 91, 154

Johnson, Margaret - 65, 134

Johnson, Ruth — 95, 100, 164

Joiner, James

Jordan, Medora - 62, 83, 174, 181

Karsnak, Marian, - 62, 154, 182

Kaster, Patricia - 64, 91, 125, 134, 164

KEARNEY, Miss June - 43, 134

Kellogg, Michael - 164

Kennedy, Lois - 84, 145

Kensinger, Richard

Kettell, Nancy - 165
Kidd, Dorothea

Kidder, Sandra - 179

Killian, Larry - 112, 154

King, Marlin

Kirchner, Dennis

Kirisits, Sandra - 62, 145

Kirtland, Wilbur - 174

KLONTZ, Mrs. Lula - 182

Konicek, Mary Lea - 65, 174

Korlewitz, Elayne - 174

Lachman, Judy - 92, 100, 145

Lamb, Larry - 165

Lamb, Ray - 62, 82, 123, 165

Lane, Irene - 91, 95, 125, 145

Lane, Lloyd - 179

Lane, Rodney - 90, 118, 126, 132, 154

Langeneger, Gordon - 81, 89, 145

LAWLOR, Mr. George - 33, 61

Lawlor, John - 65, 98, 145

Lawrence, Deeann - 174

Leiby, Judy - 166

Lepine, Suzanne - 91, 174

Leunk, Polly - 65, 83, 134, 174

Liechty, Gretchen - 134, 174

Lightly, Dorothy - 165

Lloyd, Hope

Lloyd, Joseph

Lobsiger, William - 146

Lones, Clifford

Loos, David - 62, 174

Lyme, Charlotte - 174

McClintic, Judith - 64, 174

McDONALD, Mr. Cleveland - 45, 47

McDonald, David

McDonald, Dennis - 90, 126, 128, 155

McDugle, Ronald - 61, 80, 96, 126, 165 , 182

McIntosh, Barbara

McINTOSH, Mr. Richard T. - 14, 33, 35, $61,80,86$

McKeehan, Betty - 62, 88, 146

McNamara, Lee Ann - 98, 165

McPHERSON, Mrs. Mary Lou - 182

Macdonald, Aldon - 65, 174, 185

Mackay, Miss Joy - 14, 31, 34

Maclaren, Jean - 84, 165

MADDOX, Mrs. C. $-37,83,87$

MADDOX, Dr. Clifford - 14, 55

Mahanna, LuAnn - 80, 170, 174

Maiers, Blair - 154

Marks, Sharon - 95, 100, 155

MARSHALL, Mrs. Elinor - 180

MARSHALL, Gerald "Pop" - 185

Martin, Linda - 91, 174, 182

Martin, Sheryl - 83, 155, 180, 187

Martin, Susan - 165

Mathis, Ron - 91, 94, 100, 165, 185

Mayo, Shelby

Meek, Larry - 126, 165

Merrett, Frances - 101, 174

Merryman, Valerie - 96, 174

Merwald, $\mathrm{Al}-90,126,165$

Meshew, Helen - 165

Meyers, William - 64, 175

Michaels, Judith - 155

MICK, Miss Bernice - 183
Mick, Ron - 155

Micka, Joyce - 175

Micka, Patricia - 84, 86, 98, 155

Middleton, Don - 80, 87, 146

Miller, Barbara - 100, 165

Miller, Diane - 65, 175

Miller, Janet - 65, 88, 91, 135, 165, 184

MILLER, Mr. Lloyd - 14

Miller, Terry - 64, 82, 85, 90, 126, 165

Millikin, Rita - 80, 83, 87, 101, 155

Mills, David - 155

Mitchell, Dawn - 62, 175

Montgomery, Larry - 65, 82, 98, 175

MOODY, Mr. Lane - 43, 79

Moore, Jay - 85, 88, 155

Moore, Ronald - 81, 89, 91, 175

Morgan, John - 67, 92, 94, 100, 155

Morgan, Kathleen - 83, 175

Morrell, Lois - 175, 182

Motts, Martha - 165

Mundhenk, Luann - 166

Nash, Bonnie - 65, 83, 88, 101, 146

Navorska, David

Neely, Joanne - 84, 98, 166, 182

Nettleton, Peggy - 62, 84, 166

Neufeld, Judy - 135, 155

Newcomer, Sue - 166

Newman, Robert - 65, 166

Nicklas, Norman - 62, 88, 150, 155, 182

Nimmo, Stephen - 130

Nims, David - 64, 82, 98, 175

Norris, David - 81, 166, 185

Ober, Dennis - 65, 99, 175

O'Bryon, Roger - 94, 156

Ocheltree, Ted - 64, 79, 80, 89, 90, 118, $122,126,127,130,132,146$

Oehmcke, Arlene - 83, 166

Oehmcke, Charles - 85, 146

O'Keefe, Rebecca - 97, 175, 181

Olsen, Dorothy - 65, 83, 95, 98, 175

Olsen, Jerry - 118, 176

Olsen, Philip - 101, 166

Olson, Sheryl

Opitz, Larry - 176

Osborn, Jerry - 64, 118, 122, 166

Osborne, Joe - 166

Otto, Shirley - 176, 184

Park, Dan - 82, 96, 99, 101, 156, 182

Patch, Aloha - 62, 87, 147

Pay, Ralph - 65, 82, 176

Pearce, Dennis - 166

Pearson, Ronald - 176

Peasley, Byron - 176

Pelke, Dorothy - 176

Perry, David - 62, 88, 94, 100, 107, 166

Petrie, Juliann - 64, 83, 88, 96, 166

Powell, Mary Ellen - 83, 99, 106, 156

Prather, Eugene - 176

Prosser, David - 82, 85, 88, 112, 176

Quick, Patricia - 91, 134, 176184

Quiter, Clara - 147

Ramsey, Roy - 176

Ream, Eugene - 166

REED, Mr. John -37

Reno, Paul - 85, 100,129, 166

Reynolds, Robert - 97, 99, 156 
Rice, David - 176

Rich, Richard - 88, 166

Richardson, Lawrence - 176

Rifenberick, David - 82, 85, 88, 94, 99, 100,182

Ripko, Phyllis - 65, 91, 176

Riter, William - 65, 82, 96, 156

Rivers, James

Rockwell, Denis - 62, 88, 176

Rodenberg, Nancy - 176

Rodgers, William - 176

Rodin, Harold

Roloff, Val - 82, 85, 96, 160, 167, 183

Ronk, Phyllis - 80, 176, 182

Roost, Donna - 62, 83, 167, 182

Ross, Rebecca - 83, 134, 176

Rothwell, Marian - 95, 156

Rotondi, Tony - 64, 82, 91, 126, 128, 156

Routzon, Roger - 62, 176

Rowe, Ray

Rudduck, Joyce - 65, 88, 98, 177

RUDER, Mrs. Esther - 181

Russell, Chester - 156

RUSSELL, Mr. Emerson - 39

RUSSELL, Mrs. E. -181

ST. CLAIR, Mr. Kenneth - 53, 138

Schenck, Lauren - 147

Schimkus, Phyllis

Schimkus, Richard

Schmitt, Mollie - 88, 147

Scholten, Carol Jean - 91, 98, 177, 182

Schonschek, Pat - 61, 64, 65, 80, 83, 100, 135, 147, 182

Schut Nancy - 167

Seevers, Stanley - 62, 82, 156

Senters, Cephas

Shaw, Lavonne - 91, 177

Shelton, Catherine - 148, 182

Shetler, Terry - 65, 177

Shimits, Nancy - 62, 80, 87, 99, 156

Shingleton, Michael $-167,182$

SHIRLEY, Mrs. Jessie - 182

Short, Martha - 64, 134, 135, 167

Shue, Donald - 82, 177

Shugar, Frederick - 156

Sidle, Jacquelyn - 167

Siganowick, Jean - 62, 98, 177

Simrell, Joanne - 91, 177, 182

Siplock, Judith - 65, 84, 156

Skeie, Linda - 167

Slavens, Barbara - 157

Smelser, Eleanor - 88, 99, 157
Smith, Nancy - 86, 92, 97, 98, 134, 135, 157

Smith, Norris - 90, 106, 118, 120, 122, $126,127,128,148$

Smith Patsy - 65, 88, 91, 177, 182

SMITH, Miss Ruth - 41, 84, 92, 99

Smith, William - 65, 100

SPAULDING, Miss Margaret - 180

Spear, Judy -177

SPENCER, Mr. Edward - 35, 81

Spencer, Richard - 118, 120, 123, 167

Sprague, A. James -177

Sprague, James - 64, 129, 130, 157

Stadt, Jerry - 118, 122, 126, 168

Stafford, Gerald - 157

Stephens, Dan - 168

Stephens, Marvin - 82, 88, 126, 168

Stockwell, John - 62, 93, 177

Stowell, Joseph - 93, 96, 177

Stowell, Margaret - 80, 81, 157

Sullivan, Letha - 65, 96, 98, 99, 177

Surber, Sharon - 168

Swigart, Ken - 157

TARTER, Mrs. Betty -182

TARTER, Mr. Charles - 185

Taulbee, Loretta - 177

Taylor, David - 157, 185

Taylor, Gordon - 80, 94, 97, 100, 177

Teeters, Kathleen - 62, 98, 177

Tennant, Barbara

Tennant, Donley - 80, 90, 129, 148

Tennant, Kent

Terry Patricia - 158

Thatcher, Thomas

Thomas, Daniel - 168, 185

Thompson, Arthur - 133

Thompson, Donna - 62, 91, 125, 148, 183

Thoms, Evelyn - 88, 154, 184

Thomson, Beth - 91, 177

THOMSON, Mr. Dale - 49, 119, 170

Thorne, Barbara - 65, 168

Thorne, David - 65, 82, 91, 168

THORNTON, Mrs. W. -181

THORNTON, Mr. William - 41, 79, 96, 100, 106

Tice, Lynn

Titus, Anna - 62, 168

Tremba, Janet - 169

Trumbull, David - 85, 156

Tulloch, George - 65, 170, 177

Tulloch, Marilyn - 62, 83, 101, 158

TURNBULL, Mr. Bruce -51
Twiest, Brian - 169, 188

UNDERWOOD, Mrs. Ruth - 18, 183, 184

Vanderground, David - 177

Van Horn, Janice - 62, 177

Van Wyk, Janice - 65, 98, 178

Varisco, Louise - 83, 148

Versluis, Patricia - 62, 84, 134, 169

Vesterfelt, David - 62, 158

Wagner, Nancy - 62, 178

Wagnitz, Gerald - 148

Walborn, David - 64, 178

Walborn, Jon - 90, 100, 129, 169

Walborn, Judith - 98, 107, 158

Walker, James - 158

Walker, Roosevelt - 158

Wall, Betty - 84, 158

Wallis, Eugene - 169

Walthall, Gary — 90,118, 121, 123, 158

Ward, Cornelia - 91, 135, 169

Warfield, William - 138, 149

Warkentin, Nancy - 83, 106, 149

Warren, David - 64, 80, 87, 90, 129, 150, 158

Washburn, William — 92, 96, 106, 107, 149

WEBBER, Mrs. W. - 54

WEBBER, Mr. Warren - 41, 92

Welch, Sandi - 84, 158, 181

Werner, David - 64, 96, 98, 129, 169, 182

Werner, Ralph - 80, 90, 92, 94, 96, 100, $106,149,182$

West, Mary Ellen - 159

Weyhe, Bradley - 98, 169

Whaley, Teresa $-83,91,178$

Wickell, Geraldine - 169

Wilkite, David — 64, 80, 82, 160, 169

Wilkins, Charles - 62, 170, 178, 185

Wilkinson, Gary - 178

WILliAMS, Dr. Arthur - 33, 68

Williams, Jeneen -169

Wing, Helen - 83, 92, 94, 100, 135, 169

Wing, Sylvia - 65, 84, 134, 169

Woodard, Irving - 159

Woods, Beverly - 65, 80, 86, 88, 138, 149, 180

Wright, Carole - 178

Wyse, Mrs. Rodney - 178

WYSE, Mr. Rodney - 53

Yeager, Robert - 62, 178

Young, Maxine - 178

Zeigler, James - 65, 178

Ziegler, Mervin - 82, 169, 185

Zinn, George - 41 


\section{Patron Index}

Alton Brown Street Baptist - 196

Beckley Mt. Tabor Baptist - 194

Berea Baptist - 189

Butler First Baptist - 196

Caldwell First Baptist - 194

Cedarville

Beal's Department Store - 204

Big Wheel Restaurant - 199

Cedar Cliff Beauty Salon - 203

CC Alumni Association - 199

CC Bookstore - 193

CC Dining Hall - 204

Chaplin Cleaners - 204

Chic's Barber Shop - 203

Feed \& Grain - 200

Freshman Class - 197

Grace Baptist - 193

Hardware - 200

Harner's Market - 200

Harold's Sohio Service - 206

Irvin Dairy Isle - 205

"James" Rexall Store - 200

Junior Class - 198

Leach Quick Wash - 200

Miami Deposit Bank - 206

Miracle Staff - 205

Morris Bean and Company - 204

Pickering Electric - 200

Randal \& Slormont, Inc. -204

Sophomore Class - 202

Variety Store - 200

WCDR-FM - 205

Cleveland Cedar Hill Baptist - 192

Columbus Clintonville Baptist - 192

Columbus Immanuel Baptist - 196
Covington Calvary Baptist - 191

Cresaptown Calvary Baptist - 194

Decatur Riverside Baptist - 195

Des Moines Grandview Baptist - 190

Elkhart First Baptist - 189

Euclid-Nottingham Baptist - 195

Fairborn Hoak's Greenhouse - 205

Forest City Calvary Baptist - 194

Galion First Baptist - 194

Gallipolis First Baptist - 188

Gary Central Baptist - 188

Hackensack First Baptist - 192

Haddon Heights Baptist - 195

Hamburg First Baptist - 196

Harrison First Baptist - 194

Indianapolis Windsor Village Baptist - 194

Marion Emmanuel Baptist - 194

Medina First Baptist - 194

Milford First Baptist - 194

Mishawka First Baptist - 190

Parma First Baptist - 189

Portsmouth Temole Baptist - 191

Springfield

Blessed Hope Baptist - 196

Reco Sporting Goods - 206

River Dale Dairy - 201

Springfield, Massachusetts Grace Baptisı 190

Standish Baptist - 193

Steamburg Union - 193

Xenia

Anchor Paint - 203

Art Cox Studio - 199

Band Box Music - 203
Book and Bible -203

Braun's Jewelers - 203

Camera Shop - 203

Card Shop - 203

Central Barber - 203

Cherry's Furnishings - 203

Corner Pharmacy - 203

Criterion - 205

Daum and Son - 203

Delabar Hardware - 203

Dollar Value - 203

Dutch Oven Bakery - 203

Eichman's Appliance - 203

Ehrhart Sports Center - 203

First Reformed - 194

Geyer's Restaurant - 203

Home Furniture - 203

Hurley's Florists - 203

I.T. Pizza House - 203

Main Auto Supply - 203

Modern Shoe Repair - 203

Montgomery Ward - 203

Nilson-Bone Florists - 203

Ray Cox Insurance - 203

Reece Paint and Wallpaper - 203

Rogers Jewelry - 203

Seifert Sohio Station - 203

Sherwin Williams - 203

Tiffany Jewelry -203

Xenia Area Chamber of Commerce - 203

Xenia Gazette - 203

Xenia School and Office Supply - 203

Ypsilanti Calvary Baptist - 192

Yuma-Mesa Baptist - 194 


\section{Epilogue}

In the light of this decade of Divine direction, can EPILOGUE be anything but praise to our God?

Praise God from whom all blessings flow;

Praise Him all creatures here below;

Praise Him above, ye heavenly host;

Praise Father, Son, and Holy Ghost.

Amen

Thomas Ken, 1709 


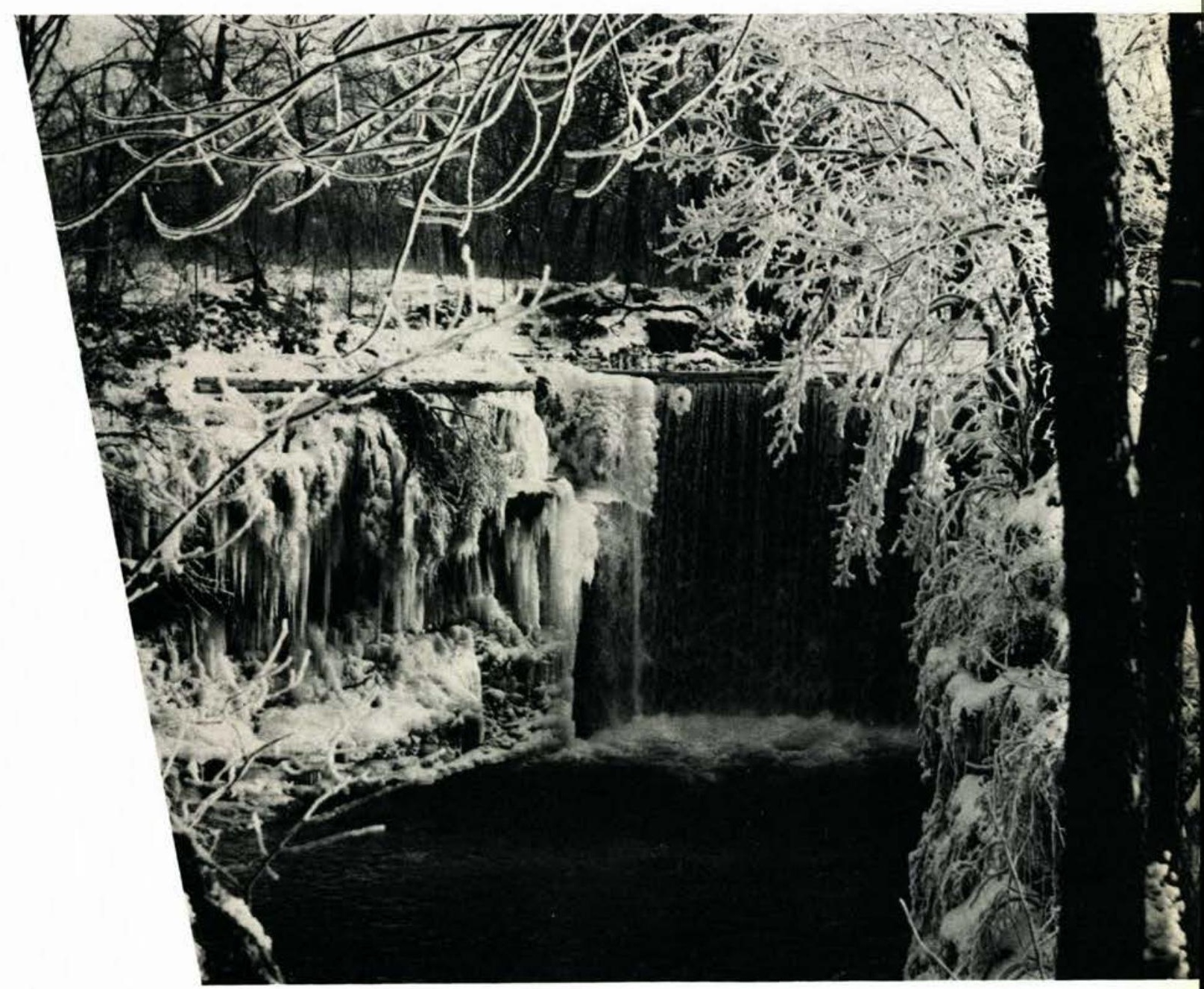






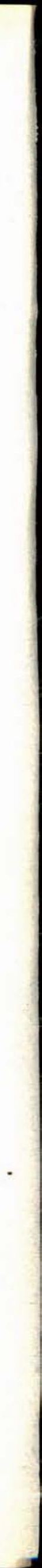




A Decade of Progress, the Record of Miracles 


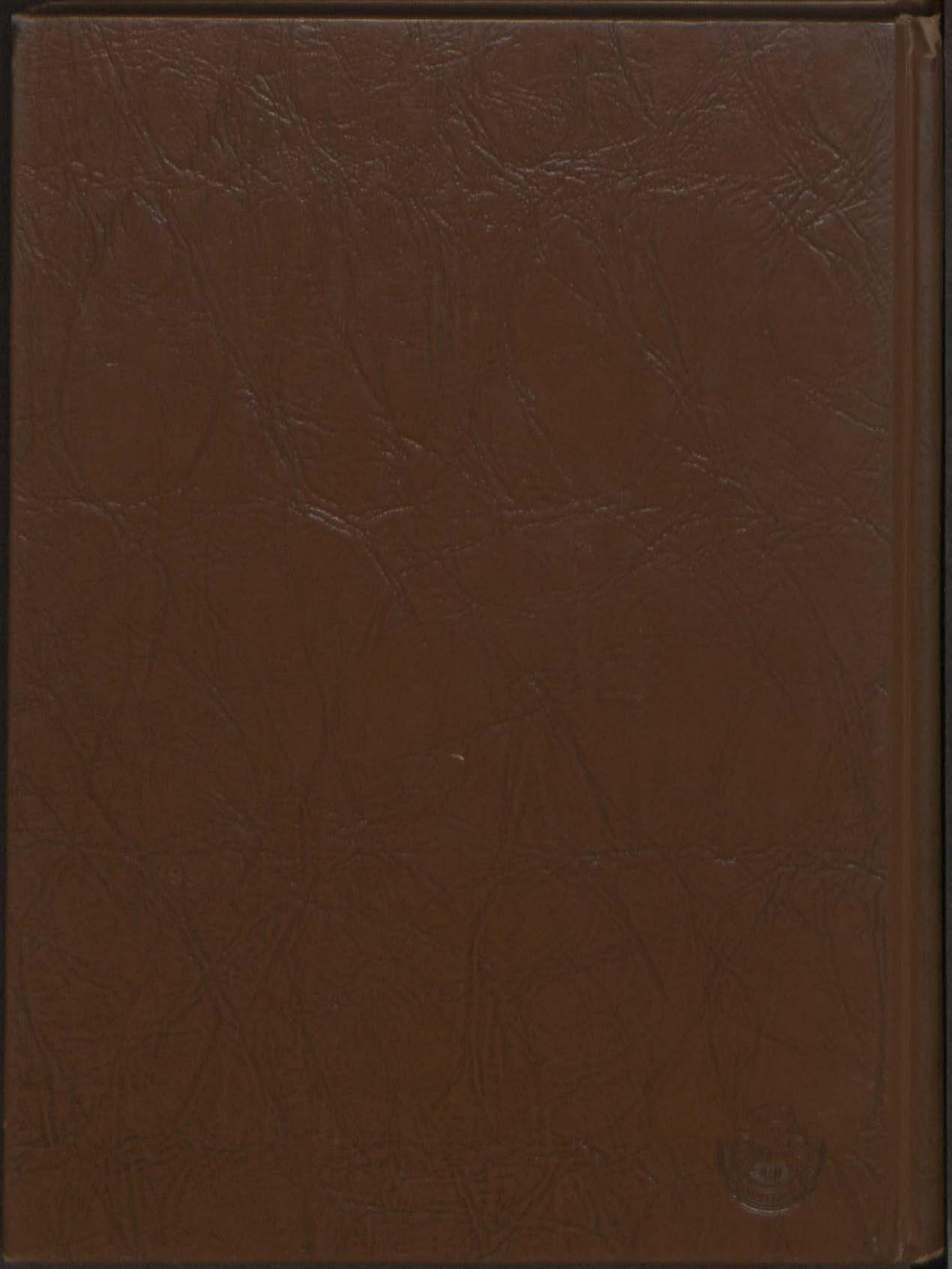

